\author{
UNIVERSIDADE DE SÃO PAULO \\ FACULDADE DE EDUCAČ̃O \\ PROGRAMA DE PÓS-GRADUAÇÃO EMM EDUCAÇÃO
}

MARILEIDE GONÇALVES FRANÇA

FINANCIAMENTO DA EDUCAÇÃO ESPECIAL: COMPLEXAS

TRAMAS, PERMANENTES CONTRADIÇÕES E NOVOS DESAFIOS 


\title{
FINANCIAMENTO DA EDUCAÇÃO ESPECIAL: COMPLEXAS TRAMAS, PERMANENTES CONTRADIÇÕES E NOVOS DESAFIOS
}

\author{
Versão corrigida
}

Tese apresentada à banca examinadora como parte dos requisitos necessários para obtenção do título de Doutor em Educação pela Faculdade de Educação da Universidade de São Paulo.

Área de Concentração: Educação Especial

Orientadora: Prof ${ }^{a}$. Dr ${ }^{a}$. Rosângela Gavioli Prieto 
AUTORIZO A REPRODUÇÃO E DIVULGAÇÃO TOTAL OU PARCIAL DESTE TRABALHO, POR QUALQUER MEIO CONVENCIONAL OU ELETRÔNICO, PARA FINS DE ESTUDO E PESQUISA, DESDE QUE CITADA A FONTE.

Catalogação na Publicação

Serviço de Biblioteca e Documentação

Faculdade de Educação da Universidade de São Paulo

379.32

França, Marileide Gonçalves

F814f

Financiamento da educação especial: complexas tramas, permanentes contradições e novos desafios / Marileide Gonçalves França; orientação Rosângela Gavioli Prieto. São Paulo: s.n., 2014.

364 p. ils.; grafs.; tabs.; anexos; apêndices

Tese (Doutorado - Programa de Pós-Graduação em Educação. Área de Concentração: Educação Especial) - - Faculdade de Educação da Universidade de São Paulo.

1. Estado 2. Financiamento da educação 3. Educação especial I. Prieto, Rosângela Gavioli, orient. 


\section{FOLHA DE APROVAÇÃO}

Nome: FRANÇA, Marileide Gonçalves França

Título: Financiamento da educação especial: complexas tramas, permanentes contradições e novos desafios

Tese apresentada à Faculdade de Educação da Universidade de São Paulo como parte dos requisitos necessários para obtenção do título de Doutor em Educação.

Aprovado em: 10 de dezembro de 2014.

Banca Examinadora

Prof. Dr. Rosângela Gavioli Prieto Instituição: USP Julgamento: Assinatura:

Prof. Dr. Rubens Barbosa de Camargo Instituição: USP Julgamento: Assinatura:

Prof. Dr. I-Juca Pirama Camargo Gil Instituição: UFRGS Julgamento: Assinatura:

Prof. Dr. Marcos Edgar Bassi Instituição: UFPR Julgamento: Assinatura:

Prof. Dr. Silvia Márcia Ferreira Meletti Instituição: UEL Julgamento: Assinatura: 
A Deus; a Jaszila, Valdemiro e Marilene, razão de minha vida; e àqueles que lutam por uma educação de qualidade como direito de todos. 


\section{AGRADECIMENTOS}

A Deus, meu Pastor, meu mestre, meu guia pelo dom da vida.

A meus pais, Jaszila e Valdemiro, pelo amor incondicional, por não medirem esforços para que este sonho se concretizasse, por compreenderem as minhas ausências durante esse período de dedicação à pesquisa, por terem me ensinado a valorizar e lutar pelas conquistas na vida. Essa Vitória é nossa!

Á minha irmã e amiga Marilene, pelo incentivo, pelo apoio, pelo companheirismo, pela cumplicidade e pelas palavras de carinho, e também por dispor de seu tempo para me ouvir nas minhas angústias, minhas dúvidas, minhas vitórias, nos meus momentos tristes e alegres, na trajetória deste trabalho.

Aos meus tios Maura e Raimundo, aos meus primos Solange, Humberto, Nilton, Alexandre, Maria e Maria Luiza, pelo amor, carinho, acolhimento e apoio incondicional durante esse percurso no estado de São Paulo. Muito obrigada.

À minha querida orientadora, professora Rosângela Gavioli Prieto, pela confiança, pela amizade, pelos momentos de trocas, pela paciência, pelas palavras de incentivo e pelo apoio durante a trajetória de pesquisa. Seu rigor e comprometimento ético-político no desenvolvimento de suas ações, aliados a sua sensibilidade, me fizeram admirá-la ainda mais como pessoa e como profissional. Aprendi muito com você!

Aos professores I-Juca Pirama Camargo Gil e Rubens Barbosa de Camargo, pela leitura e pelas reflexões desencadeadas no exame de qualificação, que muito contribuíram para o aprimoramento desta pesquisa e para minha formação.

Aos professores Marcos Edgar Bassi e Silvia Márcia Ferreira Meletti, por terem aceitado o convite para compor a banca, pela disponibilidade para a leitura e contribuições teóricas para o trabalho. 
A todos os professores da Feusp que contribuíram com a minha formação.

Aos meus amigos do grupo de orientação coletiva: Ana Lúcia, Claudine, Roseli, Fábio, Rúbens, Mariana, Elaine, Fernanda Raquel, Kate e Lisiane, pelos momentos de estudo, de amizade, de trocas, de discussões e de contribuições para o trabalho.

À Secretaria Municipal de Educação de Vitória, pela oportunidade de realização da pesquisa. Em especial, a todos os profissionais que contribuíram para a produção deste trabalho.

Á Secretaria Municipal de Fazenda, pela atenção e pela disponibilidade em colaborar para a realização da pesquisa.

Ao Instituto Federal de Educação, Ciência e Tecnologia do Espírito Santo, campus Cariacica, em especial as professoras Laiana e Isaura pela colaboração com o trabalho e aos meus amigos pedagogos: Ana Paula, Cristiane e Gláucio, pelo incentivo, pela compreensão e pelo apoio nos momentos de ausência.

Aos meus queridos amigos: Renata, Wendel, Maria da Penha, Gisele, Valéria, Marcela, Sérgio, Flávia Lima, Maykel, Flávia Batista, Marcos, Diego, Lidiane, Nayara, Cristina Ferreira e Cristina Mota, pela cumplicidade nos momentos vividos, pela alegria, pelo incentivo, pelo companheirismo e pela amizade.

Às professoras Sonia Lopes Victor, Denise Meyrelles de Jesus e Maria Aparecida Santos Correa Barreto (In memoriam), pelo incentivo e pela contribuição na minha formação.

A Maria Dalva, por sua sabedoria, seu cuidado e sua dedicação na leitura e revisão deste estudo.

A todos que, de diferentes maneiras, contribuíram para a realização deste trabalho. 
"[...] a importância da lei não é identificada e reconhecida como um conjunto de instrumento linear ou mecânico, de realização de direitos sociais. Ela acompanha o desenvolvimento contextualizado da cidadania em todos os países. A sua importância nasce do caráter contraditório que a acompanha: nela sempre reside uma dimensão de luta. Luta por inscrições

mais democráticas, por efetivações mais realistas, contra descaracterizações mutiladoras, por sonhos de justiça [...]" 


\section{RESUMO}

FRANÇA, Marileide Gonçalves. Financiamento da educação especial: complexas tramas, permanentes contradições e novos desafios. Tese (Doutorado) Faculdade de Educação, Universidade de São Paulo, São Paulo, 2014.

Este estudo analisa a ação do Poder Público no provimento de recursos financeiros à educação especial na gestão do município de Vitória, no estado do Espírito Santo, no âmbito do contexto de financiamento da educação básica, nos anos de 2008, 2009 e 2010. Partimos do pressuposto de que a garantia da educação às pessoas com deficiência, transtornos globais do desenvolvimento e altas habilidades/superdotação e a ampliação de sua oferta implicam intervenção por parte do Estado no intuito de assegurar os direitos dessa população no que tange ao acesso, à permanência e à qualidade de ensino nos sistemas educacionais brasileiros. Com apoio em Poulantzas (2000), entendemos o Estado como espaço público marcado pela correlação de forças entre classes e grupos que compõem a sociedade e participam dos processos decisórios na formulação de políticas públicas. Para o desenvolvimento do trabalho, foi realizada a pesquisa documental, por meio da consulta ao planejamento e execução orçamentária, aos demonstrativos de receitas e despesas, bem como aos documentos oficiais do município. No que se refere à gestão das verbas da educação especial, quanto à sua transparência, organização e padronização, observamos, nos demonstrativos de execução orçamentária, que as mudanças no padrão de financiamento da educação, com o Fundeb, não produziram significativas alterações nas formas de registros dos dados contábeis, nos órgãos oficiais, referentes às etapas e modalidades de ensino. Isso foi evidenciado pelas dificuldades que encontramos em visualizar as receitas e despesas destinadas à educação especial nas diferentes fontes de informação do governo federal, estadual e municipal. Os dados eram apresentados de forma agregada, o que impossibilitava identificar o que era alocado na educação especial. Assim, embora a rede de ensino do município de Vitória apresentasse matrículas nessa modalidade de ensino, os valores apresentados pareciam não corresponder às despesas reais com a manutenção da educação especial no município, por estarem agregados aos recursos de outras etapas de ensino. Nessa perspectiva, foi possível identificar que a educação especial integrava o planejamento orçamentário do município de Vitória. As receitas destinadas a essa modalidade estavam englobadas nos recursos totais dirigidos à educação no município, e os valores das despesas estavam subdimensionados, pois estavam agregados à educação infantil e ao ensino fundamental. Desse modo, o financiamento da educação especial sofre influência das correlações de forças políticas, econômicas e sociais em torno do fundo público, no âmbito do Estado brasileiro, representadas por diferentes grupos com interesses diversos, que, por sua vez, interferem na constituição de políticas públicas, engendrando implicações na consolidação de direitos de cidadania, entre os quais o direito à educação. Portanto, a concretização desse direito, ao público da educação especial, pressupõe políticas educacionais que garantam mudanças na gestão financeira, no âmbito da administração pública municipal, de modo a assegurar às pessoas com deficiência, transtornos globais do desenvolvimento e altas habilidades/superdotação educação de qualidade nos sistemas públicos de ensino.

Palavras-chave: Estado. Financiamento da educação. Educação especial. 


\begin{abstract}
FRANÇA, Marileide Gonçalves. Special education financing: complex plots, permanent contradictions and new challenges. Thesis (Doctoral degree)Faculdade de Educação, Universidade de São Paulo, São Paulo, 2014.
\end{abstract}

Key words: State.Education Financing. Special Education

This study analyzes the action of the Government in providing funds for special education in the management of the municipality of Vitória, state of Espírito Santo, within the context of the financing of basic education in the years 2008, 2009 and 2010. We start from the assumption that the guarantee of education to people with disabilities, global developmental disorders and high ability / talent and the expansion of its offer implies intervention by the State in order to ensure the rights of this population in terms of access, permanence and the quality of education in Brazilian educational system. Supported by Poulantzas (2000), we understand State as a public space marked by the correlation of forces between classes and groups that make up society and participate in decision making processes in the formulation of public policies. For development of this study, we make use of documentary research by consulting the planning and budget execution, the statements of revenues and expenses, as well as official documents of municipality. Referring to the management of funds for special education, as to its transparency, organization and standardization, we observe through the statement of budget execution, that the changes in the pattern of education funding with Fundeb had produced no significant changes in the forms of records of the accounting data in the official agencies concerning stages and types of education. This was evidenced by the difficulties encountered in visualizing the receipts and expenses for special education in different sources of information from federal, state and local government. The data were presented in aggregate form, making it impossible to identify which part was allocated for special education. Thus, although the schools of the city of Vitória present enrollment for this type of education, the amount we could verify do not seem to match the actual cost for maintenance of special education in the municipality because they were included together with the resources of other levels of education. It was therefore possible to identify that special education was part of the budget planning of the city of Vitória. The income for this type of education was totally incorporated within resources for municipality education as a whole. So, the amount of expenses was undersized and it was aggregated to early childhood education and elementary education funds. Thus, financing for special education is influenced by the correlation of political, economic and social forces considering Public Brazilian State Fund, represented by different groups with different concern. This point interferes in the formation of public policies and it causes implications for the consolidation of the rights of citizens, including the right for education. Therefore, in order to carry out this right for the audience of special education, it's necessary to involve educational policies to guarantee changes in financial management within the municipal government, and also to ensure education quality in public education systems to the people with disabilities, global developmental disorders and high ability / talent.

Key words: State. Education Financing. Special Education. 


\section{LISTA DE TABELAS}

Tabela 1 Valor aluno-ano do Fundef - Brasil 1997 a 2006 em valores nominais $(\mathrm{R} \$)$.

Tabela 2 Complementação de recursos da União - Fundeb 2007-2013 em valores nominais $(R \$)$

Tabela 3 Fatores de ponderação no valor-aluno para as diferentes etapas e modalidades de ensino 2007-2013.

Tabela 4 Fundeb: valor mínimo nacional por aluno-ano - Séries Iniciais do Ensino Fundamental Urbano 2007-2013 em valores nominais $(\mathrm{R} \$)$

Tabela 5

Valor anual por aluno estimado e receita total estimada do Fundeb para a educação especial, no âmbito dos estados e do Distrito Federal - 2007 em valores nominais $(R \$)$

Tabela 6 Valor anual por aluno estimado e receita total estimada do Fundeb para a educação especial, no âmbito dos estados e do Distrito Federal - 2008 em valores nominais $(R \$)$.

Tabela 7 Valor anual por aluno estimado e receita total estimada do Fundeb para a educação especial, no âmbito dos estados e do Distrito Federal - 2009 em valores nominais $(R \$)$

Valor anual por aluno estimado e receita total estimada do

Tabela 8 Fundeb para a educação especial, no âmbito dos estados e do Distrito Federal - 2010 em valores nominais $(R \$)$

Tabela 9 Matrículas da educação especial no Fundeb - Brasil 20072010.

Tabela 10

Porcentagem das matrículas da educação especial em relação ao total de matrículas contempladas no Fundeb - Brasil 20072010 .

Tabela 11 Valor médio do investimento aluno-ano da educação especial no Fundeb - Brasil 2007-2010 em valores nominais $(R \$)$.

Tabela 12 Diferença entre os valores aluno-ano dispostos para a educação especial no Fundeb nas unidades federativas com maior e menor valor - Brasil 2007-2010 em valores nominais $(R \$)$

Porcentagem aproximada dos recursos direcionados às matrículas da educação especial em relação aos recursos totais do Fundeb - Brasil 2007-2010 em bilhões de $\mathrm{R} \$$. 
Tabela 14 Matrículas da educação básica por etapas e modalidades Brasil 2007-2013.

Tabela 15 Índice de Desenvolvimento Humano Municipal e seus componentes - Vitória/ES 2000-2010.

Tabela 16 Fluxo escolar por faixa etária - Vitória, Espírito Santo, Brasil 2010.

Tabela 17 Quantitativo de função docente da rede de ensino municipal de Vitória/ES 2008, 2009 e 2010.

Tabela 18 Quantitativo de escolas do município de Vitória/ES 2008, 2009 e 2010.

Tabela 19 Matrículas da educação especial por etapas e modalidades Vitória/ES 2008, 2009 e 2010.

Número de matrículas por deficiência, TGD e altas habilidades/superdotação na rede municipal de ensino de Vitória - Vitória/ES 2008, 2009 e 2010.

Tabela 21 Valores previstos pela LOA à função educação - Vitória/ES 2008, 2009 e $2010(R \$)$

Tabela 22 Valores previstos pela LOA para as etapas e modalidades de ensino - Vitória/ES 2008, 2009 e 2010 (R\$).

Tabela 23 Receitas destinadas à educação - Vitória/ES 2008, 2009 e 2010 $(\mathrm{R} \$)$

Tabela 24 Receitas por fonte - Vitória/ES 2008, 2009 e 2010 (R\$)

Tabela 25 Receita Total per capita - Vitória/ES 2007-2010 (R\$) 256

Tabela 26 Receita Própria per capita - Vitória/ES 2007-2010 (R\$).

Tabela 27 Transferências de recursos do FNDE - Vitória/ES 2008, 2009 e $2010(\mathrm{R} \$)$.

Tabela 28 Receitas e despesas do Fundeb - Vitória/ES 2008, 2009 e 2010 $(\mathrm{R} \$)$

Tabela29 Despesas por Função - Vitória /ES 2008, 2009 e 2010 $(\mathrm{R} \$)$ 
Tabela 30 Despesas por Subfunção vinculada à educação - Vitória/ES 2008, 2009 e $2010(R \$)$.

Tabela 31 Despesas da Seme-Vitória segundo natureza - Vitória/ES 2008, 2009 e $2010(R \$)$

Tabela 32 Despesas com pessoal por etapa de ensino - Vitória/ES 2008, 2009 e $2010(R \$)$

Tabela 33 Despesas com custeio por etapas e modalidades - Vitória/ES 2008, 2009 e $2010(R \$)$

Tabela 34 Despesas com custeio da educação especial - Vitória/ES 2008, 2009 e $2010(R \$)$

Tabela 35 Convênios da Prefeitura Municipal de Vitória/ES 2008-2013 $(\mathrm{R} \$)$

Tabela 36 Despesas de Capital - Vitória/ES 2008, 2009 e 2010 $(\mathrm{R} \$)$

Tabela 37 Despesas em educação por Programa de Trabalho - Vitória/ES 2008, 2009 e $2010(R \$)$

Tabela 38 Valores orçamentários e liquidados da educação especial Vitória/ES 2008, 2009 e 2010 (R\$).

Tabela 39 Despesas com ações típicas de manutenção e desenvolvimento do ensino - Vitória/ES 2008, 2009 e 2010 (R\$)

Tabela 40 Número de escolas e valores recebidos do Programa Escola Acessível - Vitória/ES 2008-2012.....

Tabela 41 Escolas contempladas pelo Programa Escola Acessível Vitória/ES 2008-2012 em valores nominais.

Tabela 42 Gasto aluno-ano - Vitória/ES 2008, 2009 e 2010 (R\$). 303

Tabela 43

Comparação entre o gasto aluno-ano da educação especial do município de Vitória, o valor estimado pelo Fundeb/ES e o valor previsto pelo CAQi 2008, 2009 e 2010 (R\$). 


\section{LISTA DE QUADROS}

Quadro 1 Número de escolas e salas de recursos multifuncionais Vitória/ES 2005-2011.

Quadro 2

Unidades de ensino que receberam salas do Programa Implantação de Salas de Recursos Multifuncionais 2005-

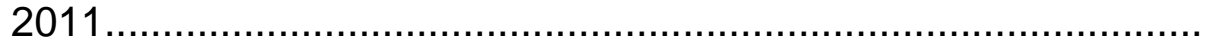

Quadro 3 Profissionais que atuavam na educação especial na rede municipal de ensino de Vitória - Vitória/ES 2008, 2009 e 230 2010. 


\section{LISTA DE GRÁFICOS}

Gráfico 1 Matrículas da educação especial Brasil 2007-2013.

Gráfico 2 Matrículas da educação especial segundo a modalidade de atendimento - Brasil 207-2013.

Gráfico 3 Matrículas da educação especial nas instituições públicas e privadas - Brasil 2007-2013

Gráfico 4 Matrículas da educação especial na rede pública de ensino Brasil 2007-2013.

Gráfico 5 Matrículas da educação especial por Dependência Administrativa - Brasil 2007-2012

Gráfico 6 Matrículas da educação especial por etapas e modalidades de ensino - Brasil 2007-2013

Gráfico 7 Movimento de matrículas da educação básica por Dependência Administrativa - Vitória/ES 2008, 2009 e 2010

Gráfico 8 Movimento de matrículas da educação especial - Vitória/ES por Dependência Administrativa 2008-2010.

Gráfico 9 Movimento de matrículas da educação básica por etapas e modalidades na rede municipal de ensino de Vitória - Vitória/ES 2008, 2009 e 2010.

Gráfico 10 Movimento de matrículas totais em classe comum da educação especial na rede municipal de ensino de Vitória - Vitória/ES 2008, 2009 e 2010

Gráfico 11 Receitas e despesas totais vinculadas à educação e à MDE Vitória/ES 2008, 2009, 2010. 


\section{LISTA DE FIGURAS}

Figura 1 Localização do município de Vitória no Espírito Santo.............. 198 


\section{LISTA DE SIGLAS}

Abahsd

ADCT

Anpae

Anped

Anpocs

Apae

BPC

Cacs-Fundef

Cademe

Capes

CAPs

CAQi

CEB

Cenesp

Cedet

CEPPPE

CF/1934

$\mathrm{CF} / 1946$

$\mathrm{CF} / 1988$

Cfaee

CMEI

Comec

Comev

CNE

Conade

Conae

Corde

CST

Dese

DPEE

EC/1996

EJA

EMEF

Emescam

Endipe

Faesa

FGTS

$\mathrm{FHC}$

FMI

Finbra

FNDE
Associação Brasileira de Altas Habilidades e Superdotação

Ato de Disposições Constitucionais Transitórias

Associação Nacional de Política e Administração da Educação

Associação Nacional de Pós-Graduação e Pesquisa em Educação

Associação Nacional de Pós-Graduação e Pesquisa em Ciências Sociais

Associação de Pais e Amigos dos Excepcionais

Benefício da Prestação Continuada de Assistência Social

Conselho de Acompanhamento e Controle Social do Fundef

Campanha Nacional de Educação e Reabilitação de Deficientes

Mentais

Coordenação de Aperfeiçoamento de Pessoal de Nível Superior

Caixas de Aposentadoria e Pensões

Custo Aluno Qualidade Inicial

Câmara de Educação Básica

Centro Nacional de Educação Especial

Centro para o desenvolvimento do potencial e talento de Vitória

Centro de Estudos e Pesquisas em Políticas Públicas de Educação

Constituição Federal de 1934

Constituição Federal de 1946

Constituição Federal de 1988

Coordenação de formação, acompanhamento à educação especial

Centro Municipal de Educação Infantil

Conselho Municipal de Educação de Cariacica

Conselho Municipal de Educação de Vitória

Conselho Nacional de Educação

Conselho Nacional dos Direitos da Pessoa com Deficiência

Conferência Nacional de Educação

Coordenadoria para Integração da Pessoa Portadora de Deficiência

Companhia Siderúrgica de Tubarão

Departamento de Educação Supletiva e Especial

Diretoria de Políticas de Educação Especial

Emenda Constitucional de 1996

Educação de Jovens e Adultos

Escola Municipal de Ensino Fundamental

Escola Superior de Ciência da Santa Casa de Misericórdia de Vitória

Encontro Nacional de Didática e Prática de Ensino

Faculdade Espírito Santense de Administração

Fundo de Garantia por Tempo de Serviço

Fernando Henrique Cardoso

Fundo Monetário Internacional

Finanças do Brasil

Fundo Nacional para o Desenvolvimento da Educação 


\begin{tabular}{|c|c|}
\hline FPE & Fundo de Participação dos Estados \\
\hline FPM & Fundo de Participação dos Municípios \\
\hline Fuefum & Fundo de Ensino Fundamental Municipal \\
\hline Fundeb & $\begin{array}{l}\text { Fundo de Manutenção e Desenvolvimento da Educação Básica e } \\
\text { de Valorização dos Profissionais da Educação }\end{array}$ \\
\hline Fundef & $\begin{array}{l}\text { Fundo de Manutenção e Desenvolvimento do Ensino } \\
\text { Fundamental e de Valorização do Magistério }\end{array}$ \\
\hline Funef & Fundo de Ensino Fundamental Estadual \\
\hline GFDE & Gerência de Formação e Desenvolvimento em Educação \\
\hline GPEdu & Gasto Público Educacional \\
\hline IAPAS & $\begin{array}{l}\text { Instituto de Administração Financeira da Previdência e } \\
\text { Assistência Social }\end{array}$ \\
\hline IAPs & Institutos de Aposentadoria e Pensões \\
\hline IBGE & Instituto Brasileiro de Geografia e Estatística \\
\hline ICMS & Imposto sobre Circulação de Mercadorias e Serviços \\
\hline IDHM & Índice de Desenvolvimento Humano Municipal \\
\hline Ifes & Instituições Federais de Ensino Superior \\
\hline Inep & $\begin{array}{l}\text { Instituto Nacional de Estudos e Pesquisas Educacionais Anísio } \\
\text { Teixeira }\end{array}$ \\
\hline INSS & Instituto Nacional do Seguro Social \\
\hline INPC & Índice Nacional de Preços ao Consumidor \\
\hline INPS & Instituto Nacional de Previdência Social \\
\hline IOF & Imposto sobre Operações Financeiras \\
\hline IPI-Exp & $\begin{array}{l}\text { Imposto sobre Produtos Industrializados, proporcional às } \\
\text { exportações }\end{array}$ \\
\hline IPTU & Imposto Predial e Territorial Urbano \\
\hline IPVA & Imposto sobre Propriedade de Veículos Automotores \\
\hline IR & Imposto de Renda \\
\hline IRRF & Imposto de Renda Retido na Fonte \\
\hline ISS & Imposto Sobre Serviços \\
\hline ITBI & Imposto sobre Transmissão de Bens Inter Vivos \\
\hline ITCMD & Imposto sobre Transmissão Causa Mortis e Doações \\
\hline ITR & Imposto Territorial Rural \\
\hline LOPs & Lei Orgânica da Previdência Social \\
\hline LDB/61 & Lei de Diretrizes e Bases da Educação Nacional de 1961 \\
\hline LDB/1996 & Lei de Diretrizes e Bases da Educação Nacional de 1996 \\
\hline LDO & Lei de Diretrizes Orçamentárias \\
\hline LOA & Lei Orçamentária Anual \\
\hline LRF & Lei de Responsabilidade Fiscal \\
\hline Mare & Ministério da Administração e Reforma do Estado \\
\hline MDE & Manutenção e Desenvolvimento do Ensino \\
\hline MEC & Ministério da Educação \\
\hline NADT & Núcleo de Apoio para o Desenvolvimento de Talentos \\
\hline ONU & Organização das Nações Unidas \\
\hline PAC & Plano de Aceleração do Crescimento \\
\hline PAR & Plano de Ações Articuladas \\
\hline Paed & $\begin{array}{l}\text { Programa de Complementação no Atendimento Educacional } \\
\text { Especializado às Pessoas Portadoras de Deficiências }\end{array}$ \\
\hline Pasep & Programa de Formação do Patrimônio do Servidor Público \\
\hline
\end{tabular}




\begin{tabular}{ll} 
PDDE & Programa Dinheiro Direto na Escola \\
PDE & Plano de Desenvolvimento da Educação \\
PEB & Professor da Educação Básica \\
PIS & Programa de Integração Social \\
PL & Projeto Lei \\
PMV & Prefeitura Municipal de Vitória \\
PNAE & Programa Nacional de Alimentação Escolar \\
PNE & Plano Nacional de Educação \\
PNEE-EI & Política Nacional de Educação Especial na Perspectiva da \\
& Educação Inclusiva \\
PNUD & Programa das Nações Unidas para o Desenvolvimento \\
PPA & Plano Plurianual \\
PSDB & Partido da Social Democracia Brasileira \\
PT & Partido dos Trabalhadores \\
QP-ICM & Quota Parte do Imposto sobre Circulação de Mercadorias \\
Reuni & Reestruturação e Expansão das Universidades Federais \\
RMGV & Região Metropolitana da Grande Vitória \\
Secadi & Secretaria de Educação Continuada, Alfabetização, Diversidade \\
& e Inclusão \\
Secrie & Secretaria de Inclusão Educacional \\
Seea & Secretaria Extraordinária de Erradicação do Analfabetismo \\
Seesp & Secretaria de Educação Especial \\
Semfa & Secretaria Municipal de Fazenda \\
Sespe & Secretaria de Educação Especial \\
Secadi & Secretaria de Educação Continuada, Alfabetização, Diversidade \\
& e Inclusão \\
Scielo & Scientific Electronic Library Online \\
Seme-Vitória & Secretaria Municipal de Vitória \\
Semas & Secretaria Municipal de Assistência Social \\
Semus & Secretaria Municipal de Saúde \\
Seneb & Secretaria Nacional de Educação Básica \\
Sesu & Secretaria de Educação Superior \\
Simec & Sistema Integrado de Monitoramento Execução e Controle do \\
Sinpas & Ministério da Educação \\
SISTN & Sistema Nacional de Previdência e Assistência Social \\
Siope & Sistema de Coleta de Dados Contábeis \\
STN & Sistema de Informações sobre Orçamentos Públicos em \\
TC-ES & Educação \\
TGD & Secretaria do Tesouro Nacional \\
UAB & Tribunal de Contas do Espírito Santo \\
UFRJ & Transtornos globais do desenvolvimento \\
& Universidade Aberta do Brasil \\
\hline Universidade Federal do Rio de Janeiro \\
\end{tabular}




\section{SUMÁRIO}

1 PRIMEIRAS PALAVRAS.

$2 \quad$ ESTADO E POLÍTICAS PÚBLICAS DE CUNHO SOCIAL $\ldots \ldots \ldots \ldots \ldots \ldots \ldots . . . \ldots \ldots$

2.1 NICOS POULANTZAS E A TEORIA RELACIONAL DO ESTADO ............ 40

2.1.1 O Estado, o poder e as classes sociais.............................................. 42

$2.2 \quad$ ESTADO E POLÍTICAS SOCIAIS ..................................................... 49

2.2.1 A constituição do Estado e da política social no Brasil....................... 70

2.3 O ESTADO DE BEM-ESTAR SOCIAL E O FUNDO PÚBLICO ................ 83

2.4 O ORÇAMENTO PÚBLICO E OS GASTOS EDUCACIONAIS................. 89

2.5 CIDADANIA COMO UM PROCESSO DE LUTA PARA A (RE)CONSTRUÇÃO DO ESPAÇO PÚBLICO....................................... 103

3 A EDUCAÇÃO ESPECIAL NO CONTEXTO DO FINANCIAMENTO DA EDUCAÇÃO NO BRASIL

3.1 A EDUCCAÇÃO ESPECIAL NO ÂMBITO DOS FUNDOS DE MANUTENÇÃO E DESENVOLVIMENTO DA EDUCAÇÃO.

3.2 AS POLÍTICAS DE EDUCAÇÃO ESPECIAL NO PERÍODO DE 2003 A 2010.

4 PERCURSOS METODOLÓGICOS

4.1 PRIMEIRO MOMENTO: CONSTITUINDO O CAMPO DE PESQUISA......

4.2 SEGUNDO MOMENTO: EM BUSCA DE INDÍCIOS

4.3 TERCEIRO MOMENTO: ORGANIZAÇÃO, SISTEMATIZAÇÃO E ANÁLISE DOS DADOS.

4.4 QUARTO MOMENTO: DIÁLOGO SOBRE A PESQUISA NA SEMEVITÓRIA.

5 O FINANCIAMENTO DA EDUCAÇÃO ESPECIAL NO MUNICÍPIO DE VITÓRIA-ES

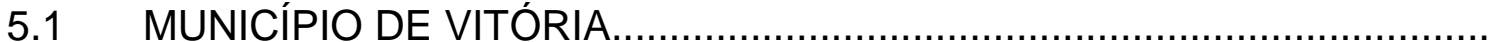

5.1.1 A educação em Vitória/ES.

5.1.2 A história da educação especial na rede municipal de ensino de Vitória.

5.1.3 A política de educação especial na rede municipal de ensino de Vitória.

5.1.4 Contexto da política de educação especial na rede de ensino do município de Vitória, no ano de 2008, 2009 e 2010.

5.1.5 Planejamento orçamentário do município de Vitória: o lugar da educação especial entre disputas e negociações.

5.1.6 Receitas da educação na rede de ensino municipal de ensino de Vitória

5.1.7 O destino dos recursos da Educação: a (in)visibilidade da educação especial na análise das despesas das etapas e modalidades de ensino

6 CONSIDERAÇÕES FINAIS: AS COMPLEXAS TRAMAS DO FINANCIAMENTO DA EDUCAÇÃO ESPECIAL. 
REFERÊNCIAS.

APÊNDICES

APÉNDICE A - Roteiro de entrevista coletiva com gestores da Seme-

Vitória.

APÊNDICE B - Termo de compromisso.

359

APÉNDICE C - Termo de consentimento livre esclarecido.

360

APÊNDICE D - Manual de demonstrativos fiscais: aplicado à União, Estados, Distrito Federal e Municípios 


\section{PRIMEIRAS PALAVRAS}

As políticas de educação especial implementadas pelo Estado brasileiro têm engendrado transformações nos sistemas públicos de ensino, com implicações no lócus de matrícula, na organização escolar e mudanças também no que se refere a sua gestão. O crescimento do número de matrículas ${ }^{1}$ de alunos com deficiência, Transtornos Globais do Desenvolvimento (TGD) e altas habilidades/superdotação² na rede regular de ensino, em classe comum, e a instituição de políticas públicas para prover suas necessidades específicas têm impulsionado a (re)constituição de planos, programas e projetos políticos educacionais em diferentes âmbitos (seja no internacional, no nacional, no estadual, seja no municipal), na tentativa de atender a todos os alunos no contexto escolar.

Historicamente, quando se investigam as políticas educacionais, entre estas as de educação especial, a discussão predominante na área se restringe aos resultados na prática escolar, pois ainda são incipientes as produções e os debates que abordem as condições de sua implantação, as quais, por sua vez, estão articuladas, em grande medida, às questões do financiamento da educação. De acordo com Candido Alberto Gomes e José Amaral Sobrinho (1996) e com Rosângela Gavioli Prieto (2009, p. 5), "[...] ainda pouco se têm divulgado análises sobre a gestão pública da educação especial em municípios e é particularmente exíguo o conhecimento sobre as formas de financiamento público adotadas para garantir o atendimento especializado".

A gestão pública integra diferentes dimensões, entre as quais as apontadas por Sofia Lerche Vieira (2009, p. 24): "[...] o valor público, as condições de implementação e as condições políticas", o que, por sua vez, pressupõe intencionalidade, disponibilidade de recursos financeiros, recursos humanos e outras condições materiais e imateriais, além de circunstâncias políticas que envolvem, na

\footnotetext{
1 De acordo com os dados do Censo 2013, houve um crescimento significativo no número de matrículas da educação especial nas escolas públicas no período de 2007 a 2013. Em 2007, 62,7\% do total de matrículas da educação especial estavam nas escolas públicas e 37,3\% nas escolas privadas. Em 2013, esses números alcançaram 78,8\% nas públicas e $21,2 \%$ nas privadas. Do total de 843.342 matrículas na educação especial, 194.421 estavam nas escolas exclusivamente especializadas e classes especiais (23\%) e 648.921 em classe comum $(77 \%)$.

${ }^{2}$ O público da educação especial foi redefinida pela Lei no 12.796 , de 4 de abril de 2013, que alterou a Lei de Diretrizes e Bases da Educação Nacional de 1996.
} 
tomada de decisões, negociações e administração de conflitos de interesses, que, por vezes, são distintos ou até mesmo antagônicos.

Em face dessas observações, a intenção deste estudo foi constituir um olhar de como o financiamento na área da educação especial, no âmbito da educação básica, vai sendo tecido no contexto de uma rede municipal de educação. Partindo da premissa que há um investimento do Estado na oferta e financiamento da educação especial de modo a assegurar o direito à educação e ao atendimento educacional especializado aos alunos com deficiência, TGD e altas habilidades/superdotação nos sistemas públicos de ensino.

O interesse em estudar essa temática - financiamento da educação especial - está vinculado à nossa pesquisa de mestrado, finalizada no ano de 2008, no município de Cariacica, estado do Espírito Santo, na qual ficou explícito como a concretização das políticas públicas referentes à inclusão escolar dos alunos com deficiência, TGD e altas habilidades/superdotação dependia e/ou estava relacionada à gestão das verbas no âmbito do sistema de ensino do município e articulada à política nacional de financiamento.

Ao investigarmos o financiamento da educação especial, partimos do pressuposto de que ele está inserido como parte de uma totalidade histórica, isto é, na dinâmica das contradições, mediações e determinações políticas, econômicas e sociais da educação no Brasil. Isso implica, necessariamente, segundo Gaudêncio Frigotto (2011, p. 236), "[...] tomá-lo na relação inseparável entre o estrutural e o conjuntural", isto é, na articulação entre a formação da estrutura desigual da sociedade brasileira e o contexto macroeconômico da produção e expansão do capital. Desse modo, tentamos compreender suas nuances, contradições e desafios no jogo das forças sociais que o materializam, ou seja, no campo das políticas públicas no Brasil, que envolve as relações entre o campo da particularidade e sua articulação com uma determinada universalidade, suas continuidades e descontinuidades.

Pesquisas realizadas nas últimas décadas (VIEIRA, 2009; DOURADO, 2007), referentes às políticas públicas de educação, mostram que houve significativas transformações nessa área no Brasil, seja na organização, ou seja na estrutura dos sistemas educacionais, expressas tanto na base legal, produzida a partir do processo de redemocratização do país, como nas diferentes configurações de 
gestão. Entretanto, a compreensão desses processos não se restringe a aspectos educacionais; articula-se a um contexto mais amplo de transformações econômicas, sociais e políticas.

Não podemos desconsiderar que as reformas educacionais brasileiras, nos últimos anos, articulam-se às transformações nos modos de produção, fundamentadas nos princípios da economia capitalista e de implantação de orientações neoliberais. Entretanto, a formulação de políticas públicas não se dá apenas no âmbito do Poder Público; segundo Sofia Lerche Vieira e Maria Gláucia Menezes Albuquerque (2002, p. 26), é "[...] na correlação de forças entre os atores sociais das esferas do Estado - a sociedade política e civil - que se definem as formas de atuação prática, as ações governamentais e, por conseguinte, se trava o jogo das políticas sociais".

Faz-se necessário destacar que as ações desencadeadas em diferentes sistemas ou redes municipais de ensino são influenciadas por orientações, compromissos e perspectivas de políticas mais amplas, formuladas e/ou implantadas em nível federal ou presentes em tratados e recomendações internacionais; por isso, princípios e/ou ações destes emanados podem ser assimilados, total ou parcialmente, pelos gestores de políticas públicas em âmbito local. Do mesmo modo, observa-se, nos documentos nacionais e internacionais, a apropriação de conceitos e concepções da política local para o global. Para Luiz Fernandes Dourado (2007, p. 922), isso “[...] implica não reduzir a análise das políticas e da gestão educacional à mera descrição [...] importando, sobremaneira, apreendê-la no âmbito das relações sociais em que se forjam as condições para sua proposição e materialidade".

Assim, faz-se necessário articular o financiamento direcionado à educação especial com a dinâmica maior da educação e com o contexto social em que é produzido. Nesse sentido, não há como dissociá-lo de uma análise política e econômica, tendo em vista que os recursos aplicados em educação trazem implicações para os diferentes sistemas educacionais e tendem a reverberar na sociedade como um todo, na medida em que possibilitam a ampliação das oportunidades educacionais à população, a partir de políticas de acesso, permanência e qualidade no processo de escolarização. 
Dessa forma, nos questionamos: Como o município de Vitória, capital do estado do Espírito Santo, vem se organizando para garantir o atendimento educacional especializado aos alunos com deficiência, TGD e altas habilidades/superdotação? Quanto tem sido despendido em termos de gasto com a educação especial para garantir a oferta dos serviços propostos nesse município? 0 que isso representa em termos de prioridade e esforço público com essa modalidade de ensino e o que significa em relação às etapas da educação básica e às outras modalidades de ensino? Qual o valor do gasto aluno-ano na educação especial, nas outras modalidades de ensino e nas outras etapas da educação básica no âmbito desse município?

Nessa perspectiva, tivemos como objetivo geral investigar/analisar a ação do Poder Público no provimento de recursos financeiros à educação especial na gestão do município de Vitória, estado do Espírito Santo, no contexto de financiamento da educação básica, especificamente nos anos de 2008, 2009 e 2010. E como objetivos específicos caracterizar a política e a organização desse sistema municipal de ensino para prover atendimento educacional especializado a alunos com deficiência, TGD e altas habilidades/superdotação; investigar como era realizada a gestão dos recursos da educação especial; analisar os gastos públicos direcionados à educação especial no âmbito desse município, nos anos referidos, e identificar o valor gasto aluno-ano em atendimento pela educação especial.

O tema financiamento da educação especial constituiu-se como eixo significativo para o processo de formulação, de implantação, de implementação e de avaliação das políticas públicas educacionais voltadas aos alunos com deficiência, TGD e altas habilidades/superdotação, na medida em que a configuração desse financiamento no âmbito do planejamento orçamentário do Estado e a sua destinação entre instituições públicas e/ou privadas podem ser determinantes na oferta e na qualidade de serviços direcionados a esse alunado nos sistemas educacionais. Nesse sentido, é importante destacar também a concepção do papel do Estado e o tipo de atendimento a ser ofertado, pois, no geral, o que se ofereceu como atendimento privado em educação especial no Brasil foi de caráter substitutivo, portanto, em desacordo com os princípios da educação inclusiva. Com essa prerrogativa, buscamos identificar estudos que focalizaram essa temática, na tentativa de compreender as contribuições e as lacunas presentes na literatura da 
área. Para tanto, consultamos os resumos de pesquisas disponíveis no Banco de Dissertações e Teses da Coordenação de Aperfeiçoamento de Pessoal de Nível Superior (Capes), os artigos publicados no banco de dados do Scientific Electronic Library Online (Scielo) e os artigos publicados em anais de eventos nacionais de educação, a saber: Reunião Anual da Associação Nacional de Pós-Graduação e Pesquisa em Educação - Anped $^{3}$ (2000 a 2013); Simpósio Brasileiro de Política e Administração da Educação, da $\operatorname{Anpae}^{4}$ (2007, 2009, 2011e 2013); Encontro Nacional de Didática e Prática de Ensino - Endipe ${ }^{5}$ (2010 e 2012); Encontro Anual da Associação Nacional de Pós-Graduação e Pesquisa em Ciências Sociais Anpocs $^{6}$ (2010 e 2011), assim como em eventos nacionais da educação especial ${ }^{7}$ : VI e VII Congresso Brasileiro Multidisciplinar de Educação Especial e VII e VIII Encontro da Associação Brasileira de Pesquisadores em Educação Especial (2011; 2013); I ao VI Seminário Nacional de Pesquisa em Educação Especial (2005 a 2011); e III, IV, V Congresso Brasileiro de Educação Especial / V, VI, VII Encontro Nacional dos Pesquisadores em Educação Especial (2008; 2010; 2012) 8 .

Cabe ressaltar que, para a compilação dos materiais do balanço de produção no Banco de Dissertações e Teses da Capes e no Scielo, não foi utilizado um critério para recorte temporal, pois a finalidade era conhecer o que já tinha sido pesquisado e publicado nessa área específica ao longo do tempo. Entretanto, a consulta aos artigos publicados nos anais de eventos científicos foi delimitada pelo acesso aos textos disponíveis nos seus portais, tendo em vista que era necessário efetuar a leitura dos trabalhos para análise e articulação com o nosso estudo. Cumpre destacar que a publicação das produções nos portais constitui uma prática recente,

\footnotetext{
${ }^{3}$ A Anped disponibiliza, em seu portal, os resumos de trabalhos e trabalhos na íntegra apresentados nas reuniões anuais, no período de 2000 a 2013; por isso, a nossa pesquisa se restringiu a esse intervalo de tempo.

${ }^{4}$ A Anpae dispõe, em seu site, os trabalhos apresentados nos anos de 2007, 2009, 2011 e 2013, desse modo, analisamos os trabalhos dessas quatro últimas edições.

5 Foram consultados os trabalhos disponíveis nos portais das últimas duas edições do Endipe, realizadas nos anos de 2010 e 2012, tendo em vista que não foi possível acesso aos trabalhos dos eventos anteriores.

${ }^{6}$ No portal da Anpocs, encontramos trabalhos disponíveis para consulta apenas das edições de 2010 e 2011.

${ }^{7} \mathrm{O}$ acesso aos trabalhos completos dos eventos mencionados da educação especial se deu por meio da consulta aos CD-ROMs, disponibilizados aos participantes dos referidos encontros, seminários ou congressos e arquivados pela pesquisadora.

${ }^{8}$ Cumpre destacar que, embora nosso estudo se delimite, especificamente, aos anos de 2008, 2009 e 2010, procuramos mapear o que já tinha sido produzido pela literatura da área até 2013, considerando o reduzido número de pesquisas vinculadas a essa temática.
} 
por isso a maioria dos estudos encontrados correspondem aos últimos cinco anos, com exceção apenas da Anped.

No Portal da Capes, foi utilizado para a coleta de dados, um conjunto de palavras-chave: financiamento educação, financiamento educação especial, gastos educação especial, receitas educação especial, custo educação especial e públicoprivado, tendo sido encontrados 7 trabalhos relacionados à temática. Em anais dos eventos científicos citados anteriormente, foi encontrado um total de $\mathbf{2 0}$ trabalhos, assim distribuídos: 4 na Reunião Anual da Anped; 5 no Simpósio Brasileiro de Política e Administração da Educação; 3 no Congresso Brasileiro Multidisciplinar de Educação Especial e Encontro da Associação Brasileira de Pesquisadores em Educação Especial; 4 no Seminário Nacional de Pesquisa em Educação Especial e 4 no Congresso Brasileiro de Educação Especial e Encontro Nacional de Pesquisadores em Educação Especial.

Do total de 27 estudos encontrados, sobressaem trabalhos em anais de eventos científicos, seguidos das dissertações e teses. Tal preponderância pode ser explicada pelo fato de os trabalhos apresentados nos referidos eventos estarem em fase de desenvolvimento e/ou de conclusão (CORRÊA, N., 2008, 2011; VIEGAS, 2009a; 2009b). Além disso, encontramos trabalhos de um mesmo autor em eventos diferentes. Vale destacar que estudos de quatro autores (BENATTI, 2007, 2011; MORAES, V., 2011a, 2011b; REBELO, 2012, 2013; VIEGAS, 2009a, 2009b, 2014) aparecem tanto no Banco da Capes quanto em eventos de educação especial. Após a leitura dos 27 trabalhos, identificamos e organizamos as seguintes temáticas que predominaram na literatura: relação público-privado (14), políticas públicas (6), políticas e gestão da educação especial (4) e custo/aluno da educação especial (3).

No conjunto dos trabalhos, é marcante a alusão à temática da relação público-privado nas produções referentes ao financiamento da educação especial. Essa relação se apresenta nessa modalidade de ensino desde os primórdios, em que o Estado não tinha compromisso efetivo com a criação e a promoção de políticas estatais com o processo de escolarização das pessoas com deficiência, TGD e altas habilidades/superdotação e atuava financiando e fortalecendo a criação e a manutenção de instituições sem fins lucrativos $^{9}$ e de cunho assistencialista.

\footnotetext{
${ }^{9}$ No decorrer do trabalho, utilizamos diferentes expressões, como instituições sem fins lucrativos, organizações especializadas, entidades privadas, filantrópicas e assistenciais, para nos referirmos às
} 
Mônica de Carvalho Magalhães Kassar (2001, p. 29) salienta que as ações dessas instituições se apresentam "[...] durante toda a história da educação especial como extremamente fortes, com lugar garantido no discurso oficial, chegando a confundirse com o próprio atendimento 'público', aos olhos da população, pela 'gratuidade' de alguns serviços". Ao mesmo tempo, ao longo da história, observamos mudanças na legislação educacional pela incorporação de direitos das pessoas com deficiência, TGD e altas habilidades/superdotação à educação como dever do Estado, o que explicita, portanto, o compromisso do Poder Público com essa modalidade de ensino. Assim, a discussão da relação público-privado na educação especial revela dimensões contraditórias e complexas, nos diferentes estudos.

Nesse sentido, Shirley Silva (2001), em evento nacional, ao analisar as políticas de educação especial no contexto das políticas sociais, a partir de uma pesquisa realizada junto a instituições sem fins lucrativos de educação especial no município de Campinas, estado de São Paulo, observou processos de privatização e terceirização de ações de responsabilidade do Poder Público, seja por meio da omissão do Estado quanto à organização de serviços na rede pública, seja por meio do financiamento de instituições especializadas. A autora ressalta que a expansão do atendimento em educação especial, no Brasil, tem sido marcada pela disparidade entre uma política de "educação para todos", compreendida como aquela que atende ao direito de todo cidadão à educação e fornecida pelo Estado, e o fortalecimento dos atendimentos por meio de organizações privadas sem fins lucrativos, filantrópicos e assistenciais.

Esse contexto ambíguo e contraditório foi observado por Daniela de Moraes Garcia de Abreu (2002), na sua dissertação, que, ao investigar o atendimento educacional especializado de alunos com necessidades educativas especiais ${ }^{10}$ na rede privada de ensino do Rio Grande do Sul, identificou a presença da tendência de educação inclusiva nos dispositivos legais, pela ampliação quantitativa de legislações referentes à garantia do direito à educação a esse alunado, e, ao mesmo tempo, evidenciou um importante elo que associa a existência das instituições

instituições privadas que oferecem serviços de educação especial e são mantidas, parcial ou totalmente, pelo Estado, com recursos públicos.

${ }^{10}$ Abreu (2002) adota o conceito ampliado de "necessidades educacionais especiais", da Declaração de Salamanca (1994) e/ou da Resolução CNE/CEB no 2, de 11 de setembro de 2001, que ampliou o conjunto de sujeitos atendidos pela educação especial, incluindo aqueles que se encontram em situação de desvantagem. 
privadas especializadas em educação especial a seu financiamento público. Além disso, constatou a escassez de informações que traduzam a realidade sobre a oferta de educação especial na rede privada, tanto em âmbito nacional quanto em âmbito estadual. O estudo vislumbrou, ainda, uma discreta participação das escolas da rede regular de gestão privada no atendimento aos alunos com necessidades educativas especiais, no estado do Rio Grande do Sul.

Em linha semelhante, Edgilson Tavares de Araújo (2006), no seu estudo de mestrado, ao desenvolver uma análise sobre os discursos e práticas do Estado e da sociedade civil para o planejamento e a gestão de parcerias direcionadas ao atendimento educacional especializado das pessoas com deficiência ${ }^{11}$ no período pós-Lei de Diretrizes e Bases da Educação Nacional de 1996 (LDB/1996), observou momentos de maior ou menor aproximação e retração entre Estado e organizações especializadas, de acordo com o contexto histórico, político e social. Foram identificadas convergências, nos discursos, quanto à ressignificação da educação especial e do papel das escolas especializadas diante das propostas de inclusão escolar; quanto à supervalorização da legalidade constituída, especialmente após a LDB/1996, como instrumento importante para a defesa dos direitos para as pessoas com deficiência, e quanto ao moralismo abstrato de inclusão escolar, quando o governo estabelece a responsabilidade por esse processo para os gestores e professores das escolas. Foram identificadas também divergências, entre o Estado e as organizações especializadas, quanto às concepções de educação, inclusão, espaço público, financiamento, gestão política e responsabilidade pela educação. $O$ estudo aponta ainda os principais dilemas e desafios atuais entre Estado e sociedade civil para mudança de cenários nas parcerias, visando à garantia do direito subjetivo à educação para pessoas com deficiência.

Nesdete Mesquita Corrêa (2008), ao apresentar os resultados parciais da sua tese em evento nacional, descreve as fontes de recursos e o valor do financiamento destinado à educação especial em Campo Grande, Mato Grosso do Sul (MS), e busca analisar como ocorre a relação entre o setor público e o privado na oferta do atendimento educacional especializado no referido município. Os dados registrados deixaram evidente para a autora, que a administração municipal vem direcionando grande parte do atendimento tanto da educação como da saúde para instituições

\footnotetext{
${ }^{11}$ Em seu trabalho, Araújo, E. (2006) faz referência apenas à população de alunos com deficiência.
} 
privadas, assim como tem destinado recursos para o financiamento dos serviços a serem prestados para alunos com deficiência, TGD e altas habilidades/superdotação na sua rede de ensino. Esses dados corroboram os resultados de pesquisa de mestrado apresentados por Marielle Moreira Santos Benatti (2007), que teve como objetivo analisar os recursos públicos vinculados às esferas federal, estadual e municipal que eram repassados às instituições públicas não estatais de educação especial do município de Campo Grande - MS, no período de 2001 a 2005. A autora afirma que a discussão do financiamento da educação especial se insere no contexto de "redefinição do papel do Estado"12, que se reestrutura por intermédio da privatização, da terceirização e da publicização. No contexto municipal, ela observa que, nesse período, houve investimento financeiro por parte do Poder Público tanto em instituições públicas não estatais como no fortalecimento das escolas regulares no município. Desse modo, o Estado mantinha financeiramente o atendimento tanto no ensino regular, quanto nas escolas especializadas não estatais de educação especial. Cumpre destacar que o repasse de recursos a estas últimas ocorre desde 1980, por meio de convênios e parcerias com o estado de Mato Grosso do Sul. O estudo ainda aponta uma nova tendência para as instituições especializadas no que tange a oferta de seus serviços: auxiliar na formação de professores das redes municipais de ensino. A autora então conclui que "o público e o privado continuarão atuando em conjunto nesta modalidade educacional, porém há uma redefinição de seus papéis, em consonância com a sociedade capitalista" (BENATTI, 2011, p. 10). Desse modo, ambas as autoras (CORRÊA, N., 2008; BENATTI, 2011) enfatizam a expressividade do terceiro setor, que, constituído por organizações da sociedade civil e em parceria com o Estado, assume os serviços delimitados às políticas sociais, entre estas as de educação especial, no estado de MS.

Nessa perspectiva, Valdete Aparecida Veiga de Moraes (2011b), na sua dissertação, ao analisar as políticas de educação especial no Paraná nas gestões do governo Requião (2003-2010), evidenciou ações que fortaleceram a expansão das entidades filantrópicas amparadas com recursos públicos. Assim, as ações da Secretaria de Estado da Educação do Paraná foram direcionadas à publicização da

12 Benatti (2007) utiliza a expressão "redefinição do papel do Estado" para fazer referência às mudanças ocorridas no Brasil na década de 1990, em que o Estado assume cada vez menos responsabilidades com as políticas sociais, ao transferir recursos destinados às demandas sociais para entidades da sociedade civil que se responsabilizam pelo atendimento dessa parcela da população. 
educação especial, que buscou garantir recursos às instituições filantrópicas por meio de contratos de gestão. Destacam-se, nesse processo, as articulações e estratégias políticas dos representantes dessas instituições, os quais, travando alianças e parcerias, conseguiram garantir a manutenção e a conservação da hegemonia desse segmento na política da educação especial no Paraná (MORAES, V., 2011b).

Na mesma direção, Cléia Demétrio Pereira (2011), ao apresentar os resultados da sua dissertação em seminário nacional, analisa a política de convênio na oferta de serviços de educação especial no município de Braço do Norte - Santa Catarina (SC). A autora observa que, embora haja ações administrativas da parte do setor público, há uma forte presença de instituições privadas sem fins lucrativos no atendimento educacional especializado aos alunos com deficiência ${ }^{13}$ no município. Assim, essas instituições mantidas por organizações da sociedade civil ainda desempenham um papel importante na implementação da política de inclusão no município de Braço do Norte - SC, situação não exclusiva desse município, pois representa uma grande parcela dos municípios catarinenses (de pequeno porte) que, para atender a população com deficiência, contam com instituições privadas de caráter filantrópico.

Em linha semelhante, Reginaldo Célio Sobrinho e Edson Pantaleão (2012), ao refletirem sobre o financiamento da educação especial no estado do Espírito Santo, no contexto público-privado, destacaram a ausência de um pronunciamento mais explícito acerca da constituição de políticas articuladas entre secretarias (saúde, habitação, transporte, moradia e educação) da esfera estadual, no oferecimento de serviços qualificados às demandas das pessoas com deficiência ${ }^{14}$, bem como a necessidade de um financiamento público em educação especial que amplie a atuação do Estado.

Carline Santos Borges et al. (2012), em seu artigo, ao analisarem aspectos da política de educação especial no estado do Espírito Santo, a partir de convênios e acordos firmados entre a administração pública e as instituições especializadas, apresentaram informações relativas ao tipo de dependência administrativa a que

\footnotetext{
${ }^{13}$ Pereira (2011) faz menção apenas à população de alunos com deficiência. Portanto, manteremos o termo utilizado pela autora.

${ }^{14}$ Em seu trabalho, Sobrinho e Pantaleão (2012) fazem referência apenas à população de alunos com deficiência.
} 
pertencem essas instituições, à categoria de instituição privada à qual estão vinculadas, à identificação de seus mantenedores e aos convênios firmados entre o Poder Público e as instituições especializadas. Os resultados apontaram a necessidade de ampliação do Estado na oferta de serviços voltados às pessoas com deficiência ${ }^{15}$, de maneira que as instituições especializadas, de caráter privado, que ofertam atendimentos restritos e ainda insuficientes a esse público, não ocupem centralidade nesse processo, entendido como responsabilidade pública.

Andressa Santos Rebelo (2012), na sua dissertação de mestrado, investiga os impactos da política de complementação/suplementação do atendimento educacional especializado para a educação das pessoas com deficiência no município de Corumbá - MS. Constata a autora que as iniciativas propostas em lei têm repercutido no crescimento tímido no número de matrículas de alunos com deficiência na rede regular de ensino, bem como em mudanças marcadas tanto pela democratização do acesso a escola pública e seu financiamento, quanto pela coexistência do ensino público com os interesses de caráter assistencial, os quais vêm conseguindo obter a garantia de recursos para oferta do atendimento educacional especializado em suas instituições.

Nessa perspectiva, Fabíola Borowsky (2013), em seu artigo, busca compreender como se materializam as parcerias entre o sistema público e o setor privado na educação especial, por meio do levantamento dos documentos que orientam a formação de convênios e aqueles que regulamentam essas parcerias. Nesse processo, a autora pôde evidenciar contradições no papel do Estado em relação à educação especial, visto que os documentos orientam a inclusão escolar dos alunos com deficiência em escolas públicas do ensino regular e, ao mesmo tempo, incentivam 0 atendimento educacional especializado em instituições privadas, por meio do repasse de recursos públicos. Por sua vez, a legislação assegura a coexistência de ambas as instituições.

Observamos, nesse contexto, que a relação público-privado nas políticas de financiamento da educação especial desempenha um papel de extrema importância para a consolidação de políticas e práticas de atendimento educacional especializado, evidenciando-se, ainda, que os recursos públicos têm se voltado também para a manutenção das instituições privadas de ensino.

15 Os autores não fazem referência aos alunos com TGD e altas habilidades/superdotação. 
A discussão das políticas públicas também se destaca nas produções sobre o financiamento público voltado à educação especial Júlio Romero Ferreira (2000), em evento nacional, ao analisar a evolução do atendimento aos alunos com deficiência, TGD e altas habilidades/superdotação na década de 1990, em termos de crescimento de matrículas junto às redes públicas e privadas, argumenta que a participação pouco expressiva da educação especial no conjunto da oferta na educação básica naturalmente se revela também quanto aos recursos orçamentários, representada pela pequena parcela de verbas públicas vinculadas à educação especial. Assim, o conjunto de dados e tendências, elaborado com base na análise dos censos educacionais, complementados com aspectos pontuais de financiamento e referências ao Plano Nacional de Educação (de 2001), no contexto das políticas públicas para a educação básica, aponta para uma pouca participação da escola pública e do ensino regular na educação desses alunos, incompatível com os preceitos constitucionais e com a legislação educacional (LDB/1996) nessa década.

Nessa direção, Reginaldo Célio Sobrinho, Camila Fuzato Lavagnoli e Maysa Guimarães da Fonseca (2011), em seu artigo, discutem os aspectos do financiamento da educação do aluno com deficiência ${ }^{16}$ no estado do Espírito Santo, com base nas publicações oficiais que identificam as políticas adotadas pelo Estado, bem como o fluxo de matrículas desses alunos em escolas municipais, estaduais e instituições privadas, no período 2005-2009. Os autores destacam o incremento do aparato legal nos anos recentes e observam que a materialização de tais políticas mantém vínculos estreitos com a perspectiva médico-clínica de deficiência, legitimando a insuficiência de recursos financeiros para a oferta de uma educação pública qualificada para atender às necessidades dos alunos.

Por sua vez, Luciane Torezan Viegas (2009a), em evento nacional, ao analisar as políticas públicas por meio das demandas estimadas, os dados da oferta de atendimento, os documentos orientadores divulgados pelos órgãos oficiais do estado do Rio Grande do Sul, considerando a área de educação especial no período de 1988 a 2002, identificou dois momentos distintos em termos de proposição de políticas. Um desses momentos foi aquele em que houve uma tendência de perspectiva mais "tradicional" das políticas públicas para a área, com ênfase nas

${ }^{16}$ Os autores não fazem referência aos alunos com TGD e altas habilidades/superdotação. 
"parcerias" com as instituições privadas, a qual priorizava o atendimento clínico em detrimento do atendimento educacional em escolas e classes especiais. O outro é um momento mais recente, no qual parece predominar a proposição de políticas com base na participação e na mobilização popular, em que a educação é concebida como direito de todos e a escola como espaço permanente de ensino e aprendizagem. Nessa perspectiva, Viegas (2009a) afirma que a educação especial, considerada como modalidade da educação escolar, conforme LDB/1996, passa a ser oferecida tanto em espaços específicos como em integração com os diferentes níveis de ensino. Assim, a autora destaca que as propostas do Poder Público foram elaboradas a partir dos aspectos relativos à concepção de educação inclusiva, à necessidade de adequação dos recursos humanos e dos ambientes físicos para acolher as pessoas com deficiência e à formação de professores. O estudo sinaliza, portanto, o descompasso entre demanda, oferta de atendimento e políticas públicas.

Viegas (2009b) numa revisão bibliográfica sobre financiamento da educação e estudos preliminares sobre financiamento da educação especial, trabalho apresentado no Seminário Nacional de Pesquisa em Educação Especial de $2009{ }^{17}$, ressalta ainda que, diante da realidade educacional brasileira, os estudos sobre financiamento da educação e manutenção do ensino remetem a uma crítica relacionada à precariedade de políticas públicas educacionais que efetivem a garantia dos direitos constitucionais. E no caso da educação especial, também se refere à necessidade de estudos que analisem a complexidade da oferta, o uso de recursos financeiros, a relação público-privado, a gestão educacional, políticas e práticas na área. Nesse sentido, em sua tese de doutorado, (VIEGAS, 2014), quando buscou compreender o processo de reconfiguração das proposições que vinculavam a educação especial à educação regular dos alunos com deficiência, teve entre seus objetivos conhecer os efeitos da política atual, no que diz respeito à dupla matrícula no atendimento educacional especializado no município de Cachoeirinha - Rio Grande do Sul. A análise mostra que os gestores revelaram conhecer a legislação do Fundeb referente à dupla contabilização para os alunos com deficiência matriculados na rede regular de ensino, com atendimento

\footnotetext{
17 O Seminário Nacional de pesquisa em Educação Especial configurou-se, no período de 2005 a 2011, como um espaço destinado prioritariamente a pesquisadores que integram programas de pósgraduação das universidades brasileiras de diferentes regiões do país e que se dedicam à formação e à pesquisa em educação especial (BAPTISTA; JESUS, 2009).
} 
educacional especializado, mas indicaram desconhecer os efeitos desse financiamento na educação especial na rede pública municipal, seja para o atendimento educacional especializado nas salas de recursos multifuncionais, seja para o centro de atendimento nas escolas especiais.

Vera Maria Vidal Peroni (2009), em seu trabalho apresentado no Grupo de Trabalho (GT) 15 da educação especial na Reunião Anual da Anped, analisa as políticas educacionais naquele período particular do capitalismo, o da redefinição do papel do Estado e de novas fronteiras entre o público-privado e suas consequências para a educação especial, como parte do direito à educação pública de qualidade. Observa ela que, desde o Império até hoje, a justificativa da não universalização pública do ensino é o erário público insuficiente. Na educação especial, esse descompromisso do Estado é ainda mais evidente. Ressalta ainda a autora que, historicamente, as fronteiras entre o público e o privado foram muito tênues na educação especial. Assim, embora haja avanços na legislação mesmo em tempos de redefinições no papel do Estado, evidenciam-se a desresponsabilização do Poder Público pelas políticas educacionais e o repasse de recursos públicos para instituições do terceiro setor, caracterizando o esvaziamento dos direitos universais e com consequências negativas para a materialização das políticas sociais e educacionais voltadas à educação especial.

Nessa direção, Maria Marta Lopes Flores (2013), em trabalho apresentado em evento nacional, discute a relação existente entre os recursos financeiros e os elementos que caracterizam a mercantilização das ações inclusivas articuladas ao funcionamento das salas de recursos multifuncionais, no estado de Goiás. A autora observa que a gestão descentralizada nas escolas levou à racionalização dos recursos destinados às políticas de educação inclusiva, principalmente, na redução da carga horária dos professores de salas de recursos multifuncionais e na ausência de materiais pedagógicos e recursos de tecnologias assistivas para o atendimento educacional especializado no âmbito dessas salas. Desse modo, ela ressalta que o governo buscou atender aos princípios do neoliberalismo econômico por meio da descentralização e da otimização de recursos, desconsiderando as demandas do processo de inclusão escolar dos alunos com deficiência, TGD e altas habilidades/superdotação. A autora ainda aponta a necessidade da criação de 
movimentos sociais capazes de fiscalizar as ações governamentais no sentido de assegurar ao público da educação especial uma educação de qualidade.

Esses estudos enfatizam a importância das políticas públicas para a consolidação dos planos, programas e projetos voltados às garantias dos direitos das pessoas com deficiência, TGD e altas habilidades/superdotação nos sistemas públicos de ensino. Além disso, destacam a ínfima participação do Poder Público no que tange a recursos voltados à educação especial e a forte presença da iniciativa privada na história, na formulação e na implantação das políticas públicas destinadas a essa modalidade de ensino.

Em contraposição, outros estudos revelam a forte presença do Estado nas políticas e na gestão da educação especial. Rosalba Maria Cardoso Garcia (2009), em seu artigo, ao discutir o modelo de gestão gerencial que perpassa a educação de alunos com deficiência, TGD e altas habilidades/superdotação nos anos 2000, mediante programas induzidos por editais, observa que a educação especial está sob as mesmas regras de gestão que estão previstas na educação nacional. Além disso, identifica que há um movimento claro de intervenção estatal na política educacional no que se refere à educação dos sujeitos da educação especial. Desse modo, destaca que a indução por editais gera um "clima político de publicação" do atendimento educacional especializado, que mostra a presença do Estado na criação de equipamentos públicos de educação especial.

Nessa direção, Roseli Kubo Gonzalez e Rosângela Gavioli Prieto (2012), em evento nacional, apresentaram os resultados de uma pesquisa em que investigaram os trâmites envolvidos na aplicação de recursos do financiamento da educação especial, em município paulista, do ano de 2009. A partir da análise das fontes de financiamento e dos gastos públicos nessa modalidade de ensino, puderam constatar que havia grande dificuldade em localizar informações sobre o financiamento do ensino municipal; destacaram também a existência de dados discrepantes se comparadas fontes municipais e nacionais; revelaram que o gasto da modalidade educação especial em relação ao das demais pode ser considerado de pouco impacto no orçamento geral da educação no município pesquisado e evidenciaram que o gasto com entidades filantrópicas era alto em relação ao total de gastos; indicaram, ainda, a necessidade de produzir estudos que compreendam 
melhor os movimentos envolvidos entre fontes de verbas e execuções orçamentárias para financiar a educação especial.

Em linha semelhante, Corrêa, N. (2011), em seu artigo, investigou os recursos financeiros destinados às salas de recursos multifuncionais da rede municipal de ensino de Campo Grande - Mato Grosso do Sul (MS) e os procedimentos da utilização desses recursos no atendimento educacional especializado. Os dados preliminares, apresentados em evento nacional, apontam indícios da consolidação do Plano de Desenvolvimento da Educação (PDE) no planejamento da política da educação especial no município de Campo Grande - MS, ao se constatar a ampliação dessas salas como apoio técnico do Ministério da Educação (MEC) por meio do Plano de Ações Articuladas (PAR). No entanto, o número de alunos que vêm recebendo atendimento educacional especializado não foi ampliado na mesma proporção em que se ampliaram as salas de recursos multifuncionais. Assim, a autora identificou a interferência por parte do Estado, por meio de ações e programas, articulados pelo governo federal, que têm, (in)diretamente, implicações nas políticas e na gestão dos sistemas educacionais no intuito de assegurar o atendimento educacional especializado aos alunos com deficiência, TGD e altas habilidades/superdotação.

No que se refere à temática custo/aluno da educação especial, encontramos apenas três estudos, como já foi mencionado. O primeiro trabalho desenvolvido por Dalva Guaracyra Martins Cardoso (1997) no seu estudo de mestrado, teve como objetivo identificar e analisar comparativamente o custo/aluno e seus componentes em escolas da rede municipal do Rio de Janeiro. Os resultados mostraram o elevado custo da educação especial comparado ao custo do ensino comum. Desse modo, os dados confirmaram diferenças significativas de custo/aluno entre a educação especial e o ensino comum, assim como entre as séries iniciais e as séries finais do ensino fundamental. Destaca-se ainda que o custo direto de financiamento aluno-ano em escolas especiais foi maior que os custos de financiamento dirigido à classe especial, principalmente no que diz respeito ao custo de pessoal. O estudo aponta ainda a necessidade de adotar critérios eficazes na alocação de recursos da educação especial, de modo a garantir a destinação de verbas às necessidades específicas da área. Foram destacados também alguns desafios quanto à gestão escolar, à formação do professor de educação especial e à 
inclusão dos alunos com deficiência, TGD e altas habilidades/superdotação em classe comum, na rede regular de ensino.

O segundo é o estudo desenvolvido por Ana Lacerda Pomilio et al. (2012), apresentado em evento nacional de educação especial. Ao analisarem as políticas de financiamento a partir da evolução das matrículas dos alunos com deficiência e necessidades especiais ${ }^{18}$ no município de Campinas - São Paulo e no estado de São Paulo, entre os anos de 2007 a 2010, os autores observaram o crescimento das matrículas do público da educação especial, que passaram a se concentrar mais na rede regular de ensino, principalmente, nas escolas municipais. No que tange ao financiamento público à educação, ficou evidente um investimento gradativo e mais intenso na educação especial, a partir do Fundo de Manutenção e Desenvolvimento da Educação Básica e de Valorização dos Profissionais da Educação ${ }^{19}$ (Fundeb). Assim, o crescimento do valor por aluno-ano da educação especial, no estado de São Paulo, induziu o aumento na taxa de incorporação dessas matrículas nos sistemas de ensino, segundo os dados apresentados pelos autores. Desse modo, os autores concluem que o fator financiamento tem grande influência para promover alterações na educação especial (POMILIO et al., 2012).

Por sua vez, o trabalho de Laura Ceretta Moreira e Ana Paula de Carvalho (2011), objetivou contribuir com reflexões sobre o Custo Aluno Qualidade inicial (CAQi) de alunos com deficiência (intelectual, física, visual e auditiva) matriculados na escola pública de nível médio, a partir do contexto socioeconômico da cidade de Curitiba - Paraná (PR). As autoras destacam que a prática inclusiva exige, no mínimo, um investimento duplicado em relação ao CAQi de aluno sem deficiência. Além disso, as autoras afirmam, com base nas simulações realizadas, que a ponderação de 1,20 calculada na lei que regulamenta o Fundeb (BRASIL, 2007b) não é satisfatória para o atendimento direcionado ao público da educação especial. Nesse sentido, o estudo contribuiu para uma visualização do CAQi aplicado aos alunos com deficiência que frequentam o ensino médio público, bem como serviu para reforçar a importância de estudos voltados ao financiamento dessa modalidade

18 Termos utilizados pelos autores para fazer menção ao público da educação especial.

19 O Fundeb foi instituído pela Emenda Constitucional no 53, de 19 de dezembro de 2006 (BRASIL, 2006e), e regulamentado pela Lei 11.494, de 20 de junho de 2007. Assim, cada unidade da federação passa a ter o seu Fundo, que aglutina recursos estaduais, municipais e - quando necessário - a complementação federal, a ser destinado, segundo art. 21, "à manutenção e ao desenvolvimento da educação básica pública e à valorização dos trabalhadores em educação, incluindo sua condigna remuneração" (BRASIL, 2007b). 
de ensino. Evidenciamos, portanto, que a produção direcionada ao custo/aluno da educação especial se apresenta ainda bastante tímida, embora haja um número significativo de pesquisas voltadas ao custo/aluno de outros níveis e modalidades de ensino.

Dessa forma, a literatura consultada aponta as diferentes configurações do papel do Estado, no que tange ao financiamento da educação especial, desde o seu descompromisso, a sua ausência, abrindo e garantindo espaço para a iniciativa privada e assistencial, até a incorporação por parte do Poder Público da responsabilidade em oferecer e manter o atendimento educacional especializado para os alunos com deficiência, TGD e altas habilidades/superdotação nos sistemas públicos de ensino.

Os estudos aqui apresentados mostraram a importância da discussão e desenvolvimento de pesquisas sobre o financiamento da educação especial para o processo de formulação, implantação e avaliação das políticas de educação especial, bem como a relevância das políticas públicas voltadas à garantia dos direitos constitucionais das pessoas com deficiência, TGD e altas habilidades/superdotação. A ênfase dos estudos está na dimensão público-privado, com foco ora nas parcerias do Estado com as instituições especializadas, por meio de convênios e contratos, ora nos serviços ofertados, ora nos recursos vinculados às instituições públicas não estatais de educação especial.

A sistematização de produções sobre o tema mostrou que há poucas pesquisas voltadas ao financiamento da educação especial, principalmente no âmbito dos municípios, de modo a analisar o esforço do Poder Público no provimento de recursos financeiros voltados a essa modalidade de ensino. Nosso estudo estabeleceu-se nessa direção, na tentativa de discutir o financiamento da educação especial nos sistemas municipais de ensino.

Este trabalho, além desta introdução e das considerações finais, está organizado em quatro capítulos. O primeiro capítulo apresenta os pressupostos teóricos para pensar o Estado como espaço de condensação material de uma relação de forças entre classes (POULANTZAS, 2000) e as distintas configurações do Estado ao longo da história, a partir da sua ação mediadora na relação capitaltrabalho, bem como as implicações dessa ação na consolidação das políticas sociais e na garantia dos direitos sociais, entre estes, o da educação. Destaca-se, ainda, o 
contexto contraditório em que se estabelece o financiamento da educação especial no capitalismo, no qual há o distanciamento do Estado das suas responsabilidades sociais e, ao mesmo tempo, a expansão das políticas direcionadas ao público da educação especial a partir do fundo público.

O segundo capítulo procura traçar uma trajetória histórica do financiamento da educação especial no contexto da política de financiamento da educação no Brasil, a partir da implantação de fundos de manutenção e desenvolvimento da educação e das políticas de educação especial implementadas no período de 2003 a 2010, suas contradições e desafios.

O terceiro capítulo aborda a metodologia utilizada no desenvolvimento do estudo, de forma a apresentar os procedimentos de coleta, organização e análise dos dados.

O quarto capítulo apresenta os resultados, a partir da caracterização da política do município pesquisado, das fontes e recursos vinculados à manutenção e desenvolvimento do ensino e, em específico, destinados à educação especial e os gastos despendidos pelo Poder Público nessa modalidade de ensino. Seguem-se a esse capítulo as considerações finais. 


\section{ESTADO E POLÍTICAS PÚBLICAS DE CUNHO SOCIAL}

Este capítulo tem como finalidade apresentar os pressupostos teóricos que fundamentaram nosso estudo acerca do financiamento da educação especial. A discussão aborda os conceitos de Estado, políticas sociais, fundo público e cidadania, pois entendemos que a definição de recursos destinados a essa modalidade de ensino sofre influência das correlações de forças políticas, econômicas e sociais em torno da disputa pelo fundo público, no âmbito do Estado, as quais, por sua vez, interferem na configuração das políticas sociais e têm implicações na consolidação dos direitos de cidadania, entre eles o direito à educação.

No próximo item, apresentaremos as contribuições de Nicos Poulantzas para pensar o Estado como espaço de condensação de correlações de forças entre diferentes classes sociais, que envolve disputa de poder, negociações e interesses distintos nos processos decisórios concernentes às políticas educacionais.

\subsection{NICOS POULANTZAS E A TEORIA RELACIONAL DO ESTADO}

Pensar o Estado como campo estratégico de lutas, de relações e de contradições é o que nos propõe Poulantzas (2000), a partir da sua teoria relacional de Estado, que nos auxilia na compreensão dos processos de constituição de políticas sociais, na contemporaneidade, entre elas, a de educação. Porém, antes de adentrarmos nesse debate, parece-nos oportuno trazer, ainda que de forma sintética, elementos da trajetória do autor que, apesar de oferecer grandes contribuições teóricas sobre a análise do Estado, ainda padece de conhecimento na área educacional.

Poulantzas nasceu em 1936 em Atenas, na Grécia. Cursou direito em sua cidade natal e continuou seus estudos na Alemanha e na França. Foi filósofo, 
sociólogo, marxista e membro do Partido Comunista da Grécia. Exilou-se em Paris, pós-Segunda Guerra Mundial, onde lecionou a partir de 1960. Faleceu em outubro de 1979, aos 43 anos. Foi aluno de Louis Althusser ${ }^{20}$, do qual recebeu forte influência. Na década de 1980, Poulantzas e a escola althusseriana foram marginalizados do debate intelectual; pouco se publicou sobre os marxistas althusserianos e suas teorias sobre o Estado, diante das inúmeras teorias que abordavam temas como micropoderes da sociedade ou questões relativas à superação do Estado moderno (MOTTA, 2009).

Entretanto, no início do século XXI, não apenas o conceito de Estado recuperou o seu prestígio, mas também a obra de Poulantzas, seja pela reedição de sua produção, seja pelos trabalhos escritos sobre sua teoria (MOTTA, 2009). Os escritos de Poulantzas estão marcados por intensas mudanças teóricas, ao longo da sua trajetória de vida intelectual,

[...] desde sua fase existencialista influenciada por Sartre, passando por sua aproximação ao marxismo estruturalista de Althusser e terminando com os seus últimos escritos, marcados por um diálogo com a obra de Foucault e as suas aproximações políticas com a esquerda eurocomunista. (MOTTA, 2009, p. 222).

Na primeira fase, a existencialista (1964-1965), a qual tem como principal referência a obra Natureza das Coisas e Direito, de 1965, o interesse de Poulantzas não recaía sobre o Estado capitalista, mas, sim, sobre o direito moderno, sob o enfoque filosófico e sociológico. Na segunda fase de seus textos (1966-1968), observa-se uma aproximação do marxismo estruturalista de Althusser e o predomínio da análise do conceito de Estado capitalista, resultando na segunda grande obra: Poder político e classes sociais, de 1968. Na década de 1970, com a publicação dos livros Fascismo e Ditadura (1972) e As classes sociais no capitalismo de hoje (1975), Poulantzas apresenta a guinada histórica de sua teoria de pensar o "[...] Estado não como uma estrutura que unifique os diferentes níveis de uma formação social, mas como um aparelho político e ideológico" (MOTTA, 2009, p. 223), aproximando-se da definição relacional de Estado. A máxima dessa

${ }^{20}$ Louis Althusser (1918-1990) foi filósofo, sendo considerado um dos principais representantes do estruturalismo francês. A partir da retomada da obra de Marx, desenvolveu uma original teoria da ideologia e dos aparelhos (repressivos e ideológicos) de Estado, bem como suas contribuições para a reprodução das relações sociais de exploração na sociedade capitalista (SILVA, 2004). 
perspectiva é apresentada em seu último livro O Estado, o poder, o socialismo, de 1978, e na coletânea que organizou em 1976, o Estado em crise.

Nesse momento, Poulantzas redefine o conceito de Estado capitalista na direção de uma concepção relacional de poder, inspirada em Foucault, na qual define o Estado como uma condensação material de forças, permeado pelas contradições e lutas sociais, distanciando-se das concepções que concebem o Estado como um instrumento de classe (visão objetivista) ou como sujeito autônomo (visão subjetivista). Nesse sentido, embora Poulantzas teça críticas ao diagrama de poder de Foucault, incorpora alguns de seus conceitos, como dispositivos, panoptismo, micropoderes, individualização e saber/poder ${ }^{21}$. Entretanto, diferentemente de Foucault, que compreende que o poder não está concentrado num lugar, mas existe de forma difusa no conjunto da sociedade, portanto, está para além do Estado, não se limitando a sua esfera, Poulantzas entende o Estado a partir da sua materialidade institucional, permeado por conflitos, contradições e relação de micropoderes em seus aparelhos. Além disso, para o autor, a fragilidade da teoria de poder de Foucault "[...] deve-se também pela subestimação do papel da lei na organização do poder e por negligenciar o papel da violência física no funcionamento do Estado na sociedade contemporânea, além da obscura resistência da plebe às relações de poder" (MOTTA, 2010, p. 226). Assim, a nosso ver, o autor apresenta significativas contribuições ao estudo da natureza do Estado capitalista e das funções econômicas e político-ideológicas das políticas sociais, a partir da teoria relacional do Estado.

\subsubsection{O Estado, o poder e as classes sociais}

Tomamos como base, em nosso estudo, o último livro de Poulantzas, 0 Estado, o poder, o socialismo, no qual o autor faz uma revisão de algumas das suas análises sobre a relação entre o Estado, o poder e as classes sociais, aprimorando sua principal contribuição teórica, a "teoria relacional do Estado" (POULANTZAS, 2000).

\footnotetext{
${ }^{21}$ Para aprofundamento desses conceitos, ver FOUCAULT, Michel (1998; 2005).
} 
Cabe ressaltar que sua obra não se configura como uma teoria geral do Estado, "[...] entendido como generalização abstrata e trans-histórica aplicável a qualquer sociedade, senão de uma teoria do Estado capitalista, ou seja, da natureza específica que assume o Estado no modo de produção capitalista" (NEVES; PRONKO, 2010, p. 98). Desse modo, essa teoria se propõe a explicar as transformações nas formações sociais onde elas se desenvolvem, isto é, nos lugares em que ocorrem luta de classes. Para Poulantzas (2000, p. 24), "[...] as formações sociais são o lugar real de existência e de reprodução, portanto, do Estado em suas formas diversas, as quais não podem ser deduzidas do modelo capitalista de Estado que designa um objeto abstrato-formal".

Nessa perspectiva, o autor desenvolve uma crítica às concepções de Estado que enfatizavam a dicotomia entre o político, o econômico e o Estado, constituindo uma relação de exterioridade, segundo suas leis de funcionamento interno. Dessa forma, se distancia da concepção liberal de "Estado como Sujeito" (concepção que remonta a Hegel, retomada por Max Weber e a corrente dominante da sociologia política), ou seja, dotado de uma vontade racionalizante, de poder próprio e de uma autonomia absoluta em relação às classes sociais, e da concepção do "Estado como Objeto" ou "Estado como coisa" (concepção instrumentalista do Estado), concebido como mero instrumento passivo, manipulado totalmente por uma única classe ou fração de classe, sem nenhuma autonomia.

Poulantzas (2000) acrescenta que a primeira abordagem destaca a relação do Estado unicamente com as relações de produção, no sentido de uma estrutura econômica, na qual a luta de classes e a dominação política só intervêm a posteriori, para explicar as mudanças no interior desse Estado. A segunda envolve a relação do Estado com a dominação política, reduzindo o Estado capitalista a uma simples concretização do Estado geral, isto é, o "Estado da burguesia" (POULANTZAS, 2000, p. 127).

Para o autor, essas abordagens não explicam as transformações históricas desse Estado, uma vez que este não pode ser considerado um bloco monolítico sem 
fissuras, cuja política se instaura de qualquer maneira, a despeito das correlações das forças, mas é constituído-dividido pelas contradições de classes sociais ${ }^{22}$.

Poulantzas (2000) afirma que o político-Estado sempre esteve presente nas relações de produção da existência e na sua reprodução. Mesmo no contexto do capitalismo, em que há a separação relativa entre as relações de Estado e da economia (acumulação do capital e produção da mais-valia), o Estado tem sua "[...] presença constitutiva do político nas relações de produção e, dessa maneira, em sua produção" (POULANTZAS, 2000, p. 18). Desse modo, a separação entre Estado e economia é a forma precisa que encobre, sob o capitalismo, a presença constitutiva do político nesse processo. Assim, as relações econômicas e políticoideológicas constituem a ossatura material própria do Estado capitalista (POULANTZAS, 2000), que se forma nas relações de produção e na divisão social do trabalho, bem como na relação entre o Estado, as classes sociais e as lutas sociais.

Poulantzas (2000, p. 128) se propõe a "[...] compreender a inscrição da luta de classes, muito particularmente da luta e da dominação política, na ossatura institucional do Estado de maneira tal que ela consiga explicar as formas diferenciais e as transformações históricas desse Estado", ou seja, do Estado capitalista, no qual a burguesia constitui a classe dominante. Contudo, essa natureza de classe do Estado não é absoluta, mas relacional, envolvendo a presença das classes dominadas e seus processos de luta.

Para Poulantzas (2000, p. 130), o Estado se configura como uma "[...] relação, mais exatamente como a condensação material de uma relação de forças entre classes e frações de classe ${ }^{23 ",}$ tal como elas expressam, de maneira sempre

\footnotetext{
22 Para Poulantzas (1975, p. 14), as classes sociais "são conjuntos de agentes sociais determinados principalmente, mas não exclusivamente, por seu lugar no processo de produção, isto é, na esfera econômica". Desse modo, "[...] uma classe social define-se pelo seu lugar no conjunto das práticas sociais, isto é, pelo seu lugar no conjunto da divisão social do trabalho, que compreende as relações políticas e as relações ideológicas. A classe social é, neste sentido, um conceito que designa o efeito de estrutura na divisão social do trabalho". (POULANTZAS, 1975, p. 14). Desse modo, a definição de classe social não se limita à determinação econômica, envolvendo também as relações políticoideológicas.

${ }^{23}$ Para Poulantzas (1977), as frações de classes correspondem às camadas sociais que se situam, embora de maneira desigual, no âmbito do Estado. O autor cita como exemplo a aristocracia operária, as cúpulas da burocracia e da administração, a burguesia nacional, industrial, comercial e financeira, entre outros. No contexto brasileiro, segundo Carvalho (2011), as frações que poderiam compor o rol da classe dominante seriam latifundiários, industriais, empresariado ligado ao comércio, donos de grandes conglomerados, banqueiros e especuladores financeiros.
} 
específica, no seio do Estado, isto é, como um espaço de disputa de poder, no qual estão em jogo diferentes interesses de acordo com as classes dos segmentos que representam o Estado. Entender este último como relação possibilita, segundo Poulantzas (2000), compreender as funções diferenciadas que ele desempenhou em cada contexto histórico-social específico em relação às classes dominantes e dominadas.

Poulantzas (2000, p. 139) ressalta, ainda, que o Estado como condensação material de uma relação de forças se revela como um "campo e um processo estratégicos", no qual se entrecruzam núcleos e redes de poder que, ao mesmo tempo, se articulam e apresentam contradições uns em relação aos outros. Esse campo estratégico é permeado por táticas implícitas e explícitas que se corporificam em determinados aparelhos estatais $^{24}$ e configuram a política do Estado. A hegemonia de uma determinada classe ou fração na ossatura do Estado depende da "[...] unidade, através de suas fissuras, do poder de Estado" (POULANTZAS, 2000, p. 139). Essa centralização do poder em favor de uma determinada classe resulta também de "[...] sua estrutura de condensação de uma relação de forças, logo do lugar preponderante em seu seio da classe ou fração hegemônica sobre as outras classes e frações do bloco do poder" (POULANTZAS, 2000, p. 139). Assim, o lugar privilegiado dessa classe é um elemento constitutivo de sua hegemonia na ossatura material do Estado; sua organização estratégica constitui centros de decisão, dispositivos e núcleos dominantes que orientam a política de Estado a favor de seus interesses.

No capitalismo, na concepção do autor, o Estado constitui-se como campo estratégico da classe dominante em sua relação com a classe dominada, configurando-se como um centro de exercício do poder, em que as políticas estão voltadas para a sustentação do capital. Desse modo, o Estado tem um papel de organização dos interesses políticos das várias frações de classe burguesas, "[...] da

\footnotetext{
24 Para o autor, o Estado abrange um conjunto de aparelhos: repressivo (exército, polícia, tribunais, prisões, administração), ideológico (igreja, escola, família, sistemas de comunicação de massa, partidos políticos, sindicatos, instituições culturais e desportivas) e econômico (o próprio Estado, como um aparelho especial, voltados para a constituição e reprodução das relações capitalistas e potencialização da acumulação do capital). Assim, o Estado não constitui uma instância monolítica do poder hegemônico; ele é, antes de tudo, o resultado das contradições internas entre os diversos aparelhos e no seio de cada um deles, ou seja, instituições sociais heterogêneas que representam o poder e os interesses particulares de uma determinada classe ou fração de classe (POULANTZAS, 2000, p. 139).
} 
unidade conflitual da aliança de poder e do equilíbrio instável dos compromissos entre seus componentes, o que se faz sob a hegemonia e direção, nesse bloco, de uma de suas classes ou frações, a classe ou fração hegemônica" (POULANTZAS, 2000 , p. 129). Isso se torna possível porque o Estado possui uma "autonomia relativa" (POULANTZAS, 2000, p. 129) em relação a classes e suas frações particulares e representa os interesses políticos do capitalismo; porém, isso não implica 0 desaparecimento das contradições que perpassam as relações intraclasses dominantes.

Nessa perspectiva, o Estado, no intuito de desenvolver a sua função de organização, consagra e reproduz a hegemonia ao estabelecer um jogo de compromissos provisórios e variáveis entre o bloco de poder e as classes dominadas, de acordo com as suas correlações de forças. Assim, "[...] os aparelhos de Estado organizam-unificam o bloco no poder ao desorganizar-dividir continuamente as classes dominadas, polarizando-as para o bloco no poder e ao curto-circuitar suas organizações políticas específicas" (POULANTZAS, 2000, p. 143). Desse modo, o poder de um determinado aparelho, no seio do Estado, não se dá apenas porque ele concentra o poder da fração hegemônica, mas porque ele consegue, ao mesmo tempo, cristalizar a função político-ideológica do Estado diante das classes dominadas.

No entanto, o Estado abrange não apenas as relações de força entre as frações do bloco no poder, mas também a relação de forças entre classes dominantes e dominadas. Conforme Poulantzas (2000, p. 131), "[...] o Estado não é pura e simplesmente uma relação, ou a condensação de uma relação; é a condensação material e específica de uma relação de forças entre classes e frações de classe". Nesse sentido, o seu desenvolvimento e consolidação dependem do seu papel frente às classes dominadas, uma vez que as "lutas populares estão inscritas na materialidade institucional do Estado" (POULANTZAS, 2000, p. 143), isto é, nas suas estruturas e nos aparelhos que o compõem. Nesse sentido, as lutas dos movimentos sociais pela garantia dos direitos sociais, entre os quais a educação, constituem as forças políticas no âmbito do Estado. Motta (2008, p. 197) afirma:

O alargamento dos direitos em direção às classes e aos grupos dominados dá-se também dentro das instituições estatais, devido à inserção e à infuência que podem exercer no interior de cada uma 
delas. Se as lutas políticas que ocorrem no Estado atravessam suas instituições, é porque essas lutas estão desde já inscritas na trama do Estado do qual elas esboçam a configuração estratégica.

Para Poulantzas (2000), o poder das classes dominadas se materializa de maneira específica no seio do Estado, por meio de focos de oposição ao poder das classes dominantes. Assim, as classes dominadas estão inscritas na trama do Estado, portanto, não lhe são exteriores. De acordo com o autor, existe a

[...] tendência de considerar que o Estado constitui, em relação às classes dominadas, um bloco monolítico que lhes é imposto de fora, e sobre o qual elas só atuam cercando-o e assediando-o de fora, como uma fortaleza impermeável e isolada delas. As contradições entre classes dominantes e classes dominadas permaneceriam contradições entre o Estado e as massas populares exteriores ao Estado. As contradições internas do Estado não passariam de decorrências das contradições entre classes e frações dominantes, a luta das classes dominadas não seria uma luta presente no Estado, consistindo simplesmente em pressões sobre 0 Estado. (POULANTZAS, 2000, p. 143).

Entretanto, para o autor, as lutas são sempre parte integrante do poder e produzem efeitos no Estado. Assim, a presença e a ação das massas no seio do Estado são condições necessárias para sua transformação, embora não sejam suficientes. Isso se explica porque a ascensão da classe trabalhadora ao poder pressupõe, necessariamente, a transformação do arcabouço institucional do Estado, o qual "[...] consiste em mecanismos internos de reprodução da relação dominaçãosubordinação: ela assegura a presença de classes dominadas em seu seio, embora exatamente como classes dominadas" (POULANTZAS, 2000, p. 145). Desse modo, a essa transformação implica, pois, substancialmente, mudanças na relação do Estado com as massas populares. Conforme o autor,

[...] como quer que seja, modificar a relação de forças interna ao Estado não significa reformas sucessivas numa contínua progressividade, conquista peça por peça de uma maquinaria estatal ou simples ocupação de postos ou cúpulas governamentais. Significa exatamente um movimento de rupturas reais, cujo ponto culminante, e certamente existirá um, reside na inclinação da relação de forças em favor das massas populares no campo estratégico do Estado. (POULANTZAS, 2000, p. 263). 
Nessa perspectiva, a política estatal resulta dessas contradições de classe e das correlações de forças que se manifestam em cada ramo ou aparelho (no executivo, no parlamento, no exército, no ministério, no aparelho municipal, central e ideológico) do Estado. Isso acontece, segundo o autor, porque as diversas classes e frações do bloco no poder só participam da dominação política e dos processos decisórios se estiverem presentes no Estado, pois, segundo Poulantzas (2000, p. 42), "o poder concentra-se e materializa-se por excelência no Estado, lugar central do exercício do poder político". Desse modo, no sistema capitalista, no contexto da luta de classes, o "poder liga-se a lugares objetivos, ancorados na divisão de trabalho, e designa a capacidade de classes de realizar seus interesses, não podendo portanto ele fugir às relações econômicas" (POULANTZAS, 2000, p. 34), políticas e ideológicas que o consagra e o legitima.

Compreender o Estado como a condensação de uma relação de forças significa entender que ele é constituído pelas contradições de classe. Desse modo, "[...] a política do Estado é o efeito de seu funcionamento no seio do Estado" (POULANTZAS, 2000, p. 135). Nesse sentido, o Estado desempenha sua função de organização no jogo dessas contradições que compõem a sua materialidade.

Assim, o autor distancia-se de uma concepção de Estado como um "dispositivo unitário de alto a baixo, fundamentado numa repartição hierárquica homogênea dos centros de poder, em escala uniforme, a partir do ápice da pirâmide para a base" (p. 153), compreendendo que a política estatal é resultante desses processos contraditórios e decisórios que constituem as relações setoriais e os aparelhos do Estado. Desse modo, a política é "[...] feita de acelerações e freadas, de recuos, de hesitações, de permanentes mudanças [...] expressão necessária da estrutura do Estado" (POULANTZAS, 2000, p. 138).

No contexto educacional, principalmente na área de educação especial, observamos como as políticas de financiamento são formuladas nesse campo de relações de forças que envolve, por um lado, a luta das famílias, movimentos sociais, profissionais da educação, representantes políticos e os próprios sujeitos pelos direitos de cidadania e, por outro lado, interesses privativos nacionais e internacionais no âmbito de discussão e de definição dos recursos públicos voltados à educação e à garantia do atendimento educacional especializado às pessoas com deficiência, TGD e altas habilidades/superdotação. Dessa maneira, as lutas 
permeiam a estrutura do Estado e interferem na formulação das políticas, que, por sua vez, são "resultantes das contradições de classe inseridas na própria estrutura do Estado" (POULANTZAS, 2000, p.134), isto é, de relações de forças e resistências que fazem do Estado uma expressão condensada da luta de classes.

A teoria desenvolvida por Poulantzas nos ajuda a compreender as dinâmicas e os efeitos das transformações das relações de produção/divisão do trabalho e das lutas políticas das classes sociais no âmbito do Estado capitalista. Nessa perspectiva, concordamos com o autor quando afirma que

[...] somente quando se percebe a inserção da dominação política no arcabouço material do Estado enquanto condensação de uma relação de força é que se pode romper com a formação dogmática de gênero "todo Estado capitalista é um Estado da burguesia", e compreender o complexo papel da luta política na reprodução histórica desse Estado. (POULANTZAS, 2000, p. 161).

A partir desses pressupostos, buscamos no próximo item, discutir a origem do Estado, as suas configurações políticas no decorrer da história, bem como a constituição das políticas sociais e suas implicações para a consolidação dos direitos sociais no Brasil.

\subsection{ESTADO E POLÍTICAS SOCIAIS}

A discussão sobre a origem do Estado é controversa. De acordo com Noberto Bobbio (1987, p. 67), o termo "Estado" "[...] passou de um significado genérico de situação para um significado específico de condição de posse permanente e exclusiva de um território e de comando sobre os seus respectivos habitantes". Delineiam-se, assim, as características desse novo Estado, instituição dotada de plena soberania dentro dos limites de determinado território (CORRÊA, D., 2010). Essa concepção, para alguns autores, como Max Weber25 (2004), representa a

25 Max Weber (1864-1920) foi economista, sociólogo e filósofo alemão. É considerado um dos fundadores da sociologia moderna. Suas obras principais são: Economia e Sociedade e $A$ ética protestante e o Espírito do Capitalismo. Suas principais contribuições estão nas áreas da sociologia da religião, sociologia política, administração pública e economia (RODRIGUES, 2002). 
ruptura entre a ideia de Estado e os ordenamentos políticos precedentes, e, dessa forma, seria adequado falar de Estado apenas para as formações políticas originadas da crise do feudalismo. Nesse sentido, o Estado teria sua origem com a modernidade. Para outros autores, como Friedrich Engels (1986), o Estado é concebido como o ordenamento político de uma comunidade, nascido na passagem da comunidade primitiva fundada pelos laços de parentesco para a comunidade civil. Desse modo, com o desenvolvimento econômico e a divisão do trabalho, o Estado emerge a partir da complexificação da sociedade e dos conflitos decorrentes da divisão da sociedade em classes. Contudo, concordamos com Bobbio (2004) quando assinala que o importante é analisar as semelhanças e diferenças entre os ordenamentos e/ou organizações sociais e políticas, suas continuidades e descontinuidades. Porém, antes de adentramos nesse debate, destacamos os discursos que tentaram legitimar a razão de existência do Estado moderno e de seu poder nas diferentes configurações sociais.

Durante um longo período na história, foi atribuída à lei divina a incumbência de definir as relações entre os indivíduos, "[...] inclusive quem os governava e como eles deveriam ser governados" (CARNOY, 1988, p. 20). As interpretações dessa lei, definidas pelas instituições religiosas e hierarquias políticas da época (na Europa, a aristocracia rural), legitimavam as relações econômicas e sociais. Assim,

[...] a lei divina vinha de uma autoridade superior, uma força sobrehumana, que estava acima e além da compreensão e controle do indivíduo e, mais ainda, dentro de cada pessoa, dando-lhe a possibilidade de uma compreensão e de um conhecimento completo. (CARNOY, 1988, p. 20).

No século XVII, com mudanças nas condições políticas e econômicas na Europa e a decadência do sistema feudal, já transformado pelo desenvolvimento das monarquias centralizadas e autoritárias, declinava-se também a existência de mecanismos de limitação do Estado e, consequentemente, da lei divina como fundamento das hierarquias políticas. Nesse contexto, ocorreu a redefinição do Estado natureza (condição natural do homem) e a formulação de teorias baseadas nos direitos individuais em substituição à lei divina (CARNOY, 1988). 
A doutrina dominante, pela qual se justificaram os Estados nacionais da Época Moderna (1453-1789), foi o contratualismo, denominado também como Escola do Direito Natural moderno, que defendia um Estado voltado para o bem comum, com base na proteção dos direitos naturais dos indivíduos. Vários autores se destacam nessa abordagem: Pufendorf, Hobbes, Locke, Leibniz, Rousseau, Kant e outros (CORRÊA, D., 2010). Embora se fundamentem na dicotomia Estado de natureza e sociedade civil, eles assumem posições distintas no que se refere a transferência consensual de direitos naturais do indivíduo em favor do Estado, sua função e organização.

Thomas Hobbes, ao desenvolver sua teoria política sobre Estado, na sua obra mais conhecida - Leviatã (1651) -, nos ofereceu subsídios teóricos para a legitimação do Estado absolutista. O autor parte da concepção de que o homem possui uma natureza egoísta; desse modo, a única forma de preservar a liberdade, o medo da violência e da guerra civil seria a instauração de um poder forte e centralizado. Para Hobbes, esse processo deveria ser realizado por meio de um contrato social entre os homens, os quais abdicariam dos direitos que seriam inerentes a sua natureza, transferindo-os para um representante encarregado de promover a paz. Segundo Darcísio Corrêa (2010, p. 357), essa lógica "[...] faz do Estado uma construção voluntária e artificial, um ente moral totalmente autônomo surgido de um acordo comum pelo qual os indivíduos renunciam integralmente à sua potência individual, transferindo-a para o poder público". Nessa perspectiva, o Estado teria como função garantir a segurança e a paz do povo. A teoria de Hobbes, num primeiro momento, sofreu grande rejeição, pois o soberano tinha o poder de nomear seus sucessores, o que não era interessante para a burguesia, que queria fortalecer seu poder político na sociedade. No entanto, posteriormente, sua formulação ganhou corpo, pois estava centrada na troca de bens no mercado livre, no qual as paixões dos homens seriam contidas pela maximização de seus interesses econômicos (CARNOY, 1988).

John Locke, como Hobbes, concordava que os homens se juntam na sociedade política para se defender da guerra contra todos. No entanto, dizia que a monarquia absoluta era incompatível como governo civil, pois o soberano não tinha a quem apelar senão a si mesmo. Para Locke, o poder político residia nos indivíduos-proprietários que compunham a sociedade civil e que entregavam "[...] 
seu poder político natural a outrem - a um poder legislativo, a um grupo de homens ou a um único homem" (CARNOY, 1988, p. 29), que teria a responsabilidade de elaborar e fazer cumprir as leis que mantivessem a propriedade de cada indivíduo e a sua segurança. Na perspectiva de Locke, o Estado (poder legislativo e executivo) era o poder dado por esses proprietários para proteção de suas propriedades e de si mesmos. Assim, se o Estado não cumprisse seu mandato, os membros da sociedade civil tinham o direito de dissolvê-lo, tendo poder para isso.

A esse debate, insere-se Jean-Jacques Rousseau, com o seu Contrato Social, de 1762. Para ele, os homens no estado de natureza estavam sem moralidade, mas ao mesmo tempo sem maldade, enquanto a sociedade civil era uma descrição de como os homens se encontravam na realidade, não como uma construção ideal. Assim, para Rousseau, a sociedade civil era imperfeita, pois foi corrompida pela propriedade e era produto de voracidade do homem. Contudo, Rousseau acreditava que os homens queriam ser livres e iguais, mas foi sua ignorância que os levou a aceitar a sociedade civil na qual viviam. Desse modo, ele afirmava que o papel do Estado era o de garantir a liberdade e a igualdade, por meio do contrato social, em que o poder do Estado residia no povo, que renunciou a sua liberdade em favor do Estado, e este, por sua vez, representava a vontade geral. (CARNOY, 1988).

De acordo com Corrêa, D. (2010, p. 342), o contratualismo constituiu uma "[...] nova tentativa de fundamentação lógica de um espaço público referenciado à cidadania, contrapondo à matriz religiosa de legitimação do Estado um remédio laico para as vicissitudes da natureza humana, tendo como centro o indivíduo". Nessa perspectiva, há a renúncia por parte dos indivíduos dos seus direitos naturais para a aceitação de um Estado de direito institucionalizado que tem a responsabilidade de proteger o bem comum e os interesses individuais.

Foi nesse contexto que se desenvolveu a teoria do Estado liberal, baseada "[...] nos direitos individuais e na ação do Estado de acordo com o bem comum, a fim de controlar as paixões dos homens, possibilitando que seus interesses se sobreponham a essas paixões" (CARNOY, 1988, p. 23). Faz-se necessário ressaltar que o Estado liberal constituiu-se como reação burguesa à extrema centralização do poder nas mãos do monarca, pois o cenário era de uma burguesia já hegemônica do ponto de vista econômico, mas não consolidada como classe politicamente 
dominante. A teoria de Adam Smith (1986), que se centrava na liberdade do indivíduo e do mercado, forneceu os pressupostos básicos do liberalismo para consolidação desse Estado. Para ele, a procura do interesse próprio pelos indivíduos, ou seja, seu desejo natural de melhorar as condições de existência e de aumentar os seus bens, tenderia a maximizar o bem-estar coletivo. Assim, defendia ele o funcionamento livre e ilimitado do mercado. O Estado deveria apenas fornecer a base legal, para que o mercado livre pudesse maximizar os benefícios aos homens. De acordo com Martin Carnoy (1988, p. 39),

[...] o papel do Estado era o mais periférico em relação à dinâmica social fundamental - a "mão invisível" do mercado livre - uma dinâmica que não somente não deveria sofrer interferência, mas exigiria, ao contrário, uma loucura humana extrema para fazer retroceder significativamente sua capacidade inexorável de prover ganho material coletivo.

Desse modo, o Estado não poderia interferir nas leis naturais da economia. Trata-se de um Estado capaz de garantir a ordem do sistema capitalista, por meio da circulação e da reprodução do capital.

Essa concepção consolidou a soberania popular nos Estados nacionais e as condições básicas para vivência da cidadania moderna, marcada por uma igualdade humana básica, política e juridicamente qualificada. Assim, o Estado de Direito engendra-se como produto cultural da vontade dos indivíduos, baseado, segundo Corrêa, D. (2010, p. 380), nas promessas da modernidade que têm como "[...] centro um homem portador de direitos inalienáveis, capaz de construir por si só sua história social com absoluta liberdade e em perfeita igualdade de condições".

Essas teorias contratualistas, segundo Corrêa, D. (2010), foram fundamentais para a consolidação do sistema capitalista e a legitimação do Estado nacional, na medida em que a emergência desse modo de produção pressupunha uma nova matriz teórica para justificar o poder político numa nova sociedade de classes.

A partir dessas considerações, retomamos a discussão acerca da constituição do Estado. Para Elaine Behring (2002, p. 135), baseada nas análises de Mandel (1982), o Estado teve sua origem a partir da separação entre as esferas privada e 
pública na sociedade. Assim, ele foi demandado "[...] no sentido de proteger e administrar, de acordo com interesses privados, o sobreproduto social". O Estado, em seus primórdios (na fase da acumulação primitiva ${ }^{26}$ ), era despótico e por muito tempo foi fundamental para a expansão das atividades comerciais da burguesia mercantil e para a consolidação do capitalismo. Contudo, com o desenvolvimento da burguesia, a partir da expansão do capital, houve um ataque às formas tradicionais de dominação política - Estado Absolutista - representada pela interferência do Estado na vida econômica, o que impedia o desenvolvimento do capitalismo com base em relações livres de trocas. Nesse contexto, os princípios do liberalismo, com sua tese principal de que o indivíduo tem direito total à liberdade econômica e política, se adequaram perfeitamente ao capitalismo concorrencial. Nessa perspectiva, o Estado teria como principal função assegurar os direitos naturais (vida, liberdade, propriedade, segurança e felicidade) do indivíduo.

Posteriormente, segundo José Paulo Netto (2005), a fim de garantir o acréscimo dos lucros capitalistas pelo controle dos mercados, ocorreu um processo de concentração da produção e de capital nas mãos de grandes corporações e a livre concorrência foi substituída pelos monopólios capitalistas, baseados na concentração e na centralização de capital por parte das grandes empresas. Foi nesse período (anos 30, do século XX) que, de acordo com muitos autores surgiu a denominada "questão social" 27 , que exigiu do Estado uma mediação legal e política, com a finalidade de regular as forças livres do mercado e as tensões sociais.

No entanto, a concorrência intercapitalista e a concentração de capital, com formação de monopólios, tornaram difícil uma representação de interesses gerais dos capitalistas que operavam individualmente no intuito de garantir as condições gerais de (re)produção. Nessa trajetória, surgiu a necessidade de um aparato estatal que, por meio de seu instrumento de planejamento econômico e socialização dos custos, passasse a subsidiar a acumulação do capital, garantindo os interesses capitalistas em nível de superestrutura e que, ao mesmo tempo, integrasse, nos

\footnotetext{
26 A acumulação primitiva refere-se, segundo Marx (2011), ao processo de dissociação entre o produtor e os meios de produção. É considerada primitiva porque constitui a pré-história do capital e do modo de produção capitalista.

${ }^{27}$ Entendemos a questão social tal como Marilda Villela lamamoto (2001, p. 11): "indissociável do processo de acumulação e dos efeitos que produz sobre o conjunto das classes trabalhadoras, o que se encontra na base da exigência de políticas sociais públicas". Todavia, leitura e análise sobre a origem e metamorfoses da questão social podem ser encontradas também em Robert Castel (1999) e Pierre Rosanvallon (1998).
} 
processos decisórios, a classe trabalhadora, organizada em partidos de massa, que pressionavam pela socialização da política e da economia. Nesse contexto do capitalismo monopolista e do imperialismo dele decorrente, houve uma forte ampliação da intervenção do Poder Público na vida econômica e social. Para Claudia Danani (2010, p. 9), o Estado foi "[...] resultado complexo e contraditório de processos de disputa de todo o tipo, abertos a correlações de forças que marcaram (e marcam) cada ciclo histórico".

Assim, as transformações sociais, econômicas e políticas, nos séculos XIX e $X X$, marcadas, principalmente, pela revolução industrial, a eclosão da democracia de massas e a constituição dos Estados nacionais produziram um novo perfil de Estado e de política social que diferiam substancialmente do padrão autoritário que vigorava até então. Daí decorre a necessidade de fazermos referência ao papel e ao lugar do Estado de Bem-Estar Social, as suas relações e implicações para a origem das políticas sociais e, particularmente, para as políticas educacionais.

O Estado de Bem-Estar Social ${ }^{28}$ se configurou como "[...] um divisor de águas entre um sistema de proteção arcaico, pré-industrial e carente de riquezas e, outro, moderno, industrial e próspero" (PEREIRA P., 2008, p. 33), com um estado social de direitos que passou a regular o processo de acumulação e, ao mesmo tempo, assumir crescentes funções sociais.

Cabe ressaltar que foi nesse contexto, do capitalismo monopolista, que Poulantzas (2000, p. 11) desenvolveu a sua teoria sobre o Estado na sociedade capitalista, na tentativa de entender "por que a burguesia geralmente recorre, com a finalidade de dominação, a este Estado nacional-popular, a este Estado representativo moderno com suas instituições próprias, e não a outro". No entanto, concordamos com Bob Jessop (2009, p. 143) quando nos diz que

[...] sua percepção de que o Estado é uma relação social não apenas revigorou sua interpretação mais abstrato-simples forma-analítica do tipo capitalismo de Estado como também forneceu uma poderosa

\footnotetext{
28 Ivanete Boschetti (2003) destaca que o termo surgiu na Inglaterra na década de 1940, porém seu significado varia em cada país. Na França, esse termo não é utilizado para designar o sistema de proteção social; adota-se État Providence. O termo Welfare State é usado como modelo de proteção social nos países anglo-saxões. Neste estudo, utilizamos os termos conforme a nomenclatura usada pelos autores citados.
} 
abordagem para lidar com as características concreto-complexas dos estados de fato existentes nas sociedades capitalistas.

Nessa perspectiva, Poulantzas (2000) observou que, com as transformações históricas e sociais, ocorreram mudanças no papel desempenhado pelo Estado na acumulação e reprodução do capital, representado pela intensificação do seu controle sobre cada esfera da vida socioeconômica e pela intervenção em domínios que até então eram considerados marginais e que passaram a ser considerados como centrais, como o urbanismo, o transporte, a saúde, a educação, o meio ambiente, equipamentos coletivos, entre outros. Desse modo, o autor percebe 0 Estado como um elemento integral na dominação política de classe, bem como insiste em seu papel crucial de assegurar importantes condições para as relações sociais de produção e, concomitantemente, de responder às demandas das classes exploradas, ora como efeito das lutas, ora como tentativa de desativação antecipada dessas lutas por parte do Estado.

$\mathrm{Na}$ literatura, encontramos diferentes abordagens para a origem do Estado de Bem-Estar Social, ora como resultado das transformações sociais do século XIX, ora como sinônimo da origem das políticas sociais no século XX.

Para Pedro Roberto Jacobi (2003), o Estado de Bem-Estar Social origina-se no final do século XIX, com a expansão do capitalismo após a Revolução Industrial e com o movimento de um Estado nacional visando à democracia e à garantia de direitos sociais. Constitui-se como uma "[...] resposta à falta de mecanismos públicos que garantam um patamar mínimo de seguridade social e de segurança socioeconômica" (JACOBI, 2003, p.1).

Faz-se necessário ressaltar que o capitalismo produziu mudanças sociais que demandavam ações de proteção social no intuito de minimizar os processos de exclusão provocados pela inserção e não inserção no mercado de trabalho no século XIX. Assim, a consolidação do Estado de Bem-Estar Social significou a adaptação do Estado liberal burguês às condições econômicas e sociais da sociedade industrial, caracterizada pelas grandes possibilidades técnicas econômicas e sociais, mas também por seus problemas relacionados à pobreza e à desigualdade social. Jacobi (2003, p. 2) afirma: 
O amadurecimento do processo de industrialização e urbanização e a emergência dos assalariados como força social criaram gradualmente as condições para uma nova etapa na política social do Estado, o nascimento do seguro social, e portanto a ruptura com a lógica de filantropia e beneficência que prevalecia.

Potyara Amazoneida Pereira Pereira (2008) identifica, na literatura, uma visão evolucionista sobre as origens do Estado de Bem-Estar Social e da política social que os considera como sinônimos. Desse modo, constituiriam "[...] fenômenos equivalentes, surgidos nos fins do século $\mathrm{XIX}$, em resposta aos conflitos sociais adensados pelo avanço da industrialização e por uma progressiva conquista popular de direitos" (PEREIRA P., 2008, p. 23), ou seja, o Welfare State seria resultante da correspondência direta entre o desenvolvimento do capitalismo, a formação dos Estados nacionais e a transformação destes em democracia de massas. Porém, há outros autores (MISHRA, 1995) que afirmam ser o Welfare State, ao contrário da política social, resultado de um contexto histórico específico decorrente da dinâmica capitalista a partir da Segunda Guerra Mundial. E a política social teria um caráter mais genérico que the permitiria estar presente em toda e qualquer ação que envolvesse intervenção do Estado no atendimento às demandas sociais. Desse modo, a política social não seria uma herança burguesa; ela estaria presente em todos os modelos de produção divididos em classe e de acordo com os regimes políticos que a sustentassem. Contudo, concordamos com Pereira P. (2008, p. 28) quando salienta que a natureza da política social "não condiz com um enfoque evolucionista, que procura encaixá-la num continuum que começa com a caridade privada passando pela beneficência e assistência, até terminar na política social como prática evoluída e estritamente associada ao Welfare State" (PEREIRA P., 2008, p. 28). Ela resulta da relação conflituosa entre Estado e sociedade, com sujeitos distintos e com interesses opostos. Nesse sentido, a política pode ser vinculada aos interesses do capital, de forma a garantir condições favoráveis à sua reprodução (por meio de subsídios, de desonerações tributárias, de incentivos fiscais, de redução da base tributária da renda do capital e de financiamento integral ou parcial dos meios de produção) ou as necessidades humanas da população, por meio do oferecimento de serviços públicos, como educação, saúde, transporte e habitação (PEREIRA P., 2008). 
Pereira P. (2008) mostra a trajetória da política social que precede a fase industrial, o surgimento da democracia de massas, a formação dos Estados-Nação e o advento do direito de cidadania até a instituição do Welfare State. Afirma a autora que a "política social e o Estado de Bem-Estar não são a mesma coisa, apesar de os dois terem se encontrado e se imbricado num momento histórico específico (19451975) e de ter sido este o melhor momento da política social" (PEREIRA, P., 2008, p. 57). O Welfare State se firmou em meados do século XX, na Europa, como instituição responsável pelo atendimento de necessidades sociais agravadas pelo desenvolvimento capitalista, por meio de políticas favorecedoras do pleno emprego e de um conjunto de benefícios e serviços que, na perspectiva dos direitos, assegurava um aceitável padrão de vida ao cidadão, como seguro social obrigatório, leis de proteção do trabalho, salários mínimos, ampliação de instituições e serviços de educação, saúde, habitação.

Em contraposição, Ricardo Montoro Romero (1998) afirma que as origens históricas do Estado de Bem-Estar Social remontam ao Estado Social de Direito, cunhado na República Federal da Alemanha em 188329. Assim, o Estado de BemEstar Social foi constituído pela difícil confluência entre Estado e sociedade. Para o autor, o Estado social, como ele o denomina, é concebido como "uma tentativa de adaptação do Estado tradicional (Estado liberal burguês) às condições sociais da civilização industrial e pós-industrial com seus novos e complexos problemas, mas também com suas grandes possibilidades técnicas, econômicas e organizativas para enfrentá-los" (ROMERO, 1998, p. 36). Nesse sentido, o Estado social se instituiu como uma forma de ordenamento coletivo que permitia o desenvolvimento das políticas sociais a partir da garantia não só dos direitos formais (liberdade e igualdade diante da lei), mas também dos direitos materiais que se realizavam mediante custos econômicos, como o direito à educação. Para Romero (1998, p. 45),

\footnotetext{
${ }^{29}$ Não se pode esquecer, como ressalta Pereira, P. (2008), que a intervenção social prevista por Bismarck (1883) tinha base conservadora e autoritária e, portanto, era avessa às ideias igualitárias da social-democracia e era voltada exclusivamente aos trabalhadores ativos fazendo com que fosse identificada com um modelo profissional de proteção social, pois estavam fora de seu alcance os não inseridos no mercado de trabalho.
} 
[...] a política social nasce como reflexo da constituição e o fortalecimento posterior do Estado nacional moderno, baseado na unificação territorial de um povo, contando com a existência de um grupo social dominante, mobilizando recursos financeiros através de uma burocracia fiscal, assegurando as fronteiras com um aparato de defesa e mantendo a ordem interna mediante o monopólio legítimo da violência.

Assim, a política social seria resultado da relação entre Estado e sociedade civil, e sua história foi marcada por situações autoritárias e paternalistas, com características repressivas e caritativas, até chegar à democracia de massa. Desse modo, Romero (1998, p. 35) afirma que a política social está atrelada diretamente à figura do Estado e que ela poderia ser entendida como "[...] instrumento característico do Estado moderno que tem permitido, por um lado resolver os conflitos sociais que vinham se arrastando desde o século XIX, e por outro lado conseguiu alcançar um grau de equiparação social”. Nessa perspectiva, para o autor, a política social é característica do Estado de Bem-Estar Social, em que todos os cidadãos são tratados de igual forma e o Estado assume um papel coletor e distribuidor de investimentos para o gasto social (ROMERO, 1998). Em termos gerais, o autor define a política social como

[...] o desenho e a execução programada e estruturada de todas aquelas iniciativas adotadas para atender uma série de necessidades consideradas básicas para a população de acordo com a escala da civilização definida por aquilo que denominamos como sociedades industriais avançadas. (ROMERO, 1998, p. 34).

Entre as necessidades básicas da população a serem atendidas estão a educação, a saúde, o trabalho, a previdência, além de outras que garantem a manutenção de condições gerais que impedem a marginalização social. Romero (1998) salienta ainda os problemas para se definir a política social, tendo em vista as concepções e ideologias que subjazem a esse conceito. Assim, a configuração e o significado das políticas sociais estão articulados aos diferentes regimes políticos, aos contextos históricos, sociais específicos, bem como aos pressupostos teóricos que fundamentam os conceitos de Estado, bem-estar e política social.

Para a concepção liberal, o papel do Estado e da política social remonta às ideias economicistas e liberais dos pensadores do século XVIII, em que o Estado 
tinha como principal função assegurar a lei e a ordem da sociedade, não interferindo nas relações sociais; primar por um bem estar individual; e pensar a política social como um sistema que restringe a liberdade, exemplo de ineficácia burocrática e de excessiva onerosidade (ROMERO, 1998). Dessa maneira, a política social assume um caráter residual e focalizado, numa perspectiva liberal, sendo destinada às pessoas que não têm condições de cuidar de si mesmas, ou seja, ela busca atender uma deficiência no desenvolvimento do mercado. Na concepção social-democrata, o Estado de Bem-Estar Social é resultado da luta de classes na definição das regras no jogo de democracia. Assim, os sociais-democratas defendem que o bem-estar deve ter um caráter coletivo, a partir da garantia de um padrão mínimo para os cidadãos, que deve ser assegurado pelo Estado, por meio das políticas sociais. Estas implicam a intervenção pública coletiva dirigida a promover o bem-estar dos indivíduos e a manutenção da integração/coesão social, como um mecanismo distributivo dos recursos disponíveis. O Estado de Bem-Estar Social europeu foi exemplo dessa perspectiva social-democrata. Na concepção marxista, o bem-estar não pode ser alcançado no sistema capitalista. Nessa perspectiva, a política social tem como objetivo reduzir as desigualdades, resultantes da ocupação desigual do indivíduo na infraestrutura produtiva. Desse modo, a política social no Estado de Bem-Estar Social é algo mais profundo e de maior alcance que um mero mecanismo regulador (ROMERO, 1998).

Pereira P. (2008) ressalta que, desde a Idade Média até o século XIV, a assistência social era de responsabilidade da Igreja, que, por sua vez, era sustentada por donativos dos membros da família real e da aristocracia. As ações estatais de proteção social se restringiam a dar respostas a desastres naturais e epidemias (JACOBI, 2003). As "Leis dos Pobres" (PoorLaws), que datam do século $\mathrm{XVI}$, na Inglaterra, constituíram um conjunto de regulações sociais assumidas pelo Estado, a partir da constatação de que "[...] a caridade cristã não dava conta de conter possíveis desordens que poderiam advir da lenta substituição da ordem feudal pela capitalista, seguida de generalizada miséria, desabrigos e epidemias" (PEREIRA P., 2008, p. 62). Essas leis concebiam os pobres não como titulares de direitos, mas como perigos à ordem pública.

Em linha semelhante, para Thomas Humphrey Marshall (1967, p. 72), as Leis dos Pobres tratavam "[...] as reivindicações dos pobres não como uma parte 
integrante de seus direitos de cidadão, mas como uma alternativa dêles - como reivindicações que poderiam ser atendidas somente se deixassem inteiramente de ser cidadãos". Para Marcos Coimbra (1987), as referidas Leis não se constituíam em políticas sociais e, sim, em políticas antissociais, pois implicavam o controle dos pobres e não apresentavam uma concepção de bem-estar.

Para Ivanete Boschetti (2012, p. 755), os sistemas de proteção social tiveram sua origem na Europa Ocidental, no contexto da revolução industrial, e ampliaramse após a Segunda Guerra Mundial, constituindo-se em conquistas civilizatórias que "[...] não foram capazes de emancipar a humanidade do sistema capitalista, mas instituíram sistemas de direitos e deveres que alteraram o padrão de desigualdade entre as classes sociais ao longo do século XX." As políticas sociais constituíram sistemas públicos de garantia de direitos e serviços sociais que asseguraram certo bem-estar para a população e, ao mesmo tempo, asseguraram condições gerais de produção capitalista por meio da socialização dos custos de produção, a partir do fundo público ${ }^{30}$. Contudo, seu desenvolvimento, configuração e abrangência se diferenciaram em cada país, considerando a história e desenvolvimento das forças produtivas, o papel do Estado e das classes sociais (BOSCHETTI, 2012).

Embora ações assistenciais (como as "Leis dos Pobres") datem do século XVI e iniciativas estatais, baseadas em seguros sociais obrigatórios ${ }^{31}$, datam do século XIX, a constituição de políticas sociais ocorreu a partir da crise de 1929, na Europa, quando, sob a orientação do Keynesianismo ${ }^{32}$, instituiu-se o Estado de Bem-Estar Social e as políticas sociais passaram a estruturar o sistema público de garantia de pleno emprego, direitos e serviços sociais (BOSCHETTI, 2012). Assim, para a autora, o que configura um sistema de proteção social "[...] é o conjunto organizado, coerente, sistemático e planejado de políticas sociais que garantem a proteção social por meio de amplos direitos, bens e serviços sociais, nas áreas de emprego, saúde, previdência, habitação, assistência e educação" (BOSCHETTI, 2012, p. 756).

\footnotetext{
30 O conceito de fundo público será desenvolvido no item 2.3.

${ }^{31}$ Conjunto de benefícios articulados pelo Estado para garantir proteção ao trabalhador e sua família em caso de risco social, decorrente da ausência de trabalho remunerado (BOSCHETTI, 2012).

32 Keynesianismo é a teoria econômica desenvolvida pelo inglês John Maynard Keynes, na sua obra "A teoria geral do emprego, do juro e da moeda", de 1936, que preconizava a intervenção do Estado na economia e propunha solucionar o problema do desemprego pela intervenção estatal, por meio do sistema tributário, da fixação das taxas de juros e do incremento dos investimentos públicos (SALVADOR, 2010).
} 
O desenvolvimento das forças produtivas, a organização da classe trabalhadora, a composição dos partidos políticos e processos de estruturação democrática atribuíram características particulares a cada sistema nacional, as quais foram analisadas por diferentes autores, como Gosta Esping-Andersen ${ }^{33}$ (1991), que desenvolveu análises comparativas de estabelecimento de modelos e proteção social, tendo como referência os sistemas bismarckiano ${ }^{34}$ (alemão) e assistencial beveridgiano $^{35}$ (inglês). Segundo Boschetti (2012, p. 764), apesar das diferentes características desses sistemas, todos apresentam "[...] forte regulação do mercado de trabalho pelo Estado, tendo como pressuposto um acordo entre capital-trabalho e como condição o estabelecimento do pleno emprego e forte arrecadação financeira".

Desse modo, ao tentarmos remontar a origem do Estado de Bem-Estar Social, observamos que ele se constituiu em um sistema nacional público que buscava responder a demandas por maior igualdade e segurança nas economias de mercado, porém as ações variavam segundo as especificidades históricas e políticas dos diferentes países. Assim, o Estado de Bem-Estar Social se constituiu nas correlações de forças entre classes e grupos sociais, com diversos interesses em diferentes contextos histórico-políticos. Nesse sentido, concordamos com as palavras de Jacobi (2003, p. 3), quando afirma que as origens do Welfare State "[...] são heterogêneas e refletem uma variedade de fatores e realidades políticas". Consequentemente, o Welfare State

\footnotetext{
${ }^{33}$ Esping Anderson (1991) identificou três regimes de Bem-Estar Social nos países desenvolvidos: liberal, conservador-corporativo e social-democrata. O regime liberal (Estados Unidos, Canadá e Austrália) é marcado pelo dualismo entre Estado e mercado, com ênfase na assistência aos mais pobres com poucas transferências universais e planos modestos de previdência social. A lógica que prevalece é a igualdade das necessidades mínimas. O regime conservador-corporativo (Áustria, França, Alemanha e Itália) é caracterizado pelo conservadorismo e corporativismo, no qual os direitos estão relacionados à classe e aos status. E, por último, o regime social-democrata (Inglaterra e Suécia) busca um Estado que promova a igualdade com um bom padrão de qualidade, ou seja, programas sociais, em que todos os setores são incorporados a um sistema universal de seguros, mesmo se os benefícios forem definidos de acordo com os ganhos.

${ }^{34} \mathrm{O}$ modelo de proteção social da Alemanha sob a direção de Bismarck, instituído entre 1883 e 1889, englobava o seguro-saúde, o seguro acidente de trabalho e os benefícios de aposentadoria por invalidez e idade, porém era restrito aos trabalhadores assalariados e o acesso aos seguros sociais era feito mediante contribuição prévia (SALVADOR, 2010).

${ }^{35} \mathrm{O}$ modelo assistencial beveridgiano, desenvolvido, na Inglaterra, após Segunda Guerra Mundial, por Willian Beveridge, preconizava a prestação pública de serviços sociais universais e uma rede de serviços de assistência, destinados a todas as pessoas, assegurando, principalmente, os mínimos sociais às pessoas em condições de necessidade. $O$ financiamento era proveniente dos impostos fiscais, e a gestão era pública e estatal (BOSCHETTI, 2007).
} 
[...] consiste num conjunto de instituições públicas que atuam como instância de distribuição secundária da renda através de transferências monetárias diretas (pensão, seguro desemprego, aposentaria, cuidados médicos gratuitos, suplementação alimentar, segurança de trabalho, e outras formas de proteção), o que caracteriza direitos e garantias. (JACOBI, 2003, p. 4).

Para Behring (2002), no contexto do Estado de Bem-Estar Social, a ação estatal tentou amenizar a crise por meio de mecanismos impensáveis pela burguesia liberal: a planificação indicativa da economia, no sentido de evitar os riscos das amplas flutuações periódicas; a intervenção na relação capital-trabalho por intermédio da política salarial e do controle de preços; a política fiscal e, dentro dela, os mecanismos de renúncia fiscal; a oferta de crédito combinada a uma política de juros; e as políticas sociais. Nessa perspectiva, o Estado, enquanto gestor de políticas anticíclicas ${ }^{36}$, implementou sistemas nacionais de proteção social, baseados nos impostos dos próprios trabalhadores, uma vez que "[...] tais sistemas nunca foram financiados pelo imposto progressivo sobre o lucro, o que poderia constituir uma verdadeira redistribuição em favor dos trabalhadores" (BEHRING, 2002, p. 167). Desse modo, as políticas sociais se instauravam no sentido de regular o processo da força de trabalho. De acordo com Behring (2002, p. 171), para o capital, "[...] a regulação estatal só faz sentido quando gera um aumento da taxa de lucros, intervindo como um pressuposto do capital em geral. Dentro disso é que se torna viável certa redistribuição horizontal e limitada na forma de salários indiretos". Assim, compreende-se o ataque do discurso neoliberal às políticas sociais, quando a regulação estatal cede aos interesses do trabalho, interferindo nas demais ações em benefício do capital. Nessa perspectiva, as políticas sociais foram importantes estratégias para sustentar o crescimento, no modo de regulação Keynesiano ${ }^{37}$, isto é, para a reprodução ampliada do capital. Contraditoriamente, também serviram como base para intervenção do Estado nas relações de produção do capitalismo nos países capitalistas da América Latina, muito embora, nesses contextos, o pleno emprego e a universalização dos direitos sociais nunca tenham sido uma realidade (BOSCHETTI, 2012). Assim, concordamos com a autora quando diz:

\footnotetext{
36 Conjunto de ações governamentais voltadas a minimizar os efeitos perniciosos do longo ciclo econômico. No contexto do capitalismo e do Estado de Bem-Estar Social, foram ações desenvolvidas pelo Poder Público com o objetivo de conter as taxas de lucros e obter controle sobre o ciclo do capital (BEHRING, 2002).

37 Ver nota $n^{\circ} 32$.
} 
O reconhecimento dos direitos sociais e, sobretudo, sua universalização nos sistemas de proteção social capitalista, seja em forma de bens e serviços, seja em forma de prestações sociais monetárias, possibilitaram a melhoria das condições de vida, certa redução das desigualdades sociais e certa socialização do fundo público, mas seguramente não desmercantilizaram as relações sociais, que continuam regidas pelas relações capitalistas fundadas na socialização da produção e apropriação privada de seus resultados. (BOSCHETTI, 2012, p. 758).

Entretanto, faz-se necessário ressaltar que o Estado de Bem-Estar Social incorporou referenciais de condições de cidadania e de acesso aos direitos sociais (como educação, saúde, habitação, trabalho, entre outros). O seu crescimento estava articulado com a expansão dos princípios socialistas e com a crescente pressão social por melhores condições de vida e trabalho, representados, principalmente, pela classe trabalhadora, sua organização e mobilização sindical. Segundo Paul Singer (2010, p. 233), a luta do "movimento operário por direitos sociais e políticos deu frutos e estes fortaleceram a classe trabalhadora e tornaram o Estado, em um número cada vez maior de países e finalmente no plano mundial, o responsável pelo respeito a esses direitos”, ou seja, o Estado foi se transformando em "agente, como disse Marx, da classe trabalhadora" (SINGER, 2010, p. 233), portanto, como instituição capaz de assegurar e implementar os direitos sociais dos trabalhadores.

Diante das transformações econômicas e sociais, para Pereira P. (1998, p. 88-89), ergue-se uma nova faceta da organização capitalista baseada em uma

[...] economia mista, por meio da qual Estado e mercado se articulam e se co-responsabilizam pela formulação e gerenciamento de políticas favorecedoras de pleno emprego e de um conjunto de benefícios e serviços que, na perspectiva dos direitos, asseguravam aceitáveis padrões de vida aos cidadãos, [...] sem, contudo, alterar a estrutura de dominação burguesa e as relações de propriedade capitalistas prevalecentes.

Isso não quer dizer, porém, que a política do Estado de Bem-Estar Social não tenha representado uma mudança no padrão de proteção social que vigorava antes dos anos de 1940 e que não tenha propiciado à classe trabalhadora ganhos sociais e políticos. No âmbito das estruturas desse Estado, consolidaram-se as forças 
sindicais, instituíram-se os direitos de cidadania e fortaleceram-se instituições democráticas (PEREIRA P., 1998).

No entanto, no início da década de 1970, o modelo de Estado de Bem-Estar Social, nos países centrais, foi colocado em xeque, devido às limitações de suas políticas "diante da internacionalização do capital com sinais de esgotamento do padrão de financiamento das políticas sociais e a reação do capital à queda das taxas de lucro, na sua sanha pela acumulação e, portanto, por superlucros" (SALVADOR, 2010, p. 92). Nessa perspectiva, se a maioria das economias capitalistas experimentara, no pós-guerra, um crescimento econômico sem precedentes, articulado à expansão de programas e sistemas de bem-estar, parece que, agora, a aliança entre as políticas econômica e social atingiu seus limites e esgotou suas potencialidades (DRAIBE; HENRIQUE, 1988).

O Estado de Bem-Estar Social começou a apresentar seu primeiro sintoma da crise ainda na década de 1970. Sonia Daibre e Wilnês Henrique (1988) sistematizaram as diferentes abordagens (da literatura internacional) que analisaram as razões da crise do sistema de proteção social. Nessa perspectiva, para alguns autores (HIRSCHAMAN, 1980; DELCOURT, 1982; PERRIN, 1981; HASLEY, 1981), o Estado de Bem-Estar Social não passou por uma verdadeira crise; sofreu antes uma mutação em sua natureza e operação, ou seja, sofreu apenas mudanças em sua natureza administrativa; por isso, eles defendiam maior efetividade dos programas sociais e a redefinição no seu financiamento. Para autores como Huntfor, 1971; Friedman, 1977; Giilder, 1982, considerados conservadores, houve uma efetiva crise, pela própria estrutura e financiamento do Estado de Bem-Estar Social, que foi por eles considerado como uma estrutura perniciosa e correspondeu a uma concepção perversa e falida do Estado, na medida em que a expansão dos gastos públicos com a área social promoveu déficits para o Estado e comprometeu os mecanismos de mercado, provocando a inflação e o desemprego. Desse modo, a solução perpassava pela redução de programas sociais, redução de benefícios e privatização dos serviços. Outros autores ainda, (ROSSANVALLON, 1981; TAMBURI, 1983; O'CONNOR, 1977), defenderam que a crise era de caráter financeiro fiscal, que se expressava no crescimento dos gastos públicos mais rápido que o crescimento do meio de financiá-los. E, por último, houve autores (SEFER, 1981; WALZER, 1982; GOUGH, 1975) que afirmaram que o problema estava na 
burocratização, na ineficácia e na centralização excessiva do Estado, aumentando a ineficiência dos programas sociais.

Nesse contexto de crise, Evilásio Salvador (2010, p. 92) destaca que "[...] a ofensiva do capital vai trazer sérios riscos à proteção social e às conquistas sociais do período após Segunda Guerra. A nova fase de acumulação capitalista vai ser capitaneada pela esfera financeira" e, no campo ideológico, pelo neoliberalismo. Nos anos de 1980, uma nova concepção econômica entrou em cena em oposição ao keynesianismo, isto é, "[...] o liberalismo econômico revisitado e adaptado ao capitalismo globalizado e à produção flexível" (SALVADOR, 2010, p. 104), de forma que a solução apontada pelos neoliberais para evitar a crise das economias de mercado é

[...] manter um Estado forte, sim, em sua capacidade de romper o poder dos sindicatos e no controle do dinheiro, mas parco em todos os gastos sociais e nas intervenções econômicas. A estabilidade monetária deveria ser a meta suprema de qualquer governo. Para isso seria necessária uma disciplina orçamentária, com a contenção dos gastos com bem-estar, e a restauração da taxa "natural" de desemprego, ou seja, a criação de um exército de reserva de trabalho para quebrar os sindicatos. Ademais, reformas fiscais eram imprescindíveis, para incentivar os agentes econômicos. (ANDERSON, 1995, p. 11).

O neoliberalismo ergueu-se depois da Segunda Guerra Mundial, na região da Europa e da América do Norte onde predominava certo tipo de capitalismo. Essa doutrina começou como forte reação teórica e política ao Estado de Bem-Estar, ou seja, contra qualquer intervenção por parte do Estado nos mecanismos de mercado. A partir da crise do modelo keynesiano em 1973, o mundo capitalista entra em profunda recessão, combinando baixas taxas de crescimento com altas taxas de inflação. E a doutrina neoliberal se expande, sendo adotada, a partir de 1979, por Margareth Thatcher na Inglaterra e Ronald Reagan nos Estados Unidos, em 1980 (ANDERSON, 1995).

Perry Anderson (1995, p. 12) descreve o pacote sistemático de medidas implantado na Inglaterra, as quais serviram de base para os demais países que adotaram o neoliberalismo: 
Os governos Thatcher contraíram a emissão monetária, elevaram as taxas de juros, baixaram drasticamente os impostos sobre os rendimentos altos, aboliram controles sobre os fluxos financeiros, criaram níveis de desemprego massivos, aplastaram greves, impuseram uma nova legislação anti-sindical e cortaram gastos sociais. E finalmente, [...] se lançaram num amplo programa de privatização, começando por habitação pública e passando em seguida a indústrias básicas como o aço, a eletricidade, o petróleo, o gás e a água.

Nesse cenário, ocorrem importantes transformações na relação capitaltrabalho, devido ao processo crescente da "[...] mundialização ${ }^{38}$ dos circuitos financeiros que criam um único mercado de dinheiro, virtualmente livre de qualquer ação de governos nacionais" (TEIXEIRA, 1996, p. 196). Os grandes beneficiados são grandes oligopólios, formados pela fusão de empresas e/ou monopólios, "pelas novas oportunidades geradas pelo desenvolvimento de tecnologias informacionais aplicadas à produção e às atividades de gestão e finanças" (SALVADOR, 2010, p. 111). Esse processo foi decisivo para mudanças no próprio sistema produtivo, marcado pelas novas formas de acumulação flexível, de gestão organizacional da produção, do avanço tecnológico e dos modelos alternativos, como o toyotismo ${ }^{39}$. E também foi primordial para a desregulamentação e a flexibilização das relações de trabalho, tendo em vista que a reestruturação produtiva e a intensificação do controle da força de trabalho geraram maior excedente de mão-de-obra e, consequentemente, o aumento significativo do desemprego (ANTUNES, 1995).

Perry Anderson (1995) ressalta que, embora o neoliberalismo tenha alcançado a hegemonia como pressuposto ideológico e alguns êxitos, como a deflação dos anos de 1970, a recuperação dos lucros e a manutenção da desigualdade por meio de altas taxas de desemprego e baixos salários, o objetivo principal, que era a reanimação do capitalismo mundial, a partir da restauração das taxas de crescimento estáveis, não foi alcançado. Um exemplo, citado por Salvador (2010, p. 107), refere-se à crise financeira de 2008, nos Estados Unidos:

\footnotetext{
38 O conceito de "mundialização" foi desenvolvido por François Chesnais (1996), em seu livro $A$ mundialização do Capital, correspondendo ao processo de internalização de capitais (produtivo, comercial e financeiro), resultante da liberalização e da desregulamentação financeira que levaram à abertura dos mercados nacionais e permitiram sua interligação em tempo real.

39 O toyotismo é uma forma de organização do trabalho que nasceu na Toyota, no Japão, após 1945. É baseado na produção flexível, de acordo com a demanda do mercado e sustenta-se na existência do estoque mínimo, sendo adotado no setor industrial e estendendo-se ao setor de serviços (SALVADOR 2010).
} 
A crise teve origem nos empréstimos hipotecários norte-americanos, se arrastando inicialmente para os bancos de investimento, seguradoras e mercados financeiros, enfim, a crise se espalhou rapidamente pela economia dos EUA e atingiu todos os continentes. Por consequência, a economia global registra uma das maiores recessões da história do capitalismo.

Esse novo contexto também trouxe consequências para o financiamento do fundo público e para as políticas sociais. Afirma Salvador (2010, p. 116):

\begin{abstract}
A característica comum a todas as crises financeiras dos últimos anos é o comparecimento do fundo público para socorrer instituições financeiras falidas durante as crises bancárias, à custa dos impostos pagos pelos cidadãos. A financeirização implica pressão sobre a política social, [...], pois aí está o nicho dos produtos financeiros. Com isso, as propostas neoliberais incluem a transferência da proteção social do âmbito do Estado para o mercado, a liberalização financeira passa pela privatização dos benefícios da seguridade social.
\end{abstract}

Assim, com a financeirização da riqueza, os mercados financeiros disputam mais recursos do fundo público para serem destinados à esfera financeira, ao pagamento de juros da dívida pública, aos incentivos fiscais e à isenção de tributos em detrimento dos serviços sociais que devem ser buscados no mercado, diante da desresponsabilização do Estado pelas políticas de proteção social. Desse modo, assiste-se à mudança da direção da intervenção estatal, deixando o Estado de ser um agente econômico e configurando-se em um Estado forte, porém mínimo. Nessa perspectiva, ampliaram-se as políticas sociais baseadas na concepção liberal, centradas na diminuição do tamanho do Estado nas questões sociais e econômicas e uma preferência por processos de mercado à provisão pública, isto é, "[...] um sistema de políticas de proteção social orientados para a privatização e a desregulamentação que permitem a entrada de firmas privadas em setores antes monopolizados pelo governo" (JACOBI, 2003, p. 8). Pereira P. (2008, p. 57) ressalta que há uma

[...] tendência capitalista global de romper com a proteção gerida pelo Estado, de privatizar o patrimônio coletivo, de atender as necessidades do capital em detrimento da satisfação de necessidades sociais e de desmontar direitos sociais conquistados pelos movimentos democráticos. 
Contudo, as políticas sociais continuam sendo requeridas, porém, sobre novas bases para seguirem os desígnios do capital, por isso, focalizadas e residuais, isto é, voltadas a grupos específicos (aqueles que estão abaixo da linha da pobreza) da sociedade que necessitam de serviços públicos, a partir de

[...] fundos sociais de emergências, e a mobilização da solidariedade individual e voluntária, bem como das organizações filantrópicas e organizações não-governamentais prestadoras de serviços de atendimento, no âmbito da sociedade civil a partir da redução dos gastos pelo Estado. (BEHRING, 2008a, p. 65).

Para Behring (2008a, p. 63), o Estado desempenha um novo papel no contexto do século XX, especialmente, nos países de capitalismo central (Estados Unidos, Alemanha, Japão), dando-se sua intervenção sob a forma do financiamento público ao capital privado, ou seja, "a reorientação do fundo público para as demandas do empresariado, combinada à queda da receita engendrada pelo ciclo depressivo e à diminuição da taxa sobre o capital, que alimentam a crise fiscal".

Para a autora, a ampliação dos gastos em detrimento das receitas gerou a "crise fiscal" do Estado, tendo em vista o aumento das despesas com as demandas de proteção social, por parte dos trabalhadores, em relação à depressão dos fatores de crescimento e as tendências de queda da taxa de lucros. Cabe destacar que, diante da crise fiscal, criou-se uma pressão sobre o orçamento público, acirrando-se a disputa em torno dos recursos públicos. Nesse contexto, as políticas sociais são concebidas como fontes de desequilíbrio e devem ser acessadas via mercado; portanto, deixam de ser consideradas como direito social (BEHRING, 2008b). Daí, erguem-se as tendências de desresponsabilização do Estado pelas políticas sociais e pelo seu financiamento, configurando um Estado mínimo para os trabalhadores e um Estado máximo para o capital (NETTO, 1993).

Diante desse cenário histórico-político, e considerando que a constituição do Estado e das políticas sociais assumiu configurações específicas nos diferentes países, faz-se necessário compreender como ocorreu esse processo no contexto brasileiro. 


\subsubsection{A constituição do Estado e da política social no Brasil}

O desenvolvimento de uma perspectiva de Estado de Bem-Estar Social no Brasil, observado a partir da promulgação da CF/1988, assumiu configurações específicas, considerando-se as tradições políticas, econômicas e socioculturais desse país, marcadas por uma dinâmica interna conservadora e por determinações advindas da relação com o exterior, ou seja, da articulação e da dependência com a dinâmica do mercado mundial, desde o processo de colonização, incluindo o período Imperial (1822-1889) e de República (1930-1945) até a atualidade (BEHRING, 2008a).

A afirmação da autora baseia-se nos pressupostos de Florestan Fernandes em sua obra A revolução Burguesa no Brasil (1987), na qual o autor apresenta uma interpretação dialética da formação social e da constituição do Estado no Brasil. Para o autor, a constituição do Estado brasileiro foi caracterizada por mudanças políticas, econômicas e sociais que contribuíram para a consolidação da ordem capitalista no Brasil, marcada pelos seguintes processos: político (abertura dos portos, em 1808, e independência, em 1822); econômico (transformações nas relações entre o capital internacional e a economia interna); sociocultural (surgimento de novos agentes humanos - o fazendeiro de café e o imigrante); e socioeconômico (iniciado com a abolição da escravatura, em 1888, até a Proclamação da República, em 1889).

Fernandes (1987) destaca que a sociedade brasileira assumiu um estilo próprio para o desenvolvimento do capitalismo. Esse processo foi impulsionado pela criação do Estado nacional brasileiro, com o processo de Independência (1822), que marca a transição da sociedade colonial para a sociedade nacional, em que o poder deixa de ser exercido de fora para dentro, para "organizar-se a partir de dentro" (FERNANDES, 1987, p. 31). Contudo, segundo o autor, esse novo cenário abrigava elementos antagônicos: o revolucionário, uma vez que procurava romper com a ordem social em busca de autonomia necessária para a formação da sociedade nacional, inspirado pelos princípios do liberalismo, incorporado pela burguesia, na tentativa de assegurar seus próprios interesses na luta contra os interesses da coroa portuguesa; e o conservador, na medida em que esse processo preservou a ordem 
social do período colonial, baseada no trabalho escravo, na concentração de renda, no monopólio do poder pelas elites sem condições materiais e morais para a construção de uma nação autônoma, na marginalização da população e na fragilidade nacional perante as grandes nações. Nesse contexto, o Estado era visto como "[...] meio de materializar os centros de decisão política e de institucionalizar o predomínio das elites nativas dominantes" (BEHRING, 2008a, p. 92). Assim, ocorreu a dominação burguesa na formação do poder político na sociedade brasileira.

No que tange ao processo econômico, Fernandes (1987) destaca que, com a ruptura do estatuto colonial, as atividades de comércio e produção foram internalizadas, ou seja, passaram a ser controladas "por dentro", e diversificadas no intuito de atender ao mercado externo e aos padrões capitalistas, estando, porém, ainda baseadas na manutenção da escravidão e em uma economia voltada para a exportação. Segundo Fernandes (1987, p. 80), "[...] estamos diante de uma evolução histórica em que o 'setor velho' da economia não se transformou nem se destruiu para gerar o 'setor novo'”. De acordo com Behring (2008a, p. 96), "cria-se uma situação de mercado, em acordo com possibilidades e limites socioeconômicos e culturais de expansão do mercado interno, numa economia voltada para a exportação". Cabe acrescentar que a internalização do processo de comercialização provocou a entrada do capital estrangeiro, a absorção de instituições econômicas e de tecnologia que contribuíram para o desenvolvimento da economia brasileira, com a introdução de padrões capitalistas no comércio e mudanças no comportamento dos agentes econômicos. Assim, a heteronomia, isto é, a dependência do capital externo, passou a ser a marca estrutural da economia brasileira (FERNANDES, 1987).

Quanto ao processo sociocultural, Fernandes (1987) destaca o surgimento de novos agentes econômicos: o fazendeiro de café, que diversificou suas atividades a partir da modernização das suas fazendas, com o abandono da mão de obra escrava e introduziu novas técnicas voltadas à ampliação da produtividade e do lucro, no intuito de manter o seu monopólio de poder e liderança na vida econômica e política, assegurando a defesa de seus interesses; e a partir de 1870, o imigrante, que trouxe novos conhecimentos e padrões culturais para a economia interna brasileira, contribuindo para ajustá-la ao modelo capitalista. 
O processo socioeconômico foi caracterizado pela abolição da escravatura (1888) e a substituição pelo trabalho livre, impulsionados pela crise do poder oligárquico-escravista e pela inserção da economia brasileira à economia internacional. A instituição de um novo regime político no Brasil, com a Proclamação da República (1889), contribuiu, de acordo com Fernandes (1987), para a consolidação do poder da elite brasileira, a partir da constituição de um "Estado burguês", na medida em que se formou um Estado para assegurar os interesses sociais, econômicos e políticos dessa classe social. De acordo com Behring (2008a, p. 91), no processo de construção de uma nova sociedade nacional, foram decisivos os processos de

[...] ruptura com a homogeneidade da aristocracia agrária, ao lado do surgimento de novos agentes econômicos, sob a pressão da divisão do trabalho [...] Contudo, esse movimento é marcado pela ausência de compromisso com qualquer defesa mais contundente dos direitos do cidadão por parte das elites econômico-políticas. (BEHRING, 2008a, p. 91).

Desse modo, permaneceram intocáveis os componentes conservadores do Estado brasileiro, no intuito de preservar a ordem social. Concordamos com Behring (2008a, p. 95) quando diz que "[...] o Estado brasileiro nasceu sob o signo de forte ambiguidade entre um liberalismo formal como fundamento e o patrimonialismo como prática no sentido de garantia dos privilégios estamentais". Em linha semelhante, Gilda Cardoso de Araújo (2007, p. 11) afirma que

[...] o surgimento do Estado não correspondeu a um processo de gradativa institucionalização da esfera pública e que, portanto, a formalização dos direitos civis e políticos coexistiam com as relações de favorecimento e tutela entre atores desiguais e que os direitos sociais vieram mais como concessão do reformismo das elites políticas do que como consequência de movimentos orgânicos de participação popular.

As primeiras medidas de proteção, no Brasil, originaram-se com mais de trinta anos de atraso em relação aos países centrais do capitalismo (SALVADOR, 2010). De acordo com Jacobi (2003), o sistema de proteção social no Brasil, antes de 1988, era fundamentado num modelo de seguro social, associado institucionalmente e 
financeiramente à área de previdência com um modelo assistencial, ou seja, como uma ação pública desprovida de reconhecimento legal como direito, para a população sem vínculos trabalhistas. Desse modo, apenas no início do século XX, temos a estruturação da proteção social brasileira, baseado no modelo bismarckiano alemão, que tinha como objetivo "[...] garantir maior segurança ao trabalhador assalariado e à sua família, em situações de inatividade, numa sociedade urbana na qual não era mais possível manter os vínculos de solidariedade que existiam na estrutura econômica rural" (SALVADOR, 2010, p. 137).

$\mathrm{Na}$ década de 1920, houve mudanças em relação à postura do Estado brasileiro, a qual, no período de 1881 a 1919, foi notadamente de cunho liberal. As alterações referem-se a uma maior intervenção do Estado nas questões sociais em resposta à pressão dos trabalhadores (BEHRING, 2008a). Assim, as políticas governamentais de cunho social tiveram seu início no Brasil junto ao processo de industrialização e urbanização do país. A literatura aponta o ano de 1923 como marco inicial desse processo, uma vez que foi estabelecida nesse ano a primeira política pública de previdência social para trabalhadores, por meio do Decreto nº 4.682, de 24 de janeiro de 1923, conhecido como a Lei Eloy Chaves. O decreto determinava a criação obrigatória, em cada ferrovia do país, de um fundo de aposentadorias e pensões, as Caixas de Aposentadoria e Pensões - CAPs. Posteriormente, o sistema das CAPs foi estendido a outros setores produtivos. De acordo com Maria Paula Gomes dos Santos (2009, p. 50), "as CAPs eram organizadas por empresas, e o Estado não participava nem do seu financiamento nem da sua administração, tendo como um papel de controle, a distância", por meio do Ministério do Trabalho. Para Jaime Antonio de Araújo Oliveira e Sonia Maria Fleury Teixeira (1985), essa seria a primeira fase da política social no Brasil, até a revolução de 1930, quando os direitos foram ampliados a um número maior de trabalhadores.

O governo de Getúlio Vargas (1930 a 1945) produziu grandes transformações políticas no Brasil. Segundo Salvador (2010), a partir de 1930, o Estado passou a intervir na organização da vida econômica e social do país e a regulamentá-la. $O$ início do processo de industrialização provocou mudanças substanciais na estrutura ocupacional da população e sua alocação em diversos setores econômicos, como agricultura, indústria e serviços, o que produziu crescimento das cidades e 
problemas sociais, como a falta de assistência à saúde, de habitação e de saneamento básico. De acordo com Oliveira e Teixeira (1985), esse período corresponde à segunda fase de política social no Brasil.

A partir de 1933, Vargas criou diversos Institutos de Aposentadoria e Pensões (IAPs), que eram instituições vinculadas aos sindicatos dos trabalhadores, responsáveis por oferecer assistência médica e outros benefícios sociais, como aposentadorias e pensões. Devido a sua vinculação com os sindicatos, os trabalhadores beneficiados eram apenas os sindicalizados; assim, um grande contingente ficou à margem desse sistema. Nessa perspectiva, o sistema de proteção social brasileiro desenvolveu-se de forma fragmentada e excludente. Cabe destacar que ocorreu, nesse contexto, contraditoriamente, o aumento do número de segurados e a conquista de inúmeros direitos trabalhistas ${ }^{40}$, representando, segundo Oliveira e Teixeira (1985), a expansão da cidadania no país.

Na CF/1934, por exemplo, foi estabelecido o custeio tríplice da Previdência social com a participação do Estado, dos empregadores e empregados. Contudo, Salvador (2010, p. 147) ressalta que o repasse dos recursos que deveria ser destinado aos institutos de previdência era desviado para outras finalidades. "Na prática, a previdência permanecia sem ônus para o Estado e, ainda, tornava-se um importante instrumento de acumulação de recursos, que foram destinados ao financiamento do processo de industrialização brasileira". O autor destaca ainda que, nesse período (1930 a 1945), reafirma-se a lógica do seguro privado e assinala-se o apogeu do regime financeiro de capitalização, uma vez que esse modelo entendia que o Estado não deveria custear, por meio do orçamento fiscal, os gastos previdenciários; assim, caberia aos próprios trabalhadores assumir essas despesas.

No período de 1945 a 1963, com o movimento de pressão social e de redemocratização do país após 1945 e com o fim do Estado Novo, os trabalhadores reivindicavam, no âmbito da previdência, a manutenção dos patamares mínimos de suas contribuições e, por outro lado, exigiam a valorização dos planos de benefícios e serviços (SALVADOR, 2010). Nesse período, o autor aponta um aumento dos

\footnotetext{
40 Getúlio Vargas criou a Justiça do Trabalho (1939) e implantou vários direitos trabalhistas como a Consolidação das Leis do Trabalho (CLT), instituição do salário mínimo, carteira profissional, semana de trabalho de 48 horas e férias remuneradas.
} 
gastos sociais pela União. Em 1960, há a aprovação da Lei Orgânica da Previdência Social (LOPS), que estabeleceu a uniformização dos planos de contribuição e benefícios entre os diversos institutos e ampliou a cobertura do sistema de seguro social, porém mantinha excluídos os trabalhadores rurais e os trabalhadores sem vínculo empregatício, inseridos em relações precárias e informais no mercado de trabalho.

Em 1966, os diversos Institutos foram unificados no Instituto Nacional de Previdência Social (INPS), no contexto de uma ordem política autoritária, com o golpe militar de 1964. No INPS, a representação dos trabalhadores e dos empregadores no conselho gestor foi reduzida e o novo conselho da Previdência foi exercido pelos representes do regime militar. Desse modo, ocorreu uma centralização das políticas sociais na execução no governo federal e a exclusão dos trabalhadores da gestão das instituições previdenciárias. Nessa direção, Jacobi (2003) afirma que o sistema de proteção social foi orientado por uma centralização do poder nas mãos de técnicos, sob a justificativa de racionalidade técnica e de eficácia administrativa e pela exclusão dos trabalhadores dos processos decisórios. Toda essa modificação ocorrida nesse período, apesar de indicar a expansão dos benefícios e da assistência, "[...] não alterou os princípios da estrutura da previdência social, que manteve a lógica de seguro, ou seja, o acesso ao benefício somente via contribuição" (SALVADOR, 2010, p. 157).

Evaldo Vieira (1985) destaca que a política social no Brasil percorreu momentos distintos do século XX. O primeiro (1930-1954), discutido anteriormente, compreende o período denominado "Política social como controle da política", em que a política social se reduziu a um conjunto de deliberações predominantemente setoriais na educação, na saúde, na habitação, na previdência social e na assistência social. Inexistia, assim, por parte da atuação governamental, qualquer preocupação mais profunda com transformações estruturais que alcançassem a essência da política social, na qual, ao contrário, "predominavam o urgente e o atenuante" (VIEIRA, 1985, p. 185), cuja finalidade era garantir a paz social, a manutenção da ordem pública, dentro da preocupação mais geral de evitar conflitos. Entretanto, Vieira (1985) ressalta que foi nesse contexto que a política social se configurou como estratégia de mobilização e, de qualquer maneira, representou um conjunto de direitos da população perante o Estado. "Devido às lutas sociais e às 
pressões sobre o poder estatal a política social irrompe como limite de concessão do capitalismo, tomando a forma dos direitos sociais e do bem-estar social" (VIEIRA, 1985, p. 232).

O segundo período corresponde à "Política social como política de controle" (1964-1988), referindo-se o autor à época da instalação da ditadura militar de 1964 até a conclusão dos trabalhos da Constituinte de 1988. A política social nesse período restringiu-se a uma série de ações setoriais, servindo em geral para desmobilizar as camadas carentes da sociedade. "Ela ofereceu serviços, antes de perguntar quais eram as necessidades reais" (VIEIRA, 1985, p. 227). Desse modo, a política social consistiu, sobretudo, em controle da população, num contexto em que desapareceu qualquer representatividade em órgãos de política social em que esta se configurou "como investimento ou encargo, a ser pago por quem já recolhe tributos" (VIEIRA, 1985, p. 232).

Assim, entre 1964 e 1970, ocorreu uma transformação no arcabouço institucional e financeiro da política social, em que foram introduzidos novos mecanismos de financiamento de programas sociais, por meio da criação do Fundo de Garantia por Tempo de Serviço (FGTS) e dos fundos do Programa de Integração Social (PIS) e o Programa de Formação do Patrimônio do Servidor Público (Pasep). Dava-se início a um sistema de financiamento por meio de fundos especiais que não integravam o sistema fiscal. Segundo Jacobi (2003, p. 14),

[...] um dos maiores problemas do modelo implantado foi o próprio modo de financiamento, sustentado basicamente por contribuições sociais com uma participação residual do sistema tributário, não desenvolvendo quaisquer tipo [sic] de função redistributiva e excluindo parcela substantiva da população.

Em 1977, foi criado o Sistema Nacional de Previdência e Assistência Social (Sinpas), a partir da junção do INPS e do Instituto de Administração Financeira da Previdência e Assistência Social (IAPAS). O sistema consistia na reformulação administrativa de atribuições ligadas à previdência e assistência social, a partir da existência de um sistema privado de saúde para o atendimento dos ricos; de planos de saúde destinados a um grupo seleto de trabalhadores assalariados; de seguro público para os contribuintes da previdência social; e os pobres ficavam à margem 
da caridade alheia (FALEIROS, 2000). Com o Sinpas, há a confirmação do caráter do seguro social pela lógica da contribuição dos beneficiários. Nessa perspectiva, Salvador (2010, p. 158) salienta que as mudanças ocorridas durante a ditadura militar não conseguiram atingir um padrão de bem-estar social, pois "[...] a expansão dos programas sociais foi seletiva e com o favorecimento do setor privado nas áreas de saúde e previdência (seguros), habitação e educação", ou seja, o Estado não conseguiu garantir, por meio de recursos públicos, os serviços sociais a todos os cidadãos.

Ao final da década de 1970, no Brasil, o padrão de proteção social existente já apresentava indícios de esgotamento e crise nos aspectos organizacionais e sociais, mas, principalmente, financeiros, marcados pela crise econômica e pela implantação de políticas de ajuste fiscal. No início dos anos de 1980, Jacobi (2003) observa mudanças nas perspectivas dos planos e programas de governo, em que a ênfase foi o fortalecimento da proteção social para as camadas mais vulneráveis da população. Faz-se necessário ressaltar, segundo Salvador (2010, p. 158), que a década de 1980 foi marcada pela recessão econômica nacional resultante do "[...] agravamento da economia capitalista decorrente, sobretudo, da instabilidade macroeconômica: hiperinflação, recessão, ciranda financeira e crise da dívida externa", comprometendo os investimentos públicos e, consequentemente, as despesas com as políticas sociais.

Foi neste cenário que o Brasil foi tomado por uma grande expansão dos movimentos sociais, com as reivindicações organizadas pelos trabalhadores, estudantes, partidos políticos, entre outros, em período de redemocratização do país, o que possibilitou a incorporação, na CF/1988, de muitas demandas sociais de expansão dos direitos sociais e políticos. Para Romualdo Portela de Oliveira (2007) um dos maiores avanços, em termos de direitos sociais, refere-se ao direito à educação, que aparece no art. 6" nos seguintes termos: "São direitos sociais a educação, a saúde, o trabalho, o lazer, a segurança, a previdência social, a proteção à maternidade e à infância, a assistência aos desamparados, na forma desta Constituição" (BRASIL, 1988). Segundo assegura o mesmo autor, no capítulo da educação, art. 205, afirma-se a responsabilidade do Estado na oferta da educação: "A educação, direito de todos e dever do Estado e da família, será promovida e incentivada com a colaboração da sociedade, visando ao pleno desenvolvimento da 
pessoa, seu preparo para o exercício da cidadania e sua qualificação para o trabalho" (BRASIL, 1988). Para viabilizar essas propostas e permitir a sua implementação, a Carta Magna estabeleceu a vinculação de percentuais mínimos da União, do Distrito Federal, dos estados e dos municípios a serem aplicados à educação. Jacobi (2003, p. 19) afirma:

A extensão dos direitos sociais se expressa através da ampliação dos deveres do Estado e da descentralização dos recursos para Estados e municípios em decorrência da reforma tributária. Na área da educação, acresce-se a aplicação obrigatória de recursos para a manutenção e desenvolvimento do ensino.

Assim, a CF/1988 abriu a possibilidade da construção de um sistema universal de proteção social, baseado na concepção social-democrata e nos pressupostos do Estado de Bem-Estar Social europeu. Porém, o processo de implantação dos direitos sociais não se concretizou; ao contrário, observou-se, segundo Behring (2008a, p. 129), um processo de contra-reforma ${ }^{41}$, que acabou com a possibilidade política, ainda que limitada, de uma "reforma democrática no país, que muito possivelmente poderia ultrapassar os próprios limites da socialdemocracia, realizando inacabadas tarefas democrático-burguesas em combinação com outras de natureza socialista". Nessa perspectiva, Araújo, G. (2007, p. 9) ressalta:

\begin{abstract}
Essa introdução tardia da concepção universalista dos direitos sociais guarda relação com a não institucionalização de uma esfera pública democrática, pois os ideais de igualdade e justiça eram e ainda são introduzidos numa sociedade marcada por relações verticalizadas e autoritárias e, portanto, fraturada internamente por suas contradições.
\end{abstract}

Nessa perspectiva, para Jacobi (2003), no governo de Fernando Collor de Mello (1990-1992), com o processo de desmantelamento da ação estatal e dos programas destinados aos setores mais pobres da população, consolidou-se um

\footnotetext{
${ }^{41}$ A autora realiza uma crítica ao termo "reforma", que, em sua opinião, é inadequado para se referir às mudanças ocorridas no Brasil nos anos 1990, tendo em vista a "apropriação indébita e fortemente ideológica da ideia reformista, a qual é destituída de seu conteúdo progressista e submetida ao uso programático, como se qualquer mudança significasse uma reforma, não importando seu sentido, suas consequências sociais e direção sociopolítica" (BEHRING, 2008a, p. 128).
} 
processo de desmonte das políticas sociais. Assim, foi nesse governo que a agenda neoliberal encontrou terreno fértil para sua implantação no Brasil, por meio das denominadas "reformas" orientadas para o mercado como complemento do processo de modernização, tendo em vista a recuperação da sua capacidade financeira e gerencial. Conforme Maria Clara Couto Soares (2009, p. 36), esse governo

[...] implementou diversos programas de estabilização, cortou gastos públicos, renegociou dívida externa, promoveu abertura comercial, flexibilizou e estimulou o ingresso de capitais estrangeiros, deu início ao programa de privatização, eliminou diversos programas de incentivo e controle de preços, aumentou exportações, além de ter desmantelado os serviços e políticas públicas.

A autora salienta, ainda, que os governos de Fernando Henrique Cardoso (1995-2002) deram continuidade às "reformas" neoliberais, por meio da ampliação do processo de abertura econômica, da intensificação da privatização e da aprovação de uma série de mudanças constitucionais que coincidem com as propostas do Banco Mundial ${ }^{42}$, como "a reforma do sistema previdenciário, a revisão do sistema tributário, a flexibilização dos monopólios, a concentração dos recursos para educação no ensino básico, entre outras" (SOARES, 2009, p. 37). Em linha semelhante, Frigotto (2011, p. 240) afirma que as reformas neoliberais, durante esse governo, "[...] em nome do ajuste, privatizaram a nação, desapropriaram o seu patrimônio, desmontaram a face social do Estado e ampliaram a sua face que se constituía como garantia do capital", solapando a possibilidade de desenvolvimento de uma concepção de Estado voltada à implantação dos direitos sociais preconizados na CF/1988.

Para Behring (2008a), essas transformações em curso, na década de 1990, não são resultantes da crise do Estado, já que se constituem, antes de tudo, em uma reação do capital ao ciclo depressivo aberto no início dos anos de 1970, que pressupunha uma redefinição do papel do Estado, tendo em vista as transformações

\footnotetext{
42 Banco Internacional para a Reconstrução e Desenvolvimento, foi criado na Conferência de Bretton Woods, em julho de 1944, como instrumento para financiar a reconstrução dos países destruídos pela Segunda Guerra Mundial, sobretudo na Europa. À medida que os países europeus se estabeleceram, - Banco Mundial passou a conceder empréstimos aos países em desenvolvimento, bem como reorientação política e econômica. Além de oferecer aconselhamento econômico e assistência técnica. (ARRUDA, 2009).
} 
no mundo do trabalho e da produção, baseada na reestruturação produtiva e na acumulação flexível. Como consequência dessa nova organização, houve um processo de desregulamentação e eliminação dos direitos trabalhistas, aliadas à precarização e terceirização da força humana do trabalho e ao desemprego. Cabe destacar, nesse período, a expansão dos princípios neoliberais articulados à privatização dos serviços públicos e à publicização das políticas sociais.

Desse modo, o centro da "reforma" seria o ajuste fiscal, representado, por um lado, pela contenção de gastos e pelos parcos investimentos por parte do Estado em políticas públicas, e, por outro, pela adoção de uma política de ajustamento às necessidades do pagamento da dívida externa (SOARES, 2009), de forma a garantir a adequação do país às demandas da nova ordem mundial. É importante ressaltar que essas ações seguem as orientações das agências multilaterais, a exemplo do Banco Mundial, que enfatizavam o equilíbrio orçamentário, a partir da melhoria na eficiência e na redução dos gastos públicos, principalmente, nos setores sociais, e o direcionamento dos recursos para o pagamento da dívida externa.

Portanto, o problema não estaria localizado no Estado, e sim na necessidade de redefinir as suas funções, diante desse novo contexto mundial,

[...] corrigindo distorções e reduzindo custos; enquanto isso, a política econômica corrói aceleradamente os meios de financiamento do Estado brasileiro por intermédio de uma inserção na ordem internacional que deixa o país à mercê dos especuladores no mercado financeiro, de forma que todo o esforço de redução de custos preconizado escoa pelo ralo do crescimento galopante das dívidas interna e externa. (BEHRING, 2008a, p. 199).

Assim, a "reforma", como foi conduzida, terminou por ter um impacto irrisório em termos de aumentar a capacidade de implementação de políticas públicas, tendo em vista sua articulação com a política econômica e a dívida pública. Nesse sentido, observa-se uma forte tendência de desresponsabilização do Estado pelas políticas sociais, associada ao capital estrangeiro, ao desemprego e a pobreza. Conforme afirma Behring ${ }^{43}$ (2008a, p. 248),

\footnotetext{
${ }^{43}$ Cabe destacar que as considerações feitas por Behring (2008a) são resultado do seu estudo de doutorado intitulado "A Contra-Reforma do Estado no Brasil", defendido em 2002, no Programa de Pós-Graduação em Serviço Social da Universidade Federal do Rio de Janeiro (UFRJ). Portanto, ao final do governo de Fernando Henrique Cardoso, 1995-2002.
} 
[...] a tendência geral é a de redução de direitos, sob o argumento da crise fiscal, transformando-se as políticas sociais - a depender da correlação de forças entre as classes sociais e segmentos de classe e do grau de consolidação da democracia e da seguridade social nos países - em ações pontuais e compensatórias daqueles efeitos mais perversos da crise.

Frigotto (2011, p. 239), ao analisar a primeira década do século XXI, que se inicia com a posse do governo de Luiz Inácio Lula da Silva (2003-2010), observa, no plano social e educacional, continuidades e descontinuidades das políticas desenvolvidas na década de 1990, "mediante o combate à desigualdade dentro da ordem de uma sociedade capitalista onde sua classe dominante é das mais violentas e despóticas do mundo". Desse modo, o autor salienta a existência, nesse governo brasileiro, de uma política macroeconômica voltada aos interesses do capital e, ao mesmo tempo, o investimento na melhoria de vida da classe trabalhadora, revelando o processo contraditório desse contexto. Contudo, ele ressalta que continuidade não significa que um mesmo projeto estrutural seja conduzido da mesma forma; assim, destaca que a política desenvolvida nessa década se diferencia da política da década de 1990 em diversos aspectos, tais como os seguintes:

[...] retomada, ainda que de forma problemática, da agenda do desenvolvimento, alteração substantiva da política externa e da postura perante as privatizações; recuperação, mesmo que relativa, do Estado na sua face social; diminuição do desemprego aberto, mesmo que tanto os dados quanto o conceito de emprego possam ser questionados; aumento real do salário mínimo (ainda que permaneça mínimo); relação distinta com os movimentos sociais, não mais demonizados nem tomados como caso de polícia; e ampliação intensa de políticas e programas direcionados à grande massa não organizada que vivia abaixo da linha da pobreza ou num nível elementar de sobrevivência e consumo. (FRIGOTTO, 2011, p. 240).

Assim, o governo, ao não defender um projeto societário antagônico ao capitalismo, que é centrado em um projeto desenvolvimentista com foco no consumo, e ao propor políticas e programas educacionais ${ }^{44}$ articulados aos interesses da classe dominante, também não "[...] disputou um projeto educacional

44 Como exemplo, o autor cita o Programa Universidade para Todos (PROUNI) e o Programa de Apoio a Planos de Reestruturação e Expansão das Universidades Federais (REUNI), que, por caminhos diversos, dão conteúdo à "universidade operacional", organização social vinculada ao mercado (FRIGOTTO, 2011). 
antagônico, no conteúdo, no método e na forma" (p. 241). Nessa direção, concordamos com Frigotto (2011, p. 242) quando afirma que

[...] as concepções e práticas educacionais vigentes na década de 1990 definem dominantemente a primeira década do século XXI, afirmando as parcerias do público e privado, ampliando a dualidade estrutural da educação e penetrando, de forma ampla, mormente nas instituições educativas públicas, mas não só, e na educação básica, abrangendo desde o conteúdo do conhecimento até os métodos de sua produção ou socialização.

No Brasil, a universalização do direito à educação apresentou características peculiares, considerando sua formação social, política, econômica e cultural. No que se refere à trajetória histórica da educação especial, ou seja, à conquista dos direitos das pessoas com deficiência, TGD e altas habilidades/superdotação à educação, evidenciamos configurações específicas no tocante ao seu processo de concretização. A educação especial iniciou-se atrelada às ações isoladas, desenvolvidas no MEC, voltadas as instituições privadas de caráter assistencial, não consideradas pertencentes à rede de ensino brasileira, mas financiadas, em grande parte, com verbas públicas da educação. Só, recentemente (no final dos anos 1950 e início da década de 1960), ela se tornou política pública, isto é, uma forma de materialização da intervenção estatal na oferta e na manutenção do atendimento educacional especializado - mantido e administrado pelo Estado - nas escolas públicas dos sistemas educacionais brasileiros (KASSAR, 2001).

A expansão desse atendimento na rede regular de ensino (a partir da década de 1990) se deu num processo de reconfiguração das funções do Estado e das políticas sociais, no âmbito do neoliberalismo, revelando o caráter contraditório em que se estabelece o financiamento da educação especial no capitalismo, no qual há o distanciamento do Estado das suas responsabilidades sociais e, ao mesmo tempo, a expansão das políticas direcionadas ao público da educação especial, a partir de recursos públicos destinados às instituições públicas de ensino. Considerando que, historicamente, os parcos recursos voltados a essa modalidade de ensino foram dirigidos às instituições filantrópicas que tinham centralidade na política e na gestão da educação especial e no provimento de serviços de caráter substitutivo, prioritariamente no atendimento especializado, haja vista que a educação dessa 
população foi pouco priorizada ou assumida pelo Estado ao longo da trajetória da educação brasileira (FERREIRA, J., 2009).

Nesse contexto, a correlação de forças entre o público e o privado, no âmbito do Estado, envolve o reordenamento jurídico normativo e os elementos que compõem o sistema de financiamento da educação no Brasil, ou seja, um conjunto de normas constitucionais que regulam o gasto da receita tributária, certo número de fontes de receita vinculadas a gastos com educação e uma estrutura burocrática complexa baseada na centralização de arrecadação de recursos e na descentralização da responsabilidade dos dispêndios (FARENZENA, 2006).

Desse modo, compreendemos que a discussão acerca do financiamento em educação deve considerar o contexto político, social e econômico, assim como "algumas formas específicas da arrecadação tributária realizada em nosso país" (ARELARO et al., 2004, p. 30). Isso se justifica pelo fato de que os principais recursos destinados à educação são oriundos da arrecadação de impostos e, consequentemente, são afetados pela política econômica, pela concepção e opção do governo sobre as decisões acerca das políticas econômicas, tributárias e fiscais que determinam tanto a arrecadação quanto a aplicação de recursos financeiros na educação.

Nessa perspectiva, o fundo público estatal configurou-se como instrumento fundamental para assegurar os direitos sociais, como a educação. Desse modo, fazse necessário conhecer como se deu o seu processo de constituição no âmbito do Estado de Bem-Estar Social europeu e no contexto do Estado brasileiro, bem como sua vinculação na reprodução do capitalismo.

\subsection{O ESTADO DE BEM-ESTAR SOCIAL E O FUNDO PÚBLICO}

Na construção do Estado de Bem-Estar Social, o fundo público, segundo Francisco de Oliveira (1998), constituiu-se no padrão de financiamento público da economia capitalista, na medida em que essa economia perdeu sua capacidade autorregulatória e a esfera privada se mostrou insuficiente para tramitar e processar as novas relações sociais. Nessa perspectiva, o Estado configurou-se como 
instância necessária de publicização, tendo em vista que ele foi forjado para "[...] assegurar os interesses privados, mas só o pode fazer, somente se torna eficaz, se eles se transformam em interesses gerais públicos" (OLIVEIRA, F., 1998, p. 51). Dessa forma, o autor afirma a impossibilidade de se conceber a formação do sistema capitalista sem a utilização de recursos públicos.

Nessa direção, Salvador (2010, p. 27) salienta que o fundo público exerceu uma função ativa tanto na esfera acumulativa produtiva como no âmbito das políticas sociais, ou seja, o "[...] fundo público tem papel relevante para a manutenção do capitalismo na esfera econômica e na garantia do contrato social".

O fundo público passou a ser a base do financiamento tanto da acumulação do capital (gastos públicos com a produção, por meio de subsídios para a agricultura, para a indústria, para o comércio, para a ciência e a tecnologia, formando amplos setores produtivos estatais, e a valorização financeira do capital por meio da dívida pública) quanto da reprodução da força de trabalho, abrangendo toda a população, por meio dos investimentos e despesas sociais (educação e saúde gratuitas, previdência social, seguro desemprego, subsídios para transporte, alimentação e habitação, subsídios para cultura e lazer, salário família, salário desemprego entre outros). Contudo, Oliveira, F. (1998) ressalta que os subsídios e auxílios públicos são constitutivos do capitalismo, não sendo específicos do Estado de Bem-Estar Social.

O fundo público é agora um ex-ante ${ }^{45}$ das condições de reprodução de cada capital particular e das condições de vida, em lugar de seu caráter ex-post, típico do capitalismo concorrencial. Ele é a referência pressuposta principal, que no jargão de hoje sinaliza as possibilidades de reprodução. (OLIVEIRA, F., 1998, p, 21).

Desse modo, o fundo público fornece as condições físicas, econômicas e políticas para a manutenção e a reprodução do capitalismo na sociedade. Entretanto, o autor salienta que

\footnotetext{
45 Para o autor, o Estado ex-ante é aquele que antecipa o que gasta, que é mais do que arrecada, que mostra um deslocamento das relações privadas para as relações públicas, ao passo que o Estado ex-post seria aquele Estado doméstico, dono de casa, que gasta apenas o que arrecada e tão só depois de arrecadar.
} 
[...] o fundo público não é capital, não podendo, senão nominalmente, senão monetariamente ser identificado com ele [...] sua necessidade estrutural insubstituível não se dá porque o capitalismo esgotou as possibilidades de acumulação; ao contrário, o fundo público comparece como viabilizador da concretização das oportunidades de expansão, em face da insuficiência do lucro frente ao avassalador progresso técnico. (OLIVEIRA, F., 1998, p.34).

No que tange à reprodução da força de trabalho, as despesas públicas destinadas à educação, à saúde e outros programas de garantias de recursos aumentaram significativamente as despesas públicas totais, por parte do Estado, na medida em que financiavam a produção de bens e serviços sociais, por meio das políticas públicas. Assim, a transferência para o financiamento público da reprodução da força de trabalho reduziu os custos internos de produção no sistema capitalista.

Vale ressaltar que, para Oliveira, F. (1998, p. 53), o fundo público não é apenas a expressão de recursos estatais destinados a sustentar ou financiar a acumulação do capital; "[...] ele é um mix que se forma dialeticamente e representa na mesma unidade, contém na mesma unidade, no mesmo movimento, a razão do Estado, que é sociopolítica, ou pública, se quisermos, e a razão dos capitais, que é privada".

Desse modo, o fundo público busca explicar a formação de uma nova sustentação da (re)produção do valor, articulando na mesma unidade a forma valor e o "antivalor46", isto é, um valor que busca a mais-valia e o lucro e outra fração, o antivalor, que "[...] por não buscar valorizar-se per se, pois não é capital, ao juntarse ao capital, sustenta o processo de valorização do valor" (OLIVEIRA, F., 1998, p. 53). Assim, o fundo público atua na reprodução simultânea do capital e da força de trabalho.

A relação entre o capital e o fundo público leva este último, segundo o autor, a comportar-se como um "anticapital", tendo em vista que "[...] essa contradição entre o fundo público que não é valor e sua função de sustentação do capital destrói o caráter auto-reflexivo do valor, central na constituição do sistema capitalista

\footnotetext{
${ }^{46}$ A metáfora que o autor utiliza vem da física: o antivalor é uma partícula de carga oposta que, no movimento de colisão com a outra partícula, o valor, produz o átomo, isto é, o novo excedente social (OLIVEIRA, F., 1998, p.53).
} 
enquanto sistema de valorização do valor" (OLIVEIRA, F., 1998, p. 29). Nessa perspectiva,

[...] o que se vislumbra com a emergência do antivalor é a capacidade de passar-se a outra fase, em que a produção do valor, ou de seu substituto, a produção do excedente social, toma novas formas [...] não como desvios do sistema capitalista, mas como necessidade de sua lógica interna de expansão. (OLIVEIRA, F., 1998, p. 35).

No que se refere à reprodução da força de trabalho, os investimentos públicos em bens e serviços sociais públicos extensivos à maioria da população, funcionam como "[...] antimercadorias sociais, pois sua finalidade não era gerar lucros nem mediante sua ação dá-se a extração da mais-valia" (OLIVEIRA, F., 1998, p. 29).

Para Oliveira, F. (1998), a crise do Estado-Providência tem levado à crise fiscal do Estado, devido à disputa entre fundos públicos destinados à reprodução do capital e fundos que financiam a produção de bens e serviços sociais públicos. Nesse processo, há o deslocamento da luta de classes da esfera das relações privadas para uma esfera pública, ou seja, para o orçamento do Estado, tendo em vista que o volume e a composição do fundo público não são meramente determinados por leis de mercado, mas refletem antes os conflitos econômicos entre classes e grupos.

Oliveira, F. (1998, p. 27) afirma que "[...] o padrão do financiamento público 'implodiu' o valor como único pressuposto da reprodução ampliada do capital, desfazendo-o parcialmente enquanto medida da atividade econômica e da sociabilidade em geral", na medida em que o padrão de financiamento público constituiu-se em uma verdadeira esfera pública, com regras estabelecidas e consensuais.

Dessa forma, o desenvolvimento do Estado de Bem-Estar Social, por meio da presença do fundo público, provocou mudanças nas condições de distribuição e consumo, do lado da força de trabalho, e das condições de circulação, do lado do capital. Nesse sentido, para Oliveira, F. (1998, p. 37), na área das políticas sociais, "[...] são os critérios antimercado os que fundamentam os direitos modernos", uma vez que a constituição de uma esfera pública se deu ao mesmo tempo em que se deram as conquistas sociais, por meio do acesso à utilização do fundo público que 
se vinculou à consolidação das políticas democráticas. Assim, a ampliação do espaço público correspondeu, na maioria dos países, a uma ampliação do Estado para publicizar e operar o deslocamento das relações privadas para relações públicas. Desse modo, a forma estatal, em muitos casos, revelou-se imprescindível e insubstituível.

Contudo, o Estado de Bem-Estar Social não deixou de ser um Estado classista, isto é, um instrumento poderoso para a dominação de classe; porém, nas palavras de Poulantzas (2000), ele se constituiu numa condensação de lutas de classes, característica da esfera pública, marcada pela "[...] construção e o reconhecimento da alteridade, do outro, do terreno indevassável de seus direitos, a partir dos quais se estruturam as relações sociais" (OLIVEIRA, F., 1998, p. 39).

A estruturação da esfera pública, mesmo nos limites do Estado classista, nega à burguesia a propriedade do Estado e sua dominação exclusiva, na medida em que o Estado constitui-se como espaço de lutas de classes, com expressões coletivas e sujeitos da história. Nas palavras de Oliveira, F. (1998, p. 41):

O ponto essencial é que as relações entre as classes sociais não são mais relações que buscam a anulação da alteridade, mas somente se perfazem numa per equação - mediada pelo fundo público -, em que a possibilidade da defesa de interesses privados requer desde 0 início o reconhecimento de que os outros interesses não apenas são legítimos, mas necessários para a reprodução social em escala ampla. A democracia representativa é o espaço institucional no qual, além das classes e grupos diretamente interessados, intervêm outras classes e grupos, constituindo o terreno do público, do que está acima do privado.

Portanto, para o autor, a construção de uma esfera de fato pública passa necessariamente pela gestão democrática do fundo público, opondo-se à gestão neoliberal e a seus ataques aos gastos sociais. Salvador (2010, p. 27) ressalta que, no Brasil o fundo público assumiu características peculiares e

[...] ganhou contornos restritivos, tanto pela ótica do financiamento como pela dos gastos sociais, muito aquém das já limitadas conquistas da social-democracia ocorrida nos países desenvolvidos. Até mesmo as "reformas" realizadas por dentro do capitalismo central não lograram o mesmo êxito em nosso país, uma vez que a estruturação das políticas sociais foi marcada por componentes 
conservadores, que obstaculizaram os avanços expressivos nos direitos de cidadania.

A CF/1988 contemplou avanços relacionados aos direitos de cidadania, como o direito à educação. Entretanto, a efetivação dessas conquistas e a perspectiva da consolidação de um Estado de Bem-Estar Social no Brasil deveriam ampliar o aporte de recursos no orçamento público para a concretização desses direitos. Nessa perspectiva, Salvador (2010, p. 180) salienta que "[...] o orçamento é um instrumento privilegiado, que deve assegurar e expressar os requisitos de cumprimento dos direitos, refletindo as prioridades definidas pelo governo na execução e na escolha das políticas públicas". Contudo, segundo o autor, esse direcionamento foi frustrado a partir da década de 1990, com o predomínio da ideologia neoliberal e da contrarreforma do Estado, evidenciado, principalmente, pelas ações do governo (reforma nos sistema de proteção social e cortes na previdência social, nos fundos de aposentadorias e pensões, nos programas assistenciais e nos serviços de saúde pública), que, por um lado, mostraram dificuldades na expansão e universalização dos gastos orçamentários que assegurassem a concretização dos direitos, e, por outro, destinavam boa parte dos seus recursos para o pagamento de juros, encargos e amortização da dívida externa. Segundo Salvador (2010, p. 28), “[...] parcelas importantes da arrecadação de receitas que deveriam ser utilizadas nessas políticas sociais, e poderiam ampliar a sua abrangência, são retidas pelo orçamento fiscal da união e destinadas para o superávit primário"47. Em linha semelhante, Frigotto (2011, p. 245) afirma que o Estado, nas primeiras décadas do século XXI, durante o governo Luiz Inácio Lula da Silva (2003-2010), "[...] em vez de alargar o fundo público na perspectiva do atendimento a políticas públicas de caráter universal, fragmenta as ações em políticas focais que amenizam os efeitos, sem alterar substancialmente as suas determinações".

Andrea Barbosa Gouveia (2002, p. 31) salienta que a necessidade de publicizar o Estado inclui uma dimensão fundamental, a questão do orçamento, na

\footnotetext{
47 Cabe destacar o estudo realizado por Salvador (2010), que, ao analisar a execução orçamentária da União no período de 2004 a 2007, verificou que os gastos orçamentários com previdência, assistência, saúde, educação e trabalho, conseguiram preservar a sua execução, pois tinham a maior parte dos seus recursos de natureza obrigatória, vinculada a receitas constitucionais ou a alguma norma legal.
} 
medida em que "[...] compreender o papel do orçamento público como cofinanciador do capital e do trabalho permite compreender as disputas políticas em torno da aprovação dos orçamentos municipais, estaduais e, sobretudo, do orçamento da União". Para entender esse processo, é necessário conhecer como o orçamento é definido no Brasil.

\subsection{O ORÇAMENTO PÚBLICO E OS GASTOS EDUCACIONAIS}

A CF/1988 prevê que a União, os estados e municípios podem instituir três tipos de tributos: impostos, taxas e contribuições. Esses três tributos compõem as fontes do orçamento público brasileiro. A existência desses tributos pode nos levar à percepção de que no Brasil se paga muito imposto. No entanto, como nos informa José Marcelino de Rezende Pinto (2000, p. 24),

[...] ao contrário dos países capitalistas desenvolvidos, onde a principal fonte de receita tributária é o Imposto de Renda, em particular da pessoa física, no Brasil há um predomínio dos tributos que, pela sua natureza, são repassados aos preços finais dos produtos [...] Considerando-se como tributos diretos o IPTU [...], o IR Pessoa Física [...], o IR na fonte, o IOF, o ITR, o IPVA e o ITBI, ainda assim constata-se que a carga de impostos (mais de $80 \%$ ) é indireta.

Assim, o Brasil permanece com arrecadação tributária centrada em tributos indiretos (ou seja, incidem sobre a produção e o consumo de bens e serviços), significando que os mais pobres pagam proporcionalmente mais tributos em relação a sua renda que os mais ricos. Assim, concordamos com Salvador (2010, p. 29) quando diz:

A estruturação do fundo público no Brasil configura um Estado Social que não reduz a desigualdade social porque se assenta nas seguintes características: i) financiamento regressivo (quem sustenta são os trabalhadores e os mais pobres), que não faz redistribuição de renda; ii) políticas sociais com padrão restritivo e básico, não universalizando direitos; e iii) distribuição desigual dos recursos no âmbito da seguridade social e, ainda, transferência de recursos para o orçamento fiscal. 
Neste trabalho, os tributos arrecadados na forma de impostos interessam diretamente, uma vez que é sobre a receita líquida de impostos e suas transferências que há a vinculação de recursos para aplicação em Manutenção e Desenvolvimento do Ensino ${ }^{48}$ (MDE). Os impostos são instituídos pelas três esferas de governo, sendo que a CF/1988 prevê mecanismos de transferências de arrecadação da União para estados e municípios e dos estados para os municípios.

$\mathrm{Na}$ tentativa de compreender como se constituem as disputas para a distribuição desses recursos públicos, faz-se necessário explicitar o que entendemos como orçamento. Este constitui elemento importante para compreender 0 financiamento educacional, pois é um instrumento técnico que vai além da sua estruturação contábil, refletindo a "correlação de forças sociais e os interesses envolvidos na apropriação dos recursos públicos, bem como a definição de quem vai arcar com o ônus do financiamento dos gastos orçamentários" (SALVADOR, 2010, p. 172). O dimensionamento desses gastos possibilita entender a importância dada a cada política pública no contexto político, social e econômico do país. No nosso caso em particular, o estudo do orçamento vinculado à educação nos permitirá conhecer qual quantitativo de recursos está sendo destinado à educação especial no âmbito dos municípios.

Partimos do pressuposto de que o "[...] orçamento público é a materialização da ação planejada do Estado para manutenção de suas atividades e execução de seus projetos, assim como permite a visualização do direcionamento das ações do Estado e de suas efetivas prioridades" (SALVADOR, 2010, p. 49).

A Lei no 4.320, de 17 de março de 1964, que fixa as normas gerais para elaboração dos orçamentos públicos e para o controle das finanças públicas, estabelece, no seu art. $2^{\circ}$, que "[...] a Lei do Orçamento conterá a discriminação da receita e da despesa de forma a evidenciar a política econômica financeira e o programa de trabalho do governo, obedecidos os princípios de unidade, universalidade e anualidade" (BRASIL, 1964).

\footnotetext{
48 Assim dispõe o art.70 da LDB/1996: "Considerar-se-á manutenção e desenvolvimento de ensino as despesas realizadas com vistas à consecução dos objetivos básicos das instituições educacionais de todos os níveis [...]" (BRASIL, 1996a).
} 
O orçamento, antes de 1988, estava todo centralizado no Poder Executivo, com esvaziamento do Poder Legislativo. A CF/1988, ao ratificar no campo das finanças públicas, os processos de reordenamento institucional e de unificação do orçamento, ampliou o fortalecimento da Federação e do papel do Congresso Nacional, recuperando as prerrogativas do Poder Legislativo em matéria orçamentária (SALVADOR, 2010). Na tentativa de recuperar o papel de planejador do Estado, foram criadas mais duas peças orçamentárias: o Plano Plurianual (PPA) e a Lei de Diretrizes Orçamentárias (LDO). Desse modo, a partir da CF/1988, art.165, o ciclo orçamentário passou a ser composto por três instrumentos distintos, mas interligados entre si: o PPA, a LDO e a Lei Orçamentária Anual (LOA), cujo objetivo é integrar as atividades de planejamento e orçamento, bem como assegurar a execução das políticas na União, no Distrito Federal, nos estados e nos municípios. Desse modo, cabe ao Poder Legislativo apreciar esses instrumentos, no âmbito de cada esfera administrativa, e aprová-los. As principais regulamentações legais para o denominado ciclo orçamentário brasileiro são a Lei № 4.320/1964, a CF/1988 e a Lei Complementar n 101, de 4 de maio de 2000, denominada "Lei de Responsabilidade Fiscal”, que estabelece normas de finanças públicas voltadas para a responsabilidade na gestão fiscal e dá outras providências.

Assim, segundo José Carlos Polo (1999), quanto ao planejamento e execução orçamentária, a CF/1988 consagrou o princípio de que o orçamento público integra um sistema em que as ações de governo deveriam ser definidas em processo amplo de planejamento, no qual se estabelecem, antecipadamente, as diretrizes, os objetivos e as metas da administração pública por certo período de tempo.

O PPA define diretrizes, objetivos e metas da administração para um período de quatro anos, com ações orçamentárias e custos da administração pública, para as despesas de capital e outras delas decorrentes, e para as relativas aos programas de duração continuada. É constituído por um conjunto de programas, por meio dos quais os governos tentam alcançar os objetivos estabelecidos no plano, de acordo com as demandas de cada esfera do governo. Apenas os programas que estão previstos no PPA podem receber recursos nos orçamentos anuais ou ser priorizados na LDO.

A LDO pauta-se nos grandes princípios e critérios apontados no PPA, visto que ela antecipa a discussão orçamentária, define metas e prioridades para o ano 
seguinte e anuncia as metas fiscais, ou seja, o montante a ser arrecadado e como será despendido; sua vigência é de um ano. De acordo com Salvador (2010), a inovação trazida pela LDO na CF/1988 permitiu ordenar a participação do Poder Legislativo na elaboração do orçamento, ampliando o prazo de discussão e participação de diferentes atores no processo orçamentário. Cabe ressaltar que, com a Lei Complementar n 101/2000, a LDO teve sua importância ampliada, tendo em vista a exigência de informação e os anexos que passaram a integrar a LDO, entre eles, o anexo de metas fiscais, que deve vir acompanhado de memória e metodologia de cálculo, justificando os resultados pretendidos pelos governos.

A LOA deve estimar as receitas de tributos e fixar as despesas que as administrações públicas da União, dos estados e dos municípios estão autorizadas a executar no exercício financeiro. Portanto, cada ente federado deve planejar suas receitas e despesas, controlá-las e limitá-las quando as metas se mostrarem comprometidas.

Nessa perspectiva, os recursos destinados à educação, assim como todas as demais despesas do Poder Público, também devem estar previstos no PPA, como diretrizes gerais; na LDO, como diretrizes orientadoras para o conjunto de receitas e despesas; e na LOA, onde deverão estar contemplados de modo detalhado para sua utilização (GOUVEIA, 2002). A LDB/1996 estabeleceu procedimento para o acompanhamento da execução orçamentária das despesas com educação, bem como do gerenciamento dos recursos da educação. De acordo com o art. 69, § 4ํㅡ, "as diferenças entre a receita e a despesa previstas e as efetivamente realizadas que resultem no não atendimento dos percentuais mínimos obrigatórios, serão apuradas e corrigidas a cada trimestre do exercício financeiro". Assim, ressalta-se que os recursos educacionais, além de se articularem com as metas fixadas nos documentos orçamentários, devem obedecer à vinculação constitucional de recursos. Entretanto, de acordo com Polo (1999), o orçamento tem sido pouco utilizado como uma das etapas conceituais do processo de planejamento para alocação racional e gerenciamento de recursos públicos, visando à prestação de serviços à população. Na mesma direção, Salvador (2010, p. 177) salienta a manutenção da "precariedade no acompanhamento da execução orçamentária e a falta de parâmetros que estabeleçam com clareza os objetivos e os compromissos da programação financeira". 
Nesse sentido, concordamos com Salvador (2010, p. 178) quando diz que o "[...] orçamento não se limita a uma peça técnica e formal ou a um instrumento de planejamento; ele é, desde suas origens, uma peça de cunho político". Assim, ele representa a correlação de forças sociais e políticas da sociedade, orienta as negociações relacionadas ao financiamento do Estado, servindo como instrumento de controle, direcionamento dos gastos e prioridades de políticas públicas. Conforme Fabrício de Oliveira (2001), o orçamento revela sobre que classe ou fração de classe recai o maior ou o menor ônus da tributação e as classes que mais se beneficiam com os gastos orçamentários; portanto, ele envolve negociações dos representantes políticos, uma vez que o orçamento é a expressão das reivindicações das classes que elas representam. Assim, foi fundamental analisarmos no planejamento orçamentário de Vitória - estado do Espírito Santo, se as demandas e necessidades do público da educação especial estavam contempladas entre as prioridades políticas do município.

Nesse contexto, cumpre destacar a importância da gestão democrática dos recursos públicos, que, segundo Melchior (1991), se constituiu pela via exclusiva da participação dos interessados nos órgãos decisórios. Na educação, uma das possibilidades seria a participação no processo de gestão do financiamento em educação, que envolve o planejamento orçamentário, discutido anteriormente, e o controle social dos recursos públicos. Entendemos a gestão democrática do ensino público de forma ampla, assim como Rubens Barbosa de Camargo e Marcos Edgar Bassi (2008, p. 97),

[...] presente em diferentes instâncias da gestão pública da educação, desde as unidades escolares até os organismos de Estado de participação institucional (conselhos de educação), sem os quais ou não são repassadas verbas de outras esferas federativas ou não se pode constituir um sistema de ensino público.

Nesse sentido, defendemos uma perspectiva de gestão que considere a implementação de mecanismos de participação nos processos de decisão nas diferentes instâncias do Estado e na formulação de políticas públicas capazes de assegurar o direito social da educação a todos. 
No ordenamento constitucional e infraconstitucional brasileiro, está prevista a função de fiscalização para cada uma das entidades da administração direta e indireta das esferas do Poder Público, por meio dos sistemas de controle interno e externo, e, ainda, há a previsão de qualquer cidadão poder examinar as contas do governo e questionar sua legitimidade.

A CF/1988 (Arts. 5ำ e 6ํ), na tentativa de garantir a democratização da gestão do Estado, menciona dois procedimentos para o aumento da participação da população em suas instâncias: "o acesso à informação e a participação de representantes nos setores específicos em órgãos da administração pública" (ADRIÃO; CAMARGO, 2007, p. 65). Nesse sentido, a Constituição assegura o direito do cidadão a participar da gestão, inclusive no controle dos recursos públicos. Cabe destacar a promulgação da nova Lei n 12.527, de 18 de novembro de 2012 que dispõe sobre os procedimentos a serem observadas pela União, estados, Distrito Federal e municípios, com o fim de garantir o acesso as informações previstas na Constituição Federal, a partir do desenvolvimento de uma cultura de transparência e controle social da administração pública. Assim, a Lei prevê no art. $5^{\circ}$ "É dever do Estado garantir o direito de acesso à informação, que será franqueada, mediante procedimento objetivos e ágeis, de forma transparente, clara e em linguagem de fácil compreensão" (BRASIL, 2011g), inclusive com o uso da tecnologia de informação.

No que se refere à educação, a CF/1988 estabelece como princípio constitucional, no inciso $\mathrm{VI}$, do art. 206, "gestão democrática ao ensino público, na forma da lei" (BRASIL, 1988). Entretanto, como apontam Theresa Adrião e Rubens Barbosa de Camargo (2007, p. 71), a omissão do texto constitucional com relação às diretrizes gerais para a constituição e a gestão de diferentes sistemas de ensino "permitiu que cada sistema definisse e regulasse sua própria organização e funcionamento, pouco ou nada avançando na criação de procedimentos diferentes dos já existentes". Esse princípio foi ratificado na LDB/1996, na qual também foi destacada a obrigatoriedade do Poder Público de publicizar as informações de arrecadação e despesa em educação, bem como o cumprimento da vinculação de recursos nos seguintes termos:

Art. 72 - As receitas e despesas com manutenção e desenvolvimento do ensino serão apuradas e publicadas nos balanços do Poder 
Público, assim como nos relatórios a que se refere o $\S 3^{\circ}$ do Art. 165 da Constituição Federal ${ }^{49}$.

Art. 73 - Os órgãos fiscalizadores examinarão, prioritariamente, na prestação de contas de recursos públicos, o cumprimento do disposto no Art. 212 da Constituição Federal, no Art. 60 do Ato das Disposições Constitucionais Transitórias e na legislação concernente. (BRASIL, 1996a).

A Lei no 11.494, de 20 de junho de 2007, também estabeleceu quem seria responsável pelo acompanhamento e pelo controle social dos recursos do Fundeb:

Art. $24 \mathrm{O}$ acompanhamento e controle social sobre a distribuição, a transferência e aplicação dos recursos dos Fundos serão exercidos, junto aos respectivos governos, no âmbito da União, dos Estados, do Distrito Federal e dos Municípios, por conselhos, instituídos especificamente para esse fim. (BRASIL, 2007b).

De acordo com Bassi e Camargo (2010), foi a introdução do Fundo de Manutenção e Desenvolvimento do Ensino Fundamental e de Valorização do Magistério (Fundef) no financiamento da educação brasileira que trouxe a oportunidade de retomar a ideia do controle social sobre o Estado, na medida em que sua legislação previa a criação de Conselhos de Acompanhamento e Controle Social (Cacs), em cada nível de governo, dos recursos do fundo, numa perspectiva de gestão educacional democrática. Essas disposições oferecem a base legal e a possibilidade da sociedade exercer o controle democrático sobre os recursos e serviços educacionais prestados pelo Estado.

O Fundeb (regulamentado pela Lei ํㅜ 11.494/2007), de acordo com Bassi e Camargo (2008, p. 116) estabeleceu novos dispositivos para elevar o alcance dos Cacs no acompanhamento e controle social do Estado, no intuito de garantir maior autonomia no desempenho do seu papel fiscalizador, "agora ampliado por uma função de supervisão da elaboração do orçamento anual da educação, entre outras medidas". Desse modo, os Cacs têm como atribuições o acompanhamento e o controle social sobre a distribuição, a transferência e a aplicação dos recursos do fundo (art. 24, caput); supervisionar o Censo Escolar e a elaboração da proposta orçamentária (art. 24, $§ 9^{\circ}$ ); e acompanhar a aplicação dos recursos federais

$49 \mathrm{O}$ art. $165 \S 3^{\circ}$ estabelece: "O Poder executivo publicará, até trinta dias após o encerramento de cada bimestre, relatório resumido da execução orçamentária" (BRASIL, 1988). 
transferidos à conta do Programa Nacional ao Transporte Escolar (Pnate) e do Programa de Apoio aos Sistemas de Ensino para atendimento à Educação de Jovens e Adultos (Peja), do Fundo Nacional de Desenvolvimento da Educação (FNDE) (art. 24, § 13). Cabe salientar que, no art. 24, § $7^{\circ}$, foi assegurada a autonomia dos Cacs: "Os conselhos atuarão com autonomia, sem vinculação ou subordinação institucional ao Poder Executivo local e serão renovados periodicamente ao final de cada mandato dos seus membros", bem como elencadas várias medidas relativas aos critérios de composição dos conselhos, ao processo eletivo dos conselheiros e aos impedimentos de participação que buscam possibilitar uma atuação mais autônoma e independente. Nesse sentido, a legislação, ao garantir um espaço público com participação popular no controle das verbas aplicadas à manutenção do ensino, possibilita a constituição de uma gestão democrática dos recursos da educação em cada esfera administrativa, visto que

[...] um conselho organizado de modo autônomo, constituído democraticamente, com representação de movimentos sociais, que fiscalize todos os recursos da educação, que possa ter um caráter propositivo ou gestor e sustentado pela administração pública pode vir a ter condições de exercer um efetivo e ativo controle social. (BASSI; CAMARGO, 2008, p. 117).

As receitas orçamentárias, segundo o art. 11 da Lei no 4.320/1964, são classificadas, em termos de categoria econômica, em receitas correntes e receitas de capital. As receitas correntes provêm de tributos e de serviços prestados pelo governo e de outras fontes previstas em lei; e as receitas de Capital abrangem recursos financeiros oriundos da constituição de dívidas, da conversão, em espécie, de bens e direitos, incluindo operações de crédito, da alienação de bens, da amortização de empréstimos, de transferências de capital e de outras receitas de capital. Desse modo, a receita do município é composta por receita tributária (imposto, taxas e contribuições de melhoria), receita patrimonial, receitas de serviços, transferências correntes, outras receitas correntes e receitas de capitais (BRASIL, 1964).

Nesse estudo, vamos analisar a receita resultante dos impostos do referido município, a qual constitui a principal fonte de recursos da educação, pois é sobre 
ela que deve incidir o percentual mínimo de 25\% para MDE. De acordo com o art. 68 da LDB/1996, são recursos públicos destinados à educação os originários de

I - receita de impostos próprios da união, dos Estados, do Distrito Federal e dos municípios;

II - receita de transferências constitucionais e outras transferências;

III - receita do salário-educação e de outras contribuições sociais;

IV- receita de incentivos fiscais;

V - outros recursos previstos em lei. (BRASIL, 1996a).

Cabe ressaltar que as transferências de recursos constitucionais realizadas de uma esfera da administração para outra, como o Fundo de Participação dos Estados (FPE) e o Fundo de Participação dos Municípios (FPM), constituídos de parcelas do Imposto de Renda e do Imposto sobre a Produção Industrial, constituem fonte importante para o financiamento da educação, uma vez que têm como finalidade "equalizar a capacidade arrecadadora e as responsabilidades na prestação de serviços das diferentes esferas da Administração pública" (OLIVEIRA, R., 2007, p. 86), principalmente, nos municípios que não apresentam uma arrecadação expressiva a partir dos impostos próprios e dependem das transferências de outras esferas.

Destacamos, ainda, a receita oriunda do salário-educação, que é uma contribuição social cobrada das empresas para com a educação. Conforme Madza Ednir e Marcos Bassi (2009, p. 56), "[...] desde 1964, elas são obrigadas a recolher $2,5 \%$ calculados sobre o valor da folha de pagamentos dos funcionários". Até 2005 , esse valor era destinado unicamente ao ensino fundamental. Com a Emenda Constitucional no 53, de 19 de dezembro de 2006 (BRASIL, 2006e), os recursos arrecadados passaram a ser aplicados a toda a educação básica. O salárioeducação é calculado "com base na alíquota de 2,5\% (dois e meio por cento) sobre o total de remunerações pagas ou creditadas, a qualquer título, aos segurados empregados" (BRASIL, 1996b, art. 15). Dos recursos arrecadados, deduz-se 1\% em favor do Instituto Nacional do Seguro Social (INSS), a título de taxa de administração, e o gerenciamento dos recursos é feito pelo FNDE, que constitui uma autarquia criada em 1968, responsável pela gestão das verbas do salário-educação. Os recursos são distribuídos pelo FNDE, "observada em noventa por cento de seu valor, a arrecadação realizada em cada Estado e no Distrito Federal, em quotas" 
(BRASIL, 2006f, art. 9). A quota federal corresponde a $1 / 3$ do montante de recursos e deve ser "aplicada no financiamento de programas e projetos voltados a universalização da educação básica, de forma a propiciar a redução dos desníveis sócio-educacionais existentes entre Municípios, Estados, Distrito Federal e regiões brasileiras" (BRASIL, 2006f, art. 9o, inciso l). A quota estadual e municipal corresponde a 2/3 do montante de recursos e deve ser redistribuída entre os estados e seus municípios de forma proporcional ao número de alunos matriculados na educação básica, nas respectivas redes de ensino, de acordo com censo educacional (BRASIL, 2006f, art. 9ㅜ, inciso II, §2). Os 10\% restantes são aplicados pelo próprio FNDE em "programas, projetos e ações voltadas para a universalização da educação básica" (BRASIL, 2006f, art. 9º, inciso I, § 4º).

As despesas também são classificadas em despesas correntes, relacionadas com a manutenção da atividade governamental, manutenção e funcionamento dos serviços públicos em geral; e despesas de capital, vinculadas ao aspecto financeiro dos gastos governamentais, "[...] com a intenção de adquirir ou construir bens de capital que contribuirão para a produção ou geração de novos bens e integrarão o patrimônio público" (CRUZ et al., 2001, p. 28).Assim, dispõe a Lei no 4.320/1964:

Art. 13. Observadas as categorias econômicas do artigo 12, a discriminação ou especificação da despesa por elementos em cada unidade administrativa ou órgão de governo, obedecerá ao seguinte esquema:

DESPESAS CORRENTES:

Despesas de Custeio

Pessoal Civil

Pessoal Militar

Material de Consumo

Serviços de Terceiros

Encargos Diversos

Transferências Correntes

Subvenções Sociais

Subvenções Econômicas

Inativos

Pensionistas

Salário Família e Abono Familiar

Juros da Dívida Pública

Contribuições de Previdência Social

Diversas Transferências Correntes. 


\author{
DESPESAS DE CAPITAL \\ Investimentos \\ Obras Públicas \\ Serviços em Regime de Programação Especial \\ Equipamentos e Instalações \\ Material Permanente \\ Participação em Constituição ou Aumento de Capital de Empresas \\ ou Entidades Industriais ou Agrícolas \\ Inversões Financeiras \\ Aquisição de Imóveis \\ Participação em Constituição ou Aumento de Capital de Empresas \\ ou Entidades Comerciais ou Financeiras \\ Aquisição de Títulos Representativos de Capital de Empresa em \\ funcionamento \\ Constituição de Fundos Rotativos \\ Concessão de Empréstimos \\ Diversas Inversões Financeiras \\ Transferências de Capital \\ Amortização da Dívida Pública \\ Auxílios para Obras Públicas \\ Auxílios para Equipamentos e Instalações \\ Auxílios para Inversões Financeiras \\ Outras Contribuições. (BRASIL, 1964).
}

Notamos que a organização das despesas em categorias econômicas, descritas acima, possibilita visualizar, no orçamento e no balanço, aquelas despesas que objetivam a manutenção de serviços anteriormente criados (despesas correntes) e os investimentos voltados à execução de obras e à aquisição de imóvel e material permanente (despesas de capital). Assim, ao analisarmos o financiamento da educação no âmbito municipal, veremos que as despesas com a educação estarão sob esta categorização.

Nesse estudo, enfatizamos as despesas com pessoal e custeio do município de Vitória. De acordo com a Lei Complementar no 101/2000, as despesas com pessoal referem-se aos recursos relativos à remuneração dos funcionários públicos do setor e aos encargos sociais pagos pela administração, como as obrigações patronais. $\mathrm{Na}$ tentativa de frear os gastos de pessoal no organismo público, a referida Lei estabelece limites a serem observados pelos entes federados. Assim, os municípios não podem despender com pessoal mais do que $60 \%$ das respectivas receitas correntes (BRASIL, 2000). Entende-se por custeio os gastos despendidos para a aquisição de bens e materiais de consumo à contratação de serviços para diversas atividades relacionadas ao adequado funcionamento dos estabelecimentos 
de ensino, desde a aquisição de equipamentos, de materiais permanentes à contratação de consultorias, à formação continuada e a pagamentos de subvenções sociais ${ }^{50}$.

As despesas em educação no município de Vitória também foram organizadas, de acordo com a classificação de despesa funcional programática e segundo a natureza da despesa. A primeira classificação foi redefinida pela Portaria no 42, de 14 de abril de 1999 (BRASIL, 1999a), que fixa o novo sistema de classificação da despesa, com o objetivo de

[...] agrupar a despesa pública de acordo com os setores de atuação do governo, primeiro de forma ampla, por funções e subfunções, e depois de forma mais detalhada, de acordo com os programas de trabalhos dos órgãos governamentais e respectivas ações a serem desenvolvidas, ou seja, por programas, projetos, atividades e operações especiais. (POLO, 1999, p. 316).

Assim, a despesa por função corresponde ao maior nível de agregação das diversas áreas de despesas que competem ao setor público, com a finalidade de especificar em que campo a ação governamental será realizada (como exemplo, educação, saúde, trabalho, cultura, entre outras funções). A despesa por subfunção representa um nível de agregação inferior à função e deve evidenciar a área de atuação do governo, por intermédio da agregação de determinado subconjunto de despesas em torno das funções (no caso da função educação, as subfunções são: educação infantil, ensino fundamental, ensino médio, educação profissional, ensino superior, educação especial e educação de jovens e adultos). A despesa por programa de trabalho constitui um instrumento de organização governamental, visando à concretização dos objetivos pretendidos e sendo mensurado por indicadores estabelecidos no plano plurianual. A partir do programa, são identificadas ações sob a forma de projetos, atividades, operações especiais, especificando os respectivos valores e metas e as unidades orçamentárias responsáveis pela realização da ação.

50 Cobertura de despesas de instituições privadas de caráter assistencial ou cultural, sem finalidade lucrativa, de acordo com os arts. 6º, parágrafo único, e 17, da Lei oㅜ 4.320/1964, observado o disposto no art. 26 da Lei Complementar no 101/2000. 
A classificação segundo a natureza tem como finalidade, segundo Polo (1999, p. 318), "[...] identificar a despesa do ponto de vista econômico, ou seja, pelos tipos de bens e serviços que estão sendo adquiridos ou tipos de encargos que estão sendo pagos". De acordo com o art. $3^{\circ}$ da Portaria Interministerial $n^{\circ} 163$, de 4 de maio de 2001, que orienta a elaboração e execução dos orçamentos a partir de 2002, a classificação da despesa segundo a natureza compõe-se de: I - Categoria econômica: Despesas correntes e Despesas de Capital; II - Grupo de Natureza da Despesa; III - Elemento de Despesa; IV - Modalidade de Aplicação (BRASIL, 2001b).

No caso da educação, os recursos fixados como despesa devem se relacionar com as metas estabelecidas no planejamento orçamentário e obedecer à vinculação constitucional de recursos voltados exclusivamente para o MDE. O art. 70 da LDB/1996 explicita o que é despesa em educação:

Art. 70 - Considerar-se-á como de manutenção e desenvolvimento do ensino as despesas realizadas com vistas à consecução dos objetivos básicos das instituições educacionais de todos os níveis, compreendendo as que se destinam a:

I- remuneração e aperfeiçoamento do pessoal docente e demais profissionais da educação;

II- aquisição, manutenção, construção e conservação de instalações e equipamentos necessários ao ensino;

III- uso e manutenção de bens e serviços vinculados ao ensino;

IV- levantamentos estatísticos, estudos e pesquisas visando precipuamente ao aprimoramento da qualidade e à expansão do ensino;

V- realização de atividades-meio necessárias ao funcionamento dos sistemas de ensino;

VI- concessão de bolsas de estudo a alunos de escolas públicas e privadas;

VII- amortização e custeio de operações de crédito destinadas a atender ao disposto nos incisos deste artigo;

VIII- aquisição de material didático-escolar e manutenção e desenvolvimento de programas de transporte escolar. (BRASIL, 1996a).

O art. 71 da LDB/1996 trata das exceções, explicitando o que não pode ser considerado despesa com MDE. Cumpre destacar o inciso IV, que exclui da vinculação os programas suplementares de alimentação, a merenda escolar, e o inciso $\mathrm{V}$, que exclui as despesas com melhoria da infraestrutura urbana, mesmo que ambas beneficiem a rede escolar. Além disso, o inciso VI proíbe o uso de recursos de MDE com os funcionários da educação "[...] quando em desvio de função ou em 
atividade alheia à manutenção e desenvolvimento do ensino" (BRASIL, 1996a). Nesse sentido, os funcionários cedidos a outras secretarias não podem ser contabilizados no MDE.

Uma das formas de que se pode servir para analisar se os recursos vinculados à educação estão sendo efetivamente aplicados à MDE é o estudo dos gastos públicos em educação. Para Jorge Abrahão de Castro (2007, p. 860), o conceito de Gasto Público Educacional (GPEdu)

[...] compreende os recursos financeiros brutos empregados pelo setor público no atendimento das necessidades e direitos educacionais e que corresponde ao custo de bens e serviços inclusive de bens de capital - e transferências, sem deduzir o valor da recuperação - depreciação e amortização dos investimentos em estoque ou recuperação do principal de empréstimos anteriormente concedidos.

Cabe destacar que os gastos em educação efetuados pelo governo devem estar articulados com os objetivos e atividades de planejamento público e com a formulação de políticas educacionais. Assim, os gastos deveriam refletir ações estatais voltadas à produção e à provisão de bens e serviços para atendimento das necessidades e direitos da população.

Para Castro (2007), o estudo dos gastos públicos em educação pelo Estado traz indicativos sobre o alcance, os limites e o caráter redistributivo das políticas sociais. No nosso estudo, vamos focar as despesas do setor público, especificamente, as despesas vinculadas à educação no município de Vitória. No plano municipal, o estudo dos mecanismos de financiamento e gastos revela as relações existentes entre as prioridades das políticas de educação e a política geral do governo.

No contexto atual, no qual se discute a necessidade de expansão do atendimento educacional especializado nos sistemas de ensino, a melhoria da qualidade da educação e a ampliação de recursos educacionais, faz-se necessário identificar e compreender o financiamento e o gasto pelo Poder Público na oferta dos serviços destinados à modalidade educação especial em âmbito municipal. Nessa perspectiva, o levantamento da magnitude dos gastos em educação especial 
esclarece se os recursos orçados são, de fato, compatíveis com as necessidades dessa modalidade de ensino nos municípios investigados.

Ao discutirmos o financiamento da educação especial no contexto da educação básica, isto é, os recursos públicos voltados a um segmento da sociedade, entendemos ser necessário explicitar o conceito de cidadania aqui adotado, uma vez que, historicamente, reconheceu-se a igualdade humana básica de todos os integrantes da comunidade política de ter "direito a ter direitos".

\subsection{CIDADANIA COMO UM PROCESSO DE LUTA PARA A (RE)CONSTRUÇÃO DO ESPAÇO PÚBLICO}

Partimos do pressuposto, com apoio em Carlos Roberto Jamil Cury (2007, p. 849), de que "[...] o financiamento da educação representa uma clara intervenção do Poder Público em uma área que se define como um direito de cidadania". Nesse sentido, pretendemos discutir como a construção histórica do conceito de cidadania relaciona-se com a constituição do espaço público estatal e com a conquista dos direitos fundamentais, como a educação.

Marshall (1967), considerado com um autor clássico do conceito de cidadania, define-a como "[...] uma espécie de igualdade humana básica associada com o conceito de participação integral na comunidade", mesmo num contexto de desigualdade econômica de classes sociais. Em outras palavras, "a cidadania é um status concedido àqueles que são membros integrais de uma comunidade. Todos aqueles que possuem o status são iguais com respeito aos direitos e obrigações pertinentes ao status" (MARSHALL, 1967, p. 76).

Nesse sentido, o autor parte do princípio de igualdade para a sua definição de cidadania e apresenta três elementos básicos formulados como direitos de cidadania: o elemento civil, composto pelos direitos necessários à liberdade individual; o elemento político, constituído pelos direitos vinculados à participação no exercício estatal; e o elemento social, que se refere aos direitos ao bem-estar econômico e à herança cultural. Assim, o conceito de cidadania implicaria possuir os mesmos direitos nas esferas civil, política e social, ou seja, que todos tivessem as 
mesmas condições de exercício de sua liberdade individual, de participação política, que implica também em votar e poder ser eleito, e de acesso aos bens e serviços na sociedade, com destaque para a educação escolar. Convém ressaltar que a análise de Marshall (1967) quanto à construção do conceito de cidadania se limitou ao contexto histórico e social da Inglaterra. Portanto, desconsiderava os processos históricos de consolidação dos direitos civis, políticos e sociais de outros países. Nesse sentido, concordamos com Ramesh Mishra (1981, p. 30) quando afirma que a "[...] narrativa de Marshall pode ser lida como a história da afirmação gradual e inevitável de certo tipo de conceito de cidadania inerente à natureza e ao desenvolvimento da sociedade inglesa”. Contudo, o autor trouxe contribuições significativas para pensar a noção de igualdade, para ele inseparável da própria ideia de cidadania. Essa concepção de cidadania, para Corrêa, D. (2010, p. 24), "significa a realização democrática de uma sociedade, compartilhada pelos indivíduos a ponto de garantir a todos o acesso ao espaço público e condições de sobrevivência digna, tendo como valor fonte a plenitude da vida".

A cidadania, como igualdade humana básica, na abordagem de Marshall (1967), vincula-se a dimensão jurídica, delineando uma pertença integral e participativa como membro da comunidade política, expressa enquanto nacionalidade. Assim, "cidadão é aquele formalmente reconhecido com um sujeito de direitos e deveres, socialmente incluído e juridicamente qualificado por um ordenamento político específico" (CORREAA, D., 2010, p. 24). Nas palavras de Maria Victória de Mesquita Benevides (1994, p. 7):

$\mathrm{Na}$ teoria constitucional moderna, cidadão é o indivíduo que tem um vínculo jurídico com o Estado. É portador de direitos e deveres fixados por uma determinada estrutura legal (Constituição, leis) que Ihe confere, ainda, a nacionalidade. Cidadãos são, em tese, livres e iguais perante a lei, porém súditos do Estado.

Entretanto, para Corrêa, D. (2010), a cidadania não se restringe à dimensão jurídica, ou seja, ao vínculo jurídico da pessoa com o Estado e com seus direitos políticos, mas implica, a partir dos escritos de Hannah Arendt, o acesso ao espaço público, "no qual a igualdade em dignidade e direitos precisa ser politicamente construída, sob o pressuposto de que os seres humanos, no chão duro da vida real, não nascem livres, muito menos iguais" (CORRÊA, D., 2010, p. 25). 
Tânia Regina de Luca (2010), ao analisar a história dos direitos sociais no Brasil, nas primeiras décadas republicanas, pôde concluir que não havia nenhuma menção na Constituição de 1891 aos direitos de natureza social; ao mesmo tempo,

[...] o direito de participar da vida pública por meio do voto não foi exercido pela imensa maioria daqueles que, segundo o texto constitucional, estavam aptos a fazê-lo. Os direitos civis, por sua vez, esbarravam no predomínio do latifúndio e no poder dos grandes proprietários, que seguiam atuando como senhores quase absolutos num país eminentemente rural. (LUCA, 2010, p. 477).

Nessa direção, a dimensão jurídica representa uma condição necessária, pois assegura a igualdade de todos perante a lei, mas não suficiente, para a efetividade da cidadania. Desse modo, Corrêa, D. (2010) propõe que seja acrescentada à dimensão jurídica da cidadania uma dimensão política que garanta condições de acesso ao espaço público, tendo em vista que a esfera do público diz respeito à igualdade construída pela cidadania. Com base nessas duas dimensões, o autor afirma que a cidadania é "[...] o processo de construção de um espaço público ${ }^{51}$ que propicie as condições necessárias para a vivência e a realização de cada ser humano, em efetiva igualdade básica, mas respeitadas as diferenças próprias de cada um" (CORRÊA, D., 2010, p. 27).

Corrêa, D. (2010) concebe a cidadania como um processo histórico, dinâmico e conflitivo de construção desse espaço público necessário à vivência humana. Processo conflitivo na medida em que temos um sistema social marcado pelas desigualdades socioeconômicas, em que os detentores das condições materiais não cedem gratuitamente aos apelos e demandas dos segmentos mais excluídos do sistema social.

Desse modo, a construção da cidadania passa pelo acesso ao espaço público que, por sua vez, se constitui nas relações de forças dos poderes de classes e demais poderes da sociedade. Afirma Corrêa, D. (2010, p. 51): "Não há uma representação única da esfera público-estatal e, sim, confronto ético-político de

51 O espaço público, na concepção do autor, não se restringe a um espaço meramente geográfico, nem se reduz às instituições políticas contrapostas ao campo das condições materiais de existência, ou seja, ao campo privado das relações econômicas, mas como um "espaço vital, necessário para cada indivíduo construir, consciente e criativamente, sua identidade, seus projetos e seus sonhos, enfim, sua dignidade de sujeito racional, a partir de direitos fundamentais socialmente reconhecidos" (CORRÊA, D., 2010, p. 27). 
discursos contraditórios e conflitivos". Nesse contexto, há ações e políticas que se voltam a grupos dominantes no aparato estatal, no intuito de manutenção do status quo, assim como pode haver referências à efetivação dos direitos direcionados às classes menos favorecidas da sociedade. Ambas as dimensões integram dialeticamente a conformação do espaço público estatal. Assim, as políticas de educação especial e a disputa pelos recursos públicos voltados ao atendimento de seu público (pelas instituições públicas e privadas) sofrem as influências das diferentes correlações de forças no âmbito do Estado brasileiro.

Cabe ressaltar que o espaço público só se concretiza a partir da constituição de políticas públicas, resultantes de diferentes forças que compõem o aparelho estatal, isto é, das relações de poder em jogo na constituição do espaço público. De acordo com Carlos Nelson Coutinho (2000), a extensão da cidadania a todos os membros do corpo social levou à ampliação da esfera política para além do âmbito do Estado, envolvendo uma complexa rede de organizações coletivas de sujeitos políticos com um papel decisivo na correlação de forças que determina os equilíbrios do poder e as ações políticas.

Assim, o Estado "[...] deixou de ser o instrumento exclusivo de uma classe para se converter na arena privilegiada da luta de classes" (COUTINHO, 2000, p. 29). Desse modo, a consolidação dos direitos de cidadania na busca de um espaço público acessível a todos depende dessa relação de forças. Conforme Corrêa, D. (2010, p. 53),

[...] perceber o Estado como a materialização institucionalizada da representação do espaço público significa que a construção da esfera pública, por meio da qual se estende a todos os cidadãos a condição da igualdade básica, é função precípua da cidadania. Embora esse espaço público - condição de igualdade e de sobrevivência da humanidade - se formalize enquanto dever-ser jurídico, no qual o cidadão é reconhecido como um sujeito com o direito a ter direitos, sua materialização está a exigir que o cidadão também se assuma como sujeito político.

O autor defende que a universalização dos direitos humanos e da cidadania depende da superação das contradições existentes na sociedade, na medida em que as desigualdades materiais do capitalismo condicionam a ocupação desigual do espaço público. E isso dependerá da organização dos sujeitos políticos (os 
excluídos, os oprimidos e os discriminados) na reconstrução do espaço público fora da lógica do lucro e da acumulação, baseados numa concepção de "cidadania capaz de oportunizar a todos o acesso a um espaço público norteado pela dignidade da vida, a ser coletiva e solidariamente efetivado" (CORRÊA, D., 2010, p. 56).

Nessa perspectiva, no âmbito desse espaço público, pretendemos discutir um dos direitos considerados fundamentais para o exercício ético e político da cidadania: o da educação, que, em determinada configuração de Estado democrático de direito, passou a ser assumida como referência para as políticas públicas. Para tanto, apresentaremos a trajetória histórica do financiamento da educação brasileira e suas implicações na configuração da educação especial. 


\section{A EDUCAÇÃO ESPECIAL NO CONTEXTO DO FINANCIAMENTO DA EDUCAÇÃO NO BRASIL}

A educação especial como política pública pressupõe investimento financeiro por parte do Poder Público para garantir a sua concretização e oferecer serviços públicos voltados ao atendimento de pessoas com deficiência, TGD e altas habilidades/superdotação. Nessa direção, ela integra o sistema de financiamento da educação no Brasil. No entanto, a sua configuração, enquanto política pública, constitui um processo recente (no final dos anos de 1950 e início da década de 1960) na sociedade brasileira (MAZZOTTA, 2011).

Partindo do pressuposto, segundo Gilberta de Martino Jannuzzi (2004) e Marcos José da Silveira Mazzotta (2011), de que o conhecimento e a análise das políticas voltadas à educação dessas pessoas só podem ser compreendidos dentro do contexto da história da educação brasileira, apresentamos um panorama breve da história do financiamento da educação, de forma a abranger a obrigatoriedade do oferecimento do ensino pelo Estado, a participação dos entes federados, os recursos disponíveis à educação e suas implicações para a educação especial. Para tanto, tomamos como base os trabalhos de João Monlevade (1997) e de Pinto (2000). Este último divide em três fases a história do financiamento educacional no Brasil.

Na primeira fase, de 1549 a 1759, período colonial brasileiro, o Estado delegou aos jesuítas a exclusividade do exercício do magistério público no país. Nesse período, a Coroa Portuguesa assegurava, na Colônia, a oferta gratuita de ensino nas escolas de primeiras letras, em troca de concessões de terras e privilégios comerciais (MONLEVADE, 1997). Tanto para Monlevade (1997) quanto para Pinto (2000), esse contexto significou a desresponsabilização e a omissão do Estado, sob o domínio português, em relação à educação pública, uma vez que a Coroa assegurava o oferecimento do ensino na Colônia sem nenhum custo. Segundo Monlevade (1997, p. 54), a tendência era o "financiamento zero". Kassar (2011a, p. 43) ressalta que a organização econômica do Brasil Colônia não requeria "[...] a alfabetização e a instrução da massa trabalhadora, visto que grande parcela da população vivia na zona rural e a economia baseava-se, inicialmente, na 
exploração de bens naturais e, posteriormente, na produção de monoculturas em grandes latifúndios". Assim, nesse momento histórico, grande parte da população não tinha acesso à instrução e era analfabeta.

Ao buscarmos, na história da educação brasileira, informações sobre o atendimento escolar às pessoas com deficiência, TGD e altas habilidades/superdotação, podemos constatar que, até o século XVIII, as práticas eram caracterizadas pelo abandono, pelo extermínio e pela exclusão. Com a difusão do cristianismo, observamos atitudes ambivalentes de proteção e maus-tratos dirigidas a essa população. Todas as pessoas que se distanciavam do modelo preestabelecido socialmente eram excluídas e recebiam o mesmo tratamento, ou seja, eram discriminadas, marginalizadas, banidas do convívio social, segregadas em hospitais e prisões, afinal, representavam uma ameaça à sociedade (MENDES, 1995).

Na segunda fase, que compreende a expulsão dos jesuítas, em 1759, até o fim da República Velha (1930), viveu-se um momento em que ou se buscavam fontes autônomas de financiamento ou se previam, nas dotações orçamentárias públicas, os recursos para o ensino. Nesse contexto, houve a substituição do modelo educacional jesuítico por um sistema de ensino não seriado, com aulas avulsas e isoladas, denominado "aulas régias". Entretanto, esse modelo carecia de recursos financeiros, condição que se tentou minimizar com a criação, em 1772, do subsídio literário, "[...] uma taxa a ser cobrada pelas câmaras municipais especificamente para o sustento das escolas, o que vale dizer, para o pagamento dos professores" (MONLEVADE, 1997, p. 55).

A Independência e a fundação do Império no Brasil, em 1822, pouco alterou o quadro educacional existente. Ainda que a Constituição Imperial de $1824^{52}$ determinasse "a instrução primária e gratuita a todos os cidadãos" (BRASIL, 1824, art. 179, inciso XXXII), o que poderia representar um maior compromisso do governo central com a escola pública, a situação continuou a mesma, tendo em vista que a educação não era obrigatória, portanto, o Estado não tinha o dever de fornecer o

52 A Constituição de 1824, segundo Vieira (2007, p. 293), revelou "princípios de um liberalismo moderno expressando a separação entre colônia e metrópole, processo marcado por ambiguidades e contradições". Cabe ressaltar o fortalecimento do Imperador, por meio da instituição do poder moderador, que possibilitou ampla margem de intervenção na vida pública do país. 
ensino primário público de forma gratuita. Observa-se, nesse momento político, pouca preocupação com a matéria educacional (VIEIRA; FARIAS, 2007).

O Ato Adicional de 1834 transferiu às províncias o direito de criar e custear as escolas públicas e, por consequência, a obrigação de manter o ensino primário e secundário, assim como desobrigou o governo central de responsabilizar-se por tal oferta, uma vez que limitou a sua competência normativa apenas às escolas da capital do Império e às vinculadas ao ensino superior (PINTO; ADRIÃO, 2006). Assim, o ato adicional delimitou competências em relação à educação no campo da instrução das províncias e do governo central. Nesse sentido, "[...] antes do nascimento da federação já se havia estabelecido a tendência de o governo central responsabilizar-se pelo ensino superior, pela criação das universidades, e as esferas locais pelas séries iniciais" (ROSSINHOLI, 2010, p. 17). Desse modo, a solução para o custeio das escolas envolveu o processo de descentralização e a responsabilização das províncias que passaram a cobrar impostos sobre o que foi denominado "circulação de mercadorias" (MONLEVADE, 1997, p. 57). Assim, segundo Monlevade (1977, p. 57), "[...] se estabelece o ritmo de crescimento das matrículas nas escolas provinciais (depois de 1889, estaduais) proporcional à arrecadação de impostos sobre a produção e o comércio de cada região".

No período do Império (de 1822 a 1888), de acordo com Jannuzzi (2004), caracterizado por uma sociedade rural e desescolarizada, a educação das pessoas com deficiência ${ }^{53}$ encontrou no país pouca manifestação, no que diz respeito tanto às instituições como aos escritos sobre sua educação.

Em 1854, foi criado, no município da Corte, o Rio de Janeiro, o Imperial Instituto dos Meninos Cegos (em 1891, passou a ser denominado Instituto Benjamin Constant) e, alguns anos depois, o Instituto dos Surdos-Mudos (1857) (posteriormente denominado Instituto Nacional de Educação de Surdos), ambos sob a manutenção e a administração do poder central. Com a criação dessas duas instituições, nota-se a importância dada, nessa época, ao ensino especializado vinculado à administração pública. Contudo, a educação especial ainda não era prioridade para o Governo Central, como política pública, portanto, era deixada em segundo plano, assim como o ensino primário. Isso se confirma quando a

\footnotetext{
53Jannuzzi (2004) faz referência apenas à população de alunos com deficiência. Portanto,
} manteremos o termo utilizado pela autora. 
responsabilidade da educação das pessoas com deficiência foi proposta como "encargo das províncias", demonstrando todo descaso com essa modalidade de ensino e com a educação da população em geral, visto que

[...] elas não eram necessárias como produtoras de mão-de-obra compulsoriamente escrava, nem como fator de ideologização, uma vez que a ordem escravocrata estava assegurada pela repressão, pela ruralização intensa, em que poucos contatos sociais se faziam nas grandes propriedades latifundiárias. (JANNUZZI, 2004, p. 20).

Após a proclamação da República, em 1889, a Constituição Federal de 1891 enfatizou o ensino leigo e sua separação da igreja ("laicidade do ensino"), bem como "[...] o papel desempenhado pelas famílias em detrimento do Estado, na garantia do direito à educação, reforçando a política oficial de alheamento do governo central em relação aos assuntos educacionais" (PINTO; ADRIÃO, 2006, p. 25). Além disso, essa Constituição não previu a obrigatoriedade e a gratuidade do ensino. Observase a interferência do governo central na educação primária somente no contexto da Primeira Guerra Mundial (1914-1918), por meio do financiamento para a reorganização das escolas. Para Cury (1996), nesse período houve o estabelecimento do federalismo brasileiro, na medida em que a instrução ficou sob a responsabilidade das unidades federadas, sendo a instrução primária encargo dos estados e municípios, o ensino secundário função dos estados e o ensino superior atribuição da União. Vale ressaltar que a iniciativa privada era permitida em todos os níveis de ensino (CURY, 1996).

O Brasil, no final do século XIX e início do século XX, atravessava um período de mudança em seu modelo econômico. Iniciava um processo de industrialização, deixava seu "modelo agrário-comercial-exportador" para assumir o "modelo capitalista-urbano-industrial” (BRZEZINSKI, 1996, p. 25). Nesse contexto, a educação passou a ser vista como fator principal para a reconstrução social, sinônimo de desenvolvimento e progresso.

Cabe ressaltar, nas primeiras três décadas do século $X X$, o fortalecimento dos movimentos sociais, inspirados pelos pressupostos marxistas, e a consequente construção de estados socialistas, bem como o início do desenvolvimento de Estados de Bem-Estar Social em países capitalistas do Ocidente, contribuindo 
significativamente para 0 debate acerca do compromisso do Estado na implementação das políticas sociais (PINTO, 2000). Nesse sentido, a agenda social passou a ser incorporada nos discursos e nas políticas do Estado brasileiro a partir da década de 1930. Marisa Rossinholi (2010, p. 21) salienta que o número de matrículas, no início da terceira década do século XX, mostra "[...] a participação do Estado e um processo de crescimento quantitativo em relação ao fornecimento do ensino e a seu papel na federação". Nessa perspectiva, com o processo de industrialização no Brasil, baseado na substituição de importações, a esfera governamental continuou a implementar algumas ações, na tentativa de atender às demandas voltadas às pessoas com deficiência. De acordo com Jannuzzi (2004), diante da nova conjuntura social, imposta pelas modificações do capitalismo mundial, o Estado começou a organizar-se para tentar minimizar o problema social da deficiência.

A defesa pela educação dos ditos "anormais 54 ", nessa época (1930), presente nos discursos e práticas dos profissionais, tinha subjacentes interesses econômicos e sociais, uma vez que a preocupação era com a ordem social e com criação de mão de obra que tornasse a pessoa com deficiência útil para ingressar no mercado de trabalho e, assim, contribuir para o aumento da produção e, consequentemente, do lucro. Desse modo, o papel da escola seria preparar as pessoas com deficiência para ocupar um lugar na sociedade. Segundo Jannuzzi (2004, p. 53), a educação dessas pessoas se dava de maneira diferenciada, pois a educação era "[...] em classes selecionadas, com professores especializados, com grandes conhecimentos científicos e um grande poder de intuição, trabalhando para aumentar nela a adaptabilidade e laboriosidade". Ao mesmo tempo, foram fundadas instituições filantrópicas especializadas que, de acordo com Enicéia Gonçalves Mendes (1995, p. 77), tinham como objetivo principal o tratamento moral, visto como "[...] um antídoto para a vida perniciosa nas grandes cidades, fazendo surgir a figura dos cuidadores profissionais que se dedicavam ao trabalho nestas instituições".

Nesse sentido, a educação para as pessoas com deficiência ${ }^{55}$ passou a ser caracterizada pelos serviços de assistência pública. Segundo Roseli Aparecida Parizzi (2000, p. 11), o início do século XX foi "[...] caracterizado pelo surgimento das

\footnotetext{
${ }^{54}$ Expressão utilizada à época para fazer referência às pessoas com deficiência.

${ }^{55}$ Parizzi (2000) não faz referência aos alunos com TGD e altas habilidades/superdotação.
} 
primeiras entidades privadas de atendimento aos deficientes ${ }^{56}$, inserindo a educação especial tanto no âmbito de instituições filantrópicas - assistencialistas como no ensino privado".

Assim, a educação geral no Brasil, nessa fase, passa a ser vista como sinônimo de progresso e desenvolvimento. Nesse contexto, foi possível vislumbrar a pressão política por parte da sociedade civil para a garantia de acesso à educação e, ao mesmo tempo, tímidas iniciativas por parte do Poder Público voltadas à garantia da educação, via educação especial, às pessoas com deficiência, representadas na busca de fontes autônomas, privadas e/ou vinculadas à arrecadação de impostos, que pudessem prover os recursos a serem destinados à educação. Cabe acrescentar o início do processo de descentralização, ou seja, a delimitação de responsabilidades de cada ente federado pela manutenção e pelo desenvolvimento do ensino, embora não houvesse essa definição em relação à educação especial.

$\mathrm{Na}$ terceira fase, que se iniciou com a Constituição Federal de 1934 (CF/1934) e perdura até hoje, apesar das interrupções nos períodos ditatoriais (1937-1945 e 1964-1985), definiu-se, como principal mecanismo, a vinculação de um percentual mínimo de recursos tributários para o financiamento da educação.

A CF/1934 mantém a estrutura anterior do sistema educacional, cabendo à União "traçar as diretrizes da educação nacional" (art. $5^{\circ}$, inciso XIX), organizar e manter os sistemas educacionais dos territórios, bem como exercer sua função supletiva. A referida Constituição, pela primeira vez, estabeleceu a vinculação de um percentual mínimo das receitas de impostos para ser aplicado em educação. Assim, caberia à União e aos municípios aplicar, na manutenção e no desenvolvimento dos sistemas educativos, nunca menos de $10 \%$ da renda resultante de impostos, e ao Distrito Federal e aos estados, no mínimo de 20\% (OLIVEIRA, R., 2007). O art. 157 da CF/1934 estabelecia que a União, o Distrito Federal e os estados deveriam reservar parte dos seus patrimônios territoriais para a formação de fundos de educação, sendo uma parte destinada ao auxílio aos alunos necessitados mediante o fornecimento gratuito de material escolar, bolsas de estudos, entre outras formas. Nessa perspectiva, segundo Rossinholi (2010, p. 25), a "[...] concepção de fundos para educação aparece pela primeira vez em uma constituição brasileira". Cumpre

\footnotetext{
56 Termo utilizado por Parizzi (2000).
} 
destacar que, ao lado de concepções liberais, o texto constitucional também expressava ideias conservadoras (VIEIRA; FARIAS, 2007), como o apoio irrestrito ao ensino privado por meio da isenção de tributos a quaisquer "estabelecimentos particulares de educação gratuita primária ou profissional, oficialmente considerados idôneos" (BRASIL, 1934, art. 154).

Outro aspecto da CF/1934 foi a obrigação das empresas de manterem o ensino primário gratuito para seus trabalhadores. No entanto, devido ao ônus financeiro e administrativo que as empresas não estavam dispostas a assumir e à baixa capacidade de regulação por parte do Estado em garantir o cumprimento da lei, essa determinação foi praticamente inócua (PINTO; ADRIÃO, 2006). Não obstante, criava-se a lógica para o estabelecimento do atual salário-educação. Em 1937, a vinculação foi retirada com a implantação do Estado Novo (até 1945) e retomada pela Constituição de 1946 (CF/1946).

A Constituição de 1937 (CF/1937) retomou a centralização no campo educacional, expressa, principalmente, pela ampliação da competência da União em fixar as bases e diretrizes da educação nacional. Para Vieira (2007, p. 298), "[...] o dever do Estado para com a educação é colocado em segundo plano, sendo-lhe atribuída uma função compensatória" na oferta escolar destinada à "infância e a juventude, a que faltarem os recursos necessários à educação em instituições particulares" (BRASIL, 1937, art. 129). Nesse cenário, o ensino pré-vocacional e profissional destinado às classes desfavorecidas era visto como prioridade e principal dever do Estado. Assim, embora o texto constitucional de 1937 estabelecesse o ensino primário como obrigatório e gratuito (art. 30), acrescentou, no mesmo artigo, o caráter parcial dessa gratuidade, na medida em que previa aos que não alegassem ou notoriamente não pudessem alegar escassez de recursos, uma contribuição módica e mensal para a caixa escolar (BRASIL, 1937). Conforme Vieira (2007, p. 298), "[...] educação gratuita é, pois, a educação dos pobres”, ou seja, destinada àqueles impossibilitados de arcar com os custos do ensino privado.

A CF/1946, por sua vez, estabeleceu que a União deveria aplicar nunca menos de $10 \%$, e o Distrito Federal, os estados e os municípios, nunca menos de $20 \%$ das suas receitas na manutenção e no desenvolvimento do ensino (art. 169). texto previa ainda que a União deveria colaborar com o desenvolvimento de sistemas de ensino, prestando "auxílio pecuniário", que, no caso do ensino primário, 
procederia do respectivo Fundo Nacional (art. 171, parágrafo único), criado em 1942, para garantir apoio financeiro da União aos estados. Para Monlevade (1997), a Constituição de 1946 propõe uma dupla via de descentralização a partir da contribuição do Distrito Federal, dos estados e dos municípios, que deveriam investir $20 \%$ de sua receita resultante de impostos na manutenção e no desenvolvimento do ensino (art. 169), como gasto direto, e, pelo subsídio indireto, por meio de dois fundos que redistribuem o Imposto de renda e o Imposto sobre produtos industrializados arrecadados nos estados mais ricos e distribuídos entre os mais pobres, no intuito de corrigir desequilíbrios de capacidade financeira entre municípios e estados de diferentes realidades econômicas. Esses fundos são o FPM e o FPE, dos quais se exige também a aplicação de $20 \%$ para o ensino. Nesse sentido, o financiamento da educação básica (em âmbito nacional, no âmbito do Distrito Federal, dos estados e dos municípios) passa a ser cada vez mais proporcional à arrecadação de impostos, em função dos percentuais crescentes e uniformes de vinculação destinados à manutenção e ao desenvolvimento do ensino.

Nas décadas de 1940 e 1950, a sociedade brasileira passou por grandes transformações econômicas, sociais e políticas. Com o processo de industrialização e urbanização, formou-se uma nova burguesia que exigia o acesso à educação. Percebe-se, nesse contexto, a retomada dos princípios liberais (de liberdade, igualdade e fraternidade) e democráticos, baseados na justiça social, na tentativa de garantir os direitos sociais a todos. Do mesmo modo, cresceram os movimentos sociais em favor da democratização da escola e pela responsabilização da educação por parte do Poder Público. Jannuzzi (2004, p. 134) traduz esse período como o do "[...] entusiasmo e otimismo pedagógico: mais educação para todos para incorporá-los na senda do progresso vivido pelas outras nações".

A educação especial foi sendo estruturada nesse contexto, porém pautada em vertentes do campo médico e psicológico, isto é, na etiologia da deficiência, relacionando causa física com o comportamento do sujeito, seus aspectos patológicos, déficits e limitações, buscando, nas deficiências, o que diferia do normal, as suas faltas. Assim, durante a década de 1950, o descaso do Poder Público e a, consequente escassez de serviços deram origem a movimentos comunitários que culminaram com a implantação de redes de escolas especiais privadas para atendimento às pessoas com deficiência (MENDES, 2006a). Desse 
modo, os serviços de educação especial se processavam por meio de escolas especiais de natureza privada e sem fins lucrativos. ${ }^{57}$ Nesse sentido, a partir dos anos 50, a Associação de Pais e Amigos dos Excepcionais (Apae) e a Associação Pestalozzi, segundo Mendes (1995, p. 277), "[...] exercem várias ações diretas e indiretas no equacionamento da educação especial no Brasil”, seja pela quantidade de serviços oferecidos, seja pela sua influência na política educacional.

Paralelamente, Mazzotta (2011) afirma que, ao final da década de 1950, o atendimento educacional às pessoas com deficiência, foi assumido explicitamente pelo Estado, em nível nacional, pelo governo federal, como política pública, com a criação de Campanhas, como a Campanha para a Educação do Surdo Brasileiro (1957), Campanha Nacional de Educação e Reabilitação de Deficientes da Visão (1958) e a Campanha Nacional de Educação e Reabilitação de Deficientes Mentais Cademe (1960). Contudo, somente a partir dos anos 1960, observa-se o aumento de número de classes especiais, nas escolas públicas (PARIZZI, 2000).

Nessa direção, em 1960, foi criado um fundo especial, de natureza bancária, em conta no Banco do Brasil S/A, sob a responsabilidade do diretor executivo da Cademe, designado pelo Ministro da Educação e Cultura, para ações da área. De acordo com Mazzotta (2011, p. 56-57),

[...] tal fundo deveria ser constituído por dotações e contribuições previstas nos orçamentos da União, estados e municípios e de entidades paraestatais de economia mista; donativos, contribuições e legados particulares; contribuições de entidades públicas e privadas, nacionais e estrangeiras; venda eventual de patrimônio da Campanha, além de dotações orçamentárias referentes a serviços educativos, culturais e de reabilitação.

Nesse sentido, a Cademe, por meio do fundo, teria como principal atribuição, segundo o art. 3ำ do Decreto no 48.961, de 22 de setembro de 1960, cooperar técnica e financeiramente com as entidades públicas e privadas que ofereciam serviços de educação, treinamento, reabilitação e assistência social às crianças e adolescentes com deficiência intelectual.

57 Faz-se necessário ressaltar, segundo Prieto (2009), que, em alguns estados brasileiros, a estruturação da educação especial apresentou configurações peculiares, por exemplo, em São Paulo, que teve como referência o trabalho com o ensino itinerante e salas de recursos. 
Em 1961, foi aprovada a primeira LDB, pela Lei $n .-94.024$, de 20 de dezembro, cuja tramitação havia se iniciado em 1948. Essa Lei previa que a União deveria aplicar em educação $12 \%$ de sua receita de impostos, e o Distrito Federal, os estados e os municípios $20 \%$, como percentual mínimo. Nesse momento, foram constituídos os fundos nacionais do ensino primário, do ensino médio e do ensino superior, com nove décimos dos recursos federais destinados à educação (BRASIL, 1961, art. 92, § 1ํ). Saviani (1997) salienta que a LDB/1961 pouco alterou a realidade educacional brasileira. Cabe ressaltar que nessa Lei foi reafirmado o direito à educação para as pessoas excepcionais ${ }^{58}$, mas, a partir da articulação com entidades privadas de assistência e/ou especializadas. Afirma Mazzotta (2011, p. 72):

No Artigo 89, dessa mesma lei, há o compromisso explícito dos Poderes Públicos de dispensar "tratamento especial mediante bolsas de estudos, empréstimos e subvenções" a toda iniciativa privada, relativa à educação de excepcionais, considerada eficiente pelos Conselhos Estaduais de Educação.

Contraditoriamente ao que foi previsto na LDB/1961, a Constituição de 1967 suprimiu o dever da União de investir na educação e manteve apenas os percentuais de impostos para a MDE dos estados e municípios, em plena ditadura militar, diminuindo, assim, os investimentos governamentais em educação. Em um contexto em que o país apresentava uma grande expansão de matrículas em virtude da migração do campo para a cidade e a ampliação da escolaridade obrigatória de quatro para oito anos, promovida pela Lei oㅡ 5.692, de 11 de agosto de $1971^{59}$, os gastos com a educação atingiram seus patamares mais baixos (MELCHIOR, 1987). De acordo com Rossinholi (2010, p. 33):

Em 1967, com a nova Constituição Federal e com o regime autoritário, houve a centralização das decisões na esfera da União. Isso pode ser verificado no sistema tributário estabelecido, que centralizou os recursos financeiros e as decisões na esfera da União e não fez referência aos mínimos orçamentários para a educação.

\footnotetext{
${ }^{58}$ A LDB/1961 utiliza a expressão "excepcionais" para fazer alusão às pessoas com deficiência e não menciona os alunos com TGD e altas habilidades/superdotação.

${ }^{59}$ Cabe destacar que a Lei 5.692/1971 não se constituiu em uma nova lei de diretrizes da educação nacional, mas estabeleceu algumas alterações na LDB/1961.
} 
Nessa perspectiva, para compensar a perda de receitas dos estados e municípios foi ratificado, na Constituição Federal de 1967, o sistema de transferências (FPM, FPE e a Quota parte do Imposto sobre Circulação de Mercadorias - QP-ICM), vinculado às categorias específicas e programas de gastos, restringindo a aplicação dos recursos. De acordo com Rossinholi (2010), a centralização de recursos permitia maior controle da política e o estabelecimento de prioridades em nível do governo federal. Assim, com as transferências, não se tinha fonte e percentual de recursos para a educação, embora a gratuidade e a obrigatoriedade do ensino primário estivessem mantidas. Dessa forma, a centralização por parte da União reduziu a autonomia política e financeira dos estados e municípios.

Cumpre destacar que, após a aprovação da Lei no 5.692/1971, inúmeras ações passaram a se desenvolver com vistas à implantação das novas diretrizes e bases para o ensino de $1^{\circ}$ e $2^{\circ}$ graus. A educação especial foi estabelecida como uma das prioridades do I Plano Setorial de Educação e Cultura (1972-1974). Nesse plano, segundo Mazzotta (2011, p. 99), foram apontadas como diretrizes da educação especial a integração e a racionalização, sendo definidas duas vertentes: "a expansão das oportunidades de atendimento educacional aos excepcionais e apoio técnico para que se ministre a educação especial". Mas, segundo Mendes (2010), o referido plano apresentou uma tendência de privilegiar a iniciativa privada em detrimento dos serviços públicos de ensino especial.

Foi nesse contexto que foi criado o Centro Nacional de Educação Especial (Cenesp), pelo Decreto ํㅜ 72.425, de 3 de junho de 1973, como órgão central de direção superior, com suas atividades sob a supervisão da Secretaria Geral do Ministério da Educação e Cultura. Criado "com a finalidade de promover em todo território nacional, a expansão e melhoria do atendimento aos excepcionais (BRASIL, 1973), o Cenesp se constituiu, segundo Mendes (2010, p. 100), "no primeiro órgão educacional do governo federal responsável pela política de educação especial". Com a sua criação, foram extintas as Campanhas cujo acervo financeiro e patrimonial foi revertido ao novo órgão. Também passou a integrar o Cenesp o acervo financeiro, pessoal e patrimonial dos Institutos Benjamin Constant e Nacional de Educação de Surdos. Assim, o Cenesp era formado por seis 
unidades: Conselho Consultivo, Gabinete, Assessoria Técnica, coordenações de acordo com determinada área de deficiência; Divisão de Pessoal e Órgãos Subordinados (Instituto Benjamin Constant e Instituto Nacional de Educação de Surdos) (MAZZOTTA, 2011).

Em 1973, com a instituição do Cenesp, também foi criado o Fundo de Educação Especial, de natureza contábil, constituído de dotações consignadas no orçamento geral da União; de repasses de outros fundos; de rendas próprias de serviços; de doações, subvenções e auxílios; de saldo verificado no final de cada exercício financeiro; de recursos provenientes de receitas diversas (BRASIL, 1973, art. 8º). Em 1977, o Ministério da Educação e Cultura elabora o / Plano Nacional de Educação Especial para o triênio 1977-1979, que tinha como diretrizes:

[...] ação de extensão do acesso à educação (destacando-se o acesso a tratamento diferenciado); ação otimizadora (aproveitamento dos recursos disponíveis e integração sob o ângulo pedagógicoadministrativo); ação preventiva (diagnóstico e atendimento precoces); ação de aperfeiçoamento (do sistema educacional, com o máximo de eficiência e o menor custo operacional possível) e ação continuada (educação permanente). (MAZZOTTA, 2011, p. 101).

Mazzotta (2011) ressalta ainda a ênfase atribuída, no documento, ao atendimento em instituições especializadas, especialmente as de caráter privado, levando à interpretação de que a maior parte dos atendimentos e com melhor qualidade era realizado por essas escolas. De acordo com o autor, tal argumentação garantiu, ao longo dos anos, respaldo para a assistência técnica e financeira do governo federal às instituições privadas de educação especial e foi reiterada em todos os documentos oficiais, servindo como eixo de ação para o MEC. Como exemplo, ele apresenta a previsão dos recursos financeiros desse Plano, "[...] de um montante de cento e quarenta e oito milhões e quatrocentos e noventa mil cruzeiros, foram previstos $58,70 \%$ para instituições privadas e $14,48 \%$ para os sistemas estaduais de ensino" (MAZZOTTA, 2011, p. 101), o que revela as prioridades e os rumos da política governamental nesse período.

Em 1977, com a criação do Ministério da Previdência e Assistência Social, e com a Portaria Interministerial no 477, de 11 de agosto, regulamentada pela Portaria Interministerial $\mathrm{n}^{-}$186, de 10 de novembro de 1978, foram estabelecidas as 
diretrizes básicas para a ação integrada no atendimento a "excepcionais", as quais dispunham sobre atendimento com "ações complementares de assistência médicopsico-social e de educação especial, definindo e delimitando sua clientela, dispondo sobre diagnóstico, encaminhamento, supervisão e controle" (MENDES, 2010, p. 101), assinalando o caráter assistencial, preventivo e corretivo do atendimento e, portanto, não educacional oferecido à população com deficiência nesse contexto. Assim, se, por um lado, as diretrizes buscam uma ação integrada entre os Ministérios para a melhoria do atendimento, por outro lado, elas revelam a tendência assumida pela política de educação especial, ou seja, de configuração da educação especial no campo terapêutico (MAZZOTTA, 2011).

Para a educação especial, os anos 70 representaram, segundo Leila Regina D’Oliveira de Paula Nunes e Júlio Romero Ferreira (1994), a sua institucionalização em nosso país, com a preocupação do sistema educacional público em garantir o acesso à escola às pessoas com deficiência ${ }^{60}$. Inicia-se a tendência ao movimento de integração social, que teve início ao final da década de 1970, com a finalidade de inserir as pessoas com deficiência nos "sistemas sociais gerais", como a educação, o trabalho e a família. Esse modelo tinha como princípio norteador a normalização, ou seja, nas palavras de Mendes (2006a, p. 389),

[...] toda pessoa com deficiência teria o direito inalienável de experienciar um estilo ou padrão de vida que seria comum ou normal em sua cultura, e que a todos indistintamente deveriam ser fornecidas oportunidades iguais de participação em todas as mesmas atividades partilhadas por grupos de idades equivalentes.

Esse processo teve como consequência, segundo a autora, o fortalecimento do processo de exclusão da escola pública das pessoas com deficiência, que eram encaminhadas às classes especiais, em processo de franca expansão, e/ou escolas especiais (MENDES, 2006a). Desse modo, a educação especial funcionava como um serviço paralelo ao sistema educacional, com métodos ainda de forte ênfase médico/psicológica, dando prioridade aos fatores orgânicos da deficiência e a

60 Os autores não mencionaram, em seu trabalho, os alunos com TGD e altas habilidades/superdotação. 
currículos próprios, desvinculados da educação escolar61 (FERREIRA, M., 2005). As classes especiais implantadas em redes públicas de ensino nas décadas de 1970 e 1980 serviram, em muitos dos casos, mais como espaços de segregação para aqueles que não se enquadravam no sistema regular de ensino, do que como uma possibilidade para ingresso na rede pública das pessoas com deficiência ${ }^{62}$, cuja maioria ainda continuava em instituições privadas (BUENO, 1993). O período de redemocratização do país (1979-1985) traz, segundo Pinto (2000, p. 56), “a luta por resgatar a melhoria da escola pública, que passa necessariamente pela garantia de mais recursos financeiros para um sistema de ensino agora, sim, mais massificado". Nesse contexto, temos o retorno à vinculação constitucional de um percentual mínimo de recursos à educação, em 1983, com a aprovação da Emenda Constitucional $n^{\circ}$ 24, de $1^{\circ}$ de dezembro de 1983, conhecida como Emenda Calmon, que determinava, no seu $\S 4$ que a União não poderia aplicar menos de $13 \%$ e 0 Distrito Federal, estados e municípios 25\%, no mínimo, da receita resultante de impostos, na manutenção e desenvolvimento do ensino (BRASIL, 1983).

Cabe ressaltar que, em 1986, no governo de José Sarney (1986-1990), foi lançado o Plano Nacional de Ação Conjunta para Integração da Pessoa Deficiente. Nesse contexto, foi instituído, no Gabinete Civil da Presidência da República, a Coordenadoria Nacional para Integração da Pessoa Portadora de Deficiência (Corde), que estabeleceu a atuação da Administração Federal, no que se refere à gestão de políticas voltadas às pessoas com deficiência, visando assegurar-lhes o pleno desenvolvimento de seus direitos básicos e a sua efetiva integração social. Nesse mesmo ano, o Cenespe foi transformado em Secretaria de Educação Especial (Sespe) pelo Decreto no 93.613, de 21 de novembro de 1986. A estrutura da Sespe era formada pela Subsecretaria de Educação e Aprimoramento da Educação Especial, Subsecretaria de Articulação de Apoio à Educação Especial, Coordenadoria de Planejamento e Orçamento, e Divisão de Serviços Administrativos. O Instituto Benjamin Constant e o Instituto Nacional de Educação de Surdos permaneceram como órgãos autônomos, vinculados à Sespe.

61 Essa perspectiva de currículo, segundo Ferreira M. (2005, p. 69), dava ênfase a "programas de treinamento de habilidades necessárias à vida diária ou vida prática, cujos programas de intervenção educativa se caracterizavam por um atendimento de natureza individualizada, orientados pela pedagogia terapêutica, objetivando a superação das incapacidades pela intervenção sobre os pontos fracos, à semelhança do princípio da cura que busca a redução de problemas orgânicos, como se dá na atuação médica".

$62 \mathrm{O}$ autor não menciona as pessoas com TGD e altas habilidades/superdotação. 
Em 1988, tivemos a aprovação da Constituição Federal (CF/1988), que fixa, no art. $6^{\circ}$, o direito à educação, como direito fundamental de caráter social, detalhado no Título VIII - "Da Ordem Social”, Capítulo III -“Da Educação, da Cultura e do Desporto", Seção I - "Da Educação", nos artigos 205 a 214, nos quais se encontram aspectos relacionados à sua concretização, tais como os seus princípios e objetivos, os deveres de cada ente da federação, a estrutura educacional, além de um sistema próprio de financiamento que prevê a vinculação constitucional de recursos (BRASIL, 1988).

A CF/1988, ao fixar, no art. 205, que a educação, "[...] direito de todos e dever do Estado e da família, será promovida e incentivada com a colaboração da sociedade", introduz a ideia de que esta é tarefa a ser compartilhada entre Estado e sociedade. Nessa perspectiva, o Estado, entendido aqui como Poder Público, representado pelos entes federados (União, Distrito Federal, estados e municípios), tem a responsabilidade de oferecer a educação em todos os níveis e modalidades de ensino a todos os cidadãos brasileiros. A sociedade, por sua vez, é convidada a colaborar para a efetivação desse direito, por meio da participação na formulação de políticas e no controle das ações do Estado. Nesse sentido, a CF/1988 aciona "a própria sociedade civil como espaço consciente de poder e controle democrático do próprio Estado, a fim de que nenhum cidadão fique sem o benefício da educação escolar" (CURY, 2002, p. 26). Entretanto, historicamente, a oferta de serviços sociais aos cidadãos no Brasil tem sido compartilhada com os representantes de organizações privadas sem fins lucrativos de caráter assistencial, conforme mostram os estudos na área educacional (CURY, 2005; PERONI, 2003). Adrião et al. (2009), ao analisarem a coexistência da oferta pública e privada na educação brasileira, salientam que essa relação não constitui uma novidade na esfera educacional, na qual, tradicionalmente, o Poder Público delega à iniciativa privada a tarefa de atender a demanda dos diferentes níveis e modalidades de ensino (como é o caso da educação especial e da educação infantil),

[...] quer seja pela dificuldade ou impossibilidade [do setor público] constituir quadros e serviços que atendam às necessidades de suporte à oferta educacional, quer seja pelas frágeis iniciativas de colaboração entre os entes federados, quer seja, ainda, pela capacidade do setor privado em se apresentar como alternativa 
tentadora aos interesses das políticas locais. (ADRIÃO et al., 2009, p. 813).

O financiamento da educação na CF/1988 caracterizou-se pela orientação da descentralização financeira, representando o aumento da participação dos estados e municípios na arrecadação tributária e nas receitas disponíveis. O percentual de verbas vinculadas à educação atribuída à União foi elevado para "nunca menos de dezoito, e os Estados, o Distrito Federal e Municípios vinte e cinco por cento, no mínimo, da receita resultante de impostos, compreendida a proveniente de transferências, na manutenção e desenvolvimento do ensino" (BRASIL, 1988, art. 212). De acordo com Castro (2005, p. 843),

[...] essa forma de financiamento para a educação - reserva de determinado porcentual do valor arrecadado mediante impostos tem sido uma das medidas políticas mais importantes para garantir a disponibilidade de recursos para cumprimento ao vasto rol de responsabilidades do poder público nessa área.

Assim, observamos transformações significativas no que tange ao âmbito jurídico-institucional, representadas pelas políticas de reestruturação de gestão, organização e financiamento da educação básica ao longo das décadas de 1930 a 1980.

Na década de 1980, no que se refere à educação especial, de acordo com Ferreira J. (2005, p. 62), com o processo de redemocratização e com a atuação propositiva dos movimentos sociais no contexto da Constituinte (1987-1988), comprometidos com a universalização do acesso e a democratização do ensino básico público, surgiram inúmeras críticas em relação ao funcionamento das classes especiais das escolas públicas, inicialmente quanto aos seus critérios de composição; depois, quanto à sua existência. Essas críticas se aliavam aos pressupostos dos movimentos locais e internacionais pela inclusão escolar, que questionavam a natureza segregadora e marginalizadora dos ambientes de ensino especial (MENDES, 2006a). Desse modo, as demandas relacionadas à educação das pessoas com deficiência começaram a ganhar visibilidade nas políticas educacionais. 
A CF/1988 estabelece, no art. 208, inciso III, o "atendimento educacional especializado aos portadores de deficiência ${ }^{63}$, preferencialmente na rede regular de ensino" (BRASIL, 1988). Cabe ressaltar, no âmbito dessa Constituição, no art. 213, a possibilidade de autorização para que sejam utilizados convênios com entidades da sociedade civil para complementar os atendimentos às pessoas com deficiência, TGD e altas habilidades/superdotação. Assim, o referido artigo dispõe:

Art. 213. Os recursos públicos serão destinados às escolas públicas, podendo ser dirigidos a escolas comunitárias, confessionais ou filantrópicas, definidas em lei, que:

I - comprovem finalidade não-lucrativa e apliquem seus excedentes financeiros em educação;

II - assegurem a destinação de seu patrimônio a outra escola comunitária, filantrópica ou confessional, ou o Poder Público, no caso de encerramento de suas atividades. (BRASIL, 1988).

Dessa maneira, observamos que a responsabilidade pelo atendimento às pessoas com deficiência, TGD e altas habilidades/superdotação continua a ser compartilhada com a sociedade civil, aspecto observado em toda a história da educação especial brasileira.

Cumpre destacar a Lei no 7.853, de 24 de outubro de 1989, que estabeleceu "normas gerais para o pleno exercício dos direitos individuais e sociais das pessoas portadoras de deficiência e sua efetiva integração social". Essa mesma lei reestrutura a Corde "[...] como órgão autônomo, administrativa e financeiramente, com definição de recursos orçamentários específicos" (MAZZOTTA, 2011, p. 86). É interessante observar que se passaram dez anos entre a publicação da referida Lei e sua regulamentação, por meio do Decreto n‥ 3.298, de 20 de dezembro de 1999 BRASIL, 1999c). Nesse mesmo ano, foi criado, no âmbito do Ministério da Justiça, o Conselho Nacional dos Direitos da Pessoa Portadora de Deficiência (Conade), por meio do Decreto no 3.076, de 1ํㅡㄹ de junho de 1999 (BRASIL, 1999b), para acompanhar e avaliar o desenvolvimento da política nacional para a inclusão da pessoa com deficiência e o desenvolvimento das políticas setoriais de educação, saúde, trabalho, assistência social, transporte, cultura, turismo, desporto, lazer e política urbana voltada a esse grupo social. Com a Medida Provisória no 483, de 24 de março de 2010 (BRASIL, 2010d), que alterou a Lei № 10.683, de 28 de maio de

${ }^{63}$ Essa é a nomenclatura utilizada na CF/1988 (BRASIL, 1988) e, atualmente, esse direito é extensivo aos alunos com TGD e altas habilidades/superdotação (BRASIL, 2013a). 
2003, o nome do Conade foi atualizado para Conselho Nacional dos Direitos da Pessoa com Deficiência. Em 2013, por meio Decreto nำ 8.162, de 18 de dezembro de 2013 (BRASIL, 2013d), o Conade passou a ser vinculado, como órgão colegiado, à Secretaria de Direitos Humanos da Presidência da República. Atualmente, a antiga Corde constitui a Secretaria Nacional de Promoção de Direitos das Pessoas com Deficiência, integrado aos Órgãos Específicos Singulares da mesma Secretaria.

Essas inúmeras alterações nos levam a refletir, assim como Mazzotta (2011), até que ponto órgãos federais com atribuições relativas às pessoas com deficiência compatibilizam suas competências ou entram em conflito na definição da estrutura do poder político nessa área.

Assim, o financiamento da educação especial, ao longo do tempo, foi se constituindo num contexto sócio-histórico contraditório, repleto de ambiguidades, conflitos e (in)definições que também perpassaram o financiamento de outras etapas e modalidades de ensino, ao longo da história da educação brasileira. Entretanto, essa trajetória histórica também apresenta peculiaridades, na medida em que observamos a presença tímida do Poder Público em relação à garantia dos direitos de acesso e permanência das pessoas com deficiência, TGD e altas habilidades/superdotação nos sistemas públicos de educação. Os serviços assistenciais, educacionais e de promoção à saúde oferecidos foram predominantemente assumidos pelas instituições privadas, organizações não governamentais e/ou sociedade civil (KASSAR, 2011b).

A década de 1990 se iniciou, de acordo com Arelaro (2000), com movimentos contraditórios marcados, por um lado, pelo processo constituinte, que gerou a CF/1988, e pelo desejo de implementação dos direitos sociais nela introduzidos e, por outro, pela assunção de Fernando Collor de Mello (1990-1992) à Presidência da República, com um projeto neoliberal, baseado na redução do papel do Estado e do financiamento voltado às políticas sociais, atendendo à lógica de mercado. Desse modo, o início dessa década foi marcado por discursos e propostas polarizados sobre o papel do Estado na organização econômica e sobre a função do Poder Público nas áreas sociais (ARELARO, 2000).

No que se refere à educação especial, com a reestruturação do $\mathrm{MEC}$, em 1990, a Sespe foi extinta. Assim, as atribuições relativas à educação especial passaram a ser da Secretaria Nacional de Educação Básica (Seneb). O Decreto nº 
99.678, de 8 de novembro de 1990, ao aprovar o regimento do MEC, incluiu como órgão da Seneb o Departamento de Educação Supletiva e Especial (Dese), com atribuições específicas em relação a essa modalidade de ensino, contando, para gerenciá-la, com uma Coordenação de educação especial. Para Mazzotta (2011, p. 87),

[...] esta alteração estrutural sugere a preocupação com 0 favorecimento da integração da educação especial com os demais órgãos centrais da administração do ensino. Pelo menos por sua localização na estrutura do MEC, a Educação Especial deixa de ser objeto de um órgão autônomo em relação aos níveis e demais modalidades de ensino.

O Instituto Benjamin Constant e o Instituto Nacional de Educação de Surdos ficaram vinculados à Seneb, mantendo-se como órgãos autônomos.

Ao final do ano de 1991, a Coordenação de educação especial foi desativada, e todas as atribuições referentes à educação especial passaram a serem exercidas pela nova direção do Dese. Em 1992, com a saída do presidente Fernando Collor de Mello, houve outra reorganização dos Ministérios, e, na nova estrutura, reapareceu a Secretaria de Educação Especial (Seesp) como órgão específico do Ministério da Educação e do Desporto, pela Lei no 8. 490, de 19 de novembro de 1992. Segundo Mazzotta (2011, p. 142), esse órgão, até a década de 1990, se caracterizou

[...] pela centralização do poder de decisão e execução, por uma atuação marcadamente terapêutica e assistencial ao invés de educacional, dando ênfase ao atendimento segregado realizado por instituições especializadas particulares.

Na década de 1990, um conjunto das reformas estruturais e educacionais e, especialmente, as políticas de educação especial no Brasil se atrelaram aos debates e eventos promovidos por organismos internacionais, como a Conferência Mundial sobre Educação para Todos, em Jomtien - Tailândia, e coube ao país, como signatário da Declaração Mundial de Educação para Todos (1990), a responsabilidade de garantir a universalização do direito à educação. Desse compromisso resultou o Plano Decenal de Educação para Todos, concluído em 1993. Nesse sentido, ainda temos a Declaração de Salamanca, decorrente da 
Conferência Mundial sobre Necessidades Especiais: acesso e qualidade, ocorrida na Espanha, em 1994. Nesse contexto, foram publicados diferentes documentos referentes à política de educação especial no Brasil. Assim, observamos a influência dos organismos internacionais nas políticas educacionais brasileiras.

Em 1994, a Seesp publicou o documento intitulado Política Nacional de Educação Especial (BRASIL, 1994), no intuito de orientar o processo de "integração instrucional", que condicionava o acesso às classes comuns do ensino regular àqueles que possuíam "[...] condições de acompanhar e desenvolver as atividades curriculares programadas do ensino comum, no mesmo ritmo que os alunos ditos normais" (BRASIL, 1994, p. 19). A educação especial, nesse documento, seria transversal e perpassaria todas as etapas e modalidades de educação. Embora mencione no seu texto o discurso da educação inclusiva, esse documento estabelece que o atendimento do alunado seja realizado preferencialmente na rede regular de ensino, trazendo como base o princípio da integração (GARCIA, 2004b), podendo, no entanto, os alunos ser atendidos tanto na classe regular, como na classe especial, na classe hospitalar, no centro integrado de educação especial e na escola especial. Assim, ao ratificar

[...] os pressupostos construídos a partir de padrões homogêneos de participação e aprendizagem, a Política não provoca reformulação das práticas educacionais de maneira que sejam valorizados os diferentes potenciais de aprendizagem no ensino comum, mas mantendo a responsabilidade da educação desses alunos exclusivamente no âmbito da educação especial. (BRASIL, 2008a, p. 3).

$\mathrm{Na}$ área econômica, política e social, as propostas de reforma estatal ${ }^{64}$ se consolidaram no primeiro mandato do governo Fernando Henrique Cardoso (19951998), que apontou o Estado como responsável pela crise, "em função de sua excessiva atuação no setor produtivo, do processo de endividamento público e processo inflacionário" (ROSSINHOLI, 2010, p. 56). Nesse contexto, o governo federal implantou e/ou fomentou ações e políticas, articuladas aos princípios

\footnotetext{
64 Os princípios da proposta da reforma do Estado estão expressos no Plano Diretor da Reforma do Aparelho do Estado, elaborado pelo Ministério da Administração e Reforma do Estado (Mare), na gestão do Ministro Luiz Carlos Bresser Pereira, e aprovados em 21 de setembro de 1995, pela Câmara da reforma do Estado, no primeiro mandato do governo do presidente Fernando Henrique Cardoso (PERONI; OLIVEIRA; FERNANDES, 2009).
} 
estabelecidos por organismos internacionais, voltadas à reforma do Estado brasileiro, tendo como base, segundo Vera Maria Vidal Peroni, Regina Tereza Cestari de Oliveira e Maria Dilneia Espíndola Fernandes (2009, p. 767),

[...] privatização - transferência para o setor privado das atividades que podem ser controladas pelo mercado; descentralização transferência para o setor privado de serviços auxiliares ou de apoio; e publicização - transformação de uma organização estatal em uma organização de direito privado, mas pública não-estatal.

$\mathrm{Na}$ educação, esse período foi marcado por mudanças nas políticas educacionais, como a aprovação da LDB/1996, e na organização do financiamento da educação, com a implantação de fundos específicos voltados à manutenção e ao desenvolvimento do ensino.

Na LDB/1996 foi estabelecido o dever do Estado com a educação, mediante a garantia de "padrões mínimos de qualidade de ensino, definidos como a variedade e quantidade mínimas, por aluno, de insumos indispensáveis ao desenvolvimento do processo de ensino-aprendizagem (BRASIL, 1996a, art. 4ํㅜ, inciso IX). Essa ideia se articula à necessidade de investir esforços no intuito de garantir a oferta e melhores condições de ensino. No Brasil, o padrão de qualidade está relacionado aos recursos mínimos disponibilizados pela vinculação constitucional e ao valor alunoano definido pela política de fundos (PINTO; ADRIÃO, 2006; OLIVEIRA, R., 2007). Essa articulação entre custo e qualidade foi tratada, especificamente, nos arts. 74 e 75 dessa mesma Lei:

Art. 74 - A União, em colaboração com os estados, o distrito federal e os municípios, estabelecerá padrão mínimo de oportunidades educacionais para o ensino fundamental, baseado no cálculo do custo mínimo por aluno, capaz de assegurar ensino de qualidade.

Parágrafo Único - O custo mínimo de que trata este artigo será calculado pela União ao final de cada ano, com validade para o ano subsequente, considerando variações regionais no custo dos insumos e as diversas modalidades ensino.

Art. 75 - A ação supletiva e redistributiva da União e dos Estados será exercida de modo a corrigir, progressivamente, as disparidades de acesso e garantir o padrão mínimo de qualidade de ensino. (BRASIL, 1996a). 
Nessa direção, a educação foi ratificada como tarefa compartilhada entre União, Distrito Federal, estados e municípios, sendo organizada sob a forma de regime de colaboração (CF/1988, art. 211 e LDB/1996, art. 8º). Cada instância é responsável pela administração, expansão e manutenção dos seus respectivos sistemas de ensino, incluindo a organização de políticas e programas voltados à educação especial. Nalú Farenzena (2006, p. 99) destaca que "o reconhecimento dos órgãos executivos do setor educacional das três esferas do governo como gestores dos recursos pode possibilitar uma administração mais eficaz e efetiva dos recursos orçamentários". No âmbito dessa Lei, ainda foi enfatizado o papel coordenador e articulador da União em relação aos demais entes federados (LDB/1996, art. $8^{\circ}$ ), tendo como uma das suas tarefas a responsabilidade pela educação de alunos com deficiência, TGD e altas habilidades/superdotação.

A educação especial, nesse cenário, apresentou avanços em termos de legislação e também sofreu implicações na sua organização e financiamento. A LDB/1996, ao estabelecer a educação especial como modalidade de educação escolar, oferecida preferencialmente na rede regular de ensino, assegura aos alunos com deficiência, TGD e altas habilidades/superdotação que:

$\S 1$ ํㅡaverá, quando necessário, serviços de apoio especializado, na escola regular, para atender às peculiaridades da clientela de educação especial.

$\S 2^{\circ} \mathrm{O}$ atendimento educacional será feito em classes, escolas ou serviços especializados, sempre que, em função das condições específicas dos alunos, não for possível a sua integração nas classes comuns de ensino regular. (BRASIL, 1996a, art. 58).

Desse modo, essa Lei garante dois tipos de serviços: de apoio especializado, oferecidos na escola regular e o atendimento educacional realizado em classes, escolas ou serviços especializados (BRASIL, 1996a). Cabe destacar que a interpretação equivocada desse dispositivo tem levado a admitir a possibilidade de substituição do ensino regular pelo especial, conforme consta no documento "O acesso de alunos com deficiência às escolas e classes comuns da rede regular de ensino" (BRASIL, 2004c), publicado pelo Ministério Público Federal. Essa compreensão errônea entra em confronto com o que dispõe a CF/1988, que garante a obrigatoriedade do ensino público e gratuito a todo cidadão brasileiro em idade 
escolar na escola comum. Desse modo, a LDB/1996 faz referência à educação especial como modalidade que perpassa todas etapas e níveis de ensino, como complemento ou suplemento ao ensino comum; portanto, o direito ao atendimento educacional especializado, previsto nos arts. 58, 59 e 60, não substitui o direito à educação oferecida em classe comum da rede regular de ensino (BRASIL, 2004c).

O art. 60 da LDB/1996 (BRASIL, 1996a) assim dispõe:

\begin{abstract}
Os órgãos normativos dos sistemas de ensino estabelecerão critérios de caracterização das instituições privadas sem fins lucrativos, especializadas e com atuação exclusiva em educação especial, para fins de apoio técnico e financeiro pelo poder Público.

Parágrafo único: o poder Público adotará, como alternativa preferencial, a ampliação do atendimento aos educandos com deficiência, TGD e altas habilidades/superdotação na própria rede pública regular de ensino, independentemente do apoio às instituições previstas neste artigo.
\end{abstract}

Nessa perspectiva, a LDB/1996 reafirma o seu compromisso em oferecer essa modalidade de ensino a partir do apoio técnico e financeiro às instituições privadas sem fins lucrativos, ressaltando a relação contraditória entre Poder Público e privado na história da educação especial, na política educacional e no financiamento público. Mas, ao mesmo tempo, o Estado assegura a ampliação do atendimento na rede regular de ensino, em classe comum, independentemente do apoio às instituições privadas, um compromisso inédito no âmbito da lei nacional brasileira sobre educação. Na trajetória da educação especial no Brasil, Carmelita Cristina Bueno e Mônica de Carvalho Magalhães Kassar (2005) evidenciaram que, a história da educação especial seria exemplar do processo de publicização proposto pelo governo federal a partir da reforma do Estado, da década de 1990, uma vez que o financiamento por parte do Poder Público às instituições não governamentais e filantrópicas, como as Apaes e a Associação Pestalozzi, bem como a outras inúmeras instituições especializadas que mantêm convênios com secretarias estaduais e municipais de educação, tende a se fortalecer nesse contexto de distanciamento do Estado com relação às políticas públicas

Assim, "os processos de gestão educacional e escolar são fortemente induzidos pela lógica decorrente do financiamento adotado, resultante da caracterização do Estado e da articulação entre as esferas pública e privada" 
(DOURADO, 2007, p. 925). Desse modo, o Poder Público atua, diretamente, tanto na oferta de serviços de educação especial, como no repasse de verbas a essas instituições, que podem conjugar várias fontes de receitas, públicas e/ou privadas, na prestação de seus serviços.

Em 2001, o Brasil adere, mediante o Decreto $\mathrm{n}^{0}$ 3.956, de 8 de outubro (BRASIL, 2001c), à Convenção de Guatemala (1999), que tinha como objetivo "prevenir e eliminar todas as formas de discriminação contra as pessoas portadoras de deficiência e propiciar a sua plena integração à sociedade".

Nesse mesmo ano, com a Lei no 10.172, de 9 de janeiro de 2001, foi aprovado o Plano Nacional de Educação (PNE), para o período de 2001 a 2010, que traçou as diretrizes e metas para a educação brasileira. No que tange à educação especial, o PNE apresentou, no seu diagnóstico, o déficit, na década de 1990, na oferta de matrículas para os alunos com deficiência nas classes comuns do ensino regular, na formação docente, no atendimento educacional especializado e na acessibilidade física, indicando a necessidade de construção de uma escola inclusiva que garanta o atendimento da diversidade humana (BRASIL, 2001a). Garcia (2013, p. 102) destaca que o PNE (2001-2010) representou um grande avanço, a ser desenvolvido na década, com criação de uma escola inclusiva, baseada na formação de recursos humanos.

A preocupação com o atendimento aos educando especiais nas
escolas regulares e nas instituições especializadas revela que a
proposta de escola inclusiva no período se aproximava de uma
compreensão de inclusão processual, desenvolvida em diferentes
espaços físicos e institucionais.

No entanto, Glat e Ferreira (2003, p. 7), ressaltam, ao analisarem a redação do capítulo sobre educação especial na proposta original do MEC, de 1997, com a redação aprovada no Congresso e mantida pela Presidência da República na Lei de 2001, alterações importantes quanto ao papel das escolas e classes especiais, ou seja, o caráter de restrição do uso desses espaços "como sinal de preferência pela classe comum foi praticamente anulado". Desse modo, o PNE (2001-2010) manteve a parceria do Estado com organizações civis e não governamentais para prestação do serviço voltado aos alunos com deficiência. Assim, ele explicita a concepção do governo acerca do atendimento da educação especial, ou seja, por meio das parcerias com o setor privado. Faz-se necessário destacar que o PNE (2001-2010) 
registrou a meta de aumentar os recursos destinados à educação especial "[...] a fim de atingir, em dez anos, o mínimo equivalente a $5 \%$ dos recursos vinculados à manutenção e desenvolvimento do ensino [...]" (BRASIL, 2001a, p. 57). Porém, entre 1995 e 2003, os valores da subfunção educação especial no orçamento da União oscilaram em torno de 0,3\% (GLAT; FERREIRA, 2003), o que ajuda a compreender a proposta do PNE (2001-2010) para a ampliação dos recursos destinados a essa modalidade de ensino.

Nesse contexto, também foi promulgada a Resolução nำ 2, de 11 de setembro de 2001, do Conselho Nacional de Educação (CNE)/Conselho da Educação Básica (CEB), que institui as Diretrizes Nacionais para a Educação Especial na Educação Básica, constituindo-se em importante dispositivo legal que normatiza os princípios da educação inclusiva, presentes no debate internacional, e destaca ações nos âmbitos políticos, técnico-científico, pedagógico e administrativo. Assim, a Resolução estabelece que os estados e municípios devem organizar, nas secretarias de educação, um setor responsável pelas questões da educação especial, dotado de recursos humanos, materiais e financeiros, visando à melhoria do atendimento ao público da educação especial. Para Garcia (2004a), essa Resolução delegou aos sistemas de ensino as tarefas gerenciais e às escolas a responsabilidade de executar a educação inclusiva.

Em 2002, com a Resolução nำ 1, do CNE/Conselho Pleno(CP), a qual estabeleceu as Diretrizes Curriculares Nacionais Para a Formação de Professores da Educação Básica (BRASIL, 2002a), foi definido que as instituições do ensino superior devem prever, em sua organização curricular, formação docente que seja voltada à diversidade e que contemple conhecimentos sobre as especificidades do público da educação especial. Nesse sentido, as diretrizes estabeleceram novos desafios à formação de professores, a partir da inclusão, no currículo dos cursos de formação inicial, de conteúdos da área da educação especial, o que, segundo Moreira (2006, p. 9), “[...] não garantirá a qualidade profissional dos futuros professores nem a inclusão escolar dos alunos", mas é indispensável para a concretização de uma proposta inclusiva, diante da inexistência de espaços no currículo para se abordar essa temática. Como consequência do debate sobre o ensino de Língua Brasileira de Sinais (Libras) e sobre o ensino Braille, tivemos a promulgação da Lei ํㅜ 10.436, de 24 de abril de 2002 (BRASIL, 2002b), que dispõe sobre a Libras, e da Portaria oㅡ 
2.678, de 24 de setembro de 2002 (BRASIL, 2002c), que aprova as diretrizes e normas para uso, ensino, produção e difusão do sistema Braille.

Rosalba Maria Cardoso Garcia e Maria Helena Michels (2011, p. 114) salientam que se, ao longo do século XX, a educação especial foi estruturada em poucas instituições públicas e em rede paralela de instituições privadas, que desenvolveram o seu trabalho em regime de convênios e parcerias com as secretarias de educação de estados e municípios, no início do século XXI, "a política de educação especial assume uma perspectiva inclusiva, estabelece uma relação mais definida com a educação básica e inicia um processo de proposições com a educação superior", no bojo do movimento de expansão do atendimento às pessoas com deficiência, TGD e altas habilidades/superdotação. É com base nessas considerações que analisamos a educação especial no contexto dos fundos destinados ao financiamento da educação.

\subsection{A EDUCAÇÃO ESPECIAL NO ÂMBITO DOS FUNDOS DE MANUTENÇÃO E DESENVOLVIMENTO DA EDUCAÇÃO}

O Fundef foi instituído pela Emenda Constitucional nำ 14, de 12 de setembro de 1996 (EC/1996), e regulamentado pela Lei $n^{0}$ 9.424, de 24 de dezembro desse mesmo ano, como fundo de natureza contábil65 em cada unidade da federação, tendo vigorado até o ano de 2006. O Fundef era composto de parte dos recursos vinculados à educação pela $\mathrm{CF} / 1988$, devendo ser aplicado exclusivamente no ensino fundamental.

\footnotetext{
${ }^{65}$ Fundo criado no âmbito de cada estado e do Distrito Federal, composto de $15 \%$ da arrecadação de quatro impostos e transferências constitucionais (FPE; FPM; Imposto sobre Operações relativas à Circulação de Mercadorias e sobre Prestação de Serviços de Transporte Interestadual e Intermunicipal e de Comunicação (ICMS); Imposto sobre Produtos Industrializados, proporcional às exportações (IPI-Exp); e Ressarcimento pela Desoneração de Exportações, de que trata a Lei Complementar no 87, de 13 de setembro de 1996, chamada Lei Kandir). Esse fundo tinha como finalidade "redistribuir os seus recursos dentro do próprio Estado. Portanto, o efeito, dentro de um Estado, é o de retirar os recursos de alguns municípios e os remeter para outros, de tal modo que uniformiza, em todo o Estado o valor aplicado por estudantes do ensino fundamental" (AMARAL, 2012, p. 132).
} 
A EC/1996 também alterou a redação do art. 60 do "Ato das Disposições Constitucionais Transitórias" (ADCT) da CF/1988. Desse modo, essa Emenda Constitucional estabeleceu que

[...] os Estados, o Distrito Federal e os municípios destinarão não menos de sessenta por cento dos recursos a que se refere o "caput" do Art. 212 da Constituição Federal, à manutenção e ao desenvolvimento do ensino fundamental, com o objetivo de assegurar a universalização de seu atendimento e a remuneração condigna do magistério. (BRASIL, 1996c).

Cabe destacar que essa modificação aumentou o percentual, de 50\% para $60 \%$, dos recursos de cada ente federado, a ser aplicado nessa etapa de ensino. 0 restante dos recursos manteve sua destinação às outras etapas e modalidades da educação básica, conforme a responsabilidade na oferta do Distrito Federal, estados e municípios, estabelecida no art. 211 da CF/198866 (BRASIL, 1988).

Porém, observa-se uma redução na participação da União, que, anteriormente, deveria aplicar pelo menos $50 \%$ dos recursos, a que se refere 0 art. 212 da CF/1988, na eliminação do analfabetismo e na universalização do ensino fundamental. Com a EC/1996 esse percentual passou para nunca menos que o equivalente a $30 \%$, a serem aplicados na "erradicação67" do analfabetismo e na manutenção e no desenvolvimento do ensino fundamental, assumindo, assim, a União uma função secundária e de coordenação (OLIVEIRA, R., 2007; ROSSINHOLI, 2010).

A distribuição dos recursos do Fundef era proporcional ao número de alunos nas respectivas redes de ensino fundamental. (BRASIL, 1996b). Sua normatização determinava que, no mínimo, $60 \%$ dos recursos do fundo deveriam ser aplicados ao pagamento dos professores do ensino fundamental em efetivo exercício do magistério e os $40 \%$ deveriam ser destinados na manutenção e desenvolvimento do ensino fundamental (BRASIL, 1996b).

\footnotetext{
${ }^{66}$ Cabe destacar que a EC/96 alterou também o art. 211 da CF/88, redefinindo as competências de cada ente federado, assim, estabeleceu: " $\S 2^{\circ}$ Os municípios atuarão prioritariamente no ensino fundamental e na educação infantil" e " $\S 3^{\circ}$ "Os estados e o Distrito Federal atuarão prioritariamente no ensino fundamental e na educação infantil".

67 Termo utilizado na CF/1988 (BRASIL, 1988).
} 
A EC/1996 estabeleceu, ainda, a instituição de um valor mínimo, definido nacionalmente, pelo governo federal, a ser aplicado por aluno em cada ano, cabendo à União complementar os fundos dos estados que não apresentassem condições de fazê-lo com recursos próprios. Assim, a fixação do valor mínimo alunoano foi de extrema importância para estabelecer a participação da complementação da União, considerando que "o mecanismo do Fundef não altera a base fiscal vinculada ao fundo, como também não promove a redistribuição de recursos entre as unidades" (VAZQUEZ, 2005, p. 150). Esse desenho operacional era justificado para minimizar as desigualdades de condições de oferta do ensino fundamental nos estados brasileiros. Segundo Oliveira, R. (2007, p. 110), "[...] o valor nacional seria o gasto mínimo nacional por aluno-ano". Assim, a EC/1996 assim estabeleceu:

§ 4ํㅡ A União, os Estados, o Distrito Federal e os municípios ajustarão progressivamente, em um prazo de cinco anos, suas contribuições ao Fundo, de forma a garantir um valor por aluno correspondente a um padrão mínimo de qualidade de ensino, definido nacionalmente. (BRASIL, 1996c).

Nessa perspectiva, de acordo com Oliveira, R. (2007, p.110), o padrão de qualidade de ensino seria expresso em um gasto por aluno-ano, e não no "custoaluno qualidade", que "[...] seria o valor monetário que expressaria a quantidade de bens e serviços necessários por aluno para que se tenha um ensino de qualidade".

O valor mínimo aluno-ano era estabelecido por ato do Presidente da República, considerando o critério do cálculo fixado pelo art. $6^{\circ}$, $\S 1^{\circ}$ da Lei $n^{\circ}$ 9.424/1996: "O valor mínimo anual por aluno [...] nunca será inferior à razão entre a previsão da receita total para o fundo e a matrícula total do ensino fundamental no ano anterior, acrescida do total estimado de novas matrículas" (BRASIL, 1996b). Desse modo, o valor mínimo encontrava-se vinculado ao cálculo definido nessa fórmula legal, podendo fixar-se um valor acima dessa média, mas nunca abaixo dela. Esse critério deveria prevalecer por cinco anos, portanto até 2001; nos anos seguintes, o valor mínimo deveria corresponder ao custo-aluno qualidade. Entretanto, o valor mínimo anual por aluno, divulgado pelo governo federal ao longo dos anos, foi questionado por pesquisadores da área de financiamento da educação, como Nicholas Davies (1998), João Monlevade e Eduardo Batista Ferreira (1997) e Daniel Arias Vazquez (2005). Os autores mostraram, em seus estudos, que o valor 
apresentado era inferior à média nacional, segundo os critérios de cálculo estabelecidos no art. 6º da Lei no 9.424/1996. Eles apontaram, ainda, redução na participação da União, em razão do baixo valor mínimo aluno-ano estabelecido anualmente. Os reajustes realizados, nesse valor, foram inferiores ao aumento da arrecadação das receitas que compunham o fundo, o que contribuiu para a diminuição do aporte de recursos federais destinados à complementação do Fundef. Dessa maneira, segundo eles, o governo federal deixava de cumprir o estabelecido na legislação.

Outro instrumento importante introduzido pelo Fundef, de incentivo à participação da sociedade civil e controle social de verbas destinadas à educação, foi a criação, no âmbito da União, do Distrito Federal, dos estados e dos municípios, de um Conselho de Acompanhamento e Controle Social do Fundef (CACS-Fundef), responsável por acompanhar e fiscalizar a repartição, a transferência e a aplicação de recursos (BRASIL, 1996b). Para além do papel dos conselhos, Vazquez (2005, p.150) destaca ainda que

[...] a existência de uma conta única e específica para os recursos do fundo tem o intuito de dar maior visibilidade à gestão das verbas vinculadas à educação, facilitando a fiscalização, 0 acesso às informações sobre a utilização das verbas do Fundo e a elaboração de denúncias aos órgãos competentes sobre eventuais irregularidades na utilização dos recursos do Fundef.

A instituição desses mecanismos contribuiu, segundo o autor, para a gestão democrática das políticas públicas e para o fortalecimento do controle social e fiscalização das ações da administração pública (VASQUEZ, 2005).

Os impactos do Fundef foram analisados por diferentes autores (MELCHIOR, 1987; OLIVEIRA, R., 2007; MONLEVADE; FERREIRA, 1997), que ressaltaram os principais problemas e as consequências do referido fundo para a educação. Entre esses problemas estão a não destinação de novos recursos para a educação; a concentração de recursos no ensino fundamental; a utilização dos recursos do salário-educação pela União, para complementação dos fundos dos estados que não atingissem o valor mínimo nacional; e o não cumprimento dos dispositivos legais pelo governo federal do valor aluno-ano. 
Oliveira, R. (2007) destaca que, embora não tenha significado um aumento de recursos para a MDE, como previsto na $\mathrm{CF} / 1988$, o Fundef trouxe a definição de mecanismos de distribuição de recursos, instituindo um novo padrão de gestão da educação básica. Para os municípios, o Fundef significou o aumento no número de matrículas e a ampliação de sua responsabilidade com esse nível de ensino, uma vez que o número de alunos matriculados era superior a sua capacidade de financiamento, comprometendo o seu orçamento (ARELARO, 2004).

No tocante à educação especial, especificamente em relação aos alunos matriculados no ensino fundamental, a legislação do Fundef prescreveu a definição de um valor mínimo por aluno-ano diferenciado do valor mínimo nacional, de acordo com o nível de ensino e o tipo de estabelecimento, que levasse em conta o custo por aluno (BRASIL, 1996b). Vale ressaltar que, até 1999, não houve nenhum tipo de diferenciação de valores nos custos do Fundef em relação aos estabelecidos para todas as etapas e modalidades de ensino; de 2000 a 2004, estipulou-se um acréscimo de $5 \%(1,05)$ para alunos de $5^{\text {a }}$ a $8^{\text {a }}$ séries e da educação especial, superior ao definido para o das séries iniciais urbanas do ensino fundamental $(1,00)$. Cumpre acrescentar que, em 2003, já no governo Lula (2003-2010), segundo Ferreira, J. (2009, p. 62), "o governo federal vetou projeto aprovado pelo Congresso que incluía as instituições filantrópicas de educação especial nos recursos do Fundef e atendia a reivindicação das instituições: serem consideradas entidades públicas de educação especial". Segundo o autor, o governo divulgou que a temática poderia ser resolvida na discussão do Fundeb e, como medida paliativa, criou o Programa de Complementação no Atendimento Educacional Especializado às Pessoas Portadoras de Deficiências (Paed), por meio da Lei oㅜ 10.845, de 5 de março de 2004 (BRASIL, 2004a), regulamentado pelas Resoluções ํㅜ 4, de 13 de março de 2006 (BRASIL, 2006b), e no 28, de 14 de julho de 2006 (BRASIL, 2006c), ambas do Conselho Deliberativo do FNDE. O Programa tinha como finalidade garantir a universalização do atendimento educacional especializado aos "educandos portadores de deficiência" e sua progressiva inserção em classes comuns do ensino regular, por meio de assistência financeira às entidades privadas sem fins lucrativos que ofereciam serviços gratuitos na modalidade de educação especial. De acordo com Ferreira, J. (2009, p. 62), o repasse anual era de 
[...] $R \$ 33,50$ por aluno para essas instituições (em 2005, cerca de $\mathrm{R} \$ 8$ milhões), independente dos apoios concedidos por estados e municípios na forma de cessão de pessoal, material didático, transporte, merenda, construções/reformas e aquisição de equipamentos.

Desse modo, por meio do Paed, as instituições privadas de educação especial garantiram participação no fundo público federal para manutenção e funcionamento de suas atividades, para além dos recursos que já recebiam dos estados e municípios por meio de convênios, para a oferta de serviços ao público da educação especial. Em 2005, nova diferenciação elevou o fator de ponderação para 7\% $(1,07)$ para essa modalidade de ensino, com o Decreto ํㅜ 5.374, de 17 de fevereiro (BRASIL, 2005a). Assim, tendo como base o valor do fator de ponderação por aluno no ensino fundamental, estabelecido para alunos da educação especial do ensino fundamental urbano e rural, o valor mínimo nacional garantido pela União, em 2005, para a educação especial foi de $\mathrm{R} \$ 664,00$ reais.

A Lei ํㅜ 9.424/1996 estabelecia que a distribuição de recursos do Fundef deveria considerar a diferenciação de custo por aluno, segundo as etapas de ensino e tipos de estabelecimento, adotando-se a metodologia de cálculo e as correspondentes ponderações ${ }^{68}$. A objetivação de critérios para fixação e distribuição de recursos instituiu-se, segundo Farenzena (2006, p.108),

[...] no contexto de uma racionalização instrumental da previsão e uso dos recursos financeiros, a partir da predominância do modelo de gasto-aluno, ou seja, pela fixação de parâmetros de custos com base nos recursos disponíveis estimados para cada esfera de governo e, consequentemente, a definição de custo por aluno ou de padrões de qualidade de ensino a partir desta referência, indicando que o objetivo central da política educacional de equalização das oportunidades educacionais pode ser traduzido como realocação dos (mesmos) recursos para oferecer o mínimo (não ótimo) a todos.

Observa-se predomínio de uma lógica pragmática de financiamento em detrimento de uma racionalidade ético-política (FARENZENA, 2006), assim como uma homogeneização de critérios e sistemáticas oriundas do modelo de gastoaluno, desconsiderando-se as desigualdades regionais, pedagógicas e

68 A União prevê um valor anual mínimo por aluno, e esse valor é multiplicado por um número, denominado "fator de ponderação", ou na forma de um percentual, que varia de acordo com a etapa e modalidade do ensino (BRASIL, 2007b). 
organizacionais dos sistemas de ensino. Nesse contexto, temos as quatro primeiras tipologias criadas, supondo custos diferentes entre si, dentro do ensino fundamental regular, e gerando subcategorias, conforme demonstrado na Tabela 1.

Tabela 1 - Valor aluno-ano do Fundef - Brasil 1997 a 2006 em valores nominais $(\mathrm{R} \$)$

\begin{tabular}{|c|c|c|c|c|c|c|c|}
\hline Ano & $\begin{array}{c}1^{\mathrm{a}} \text { a } 8^{\mathrm{a}} \\
\text { série }\end{array}$ & $\begin{array}{l}1^{\mathrm{a}} \text { a } 4^{\mathrm{a}} \\
\text { série }\end{array}$ & $\begin{array}{c}5^{\mathrm{a}} \text { a } 8^{\mathrm{a}} \\
\text { série e } \\
\text { educação } \\
\text { especial }\end{array}$ & $\begin{array}{l}\text { Séries } \\
\text { iniciais } \\
\text { zona } \\
\text { urbana }\end{array}$ & $\begin{array}{c}\text { Séries } \\
\text { iniciais } \\
\text { zona } \\
\text { rural }\end{array}$ & $\begin{array}{l}\text { Quatro } \\
\text { séries } \\
\text { finais zona } \\
\text { urbana }\end{array}$ & $\begin{array}{c}\text { Quatro séries } \\
\text { finais - rural } \\
\text { e educação } \\
\text { especial } \\
\text { zonas urbana } \\
\text { e rural } \\
\end{array}$ \\
\hline $1997^{69}$ & 300,00 & & & & & & \\
\hline 1998 & 315,00 & & & & & & \\
\hline 1999 & 315,00 & & & & & & \\
\hline 2000 & & 333,00 & 349,65 & & & & \\
\hline 2001 & & 363,00 & 381,15 & & & & \\
\hline 2002 & & 418,00 & 438,90 & & & & \\
\hline 2003 & & 462,00 & 485,10 & & & & \\
\hline 2004 & & 564,63 & 592,86 & & & & \\
\hline 2005 & & & & 620,56 & 632,97 & 651,59 & 664,00 \\
\hline 2006 & & & & 682,60 & 696,25 & 716,73 & 730,38 \\
\hline
\end{tabular}

Fonte: FNDE, consultado em jun. 2014.

Luciane Torezan Viegas e Marcos Edgar Bassi (2009) observaram que, nesse mesmo período, houve uma expansão no número de matrículas de educação especial no ensino regular. Assim, no cômputo das matrículas na educação básica, considerando as matrículas em escolas exclusivamente especializadas ou em classes especiais de escolas regulares e em classes comuns, com e sem salas de recursos, notaram os autores um crescimento de $87 \%$ da oferta total (de 374.699 matrículas em 1999 para 700.624 em 2006), crescimento esse impulsionado pelo aumento das matrículas integradas em classes comuns, cerca de $453 \%$ (com salas de recursos) e $388 \%$ (sem salas de recursos).

Em contraposição, as matrículas em escolas exclusivamente especializadas e em classes especiais cresceram apenas $21 \%$, apesar de, em 2006, manterem ainda maior participação relativa, $54 \%$ da soma total. Os autores consideram o fundo, por meio das diferenciações promovidas no valor aluno-ano em 2000 e em 2005, um fator decisivo no estímulo e na expansão das matrículas no setor público, ainda que

${ }^{68}$ Em 1997, esse valor diferenciado só foi destinado ao Estado do Pará. 
induzidas pela busca de recursos do Fundef. Eles destacam, ainda, a existência de programas $^{70}$ e recursos do FNDE e as iniciativas da Seesp, que direcionaram fontes adicionais de recursos financeiros para essa modalidade de ensino (VIEGAS; BASSI, 2009). Nesse sentido, apesar da melhoria na equiparação do valor nacional por aluno-ano no ensino público e das diferenciações feitas a partir de 2000, faz-se necessário atentar, com apontam Viegas e Bassi (2009), para os baixos valores anuais gastos por aluno, muito distantes de um custo-aluno condizente e suficiente. "Tal quadro é agravado pela manutenção das desigualdades de gastos interregionais ao longo de todo o período, decorrentes da omissão da União na função de complementação" (VIEGAS; BASSI, 2009, p. 11).

No ano de 2007, tivemos a implantação do Fundeb, criado pela Emenda Constitucional no 53/2006 e regulamentado pela Lei $n^{0}$ 11.494/2007 e pelo Decreto nํ 6.253, de 13 de novembro de 2007 (BRASIL, 2007c), em substituição ao Fundef. O período de vigência estabelecido para o Fundeb foi de 2007 a 2020. Sua implantação começou em 1ำ de janeiro de 2007, sendo concluída em 2009, quando o total de alunos matriculados na rede pública foi considerado na distribuição dos recursos e o percentual de contribuição do Distrito Federal, estados e municípios para a formação das receitas do Fundo atingiu o patamar de $20 \%$.

O Fundeb constitui um fundo especial, de natureza contábil, no âmbito estadual, e sua formação resulta da aplicação de percentuais, vinculados à receita arrecadada de impostos ${ }^{71}$ do Distrito Federal, dos estados e dos municípios, direcionados à educação por força do disposto no art. 212 da CF/1988. Ainda compõe o Fundeb, a título de complementação, uma parcela de recursos da União, sempre que, no âmbito do Estado, seu valor por aluno não alcançar o mínimo definido nacionalmente, em cada uma das etapas ou modalidades de ensino, fixado pelo Poder Executivo, de acordo com o inciso V, do art. $2^{\circ}$ da Emenda Constitucional

\footnotetext{
70 Programa de Complementação ao Atendimento Educacional Especializado às Pessoas Portadoras de Deficiência (Paed), criado em 2004, no âmbito do FNDE.

${ }^{71}$ No Fundeb, estão incluídos os impostos que já faziam parte do Fundef: Imposto sobre Circulação de Mercadorias e Serviços - ICMS, Fundo de Participação dos Municípios - FPM, Fundo de Participação dos Estados - FPE, Imposto sobre Produtos Industrializados, proporcional às exportações - IPI-exp e ressarcimento pela desoneração de Exportações de que trata a LC no 87/1996 (aumentados de 15\% para 20\%), acrescidos do Imposto sobre Propriedade de Veículos Automotores - IPVA, Imposto Territorial Rural - ITR e Imposto sobre Transmissão Causa Mortis e Doações - ITCMD, que foram gradativamente elevados em três anos até atingir $20 \%$ em 2009 . Também compõem o Fundo as receitas da dívida ativa e de juros e multas incidentes sobre as fontes relacionadas.
} 
n 53/2006. Essa participação foi estabelecida originalmente em $R \$ 2$ bilhões para 2007, R $\$ 3$ bilhões para 2008, R\$ 4,5 milhões para 2009 e, a partir de 2010, em 10\% do valor total da contribuição do Distrito Federal, dos estados e dos municípios. Independentemente da origem, todo o recurso gerado é redistribuído para aplicação exclusiva na educação básica. A Tabela 2 traz os números de complementação do governo federal no Fundeb.

Tabela 2 - Complementação de Recursos da União - Fundeb 2007-2013 em valores nominais $(R \$)$

\begin{tabular}{|c|c|c|c|}
\hline ANO & $\begin{array}{c}\text { R\$ FUNDEB } \\
\text { Complementação da União }\end{array}$ & $\begin{array}{c}10 \% \text { Art. } 4^{\circ} \\
\text { Lei } 11.494 / 07 \\
\end{array}$ & $\begin{array}{c}\text { TOTAL } \\
\text { COMPLEMENTAÇÃO }\end{array}$ \\
\hline 2007 & 2.012,4 bilhões & & \\
\hline 2008 & 3.14,3 bilhões & & \\
\hline 2009 & $5.070,1$ bilhões & & \\
\hline 2010 & $6.861,1$ bilhões & 762,3 milhões & 7.623,4 bilhões \\
\hline 2011 & 7.925,2 bilhões & 881,0 milhões & $8.806,0$ bilhões \\
\hline 2012 & $8.472,0$ bilhões & 941,3 milhões & $9.413,0$ bilhões \\
\hline 2013 & $9.180,1$ bilhões & $1.020,0$ bilhões & 10.200,2 bilhões \\
\hline
\end{tabular}

Fonte: Elaborado pela autora com base nas Leis no 9.424/96 e no⒒494/07.

Cumpre destacar que, a partir de 2010, parcela da complementação da União, limitada a até $10 \%$, poderá ser distribuída para os fundos por meio de programas direcionados à melhoria da qualidade da educação básica (§2, art. 4ํe art. $7^{0}$ da Lei 11.494/07). Nessa direção, concordamos com Pinto (2007, p. 890) quando afirma que,

[...] embora a intenção seja boa permitindo o estímulo a projeto em regime de colaboração entre estados e municípios, ou voltados à qualificação de professores, a nossa história educacional sobre este tipo de iniciativa, que foi muito comum em relação aos recursos do salário-educação, indica o predomínio de critérios político-partidários e a má utilização dos recursos.

O aumento da participação da União no Fundeb (de $\mathrm{R} \$ 249$ milhões, em 2006, no Fundef, para mais de $R \$ 9$ bilhões, em 2013) constitui um avanço importante para a educação, considerando que sua participação no Fundef era de aproximadamente $1,5 \%$, no seu período final. Porém, sua contribuição está muito 
aquém de sua participação na receita tributária nacional, portanto ainda insuficiente para a universalização de uma educação de qualidade e distante das reivindicações dos movimentos sociais. Rubens Barbosa de Camargo, José Marcelino de Rezende Pinto e José Luiz Guimarães (2008, p. 825) afirmam:

\begin{abstract}
Não se pode negar o avanço que o Fundeb representa em relação ao Fundef, no que se refere ao aumento da contribuição financeira da União, à melhora do controle social e à recuperação do conceito de financiamento da educação básica como um todo. Contudo, não se pode esquecer que os recursos da União no novo fundo serão da ordem de apenas $10 \%$ dos recursos aportados pelos estados e municípios, enquanto a sua participação na carga tributária líquida é de cerca de $60 \%$.
\end{abstract}

Os autores acrescentam ainda que, na tradição orçamentária do Brasil, no que tange ao investimento na área de educação, o "mínimo" tende a transformar-se em "máximo". Nessa perspectiva, a União teria condições de aumentar a sua participação, tendo em vista a sua capacidade financeira e o volume de recursos públicos alocados para o pagamento da dívida externa. Assim, concordamos com a indicação da Conferência Nacional de Educação (CONAE, 2010) de que há a necessidade de ampliação de investimento público em educação. Desse modo, o documento destaca que o novo PNE deveria ter como meta atingir, no final de sua vigência, um patamar equivalente a $10 \%$ do PIB para a educação pública. Cabe ressaltar que o PNE 2014-2024, aprovado pela Lei no 13.005, de 25 junho de 2014, prevê no mínimo 10\% do PIB para a educação. Entretanto, como nos aponta Davies (2014, p. 198), a Lei estabelece esse percentual "para o final da vigência do PNE, ou seja, 10 anos a contar de 2014, sendo no mínimo 7\% do PIB, no quinto ano, a saber, em 2019”. E o "Poder Público, no cálculo do investimento em educação, previsto no inciso VI do art. 214 da CF, poderá considerar os recursos públicos destinados a programas que beneficiam instituições privadas" (DAVIES, 2014, p. 198).

Cumpre destacar que o Fundeb garante que a maior parte dos recursos vinculados à educação seja aplicada na educação básica, por meio de seu mecanismo de distribuição de recursos com base no número de alunos das diversas etapas e modalidades, informado no Censo Escolar do ano anterior, sendo computados os estudantes matriculados nos respectivos âmbitos de atuação prioritária (art. 211, CF/1988). Na versão final do Fundeb, foram acrescentadas as 
matrículas de educação infantil e da educação especial da rede conveniada sem fins lucrativos. De acordo Pinto (2007, p. 888), essa inclusão

[...] representa um duro golpe no princípio de que recursos públicos devem se destinar às instituições públicas, decorreu da constatação de que um número significativo de prefeituras mantém convênios com aquelas instituições e sua exclusão significaria deixar milhares de crianças sem atendimento.

E o autor adverte que o grande risco é que o crescimento das matrículas da educação infantil e da educação especial se dê pela via das instituições conveniadas, haja vista que o repasse de recursos do poder público a essas instituições é muito inferior aos custos do atendimento direto. Cabe ressaltar que a alteração na legislação do Fundeb, com a continuidade da garantia de recursos públicos às entidades privadas foi resultante de seu forte poder político junto a elite brasileira, no âmbito do Estado brasileiro (por meio da articulação com deputados, senadores, na Câmara dos Deputados e no Congresso Nacional) e fora dele (mídia), assegurando a sua participação no fundo público.

A distribuição de recursos também considera os fatores de ponderação que são definidos anualmente pela Comissão Intergovernamental de Financiamento para a Educação Básica de Qualidade, conforme previsto no inciso I, do art. 13 da Lei no 11. 494/2007. Assim, de acordo com Viegas e Bassi (2009), as etapas e modalidades são consideradas com pesos diferenciados na distribuição de recursos, no novo desenho do financiamento da educação, situados em uma escala entre 0,7 a 1,3 pontos. A posição de cada especificidade nessa escala toma como referência o fator de ponderação de valor 1,0 definido para a matrícula das séries iniciais urbanas do ensino fundamental. O valor mínimo por aluno-ano da educação especial passa a receber um peso ponderado $20 \%$ superior ao valor por aluno de referência, em uma escala cujo valor mais elevado alcança 30\%, conforme apresentado na Tabela 3. Os maiores fatores de ponderação são os do Ensino Médio em Tempo Integral e do Ensino Médio Integrado à Educação Profissional $(1,30)$, o que significa $30 \%$ maior que o padrão de referência das séries iniciais do Ensino Fundamental urbano. Os menores fatores são os das creches em tempo parcial $(0,80)$, o que representa $20 \%$ menores que o valor do padrão de referência. 
Tabela 3 - Fatores de ponderação no valor-aluno para as diferentes etapas e modalidades de ensino 2007-2013

\begin{tabular}{|c|c|c|c|c|c|c|c|}
\hline \multirow[t]{2}{*}{ Etapa ou modalidade } & \multicolumn{7}{|c|}{ Fator de ponderação } \\
\hline & 2007 & 2008 & 2009 & 2010 & 2011 & 2012 & 2013 \\
\hline creche & 0,8 & & & & & & \\
\hline $\begin{array}{l}\text { creche pública em } \\
\text { tempo integral }\end{array}$ & & 1,1 & 1,1 & 1,1 & 1,2 & 1,3 & 1,3 \\
\hline $\begin{array}{l}\text { creche pública em } \\
\text { tempo parcial }\end{array}$ & & 0,8 & 0,8 & 0,8 & 0,8 & 0,8 & 0,8 \\
\hline $\begin{array}{l}\text { creche conveniada em } \\
\text { tempo integral }\end{array}$ & & 0.95 & 0.95 & 11 & 11 & 11 & 11 \\
\hline creche conveniada em & & & & & & & \\
\hline tempo parcial & & 0,8 & 0,8 & 0,8 & 0,8 & 0,8 & 0,8 \\
\hline pré-escola & 0.9 & & & & & & \\
\hline $\begin{array}{l}\text { pré-escola em tempo } \\
\text { integral } \\
\text { pré-escola em tempo }\end{array}$ & & 1,15 & 1,2 & 1,25 & 1,3 & 1,3 & 1,3 \\
\hline $\begin{array}{l}\text { parcial } \\
\text { anos iniciais do ensino }\end{array}$ & & 0,9 & 1 & 1 & 1 & 1 & 1 \\
\hline $\begin{array}{l}\text { fundamental urbano } \\
\text { anos iniciais do ensino }\end{array}$ & 1 & 1 & 1 & 1 & 1 & 1 & 1 \\
\hline $\begin{array}{l}\text { fundamental no campo } \\
\text { anos finais do ensino }\end{array}$ & 1,05 & 1,05 & 1,05 & 1,15 & 1,15 & 1,15 & 1,15 \\
\hline fundamental urbano & 1,1 & 1,1 & 1,1 & 1,1 & 1,1 & 1,1 & 1,1 \\
\hline $\begin{array}{l}\text { fundamental no campo } \\
\text { ensino fundamental em }\end{array}$ & 1,15 & 1,15 & 1,15 & 1,2 & 1,2 & 1,2 & 1,2 \\
\hline tempo integral & 1,25 & 1,25 & 1,25 & 1,25 & 1,3 & 1,3 & 1,3 \\
\hline ensino médio urbano & 1,2 & 1,2 & 1,2 & 1,2 & 1,2 & 1,2 & 1,2 \\
\hline $\begin{array}{l}\text { ensino médio no } \\
\text { campo } \\
\text { ensino médio em tempo }\end{array}$ & 1,25 & 1,25 & 1,25 & 1,25 & 1,25 & 1,3 & 1,3 \\
\hline $\begin{array}{l}\text { integral } \\
\text { ensino médio integrado }\end{array}$ & 1,3 & 1,3 & 1,3 & 1,3 & 1,3 & 1,3 & 1,3 \\
\hline à educação profissional & 1,3 & 1,3 & 1,3 & 1,3 & 1,3 & 1,3 & 1,3 \\
\hline educação especial & 1,2 & 1,2 & 1,2 & 1,2 & 1,2 & 1,2 & 1,2 \\
\hline $\begin{array}{l}\text { educação indígena e } \\
\text { quilombola } \\
\text { educação de jovens e }\end{array}$ & 1,2 & 1,2 & 1,2 & 1,2 & 1,2 & 1,2 & 1,2 \\
\hline adultos & 0,7 & 0,7 & 0,8 & 0,8 & 0,8 & 0,8 & 0,8 \\
\hline $\begin{array}{l}\text { EJA integrada à } \\
\text { educação profissional } \\
\text { de nível médio }\end{array}$ & 0,7 & 0,7 & 1 & 1 & 1,2 & 1,2 & 1,2 \\
\hline
\end{tabular}

Fonte: Elaborada pela autora com base na Lei $n^{0} 11.494 / 2007$ e nas Portarias $n^{0}$ 41, de 27 de dezembro de 2007; ํㅜ 932, de 30 de junho de 2008; ํㅡ 777, de 14 agosto de 2009, ํo 873, de 1ํㅡㄹ de junho de 2010; oㅜ 1.322, de 21 de setembro de 2011; e № 8 , de 25 de julho de 2012. FNDE. Acesso em jun. 2014. 
No tocante à educação especial, os valores de ponderação não sofreram alterações no período de 2007 a 2013, desde o início do Fundeb; foram de 1,20, o que resulta em valor $20 \%$ maior que o padrão de referência. Desse modo, segundo Bassi (2012, p. 5), "os fatores de ponderação paulatinamente asseguram receitas mais elevadas, o que ressaltou o aspecto indutor aos governos municipais e estaduais que mantinham ou que viessem a manter matrículas de educação especial". Cabe destacar que as matrículas das instituições do setor privado filantrópico conveniado ao poder público passaram a ser consideradas, no Fundeb, com o mesmo peso das do ensino público. O critério utilizado na definição dos valores de ponderação, estabelecidos pelo governo federal como parâmetro de distribuição de recursos, segundo Pinto (2007, p. 891), "esteve longe de ser o custo real dessas etapas e modalidades", uma vez que a decisão ficou restrita a negociações políticas entre estados e municípios, não tendo apresentado dados técnicos que justificassem ou explicitassem os fatores que levaram às diferenças entre os valores de ponderação. Analisada a forma de ponderação entre as várias etapas e modalidades de ensino, faz-se necessário avaliar os valores definidos nacionalmente, no período de 2007 a 2013, no Fundeb, na tentativa de garantir um padrão mínimo de qualidade do ensino. O padrão de referência para o valor mínimo por aluno, segundo o art. 4ํㅜㄹ da Lei nํ⒒494/2007, são as Séries Iniciais do Ensino Fundamental Urbano, sendo levados em consideração, para as outras etapas e modalidades, os fatores de ponderação apresentados anteriormente com relação ao padrão de referência. A Tabela 4 informa os valores por aluno-ano das séries iniciais do ensino fundamental urbano, de 2007 a 2013.

Tabela 4 - Fundeb: valor mínimo nacional por aluno-ano - Séries Iniciais do Ensino Fundamental Urbano 2007-2013 em valores nominais $(R \$)$

\begin{tabular}{|c|c|c|c|c|c|c|c|c|}
\hline \multirow{3}{*}{ 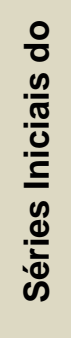 } & \multirow{3}{*}{ 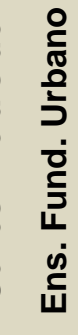 } & 2007 & 2008 & 2009 & 2010 & 2011 & 2012 & 2013 \\
\hline & & $\begin{array}{c}\text { Port. no } \\
1.462 \\
01 / 12 / 2008\end{array}$ & $\begin{array}{c}\text { Port. no } \\
386 \\
17 / 04 / 2009\end{array}$ & $\begin{array}{c}\text { Port. no } \\
496 \\
16 / 04 / 2010\end{array}$ & $\begin{array}{c}\text { Port. no } \\
380 \\
06 / 04 / 2011\end{array}$ & $\begin{array}{c}\text { Port. no } \\
437 \\
20 / 04 / 2012\end{array}$ & $\begin{array}{c}\text { Port. no } \\
344 \\
24 / 04 / 2013\end{array}$ & $\begin{array}{c}\text { Port. no } \\
364 \\
28 / 04 / 2014\end{array}$ \\
\hline & & 941,68 & $1.172,85$ & $1.227,17$ & $1.529,97$ & $1.846,56$ & $2.020,79$ & $2.287,87$ \\
\hline
\end{tabular}

Fonte: Elaborada pela autora com base nas Portarias $n^{\circ} 1.462$, de $1^{\circ}$ de dezembro de 2008; no 386, de 17 de abril de 2009; no 496, de 16 de abril de 2010; № 380, de 6 de abril de 2011; no 437, de 20 de abril de 2012; no 344, de 24 de abril de 2013; e o 364, de 28 de abril de 2014. FNDE. Acesso em jun. 2014. 
Constatamos que os valores por aluno-ano obtiveram uma trajetória ascendente de 2007 a 2013, um aumento de aproximadamente 143\%. Assim, esse movimento vincula-se às correções monetárias do Fundeb e ao aumento da participação da União. Desse modo, concordamos com Pinto (2009) quando diz que o maior aporte da União gerou um aumento significativo, em termos reais, do valor mínimo nacional. Considerando que o valor anual mínimo por aluno, nacionalmente, é determinado contabilmente em função da complementação da União (BRASIL, 2007b, art. 4\%). Com base nos valores fixados para as Séries Iniciais do Ensino Fundamental Urbano, passamos, neste momento, a trabalhar, exclusivamente, com os números da educação especial no Fundeb ${ }^{72}$. Analisamos, inicialmente, as matrículas consideradas em cada estado e seus respectivos valores aluno-ano e o total nacional da educação especial. Iniciamos por 2007 (Tabela 5).

Tabela 5 - Valor anual por aluno estimado e receita total estimada do Fundeb para educação especial, no âmbito dos estados e do Distrito Federal - 2007 em valores nominais $(\mathrm{R} \$)$

\begin{tabular}{cccc}
\hline UF & $\begin{array}{c}\text { MATRÍCULAS } \\
\text { (CENSO ESCOLAR 2006) }\end{array}$ & $\begin{array}{c}\text { VALOR ALUNO-ANO } \\
\text { EDUCAÇÃO } \\
\text { ESPECIAL }\end{array}$ & $\begin{array}{c}\text { RECEITA TOTAL } \\
\text { EDUCAÇÃO } \\
\text { ESPECIAL }\end{array}$ \\
\hline AC & $1.745,0$ & $2.039,82$ & $3.559 .485,90$ \\
AL & $3.903,0$ & $1.136,69$ & $4.436 .501,07$ \\
AM & $3.332,7$ & $1.172,32$ & $3.906 .990,86$ \\
AP & $1.380,0$ & $2.149,66$ & $2.966 .530,80$ \\
BA & $20.694,3$ & $1.136,69$ & $23.523 .003,87$ \\
CE & $22.648,7$ & $1.136,69$ & $25.744 .550,80$ \\
ES & $6.959,3$ & $2.387,01$ & $16.611 .918,69$ \\
GO & $11.877,0$ & $1.414,59$ & $16.801 .085,40$ \\
MA & $10.792,0$ & $1.136,69$ & $12.267 .158,50$ \\
MG & $45.229,3$ & $1.459,13$ & $65.995 .428,51$ \\
MS & $6.822,3$ & $1.862,85$ & $12.708 .921,60$ \\
MT & $5.137,7$ & $1.462,08$ & $7.511 .728,42$ \\
PA & $14.096,7$ & $1.136,69$ & $16.023 .577,92$ \\
PB & $9.358,7$ & $1.136,69$ & $10.637 .940,70$ \\
PE & $12.386,7$ & $1.136,69$ & $14.079 .838,02$ \\
PI & $7.374,0$ & $1.136,69$ & $8.381 .952,10$ \\
PR & $35.420,7$ & $1.527,40$ & $54.101 .577,20$ \\
RJ & $26.304,7$ & $1.489,47$ & $39.180 .061,51$ \\
RN & $6.808,0$ & $1.444,87$ & $9.836 .675,00$ \\
RO & $2.973,7$ & $1.622,25$ & $4.824 .084,83$ \\
& & &
\end{tabular}

Continua

\footnotetext{
$72 \mathrm{~A}$ organização dos dados do Fundeb referentes à educação especial foi realizada com base no estudo de Marcelo Pagliosa Carvalho (2011), intitulado: As políticas para a educação de jovens e adultos no governo Lula (2003-2010).
} 


\begin{tabular}{cccc}
\hline UF & $\begin{array}{c}\text { MATRÍCULAS } \\
\text { (CENSO ESCOLAR 2006) }\end{array}$ & $\begin{array}{c}\text { VALOR ALUNO-ANO } \\
\text { EDUCAÇÃO } \\
\text { ESPECIAL }\end{array}$ & $\begin{array}{c}\text { RECEITA TOTAL } \\
\text { EDUCAÇÃO } \\
\text { ESPECIAL }\end{array}$ \\
\hline RR & 892,7 & $2.457,59$ & $2.193 .890,60$ \\
RS & $23.801,0$ & $1.889,70$ & $44.976 .749,70$ \\
SC & $8.932,0$ & $1.668,92$ & $14.906 .793,44$ \\
SE & $3.089,3$ & $1.508,08$ & $4.658 .911,54$ \\
SP & $69.077,3$ & $2.214,91$ & $153.000 .002,54$ \\
TO & $5.365,7$ & $1.773,50$ & $9.516 .069,00$ \\
DF & $8.140,3$ & $2.184,62$ & $17.783 .462,20$ \\
TOTAL & $\mathbf{3 7 4 . 5 4 2 , 8}$ & $\mathbf{1 . 6 0 2 , 3 1 ^ { * }}$ & $\mathbf{6 0 0 . 1 3 4 . 8 9 0 , 7 2}$ \\
\hline
\end{tabular}

Fonte: Elaborada pela autora com base no estudo de Carvalho (2011) e na Portaria Interministerial no 1.030, de 6 de novembro de 2007 - Anexo I.

*Valor médio aluno-ano da educação especial.

Em 2007, ano de implantação do Fundeb, como já mencionado, o total de matrículas de educação especial computadas pelo Fundo, de acordo com o Censo Escolar de 2006, foi de aproximadamente 375 mil, considerando as matrículas em escolas exclusivamente especializadas, em classes especiais e em classes comuns do ensino regular de instituições públicas e privadas.

O valor médio por aluno-ano foi de $\mathrm{R} \$$ de $1.602,31$, acima do valor anual mínimo nacional por aluno das Séries Iniciais do Ensino Fundamental Urbano, considerando o valor de ponderação de 1,20. Identificamos que a unidade federativa com o maior valor aluno-ano foi Roraima $(\mathrm{R} \$ 2.457,59)$ e que o menor valor ficou com oito estados: Alagoas, Bahia, Ceará, Maranhão, Pará, Paraíba, Pernambuco e Piauí $(R \$ 1.136,69)$, que receberam complementação da União. Cabe destacar que Roraima apresenta um número reduzido de alunos, o que repercute no alto valor aluno-ano em relação aos outros estados brasileiros. $O$ total de receitas estimadas do Fundeb, dirigidas à educação especial, foi de aproximadamente $R \$ 600$ milhões.

Convém esclarecer, assim como nos alerta Carvalho (2011, p. 295), que não se tem garantia de que esses recursos foram realmente investidos na modalidade a que se destinavam, tendo em vista que "a legislação do Fundeb permite aos entes administrativos certa flexibilidade no investimento dos recursos entre as diversas etapas e modalidades". Assim, a educação especial pode ter recebido ou não as verbas repassadas de acordo com o número de matrículas. Vejamos os dados de 2008, dispostos na Tabela 6. 
Tabela 6 - Valor anual por aluno estimado e receita total estimada do Fundeb para a educação especial, no âmbito dos estados e do Distrito Federal - 2008 em valores nominais $(\mathrm{R} \$)$

\begin{tabular}{|c|c|c|c|}
\hline UF & $\begin{array}{c}\text { MATRÍCULAS } \\
\text { (CENSO ESCOLAR 2007) }\end{array}$ & $\begin{array}{l}\text { VALOR ALUNO-ANO } \\
\text { EDUCAÇÃO ESPECIAL }\end{array}$ & $\begin{array}{c}\text { RECEITA TOTAL } \\
\text { EDUCAÇÃO ESPECIAL }\end{array}$ \\
\hline$A C$ & $1.475,0$ & $2.361,05$ & $3.482 .548,75$ \\
\hline$A L$ & $3.287,3$ & $1.358,81$ & $4.466 .816,11$ \\
\hline AM & $3.487,30$ & $1.358,81$ & $4.738 .578,11$ \\
\hline AP & $1.178,0$ & $2.466,85$ & $2.905 .949,30$ \\
\hline BA & $20.027,0$ & $1.358,81$ & $27.212 .887,87$ \\
\hline $\mathrm{CE}$ & $17.723,0$ & $1.358,81$ & $24.082 .189,63$ \\
\hline ES & $6.613,0$ & $2.680,03$ & $17.723 .038,39$ \\
\hline GO & $9.561,7$ & $1.675,77$ & $16.023 .210,01$ \\
\hline MA & $9.215,0$ & $1.358,81$ & $12.521 .434,15$ \\
\hline MG & $31.278,0$ & $1.698,04$ & $53.111 .295,12$ \\
\hline MS & $4.396,7$ & $2.146,99$ & $9.439 .670,93$ \\
\hline MT & $5.037,3$ & $1.889,43$ & $9.517 .625,74$ \\
\hline PA & $11.325,3$ & $1.358,81$ & $15.388 .930,90$ \\
\hline PB & $5.850,7$ & $1.358,81$ & $7.949 .989,70$ \\
\hline $\mathrm{PE}$ & $13.322,3$ & $1.358,81$ & $18.102 .474,46$ \\
\hline $\mathrm{PI}$ & $3.115,3$ & $1.358,81$ & $4.233 .100,80$ \\
\hline PR & $38.266,0$ & $1.619,89$ & $61.986 .710,74$ \\
\hline RJ & $24.484,7$ & $1.613,47$ & $39.505 .328,90$ \\
\hline $\mathrm{RN}$ & $4.357,7$ & $1.593,28$ & $6.943 .036,26$ \\
\hline RO & $2.167,7$ & $1.841,78$ & $3.992 .426,51$ \\
\hline $\mathrm{RR}$ & 657,7 & $3.082,86$ & $2.027 .597,02$ \\
\hline RS & $21.534,0$ & $2.020,72$ & $43.514 .184,48$ \\
\hline SC & $8.976,3$ & $1.875,61$ & $16.836 .038,04$ \\
\hline SE & $1.940,3$ & $1.697,47$ & $3.293 .601,04$ \\
\hline SP & $94.053,0$ & $2.467,42$ & $232.068 .253,26$ \\
\hline TO & $5.703,7$ & $2.055,09$ & $11.721 .616,83$ \\
\hline DF & $9.852,3$ & $2.254,38$ & $22.210 .828,10$ \\
\hline TOTAL & $358.886,3$ & $1.880,82$ & 674.999.361,15 \\
\hline
\end{tabular}

Fonte: Elaborada pela autora com base no estudo de Carvalho (2011) e na Portaria Interministerial no 1.027 , de 19 de agosto de 2008 - Anexo I.

O total de matrículas de educação especial no ano de 2008 foi de aproximadamente 359 mil, o que representa um decréscimo de $4 \%$ em relação ao ano de 2007. Nesse total, estão abrangidas as matrículas em escolas exclusivamente especializadas, em classes especiais e em classes comuns do ensino regular, de instituições públicas e privadas. O valor médio por aluno-ano foi de $\mathrm{R} \$ 1.880,82$. Roraima apresentou o maior valor ( $\mathrm{R} \$ 3.082,86$ ), e o estado de Amazonas entrou para o grupo de unidades federativas que tiveram o menor valor ( $R \$ 1.358,81)$, recebendo complementação da União. O total disposto para a educação especial foi de $\mathrm{R} \$ 675$ milhões, apresentando um crescimento de $12 \%$ em 
relação ao ano de 2007. Cabe ressaltar que o decréscimo no número de matrículas, em 2008, pode ter contribuído para o aumento do valor médio aluno-ano e da receita total destinada à educação especial. Vamos aos dados de 2009, elencados na Tabela 7.

Tabela 7 - Valor anual por aluno estimado e receita total estimada do Fundeb para a educação especial, no âmbito dos estados e do Distrito Federal - 2009 em valores nominais $(\mathrm{R} \$)$

\begin{tabular}{cccc}
\hline UF & $\begin{array}{c}\text { MATRÍCULAS } \\
\text { (CENSO ESCOLAR } \\
\text { 2008) }\end{array}$ & $\begin{array}{c}\text { VALOR ALUNO-ANO } \\
\text { EDUCAÇÃO } \\
\text { ESPECIAL }\end{array}$ & $\begin{array}{c}\text { RECEITA TOTAL } \\
\text { EDUCAÇÃO } \\
\text { ESPECIAL }\end{array}$ \\
\hline AC & 2.655 & $2.131,20$ & $5.658 .336,00$ \\
AL & 4.949 & $1.465,60$ & $7.253 .254,40$ \\
AM & 4.517 & $1.465,60$ & $6.620 .115,20$ \\
AP & 1.509 & $2.313,05$ & $3.490 .392,45$ \\
BA & 24.126 & $1.465,60$ & $35.359 .065,60$ \\
CE & 20.030 & $1.465,60$ & $29.355 .968,00$ \\
ES & 10.071 & $2.561,75$ & $25.799 .384,25$ \\
GO & 13.595 & $1.756,58$ & $23.880 .705,10$ \\
MA & 11.073 & $1.465,60$ & $16.228 .588,80$ \\
MG & 36.835 & $1.763,76$ & $64.968 .099,60$ \\
MS & 4.937 & $2.216,47$ & $10.942 .712,39$ \\
MT & 5.385 & $2.003,96$ & $10.791 .324,60$ \\
PA & 13.584 & $1.465,60$ & $19.908 .710,40$ \\
PB & 7.666 & $1.465,60$ & $11.235 .289,60$ \\
PE & 15.486 & $1.465,60$ & $22.696 .281,60$ \\
PI & 4.344 & $1.465,60$ & $6.366 .566,40$ \\
PR & 30.483 & $1.663,26$ & $50.701 .154,58$ \\
RJ & 27.511 & $1.651,27$ & $45.428 .088,97$ \\
RN & 4.501 & $1.592,64$ & $7.168 .472,64$ \\
RO & 3.170 & $1.844,16$ & $5.845 .987,20$ \\
RR & 624 & $2.830,36$ & $1.766 .144,64$ \\
RS & 28.906 & $2.171,77$ & $62.777 .183,62$ \\
SC & 11.470 & $1.925,27$ & $22.082 .846,90$ \\
SE & 2.542 & $1.695,58$ & $4.310 .164,36$ \\
SP & 111.972 & $2.357,80$ & $264.007 .581,60$ \\
TO & 4.980 & $2.081,62$ & $10.366 .467,60$ \\
DF & 11.761 & $2.048,85$ & $24.096 .524,85$ \\
TOTAL & 418.682 & $1.908,62$ & $799.105 .411,35$ \\
\hline
\end{tabular}

Fonte: Elaborada pela autora com base no estudo de Carvalho (2011) e na Portaria Interministerial $n^{\circ} \mathbf{7 8 8}$, de 14 de agosto de 2009 - Anexo I.

As matrículas de educação especial, computadas no ano de 2009 no Fundeb, foram de aproximadamente 419 mil, em 2009, o que representava um aumento de $17 \%$ em relação ao total de matrículas de 2008 , considerando as matrículas em 
escolas exclusivamente especializadas, em classes especiais e em classes comuns do ensino regular, de instituições públicas e privadas.

O valor médio por aluno-ano foi de $\mathrm{R} \$ 1.908,62$. Como nos anos anteriores, Roraima apresentou o maior valor, de $R \$ 2.830,36$, e o menor valor foi de $R \$$ 1.465,60, para os estados de Alagoas, Amazonas, Bahia, Ceará, Maranhão, Pará, Paraíba, Pernambuco e Piauí. O total despendido para a educação especial foi de $\mathrm{R} \$ 799$ milhões, um aumento de 18\% em relação ao ano de 2008.

Na Tabela 8, podemos visualizar os dados da educação especial no ano de 2010.

Tabela 8 - Valor anual por aluno estimado e receita total estimada do Fundeb para a educação especial, no âmbito dos estados e do Distrito Federal - 2010

\begin{tabular}{|c|c|c|c|c|}
\hline \multirow[t]{2}{*}{ UF } & \multicolumn{2}{|c|}{$\begin{array}{c}\text { MATRÍCULAS } \\
\text { (CENSO ESCOLAR 2009) }\end{array}$} & \multirow{2}{*}{$\begin{array}{l}\text { VALOR ALUNO-ANO } \\
\text { EDUCAÇÃO } \\
\text { ESPECIAL /AEE }\end{array}$} & \multirow{2}{*}{$\begin{array}{c}\text { RECEITA TOTAL } \\
\text { EDUCAÇÃO } \\
\text { ESPECIAL/AEE }\end{array}$} \\
\hline & Educação Especial & AEE & & \\
\hline$A C$ & 2.684 & 1.588 & $2.256,00$ & $9.637 .632,00$ \\
\hline $\mathrm{AL}$ & 5.824 & 462 & $1.697,82$ & $10.672 .496,52$ \\
\hline AM & 4.712 & 537 & $1.697,82$ & $8.911 .857,18$ \\
\hline$A P$ & 1.648 & 541 & $2.549,02$ & $5.579 .804,78$ \\
\hline BA & 26.354 & 1.405 & $1.697,82$ & $47.129 .785,38$ \\
\hline CE & 19.650 & 1.488 & $1.697,82$ & $35.888 .519,16$ \\
\hline ES & 6.679 & 1.021 & $2.548,60$ & $19.624 .220,00$ \\
\hline GO & 11.422 & 762 & $2.034,32$ & $24.786 .154,88$ \\
\hline MA & 12.630 & 460 & $1.697,82$ & $22.224 .463,80$ \\
\hline$M G$ & 29.851 & 6.305 & $1.951,55$ & $181.301 .241,80$ \\
\hline MS & 5.834 & 3.101 & $2.467,22$ & $22.044 .610,70$ \\
\hline MT & 4.475 & 1.019 & $2.144,63$ & $11.782 .597,22$ \\
\hline PA & 13.202 & 685 & $1.697,82$ & $23.577 .626,34$ \\
\hline PB & 6.731 & 322 & $1.697,82$ & $11.974 .724,46$ \\
\hline PE & 14.520 & 589 & $1.697,82$ & $24.752 .362,38$ \\
\hline $\mathrm{PI}$ & 5.521 & 393 & $1.697,82$ & $10.040 .907,48$ \\
\hline PR & 26.620 & 8.269 & $1.883,71$ & $65.720 .758,19$ \\
\hline RJ & 24.347 & 2.855 & $2.061,95$ & $56.089 .163,90$ \\
\hline $\mathrm{RN}$ & 4.949 & 950 & $1.762,38$ & $10.396 .279,62$ \\
\hline RO & 3.005 & 657 & $2.045,50$ & $7.490 .621,00$ \\
\hline $\mathrm{RR}$ & 719 & 75 & $3.197,97$ & $2.539 .188,18$ \\
\hline RS & 25.194 & 7.030 & $2.403,67$ & $77.455 .862,08$ \\
\hline SC & 10.835 & 3.077 & $2.173,38$ & $30.236 .062,56$ \\
\hline SE & 2.711 & 197 & $1.946,62$ & $5.660 .770,96$ \\
\hline
\end{tabular}




\begin{tabular}{|c|c|c|c|c|}
\hline \multirow{3}{*}{ UF } & \multirow{2}{*}{\multicolumn{2}{|c|}{$\begin{array}{c}\text { MATRÍCULAS } \\
\text { (CENSO ESCOLAR 2009) }\end{array}$}} & \multirow{3}{*}{$\begin{array}{l}\text { VALOR ALUNO-ANO } \\
\text { EDUCAÇÃO } \\
\text { ESPECIAL / AEE }\end{array}$} & \multirow{3}{*}{$\begin{array}{l}\text { Conclus } \\
\text { RECEITA TOTAL } \\
\text { EDUCAÇÃO } \\
\text { ESPECIAL/AEE }\end{array}$} \\
\hline & & & & \\
\hline & Educação Especial & AEE & & \\
\hline SP & 121.816 & 26.274 & $2.776,85$ & $411.223 .716,50$ \\
\hline TO & 5.253 & 1.579 & $2.302,20$ & $15.728 .630,40$ \\
\hline DF & 9.817 & 3.124 & $2.590,77$ & $33.527 .154,57$ \\
\hline TOTAL & 407.003 & 74.765 & & \\
\hline $\begin{array}{l}\text { TOTAL } \\
\text { GERAL }\end{array}$ & 481.768 & & $2.462,00$ & $1.185 .997 .212,04$ \\
\hline
\end{tabular}

Fonte: Elaborada pela autora com base no estudo de Carvalho (2011) e na Portaria Interministerial no 538-A, de 26 de abril de 2010 - Anexo I.

Evidenciamos, na Tabela 8, no ano de 2010, a divisão de dois grupos que passaram a ser contabilizados na educação especial: 1) educação especial; e 2) atendimento educacional especializado, considerando o que estabelece o Decreto $\mathrm{n}^{-}$ 7.611, de 17 de novembro de 2011, que altera o Decreto o 6.253/2007 (BRASIL, 2007c), que dispõe sobre o Fundeb: "Para efeito da distribuição dos recursos do FUNDEB, será admitida a dupla matrícula dos estudantes da educação regular da rede pública que recebem atendimento educacional especializado" (BRASIL, 2011, art. 9-A).

Assim, as matrículas do primeiro grupo, "educação especial", corresponderam, em 2010, a 407.003 mil, representando aproximadamente $85 \%$ do total de matrículas, e as matrículas do segundo grupo, "atendimento educacional especializado", contabilizaram 74.765 , ou seja, $16 \%$ do total de matrículas. Os dois agrupamentos tinham, em 2010, o mesmo fator de ponderação $(1,20)$, por isso tiveram o mesmo valor médio por aluno, de $R \$ 2.462,00$. Roraima continuou com o maior valor ( $R \$ 3.197,97$ ), e o menor valor foi de $R \$ 1.697,82$ para os estados de Alagoas, Amazonas, Bahia, Ceará, Maranhão, Pará, Paraíba, Pernambuco e Piauí. O total despendido para a educação especial foi de aproximadamente $R \$ 1,2$ bilhões, representando um aumento de $48 \%$ em relação ao ano de 2009 , o que se explica pelo fato de as matrículas no atendimento educacional especializado serem financiadas com o segundo fator de ponderação do Fundeb para cada aluno registrado como usuário desse serviço complementar ou suplementar. Analisamos, a seguir, as matrículas nacionais de educação especial que foram computadas para receber recursos do Fundeb (Tabela 9). 
Tabela 9 - Matrículas da educação especial no Fundeb - Brasil 2007-2010

\begin{tabular}{cccc}
\hline ANO & $\begin{array}{c}\text { MATRÍCULAS DE } \\
\text { EDUCAÇÃO } \\
\text { ESPECIAL }\end{array}$ & $\begin{array}{c}\text { MATRÍCULAS DO } \\
\text { AEE }\end{array}$ & $\begin{array}{c}\text { TOTAL DE MATRíCULAS } \\
\text { DA EDUCAÇÃO } \\
\text { ESPECIAL }\end{array}$ \\
\hline 2007 & $374.542,8$ & - & - \\
2008 & $358.886,3$ & - & - \\
2009 & 418.682 & - & - \\
2010 & 407.003 & 74.765 & 481.708 \\
\hline
\end{tabular}

Fonte: Elaborada pela autora com base no estudo de Carvalho (2011) e nas

Portarias Interministeriais no 1030/2007; no 1.027/2008; nº 788/2009; nํ538-A/2010.

Observamos que as matrículas dessa modalidade de ensino sofreram oscilações no período de 2007 a 2010, tendo um decréscimo de 4\% de 2007 para 2008, um aumento de 17\% de 2008 para 2009 e um crescimento de aproximadamente $15 \%$ de 2009 para 2010. Se compararmos o total de matrículas em 2007 e o total de matrículas em 2010, evidenciamos um aumento de aproximadamente 29\%. Cumpre destacar que apenas em 2010 temos as matrículas do atendimento educacional especializado. Se compararmos a porcentagem das matrículas de educação especial com o total de matrículas em todas as etapas e modalidades contempladas no Fundeb, perceberemos que, em termos percentuais, as matrículas da educação especial ficam em torno de $1 \%$ em relação ao total de matrículas, como podemos visualizar na Tabela 10.

Tabela 10 - Porcentagem das matrículas da educação especial em relação ao total de matrículas contempladas no Fundeb - Brasil 2007-2010

\begin{tabular}{|c|c|c|c|}
\hline ANO & $\begin{array}{c}\text { MATRÍCULAS EM TODAS } \\
\text { AS ETAPAS E } \\
\text { MODALIDADES NO } \\
\text { FUNDEB }\end{array}$ & $\begin{array}{c}\text { MATRÍCULAS DA } \\
\text { EDUCAÇÃO ESPECIAL } \\
\text { NO FUNDEB }\end{array}$ & $\begin{array}{c}\text { MATRICCULAS DA EE EM } \\
\text { RELAÇÃO AO TOTAL DE } \\
\text { MATRÍCULAS NA } \\
\text { EDUCAÇÃO BÁSICA, } \\
\text { CONSTANTES DOS DADOS } \\
\text { DO FUNDEB }\end{array}$ \\
\hline 2007 & $35.587 .396,7$ & $374.542,8$ & $1 \%$ \\
\hline 2008 & $40.180 .824,7$ & $358.886,3$ & $0,89 \%$ \\
\hline 2009 & 45.279 .931 & 418.682 & $0,92 \%$ \\
\hline 2010 & 44.630 .305 & 481.768 & $1 \%$ \\
\hline
\end{tabular}

Nessa perspectiva, se compararmos esses percentuais de matrículas da educação especial, no período de 2007 a 2010, com as informações do Instituto 
Brasileiro de Geografia e Estatística - IBGE - (2010), sobre o total de pessoas com deficiência em idade escolar no Brasil (7,5\% das pessoas de zero a 14 anos), notamos que 0 atendimento está distante do necessário para garantir o acesso das pessoas com deficiência à educação, nos sistemas de ensino brasileiros.

Podemos visualizar, a seguir, o valor médio aluno-ano do investimento em educação especial no Fundeb, de 2007 a 2010 (Tabela 11).

Tabela 11 - Valor médio do investimento aluno-ano da educação especial no Fundeb - Brasil 2007-2010em valores nominais $(\mathrm{R} \$)$

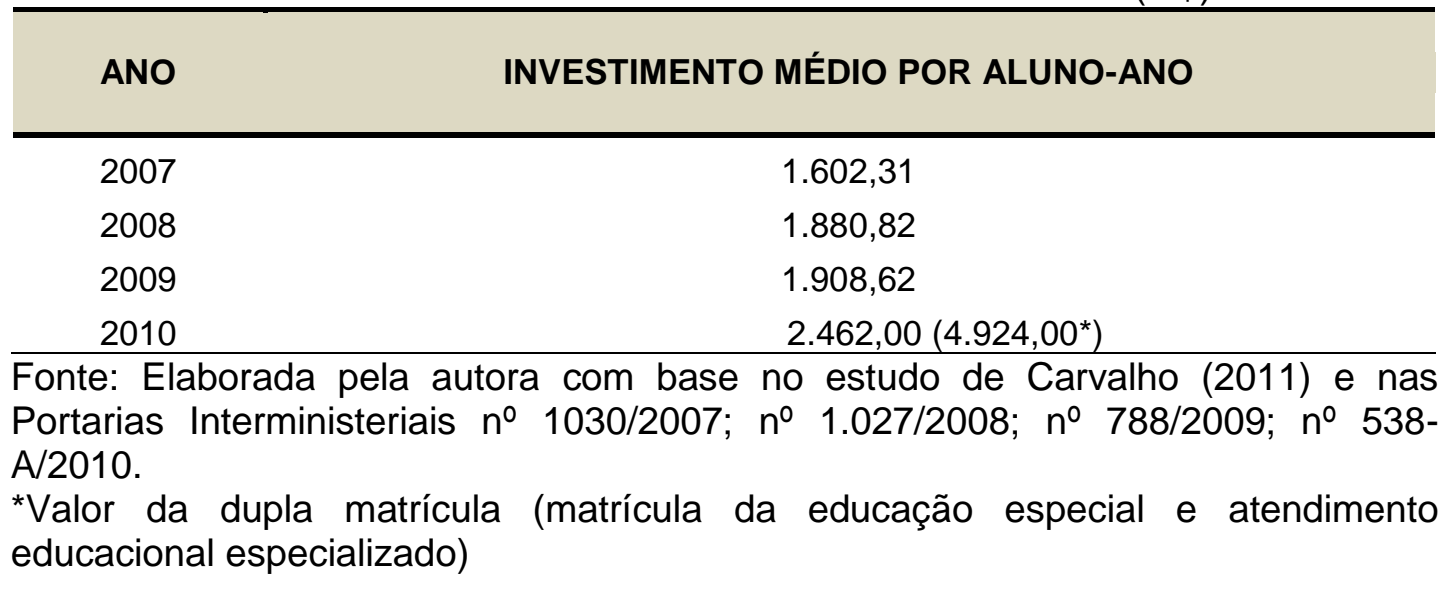

O valor médio aluno-ano da educação especial teve aumento real em todos os anos, sendo a valorização entre 2007 e 2010 de aproximadamente 54\%. Vale ressaltar que esse intervalo corresponde ao período de implantação do Fundeb, concluído em 2009, bem como que se articulam as correções monetárias do Fundeb e o aumento da participação da União. Se considerarmos que os coeficientes da educação especial $(1,20)$ não sofreram alteração entre 2007 e 2010, observaremos que o ritmo de crescimento foi importante. Cabe destacar ainda que, em 2010, o investimento médio por aluno-ano matriculado na classe comum e no atendimento educacional especial foi de $\mathrm{R} \$ 4.924,00$, considerando a dupla matrícula da educação especial no Fundeb, instituída pelo Decreto no 7.611/2011.

Consideramos também as unidades federativas que dispuseram do maior valor aluno-ano (RR) e as que dispuseram do menor valor (Alagoas, Amazonas, Bahia, Ceará, Maranhão, Pará, Paraíba, Pernambuco, Piauí) para o investimento em educação especial, dados esses disponibilizados na Tabela 12. 
Tabela 12 - Diferença entre os valores aluno-ano dispostos para a educação especial no Fundeb nas unidades federativas com maior e menor valor - Brasil 2007-2010 em valores nominais $(R \$)$

\begin{tabular}{ccccc}
\hline ANO & $\begin{array}{c}\text { MAIOR VALOR } \\
\text { (RR) - em R\$ }\end{array}$ & $\begin{array}{c}\text { MENOR VALOR } \\
\text { (AL, AM, BA, CE, } \\
\text { MA, PA, PB, PE } \\
\text { PI) em R\$ }\end{array}$ & DIFERENÇA & $\begin{array}{c}\text { PORCENTAGEM DO } \\
\text { MENOR VALOR EM } \\
\text { RELAÇÃO AO MAIOR } \\
\text { VALOR }\end{array}$ \\
\hline 2007 & $2.457,59$ & $1.136,69$ & $1.320,90$ & $46 \%$ \\
2008 & $3.082,86$ & $1.358,81$ & $1.724,05$ & $44 \%$ \\
2009 & $2.830,36$ & $1.465,60$ & $1.364,76$ & $48 \%$ \\
2010 & $3.197,97$ & $1.697,82$ & $1.500,15$ & $53 \%$ \\
\hline
\end{tabular}

Fonte: Elaborada pela autora com base no estudo de Carvalho (2011) e nas Portarias Interministeriais no 1030/2007; ํo 1.027/2008; ํo 788/2009; no 538-A/2010.

Evidenciamos que, mesmo no âmbito da aplicação do Fundeb, as desigualdades regionais no que se referem aos investimentos educacionais ainda se mantêm no Brasil e, no caso da educação especial, o estado de Roraima chega a investir quase duas vezes mais recursos por aluno do que os estados que possuem menos recursos, apesar da diferença, em termos percentuais, ter sido ainda maior no período inicial do fundo. Para Farenzena (2012c, p. 199),

[...] as desigualdades no acesso à educação e nas condições de qualidade da educação estão associadas aos desequilíbrios entre a oferta da educação e a capacidade de financiamento da educação entre os entes federativos que são os principais responsáveis pela oferta educacional.

Nesse sentido, a autora ressalta a importância do papel da União, por meio da prestação técnica e financeira aos estados e municípios, no exercício da sua função supletiva e redistributiva, visando à garantia do padrão mínimo de qualidade do ensino e à equalização de oportunidades educacionais.

Procuramos, ainda, comparar, na Tabela 13, o percentual aproximado de recursos direcionados a essa modalidade de ensino em relação aos recursos totais do Fundeb. 
Tabela 13 - Porcentagem aproximada dos recursos direcionados às matrículas da educação especial em relação aos recursos totais do Fundeb - Brasil 2007-2010 em bilhões de $\mathrm{R} \$$

\begin{tabular}{cccc}
\hline ANO & $\begin{array}{c}\text { RECURSOS } \\
\text { TOTAIS DO } \\
\text { FUNDEB }\end{array}$ & $\begin{array}{c}\text { RECURSOS DO FUNDEB } \\
\text { REFERENTE A } \\
\text { EDUCAÇÃO ESPECIAL }\end{array}$ & $\begin{array}{c}\text { PORCENTAGEM DOS } \\
\text { RECURSOS DA EE EM } \\
\text { RELAÇÃO AOS RECURSOS } \\
\text { TOTAIS DO FUNDEB }\end{array}$ \\
\hline 2007 & 48,231 & 0,600 & $1,24 \%$ \\
2008 & 64,896 & 0,675 & $1,04 \%$ \\
2009 & 73,957 & 0,799 & $1,08 \%$ \\
2010 & 83,095 & 1,185 & $1,43 \%$ \\
\hline
\end{tabular}

Fonte: Elaborada pela autora com base no estudo de Carvalho (2011) e nas Portarias Interministeriais no 1030/2007; ํㅡ 1.027/2008; № 788/2009; no 538-A/2010.

Constatamos que houve um aumento contínuo nos recursos do Fundeb referentes à educação especial de $R \$ 0,6$ bilhões (2007) para $R \$ 1,2$ bilhões (2010). No que se refere à porcentagem dos recursos da educação especial em relação ao total do Fundeb, observamos um decréscimo de 2007 para 2008 (de 16\%), tendo em vista a redução no número de matrículas dessa modalidade de ensino (de 4\%), e o aumento a partir de 2009 (de 16\% em 2009 e 33\% em 2010), considerando a expansão no número de matrículas (de 14\% em 2009 e 13\% em 2010).

Assim, podemos notar que a política do Fundeb tem garantido mais recursos para a educação especial, principalmente a partir do Decreto $n^{0}$ 7.611/2011, na tentativa de garantir acesso e permanência dos alunos com deficiência, TGD e altas habilidades/superdotação na escola. Entretanto, não temos como afirmar que esse montante tenha sido investido exclusivamente nessa modalidade de ensino, no âmbito dos sistemas públicos de ensino, visto que, até 2011, não havia nenhuma legislação que regulamentasse essa prestação de contas. Cabe acrescentar ainda que essas verbas públicas podem ser destinadas às entidades privadas de educação especial, prevista na legislação do Fundeb, para oferecimento de serviços a essa população, refletindo as correlações de forças em torno dos recursos públicos no âmbito do Estado. Faz-se necessário considerar, como aponta Farenzena $(2014$, p. 83) que o

[...] Fundeb é uma política que envolveu e envolve uma pluralidade de atores na sua formulação (período inicial e reformulações constantes) e na sua implementação. Há atores governamentais: executivos, legislativos, do sistema de justiça, tribunais de contas, 
conselhos e comissões; há também intervenção de atores não governamentais, como sindicatos, movimentos, partidos, associações, instituições particulares de educação.

Desse modo, os diferentes atores dentro de um processo permanente, regulado e negociado, no âmbito do Estado, determinam as distribuições, a alocação e a aplicação de recursos, bem como a publicização e a transparência de informações. Diante desse contexto, destacamos a necessidade de reformulações quanto ao controle social das verbas destinadas à educação especial no âmbito do Fundeb.

Um importante instrumento no sentido de romper com a lógica que pauta 0 financiamento da educação no Brasil tem sido a definição dos referenciais do Custo Aluno-Qualidade Inicial (CAQi), elaborado pela Campanha Nacional pelo Direito à Educação no documento Educação pública de qualidade (BRASIL, 2011d), com o objetivo de definir um custo por aluno capaz de garantir padrão mínimo de qualidade, como previsto na CF/1988 e na LDB/1996. Nesse sentido, o CAQi tem como matriz três vertentes: os desafios referentes as desigualdades na educação (econômica, de gênero, de raça/etnia, etc.); as dimensões fundamentais dos processos de ensino e aprendizagem (conhecimento, estética, ambiental e dos relacionamentos humanos); e os insumos (relacionados à estrutura e ao funcionamento, à valorização dos profissionais da educação, à gestão democrática e ao acesso e à permanência), que, articulados, buscam responder ao desafio de construção de uma educação de qualidade para todos, considerando as diferentes etapas e modalidades de ensino (BRASIL, 2011d). Nessa direção, o documento elaborado pela Campanha ainda apresenta dois mecanismos vinculados ao CAQi: os CAQis específicos ou por modalidades e o adicional CAQi. Quanto ao CAQi educação inclusiva, os autores no documento identificaram a necessidade de realização de estudos mais específicos para definição desses custos; porém, destacaram que, após algumas simulações, assumindo uma escola que inclua, em classe comum, alunos com deficiência,

[...] o CAQi de uma pessoa com deficiência deve ser, no mínimo, o dobro do custo aluno-qualidade de uma pessoa sem deficiência. Ou seja, a escola que atender um aluno ou uma aluna com deficiência deverá receber por ele ou ela o dobro do recurso correspondente a 
um aluno ou uma aluna sem deficiência. De qualquer forma, há uma grande diferença nos impactos do custo aluno em função do tipo de deficiência. (BRASIL, 2011d, p. 51).

Desse modo, o documento da Campanha Nacional pelo Direito à Educação aponta para a necessidade de que o CAQi educação inclusiva seja duplicado em relação ao CAQi de uma pessoa sem deficiência, bem como para a necessidade de realização de pesquisas e aprofundamento da negociação com organizações diversas para a criação de bases para esse CAQi específico, no intuito de garantir a ampliação do acesso e a melhoria na qualidade de educação (BRASIL, 2011d). Destacamos, ainda, que os valores estimados pela Campanha foram atualizados no Parecer CNE/CEB o 8, de 5 de maio de 2010 (BRASIL, 2010f), ainda não homologado pelo MEC, que pretende normatizar os padrões mínimos de qualidade do ensino para a educação básica pública de acordo com o CAQi.

Com base no exposto, referente à caracterização da educação especial nos contextos dos fundos de manutenção e desenvolvimento de ensino, apresentamos, no próximo item, as políticas direcionadas a essa modalidade de ensino no Brasil, no período de 2003 a 2010.

\subsection{AS POLÍTICAS DE EDUCAÇÃO ESPECIAL NO PERÍODO DE 2003 A 2010}

Apresentamos, neste item, um breve panorama da educação especial no governo Lula (2003-2010), que compreende o período do nosso estudo (2008, 2009 e 2010), no que tange à sua disposição no MEC, às políticas e ações voltadas a essa modalidade de ensino, e à sua oferta no Brasil.

Porém, antes de nos adentrarmos na discussão das políticas desenvolvidas nesse governo, cabe ressaltar que importantes mudanças ocorreram nas gestões do governo Fernando Henrique Cardoso (1995-1998/1999-2002), as quais, apoiadas no discurso e nas orientações de organismos internacionais (como Fundo Monetário Internacional - FMI e do Banco Mundial, entre outros), trouxeram implicações significativas no campo das políticas educacionais e também para as políticas de educação especial, como já salientado em capítulos anteriores. Entre elas, podemos 
citar a: promulgação da LDB/1996 que ratifica o direito à educação, inclusive das pessoas com deficiência, TGD e altas habilidades/superdotação; a criação do Fundef, que alterou o padrão de financiamento da educação e focalizou os gastos educacionais no ensino fundamental, em detrimento de outras modalidades de ensino; a instituição do PNE, que traçou diretrizes e metas para a educação brasileira no período de 2001 a 2010; a aprovação da Resolução n 2/2001, que estabelece as diretrizes nacionais da educação especial; entre outras leis, decretos e documentos que mostraram as concepções do governo, marcadas por um processo de desregulamentação da administração federal e pública e um processo de descentralização administrativa, financeira e pedagógica, delineados pelo Plano Diretor da Reforma do Aparelho de Estado (BRASIL, 1995), que delimitou as funções e o tamanho do Estado, o aumento da governança, ou seja, da capacidade de tornar efetivas decisões governo e o aumento da governabilidade, isto é, do poder do governo (KASSAR, 2001). Essa lógica de racionalidade financeira iniciada pelo governo de Fernando Henrique Cardoso (1995-2002), segundo Arelaro (2004), foi continuada pelo governo Lula (2003-2010). No início do seu governo,

[...] além de não ter apresentado um projeto que traduzisse uma verdadeira reforma tributária, dentro do lema justiça social, de abrangência ampla, "quem tem mais, paga mais" nas discussões preliminares realizadas e nas contrapropostas apresentadas, durante os anos de 2003 e 2004, infelizmente, pouco se avançou, em relação à situação atual. Pode-se afirmar que não existe uma proposta consistente, com um projeto de redistribuição de renda a ser implantado no Brasil, mas sim alternativas "mornas" que mantêm, e por consequência, fortalecem, as estratégias propostas pelos organismos internacionais, como condição de manutenção e concessão de novos empréstimos financeiros ao Brasil. Estratégias estas que têm como pressuposto de avaliação positiva, ou de "competência qualitativa do gasto", a redução expressiva dos gastos com as áreas sociais, em especial, com a educação, a saúde, a habitação, a previdência e assistência social. (ARELARO, 2004, p. 15).

Para Pinto (2009), a eleição de Lula para presidente, em 2002, produziu grande expectativa de mudança no seio da sociedade brasileira, principalmente, na área de educação, e não há como não reconhecer os avanços ocorridos nas suas gestões para a educação básica, no que tange às políticas de gestão e financiamento, por exemplo, a aprovação do Fundeb e a ampliação dos recursos da 
União com o novo fundo, ainda que esse aumento estivesse longe de assegurar um padrão mínimo de qualidade. Porém, o autor também ressalta as contradições que marcaram o seu governo, como o Plano de Desenvolvimento da Educação (PDE), lançado em 2007, que, segundo Pinto (2009, p. 328), apresentou um "claro sentido de esvaziamento do dever do Estado para com a garantia do direito à educação", pois tinha como referência as metas de um grupo de empresários que haviam lançado, em 2006, o "Movimento Compromisso Todos pela Educação73".

No que se refere à educação especial, os governos de Lula (2003-2006/20072010), assim como os governos anteriores, desde a década de 1990, continuaram a difusão dos princípios de inclusão, orientados pelos princípios das agências internacionais. Assim, o governo Lula adota o termo "inclusão" em seus Planos Plurianuais (Plano Brasil de Todos: participação e inclusão - 2004-2007; e o Plano de Desenvolvimento com inclusão social e educação de qualidade - 2008-2011). Desse modo, segundo Kassar (2011a, p. 52), "apresentada como prioridade nacional, a educação deveria promover a equidade, valorizar a diversidade e proporcionar a inclusão social, discurso coerente ao propagado pela Organização das Nações Unidas".

Assim, na sua primeira gestão (2003-2006), em que a inclusão social foi estabelecida como um dos quatro eixos estratégicos de sua política educacional, com Cristovam Buarque como ministro da Pasta da Educação, foram criadas duas secretarias: a Secretaria Extraordinária de Erradicação do Analfabetismo (Seea) e a Secretaria de Inclusão Educacional (Secrie). Ambas tinham como objetivos a inclusão educacional, a equidade e a melhoria da situação de desigualdade e vulnerabilidade social e educacional. A Secrie tinha a responsabilidade pelo Programa Bolsa-Escola e iniciou suas atividades com a constituição de uma Rede de Agentes de Inclusão Educacional. Essa Secretaria procurou, entre outras ações, cadastrar o conjunto de crianças que, em 2003, estavam fora da escola no país. A Seea, por sua vez, realizou um trabalho de cadastro da população analfabeta (MOEHLECKE, 2009).

\footnotetext{
${ }^{73}$ Movimento lançado em 6 de setembro de 2006, em São Paulo, como uma iniciativa da sociedade civil, conclamando a participação de todos os setores sociais, esse movimento se configurou, de fato, segundo Saviani (2009), como um aglomerado de grupos empresariais, entre outros, exercendo forte influência nas políticas educacionais no Brasil.
} 
Essas secretarias tiveram uma curta vida institucional. Com a substituição do ministro Cristovam Buarque por Tarso Genro, no início do segundo ano de governo, foi criada uma nova secretaria no MEC, a Secretaria de Educação Continuada, Alfabetização e Diversidade, resultante da fusão da Seea e Secrie e da incorporação de programas antes localizados em outras secretarias do ministério, pelo Decreto Presidencial no 5.159, de 28 de julho de 2004 (BRASIL, 2004b). Assim, a Secad ficou dividida em quatro departamentos: EJA; educação para diversidade e cidadania; desenvolvimento e articulação institucional; e avaliação e informações educacionais (MOEHLECKE, 2009).

No que se refere à Seesp, essa Secretaria permaneceu com uma vinculação institucional autônoma e distinta, não tendo sofrido alterações com as mudanças em 2004. Nesse mesmo ano, de acordo com Sabrina Moehlecke (2009, p. 471), "quando foram criadas as câmaras temáticas, à educação especial não foi destinada representação na Câmara de Diversidade na Educação; ao invés disso, criou-se uma câmara temática específica para tratar dessa modalidade de ensino". Segundo a autora, uma solução que foi adotada por essa gestão, na tentativa de responder às reivindicações de diferentes grupos sociais, identificados por sua situação de discriminação e exclusão social, foi a criação de secretarias ou conselhos específicos e/ou câmaras temáticas. Para ela, se, por um lado, essa medida assegura o desenvolvimento de ações que em outras instâncias não seriam levadas em consideração, por outro, há o risco de fragmentar esse trabalho com a criação de guetos. Outra solução foi a instituição de comissões de assessoramento ou de parcerias na execução de programas e projetos, buscando "utilizar uma estratégia de ação descentralizada, baseada na articulação e indução de políticas nos três níveis de governo, com o envolvimento também de atores não governamentais" (MOEHLECKE, 2009, p. 470). A autora salienta ainda que a adoção de tais soluções e/ou estratégias pode se constituir num importante canal de comunicação e diálogo entre o MEC e os grupos sociais organizados, mas também pode representar "meios de atenuar as tensões e as constantes e crescentes pressões que eventualmente recaem sobre o governo" (MOEHLECKE, 2009, p. 470).

Em 2005, Fernando Haddad assumiu o MEC, porém ele já atuava nesse órgão desde 2004, como secretário executivo de Tarso Genro. Sua principal marca na gestão do MEC, segundo Pinto (2009), foi o PDE, que contribuiu para a sua 
manutenção como ministro na transição dos dois mandatos do presidente Lula. Além disso, ele desenvolveu ações importantes nesse período, como a Universidade Aberta do Brasil (UAB), o Programa de Apoio a Planos de Reestruturação e Expansão das Universidades Federais (REUNI) e o Fundeb (PINTO, 2009).

Em 2011, no governo Dilma Russef (2011-2014), houve uma nova reestruturação no MEC, por meio do Decreto no 7.480, de 16 de maio de 2011 (BRASIL, 2011b). A Secad passou a ser a Secretaria de Educação Continuada, Alfabetização, Diversidade e Inclusão (Secadi). A educação especial perdeu a condição de secretaria, e, com a extinção da Seesp, as suas atribuições passaram para a Diretoria de Políticas de Educação Especial, vinculada à Secadi. Essa Secretaria, a partir do Decreto n 7.690, de 2 de março de 2012 (BRASIL, 2012a), que trata da estrutura organizacional do MEC, passou a ser composta por cinco diretorias, a saber, a de Políticas de Educação do Campo, Indígena, e para Relações Étnico-Raciais; Políticas de Alfabetização e Educação de Jovens e Adultos; Políticas de Educação em Direitos Humanos e Cidadania; Políticas de Educação Especial; e Políticas de Educação para Juventude, acumulando, portanto, atribuições amplas e complexas, na medida em que busca aglutinar diferentes grupos sociais, com interesses distintos sob a égide do compromisso com a sua inclusão escolar e social e o reconhecimento da diversidade humana (BEZERRA, 2013). De acordo com Giovani Ferreira Bezerra (2013, p. 952), no interior da Secadi, "observa-se um mosaico de temas e interesses diversos, de tal forma que não é preciso esforço para perceber o caráter difuso que deverá marcar sua atuação, haja vista a amplitude dos trabalhos e das demandas a serem atendidas". Desse modo, o autor critica o ecletismo da Secadi e salienta que essa configuração trará implicações para o modo como se pretende (re)conduzir as políticas educacionais no Brasil, em especial, as políticas de educação especial, voltadas para o atendimento das necessidades dos alunos com deficiência, TGD e altas habilidades/superdotação.

Cumpre ressaltar que as alterações do espaço político da educação especial, no âmbito do MEC, não constituem apenas mudanças técnico-administrativas de um determinado governo; elas representam, antes de tudo, forças políticas de diferentes grupos sociais que estão presentes no Estado. Nessa perspectiva, podemos visualizar as correlações de forças que ocorrem no interior dos seus aparelhos, no 
caso específico da Secadi/MEC, na tentativa de assegurar participação e a representatividade de diferentes grupos e suas respectivas demandas nos processos decisórios de formulação de políticas públicas.

Em relação às políticas de educação especial desenvolvidas ao longo do mandato do Presidente Lula (2003-2010), período que abrange o nosso estudo, Márcia Denise Plestch (2012) afirma que houve uma ampliação de investimentos financeiros voltados à garantia dos direitos das pessoas com deficiência, TGD, altas habilidades/superdotação, no contexto de implementação de políticas de inclusão social e educacional direcionadas a diferentes grupos sociais. No caso da educação especial, as iniciativas se desenvolveram por meio de programas voltados à educação básica e ao ensino superior: Programa Educação Inclusiva: direito à diversidade; Programa Implantação de Salas de Recursos Multifuncionais; Programa Incluir; Programa Escola Acessível; e Programa Benefício da Prestação Continuada da Assistência Social na escola, que serão detalhados mais adiante. Além disso, ocorreram mudanças significativas na estrutura e no funcionamento da educação especial, tendo em vista a elaboração de diretrizes para formulação de políticas públicas.

Assim, no âmbito federal, foram desencadeadas ações e políticas a fim de garantir e ampliar o direito do público da educação especial, assim como assegurar o acesso ao atendimento educacional especializado no contexto da escola.

Em 2004, foi publicado pelo Ministério Público Federal, o documento $O$ acesso de alunos com deficiência às escolas e classes comuns da rede regular (BRASIL, 2004c), com a finalidade de disseminar os conceitos e diretrizes mundiais para a inclusão escolar, ratificando o direito de acesso à escola e os benefícios da escolarização de alunos com e sem deficiências nas classes comuns dos sistemas de ensino brasileiros. Cabe destacar que esse documento representa um avanço no sentido de minimizar as interpretações equivocadas das normas e diretrizes educacionais no que se refere ao direito de acesso e permanência nas classes comuns da população com deficiência. Assim, entre outras orientações, o documento ressalta, de forma inovadora, que o termo "preferencialmente", presente na CF/1988, refere-se ao "atendimento educacional especializado, ou seja, aquilo que é necessariamente diferente no ensino regular para melhor atender às 
especificidades dos alunos com deficiência" (BRASIL, 2004c, p. 8). Portanto, esse atendimento, de caráter complementar, não substitui a escola comum.

Em 2006, o Brasil torna-se signatário da Convenção sobre os Direitos das Pessoas com Deficiência, aprovada pela Assembleia Geral da Organização das Nações Unidas (ONU, 2006), que estabeleceu, para os estados participantes do evento, o compromisso em assegurar um sistema educacional inclusivo em todos os níveis de ensino, bem como o aprendizado ao longo de toda a vida. Com o Decreto no 186, de 9 de julho de 2008 (BRASIL, 2008d), o texto passou a ser incorporado à legislação brasileira com equivalência de Emenda Constitucional. Desse modo, todas as leis que abrangem os direitos e as demandas das pessoas com deficiência "deverão se adequar ao seu conteúdo, sob a pena de serem invalidadas por inconstitucionalidade" (CAIADO, 2009, p. 330). A autora destaca, ainda, o envolvimento da sociedade civil, especialmente das pessoas com deficiência, na elaboração do documento supracitado.

A originalidade deste documento é a de que foi elaborado com a participação de organizações de pessoas com deficiência de várias partes do mundo. Resultado da mobilização de organizações da sociedade civil, compostas por pessoas com deficiências e pessoas que lutam pelos direitos das pessoas com deficiência, ativistas de direitos humanos, agências internacionais e representantes de 192 países, num longo processo de debate que se iniciou em 2001 e finalizou em 2003 com a aprovação do texto em Assembleia Geral da ONU. (CAIADO, 2009, p. 330).

Em 2007, o Decreto no 6.094, de 24 de abril, estabeleceu as diretrizes do Plano de Metas Compromisso Todos pela Educação (BRASIL, 2007a) e o Plano de Ações Articuladas (PAR) (BRASIL, 2007a), definindo a participação da União, do Distrito Federal, dos estados e dos municípios em regime de colaboração e ação compartilhada com as famílias e comunidades, mediante programas e ações de assistência técnica e financeira, em favor da melhoria da qualidade da educação básica. Nesse contexto, foi lançado pelo MEC o PDE (BRASIL, 2007f), abrangendo diferentes ações destinadas às etapas e modalidades de ensino, além de medidas de apoio e infraestrutura. Nesse documento, a educação especial foi representada pelos seguintes programas: Programa de Salas de Recursos Multifuncionais; Programa Incluir: de Acessibilidade na Educação Superior; Programa Olhar Brasil; e 
o Programa de Acompanhamento e Monitoramento do Acesso e Permanência na Escola das Pessoas com Deficiência Beneficiárias do Benefício de Prestação Continuada da Assistência Social. Nesse sentido, concordamos com Saviani (2009, p. 27) quando afirma que o PDE não constitui um plano, "[...] ele define-se, antes, como um conjunto de ações que, teoricamente, se constituíram em estratégias para a realização dos objetivos e metas previstos no PNE. [...] ações que não se articulam organicamente com este". Apresentamos, a seguir, de maneira sucinta, alguns desses programas.

O Programa Educação Inclusiva: direito à diversidade, criado em 2003 e desenvolvido pelo MEC/Seesp ${ }^{74}$, tinha como objetivo

[...] a formação de gestores e educadores para efetivar a transformação dos sistemas educacionais inclusivos, tendo como princípio, a garantia do direito dos alunos com necessidades educacionais especiais de acesso e permanência, com qualidade, nas escolas regulares. (BRASIL, 2005b, p. 9).

De acordo com Garcia e Michels (2011, p. 112), o programa apresenta uma lógica de municípios-polos que exercem o papel de multiplicadores, e sua preocupação era "divulgar a perspectiva inclusiva junto aos gestores para fomentar sua implementação política”.

O Programa Implantação de Salas de Recursos Multifuncionais foi lançado pelo Edital ํㅜ 01, de 26 de abril de 2007, com o seguinte objetivo geral:

Apoiar os sistemas de ensino na organização e oferta do atendimento educacional especializado, por meio da implantação de salas de recursos multifuncionais nas escolas de educação básica da rede pública, fortalecendo o processo de inclusão nas classes comuns de ensino regular. (BRASIL, 2007d).

Assim, a proposta do programa visava promover condições de acesso, participação e aprendizagem do público da educação especial no ensino regular, por meio do atendimento educacional especializado em salas de recursos

74 A Seesp foi extinta em 2011, pelo Decreto no 7.480 , de 16 de maio - revogado pelo Decreto no 7.690 , de 2 de março de 2012 -, e seus programas e ações foram vinculados à Secretaria de Educação Continuada, Alfabetização, Diversidade e Inclusão (Secadi). 
multifuncionais, espaço organizado com equipamentos de informática, materiais pedagógicos e mobiliários adaptados, para atendimento às necessidades educacionais especiais dos alunos (BRASIL, 2007d). Cabe ressaltar que o atendimento educacional especializado, nessa perspectiva, assumiu função complementar ou suplementar e, portanto, não substitutivo à escolarização. Para Garcia (2009), o Programa Implantação de Sala de Recursos Multifuncionais estabeleceu a educação especial como um serviço educacional especializado complementar ou suplementar enquadrando-a num "modelo gerencial de gestão", uma vez que redimensiona a responsabilidade de execução do atendimento educacional especializado às unidades escolares e a coordenação desse atendimento para um órgão gestor de educação especial nos diferentes sistemas de ensino, responsável "[...] pela orientação, avaliação, estabelecimentos de convênios e parcerias e organização de censos, dentre outros" (GARCIA, 2009, p. 6), reproduzindo uma forma descentralizada de administração.

O Programa de Acessibilidade na Educação Superior (Incluir), criado em 2005 e implementado até $2011^{75}$, por meio de chamadas públicas, realizadas pela Seesp e pela Secretaria de Educação Superior (Sesu), teve como finalidade promover o desenvolvimento de políticas institucionais de acessibilidade nas Instituições Federais de Ensino Superior (Ifes), no intuito de "[...] eliminar barreiras físicas, pedagógicas, nas comunicações e informações, nos ambientes, instalações, equipamentos e materiais didáticos" (BRASIL, 2013b). Assim, de acordo com Garcia e Michels (2011), o programa previa a participação de universidades e institutos federais de educação superior, que submetiam as suas propostas à avaliação e, caso fossem selecionados, recebiam recursos para implementação dos núcleos de acessibilidade. As autoras ressaltam, ainda, que esse tipo de gestão por editais "[...] tem apresentado definições políticas para o setor, induzindo uma adesão ao modelo assumido no projeto do governo federal” (GARCIA; MICHELS, 2011, p. 114).

O Programa Escola Acessível, criado em 2007, tinha como objetivo promover a inclusão de alunos com deficiência, TGD e altas habilidades/superdotação, bem como garantir a acessibilidade ao ambiente físico, aos recursos didáticos e

\footnotetext{
${ }^{75}$ A partir de 2012, o MEC, por intermédio da Secadi e da Sesu, passou a apoiar projetos das Ifes, com aporte de recurso financeiro, diretamente, previsto na matriz orçamentária das instituições, com a finalidade de institucionalizar ações de políticas de acessibilidade na educação superior, por meio dos Núcleos de Acessibilidade (BRASIL, 2013b)
} 
pedagógicos e à comunicação e informação (BRASIL, 2013c). Os recursos financeiros eram viabilizados por meio do Programa Dinheiro Direto na Escola (PDDE), diretamente às unidades executoras das escolas de educação básica das redes estaduais, municipais e distrital, contempladas pelo Programa Implantação de Salas de Recursos Multifuncionais.

O Programa BPC na escola, instituído pela Portaria Normativa Interministerial no 18, de 24 de abril de 2007 (BRASIL, 2007e), realiza o acompanhamento do acesso e permanência na escola das pessoas com deficiência, beneficiárias do BPC, na faixa etária de zero a 18 anos, por meio da articulação das políticas de educação saúde, assistência social e direitos humanos. Cumpre destacar que esses programas, desenvolvidos pelo governo federal, eram financiados pelos recursos do PDE e pelo Plano de Aceleração do Crescimento - PAC -, tendo como eixos a acessibilidade arquitetônica dos prédios escolares, a implantação de salas de recursos e a formação docente para o atendimento educacional especializado (BRASIL, 2008a).

Em 2008, foi publicado o documento "Política Nacional de Educação especial na Perspectiva da Educação Inclusiva" - PNEE-EI/2008 - (BRASIL, 2008a), que passou a orientar os sistemas de ensino para a organização de serviços e recursos de educação especial. O objetivo era promover respostas às necessidades educacionais Especiais dos alunos com deficiência, TGD e altas habilidades/superdotação, reafirmando a educação especial como modalidade da educação escolar que, portanto, perpassa todos os níveis de ensino, desde a Educação Infantil até a educação superior, abrangendo também as modalidades (educação especial e EJA). Assim, as respectivas respostas devem contemplar a proposta pedagógica da escola, como descrito no documento:

Na perspectiva da educação inclusiva, a educação especial passa a integrar a proposta pedagógica da escola regular, promovendo o atendimento às necessidades educacionais especiais de alunos com deficiência, transtornos globais de desenvolvimento e altas habilidades/superdotação. Nestes casos e outros, que implicam em transtornos funcionais específicos, a educação especial atua de forma articulada com 0 ensino comum, orientando para 0 atendimento às necessidades educacionais especiais desses alunos. (BRASIL, 2008a, p. 9). 
Essa concepção se contrapõe à caracterização que a educação especial vem assumindo ao longo da história, no que diz respeito à estrutura e à forma de atendimento, como sistema paralelo ao ensino regular, em substituição à escolarização de seu público em classe comum. A perspectiva do documento é que haja uma ampliação de recursos e serviços de apoio ao processo de escolarização dos alunos com deficiência, TGD e altas habilidades/superdotação nas unidades de ensino. Contudo, a perspectiva adotada pelo MEC de atendimento educacional especializado está direcionada às salas de recursos multifuncionais, no contraturno ao horário de aula. Assim, Garcia (2008, p. 5) destaca que o modelo de educação especial difundido pela política nacional tem "[...] finalidade educacional e complementar/suplementar à educação básica e que a proposição hegemônica em termos de organização escolar é a sala de recursos como estratégia de serviço educacional especializado".

No intuito de garantir a implementação da PNEE-EI/08 (BRASIL, 2008a), que traduzia certa expectativa em relação à ampliação de recursos e serviços como apoio ao processo de escolarização dos alunos com deficiência, TGD e altas habilidades/superdotação nas unidades de ensino, foi aprovado o Decreto Presidencial de oㅜ 6.571, de 17 de setembro de 2008 (BRASIL, 2008b), com a finalidade de garantir o compromisso da União na prestação de apoio técnico e financeiro aos sistemas públicos de ensino do Distrito Federal, dos estados e dos municípios, para o atendimento educacional especializado. Porém, esse decreto foi revogado e substituído pelo Decreto Presidencial de oㅜ 7.611/ 2011 (BRASIL, 2011a) que dispõe:

Art.14. Admitir-se-á, para efeito da distribuição dos recursos do FUNDEB, o cômputo das matrículas efetivadas na educação especial oferecida por instituições comunitárias, confessionais ou filantrópicas sem fins lucrativos, com atuação exclusiva na educação especial, conveniadas com o Poder Executivo competente.

$\S 1^{\circ}$ Serão consideradas, para a educação especial, as matrículas na rede regular de ensino, em classes comuns ou em classes especiais de escolas regulares, e em escolas especiais ou especializadas.

$\S 2$ 2 O credenciamento perante o órgão competente do sistema de ensino, na forma do art. 10, inciso IV e parágrafo único, e art. 11, inciso IV, da Lei no 9.394 de 1996, depende de aprovação de projeto pedagógico $^{76}$. (NR) (BRASIL, 2011a).

\footnotetext{
${ }^{76}$ A aprovação do Projeto Pedagógico é realizada pela Secretaria de Educação ou órgão equivalente
} dos estados, do Distrito Federal ou dos municípios, de acordo com a Nota Técnica oํ 55, de maio de 
Nessa perspectiva, observamos que, nesse contexto de (re)definição de financiamento da educação especial, ainda se mantém a destinação de recursos públicos para instituições sem fins lucrativos que atuam exclusivamente nessa modalidade de ensino.

O Decreto № 7.611/2011 também acrescenta dispositivo ao Decreto no 6.253/2007 (BRASIL, 2007c), que dispõe sobre o Fundeb, passando este a vigorar acrescido do seguinte artigo:

Art.9- A. Para efeito da distribuição dos recursos do FUNDEB, será admitida a dupla matrícula dos estudantes da educação regular da rede pública que recebem atendimento educacional especializado.

$\S 1^{\circ}$ A dupla matrícula implica o cômputo do estudante tanto na educação regular da rede pública, quanto no atendimento educacional especializado.

$\S 2^{\circ} \mathrm{O}$ atendimento educacional especializado aos estudantes da rede pública de ensino regular poderá ser oferecido pelos sistemas públicos de ensino ou por instituições comunitárias, confessionais ou filantrópicas sem fins lucrativos, com atuação exclusiva na educação especial, conveniadas com o Poder Executivo competente, sem prejuízo do disposto no art. 14. (NR)

A partir de 2010, os alunos com deficiência, TGD e altas habilidades/superdotação passaram a ser contabilizados duplamente no âmbito do Fundeb, quando matriculados em classes comuns do ensino regular e também no atendimento educacional especializado, podendo este ser realizado na mesma escola que o aluno frequenta, em outra do seu entorno, ou por instituições comunitárias, confessionais ou filantrópicas sem fins lucrativos, que prestem esse tipo de serviço. De acordo com Juca Gil et al. (2010, p. 20), com a implantação do Fundeb, vislumbram-se

[...] novos rearranjos da organização estatal, sendo importante notar que os dois fundos previram valores financeiros diferenciados a serem destinados às instituições que atendem a educação especial. Estes valores, mais elevados do que os aportados às escolas comuns, ainda carecem de estudos quanto ao seu dimensionamento, sendo utilizados, até o momento, índices diferenciados, que refletem tanto a disponibilidade financeira dos governos quanto a correlação de forças políticas em disputa pelos parcos recursos.

2013 do MEC/SECADI/DPEE, que orienta a atuação dos Centros de atendimento educacional especializado, na perspectiva da educação inclusiva. 
Cabe destacar ainda que os princípios definidos na atual política do governo federal (PNEE-El/2008) foram confirmados, em 2010, pela Conae, que mobilizou, no território nacional, diferentes grupos sociais na discussão de diretrizes e estratégias para a construção de um novo Plano Nacional de Educação (LAPLANE; PRIETO, 2010). O documento final abrangia seis eixos: Papel do Estado na garantia do direito à educação de qualidade: organização e regulação da educação nacional; Qualidade da Educação, Gestão Democrática e Avaliação; Democratização do Acesso, Permanência e Sucesso Escolar; Formação e Valorização dos Profissionais da Educação; Financiamento da Educação e do Controle Social; e Justiça Social, Educação e Trabalho: Inclusão. Este último contempla o tema "Educação Especial”, com 23 propostas que "reafirmam o direito de acesso irrestrito à educação, pautado na garantia de condições para a implementação de uma Política Nacional de Educação Inclusiva" (LAPLANE; PRIETO, 2010, p. 927) às pessoas com deficiência, TGD e altas habilidades/superdotação nas classes comuns. As autoras ainda salientam a transversalidade do Eixo VI no documento final, e afirmam que o texto desse eixo "reitera a universalidade de direito, a necessidade de superar desigualdades sociais e incorporar o respeito à diversidade no sistema educacional" (LAPLANE; PRIETO, 2010, p. 926).

As discussões da Conae (2010) resultaram em um documento final com análises, diretrizes, metas, ações e estratégias que serviram de base para a composição do Projeto Lei no 8.035, de 20 de dezembro 2010 (PL/2010), que tratava da aprovação do novo PNE, de autoria do Poder Executivo, que chegou ao Congresso Nacional legitimado pelos vários seminários e debates com toda a sociedade (OLIVEIRA, R. P., 2011). O PL/2010 foi discutido na Câmara dos Deputados e encaminhado ao Senado que elaborou Emenda/Substitutivo ao Projeto da Lei da Câmara nำ 103, de 25 de outubro de 2012 (BRASIL, 2012b). O Documento Substitutivo foi aprovado pela Comissão Especial da Câmara dos Deputados, que teve como relator o Senador Angelo Vanhoni (PT-PR), garantindo que recursos públicos fossem destinados às instituições privadas de ensino para efeito de contabilização dos $10 \%$ do PIB. Oliveira, R. P. (2011, p. 4) resume o que foi esse processo: 
[...] o governo federal, ao encaminhar sua proposta de PNE ao Congresso Nacional, desconsiderou as principais formulações aprovadas na Conae e se submeteu aos ditames de uma política de controle das contas públicas, tímida, imediatista e incapaz de compreender os imensos desafios que se apresentam ao país, nos próximos anos, em síntese, não atribuindo à educação a importância que esta tem no processo de construção da cidadania e de preparação do país para se inserir em condições mais favoráveis nas difíceis condições de competitividade da economia do século XX.

Após quase quatro anos de tramitação entre o MEC, o Congresso Nacional, o PNE foi aprovado pela Lei no 13.005, de 25 junho de 2014, com 14 artigos, 20 metas e 254 estratégias que, durante os próximos 10 anos, orientarão as diretrizes e as políticas educacionais. No PNE (2014-2024), a educação especial foi contemplada na Meta 4, que consiste em:

[...] universalizar, para a população de 4 (quatro) a 17 (dezessete) anos com deficiência, transtornos globais do desenvolvimento e altas habilidades ou superdotação, o acesso à educação básica e ao atendimento educacional especializado, preferencialmente na rede regular de ensino, com a garantia de sistema educacional inclusivo, de salas de recursos multifuncionais, classes, escolas ou serviços especializados, públicos ou conveniados. (BRASIL, 2014a).

Para alcançar essa meta, o PDE estabelece 19 estratégias, que abrangem o financiamento dessa modalidade de ensino; a universalização do atendimento das crianças de zero a três anos; a implantação de salas de recursos multifuncionais e formação continuada de professores para o atendimento educacional especializado; a criação de centros multidisciplinares de apoio, pesquisa e assessoria para o trabalho com o público da educação especial; a manutenção de programas que promovam condições de acesso e permanência por meio da adequação arquitetônica, transporte acessível e materiais didáticos próprios; a garantia da oferta de educação bilíngue; o incentivo à pesquisa; a articulação intersetorial entre órgãos e políticas públicas de saúde, assistência social e direitos humanos; a definição de indicadores de qualidade; a inclusão de referenciais teóricos específicos para a formação de professor; a parceria com instituições comunitárias, confessionais ou filantrópicas sem fins lucrativos, conveniadas com o Poder Público para ampliar as condições de apoio ao atendimento integral dos alunos com deficiência, TGD e altas habilidades ou superdotação, para a oferta de formação continuada, para a 
produção de material didático acessível e para participação das famílias e da sociedade na construção do sistema educacional inclusivo (BRASIL, 2014a).

Cumpre destacar que o processo de tramitação e aprovação do PNE (20142024) mais uma vez apresentou as correlações de forças existentes, historicamente, na definição de políticas da educação especial, marcadas pelas disputas entre os grupos das entidades privadas, as organizações do setor público e o governo, para a oferta do atendimento educacional às pessoas com deficiência, TGD e altas habilidades/superdotação e para a obtenção dos recursos públicos destinados à educação especial. Ficou evidente a forte capacidade das entidades privadas de influenciar os parlamentares na garantia da manutenção do atendimento educacional especializado pelas instituições comunitárias, confessionais ou filantrópicas sem fins lucrativos por meio de convênios com o Poder Público.

A discussão acerca da exclusividade de recursos públicos para a escola pública não foi temática de consenso na discussão da Conae (2010), como apontado por Andréa Barbosa Gouveia e Ângelo Ricardo de Souza (2010). Enquanto a maioria dos segmentos apresentou acordo para explicitar prazos para o fim de subvenções sociais na educação básica, o mesmo não ocorreu no caso da educação superior. Dessa forma, se no campo de forças da Conae (2010) foi possível retomar esse princípio, os autores alertavam para a possibilidade de mudanças na proposição quando ela adentrasse "outras esferas de disputas públicas, numa sociedade marcada por experiências subjetivas de privatização da vida cotidiana" (GOUVEIA; SOUZA, 2010, p. 794). Ao que nos parece, foi o que aconteceu no processo de tramitação do PNE (2014-2024), em que foram assegurados recursos públicos às instituições privadas de ensino, inclusive para as entidades sem fins lucrativos da educação especial, para o oferecimento do atendimento educacional especializado. Cabe ressaltar que, na primeira versão do Projeto de Lei no 8.035/2010, o texto focava apenas na expansão do atendimento escolar a essa população: "Universalizar para a população de quatro a dezessete anos, o atendimento escolar aos estudantes com deficiência, transtornos globais do desenvolvimento e altas habilidades ou superdotação na rede regular de ensino" (BRASIL, 2010b). O novo texto da Meta 4, apresentado anteriormente, pode levar à compreensão da possibilidade de um atendimento paralelo, substitutivo ao ensino comum, e não da criação de um sistema educacional inclusivo, como preconizado 
na PNEE-El/2008 e na Convenção sobre os Direitos das Pessoas com Deficiência (ONU, 2006) ratificada pelo Brasil com força de Emenda Constitucional (Decretos no 186/2008 e no 6.949/2009).

$\mathrm{Na}$ tentativa de analisar a relação existente entre as políticas de educação especial desencadeadas no âmbito do governo federal e a oferta dessa modalidade de ensino no Brasil, apresentamos a trajetória de matrículas da educação especial no contexto da educação básica, no período de 2007 a $2013^{77}$.

$\mathrm{Na}$ Tabela 14, evidenciamos o total de matrículas da educação básica por etapas e modalidades, conforme disponibilizado em sinopses estatísticas divulgadas pelo Instituto Nacional de Estudos e Pesquisas Educacionais Anísio Teixeira (Inep) sobre o Censo Escolar, partindo do pressuposto de que tais informações são relevantes na elaboração de políticas públicas, em especial as de financiamento, destinadas à educação especial.

Tabela 14 - Matrículas da educação básica por etapas e modalidades - Brasil 2007-2013

\begin{tabular}{|c|c|c|c|c|c|c|c|}
\hline $\begin{array}{c}\text { ETAPAS E } \\
\text { MODALIDADES }\end{array}$ & 2007 & 2008 & 2009 & 2010 & 2011 & 2012 & 2013 \\
\hline EducaçãoInfantil & 6.509 .868 & 6.719 .261 & 6.762 .631 & 6.756 .698 & 6.980 .052 & 7.295 .512 & 7.590 .600 \\
\hline Ensino Fundamental & 32.122 .273 & 32.086 .700 & 31.705 .528 & 31.005 .341 & 30.358 .640 & 29.702 .498 & 29.069 .281 \\
\hline EnsinoMédio & 8.369 .369 & 8.366 .100 & 8.337 .160 & 8.357 .675 & 8.400 .689 & 8.376 .852 & 8.312 .815 \\
\hline EJA & 4.985 .338 & 4.945 .424 & 4.661 .332 & 4.287 .234 & 4.046.169 & 3.906 .877 & 3.772 .670 \\
\hline Educação Especial* & 348.470 & 319.924 & 252.687 & 218.271 & 193.882 & 199.656 & 194.421 \\
\hline EducaçãoProfissional & 693.610 & 795.459 & 861.114 & 924.670 & 993.187 & 1.063 .655 & 1.102 .661 \\
\hline TOTAL & 53.028 .928 & 53.232 .868 & 52.580 .452 & 51.549 .889 & 50.972 .619 & 50.545 .050 & 50.042 .448 \\
\hline
\end{tabular}

77 Cabe ressaltar que apresentamos os dados de matrículas de 2007 a 2013, no intuito de garantir ao leitor uma trajetória histórica das matrículas da educação básica, em especial, da educação especial no Brasil, embora, o nosso estudo compreenda os anos de 2008, 2009 e 2010. 
Com base nos dados da Tabela 14, constatamos que, no período de 2007 a 2013, o total de matrículas da educação básica sofreu um decréscimo de aproximadamente $5,7 \%$, ao contrário do que se esperava com a implantação do Fundeb, ou seja, um incremento no número de matriculas, considerando a inclusão de todas as etapas e modalidades e a nova versão de mecanismo da complementação da União no Fundo. De acordo com Sandro Coelho Costa (2014), Isabelle Fiorelli Silva (2014) e Bassi (2014), a redução no total de matrículas da educação básica pode ser explicada pela queda na demanda da população na faixa etária de escolarização obrigatória e pela queda no total de matrículas no ensino fundamental que durante o período de 1996 a 2006 (Fundef) foi o foco das políticas educacionais.

Vale destacar que, mesmo com esse decréscimo, a educação infantil e a educação profissional tiveram um crescimento no seu número de matrículas de $17 \%$ e 59\%, respectivamente de 2007 a 2013. Em contraposição, o ensino fundamental, a EJA e o ensino médio apresentaram redução no número de matrículas, de aproximadamente 10\%, 24\% e 0,7\% respectivamente de 2007 a 2013.

No que se refere à trajetória de matrículas da educação especial em classes especiais e escolas exclusivamente especializadas (tanto públicas quanto privadas), disposta na Tabela 14, evidenciamos um decréscimo de 44\% no período 2007 a 2013, de acordo com o Censo Escolar.

Contudo, se considerarmos o total de matrículas da educação especial no Brasil, abrangendo as matrículas das classes especiais, escolas especializadas e alunos incluídos nas classes comuns, observaremos uma evolução crescente no número de matrículas da educação especial no Brasil, entre 2007 e 2013, como podemos observar no Gráfico 1. 
Gráfico 1 - Matrículas da educação especial - Brasil 2007-2013

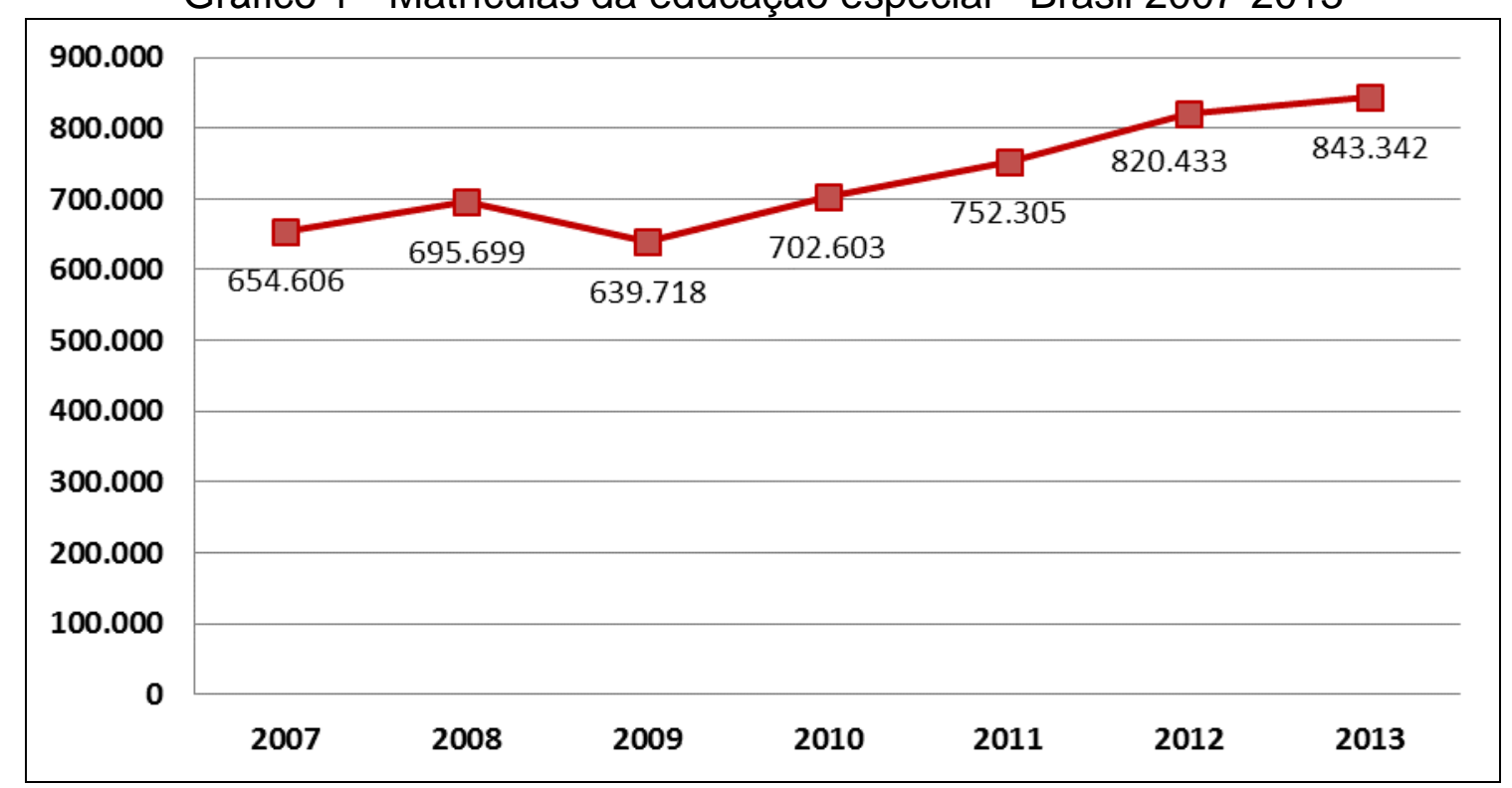

Fonte: Inep/Sinopses Estatísticas 2007 a 2013. Elaboração própria.

Desse modo, evidenciamos que, no período de 2007 a 2013, o total de matrículas da educação especial teve um crescimento de aproximadamente $29 \%$. Em relação ao total de matrículas da educação básica (Tabela 14), o total de matrículas da educação especial apresentou aumento em todos os anos. Assim, em 2007, as matrículas da população da educação especial correspondiam a 1,23\% do total de matrículas da educação básica, e, em 2013, representavam 1,69\% do total.

Nesse percurso, a composição do atendimento da população de educação no Brasil, em escolas exclusivamente especializadas e classes especiais e em classes comuns, apresentou significativas alterações, como podemos observar no Gráfico 2. 
Gráfico 2 - Matrículas da educação especial segundo a modalidade de atendimento - Brasil 2007-2013

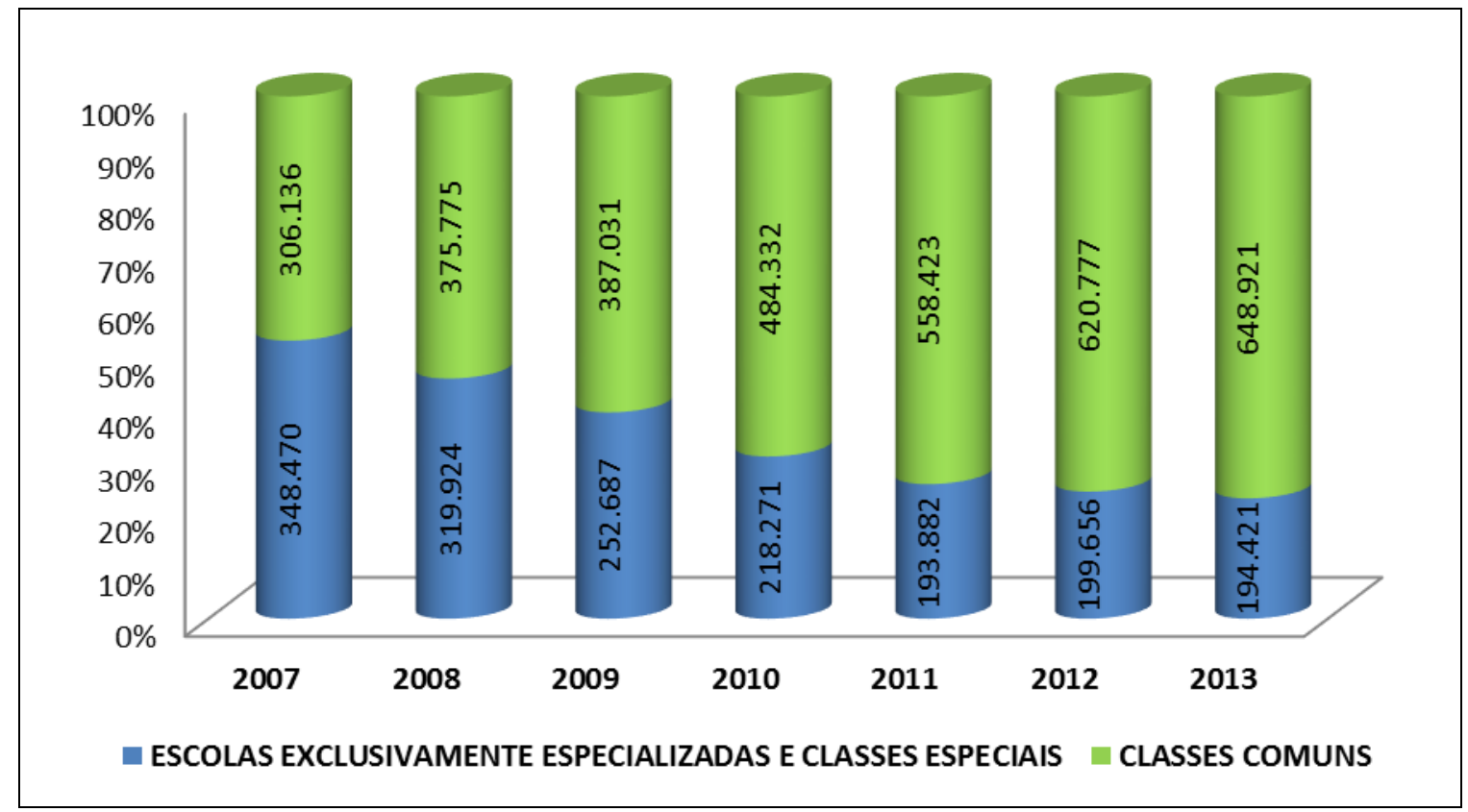

Fonte: Inep/Sinopses Estatísticas 2007 a 2013. Elaboração própria.

A distribuição das matrículas de educação especial segundo a modalidade de atendimento evidencia um aumento expressivo de $112 \%$ nas classes comuns no período analisado, de 306.136 mil matriculas em 2007 para 648.921 mil em 2013. Em contraposição, nas escolas exclusivamente especializadas e classes especiais, a trajetória foi decrescente de 348.470 mil matrículas em 2007 para 194.421 mil em 2013. A exceção é registrada em 2012 (em relação a 2011), em que observamos um aumento de $3 \%$, sem que fossem encontradas justificativas para tal nas fontes consultadas para esta pesquisa.

Assim, o percentual crescente de matrículas de 2007 a 2013 nas classes comuns no ensino regular acompanha a redução equivalente no ensino especial (escolas exclusivamente especializadas e classes especiais), em 44\%, mostrando uma migração de matrículas de uma modalidade de atendimento para a outra. Isso demonstra que as políticas de educação especial, visando assegurar a inclusão escolar de alunos com deficiência, TGD e altas habilidades/superdotação, desenvolvidas pelo governo federal, têm repercutido na incorporação das matrículas dessa modalidade de ensino nos sistemas educacionais brasileiros. 
Esse resultado apareceu também em estudos realizados em anos anteriores com base nos dados do Censo Escolar, conforme Viegas (2014) e Bassi (2012). Essa informação é ratificada quando observamos que esse crescimento no total de matrículas da educação especial no Brasil se deu, principalmente, na rede pública de ensino, como podemos visualizar no Gráfico 3.

Gráfico 3 - Matrículas da educação especial nas instituições públicas e privadas Brasil 2007-2013

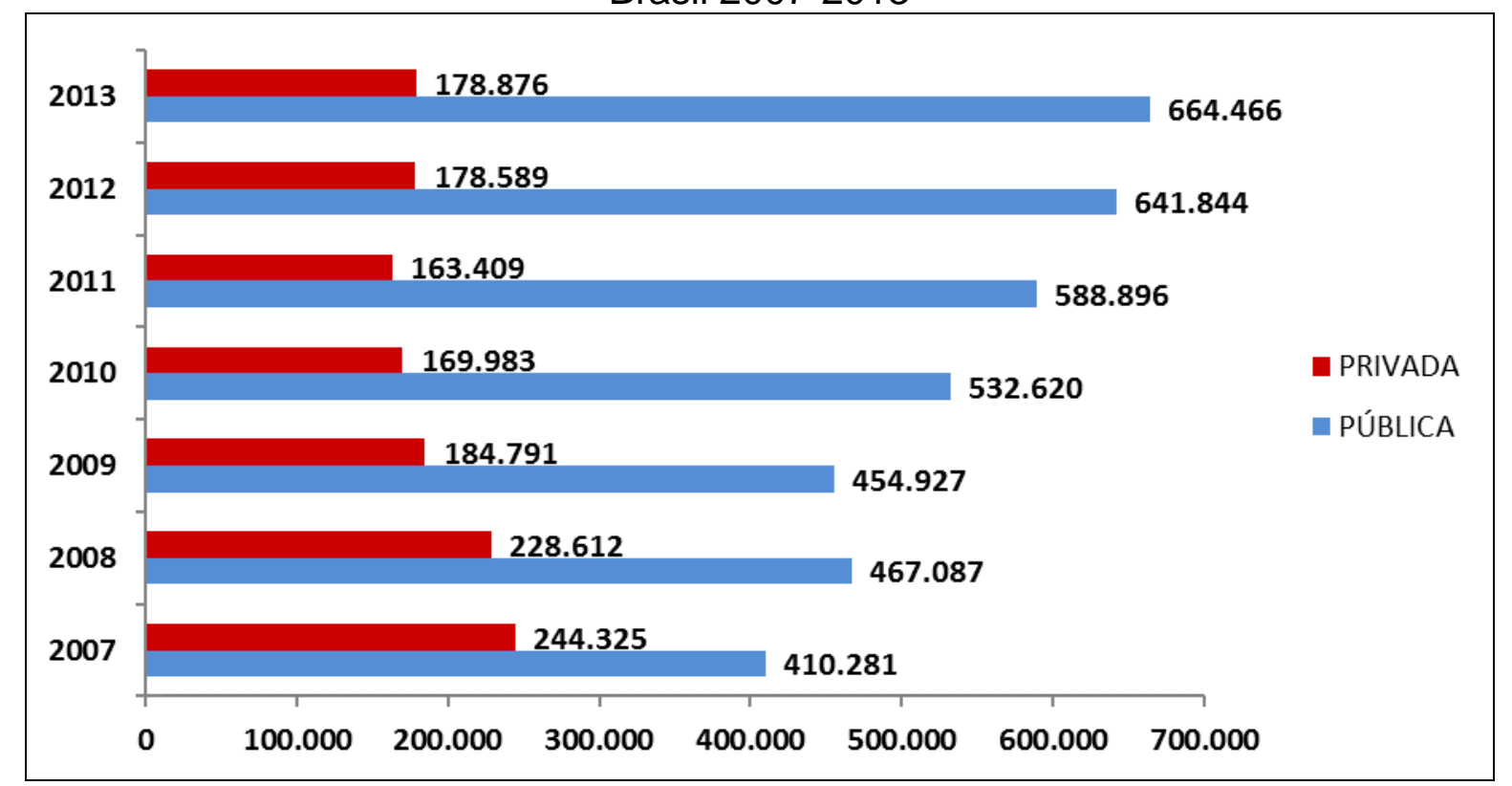

Fonte: Inep/Censo Escolar 2007 a 2013. Elaboração Própria.

Desse modo, se, em 2007, tínhamos 37\% de matrículas da educação especial na rede privada de ensino, em 2013 essa porcentagem caiu para 21\%. Em contraposição, a porcentagem na rede pública de ensino, em 2007 , era de $63 \%$ e em 2013 esse percentual alcançou 79\%, um crescimento de 62\%. Esse aumento na rede pública de ensino se deu de forma preponderante nas classes comuns do ensino regular como podemos visualizar no Gráfico 4. 
Gráfico 4 - Matrículas da educação especial na rede pública de ensino - Brasil 2007-2013

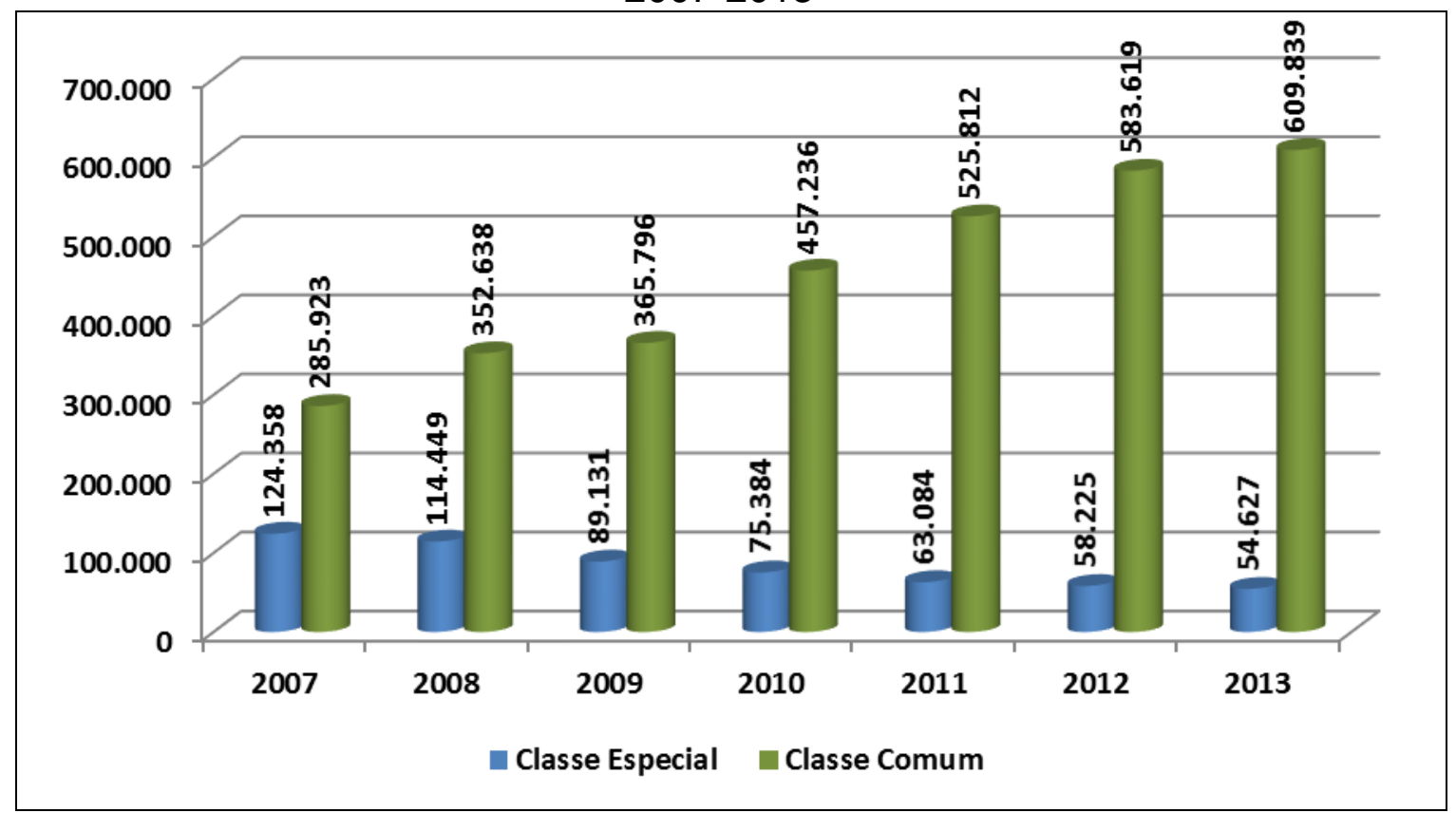

Fonte: Inep/Censo Escolar 2007 a 2013. Elaboração Própria.

Os dados revelaram que, no período analisado, o número de alunos nas classes especiais públicas apresentou uma redução de 56\%. Em contraposição, há um crescimento de $113 \%$ nas classes comuns, impulsionado certamente pelas políticas e ações voltadas ao atendimento educacional especializado no contexto do ensino regular, como a PNEE-El/2008, a Resolução no4/2009, o Programa de Salas de recursos Multifuncionais, que apontam o encaminhamento de matrículas da população da educação especial para a rede regular de ensino e a oferta do atendimento educacional especializado como complementar ou suplementar, portanto, não substitutivo as classes comuns. De acordo com o resumo técnico Educacenso de 2012, esses dados resultam da "efetivação da educação inclusiva e do empenho das redes de ensino em envidar esforços para organizar uma política pública universal e acessível às pessoas com deficiência" (BRASIL, 2013e).

A distribuição do total de matrículas de educação especial por Dependência Administrativa, disposta no Gráfico 5, nos mostra o ente federado que tem assumido preponderantemente a oferta dessa modalidade no Brasil, qual seja, a esfera municipal. 
Gráfico 5- Matrículas da educação especial por Dependência Administrativa Brasil 2007-2013

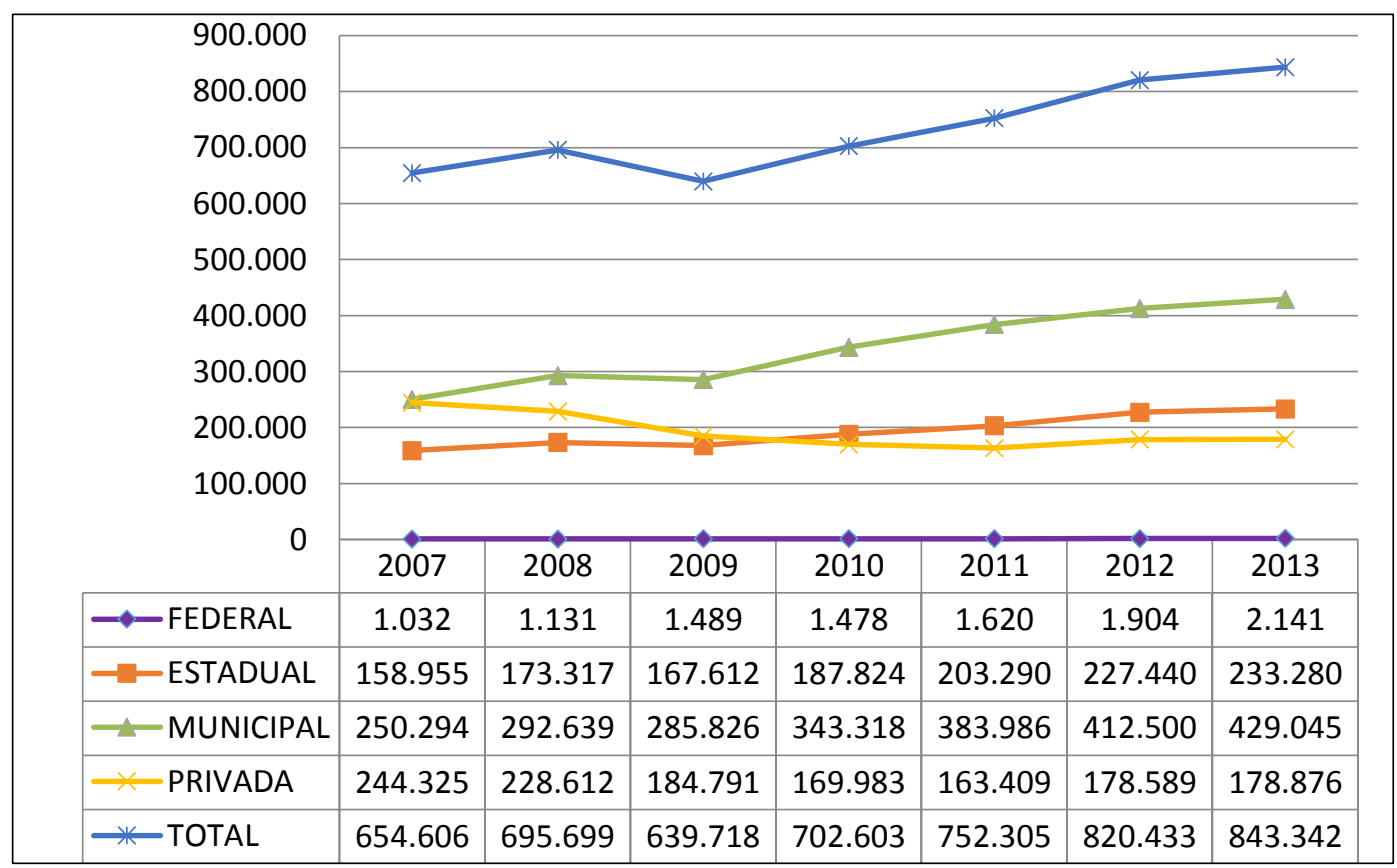

Fonte: Inep/Censo Escolar 2007 a 2013. Elaboração Própria.

Com base nos dados, notamos que a repartição de matrículas da educação especial, no período analisado, demonstrou a predominância da oferta municipal e a tendência crescente ao longo do período (de 38\% em 2007, 42\% em 2008, 45\% em 2009, 49\% em 2010, 51\% em 2011, 50\% em 2012 e de 51\% em 2013). Os dados corroboram o estudo de Prieto (2001), que retratava o maior percentual de atendimentos educacionais do público da educação especial na esfera municipal, no período e 1988 a 1998. Cumpre ressaltar a trajetória ascendente da oferta da educação especial na esfera federal (ainda tímida) e estadual (exceto em 2009) no Brasil, principalmente nos sistemas regulares de ensino.

O Gráfico 6 apresenta o total de matrículas da educação especial por etapas e modalidades da educação básica. 
Gráfico 6- Matrículas da educação especial por etapas e modalidades de ensino - Brasil 2007-2012 ${ }^{78}$

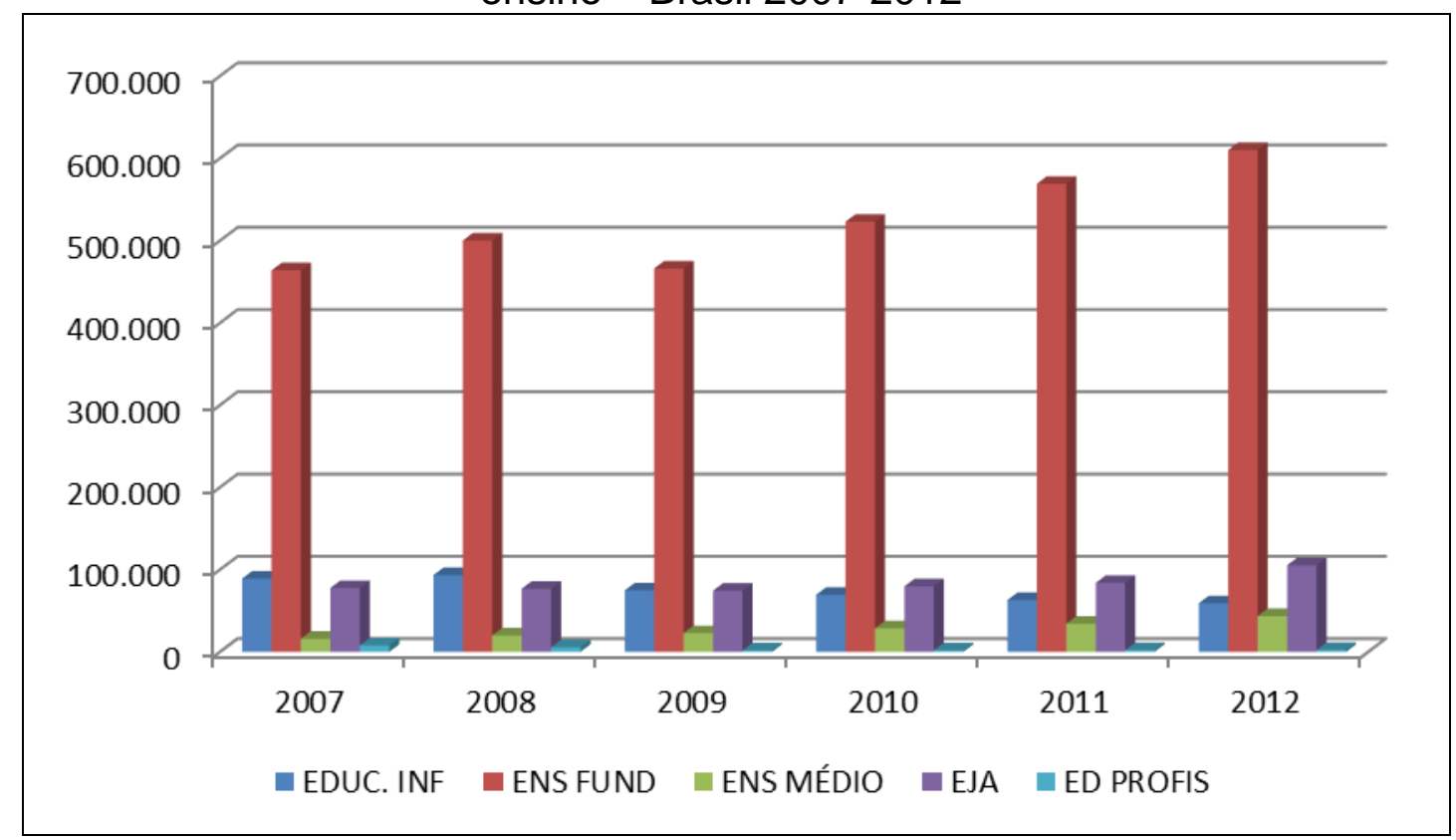

Fonte: Inep/Censo Escolar 2007 a 2012. Elaboração Própria.

Com base nas informações do Gráfico 6, observamos que o maior número de matrículas de educação especial no Brasil estava registrado no ensino fundamental. Segundo Bassi (2012), a obrigatoriedade estabelecida pela CF/1988, ratificada pela LDB/1996 e pelo financiamento do Fundef, justificam essa posição destacada dessa etapa de ensino. Nessa direção, Aline Dazzi Tezza Loureiro e Katia Regina Morena Caiado (2013) também observaram, em seu estudo, uma grande concentração de matrículas de alunos com deficiência na etapa de ensino fundamental, tanto nas instituições exclusivamente especializadas como na classe comum. As autoras salientam que, "em contrapartida, há uma vasta evasão na etapa de ensino infantil, cuja importância é negligenciada, e nas etapas posteriores, evidenciando que estes não conseguem avançar na etapa considerada obrigatória" (LOUREIRO; CAIADO, 2013, p. 54). Assim, o acesso às outras etapas e modalidades de ensino ainda constituem um desafio para os sistemas educacionais brasileiros.

Diante desse cenário, concordamos com Garcia e Michels (2011, p. 116) quando afirmam que há um movimento claro de intervenção estatal na política educacional no que se refere à educação do público da educação especial, por meio

\footnotetext{
${ }^{78}$ Cumpre destacar que não tivemos como acessar os dados do ano de 2013, referentes a matrículas da educação especial, por etapas e modalidades de ensino, no Brasil, por isso as informações se restringem ao ano de 2012.
} 
"[...] da presença do Estado na criação de equipamentos públicos de educação especial", nas redes de ensino estaduais e municipais, embora as diretrizes da PNEE-El/08, a Resolução №4/2009 e o Decreto oㅜ 7.611/2011 assegurem que o atendimento educacional especializado pode ser realizado pelas instituições privadas sem fins lucrativos.

Nessa perspectiva, o financiamento da educação especial foi resultado, ao longo do tempo, da configuração do Estado na sociedade brasileira para a oferta da educação obrigatória e gratuita a todos os cidadãos, seja por sua ausência, no que tange a políticas públicas voltadas à garantia desse direito a população com deficiência, TGD e altas habilidades/superdotação, seja por sua presença, por meio de recursos públicos direcionados às instituições privadas e/ou aos sistemas públicos de ensino. Além disso, articula-se à constituição do federalismo brasileiro, à vinculação constitucional de recursos voltados à educação, ao regime de colaboração, a partir da definição de responsabilidades de cada ente federado, e aos processos de (des)centralização das políticas públicas.

Portanto, as políticas de financiamento da educação especial são resultantes do contexto histórico, social e político em que são produzidas, expressando as correlações de forças presentes no âmbito do Estado em torno no fundo público, ou seja, da disputa entre classes e grupos sociais no interior da esfera pública pelo orçamento do Estado (OLIVEIRA, F.,1998), na tentativa de garantir políticas direcionadas à manutenção e a reprodução dos interesses do capital, representado pelo financiamento público às instituições privadas de educação especial, e/ou a ampliação do aporte de recursos para a concretização dos direitos sociais, como a educação, nos sistemas públicos de ensino à população da educação especial. 


\section{PERCURSOS METODOLÓGICOS}

No Brasil, nos últimos anos, percebemos inúmeras mudanças no que tange às políticas de inclusão escolar de alunos com deficiência, TGD e altas habilidades/superdotação, em diferentes municípios, impulsionadas pelas políticas de educação para todos, trazendo subjacentes contradições e ambiguidades acerca desse processo. Analisar as ações do Poder Público no provimento de recursos financeiros à educação especial na gestão do município de Vitória, no contexto de financiamento da educação básica, constituiu o nosso grande desafio.

Para o desenvolvimento do nosso trabalho, propusemos a pesquisa documental, na tentativa de compreender e analisar como se caracterizava a gestão da educação especial e de seus recursos no município de Vitória, capital do Estado do Espírito Santo. A pesquisa documental, segundo Antônio Carlos Gil (1991), valese de materiais que não receberam ainda um tratamento analítico, ou que ainda podem ser reelaborados de acordo com os objetos da pesquisa. Desse modo, os documentos trouxeram informações, indicações e esclarecimentos que nos auxiliaram na compreensão de determinadas questões envolvidas no processo de financiamento da educação especial.

Para André Cellard (2008, p. 295), por possibilitar alguns tipos de reconstrução, o documento escrito constitui "[...] uma fonte extremamente preciosa para o pesquisador", na medida em que permite "acrescentar a dimensão do tempo à compreensão do social". Nessa perspectiva, as fontes documentais nos auxiliaram na análise e na reflexão acerca das políticas e dos investimentos num determinado contexto histórico.

Em linha semelhante, Menga Lüdke e Marli Elisa Dalmazo Afonso de André (1986, p. 39) afirmam que a produção de dados via documentos apresenta vantagens no desenvolvimento da pesquisa, uma vez que

[...] os documentos constituem também uma fonte poderosa de onde podem ser retiradas evidências que fundamentam afirmações e declarações do pesquisador. Representam ainda uma fonte "natural" de informação. Não são apenas uma fonte de informação 
contextualizada, mas surgem num determinado contexto e fornecem informações sobre esse mesmo contexto.

Nesse sentido, o uso de fontes documentais configurou-se como elemento fundamental para a pesquisa qualitativa, pois às vezes são exatamente os documentos "[...] as únicas fontes que registram os princípios, objetivos, metas da política em análise, e que podem explicitar a base conceitual dos planos e programas e definir as fronteiras de atuação do poder público" (PRIETO, 2006, p. 52). É preciso ressaltar que os documentos produzidos num determinado contexto histórico-social apresentam concepções políticas e ideológicas que norteiam as ações educacionais, destinadas aos alunos com deficiência, TGD e altas habilidades/superdotação.

Os documentos oficiais, para Eneida Oto Shiroma, Rosilene Fátima Campos e Rosalba Maria Cardoso Garcia (2005, p. 429), "[...] são relevantes tanto porque fornecem pistas sobre como as instituições explicam a realidade e buscam legitimar suas atividades, quanto pelos mecanismos utilizados para sua publicização [...]". Entretanto, as recomendações presentes nos documentos das políticas educacionais não são prontamente assimiláveis; sua implementação exige que sejam traduzidas e interpretadas de acordo com o contexto social e político em que foram produzidos e segundo dada concepção teórica, na medida em que os documentos são resultantes de processos que envolvem contradições e negociações políticas que marcaram a sua produção.

Nesse sentido, Shiroma, Campos e Garcia (2005, p. 432) ressaltam que as "[...] intenções políticas podem conter ambiguidades, contradições e omissões que fornecem oportunidades particulares para serem debatidas no processo de sua implementação". Assim, as orientações políticas dos documentos oficiais não são simplesmente apropriadas e implementadas, mas, no contexto da prática, estão sujeitas à interpretação e ressignificação. Assim, a pesquisa documental objetiva apreender as múltiplas dimensões e implicações do objeto pesquisado, de forma a abranger uma visão ampla das realidades em foco, sem, contudo, termos a pretensão de abarcar todos os sentidos e imbricações apresentadas por esse objeto.

Partimos da compreensão de que os documentos públicos constituem possíveis fontes de onde se podem extrair dados para investigar as políticas 
educacionais. Assim, verificamos, inicialmente, os dados disponíveis nos meios eletrônicos e, posteriormente, analisamos os documentos produzidos pelos órgãos públicos: balanços da execução financeira dos municípios, relatórios anuais de atividades, além de documentos oficiais como resoluções, portarias e decretos referentes à educação especial e ao financiamento da educação do sistema de ensino municipal. De acordo com Eliane Marta Teixeira Lopes e Ana Maria de Oliveira Galvão (2001, p. 93),

[...] um trabalho é mais rico e mais confiável quanto maior for o número e tipos de fontes a que se recorreu e com quanto maior rigor tenha sido exercido o trabalho de confronto entre elas. Quanto mais se dispuser de uma pluralidade de documentos, mais possibilidades se têm de melhor explorá-los, compreendê-los e produzir conhecimento sobre o tema de pesquisa.

Entretanto, concordamos com Olinda Evangelista (s. d., p. 6), quando afirma que, na pesquisa documental, não podemos dar conta de todas as fontes existentes, ou seja, que é impossível ter acesso a todos os documentos que se relacionam ao tema; porém, a tarefa do pesquisador consiste em "envidar todos os esforços para encontrar fontes significativas", de modo a encontrar os documentos e conhecer o contexto estudado.

Cellard (2008) destaca que, no desenvolvimento da pesquisa documental, é necessário atentar para o contexto político, econômico, social e cultural no qual foi produzido o documento e estava mergulhado seu autor e para que público foi destinado. Tal conhecimento possibilita apreender as concepções de seus autores, a sua organização social e histórica e auxilia na análise e interpretação dos dados. Desse modo, faz-se mister verificar a autenticidade, a confiabilidade e a natureza do texto, ou seja, o contexto particular de sua produção. Nesse sentido, tentamos, no decorrer do texto, caracterizar o referido município, no período investigado, a partir das leis, resoluções e relatórios disponíveis no âmbito do município.

Partimos da premissa de que o trabalho com os documentos pressupõe, segundo Evangelista (s. d., p. 5), "[...] considerá-los resultado de práticas sociais e expressão da consciência humana possível em um dado momento histórico", portanto, como produto de um determinado processo histórico que envolve conflitos, interesses, contradições e projetos políticos. Dessa maneira, “importará 
compreender sua posição em relação à sua história, à história de seu tema e à história da produção de sua empiria" (EVANGELISTA, s. d., p. 6), no intuito de compreender os significados históricos dos materiais analisados. Nesse percurso, cabe ao pesquisador, conforme Evangelista (s. d., p. 7),

[...] encontrar o sentido dos documentos e com eles construir conhecimentos que permitam não apenas o entendimento da fonte, mas dos projetos históricos ali presentes e das perspectivas que não raro obliteradas no teto - estão em litígio e em disputa pelo conceito, pelo que define o mundo, pelo que constitui a história.

Em linha semelhante, Augusto Nibaldo Silva Triviños (1987, p. 102) ressalta a importância de o pesquisador, no processo de análise dos documentos, não se deter exclusivamente no conteúdo manifesto, mas procurar desvendar o conteúdo latente que os documentos possuem, no intuito de "[...] descobrir ideologias, tendências das características dos fenômenos sociais que se analisam [...] e suas vinculações com variáveis complexas da vida social, com os modos de produção e as classes sociais e suas formações históricas em determinadas sociedades". Faz-se necessário ressaltar que a opção por analisar o financiamento da educação especial no âmbito municipal se justifica pelo fato de que a maioria das matrículas de educação especial se encontra no ensino fundamental e na educação infantil (MELETTI; BUENO, 2011), etapas de ensino que estão sob a responsabilidade prioritária dos municípios, de acordo com a LDB/1996. Cabe acrescentar o número reduzido de estudos relacionados a essa temática (GIL, J. et al., 2010), considerando que o financiamento constitui a base de sustentação para o desenvolvimento de toda política pública.

A escolha do município de Vitória para a realização da pesquisa levou em consideração alguns fatores: 1) a oferta da educação especial era realizada prioritariamente por meio de serviços públicos municipais, considerando que o município vinha, desde a década de 1990, desenvolvendo ações voltadas à inclusão de alunos com deficiência, TGD e altas habilidades/superdotação nas unidades escolares, o que repercutiu no crescimento de matrículas e na ampliação de atendimentos nesse segmento da educação municipal; 2) o município era de grande porte, com mais de 327.000 mil habitantes, segundo a categorização do IBGE 
quanto à sua densidade populacional ${ }^{79}$; 3) apresentava Índice de Desenvolvimento Humano Municipal (IDHM) de 0, $845 \mathrm{em}$ 2010, situado na faixa de desenvolvimento humano muito alto (IDHM entre 0,8 e 1), sendo a educação a dimensão que mais cresceu em termos absolutos, no período de 2000 a 2010, o que repercutiu no aumento dos percentuais de proporção de crianças na escola que superaram as taxas do estado do Espírito Santo e do Brasil $(97,91 \%$ de 5 a 6 anos na escola, $88,94 \%$ de 11 a 13 anos nos anos finais do ensino fundamental ou com fundamental completo e $74,65 \%$ de 15 a 17 anos com o fundamental completo) (PNUD, 2013); 4) acrescenta-se, ainda, a proximidade e a facilidade de acesso para a pesquisadora, visto que ela reside e trabalha no estado do Espírito Santo, favorecendo o seu deslocamento e a coleta de dados. Esses fatores foram fundamentais para a escolha do município para o desenvolvimento do estudo.

O período histórico escolhido foi de 2008 a 2010. A escolha por partir do ano de 2008 considera as mudanças ocorridas com o novo padrão de financiamento da educação adotado com a implantação do Fundeb, iniciada em 2007, que passou a abranger todas as etapas e modalidades de ensino; as alterações na legislação da educação especial, com a promulgação da PNEE-El/2008, da Resolução ํㅜ 4, de 2 de outubro de 2009 (BRASIL, 2009a) e do Decreto oㅜ 7.611/2011, que acrescenta dispositivo ao Decreto no $6.253 / 2007$, que dispõe sobre o Fundeb; e a instituição de programas vinculados a recursos para garantir 0 atendimento educacional especializado nas classes comuns. Já a delimitação 2010, como o último ano, se deu porque, até o momento de finalização da coleta dos dados, eram as informações mais atuais disponíveis nos balanços do município de Vitória. Nessa perspectiva, tentamos descrever os movimentos do estudo, que compreenderam as etapas descritas a seguir.

\subsection{PRIMEIRO MOMENTO: CONSTITUINDO O CAMPO DE PESQUISA}

Nesse primeiro momento, enviamos uma carta à Secretaria Municipal de Educação de Vitória (Seme-Vitória) (ANEXO A) com a intenção de mostrar o

79 Segundo o IBGE, município de grande porte possui entre 100.001 até 900.000 mil habitantes (BRASIL, 2010a). 
interesse de investigação no município, bem como os objetivos do estudo para posterior aprovação, autorização e realização da pesquisa. Esse processo se iniciou no ano de 2011, no município, pois tínhamos a preocupação de que as eleições municipais, previstas para o final de 2012, comprometessem o processo de coleta de dados, dada a possibilidade de mudança na gestão do município.

Assim, para compreendermos como se caracterizava o financiamento da educação especial no município, o primeiro contato se deu com a equipe da educação especial. $\mathrm{Na}$ conversa inicial, a temática de financiamento causou estranhamento, pois até então ninguém havia procurado conhecer e investigar as fontes e recursos destinados à educação especial, bem como os seus gastos. A coordenadora da equipe no município de Vitória, na ocasião, disse-me que desconhecia como se dava esse processo, na medida em que esses dados não ficavam sob sua responsabilidade, tampouco ela participava da definição do planejamento orçamentário. Ressaltou ainda que apenas tinha a informação de que a secretaria municipal de educação, ao qual estava vinculada, recebia repasses do governo federal via Fundeb, recursos vinculados a alguns programas específicos da educação especial (como o programa Escola Acessível) e da própria prefeitura, para ações voltadas a essa área. Desse modo, foi necessário estabelecer contato com outros setores da Secretaria de Educação, responsáveis pela sistematização dos dados referentes aos balanços orçamentários da educação.

\subsection{SEGUNDO MOMENTO: EM BUSCA DE INDÍCIOS}

Se o documento existe fora do pesquisador, para que possa extrair dele dados da realidade, é preciso que assuma uma posição ativa na produção de conhecimento: localiza, seleciona, lê, relê, sistematiza, analisa as evidências que apresenta. (EVANGELISTA, s. d.,

Para contextualizar o nosso campo de estudo, fez-se necessário, nesse momento, a busca pelos documentos, no âmbito da Seme-Vitória, no que diz respeito à legislação educacional, aos serviços oferecidos de educação especial, a organização do sistema de ensino e dos balanços anuais. Para isso, foi necessário 
adentrar os diferentes setores da Seme-Vitória, como o de educação especial, o setor de recursos humanos e a secretaria de planejamento, na tentativa de constituir um corpus de dados que nos ajudasse a descrever a educação nesse município, assim como a identificar os documentos referentes à educação especial.

A coleta de dados em alguns setores da secretaria foi um processo moroso e difícil, marcado por idas e vindas. O principal argumento para não se obterem os dados em valores da educação especial era que os recursos e os gastos da educação especial estavam agregados às outras etapas e modalidades de ensino, sendo, assim, impossível chegar aos seus valores inteiros. Além disso, alguns profissionais e/ou setores mostraram certo receio em apresentar e/ou disponibilizar as planilhas dos balanços da secretaria e em expor à pesquisa a realidade dos gastos com a educação.

O início da pesquisa, na Prefeitura Municipal de Vitória (PMV), foi em 31 outubro de 2011, quando a coordenadora da Coordenação de Formação, Acompanhamento à Educação Especial ${ }^{80}$ (Cfaee) entrou em contato com a pesquisadora para informar sobre a autorização da pesquisa. Posteriormente, foi agendada uma reunião com a equipe (22 de novembro de 2011), para apresentação dos objetivos do estudo, e, em seguida, foi necessário também conversar com a subsecretária de educação (14 de fevereiro de 2012) já que a pesquisa envolvia outros setores. Ela nos encaminhou ao setor de Gerência Orçamentária e Financeira da Seme-Vitória para ter acesso aos balanços da secretaria. Porém, após nos reunirmos com o coordenador do setor (4 de maio de 2012), ele informou que não seria possível ter acesso aos dados brutos do balanço da secretaria e disse que iria realizar um levantamento dos gastos referentes à educação especial. Entretanto, o relatório entregue à pesquisadora (10 de maio de 2012) foi sintético e superficial, sem indicações de fonte e, portanto, inviável para se constituir como material de pesquisa. Como não foi possível ter acesso aos balanços pela via da Gerência Orçamentária e Financeira, recorremos à Secretaria Municipal de Fazenda (Semfa), que disponibilizou, com rapidez, os Demonstrativos da natureza e despesa - Anexo 2; do Programa de Trabalho - Anexo 6; das funções, subfunções e Programas por

80 O Cfaee desenvolve ações relacionadas às especificidades do setor de educação especial no âmbito da educação infantil, do ensino fundamental e da educação de jovens e adultos, além do levantamento de demandas e do encaminhamento de temáticas específicas da área para formação continuada. 
categorias econômicas - Anexo 7 da Seme-Vitória; Relatórios Resumidos de Execução Orçamentária (RREO) - Demonstrativo das receitas e despesas com manutenção e desenvolvimento do ensino - Anexo X (Lei 9.394/1996, art. 72) e Demonstrativo da execução das despesas por função e subfunção - Anexo II (LRF, art. 52, alínea c), onde foi possível visualizar as receitas e despesas destinadas à educação no município de Vitória.

$\mathrm{Na}$ busca de outra fonte de dados que nos auxiliasse no desenvolvimento da pesquisa, recorremos ao Tribunal de Contas do Estado do Espírito Santo (TC-ES). Assim, na tentativa de obter autorização para consulta, protocolamos a solicitação em 6 de novembro de 2013 e no dia 20 de novembro de 2013, recebemos a resposta com o deferimento do processo para termos acesso aos relatórios de prestação de contas do município de Vitória. A partir da leitura dos documentos, observamos que os demonstrativos de despesas eram os mesmos disponibilizados pela Semfa, porém com os valores empenhados.

Outra fonte que nos ajudou a compreender o processo de financiamento da educação e ter acesso aos dados dos demonstrativos de despesas do município foram os relatórios do Conselho Municipal de Educação de Vitória (Comev), responsável por participar da elaboração, do acompanhamento e da avaliação de planos, programas e projetos educacionais, bem como por acompanhar e avaliar a prestação de contas no que se refere à aplicação de recursos do Fundeb. Assim, tivemos acesso aos relatórios do Comev dos anos 2008, 2009 e 2010.

De posse desse material, iniciamos a árdua tarefa de nos apropriarmos da linguagem técnica e contábil para ser possível mapear e compreender as receitas e despesas relacionadas à educação no âmbito do município. O que parecia tarefa simples tornou-se tarefa extremamente complexa, pois exigiu pesquisa e conhecimento prévio de terminologias e conceitos da área da administração pública.

Nesse processo, também consultamos documentos oficiais que traziam informações totais ou parciais das receitas e despesas realizadas pelos municípios. $\mathrm{Na}$ legislação brasileira, encontramos normas gerais que orientam a elaboração e o controle dos orçamentos e balanços da União, do Distrito Federal, dos estados e dos municípios, na tentativa de assegurar a transparência, o controle e a fiscalização dos recursos públicos. A Lei 4.320/1964 assim estabelece: 
Art. 111. O Conselho Técnico de Economia e Finanças do Ministério da Fazenda, além de outras atribuições, para fins estatísticos, de interesse nacional, organizará e publicará o balanço consolidado das contas da União, Estados, Municípios e Distrito Federal, suas autarquias e outras entidades, bem como um quadro estruturalmente idêntico, baseado em dados orçamentários. [...]

Art. 112. Para cumprimento do disposto no artigo precedente, a União, os Estados, os Municípios e o Distrito Federal remeterão ao mencionado órgão, até 30 de abril, os orçamentos do exercício, e até 30 de junho, os balanços do exercício anterior. [...]. (BRASIL, 1964).

Na Lei Complementar nำ101/2000, no capítulo IX, "Da transparência, controle e fiscalização", encontramos os mecanismos utilizados para garantir a transparência da gestão fiscal.

Art. 48 São instrumentos de transparência da gestão fiscal, aos quais será dada ampla divulgação, inclusive em meios eletrônicos de acesso público: os planos, orçamentos e leis de diretrizes orçamentárias; as prestações de contas e o respectivo parecer prévio; o Relatório Resumido da Execução Orçamentária e o Relatório de Gestão Fiscal; e as versões simplificadas desses documentos. [...]

Art. 49 As contas apresentadas pelo Chefe do poder executivo ficarão disponíveis durante todo o exercício, no respectivo poder Legislativo e no órgão Técnico responsável pela sua elaboração, para consulta e apreciação pelos cidadãos e instituições da sociedade. [...]

Art. 51 O Poder executivo da União promoverá, até o dia trinta de junho, a consolidação, nacional e por esfera de governo, das contas dos entes a Federação relativas ao exercício anterior, e a sua divulgação, inclusive por meio eletrônico de acesso público.

$\S 11^{\circ}$ Os Estados e os Municípios encaminharão suas contas ao Poder Executivo da União nos seguintes prazos:

I- Municípios, com cópia para o Poder Executivo do respectivo Estado, até trinta de abril;

II- Estados, até trinta e um de maio.

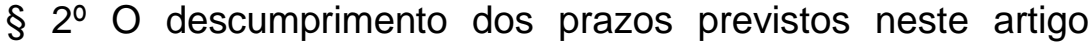
impedirá, até que a situação seja regularizada, que o ente da Federação receba transferências voluntárias e contrate operações de crédito, exceto as destinadas ao refinanciamento do principal atualizado da dívida imobiliária. (BRASIL, 2000).

Cabe ressaltar ainda o que prevê a Lei 12.527/2011:

Art. $8^{\circ}$ - É dever dos órgãos e entidades públicas promover, independentemente de requerimentos, a divulgação em local de fácil acesso, no âmbito de suas competências, de informações de interesse coletivo ou geral por eles produzidas ou custodiadas. 
$\S 1^{\circ} \mathrm{Na}$ divulgação das informações a que se refere o caput, deverão constar, no mínimo:

I - registro das competências e estrutura organizacional, endereços e telefones das respectivas unidades e horários de atendimento ao público;

II - registros de quaisquer repasses ou transferências de recursos financeiros;

III - registros das despesas;

IV- informações concernentes a procedimentos licitatórios, inclusive os respectivos editais e resultados, bem como a todos os contratos celebrados;

V- dados gerais para o acompanhamento de programas, ações, projetos e obras de órgãos e entidade; e

VI- resposta a perguntas mais frequentes da sociedade.

$\S 2^{\circ}$ Para cumprimento do disposto no caput, os órgãos e entidades públicas deverão utilizar todos os meios e instrumentos legítimos de que dispuserem, sendo obrigatória a divulgação em sítios oficiais da rede mundial de computadores (internet). [...].

Assim, a Secretaria do Tesouro Nacional (STN), criada em 10 de março de 1986 e vinculada ao Ministério da Fazenda, configura-se como órgão central dos sistemas de administração financeira e de contabilidade federal. E, por meio da integração dos sistemas de programação financeira, de execução orçamentária e de controle interno do Poder Executivo, gera informações gerenciais da União, dos estados, do Distrito Federal e dos municípios, para fins de transparência e controle da gestão fiscal. Contudo, como nos alerta Ana Paula Santiago Nascimento (2012, p. 32), a coleta de dados orçamentários e financeiros no Brasil deve ser feita com cautela, considerando que as informações são ainda incipientes e contraditórias:

\footnotetext{
A maioria dos dados disponíveis nos diferentes sites utiliza-se de metodologias distintas, agrega receitas e despesas sem especificações claras, nas quais não é possível descobrir quais os critérios utilizados para a contabilização e o que de fato está agregado, sendo que, por vezes, não possuem séries históricas ou são coletados diferentemente ano a ano, o que impossibilita tal análise, além de serem publicados e republicados para correções contábeis sem indicações de atualizações, entre outras coisas.
}

Nesse sentido, escolhemos com fonte de dados para as receitas municipais a STN, por meio do banco de dados Finbra, e o FNDE, recorrendo ao Sistema de Informações sobre Orçamentos Públicos em Educação (Siope). 
O Finbra constitui um banco de dados com informações da execução orçamentária (receitas e despesas por função e subfunção), a posição patrimonial (ativo e passivo) e o demonstrativo de variações patrimoniais, dados esses extraídos dos balanços consolidados, individualizados, dos municípios brasileiros, divulgados pela STN. Sua criação decorre das disposições dos arts. 111 e 112 da Lei no 4.320/1964 e do art. 51 da Lei Complementar nº. 101/2000, relacionadas com a obrigatoriedade da organização e publicação, até 30 de junho de cada ano, das contas consolidadas dos entes da federação, relativas ao ano anterior. A coleta de informações do Finbra era realizada pelo Sistema de Coleta de Dados Contábeis SISTN - da Caixa Econômica Federal. Assim, compete aos municípios ${ }^{81}$ preencher o formulário "Quadro dos Dados Contábeis Consolidados Municipais", previsto na Portaria STN no 683, de 6 de outubro de 2011 (BRASIL, 2011c), com os dados extraídos dos seus balanços, e encaminhá-los, sob a forma de papel, disquetes ou, preferencialmente, via internet, para a Caixa. Esta recebe os dados, consolida-os em arquivo eletrônico próprio e providencia o seu encaminhamento à STN, que, por sua vez, promove o tratamento dos dados recebidos com o propósito de cumprir suas atribuições legais e atender às suas demandas de informações. Na base de dados do Finbra, consultamos os anos de 2008, 2009 e 2010 e as informações disponíveis no "Quadro dos Dados Contábeis Consolidados municipais - Balanço Patrimonial Ativo", em 30 de março de 2014.

O Siope constitui um sistema eletrônico, operacionalizado pelo FNDE, instituído pela Portaria no 844, de 8 de julho de 2008 (BRASIL, 2008c), para coleta, processamento, disseminação e acesso público às informações referentes aos orçamentos da educação da União, dos estados, do Distrito Federal e dos municípios. Os poderes executivos de cada ente federado, de acordo com suas respectivas competências, eram responsáveis pela exatidão e fidedignidade das informações prestadas nesse sistema ${ }^{82}$. A partir de $1^{\circ}$ de janeiro de 2009, 0 preenchimento completo e atualizado do Siope pelos estados, pelo Distrito Federal e pelos municípios se tornou condição para a celebração de convênios e termos de cooperação com o MEC ou órgãos da administração direta a ele vinculados. Essa base de dados foi utilizada para a correção dos valores de receita apresentados pelo

\footnotetext{
81 No caso do município de Vitória, essa ação era realizada pela Semfa.

82 No município de Vitória quem realizava o preenchimento do formulário do Siope era o coordenador da Gerência Orçamentária e Financeira da Seme-Vitória.
} 
Finbra, no que tange aos valores de multas, juros de mora e dívida ativa, bem como aos valores de aplicação financeira do Fundeb e de transferências do FNDE, não apresentados no Finbra.

Cumpre destacar que os dados de receita obtidos no Finbra e no Siope foram comparados aos dados fornecidos pela Semfa, os quais também não apresentavam os valores de aplicação financeira do Fundeb e de transferências do FNDE. A constatação das discrepâncias nos valores das receitas e despesas do município, nas diferentes fontes, permite deduzir que a contabilização das receitas e despesas não segue a regra ou norma padronizada.

A fonte para os dados de despesa foi a Semfa do município de Vitória, responsável pela gestão financeira e tributária do município. Optamos por essa escolha, tendo em vista que a Semfa disponibilizou para pesquisa dados com valores empenhados e liquidados do Demonstrativo de Despesa da Secretaria de Educação, bem como o detalhamento das despesas (correntes e de capital), o que era fundamental para visualizar as despesas dirigidas à educação especial, uma vez que isso não foi possibilitado com as outras fontes ${ }^{83}$. Desse modo, utilizamos os valores de despesa liquidada ${ }^{84}$

Os dados sobre matrículas das etapas e modalidades da educação básica foram extraídas das páginas do Censo Escolar e Microdados do Censo Escolar, no site do Inep. As informações sobre os recursos financeiros no Fundeb foram extraídas do site do FNDE. E algumas informações foram complementadas pelos dados fornecidos pelo Sistema de Monitoramento, Execução e Controle (Simec), módulo público, desenvolvido pelo MEC. Esse sistema viabilizava informações sobre a gestão integrada de funções administrativas, como a programação orçamentária, a gestão de projetos e o planejamento de metas, desenvolvidos no âmbito desse Ministério, por regiões, estados, municípios, ações, programas e secretarias. Diante da existência de diferentes fontes de dados utilizados para análise, todas foram indicadas nos gráficos, nos quadros ou nas tabelas, no decorrer do texto.

83 Os dados de despesa do Finbra correspondiam aos valores empenhados, por isso foram desconsiderados. As informações disponíveis no Siope não apresentavam os dados pormenorizados da educação especial, por isso não foram utilizados, e seus valores eram distintos dos disponíveis do Finbra e da Semfa.

${ }^{84}$ Verificação do direito adquirido pelo credor de receber o pagamento (BRASIL, 1964). É o segundo estágio da execução de despesa, precedido do empenho e antecedido do pagamento. 
Cabe destacar as discrepâncias no número de matrículas do público da educação especial nas distintas fontes que ofereciam informações sobre a distribuição por tipo de deficiência, mesmo em fontes de informação oficiais (como o caso do Simec e dos Microdados) que têm como base o Censo Escolar. Essas diferenciações podem ser compreendidas a partir de alguns aspectos: o primeiro refere-se as mudanças nas categorias do Censo Escolar. O segundo se remete à observação encontrada no portal do Simec, em que se afirmava que "nesse indicador pessoas com mais de um tipo de deficiência, TGD e altas habilidades/superdotação é contado em duplicidade" (SIMEC, 2014). O terceiro aspecto se relaciona com a inserção ou não das matrículas do atendimento educacional especial, a partir de 2010, com a contabilização da dupla matrícula da educação especial no Fundeb. Assim, observamos que algumas fontes duplicaram o número de matrículas no seu banco de dados (como o microdados) e outras não (como o Simec e a Seme-Vitória); e o quarto se refere à data de coleta de dados e a quem informa esses dados ao Censo Escolar, bem como a quem sistematiza essas informações no âmbito das secretarias de educação.

Para organização dos dados, foi necessário, em primeiro lugar conhecer as informações disponíveis, entender a forma de prestação de contas do município, para, assim, reconhecer quais informações disponíveis estavam adequadas à pesquisa. Posteriormente, realizamos a conversão de dados para planilha do Excel, a organização em tabelas e gráficos, a atualização monetária pelo Índice Nacional de Preços ao Consumidor (INPC) do IBGE, de dezembro de 2014 e a discussão das análises.

\subsection{TERCEIRO MOMENTO: ORGANIZAÇÃO, SISTEMATIZAÇÃO E ANÁLISE DOS DADOS}

Para a organização, sistematização e análise dos dados, optamos pela análise de conteúdo, que, segundo Laurence Bardin (1995, p. 42), consiste em

[...] um conjunto de técnicas de análises das comunicações visando obter, por procedimentos sistemáticos e objetivos de descrição do conteúdo das mensagens, indicadores (quantitativos ou não) que 
permitam a inferência de conhecimentos relativos às condições de produção/recepção (variáveis inferidas) destas mensagens.

Nesse sentido, buscamos, a partir da análise dos conteúdos dos documentos, compreender os significantes e significados presentes nos textos. Assim, foram analisados os documentos que orientavam a política de educação especial no município.

Para Antônio Chizzotti (1995, p. 98), a análise de conteúdo constitui um método de tratamento e análise de informações, cujo objetivo é "[...] compreender criticamente o sentido das comunicações, seu conteúdo manifesto ou latente, as significações explícitas ou ocultas". Em linha semelhante, Maria Cecília de Souza Minayo $(2007$, p. 308$)$ afirma que

[...] a análise de conteúdo parte de uma leitura de primeiro plano das falas, depoimentos e documentos, para atingir um nível mais profundo, ultrapassando os sentidos manifestos do material. Geralmente, todos os procedimentos levam a relacionar estruturas semânticas (significantes) com estruturas sociológicas (significados) dos enunciados e a articular a superfície dos enunciados dos textos com os fatores que determinam suas características: variáveis psicossociais, contexto cultural e processo de produção da mensagem.

Assim, buscamos não nos restringir à análise do conteúdo manifesto nos documentos, mas tentamos captar nas entrelinhas as motivações, as descontinuidades, as contradições e os significados. Nessa perspectiva, Chirtian Laville e Jean Dionne (1999, p. 214) afirmam que o princípio da análise de conteúdo "[...] consiste em desmontar a estrutura e os elementos desse conteúdo para esclarecer suas diferentes características e extrair sua significação" no intuito de procurar os sentidos, captar as intenções e os significados.

Para análise dos dados financeiros, relacionados às receitas e aos gastos da educação especial, realizamos uma interpretação quantitativa. Nesse sentido, Robert Bogdan e Sari Biklen (1994) observam que os dados quantitativos podem sugerir tendências e servir como verificação para as ideias que se desenvolvem durante o processo de investigação. Para Minayo et al. (1994, p. 22), "[...] o conjunto de dados quantitativos e qualitativos não se opõem, ao contrário, se complementam, 
pois a realidade abrangida por eles interage dinamicamente, excluindo qualquer dicotomia". Assim, a pesquisa parte de um levantamento quantitativo para, na sequência, trabalhar com a análise qualitativa. Desse modo, a partir de uma análise qualitativa, tentamos apresentar as ações do Poder Público no provimento de recursos financeiros à educação especial, na gestão do município de Vitória, no contexto de financiamento da educação básica.

\subsection{QUARTO MOMENTO: DIÁLOGO SOBRE A PESQUISA NA SEME-VITÓRIA}

Durante o processo de organização dos dados, desenvolvidas as primeiras análises, tivemos a necessidade de retornar à Seme-Vitória para realização de uma entrevista coletiva, na tentativa de compreender alguns dados e obter algumas informações que não ficaram claras com a leitura dos documentos e dos balanços financeiros da Secretaria de Educação. Para tanto, entramos em contato com a coordenadora da educação especial do município, para que ela nos ajudasse na organização desse momento. Ela nos orientou a abrir um processo com tal solicitação, para ciência da nova secretária de educação. Após resposta positiva do processo, a secretária nos encaminhou à Gerência de Formação e Desenvolvimento em Educação (GFDE), responsável em acompanhar o desenvolvimento de pesquisas relacionadas à educação no município. A Gerência agendou um encontro, realizado no mês de maio de 2014 , com os coordenadores e representantes das gerências do ensino fundamental, da educação infantil, da educação especial, da EJA, dos recursos humanos, da área orçamentária e financeira, da área administrativa, da gestão democrática e da coordenação técnica de estatística e fluxo escolar, para apresentação da pesquisa e realização da entrevista.

$\mathrm{Na}$ entrevista coletiva, segundo Sonia Kramer e Mariana Fernanda Nunes (2007, p. 430), "[...] os entrevistados falam, dividem opiniões, discutem, trazendo à tona os fatores críticos de determinada problemática, que dificilmente aparecem, tanto nos questionários fechados como nas entrevistas individuais abertas". Assim, os sujeitos têm a oportunidade de se pronunciar sobre a temática em questão. 
Para realização da entrevista, elaboramos um roteiro semiestruturado (APÊNDICE A) com questões relativas aos dados educacionais, ao processo do planejamento orçamentário e aos dados de receitas e despesas da educação no município. A entrevista semiestruturada é concebida como aquela em que as perguntas são elaboradas previamente, de acordo com os objetivos do estudo, podendo o pesquisador fazer perguntas adicionais. Para Trivinõs (1987, p. 146), a entrevista semiestruturada

[...] parte de certos questionamentos básicos, apoiados em teorias e hipóteses, que interessam à pesquisa, e que, em seguida, oferecem amplo campo de interrogativas, fruto de novas hipóteses que vão surgindo à medida que se recebem as respostas do informante. Dessa maneira, o informante, seguindo espontaneamente a linha do seu pensamento e de suas experiências dentro do foco principal colocado pelo investigador, começa a participar na elaboração do conteúdo da pesquisa.

No momento da entrevista, foi firmado o compromisso (APÊNDICE B), por parte da pesquisadora, quanto à preservação das identidades. Foi elaborado ainda um Termo de Consentimento Livre e Esclarecido (APÊNDICE C) em que foi selada a autorização para a divulgação dos dados em trabalhos de caráter científico. Também utilizamos a gravação em áudio, visando à retomada fidedigna do conteúdo para a análise posterior. No próximo capítulo, apresentaremos os resultados do estudo, no que tange ao financiamento da educação especial na rede municipal de ensino de Vitória. 


\section{O FINANCIAMENTO DA EDUCAÇÃO ESPECIAL NO MUNICÍPIO DE VITÓRIA/ES}

Neste capítulo, buscamos sistematizar e analisar os dados de financiamento destinado à educação na rede municipal de ensino de Vitória. Optamos por organizar o capítulo em torno de três vertentes, para melhor visualização e compreensão das informações em cada município: planejamento e execução orçamentária, as receitas e as despesas educacionais. Porém, antes de adentramos especificamente nesses dados, apresentaremos as informações relativas ao município, no que se refere à sua localização, população, história, caracterização do sistema de ensino municipal, oferta educacional e políticas de educação e educação especial.

\subsection{MUNICÍPIO DE VITÓRIA}

Vitória, capital do Espírito Santo, fundada no século XVI, é considerada a segunda capital mais antiga do país. Compõe, juntamente com os estados de Minas Gerais, Rio de Janeiro e São Paulo, a região Sudeste do Brasil. E com os municípios de Serra, Cariacica, Viana, Vila Velha, Fundão e Guarapari, a Região Metropolitana da Grande Vitória (RMGV).

Segundo o censo populacional de 2010, realizado pelo IBGE, o município cobria uma faixa de $98.194 \mathrm{~km}^{2}$, constituído por uma ilha principal, várias ilhas menores no seu entorno e uma parte continental, situada ao norte. Integram-se também à sua área as llhas de Trindade e Martins Vaz, situadas a $140 \mathrm{~km}$ da costa. Sua extensão territorial, como podemos observar na Figura 1, limita-se ao norte com o município da Serra, ao sul com Vila Velha, a oeste com Cariacica e a leste com o Oceano Atlântico. 
Figura 1 - Localização do município de Vitória no Espírito Santo

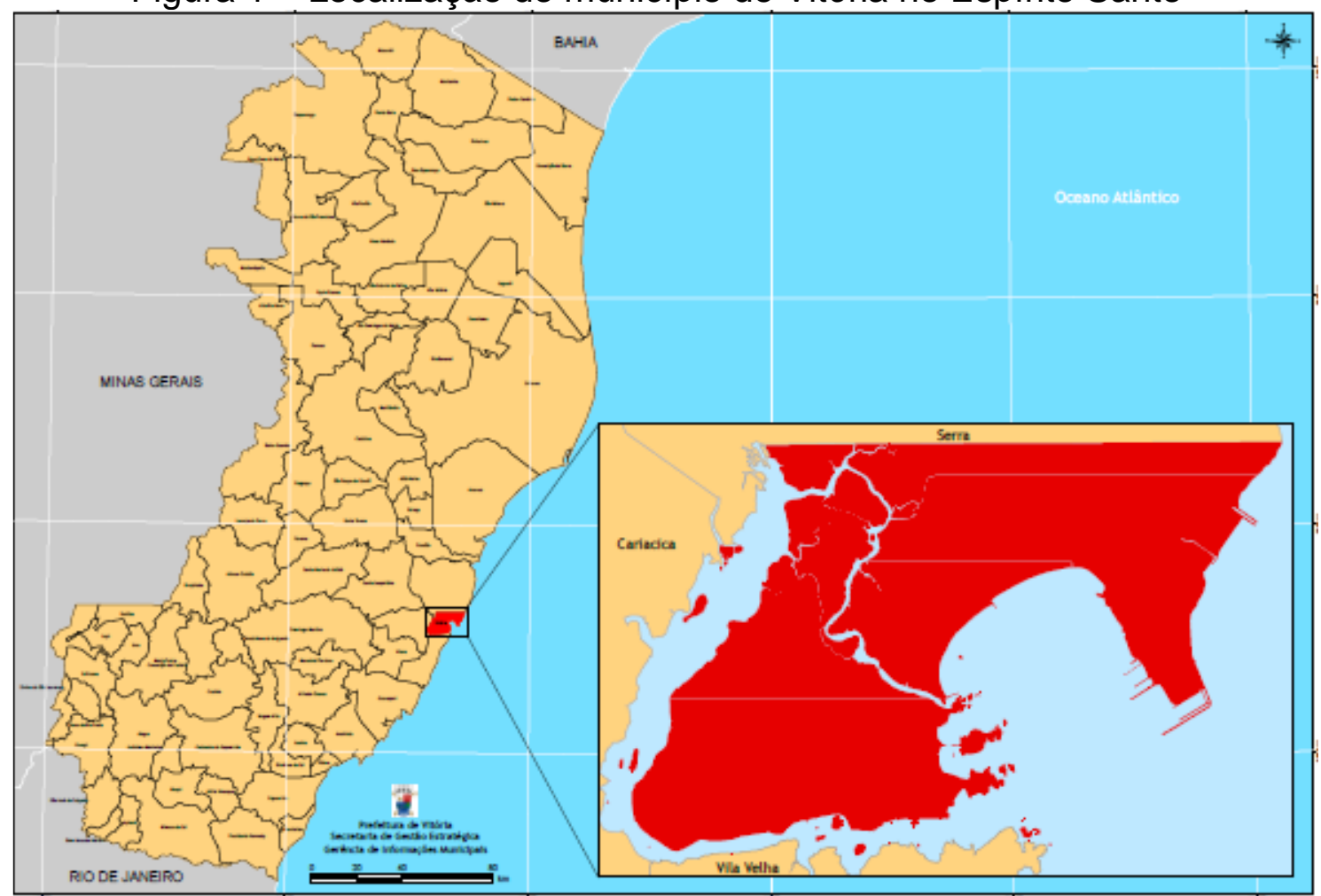

Fonte: Vitória em Dados - Vitória em Mapas (VITÓRIA, 2012b).

Em 2010, tinha sua população estimada em 327.801 mil habitantes, o que representava 9,33\% da população do estado do Espírito Santo. Era considerado um município de grande porte, pois segundo a categorização do IBGE, era classificado como de grande porte o município de 100.001 até 900.000 habitantes. E sua densidade populacional era de 3.327,73 hab./km² (BRASIL, 2010a). A população era prioritariamente urbana, composta, em sua maioria, de pessoas em idade ativa entre 15 e 64 anos (72,52\%) (PNUD, 2013). De acordo com Prieto e Gil (2011), conhecer o porte do município é de extrema importância para pensar e subsidiar o processo de gestão, planejamento e avaliação das políticas públicas.

O valor da renda per capita ${ }^{85}$, em 2010 , era de $\mathrm{R} \$ 1.866,58$ reais, com uma taxa média anual de crescimento de $41,88 \%$ no período de 2000 a 2010 . A extrema pobreza $^{86}$ passou de 2,90\% em 2000 para $0,64 \%$ em 2010. Entretanto, a

\footnotetext{
${ }^{85}$ Rendimento mensal total domiciliar per capita nominal em 2010.

${ }^{86}$ Medida pela proporção de pessoas com renda domiciliar per capita inferior a $R \$ 70,00$ reais em agosto de 2010 (PNUD, 2013).
} 
desigualdade aumentou e, de acordo com o Índice de Gini ${ }^{87}$, passou de 0,6083 em 2000 para 0,6124 em 2010 (PNUD, 2013).

O Índice de Desenvolvimento Humano Municipal (IDHM) de Vitória era de 0,845 em 2010, situado na faixa de desenvolvimento humano muito alto (IDHM entre 0,8 e 1), por isso foi considerada a segunda capital com melhor IDHM nesse ano, ocupou a quarta posição em relação aos 5.565 municípios do Brasil e a primeira posição em relação aos 78 municípios do estado do Espírito Santo (PNUD, 2013; BRASIL, 2010). Cabe destacar ainda que Vitória, em 2011, foi considerada a capital com o maior PIB per capita do país, $\mathrm{R} \$$ 85.794,33 (BRASIL, 2010a).

A escolha do nome Vitória para a cidade, se deve ao fato ocorrido em 8 de setembro de 1551, quando os portugueses venceram acirrada batalha contra os índios Goitacazes e, entusiasmados pela vitória, passaram a chamar o local de llha de Vitória.

A data de emancipação política do município foi 24 de fevereiro de 1823, quando um Decreto-Lei Imperial concedeu Fórum de Cidade a Vitória. Os índios chamavam a Ilha de Vitória de Guanaaní ou "Ilha do Mel" pela beleza de sua geografia e amenidade do clima, com a baía de águas viscosas e manguezal repleto de moluscos, peixes, pássaros e muita vida (VITÓRIA, 2012b).

A história política e econômica do município de Vitória se articula à história do Estado do Espírito Santo, que tinha, até os anos de 1950, sua economia voltada para monocultura do café, caracterizando-se como um Estado eminentemente agroexportador. Assim, o espaço urbano de Vitória era organizado pelos interesses em torno do poder político local, ou seja, interesses mercantis exportadores. Se inicialmente, as atividades estavam voltadas à comercialização do café, posteriormente, a cidade incorporaria novos serviços e modalidades de inserção na economia nacional e internacional, devido à ampliação dos serviços portuários e à implantação de grandes empresas industriais.

Nos anos de 1960, a base econômica se alterou radicalmente, na tentativa do desenvolvimento do processo de industrialização, a partir da erradicação dos cafezais e da estratégia de desenvolvimento articulada a grandes empresas como

${ }^{87}$ É um instrumento utilizado para medir o grau de concentração de renda. Ele aponta a diferença entre os rendimentos dos mais pobres e dos mais ricos e numericamente varia de 0 (situação de total igualdade) a 1 (completa desigualdade de renda) (PNUD, 2013). 
Companhia Siderúrgica de Tubarão (CST) e Vale (voltada à produção de minério de ferro e níquel). Esse processo trouxe grandes consequências para 0 desenvolvimento social de Vitória, uma vez que representou um aumento significativo de número de pessoas que deixaram o interior do Estado para a cidade de Vitória, o que resultou no crescimento contraditório e desordenado do município. Por outro lado, observou-se a intensificação da atividade industrial, os denominados grandes projetos industriais, voltados à complementação e à integração do parque produtivo nacional. Essas empresas contribuíram para diversificação das atividades produtivas da Capital, agora não mais voltados exclusivamente ao café, mas às exportações de produtos semielaborados de indústrias extrativa, metalúrgica, de papel e celulose e de minério de ferro.

Contudo, os grandes projetos não trouxeram os impactos de desenvolvimento industrial que se esperavam, na medida em que se restringiu na criação de condições para que a lógica de interesses mercantis exportadores se mantivesse, fornecendo os contornos de uma economia voltada para o global, e não para o desenvolvimento local.

Desse modo, ao incentivar atividades relacionadas ao comércio exterior, o governo estadual deixou de investir em setores que geravam renda e emprego e poderiam alterar elementos do tecido social capixaba. Assim, Vitória chegou à década de 1990 com problemas de urbanização e desigualdade social. Nesse sentido, as políticas sociais articuladas pelo Poder Público local voltaram-se à redução dos problemas gerados a partir do desenvolvimento industrial dos anos de 1970.

Ressaltamos que, no ano de 1988, um fato político proporcionou mudanças nos aspectos da política municipal, a eleição para o executivo municipal do candidato Vitor Buaiz, do Partido dos Trabalhadores (PT), que, na gestão de 1989 a 1992, ampliou a participação popular na gestão do município, com a implantação do Orçamento Participativo, a mobilização das lideranças comunitárias, a transparência das contas públicas, a eleição de diretores das unidades de ensino, entre outras ações (VITÓRIA, 1996). Cabe destacar que esse contexto revela maior pressão popular, por parte dos setores organizados da sociedade civil, ao Estado, a fim de garantir participação na gestão pública e no controle social das políticas, bem como assegurar acesso aos direitos sociais, entre eles os educacionais. 
O seu sucessor, Paulo César Hartung Gomes (1993-1996), do Partido da Social Democracia Brasileira (PSDB), manteve os procedimentos de participação popular na gestão, porém articulada com a perspectiva de eficiência administrativa e da integração da cidade ao mercado global, ligadas ao comércio exterior (VITÓRIA, 1996). Os objetivos de sua gestão foram explicitados no plano estratégico para a cidade, denominado "Vitória do Futuro" (VITÓRIA, 1996), apresentado no final de sua gestão, o qual estabeleceu ações e projetos a serem desenvolvidos até 2010.

Esse plano de desenvolvimento econômico e social foi desenvolvido pelo seu sucessor do PSDB, Luiz Paulo Vellozo Lucas, na sua primeira gestão, de 1997 a 2000, com ações governamentais voltadas para as áreas das políticas sociais. No ano de 2002, o projeto foi revisto com o objetivo de traçar estratégias de desenvolvimento econômico e social para a cidade até 2015, ou seja, políticas capazes de transformar a cidade em atrativo polo de serviços, turismo, ciência e tecnologia. Do ponto de vista das ações sociais capazes de se articular com essa vocação da cidade, as definições do documento conceituavam essas ações, conferindo-Ihes o nome de "política social integrada e integral" (MALHEIROS, 2002). Afirma V. Malheiros (2002, p. 1),

\begin{abstract}
A política proposta constitui-se de um conjunto de ações que de forma integrada visam ao atendimento às famílias em situação de pobreza e indigência. Consistem na integração das políticas setoriais nas mais diversas áreas, visando à promoção social integral de todos os membros que compõem a família.
\end{abstract}

Nesse sentido, além de definir aspectos gerais das políticas sociais, esse documento definia linhas de ação denominadas setoriais. Afirma ainda Malheiros (2002, p. 3):

\footnotetext{
A política setorial proposta constitui-se de um conjunto de ações que de forma integrada visam o atendimento a público-alvo de ações setoriais. Consiste no desenvolvimento de ações preventivas e de atuação sobre os problemas específicos de uma determinada parcela da família e da população.
}

Assim, a política definia o seu público: crianças e adolescentes socialmente vulneráveis e em situação de risco pessoal e social; desempregados com baixa 
qualificação profissional; população adulta em situação de rua; migrantes carentes; idosos; pessoas portadoras de deficiência ${ }^{88 ;}$ minorias discriminadas; e famílias ocupantes de área de risco, insalubres ou impróprias (MALHEIROS, 2002). Um último aspecto da política social recomendado pelo "Vitória do Futuro/2002" (VITÓRIA, 2002) era a noção de gestão social, que foi definida como política de gestão social.

\begin{abstract}
A política de gestão social proposta constitui-se de um conjunto de ações - meios que darão subsídios ao desenvolvimento de Políticas Sociais Integradas e Setoriais. Consiste no desenvolvimento de mecanismos e aplicação de ferramentas gerenciais que proporcionem segurança na proposição de projetos e ações. Consiste também nas estratégias e na forma da participação da sociedade civil através de Conselhos e de termos de parcerias. (MALHEIROS, 2002, p. 11).
\end{abstract}

Nessa perspectiva, nos anos de 1990 e de início do século XXI, três elementos constituíram o pilar da formulação de políticas sociais no município de Vitória: ações sociais integrais, ações setoriais e a gestão social.

Cabe ressaltar que, passados doze anos, a cidade de Vitória voltou a ser governada pelo PT, com João Carlos Coser, que teve o seu primeiro mandato no período de 2005 a 2008 e, o segundo, de 2009 a 2012. No início da gestão, foi implantado um novo modelo de gestão, pautado no fortalecimento da democracia e na expansão da cidadania, tendo como objetivos o desenvolvimento da cidade e a inclusão social. O modelo de gestão da cidade foi baseado em três eixos: 1) defesa da vida e respeito aos direitos humanos; 2) desenvolvimento sustentável com inclusão social; e 3) democratização da gestão pública.

Diante das novas perspectivas para o desenvolvimento do Estado e da Região Metropolitana e em vista das mudanças ocorridas nos últimos anos, foi necessário rever as possibilidades e desafios para o desenvolvimento da cidade e preparar um novo plano estratégico para orientar seu desenvolvimento em longo prazo (VITÓRIA, 2008a). Então, foi elaborada a "Agenda Vitória 2008/2028" (VITÓRIA, 2008a), que estava estruturada em três eixos temáticos: econômico, urbano-ambiental e sociocultural, que nortearam as análises e a construção de

${ }^{88}$ Expressão utilizada no documento "Vitória do Futuro/2002", do município de Vitória, para fazer referência à população com deficiência. 
propostas. Esse material serviu de base ao planejamento estratégico de governo, bem como à proposição de políticas setoriais. Em 2009, foi utilizado como diretriz para a elaboração do PPA 2010-2013 de Vitória.

A partir da caracterização histórica e política do município de Vitória, apresentaremos, no próximo item, a educação na rede municipal de Vitória.

\subsubsection{A educação em Vitória/ES}

O sistema municipal de ensino de Vitória ${ }^{89}$, ao longo dos anos, buscou assegurar o direito à educação a todos os cidadãos, mediante a garantia do ensino fundamental e da educação infantil e das modalidades de ensino: educação especial e educação de jovens e adultos. Assim dispõe a Lei no 4.747, de 27 de julho de 1998,

${ }^{89}$ Criado em 1998 (Lei no 4.747/1998) quando também foi implantado o Conselho Municipal de Educação (Lei ํㅜ 4.746, de 27 de julho de 1998 (alterado pela Lei ํㅜ 7.124, de 15 de novembro de 2007), com funções consultivas, deliberativas e fiscalizadoras, seguindo a própria determinação da Lei Orgânica do Município (VITÓRIA, 1990).

Art. 5․ O dever do Município com a educação escolar pública será efetivado mediante a garantia de:

I - ensino fundamental, obrigatório e gratuito, inclusive para os que a ele não tiveram acesso na idade própria;

II - atendimento educacional especializado gratuito aos educandos com necessidades educativas especiais, preferencialmente, na rede de ensino;

III - atendimento gratuito em Centros de Educação Infantil às crianças de até seis anos;

IV - oferta do ensino noturno regular, adequado às condições do educando;

V - oferta de educação escolar regular para jovens e adultos, com características e modalidades adequadas às suas necessidades e disponibilidades, garantindo-se aos que forem trabalhadores as condições de acesso e permanência na escola;

$\mathrm{VI}$ - atendimento ao educando por meio de programas suplementares de material didático-escolar, alimentação, assistência à saúde;

VII - padrões essenciais de qualidade de ensino, definidos como a variedade e quantidade mínimas, por aluno, de insumos indispensáveis ao desenvolvimento do processo ensino aprendizagem. (VITÓRIA, 1998a, grifo nosso). 
O município, segundo o PNUD (2013), apresentou, nas últimas décadas, uma melhora significativa nos seus indicadores de acesso à educação, no que se refere à redução da taxa de analfabetismo (4,1\%, em 2000, para 2,5\%, em 2010, na população de 15 anos ou mais de idade; e 5,9\%, em 2000, para 3,6\%, em 2010, na população de 18 anos ou mais), à média de estudos da população (10,04 anos, em 2010) e ao IDHM, como podemos visualizar na Tabela 15. De acordo com os dados do PNUD (2013), entre 2000 e 2010, a dimensão que mais cresceu em termos absolutos foi educação (com crescimento de 0,105 ), seguida por longevidade e por renda.

Tabela 15 - Índice de Desenvolvimento Humano Municipal e seus componentes - Vitória/ES 2000-2010

\begin{tabular}{lcc}
\hline \multicolumn{1}{c}{ IDHM E COMPONENTES } & ANO \\
\hline IDHM Educação & $\mathbf{2 0 0 0}$ & $\mathbf{2 0 1 0}$ \\
\hline \% de 18 anos ou mais com ensino fundamental completo & $\mathbf{0 , 7 0 0}$ & $\mathbf{0 , 8 0 5}$ \\
\% de 5 a 6 anos na escola & 66,96 & 78,94 \\
\% de 11 a 13 anos nos anos finais do fundamental ou com & 90,15 & 97,91 \\
fundamental completo & 84,47 & 88,94 \\
\% de 15 a 17 anos com fundamental completo & 64,41 & 74,56 \\
\% de 18 a 20 anos com médio completo & 47,05 & 63,81 \\
IDHM Longevidade & $\mathbf{0 , 7 6 2}$ & $\mathbf{0 , 8 5 5}$ \\
Esperança de vida ao nascer (em anos) & 70,74 & 76,28 \\
IDHM Renda & $\mathbf{0 , 8 2 0}$ & $\mathbf{0 , 8 7 6}$ \\
Renda per capita & $1.315,63$ & $\mathbf{1 . 8 6 6 , 5 8}$ \\
\hline
\end{tabular}

Fonte: Atlas do Desenvolvimento Humano no Brasil - PNUD, 2013.

Assim, observamos que a proporção de crianças na escola em todas as faixas etárias cresceu nesse período. Os percentuais de Vitória em 2010 superaram as taxas do estado do Espírito Santo e do Brasil, como podemos vislumbrar na Tabela 16. 
Tabela 16 - Fluxo escolar por faixa etária - Vitória, Espírito Santo, Brasil - 2010

\begin{tabular}{lccc}
\multicolumn{1}{c}{ Faixa Etária } & Vitória & Espírito Santo & Brasil \\
\hline \% de 5 a 6 anos na escola & 97,91 & 90,98 & 91,12 \\
\% de 11 a 13 anos nos anos finais do fundamental ou & 88,94 & 87,09 & 84,86 \\
com fundamental completo & 74,56 & 61,27 & 57,24 \\
\% de 15 a 17 anos com fundamental completo & 63,81 & 44,93 & 41,01 \\
\hline \% de 18 a 20 anos com médio completo &
\end{tabular}

Fonte: Atlas do Desenvolvimento Humano no Brasil - PNUD, 2013.

Entretanto, segundo o PNUD (2013), em 2010, 2,76\% das crianças de 4 a 5 anos e 2,39\% das crianças de 6 a 14 anos ainda não frequentavam a escola, percentual que, entre jovens de 15 a 17 anos, atingia $11,87 \%$, o que ainda constituía um desafio a ser enfrentado pela gestão do município de Vitória. Se compararmos os percentuais de Vitória com as taxas do Brasil, observaremos que o município apresentou indicadores acima da média nacional. No Brasil, em 2010, 19,90\% das crianças de 4 a 5 anos, 3,31\% das crianças de 6 a 14 anos e 16,68\% entre jovens de 15 a 17 anos ainda não frequentavam a escola (PNUD, 2013).

$\mathrm{Na}$ educação infantil, o município empreendeu esforços na tentativa de ampliação do acesso das crianças à escola e ao longo dos anos, se destacou no trabalho com esse nível de ensino. Em 2001, a Seme-Vitória recebeu o Prêmio Unice ${ }^{90}$ de melhor capital do Brasil para crianças até seis anos; em 2003, a cidade foi considerada capital líder nacional em educação infantil, de acordo com os dados do Inep/Censo Escolar; porém, ainda se observa um pequeno déficit na oferta de vagas para atendimento a essa população no município. Cabe destacar o documento norteador da educação infantil na rede municipal "A educação infantil no município de Vitória: outro olhar" (VITÓRIA, 2006a), que resultou do trabalho de diferentes sujeitos mobilizados para discussão e definição de uma política pública para a educação infantil no município. A educação infantil no município compreendia as creches, para crianças até três anos de idade, e a pré-escola, para crianças de quatro a seis anos de idade. Os parâmetros para organização dos grupos eram estabelecidos pela Resolução no 6, de 20 de outubro de 1999 (VITÓRIA, 1999), que

${ }^{90}$ Fundo de Nações Unidas para a Infância. 
fixava as normas para a educação infantil no sistema municipal de ensino do município de Vitória:
Art. 9ํ - Os parâmetros para organização de grupos de alunos decorrerão, inclusive das especificidades da proposta pedagógica, recomendada a seguinte relação professor/criança:
1- crianças de 0 a 1 ano - até 9 crianças por professor;
2- crianças de 1 a 2 anos - até 12 crianças por professor;
3- crianças de 2 a 3 anos - até 15 crianças por professor;
4- crianças de 3 a 6 anos - até 25 crianças por professor.
Parágrafo único - As turmas de 0 a 2 anos contarão, ainda, com funcionário auxiliar. (VITÓRIA, 1999).

A avaliação na educação infantil, segundo o art. 8 da referida Resolução, era realizada mediante acompanhamento e registro do desenvolvimento da criança, tomando como referência os objetivos estabelecidos para essa etapa da educação, sem objetivo de promoção, mesmo para o acesso ao ensino fundamental (VITÓRIA, 1999).

No ensino fundamental, embora o acesso tenha alcançado 97,61\% em 2010, os índices, disponibilizados no portal do Inep (2010), de rendimento escolar $(87,7 \%$ de aprovação, 10,2\% de reprovação e 2,1\% de abandono) e de distorção idade/série (20,5\%) ressaltavam a necessidade de atentar-se para as condições de permanência e término desse nível de ensino. Vale destacar que, no Brasil, o acesso ao ensino fundamental alcançou 96,69\% em 2010 e os índices, disponibilizados no portal do Inep (2010), de rendimento escolar foram de $86,6 \%$ de aprovação, $10,3 \%$ de reprovação e de $3,1 \%$ de abandono.

Cumpre destacar que no ano de 2008, o Comev fixou as normas relativas à organização e ao funcionamento do ensino fundamental de ensino de Vitória, na Resolução n 7, de 17 de dezembro de 2008, em cumprimento da LDB/1996, art. 11, inciso III, e da Lei 4.747/1998, que instituiu o Sistema Municipal de Ensino de Vitória. Desse modo, o Comev estabeleceu que a duração do ensino fundamental fosse de nove anos, respeitado o período de extinção gradativa do ensino fundamental de oito anos, com matrícula a partir de seis anos de idade, e que ele seria organizado em ciclos. A organização das turmas obedeceu aos seguintes parâmetros: do 1ำ ao $3^{\circ}$ ano, 25 alunos; no $4^{\circ}$ e $5^{\circ}$ anos, 28 alunos, e do $6^{\circ}$ ao $9^{\circ}$ ano, no máximo 32 alunos por turma. Além disso, estabeleceu o limite mínimo de 1,20 $\mathrm{m}^{2}$ por aluno em 
sala de aula com afastamento de 1,20 $\mathrm{m}^{2}$, sendo este espaço devidamente ampliado no caso de alunos ou professores que utilizassem cadeiras de rodas e/ou outro equipamento ou prótese de locomoção ou com especificidades que requeressem maior espaço (VITÓRIA, 2008d). A avaliação no ensino fundamental, de acordo com o art. 31 da Resolução no 7/2008, incluiu os seguintes aspectos: a avaliação do processo educativo em todas as suas dimensões e a avaliação do aproveitamento escolar do aluno (VITÓRIA, 2008d). Os critérios de aprendizagem foram organizados em trimestres, e seus resultados expressos em pontos, em uma escala de zero a cem pontos, ou por objetivos (VITÓRIA, 2008d).

O município também buscava a ampliação da oferta da EJA. No ano de 2007, implementou um novo modelo de organização dessa modalidade de ensino, com duração de seis anos: três anos para o primeiro segmento e três anos para o segundo segmento. Cada segmento era ordenado em três fases: inicial, intermediário e conclusivo. Essa nova estruturação buscava contribuir para a melhoria da qualidade da educação ofertada, atender aos tempos de aprendizagem demandados pelos alunos, bem como romper com a concepção supletiva, tão enraizada no atendimento dos sujeitos que não tiveram acesso à educação. Contudo, houve a necessidade de acompanhamento e avaliação desse processo de reestruturação da EJA no município, de modo a garantir a participação e a permanência do aluno trabalhador na escola. Foi possível identificar ainda esforços na tentativa de ampliação da jornada escolar, por meio do programa tempo integral para toda a rede municipal e da consolidação das atividades do contraturno escolar de modo a qualificar e ampliar a vida cultural dos alunos (VITÓRIA, 2008a).

O Programa Educação em Tempo Integral era voltado para alunos da educação infantil e ensino fundamental. Visava à permanência dos alunos na escola, em que seriam assistidos em suas necessidades básicas e educacionais. O projeto era resultado da articulação das Secretarias Municipais de Educação, Saúde e Assistência Social em parceria com outras instituições públicas, privadas e organizações da sociedade civil. O início de suas atividades foi em 2005, com o atendimento às crianças de seis meses a seis anos, no Centro Municipal do Ensino Infantil (CMEI). Em 2007, o programa foi ampliado para os alunos do ensino fundamental. Nesse mesmo ano, ampliou-se também o atendimento às crianças de quatro a seis anos, em espaços denominados Núcleos Brincartes. 
O Núcleo Brincarte constitui-se em parceria com Organizações Nãogovernamentais (ONGs), que administram os recursos públicos e realizam a gestão do projeto com o acompanhamento de profissionais vinculados às Secretarias envolvidas no projeto. Todos os recursos humanos, didáticos e pedagógicos bem como a manutenção do espaço físico eram assegurados pela PMV.

Na educação infantil, as crianças de seis meses a três anos frequentavam os CMEls em horário parcial e/ou integral, de acordo com os critérios fixados pelo Decreto no 15.071, de 21 de junho de 2011. Já as crianças de quatro a seis anos eram transportadas por ônibus contratados pela PMV para o horário estendido nos Núcleos Brincarte. No ensino fundamental, os alunos assistiam às aulas no horário regular e, no contraturno, frequentavam outros espaços de socialização da cidade, como parques, museus, teatros, clubes e escolas da ciência.

Nesses espaços, eram oferecidas atividades educativas extracurriculares, com oferta de esporte, lazer, cultura, música, artes cênicas, dança e conhecimentos gerais (SANTOS, 2011). Maria Aparecida Rodrigues da Costa Santos (2011, p. 4), ao analisar as implicações do Brincarte no âmbito do Programa de educação integral no município, afirma que

[...] a parceria, como uma das alternativas da gestão pública educacional do Estado, [...] vem se constituindo no Município de Vitória, justificada pelos altos custos com infraestrutura e mão de obra que a implementação desse projeto geraria aos cofres do município. Sendo assim, o município transfere às ONGs recursos para que estas, a partir dos custos vinculados ao atendimento às crianças, façam uso dos mesmos.

Assim, a parceria público-privada constitui-se num contexto social e político de desresponsabilização do Estado, que não consegue garantir uma efetiva igualdade de oportunidades para toda a população.

No que se refere aos profissionais da educação, a Lei ํo. 6.754 , de 16 de novembro de 2006, instituiu o Plano de cargos, carreira e vencimentos do servidor do magistério público do município de Vitória que se fundamentava nos seguintes princípios: ingresso na carreira exclusivamente por concurso público de provas e títulos; estímulo ao desenvolvimento profissional; valorização do desempenho 
profissional; racionalização da estrutura de cargos e carreira; evolução funcional e estabelecimento do piso de vencimento.

O quadro do magistério compreendia os grupos de docentes e de técnico pedagógicos. O primeiro grupo integrava: a) Professor da Educação Básica I (PEB I), para a educação infantil; b) Professor da Educação Básica II (PEB II), para o ensino fundamental do $1^{\circ}$ ao $5^{\circ}$ ano; c) Professor de Educação Básica III (PEB III), para o ensino fundamental (disciplinas de artes, educação física, informática educativa- do 1ำ ao 9a ano- e demais disciplinas do 6ำ ao 9ano); e d) Professor de Educação Básica III (PEB III - dinamizador) - da área de artes e de educação física para atuação na educação infantil. O segundo grupo incluía: a) Professor de Educação Básica IV (PEB IV) - especialista educacional; b) Professor de Educação Básica IV (PEB IV) - coordenador de Turno; c) Professor de Educação Básica IV (PEB IV) - em função Pedagógica (VITÓRIA, 2006b).

A jornada de trabalho do servidor do magistério era de 25 ou 40 horas semanais, com a seguinte composição: para os cargos de PEB-I, PEB-II e PEB-III que atuavam na educação infantil, com $20 \%$ de hora-atividade destinados ao trabalho pedagógico individual e/ou coletivo; e para os que atuavam no ensino fundamental, $25 \%$ de hora-atividade destinados ao trabalho pedagógico individual e/ou coletivo (VITÓRIA, 2006b) ${ }^{91}$.

A remuneração do servidor do magistério era determinada pelo enquadramento, jornada e evolução funcional. Os princípios e regulamentações previstos nesse Plano eram aplicados também ao Quadro Suplementar de Cargos do Magistério, formado pelos cargos de berçarista, auxiliar de berçarista, orientador de educação física, secretário escolar e musicoterapeuta (VITÓRIA, 2006b).

A composição quantitativa do quadro de professores $^{92}$ vinculados à SemeVitória nos anos de 2008, 2009 e 2010 foi apresentada na Tabela 17.

\footnotetext{
91 Cabe destacar que a Lei $n^{\circ} 11.738$, de 16 de julho de 2008, que regulamenta o piso salarial profissional nacional para os profissionais do magistério público da educação básica, prevê no Art. $2^{\circ}$, $\S 4^{\circ}$ "Na composição da jornada de trabalho, observar-se-á o limite máximo de $2 / 3$ (dois terços) da carga horária para o desempenho das atividades de interação com os educandos".

$92 \mathrm{O}$ acesso as informações referentes ao total de profissionais do magistério não foi possível até o término da pesquisa.
} 
Tabela 17 - Quantitativo de função docente da rede de ensino municipal de Vitória/ES 2008, 2009 e 2010

\begin{tabular}{lccc}
\hline ETAPAS E MODALIDADES & 2008 & 2009 & 2010 \\
\hline EDUCAÇÃO INFANTIL & & & \\
CRECHE & 686 & 848 & 1.257 \\
PRÉ-ESCOLA & 789 & 942 & 762 \\
SUBTOTAL (A) & 1.475 & 1.790 & $\mathbf{2 . 0 1 9}$ \\
ENSINO FUNDAMENTAL & & & \\
ANOS INICIAIS & 2.679 & 2.741 & 3.023 \\
ANOS FINAIS & 5.590 & 5.247 & 5.380 \\
SUBTOTAL (B) & $\mathbf{8 . 2 6 9}$ & $\mathbf{7 . 9 8 8}$ & $\mathbf{8 . 4 0 3}$ \\
EJA (C) & 457 & 842 & 1.188 \\
EDUCAÇÃO ESPECIAL (D) & 0 & 0 & 0 \\
TOTAL (A+B+C+D) & 10.201 & 10.620 & 11.610 \\
\hline
\end{tabular}

Fonte: Inep/Microdados do Censo Escolar 2008, 2009 e 2010. Elaboração própria.

Observamos que, no ano de 2008, a rede de ensino municipal de Vitória apresentava um total de 10.201 professores, sendo 1.475 da educação infantil, 8.269 do ensino fundamental e 457 da EJA. No ano de 2009, o total de professores era de 10.620, com 1.790 na educação infantil, 7.988 no ensino fundamental e 842 na EJA. No ano de 2010, 2.019 professores atuavam na educação infantil, 8.403 no ensino fundamental e 1.188 na EJA, totalizando 11.610 professores. Os dados indicam que, na educação infantil e na EJA, o número de professores aumentou no período de 2008 a 2010. Entretanto, no ensino fundamental, observamos um decréscimo no ano de 2009. Vale ressaltar que o número de professores da educação especial da rede de ensino do município de Vitória, apresentados no Microdados do Censo Escolar (2008, 2009 e 2010), estava zerado, tendo em vista que o município não apresentava uma classificação funcional para os professores que atuavam nessa modalidade, os quais estavam localizados na educação infantil ou no ensino fundamental.

Cumpre destacar, na gestão e na política de educação de Vitória, a presença de princípios de gestão democrática do ensino público, descritos na Lei $n^{\circ}$ 4.747/1998, que estabelece "a gestão democrática do ensino público nas três esferas da administração - classe, escola, secretaria de Educação" e reconhece a 
autonomia pedagógica, administrativa e de gestão financeira dos estabelecimentos de ensino mantidos pelo governo municipal (VITÓRIA, 1998a). Essa Lei prevê, ainda, a instituição de conselhos de classe, a criação de grêmios estudantis, a eleição direta para diretores, a formação dos conselhos de escola - como espaço de deliberação conjunta sobre as atividades desenvolvidas e relacionadas aos aspectos pedagógicos, administrativos e financeiros da escola -, o funcionamento do Conselho Municipal de Educação ${ }^{93}$ e/ou do Conselho de Alimentação Escolar do município de Vitória94. Segundo Vânia Carvalho de Araújo (2011), outras ações também integravam a gestão da rede municipal de ensino de Vitória, como a realização do congresso das famílias, a promoção da alimentação escolar orgânica, espaços formativos para os profissionais da educação dentro e fora do horário de trabalho e a implementação de um sistema municipal de avaliação, na tentativa de garantir a qualidade social dos serviços oferecidos à população.

A rede municipal de ensino de Vitória era constituída por unidades de ensino fundamental e unidades de educação infantil. O quantitativo de escolas nos anos de 2008, 2009 e 2010 foi disposto na Tabela 18.

Tabela 18 - Quantitativo de escolas do município de Vitória/ES 2008, 2009 e 2010

\begin{tabular}{|c|c|c|c|c|c|c|}
\hline \multirow{2}{*}{ ANO } & \multicolumn{2}{|c|}{ EDUCAÇÃO INFANTIL } & \multicolumn{2}{|c|}{$\begin{array}{c}\text { ENSINO } \\
\text { FUNDAMENTAL }\end{array}$} & \multirow{2}{*}{$\begin{array}{l}\text { TOTAL DE } \\
\text { ESCOLAS }\end{array}$} & \multirow{2}{*}{$\begin{array}{l}\text { TOTAL DE } \\
\text { TURMAS }\end{array}$} \\
\hline & ESCOLAS & TURMAS & ESCOLAS & TURMAS & & \\
\hline 2008 & 44 & 805 & 51 & 1.065 & 95 & 1.870 \\
\hline 2009 & 45 & 836 & 51 & 1.088 & 96 & 1.924 \\
\hline 2010 & 45 & 842 & 52 & 1.152 & 97 & 1.994 \\
\hline
\end{tabular}

Fonte: Simec 2008 a 2010. Elaboração própria.

93 O Comev foi instituído pela Lei 4.746/1998 que dispõe sobre sua organização e funcionamento, como órgão colegiado do Sistema Municipal de Ensino com funções de caráter normativo, consultivo e deliberativo sobre a formulação e o planejamento das políticas de educação do município.

94 O Conselho de Alimentação Escolar do município de Vitória - CAE foi instituído pelo Decreto no 13.747, 28 de fevereiro de 2008 (VITÓRIA, 2008b), como órgão deliberativo, de fiscalização e de assessoramento à execução do Programa Nacional de Alimentação Escolar, por meio da participação da sociedade civil local nas ações desenvolvidas pelo Poder Público municipal por intermédio da Seme-Vitória. 
Com base nas informações da Tabela 18, notamos que, em 2008, a rede municipal de ensino de Vitória possuía 95 escolas e 1.870 turmas, sendo 44 escolas de educação infantil, com 805 turmas, e 51 escolas de ensino fundamental, com 1.605 turmas. Em 2009, com a construção de mais uma unidade de ensino da educação infantil, o número de turmas dessa etapa de ensino foi ampliado para 836. O ensino fundamental também apresentou um aumento no número de turmas para 1.088, embora não tenha ampliado o seu número de escolas, o que ocorreu apenas em 2010, com a criação de mais uma escola. Essa ampliação no número de turmas pode se constituir em um indicativo de redução do número de alunos por sala de aula, conforme estabelecem as Resoluções n 7/2008 e nº 6/1999. Assim, em 2010, o município de Vitória tinha 52 escolas de ensino fundamental, com 1.152 turmas, e 45 escolas de educação infantil, com 842 turmas.

Cabe destacar que a rede de ensino de Vitória oferecia ainda o que denominava Ensino Complementar à população escolar do município, em outros espaços educativos, organizados e mantidos tanto pela PMV, bem como por outras instituições. Eram esses espaços: a Escola de Ciência e Física, que tinha como finalidade popularizar a física, abordando conceitos ligados à eletricidade, à óptica e à mecânica, de forma a despertar a curiosidade e ajudar na compreensão dos fenômenos científicos; a Escola da Ciência Biologia e História, que constituía um centro de ciência, educação e cultura e destacava a natureza e a cultura regional, por meio de uma exposição centrada em temáticas capixabas e acervo com maquetes do patrimônio histórico e regional, artefatos arqueológicos, entre outros elementos; o Planetário, mantido por meio de uma parceria entre a Seme-Vitória e a Universidade Federal do Espírito Santo (Ufes), que era ambiente para os visitantes conhecerem os planetas, as constelações, os movimentos de translação e rotação e as lendas que envolvem o universo; e a Praça da Ciência, que oferecia oficinas e equipamentos para o estudo dos conceitos científicos ligados à física (VITÓRIA, 2011).

Na tentativa de traçar um panorama do município de Vitória, apresentamos o movimento de matrículas na educação básica, no período de 2007 a 2013, considerando o conjunto das dependências administrativas e sua oferta. Para análise das matrículas do município, optamos pela utilização do sistema de consulta à matrícula do Censo Escolar, disponibilizado no portal do Inep. A opção de 
observar os dados de oferta educacional das etapas e modalidades da educação básica no município parte do pressuposto de que o movimento de matrículas tem implicações no montante de recursos destinados à educação no âmbito municipal e no valor aluno-ano. Faz-se necessário ressaltar que os recursos do Fundeb têm como base o número de alunos matriculados na educação básica (BRASIL, 2007b).

A oferta educacional no município de Vitória, por Dependência Administrativa de 2008 a 2010, no que tange ao total de matrículas na educação básica, apresentou um decréscimo de aproximadamente $2 \%$, como podemos observar no Gráfico 7. Essa tendência de redução de matrículas na educação básica também se observa em nível nacional, em que se registrou uma queda de aproximadamente $5,7 \%$, no mesmo período.

Gráfico 7 - Movimento de matrículas da educação básica por Dependência Administrativa - Vitória/ES 2008, 2009 e 2010

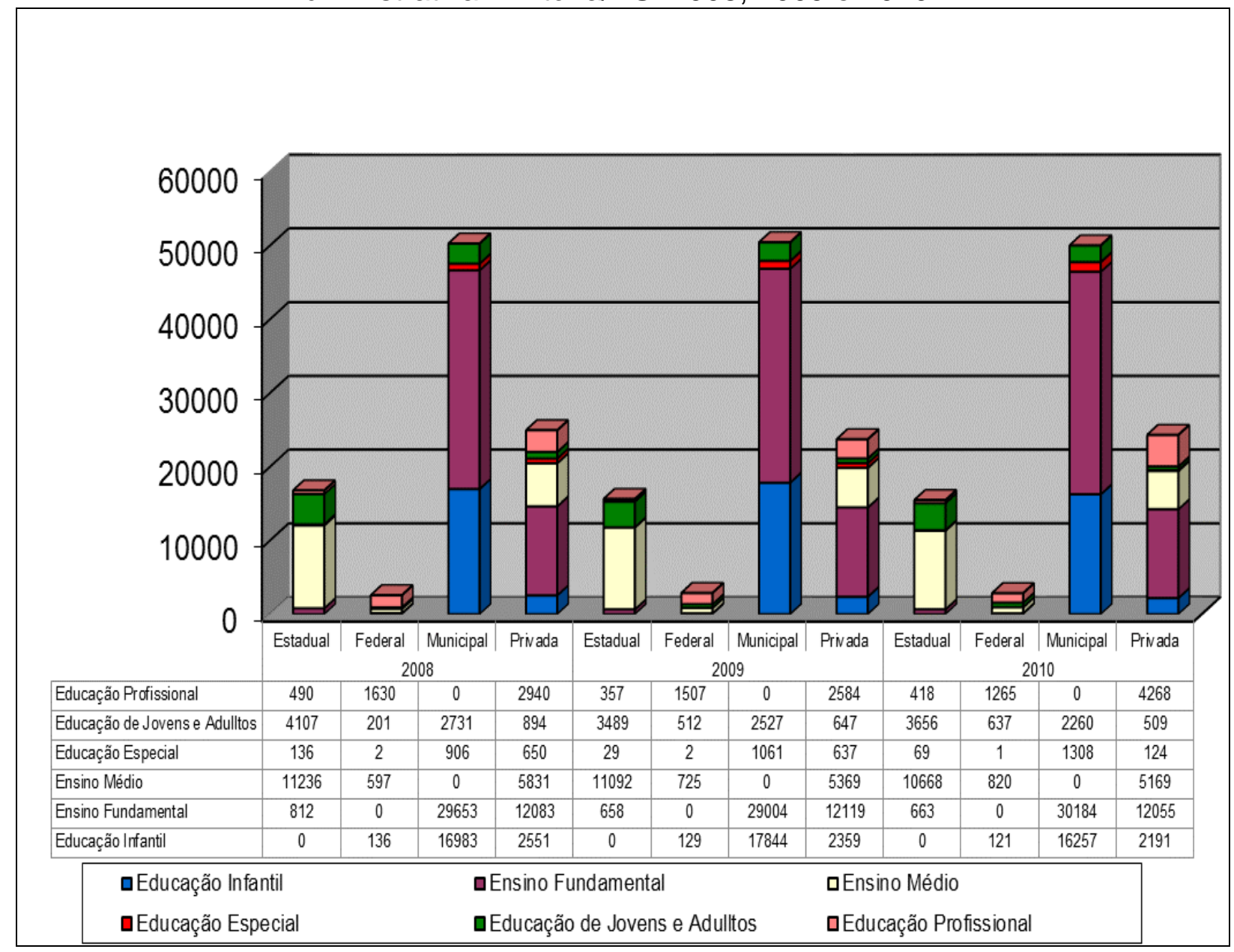

Fonte: Inep/Censo Escolar 2008, 2009 e 2010. Elaboração própria. 
Os dados evidenciaram ainda que o atendimento na educação básica era feito, prioritariamente, na rede pública de ensino, embora a dependência administrativa privada tivesse uma alta participação na oferta das etapas e modalidades de ensino no município de Vitória. A composição da oferta educacional, no período de 2008 a 2010, no município, era dividida entre as dependências administrativas: estadual (18\% em 2008 e 17\% em 2009 e 2010), federal (3\% em 2008, 2009 e 2010), municipal (53\% em 2008 e 54\% em 2009 e 2010) e privada (26\%). Essa composição é resultante do processo de municipalização do contingente de matrículas do ensino fundamental, antes atendido pelo Estado, no município de Vitória, que provocou a ampliação da sua rede de ensino, acompanhado do aumento no número de escolas, professores, funcionários e no número de matrículas ${ }^{95}$. Cabe acrescentar ainda, as orientações definidas pelo art.

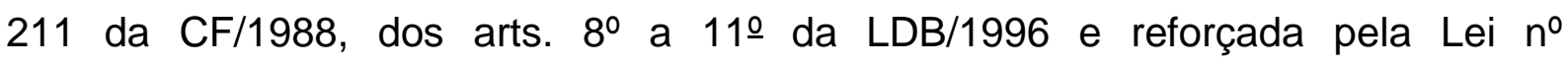
11.494/2007, que implantou o Fundeb, nos quais são estabelecidos o regime de colaboração entre os entes federados para a organização dos sistemas de ensino; e as competências prioritárias, não exclusivas, dos entes federados quanto à oferta, organização e manutenção da educação (BRASIL, 1996a; 2007b). Assim, compete, prioritariamente, aos municípios ofertar e manter a educação infantil e o ensino fundamental, e compete aos estados e Distrito Federal ofertar e manter o ensino fundamental e o médio, conforme já mencionado.

Nessa perspectiva, também os recursos do Fundo devem ser aplicados, pelos estados e municípios, nas etapas e modalidades da educação básica de seus respectivos âmbitos de atuação prioritária (BRASIL, 2007b, art. 21). Faz-se necessário ressaltar, como apontado por Araújo, G. (2010), que há a ausência de uma definição clara quanto ao regime de colaboração na CF/1988 e que os dispositivos constitucionais de atuação prioritária não resolveram os problemas de gestão relacionados aos serviços educacionais e geraram sérias implicações para a oferta e organização dos sistemas de ensino no que tange às possibilidades de melhoria das políticas de acesso à educação e de permanência na escola ${ }^{96}$.

$95 \mathrm{O}$ processo de municipalização em Vitória foi coordenado pelo Estado junto ao governo local, por meio da Lei no 5.474, de 6 de outubro de 1997, que dispõe sobre o processo de municipalização do ensino público no Espírito Santo. Para aprofundamento, consultar Viana (2006).

${ }_{96}$ Para aprofundamento, consultar Araújo (2010) e Abrucio (2000). 
No município de Vitória, a rede estadual respondia, prioritariamente, pelo ensino médio, pela EJA e pela educação profissional. De 2008 para 2009, houve uma redução de 19\% (154 matrículas) no número de matrículas do ensino fundamental na rede estadual; porém, em 2010, o número de matrículas teve um crescimento de 0,8\% (5 matrículas) em relação ao ano de 2009. Em contraposição, o número de matrículas dessa etapa de ensino na rede municipal apresentou um declínio de aproximadamente 2\% (649 matrículas), no período de 2008 para 2009 e um aumento de 4\% (1.180 matrículas) de 2009 para 2010, sem que fossem encontradas justificativas para tal nas fontes consultadas para esta pesquisa. Vale ressaltar que, mesmo sendo o ensino fundamental etapa de atuação prioritária do município, o atendimento é previsto em colaboração com os estados, conforme redação dos arts. 10 e 11 da LDB/1996 (BRASIL, 1996a).

A dependência federal apresentava uma participação pequena na oferta educacional no município, de aproximadamente 3\%, e atendia prioritariamente 0 ensino médio, a EJA e a educação profissional, etapas e modalidades atendidas pelo campus Vitória do Instituto Federal do Espírito Santo. A oferta ínfima da educação infantil se restringia à Escola de Aplicação vinculada à Ufes.

A rede privada tinha uma participação alta na oferta educacional no município, de aproximadamente $26 \%$, com o atendimento em todas as etapas da educação básica e modalidades de ensino (educação especial, EJA e educação profissional). Esse aspecto também foi observado por Andrea Barbosa Gouveia, Thiago Alves e Maria Angélica Minhoto (2013, p. 15), quando afirmam:

Outro elemento que chama a atenção como especificidade das capitais é a participação da oferta na iniciativa privada. Comparativamente à participação da rede privada no total da matrícula nos Estados, as capitais apresentam em geral o dobro e às vezes até o triplo da oferta. Este fenômeno certamente tem relação com o poder aquisitivo das populações, ou seja, a possibilidade de concentração de renda nas capitais dos estados gera mercado para educação privada.

Para o tema que nos interessa aqui, financiamento da educação especial, cabe considerar a participação da rede privada no atendimento ao público da educação especial, observada ao longo da história. À frente, serão apresentadas 
análises sobre a dependência administrativa municipal. No que se refere à oferta da educação especial, as dependências administrativas estadual, federal e privada apresentaram um movimento de matrículas pouco expressivo se comparado ao movimento de matrículas por dependência administrativa no Brasil, conforme já apresentado, no período de 2008 a 2010. É o que podemos observar no Gráfico 8.

Gráfico 8 - Movimento de matrículas da educação especial - Vitória/ES por Dependência Administrativa 2008 a 2010

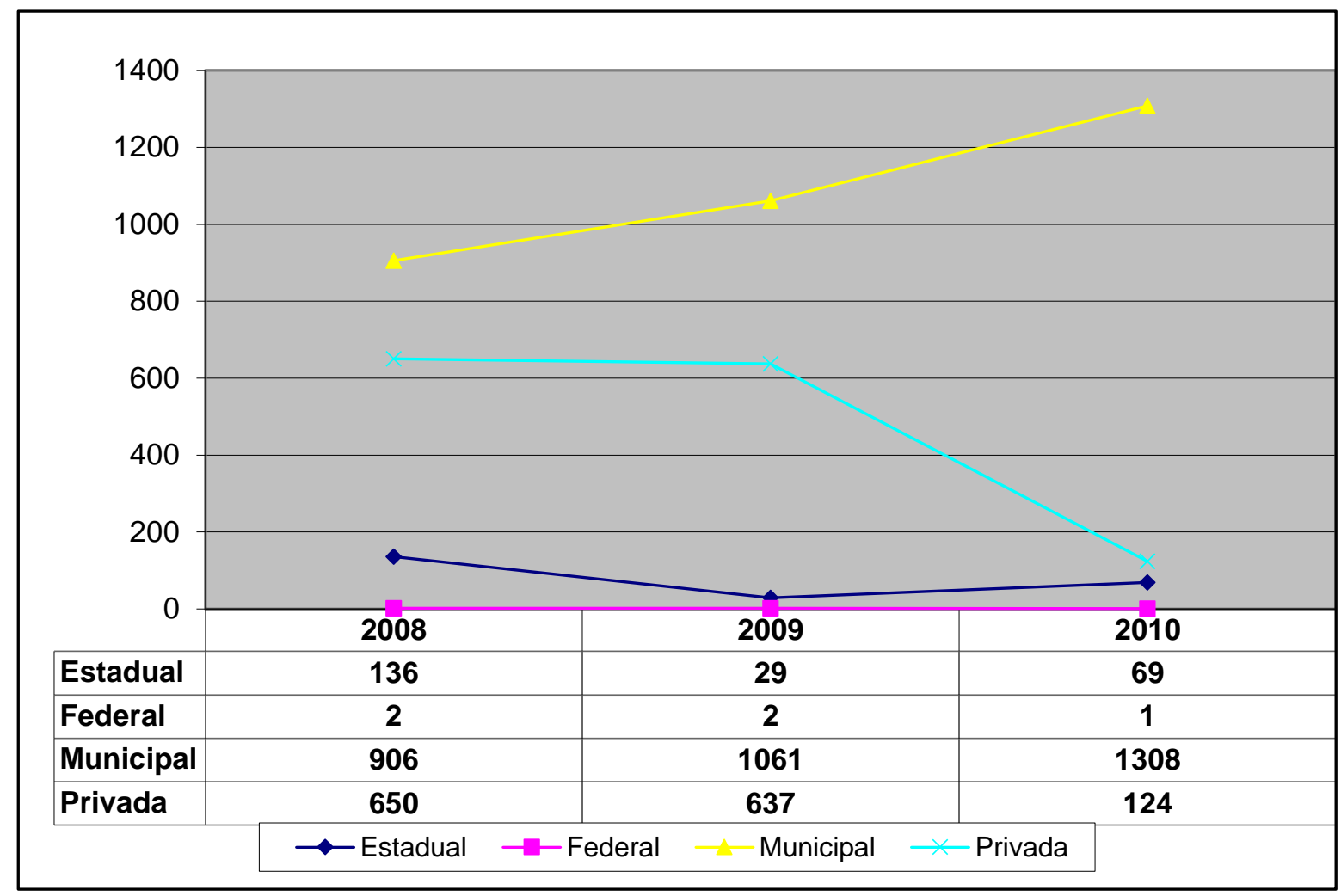

Fonte: Inep/Censo Escolar 2008, 2009 e 2010. Elaboração Própria.

A participação estadual e federal na oferta de matrícula de educação especial era ínfima, aproximadamente de 8\% em 2008, 1,7\% em 2009 e 4,6\% em 2010 e de 0,1\% em 2008, 2009 e 2010 do total, respectivamente. Faz-se necessário destacar o aumento de 138\% no número de matrículas de 2009 (26) para 2010 (69) na rede estadual de ensino de Vitória. A rede privada apresentou uma participação importante na oferta dessa modalidade de ensino, aproximadamente 38,4\% (650) em 2008, 36,8\% (637) em 2009 e 8,3\% (124) em 2010 do total, com um decréscimo de $81 \%$ de matrículas no período de 2008 a 2010 em classes comuns e escolas exclusivamente especializadas da esfera privada de ensino. Vale destacar que essa 
queda no número de matrículas da educação na rede privada de ensino pode ser compreendida a partir das mudanças na legislação nacional (Decreto nํㅜ 6.571/2008, Resolução no-4/2009) e estadual (Resolução no 2.152, de 7 de janeiro de 2010) que estabeleceram novas diretrizes para a oferta e financiamento do atendimento educacional especializado, de forma complementar ou suplementar ao ensino regular, desencadeando a reorganização dos atendimentos das escolas especiais, transformadas em centros de atendimento educacional especializado, a fim de garantir recursos com as matrículas dos alunos com deficiência, TGD e altas habilidades/superdotação. Esse processo, fez com que muitos alunos que frequentavam exclusivamente as escolas especiais (a Apae no caso do município de Vitória) ingressassem na rede regular de ensino.

A rede municipal de ensino de Vitória era a principal responsável pela oferta da educação especial, com participação de aproximadamente 53,5\% em 2008, $61,4 \%$ em 2009 e 87\% em 2010. Esses dados confirmam a tendência, observada por Prieto (2001) e Bassi (2012), de expansão das matrículas na educação especial na dependência administrativa municipal.

Assim, direcionando nossa análise à dependência administrativa municipal, observamos uma participação significativa, de aproximadamente 53\% em 2008 e $54 \%$ em 2009 e 2010, na oferta educacional e na atuação prioritariamente na educação infantil, no ensino fundamental, na educação especial e na EJA, como podemos observar no Gráfico 9. Nesse sentido, esse panorama retrata a lógica que se iniciou com o Fundef e continua com o Fundeb, ou seja, maior número de matrículas de ensino fundamental e educação infantil no âmbito municipal. 
Gráfico 9 - Movimento de matrículas da educação básica por etapas e modalidades na rede municipal de ensino de Vitória - Vitória/ES 2008, 2009 e 2010

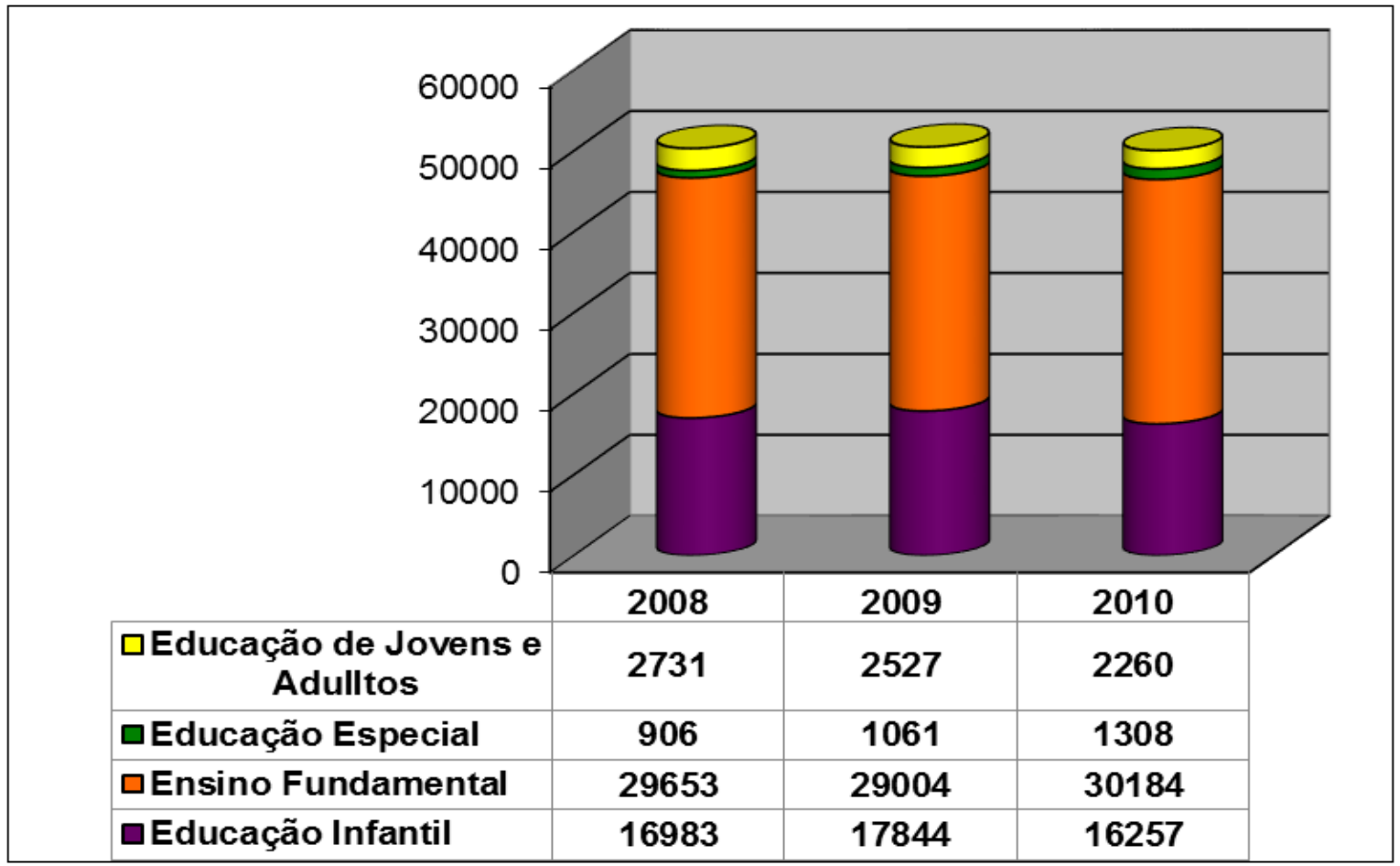

Fonte: Inep/Censo Escolar 2008, 2009 e 2010. Elaboração própria.

Observamos que a rede de ensino municipal de Vitória, no que se refere à educação básica, teve um decréscimo no número de matrículas de aproximadamente 0,5\% (264 matrículas) entre 2008 a 2010, acompanhando o movimento de matrículas no âmbito nacional. Observamos ainda alterações na composição de matrículas. A educação infantil apresentou uma variação no período de 2008 a 2010, com um crescimento de 5\% (861 matrículas) de 2008 para 2009 e um decréscimo de $9 \%$ (1.587 matrículas) em 2010. Esse período coincide com a ampliação da obrigatoriedade estendida às crianças de seis anos de idade, que passaram a ser matriculadas no ensino fundamental (BRASIL, 2006a). Este último teve retração de matrícula de 2\% (649 matrículas) de 2008 para 2009. De acordo com Silva (2014) e Costa (2014), os fatores que podem explicar, em parte, esse resultado estão relacionados à política do Fundef e à "correção do fluxo escolar, ou seja, a redução da distorção idade/ano de escolaridade das crianças do ensino fundamental" (COSTA, 2014, p. 122). Cabe ressaltar que, em 2010, as matrículas do ensino fundamental retomaram o seu crescimento. Assim, a participação da rede municipal na oferta do ensino fundamental era de aproximadamente $70 \%$, ficando a 
rede estadual com $2 \%$ e as instituições privadas de ensino com $28 \%$ nos anos de 2008, 2009 e 2010.

Em síntese, constatamos que o número de matrículas, no ano de 2008, na rede municipal de ensino de Vitória correspondia a 50.273, assim distribuídas: 16.983 na educação infantil, 29.653 no ensino fundamental, 2.731 na EJA. Desse quantitativo, 906 apresentavam deficiência, TGD e altas habilidades/superdotação. No ano de 2009, o número de matrículas aumentou para 50.436, sendo 17.844 na educação infantil, 29.004 no ensino fundamental, 2.527 na EJA e 1.061 na educação especial. No ano de 2010, houve uma redução no número total de matrículas para 50.009. Entretanto, observamos mudanças no quantitativo de matrículas nas etapas e modalidades de ensino. As matrículas de educação infantil e da EJA apresentaram um decréscimo, para 16.257 e 2.260, respectivamente. Em contraposição, houve um aumento no número de matrículas no ensino fundamental e educação especial: 30.184 e 1.308, respectivamente, 5\% e 19\% a mais, em relação ao ano anterior.

Cabe ressaltar que a evolução das matrículas de educação especial, na rede municipal de ensino de Vitória, registrou trajetória de expansão do atendimento, como podemos observar no movimento de matrículas totais em classes comuns, apresentado no Gráfico 10. O número de matrículas teve um crescimento de aproximadamente $44 \%$ no período de 2008 a 2010 .

Gráfico 10 - Movimento de matrículas totais em classe comum da educação especial na rede municipal de ensino de Vitória Vitória/ES 2008, 2009 e 2010

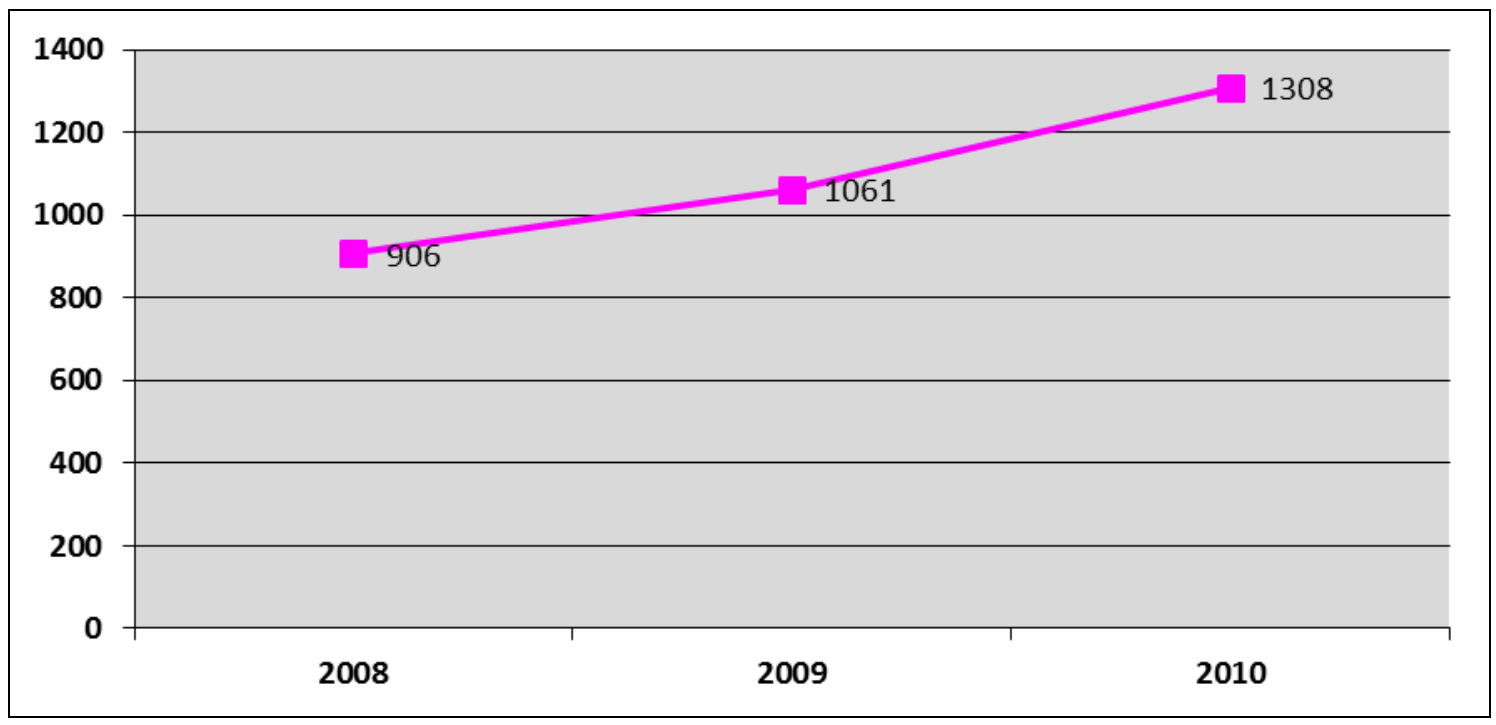

Fonte: Inep/Censo Escolar 2008, 2009 e 2010. Elaboração própria. 
A ampliação do atendimento do público da educação especial em classes comuns na rede de ensino municipal de Vitória corrobora com o movimento de matrículas dessa modalidade no âmbito nacional. De acordo com os dados do Censo Escolar, as matrículas de alunos com deficiência, TGD e altas habilidades em classes comuns na rede pública no Brasil tiveram um aumento 1\%, de 695.699, em 2008, e para 702.603, em 2010. Essa tendência também foi observada por Bassi (2012) quando afirma a preponderância das matrículas nas classes comuns do setor público. Cumpre destacar que as políticas de educação especial em nível nacional, como a PNEE-EI/2008 e a Resolução no 4/2009, apontam para a matrícula dessa população na rede regular de ensino.

A seguir, apresentamos a distribuição das matrículas da educação especial por etapas e modalidades, na rede municipal de ensino de Vitória, nos anos de 2008, 2009 e 2010, dispostos na Tabela 19.

Tabela 19 - Matrículas da educação especial por etapas e modalidades Vitória/ES 2008, 2009 e 2010

\begin{tabular}{|c|c|c|c|}
\hline \multirow{2}{*}{ ETAPAS E MODALIDADES } & \multicolumn{3}{|c|}{ ANO } \\
\hline & 2008 & 2009 & 2010 \\
\hline Educação Infantil & 123 & 161 & 151 \\
\hline Ensino Fundamental & 735 & 850 & 1.053 \\
\hline EJA & 48 & 50 & 104 \\
\hline TOTAL & 906 & 1.061 & 1.308 \\
\hline
\end{tabular}

Fonte: SIMEC 2008, 2009 e 2010. Elaboração própria.

Com base nas informações da Tabela 19, observamos que do total de matrículas da educação especial na rede municipal de ensino de Vitória, havia prevalência de matrículas no ensino fundamental (81\% em 2008, 80\% em 2009 e $81 \%$ em 2010). Esse resultado corrobora o movimento de matrículas no Brasil e no estado do Paraná, observado por Silvia Márcia Ferreira Meletti (2014), em que as 
matrículas estavam concentradas no ensino fundamental, etapa obrigatória de ensino.

O número de matrículas na EJA representava 5\% em 2008 e 2009 e 8\% em 2010. Esse percentual reduzido de matrículas do público de educação especial na EJA, segundo Meletti e Bueno (2011, p. 11), mostra a "[...] expressão localizada do problema que envolve toda a educação básica no Brasil, qual seja a de que, apesar do incremento das matrículas em geral, os níveis de aprendizagem são muito baixos, o que implica retorno à escola por essa modalidade".

$\mathrm{Na}$ educação infantil, o percentual correspondia a 14\% em 2008, 15\% em 2009 e 12\% em 2010. Em relação à educação infantil, Mendes (2006b, p. 4) afirma que, no contexto atual do nosso sistema educacional, ainda identificamos tímidas iniciativas de atendimento a essa população, porque

[...] ainda parece escasso o processo de atenção a essa população na faixa etária de zero a seis anos, sendo que uma política de inclusão poderia caminhar no sentido da universalização, num momento onde [sic] há uma bandeira mais ampla no país, que defende a ampliação das oportunidades educacionais na educação infantil para todas as crianças.

Os dados apresentados na Tabela 20 mostraram as matrículas de alunos com deficiência (física, intelectual, visual e auditiva), TGD (autismo infantil, síndrome de Asperger, síndrome de Rett e transtorno desintegrativo da infância) e altas habilidades/superdotação, na rede municipal de ensino de Vitória, nos anos de 2008, 2009 e 2010, de acordo com as categorias estabelecidas pelo Censo Escolar. Cabe destacar que, no ano de 2008, ainda apareciam as categorias Síndrome de Down (incluída na deficiência intelectual) e transtornos invasivos (integrada às categorias específicas vinculadas ao TGD), que foram extintas nas últimas edições do Censo Escolar (2009, 2010, 2011, 2012 e 2013). Podemos observar ainda as diferenças no número de matrículas do público da educação especial nas fontes oficiais do governo federal. Desse modo, as discrepâncias observadas em dados referentes a um mesmo ano nas diferentes fontes oficiais, dificulta o levantamento estatístico das pessoas com deficiência, TGD e altas habilidades/superdotação, bem como a constituição de políticas públicas destinadas à essa população (MELETTI; BUENO, 2011), tendo em vista que os dados obtidos em tais levantamentos são 
determinantes para a elaboração e implementação de ações voltadas à educação especial.

Tabela 20- Número de matrículas por deficiência, TGD e altas habilidades/superdotação na rede municipal de ensino de Vitória -Vitória/ES 2008, 2009 e 2010

\begin{tabular}{|c|c|c|c|c|c|c|c|c|c|}
\hline \multirow{2}{*}{$\begin{array}{c}\text { ANO } \\
\text { FONTE DE DADOS }\end{array}$} & \multicolumn{3}{|c|}{2008} & \multicolumn{3}{|c|}{2009} & \multicolumn{3}{|c|}{2010} \\
\hline & Simec $^{97}$ & $\begin{array}{c}\text { Seme- } \\
\text { Vitória }^{98}\end{array}$ & $\begin{array}{l}\text { Micro- } \\
\text { dados }\end{array}$ & Simec & $\begin{array}{l}\text { Seme- } \\
\text { Vitória }\end{array}$ & $\begin{array}{l}\text { Micro- } \\
\text { dados }\end{array}$ & Simec & $\begin{array}{l}\text { Seme- } \\
\text { Vitória }\end{array}$ & $\begin{array}{l}\text { Micro- } \\
\text { dados }\end{array}$ \\
\hline Cegueira & - & - & 9 & 7 & 7 & 9 & 7 & 8 & 13 \\
\hline Baixa Visão & - & - & 70 & 60 & 47 & 55 & 39 & 60 & 79 \\
\hline Surdez & - & - & 42 & 76 & 51 & 56 & 51 & 47 & 59 \\
\hline Def. Auditiva & - & - & 33 & 64 & 38 & 51 & 27 & 51 & 63 \\
\hline Surdocegueira & - & - & 0 & 0 & 1 & 2 & 0 & 0 & 0 \\
\hline Def. Física & - & - & 65 & 75 & 64 & 74 & 54 & 115 & 145 \\
\hline Def. Intelectual & - & - & 217 & 505 & 381 & 471 & 423 & 605 & 848 \\
\hline $\begin{array}{l}\text { Síndrome de Down } \\
\text { Transtornos }\end{array}$ & - & - & 54 & 0 & 0 & 0 & 0 & 0 & 0 \\
\hline Invasivos & - & - & 268 & 0 & 0 & 0 & 0 & 0 & 0 \\
\hline $\begin{array}{l}\text { Autismo Clássico } \\
\text { Síndrome de }\end{array}$ & - & - & 0 & 49 & 47 & 47 & 53 & 53 & 64 \\
\hline Asperger & - & - & 0 & 17 & 13 & 19 & 13 & 21 & 26 \\
\hline $\begin{array}{l}\text { Síndrome de Rett } \\
\text { TDI (Trans.Des. }\end{array}$ & - & - & 0 & 2 & 1 & 1 & 2 & 2 & 2 \\
\hline Infância) & - & - & 0 & 50 & 29 & 39 & 42 & 39 & 56 \\
\hline $\begin{array}{l}\text { Deficiência Múltipla } \\
\text { Altas }\end{array}$ & - & - & 66 & 92 & 75 & 91 & 94 & 80 & 105 \\
\hline Hab./Superdotação & - & - & 82 & 328 & 342 & 322 & 126 & 420 & 628 \\
\hline TOTAL & - & 1.020 & 906 & 1.325 & 1.096 & 1.237 & 931 & 1.501 & 2.088 \\
\hline
\end{tabular}

Fonte: Simec, Seme-Vitória e Inep/ Microdados do Censo Escolar 2008, 2009 e 2010. Elaboração própria.

Como a Tabela 20 evidenciou, a deficiência que apresentava maior incidência de matrículas era de alunos classificados na categoria deficiência intelectual. Esse resultado apareceu também no estudo realizado por Loureiro e Caiado (2013). Desse modo, o número de matrículas de alunos com deficiência, TGD e altas habilidades/superdotação no município de Vitória mostrou que os municípios, no Brasil, além de serem

\footnotetext{
${ }^{97}$ No Simec não estavam disponíveis os dados por deficiência, TGD e altas habilidades/superdotação do ano de 2008.

${ }^{98}$ Nos dados apresentados pela Seme-Vitória não foram especificados o número de matrículas por deficiência, TGD e altas habilidades/superdotação do ano de 2008.
} 
[...] interpelados a assumir a educação infantil e o ensino fundamental, recebem também como tarefa a criação ou manutenção de uma estrutura referente à educação especial ou, em alguns casos, na instituição de serviços identificados como promotores de uma educação escolar "inclusiva" [...] A chamada perspectiva "inclusiva" vem confrontando as redes municipais de ensino a uma reorganização propondo novas demandas e redefinindo competências e responsabilidades. (GARCIA, 2008, p. 4).

Entretanto, esse contexto também nos faz pensar/questionar acerca das pessoas que estavam na escola, mas não foram identificadas, ou estavam privadas do convívio social, sem o direito à educação e, consequentemente, sem nenhum tipo de atendimento, seja por instituição especializada, seja por escola regular.

Em síntese, a trajetória de atendimento público municipal de Vitória teve um percurso semelhante ao movimento de matrículas em nível nacional, em que, como apontado por Gouveia, Alves e Minhoto (2013), a educação infantil cresceu, o ensino fundamental teve uma retração de matrículas e as modalidades (educação especial e EJA) apresentaram uma tendência crescente.

Faz-se necessário destacar que as alterações no movimento de matrículas no município de Vitória ocorreram no âmbito da implantação do Fundeb, que passou a vigorar em 2007 e reorientou os recursos para todas as etapas e modalidades da educação básica. Assim, os dados apontam que o Fundeb tem contribuído para o aumento do número de matrículas de etapas e modalidades que antes não eram contempladas pelo Fundef, uma vez que os recursos estavam restritos ao ensino fundamental.

O movimento no número de matrículas, ou seja, sua expansão ou retração, implica diretamente o quantitativo de recursos voltados à educação, tendo em vista o número de profissionais em educação e os gastos com a manutenção e desenvolvimento das etapas e modalidades de ensino no âmbito do município, na tentativa de garantir atendimento com qualidade aos alunos matriculados da rede municipal de ensino. No próximo item, apresentaremos a história da educação especial na rede municipal de ensino de Vitória. 


\subsubsection{A história da educação especial na rede municipal de ensino de Vitória}

O município de Vitória, desde a década de 1990, vem desenvolvendo ações direcionadas ao atendimento ao público da educação especial.

Em 1995, a Seme-Vitória implantou o programa "Sucesso Escolar", no qual a política de atendimento aos alunos com deficiência, TGD e altas habilidades/superdotação se tornou prioritária. Em 1999, foi desenvolvido o projeto “Unidade Pólo" (GOBETE, 2005), que consistia no oferecimento de serviços de apoio especializado nas escolas comuns da rede, localizadas nas regiões administrativas do município. Com a implantação do projeto, o atendimento educacional especializado se dava em espaços específicos, denominados "Laboratório Pedagógico", que eram acompanhados e assessorados por profissionais da equipe de educação especial localizados na Seme-Vitória. Era oferecido atendimento na área de deficiência visual, intelectual e auditiva em horário contrário ao ensino comum, por professor de educação especial. Cumpre destacar que, nesse contexto, a administração municipal passou a oferecer estágios remunerados a alunos que cursavam licenciatura, para atuarem nas escolas de modo a auxiliar nas atividades do professor, especialmente, no trabalho com os alunos com deficiência, TGD e altas habilidades/superdotação (GOBETE, 2005).

Em 2002, a Seme-Vitória reconfigurou a forma de atendimento aos alunos da educação especial, dando ênfase à implantação dos laboratórios pedagógicos em diferentes escolas de ensino fundamental e educação infantil. Os referidos laboratórios eram assim caracterizados, no Plano de Trabalho - 2003:

Serviços de apoio à escolarização, montados em espaços próprios e equipados de acordo com as necessidades dos alunos. Os serviços são prestados por um coordenador e professores especializados nas áreas de DM, DA, DV e Altas Habilidades para atender aos alunos que apresentam NEE de forma individual ou em pequenos grupos. (VITÓRIA, 2003, p. 8).

O atendimento nesses espaços era realizado duas ou três vezes por semana no turno oposto ao do ensino regular. Nesse contexto, foi instituída a função do coordenador do laboratório pedagógico, objetivando a descentralização das ações 
de assessoria. Assim, os coordenadores passaram a atuar nas escolas de cada região, embora compusessem a equipe de educação especial da Seme-Vitória. Eles tinham diversas funções, que envolviam o planejamento das ações do laboratório pedagógico; o encaminhamento de alunos para avaliação em instituições conveniadas a PMV; a organização e orientação do trabalho dos estagiários; e a articulação das atividades dos professores do laboratório e demais profissionais da escola (VITÓRIA, 2003).

No decorrer dos anos, esse modelo de atendimento sofreu inúmeras críticas por parte dos profissionais, das famílias e das análises de estudos (ALMEIDA, 2004; GOBETE, 2005; MARTINS, 2005) desenvolvidos no âmbito do município pelo Programa de Pós-Graduação em Educação da Ufes, principalmente, pela desarticulação entre as práticas pedagógicas desenvolvidas nos laboratórios pedagógicos e nas salas de aula. Em 2007, a Cfaee redimensionou a coordenação de serviços especializados para a equipe de gestão da escola, e a função de coordenador foi extinta. Assim previa o Plano de Trabalho - 2007:

Cada unidade de ensino, de acordo com sua própria demanda, e a partir da gestão de seus recursos e/ou busca de recursos próprios via caixa escolar, adquirirá seus equipamentos, materiais didáticos, ampliação de seus espaços, dentre outros recursos necessários provenientes do FNDE/EE, SEME/CFAEE, SEME/GGD, ao atendimento dos alunos com necessidades educacionais especiais ${ }^{99}$. (VITÓRIA, 2007c, p. 5).

Para efetivação das ações pedagógicas no atendimento educacional especializado, esse documento enfatizava a necessidade do trabalho colaborativo entre professores especializados e o professor da classe comum, seja no acompanhamento ao aluno no contexto da sala de aula e/ou nos momentos de planejamento quando discutiam os processos de aprendizagem dos alunos.

Os planos de trabalho de 2008 e 2009 apontavam para a continuação do trabalho colaborativo nas unidades de ensino de modo a garantir o atendimento educacional especializado aos alunos com deficiência, TGD e altas habilidades/superdotação. Contudo, os professores das áreas de surdos, de deficiência visual e de deficiência múltipla passaram a atuar em caráter de

${ }_{99}$ Termo utilizado no Plano de Trabalho da Cfaee para se referir ao público da educação especial. 
itinerância nas escolas, no intuito de orientar os professores e encaminhar para diagnósticos os alunos com indicativos de necessidades de apoio, complementação e suplementação na educação especial (VITÓRIA, 2008c). Para os professores da área de altas habilidades/superdotação, a localização do trabalho seria no Centro de Desenvolvimento de Potencial e do Talento de Vitória100 (Cedet), a partir do desenvolvimento das oficinas, projetos de enriquecimento curricular e oferecimento de assessorias às escolas.

Faz-se necessário ressaltar que a PMV, ao longo da sua história de atendimento à população de educação especial (desde a década de 1990 até a presente data), estabeleceu convênios, contratos e parcerias com algumas instituições, como Apae, Oficina Artes de Vitória, Clínicas Psiquiátricas e Psicológicas, Associação Brasileira para Altas Habilidades/Superdotados, entre outras, com o objetivo de oferecer outros atendimentos necessários para o desenvolvimento dos alunos. Os alunos eram encaminhados, a esses atendimentos, pela equipe pedagógica da escola e família com apoio, quando necessário, dos profissionais que atuavam na Secretaria (VITÓRIA, 2007c; 2008c).

No ano de 2009, a Cfaee redimensionou 0 atendimento educacional especializado nas unidades de ensino, a fim de garantir a efetiva oferta desse serviço nas salas de recursos multifuncionais, aprimorar as práticas pedagógicas e disseminar as discussões acerca da educação inclusiva no cotidiano da escola. Segundo consta no Plano de Trabalho - 2008/2009, o objetivo era

[...] alavancar um trabalho pedagógico que sustente e efetive a política de inclusão no município de Vitória, assim como instigue e potencialize todos os profissionais das escolas para a busca de ações educativas que contemplem não apenas uns, mas todo o alunado da escola, em seu compromisso e função social, que é a de ensinar a todos. (VITÓRIA, 2008c, p. 5).

Cumpre destacar que o atendimento educacional especial, como ação complementar ou suplementar para subsidiar a aprendizagem de alunos com

100 O Cedet foi idealizado pela professora ZenitaGuenther, em 1992, na cidade de Lavras, Minas Gerais, como um espaço para dinamização da metodologia Caminhos para Desenvolver Potencial e Talento - Cedet - e para oferecimento de apoio ao aluno com altas habilidades/superdotação em diferentes escolas, nos diferentes sistemas de ensino. No município de Vitoria, o Cedet oferecia aos alunos possibilidade de participar de diferentes projetos e áreas do conhecimento, como línguas e humanidades; ciência e tecnologia; e artes e habilidades de expressão. 
deficiência, TGD e altas habilidades/superdotação e o seu acesso ao currículo escolar, nas salas de recursos multifuncionais, foi iniciado, no município de Vitória, em 2005, de acordo com o Quadro 1.

Quadro 1 - Número de escolas e salas de recursos multifuncionais - Vitória/ES 20052011

\begin{tabular}{|c|c|c|c|c|c|c|c|c|}
\hline \multirow{2}{*}{ ANO } & \multicolumn{2}{|c|}{ TIPO $\mathbf{1}^{\mathbf{1 0 1}}$} & \multicolumn{2}{c|}{ TIPO $\mathbf{2}^{\mathbf{1 0 2}}$} & \multicolumn{2}{c|}{$\begin{array}{c}\text { KITS DE } \\
\text { ATUALIZAÇÃO }\end{array}$} & \multicolumn{2}{c|}{ TOTAL GERAL } \\
\cline { 2 - 8 } & $\begin{array}{c}\text { No } \\
\text { ESCOLAS }\end{array}$ & $\begin{array}{c}\text { No } \\
\text { SRMs }\end{array}$ & $\begin{array}{c}\text { No } \\
\text { ESCOLAS }\end{array}$ & $\begin{array}{c}\text { No } \\
\text { SRMs }\end{array}$ & $\begin{array}{c}\text { No } \\
\text { ESCOLAS }\end{array}$ & $\begin{array}{c}\text { No } \\
\text { SRMs }\end{array}$ & No ESCOLAS & $\begin{array}{c}\text { No } \\
\text { SRMs }\end{array}$ \\
\hline $\mathbf{2 0 0 5}$ & 1 & 1 & - & - & - & - & 1 & 1 \\
\hline 2008 & 12 & 12 & - & - & - & - & 12 & 12 \\
\hline $\mathbf{2 0 0 9}$ & 21 & 21 & - & - & - & - & 20 & 21 \\
\hline $\mathbf{2 0 1 0}$ & 7 & 7 & 1 & 1 & - & - & 8 & 8 \\
\hline $\mathbf{2 0 1 1}$ & 9 & 9 & 1 & 1 & 1 & 1 & 10 & 11 \\
\hline TOTAL & $\mathbf{5 0}$ & $\mathbf{5 0}$ & $\mathbf{2}$ & $\mathbf{2}$ & $\mathbf{1}$ & $\mathbf{1}$ & $\mathbf{5 1}$ & 53 \\
\hline
\end{tabular}

Fonte: Simec 2005 a 2008. Elaboração própria.

Programa Salas de Recursos Multifuncionais disponibilizava equipamentos, mobiliários, materiais didáticos e pedagógicos para organização das salas e a oferta do atendimento educacional especializado. Assim, ao final de 2011, 51 escolas do município de Vitória ofereciam atendimento educacional especializado, em 53 salas de recursos multifuncionais, incluindo unidades de educação infantil e ensino fundamental, tendo uma escola sido contemplada com duas salas do tipo I e outra

101 A sala do Tipo I incluía os seguintes itens: equipamentos - 2 microcomputadores, 1 laptop, 1 estabilizador, 1 scanner, 1 impressora laser, 1 teclado com colmeia, 1 acionador de pressão, mouse com entrada para acionador, 1 lupa eletrônica; Mobiliários: 1 mesa redonda, 4 cadeiras, 1 mesa para impressora, 1 armário, 1 quadro branco, 2 mesas para computador, 2 cadeiras; Materiais didáticos pedagógicos:1 material dourado,1 esquema corporal,1 bandinha rítmica, 1 memória de numerais I, tapete alfabético encaixado, 1 software comunicação alternativa, 1 sacolão criativo monta-tudo, 1 quebra-cabeças sequência lógica, 1 dominó de associação de ideias, 1 dominó de frases, 1 dominó de animais em libras, 1 dominó de frutas em libras, 1 dominó tátil, 1 alfabeto Braille, 1 kit de lupas manuais, 1 plano inclinado, e 1 memória tátil (BRASIL, 2010g).

102 A sala do tipo 2 contém todos os recursos da sala do tipo I, adicionados os recursos de acessibilidade para alunos com deficiência visual: 1 impressora em Braille, 1 máquina de datilografia em Braille, 1 reglete de mesa, 1 punção, 1 soroban, 1 guia de assinatura, 1 kit de desenho geométrico e 1 calculadora sonora (BRASIL, 2010g).

${ }_{103}$ Os kits de atualização no ano de 2011 foram compostos por recursos de tecnologia assistiva destinados ao atendimento educacional especializado dos alunos com deficiência visual: 1 impressora Braille, 1 scanner com voz, 1 máquina de escrever em Braille, 1 globo terrestre tátil, 1 calculadora sonora, 1 kit de desenho geométrico, 2 regletes de mesa, 4 punções, 2 soroban, guias de assinatura, 1 caixinha de números e 2 bolas com guizo (BRASIL, 2010g). 
escola com uma sala de tipo II e um kit de atualização, como podemos visualizar no Quadro 2.

Quadro 2 - Unidades de ensino que receberam salas do Programa Implantação de Salas de Recursos Multifuncionais 2005-2011

\begin{tabular}{|c|c|c|c|}
\hline & ESCOLAS & TIPO DE SRMS & QUANT. \\
\hline \multirow{9}{*}{ 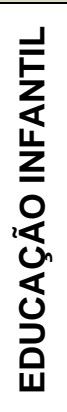 } & CMEI ANA MARIA CHAVES COLARES & Tipo I & 1 \\
\hline & CMEI CECILIA MEIRELES & Tipo I & 1 \\
\hline & CMEI DR DENIZART SANTOS & Tipo I & 1 \\
\hline & CMEI JACYNTHA FERREIRA DE SOUZA SIMOES & Tipo I & 1 \\
\hline & CMEI JOAO PEDRO DE AGUIAR & Tipo I & 1 \\
\hline & CMEI MAGNOLIA DIAS MIRANDA CUNHA & Tipo I & 1 \\
\hline & CMEI RUBEM BRAGA & Tipo I & 1 \\
\hline & CMEI ZELIA VIANA DE AGUIAR & Tipo I & 1 \\
\hline & CMEI ZENAIDE GENOVEVA MARCARINI CAVALCANTI & Tipo I & 1 \\
\hline \multirow{31}{*}{ 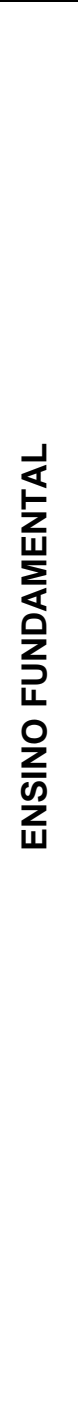 } & EMEF ADAO BENEZATH & Tipo I & 1 \\
\hline & EMEF ADEVALNI S FERREIRA DE AZEVEDO & Tipo I & 1 \\
\hline & EMEF ADILSON DA SILVA CASTRO & Tipo I & 1 \\
\hline & EMEF ALBERTO DE ALMEIDA & Tipo I & 1 \\
\hline & EMEF ALVARO DE CASTRO MATTOS & Tipo I & 1 \\
\hline & EMEF ALVIMAR SILVA & Tipo I & 1 \\
\hline & EMEF AMILTON MONTEIRO DA SILVA & Tipo I & 1 \\
\hline & EMEF ANACLETA SCHNEIDER LUCAS & Tipo I & 1 \\
\hline & EMEF ARISTOBULO BARBOSA LEAO & Tipo I & 1 \\
\hline & EMEF ARTHUR DA COSTA E SILVA & Tipo I & 1 \\
\hline & EMEF CASTELO BRANCO & Tipo I & 1 \\
\hline & EMEF CECILIANO ABEL DE ALMEIDA & Tipo I & 1 \\
\hline & EMEF CUSTODIA DIAS DE CAMPOS & Tipo I & 1 \\
\hline & EMEF EBER LOUZADA ZIPPINOTTI & Tipo I & 1 \\
\hline & EMEF ELIANE RODRIGUES DOS SANTOS & Tipo I & 1 \\
\hline & EMEF ELZIRA VIVACQUA DOS SANTOS & Tipo I & 1 \\
\hline & EMEF EXPERIMENTAL DE VITORIA - UFES & Tipo I & 1 \\
\hline & EMEF FRANCISCO LACERDA DE AGUIAR & Tipo I & 1 \\
\hline & EMEF HELOISA ABREU JUDICE DE MATTOS & Tipo I & 1 \\
\hline & EMEF IRMA JACINTA SOARES DE SOUZA LIMA & Tipo I & 2 \\
\hline & EMEF IZAURA MARQUES DA SILVA & Tipo I & 1 \\
\hline & EMEF JOSE AUREO MONJARDIM & Tipo I & 1 \\
\hline & EMEF JUSCELINO KUBITSCHEK DE OLIVEIRA & Tipo I & 1 \\
\hline & EMEF LENIR BORLOT & Tipo I & 1 \\
\hline & EMEF MAL MASCARENHAS DE MORAES & Tipo I & 1 \\
\hline & EMEF MARIA JOSE COSTA MORAES & Tipo I & 1 \\
\hline & EMEF MARIA LEONOR PEREIRA DA SILVA & Tipo I & 1 \\
\hline & EMEF MARIA MADALENA DE OLIVEIRA DOMINGUES & Tipo II e Kit & 2 \\
\hline & EMEF MARIETA ESCOBAR & Tipo I & 1 \\
\hline & EMEF MAURO BRAGA & Tipo I & 1 \\
\hline & EMEF MOACYR AVIDOS & Tipo I & 1 \\
\hline
\end{tabular}




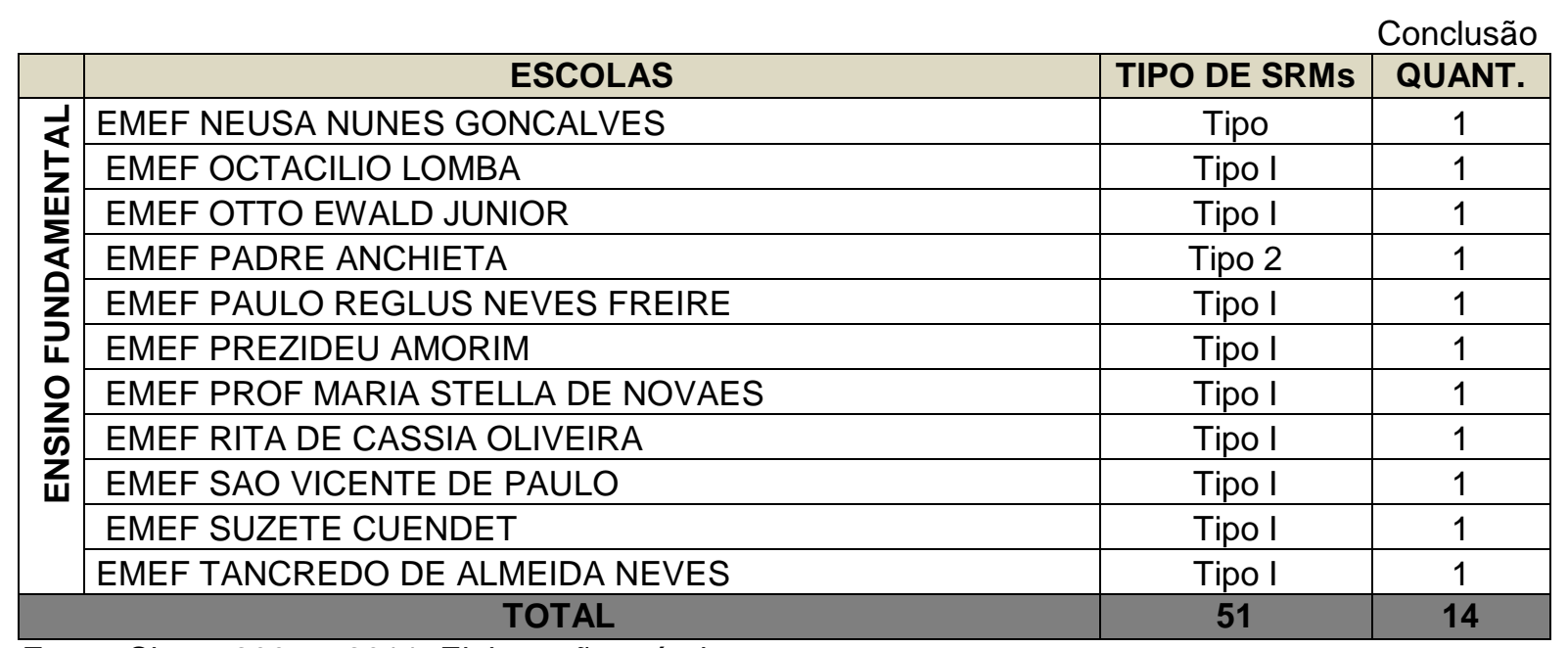

Fonte: Simec 2005 a 2011. Elaboração própria.

O município de Vitória disponibilizava professores de educação especial para o atendimento educacional especializado, no turno oposto ao do ensino regular (na própria escola), nas áreas de deficiência intelectual, TGD, deficiência física, deficiência visual (ensino do código Braille, do sorobã e orientação e mobilidade), na área de surdos, com a política de educação bilíngue (professor bilíngue, instrutor de Língua Brasileira de Sinais - Libras - e tradutor/intérprete de Libras) e na área das altas habilidades/superdotação, em espaço específico, com o objetivo de atender os interesses dos alunos nas diferentes áreas do conhecimento, com proposta de planos de trabalhos individualizados e/ou coletivos e na busca de parcerias com instituições superiores, técnicas, de esporte, de artes, entre outras (VITÓRIA, 2008c). Entretanto, o município não tinha concurso específico para professores de educação especial e, portanto, uma classificação funcional para esses profissionais. Esses professores eram selecionados por meio de um processo interno, do quadro efetivo da PMV, da educação infantil e do ensino fundamental, ou eram admitidos em regime de contratação temporária (VITÓRIA, 2008c). Situações como essa são resultantes, conforme Ferreira J. (2005, p. 63), de "[...] medidas administrativas muitas vezes dissociadas da ampliação de recursos orçamentários e do compromisso com a qualidade".

Para atuar como professor de educação especial nas salas de recursos multifuncionais e, no contexto da escola, como apoio e/ou em colaboração com o professor regente em sala de aula, o professor deveria ter formação específica na educação especial. Suas atribuições abrangeriam a produção e a organização dos 
serviços, recursos pedagógicos e estratégias de acordo com as necessidades específicas dos alunos; a organização e planejamento dos atendimentos, 0 estabelecimento de parcerias com áreas intersetoriais na elaboração de estratégias e na disponibilização de recursos de acessibilidade, orientação de professores e famílias e articulação com os professores de sala de aula comum visando à participação dos alunos nas atividades escolares.

O número de profissionais que atuavam nos anos de 2008, 2009 e 2010 foi registrado no Quadro 3.

Quadro 3 - Profissionais que atuavam na educação especial na rede municipal de ensino de Vitória - Vitória/ES 2008, 2009 e 2010

\begin{tabular}{|c|c|c|c|}
\hline \multirow{2}{*}{ PROFISSIONAIS } & \multicolumn{3}{|c|}{ ANO } \\
\hline & 2008 & 2009 & 2010 \\
\hline Deficiência intelectual e múltipla & 88 & 119 & 128 \\
\hline Deficiência visual & 18 & 18 & 18 \\
\hline Altas habilidades/superdotação & 10 & 10 & 13 \\
\hline Surdo ${ }^{104}$ & 38 & 43 & 39 \\
\hline TOTAL & 154 & 190 & 198 \\
\hline Estagiários & _- & _- & 494 \\
\hline Auxiliares de Suporte Operacional (ASO) ${ }^{105}$ & - & - & 17 \\
\hline TOTAL GERAL & 154 & 190 & 709 \\
\hline
\end{tabular}

Fonte: Setor de Educação Inclusiva - Seme-Vitória 2008, 2009 e 2010.

Para o desenvolvimento do trabalho na educação especial, o município dispunha, em 2008, de 154 professores das áreas de deficiência intelectual, de deficiência múltipla, de deficiência visual, de surdos e de altas habilidades/superdotação. Em 2009, de 190 professores, e, em 2010, de 709, sendo 198 professores, 494 estagiários e 17 auxiliares de suporte operacional. Essas duas últimas categorias não apareceram nos dados informados pela Seme-Vitória nos anos de 2008 e 2009. Segundo constava no Plano de Trabalho - 2010-2013 da

\footnotetext{
104 Nesse item estavam, incluídos os professores de Libras, professores bilíngues, tradutores, intérpretes e instrutores de Libras.

105 O Agente de Suporte Operacional (ASO) constitui um cargo de nível fundamental na PMV e tem como atribuições executar, sob supervisão, tarefas manuais simples que necessitam de esforço físico, relacionados aos serviços de limpeza, obras, copa-cozinha, segurança patrimonial, e outros serviços em edifícios, logradouros, escolas, creches, ambulatórios, cemitérios e demais instalações municipais (VITÓRIA, 2006b).
} 
Cfaee, para apoio à locomoção, à higienização e à alimentação dos alunos que apresentavam maiores comprometimentos físicos e psíquicos, o município oferecia auxiliares de suporte operacional, além da ação de estudantes de pedagogia e de licenciaturas que realizavam estágio extracurricular (VITÓRIA, 2010a). Faz-se necessário ressaltar que estes últimos eram profissionais com baixa qualificação ou em processo de formação (no caso dos estagiários) e com reduzidos salários, no lugar de outros que deveriam ter características opostas e que, portanto, necessitariam de maior investimento por parte do município.

Cabe destaque o quantitativo de professores da área de deficiência intelectual, considerando que o número maior de alunos identificados, como público da educação especial, no levantamento da Seme-Vitória, apresentava essa deficiência. Merece também destaque o número significativo de estagiários, em 2010, para apoio e acompanhamento dos alunos com deficiência e TGD (VITÓRIA, 2010a).

O município integrava ainda o Programa Escola Acessível, programa vinculado à Diretoria de Políticas de Educação Especial, da Secadi do MEC, tendo como finalidade a promoção de acessibilidade arquitetônica nos prédios escolares e compra de materiais e inclusão de alunos com deficiência, TGD e altas habilidades/superdotação nas classes comuns do ensino regular (BRASIL, 2013c). Os recursos do programa eram repassados por meio do PDDE, que consiste na destinação anual, pelo FNDE, de recursos financeiros, em caráter suplementar, à escola, calculados de acordo com o número de alunos matriculados constantes no Censo Escolar no ano anterior ao do repasse. Esses recursos eram destinados à aquisição de materiais permanentes e bens e/ou à contratação de serviços para construção e adequação de rampas, alargamento de portas e passagens, instalação de corrimão, construção de sanitários e colocação de sinalização visual, tátil e sonora, aquisição de cadeira de rodas, bebedouros e mobiliários acessíveis e outros recursos de tecnologia assistiva (BRASIL, 2013c). No ano de 2008, 20 escolas foram contempladas no programa; em 2009, apenas uma escola, e, em 2010, treze escolas. Assim, ao final de 2010, o município tinha 34 escolas contempladas no Programa Escola Acessível.

No intuito de assegurar a frequência dos alunos com deficiência e TGD ao ensino regular e ao atendimento educacional especializado, a Seme-Vitória concedia 
vales sociais para o transporte público municipal, garantindo o deslocamento desses alunos, na medida em que o local de atendimento em escola de referência - escolas que ofereciam serviços e atendimentos específicos numa área específica de deficiência, concentrando recursos humanos e materiais que atendessem às necessidades específicas dos alunos de uma determinada região do município, -, muitas vezes era distante de seu bairro de residência. Essa ação também se destinava aos alunos com altas habilidades/superdotação que participavam de atividades extracurriculares em diferentes locais da cidade. A seguir delineamos a política de educação especial voltada aos alunos com deficiência, TGD e altas habilidades/superdotação na rede municipal de ensino de Vitória.

\subsubsection{A política de educação especial na rede municipal de ensino de Vitória}

A política de educação especial no município de Vitória estava vinculada às orientações legais nacionais (LDB/1996; PNEE-El/2008), no que tange à política de educação inclusiva, com vistas a garantir o direito dos alunos com deficiência, TGD e altas habilidades/superdotação à educação. E o seu delineamento, no que se refere a princípios, diretrizes, objetivos, público, serviços oferecidos, entre outros, perpassava os documentos gerais da educação do sistema municipal de ensino de Vitória.

Desse modo, tentamos analisar e compreender a política instituída no município, levando em consideração que a concretização dessa política nas escolas envolvia diversos fatores, tais como prioridade de gestão governamental, recursos financeiros e planejamento. Assim, partimos do pressuposto de que as políticas públicas resultam de "[...] múltiplos fatores que se articulam a ponto de formarem uma teia complexa e multifacetada, são de difícil apreensão, requerendo que sejam consideradas suas diferentes ordenações" (PRIETO, 2006, p. 42).

Nesse sentido, a Lei $n^{\circ}$ 4.747/1998, em seu art. 4ํㅜㄹ, inciso I, estabelece, como um dos seus princípios, que o ensino será ministrado com base na "igualdade de condições para o acesso e permanência na escola". E, em seu art. $5^{\circ}$, caput e inciso II, assegura: 
Art. 5o $\mathrm{O}$ dever do município com a educação escolar pública será efetivado mediante a garantia de:

$[\ldots]$

II - atendimento educacional especializado gratuito aos educandos com necessidades educativas especiais ${ }^{106}$, preferencialmente, na rede regular de ensino. (VITÓRIA, 1998a).

Assim, a referida Lei articula-se às principais discussões e políticas educacionais que enfatizam o direito de todos à educação, a partir do atendimento às suas necessidades específicas no contexto da escola. No âmbito dessa Lei, é destinada uma seção específica à educação especial. Nessa perspectiva, na Seção IV, Da Educação Especial, estabelece:

Art. 28. A educação especial, modalidade da educação escolar, para educandos portadores de necessidades educativas especiais, será oferecida, preferencialmente, nas escolas de ensino fundamental, nos Centros de Educação infantil e em centros integrados de educação especial. (VITÓRIA, 1998a).

Dessa maneira, a Lei no 4.747/1998 articula-se aos pressupostos da LDB/1996, que estabelece a educação especial como modalidade da educação escolar que perpassa os diferentes níveis de ensino.

Quanto à definição do público da educação especial, notamos que a política de educação especial, no município de Vitória, adota o conceito abrangente de "Necessidades Educacionais Especiais" da Resolução CNE/CEB no 2/2001:

Art. 5ํㅡㄴ Consideram-se educandos com necessidades educacionais especiais os que durante o processo educacional apresentarem:

I - dificuldades acentuadas de aprendizagem ou limitações no processo de desenvolvimento que dificultem o acompanhamento das atividades curriculares, compreendidas em dois grupos:

a) aquelas não vinculadas a uma causa orgânica específica;

b) aquelas relacionadas a condições, disfunções, limitações ou deficiências;

II - dificuldades de comunicação e sinalização diferenciadas dos demais alunos, demandando a utilização de linguagens e códigos aplicáveis;

III - altas habilidades/superdotação, grande facilidade de aprendizagem que os leve a dominar rapidamente conceitos, procedimentos e atitudes. (BRASIL, 2001d).

106 Termo utilizado na Lei 4.747/98 para se referir ao público da educação especial. 
O conceito de necessidades educacionais especiais amplia o contingente de alunos a ser contemplado pela educação especial, abrangendo inclusive aqueles que apresentam processos diferenciados de aprendizagem que não, necessariamente, estão vinculados à deficiência. Ferreira, J. (1999, p. 2) fala da preocupação dos pesquisadores da área, "de que não se tenha na educação especial um recurso paliativo para o fracasso escolar, em certa medida legitimando os equívocos do ensino regular, o que tenderia a ocorrer com a utilização de categorias muito abrangentes", engendrando novos/outros sujeitos para essa modalidade de ensino. Assim, esse processo nos remete à reflexão acerca da escola, sobre como se organiza, de modo a constituir respostas diversas na organização do seu currículo, dos processos pedagógicos e avaliativos, as quais contemplem as necessidades educacionais dos diferentes sujeitos que compõem o contexto escolar.

Esse conceito também traz implicações diretas para a concretização da política de educação inclusiva no município, pois, uma vez que se adota esse conceito de maneira ampliada, também se expande a área de intervenção desses profissionais e da equipe de educação inclusiva, tendo em vista que a política não se restringe às crianças que apresentam deficiência, TGD e altas habilidades/superdotação, mas abrange um número elevado de alunos que apresentam necessidades adquiridas por diferentes motivos e são rotulados indevidamente e estigmatizados no contexto da escola. Estamos nos referindo, portanto, à contratação de mais profissionais para atuarem nas diferentes escolas do município, a um maior investimento na formação continuada de professores regentes e especializados, à ampliação de locais diversificados de atendimento específico em caráter complementar, assim como a recursos didáticos e pedagógicos para o desenvolvimento do trabalho na rede municipal. Nesse sentido, a educação especial demanda uma forte intervenção por parte do Poder Público com vistas a manter e desenvolver políticas públicas que minimizem as discrepâncias produzidas pelas desigualdades econômicas e sociais. De acordo com Bueno (2006), se é um avanço incluir a educação das pessoas com deficiência ${ }^{107}$ no âmbito da educação dos alunos com necessidades educacionais

107 Idem nota no 62 . 
especiais, isto é, das discussões sobre o fracasso escolar, na tentativa de romper com o dualismo existente entre educação regular e especial,

[...] não se pode descurar de que eles [pessoas com deficiência] possuem características diferentes das demais categorias que compõem o universo dos sujeitos com necessidades educativas especiais [...] e que sem dúvida acarretam diferentes necessidades de adaptações escolares a essas características. (BUENO, 2006, p.114).

Nessa direção, o público da educação especial necessita de ações e políticas que contemplem as suas necessidades específicas quanto ao acesso ao sistema escolar, à permanência na escola e à qualidade de ensino. Desse modo, as políticas de educação especial, precisam de investimentos adicionais de maneira a garantir o atendimento as necessidades específicas presentes na escola. Quanto aos espaços para realização de atendimento, a política previa preferencialmente as classes comuns das escolas regulares de educação infantil e de ensino fundamental, além dos centros integrados de educação especial que correspondiam aos centros de atendimento dos alunos com altas habilidades/superdotação e também as escolas especializadas em educação especial, como a Apae.

Faz-se necessário ressaltar que os documentos publicados posteriormente, referentes à educação infantil (Resolução no 6/1999), e ao ensino fundamental (Resolução no 7/2008), baseados nesses pressupostos, também traziam orientações à política de educação especial no município de Vitória.

A Resolução nํ 6/1999, que fixava as normas para educação infantil no sistema municipal de ensino de Vitória, previa no art. $3^{\circ}, \S 3^{\circ}$ : "As crianças com necessidades especiais serão preferencialmente atendidas na rede regular de creches e pré-escolas, respeitado o direito a atendimento adequado em suas diferentes necessidades" (VITÓRIA, 1999).

A Resolução n 7/2008, que estabelecia as normas relativas à organização e ao funcionamento do ensino fundamental, fixava no art. $1^{\circ}$, inciso IV: "Na Rede Pública de Ensino de Vitória, a modalidade de Educação Especial será trabalhada em todas as formas de organização do Ensino Fundamental, conforme regulamentação específica deste Conselho" (VITÓRIA, 2008d). Para concretizar 
essa política, a Resolução previa ainda, no art. 30, semelhantemente ao que é disposto na LDB/1996:

I - currículos, métodos, técnicas, recursos educativos e organização específicos, para atender as suas necessidades;

II - terminalidade específica para aqueles que não puderam atingir o nível exigido para a conclusão do ensino fundamental, em virtude de suas deficiências e aceleração para concluir em menor tempo o programa escolar para os superdotados;

III - professores com especialização adequada em nível superior, para atendimento especializado, bem como professores do ensino regular capacitados para a integração desses educandos nas classes comuns;

IV - articulação com os órgãos oficiais afins, para oferta da educação especial para o trabalho. (VITÓRIA, 2008d).

Cumpre destacar que o art. 30, inciso III, da Resolução no 7/2008, definia quem eram os professores que poderiam atuar como professores de educação especial no município de Vitória, ou seja, professores capacitados e especializados, de acordo com a LDB/1996 e com a Resolução no 2/2001 do Conselho Nacional de Educação. Outro aspecto que merece ser ressaltado refere-se à ausência de um concurso público específico para professores de educação especial no município, como já mencionado, razão pela qual os professores que atuavam nessa modalidade eram oriundos de processos seletivos via remoção interna (da educação infantil e do ensino fundamental) e de contratação temporária. Nessa perspectiva, compreendemos, assim como Prieto (2006, p. 48), que

[...] a construção de condições escolares apropriadas para atender a diversidade de necessidades dos alunos deve prever custos adicionais empregados dentre outros na admissão e qualificação de profissionais, bem como na provisão de materiais e de equipamentos específicos.

No que tange ao currículo, que era de responsabilidade e autonomia de cada unidade escolar, a orientação expressa no art. 9 da Resolução nำ 7/2008 consistia em que, na organização do seu projeto político pedagógico, fossem respeitadas as especificidades das etapas e modalidades de ensino ofertadas pelo Sistema Municipal de Ensino (VITÓRIA, 2008d). Desse modo, o art. 10 do documento assim dispunha: 
Art. 10. O currículo, na perspectiva de uma educação inclusiva, organizar-se-á de modo a oportunizar aprendizagens significativas e alicerçar-se-á em pressupostos sociais, éticos, políticos e epistemológicos consoantes com a legislação vigente, que atendam às especificidades de todos (as) os (as) alunos (as). (VITÓRIA, 2008d).

Quanto à terminalidade específica, a Resolução definia, no seu art. 36, inciso $\mathrm{V}$, quem eram os sujeitos que poderiam usufruir esse direito:

\begin{abstract}
Art. $36[\ldots]$
$[\ldots]$

V - aos alunos com grave deficiência intelectual ou deficiência múltipla que não apresentarem resultados de conclusão de escolarização previstos no inciso II $^{108}$ será dada a terminalidade específica do Ensino Fundamental de acordo com as normatizações definidas em Resolução ${ }^{109}$ própria para a modalidade de Educação Especial. (VITÓRIA, 2008d).
\end{abstract}

Nessa perspectiva, para esses alunos estava garantida a flexibilização do tempo para a conclusão do ensino fundamental e posterior certificação, com vistas a terem maiores possibilidades de continuidade do seu processo de escolarização e encaminhamento a outras instâncias educacionais e de trabalho. O Poder Público municipal, de acordo com o art. 4 da LDB/1996, deve prover as unidades de ensino de condições para a oferta do ensino, com profissionais devidamente habilitados, prédios em boas condições de uso e funcionamento, equipamentos, mobiliário e materiais próprios suficientes e adequados, com vistas a garantir a qualidade social do ensino (BRASIL, 1996a). Nesse sentido, a LDB/1996 estabelece no art. 44, inciso I, alínea d que:

\footnotetext{
Art. $44[\ldots]$

I - as condições de uso dos prédios para funcionamento das Unidades de Ensino de que trata o caput desse artigo devem considerar:

[...]

d) adaptação arquitetônica e de equipamentos dos edifícios escolares para atendimento aos (as) alunos (as) com necessidades especiais. (BRASIL, 1996a).
}

108 "Il - Será considerado promovido no ano, o aluno que obtiver um percentual igual ou superior a $60 \%$ dos pontos, por área de conhecimento ou disciplina". (VITÓRIA, 2008d, art. 36).

${ }^{109}$ Resolução CNE/CEB no 2 de 2001 (BRASIL, 2001d). 
Diante desse contexto, notamos que as diretrizes da política de educação especial do município perpassavam os documentos da educação infantil e do ensino fundamental, portanto, não estavam definidas em um documento específico dessa modalidade de ensino no âmbito do sistema educacional de Vitória. Pelas consultas realizadas na Seme-Vitória e pelo diálogo com a gestora da educação especial, constatamos que essas referidas diretrizes estavam sendo construídas a partir do ano de 2012.

$\mathrm{Na}$ tentativa de caracterizar a política de atendimento aos alunos com deficiência, TGD e altas habilidades/superdotação na rede municipal de ensino de Vitória, nos anos de 2008, 2009 e 2010, apresentaremos, no próximo item, aspectos relacionados à sua implementação.

\subsubsection{Contexto da política de educação especial no município de Vitória, nos anos de 2008, 2009 e 2010}

Procuramos descrever, neste item, a política de atendimento aos alunos com deficiência, TGD e altas habilidades/superdotação no município de Vitória, nos anos de 2008, 2009 e 2010, a partir das ações descritas nos planos de trabalho da Cfaee.

O Plano de Trabalho - 2008/2009 se fundamentou na PNEE-El/2008, tendo como público da educação especial no município alunos com deficiência, TGD e altas habilidades/superdotação e estabeleceu como objetivo geral "[...] redimensionar o atendimento educacional especializado nas unidades de ensino do sistema municipal de Vitória, a fim de aprimorar as práticas pedagógicas e a discussão acerca da educação inclusiva no cotidiano da escola" (VITÓRIA, 2008c), p. 5). Faz-se necessário destacar que, segundo consta no referido plano, esse objetivo atendia às avaliações realizadas nas reuniões, grupos de formação, fóruns e outros dispositivos de escuta à comunidade escolar e na experiência do modelo de atendimento aos alunos com deficiência, TGD e altas habilidades/superdotação em laboratórios pedagógicos (VITÓRIA, 2008c). O plano buscou dar continuidade aos trabalhos realizados em 2007, com a proposição de fortalecer as ações e políticas 
para o biênio 2008/2009. Nesse sentido, reforçou os objetivos propostos em 2007 e ampliou-os:

a) oportunizar a um maior número de unidades de Ensino condições para reflexão e elaboração teórico-prática, acerca da educação especial na perspectiva da inclusão;

b) universalizar o acesso dos alunos ao atendimento educacional especializado, potencializando 0 trabalho dos professores especializados localizados nas escolas;

c) aprimorar e estreitar as relações e as trocas de experiências das práticas pedagógicas realizadas, com os alunos, pelos professores especializados em educação especial e pelos professores de sala comum, diretores, pedagogos, coordenadores de turno e outros profissionais da escola;

d) implementar a Política Bilíngue, nas escolas referência, em atenção às necessidades educacionais dos alunos com surdez, no uso e difusão da Língua Brasileira de Sinais - Libras. (VITÓRIA, 2008c, p. 5).

Como serviços para a operacionalização das ações, estavam previstos: a) professores especializados em educação especial, responsáveis pela identificação das necessidades educacionais especiais, planejamentos coletivos e individuais, trabalho colaborativo, atendimento educacional especializado, entre outras ações; b) atendimento educacional especializado nas Unidades de Ensino, que deveria ser realizado mediante complementação ou suplementação curricular em salas de apoio pedagógico no turno inverso ao da escolarização, atuação colaborativa do professor de educação especial com os professores de classe comum do ensino regular, atuação de professores intérpretes, das linguagens e códigos aplicáveis, além de instrutores e tradutores de Libras, atuação de professores itinerantes intra e interinstitucionais, e disponibilização de outros apoios necessários à aprendizagem, à locomoção e à comunicação; c) assessorias da educação especial realizadas em colaboração com outras assessorias do ensino fundamental, educação infantil e educação de jovens e adultos; d) equipe multi e interdisciplinar da Seme-Vitória, formada por profissionais especialistas em educação especial, tanto das áreas específicas das deficiências e altas habilidades/superdotação, quanto da formação geral, como pedagogos, psicólogo e fonoaudiólogo a fim de subsidiar a construção de um sistema educacional inclusivo (VITÓRIA, 2008c).

A localização dos professores especializados em educação especial variava de acordo com sua área de atuação. Nesse sentido, os profissionais da área de 
surdos (professores bilíngues, instrutores, professores de Libras, tradutores e intérpretes) localizavam-se nas escolas de referência ${ }^{110}$, que ofereciam educação bilíngue para os alunos surdos, distribuídas pelo município.

Os professores da área de altas habilidades/superdotação ficavam localizados em uma determinada escola de ensino fundamental, referência para esse público, e no Cedet, para realização do atendimento educacional especializado, oferecendo oficinas e projetos de enriquecimento curricular e assessoria às escolas do sistema municipal de ensino de Vitória (VITÓRIA, 2008c).

Os professores da área de deficiência visual e intelectual atuavam nas escolas de educação infantil e ensino fundamental, no ensino colaborativo ou nas salas de recursos multifuncionais (VITÓRIA, 2008c).

A carga horária dos professores de educação especial era a mesma da dos demais profissionais do magistério, ou seja, 25 ou 40 horas semanais, visto que o município não tinha um cargo específico para professores de educação especial, como já informado. Desse modo, estes compunham os cargos de professores de educação básica de ensino fundamental ou educação infantil e, para atuação nessa modalidade de ensino, passavam por um processo seletivo interno e eram encaminhados às escolas e às salas de recursos multifuncionais (VITÓRIA, 2008c).

No que se refere aos recursos materiais para atendimento a esse alunado, 0 plano previa que os recursos seriam oriundos de cada escola. Desse modo, estabelecia:

Cada Unidade de ensino, de acordo com sua própria demanda, e a partir da gestão de seus recursos e/ou busca de recursos próprios via Conselho de escola, adquirirá seus equipamentos, materiais didáticos, ampliação de seus espaços, dentre outros para 0 atendimento dos alunos com NEE. (VITÓRIA, 2008c, p. 8).

Quanto aos encaminhamentos a serem realizados pelas escolas, estavam previstos: a) convênio Apae com a Seme-Vitória, Secretaria Municipal de Saúde (Semus) e Secretaria Municipal de Assistência Social (Semas) para avaliação multidisciplinar dos alunos com deficiência intelectual. Cabe ressaltar que os demais

\footnotetext{
110 A rede municipal de ensino Vitória tinha sete escolas de referência para matrícula de alunos surdos: CMEI Denizart Santos, CMEI Jacyntha Ferreira de Souza Simões, EMEF Izaura Marques da Silva, EMEF Aristóbulo Barbosa Leão, EMEF Adevalni Sysesmundo Ferreira de Azevedo, EMEF Juscelino Kubitscheck de Oliveira e EMEF Maria José Costa Moraes.
} 
encaminhamentos médicos, sociais e terapêuticos dos alunos com deficiência, TGD e altas habilidades/superdotação deveriam ser conduzidos por pedagogos junto aos demais profissionais da escola, às Unidades de Saúde ou a outros parceiros; b) Projeto Integrartes, parceria da Seme-Vitória e Cfaee com a Oficina de Artes de Vitória, que oferecia aos alunos com deficiência, TGD e altas habilidades/superdotação uma multiplicidade de atividades artísticas, desenvolvidas por profissionais especializados e oferecidas no contraturno do aluno; c) convênio Seme-Vitória e Associação Brasileira de Altas Habilidades e Superdotação (Abahsd), que proporcionou a organização do Centro de Desenvolvimento do Talento com o objetivo de localizar, encaminhar e orientar o projeto educacional para alunos com indicativos de altas habilidades/superdotação (VITÓRIA, 2008c).

O Plano de Trabalho da Cfaee no ano de 2010 (VITÓRIA, 2010a) foi realizado dentro de um planejamento de ações a serem desenvolvidas no período de 2010 a 2013, no âmbito do programa "Acesso e permanência na educação básica com qualidade", e na ação "Acompanhamento e atendimento na modalidade de educação especial". As ações foram divididas em três dimensões, que, por sua vez, estavam articuladas aos indicadores do PAR e do PPA, a saber: Gestão educacional; formação de professores e dos profissionais de serviços e apoio escolar; práticas pedagógicas e avaliação; e infraestrutura física e recursos pedagógicos (VITÓRIA, 2010a). No que diz respeito às ações relacionadas à gestão educacional a serem realizadas no ano de 2010, estavam previstas no Plano: proceder à emissão de dados corretos sobre a matrícula de alunos com deficiência, TGD e altas habilidades/superdotação no Educacenso; redimensionar a equipe Cfaee, para atender à demanda interna da gestão da modalidade de educação especial/Seme-Vitória, as interfaces externas, a formação específica e o acompanhamento técnico pedagógico regionalizado às unidades de ensino; instituir uma política de educação especial para atender às especificidades dos alunos da EJA; redimensionar o atendimento educacional especializado para alunos com altas habilidades/superdotação; garantir a aquisição de vale social para alunos que necessitavam de transporte para se deslocar para o atendimento educacional especializado no turno oposto ao do ensino regular; realizar junto à Gerência de Recursos Humanos os processos seletivos para remoção interna e contratação temporária de instrutores de Libras, professores bilíngues e intérpretes, para 
trabalhar nas escolas bilíngues; inserir na organização curricular das escolas bilíngues o ensino de língua portuguesa escrita como segunda língua - L2, para alunos surdos; garantir aos profissionais que atuavam nas unidades de ensino com alunos que apresentavam deficiência múltipla orientação e apoio pedagógico, em caráter de itinerância; manter apoio pedagógico de estagiários nas turmas com alunos com deficiência e TGD; garantir alimentação escolar para alunos com sondas alimentares ou que demandavam cardápios referentes a outras dietas específicas; viabilizar acesso de alunos com deficiência, TGD e altas habilidades/superdotação em situação de risco social à educação em tempo integral; garantir aos alunos com altas habilidades/superdotação acesso ao desenvolvimento de seus talentos, potencialidades e interesses científicos culturais específicos; garantir aos alunos com deficiência, TGD e altas habilidades/superdotação acesso ao Projeto Integrartes, oferta aos alunos com autismo, deficiência intelectual e deficiência múltipla, de atendimento educacional especializado na Apae; e, por último, desenvolver ações compartilhadas intersecretarias, com instituições governamentais e não governamentais, e com a sociedade civil, para promoção do processo de inclusão escolar desse alunado (VITÓRIA, 2010a).

Quanto à formação de professores e dos profissionais de serviços e apoio escolar, eram ações previstas no Plano: garantir formação contínua de professores que atuavam nas áreas de deficiência visual, de deficiência intelectual, de altas habilidades/superdotação, de deficiência física e de surdos; investir em cursos para professores de educação básica que atuavam em classe comum do ensino regular com vistas à atuação na modalidade de educação especial; formar anualmente gestores e educadores de vinte municípios da área de abrangência do polo de Vitória para fomentar a construção de sistemas educacionais inclusivos (VITÓRIA, 2010a).

No que se refere às práticas pedagógicas e à avaliação, eram previstas as seguintes ações: assegurar as devidas adequações pedagógicas, os recursos de tecnologias assistivas e de comunicação alternativa e ampliada, o uso de Libras e do Braille para acesso ao currículo dos alunos com deficiência e/ou surdos; considerar, para avaliação dos alunos com deficiência, as peculiaridades nos modos de ensinar e aprender, o acesso a recursos de tecnologias assistivas e de comunicação alternativa e ampliada, o uso de Libras e do Braille; adequar o sistema avaliativo 
institucional considerando a acessibilidade aos profissionais e alunos com comprometimento sensorial, motor, de comunicação, etc. (VITÓRIA, 2010a).

No que tange à infraestrutura física e aos recursos pedagógicos, eram ações previstas: garantir adequações arquitetônicas nas escolas; adequar os espaços físicos destinados às salas multifuncionais; disponibilizar espaço físico adequado ao atendimento educacional especializado; orientar os gestores das unidades de ensino sobre como utilizar a verba da escola para os seguintes fins: aquisição de recursos pedagógicos, de tecnologias assistivas, de comunicação alternativa e aumentativa, visuais, de mobiliário e equipamentos para atender às necessidades específicas dos alunos com deficiência; aquisição de equipamentos de tecnologias assistivas para os laboratórios de informática; formação de professores do laboratório de informática para o uso de tecnologias assistivas; formação de professores de educação especial para utilização dos recursos tecnológicos de comunicação alternativa e aumentativa que compõem os recursos pedagógicos das salas de recursos multifuncionais; formação de professores da educação especial para utilização dos softwares livres no atendimento educacional especializado (VITÓRIA, 2010a).

Cabe destacar que as ações descritas no Plano de Trabalho - 2010/2013, para serem desenvolvidas e operacionalizadas, previam interfaces com outras gerências de ensino (educação infantil, ensino fundamental, educação de jovens e adultos, tecnologia educacional); outros setores administrativos da Seme-Vitória (gestão de recursos humanos, gerência de formação continuada); outras coordenações, programas, secretarias e/ou órgãos públicos (coordenação da educação em tempo integral, programa municipal de alimentação escolar, Semus, Ministério Público); programas específicos do MEC, como os financiados pelo PDDE: Programa Escola acessível, Programa Implantação de Salas de Recursos Multifuncionais, Formação para a Diversidade; recursos próprios de cada unidade de ensino; e ações compartilhadas com entidades privadas e organizações não governamentais/sem fins lucrativos, como Apae, Faculdade Espírito-Santense de administração (Faesa), Escola Superior de Ciências da Santa Casa de Misericórdia de Vitória (Emescam), Abahsd, entre outras (VITÓRIA, 2010a).

Diante desse contexto histórico e político da rede de ensino de Vitória, iniciaremos, no próximo item, a análise e discussão do planejamento orçamentário do município. 


\subsubsection{Planejamento orçamentário no município de Vitória: o lugar da educação especial entre disputas e negociações}

"O orçamento público não se limita a uma peça técnica e formal ou a um instrumento de planejamento, ele é, desde suas origens, uma peça de cunho político".

(SALVADOR, 2012, p.19).

Partindo do pressuposto da epígrafe acima, ao analisarmos o PPA de 2006 a 2009, aprovado pela Lei nº 6.375, de 14 de setembro de 2005, do município de Vitória, encontramos cinco programas voltados à educação e vinculados à SemeVitória. Entre eles, destacamos o programa intitulado "Universalização do Acesso ao Ensino Fundamental com Qualidade", que tinha como objetivo "garantir acesso e educação com qualidade social às crianças, jovens e adultos do município de Vitória que demandam o Ensino Fundamental” (VITÓRIA, 2005). Entre as ações previstas no programa, uma fazia menção à educação especial: "Inclusão de Crianças, Adolescentes, Jovens e Adultos com Necessidades Especiais". A meta consistia em ampliar o quantitativo desses alunos no ensino fundamental. Cabe ressaltar que esse programa tentava atender à Lei no 11.274, de 6 de fevereiro de 2006 (BRASIL, 2006a), que altera a redação dos artigos 29, 30, 32 e 87 da LDB/1996, que estabelece as diretrizes e bases da educação nacional, dispondo sobre a educação de nove anos para o ensino fundamental, com matrícula obrigatória a partir dos seis anos de idade.

Na Lei no 7.845, de 9 de dezembro de 2009 (VITÓRIA, 2009a), que dispunha sobre o PPA para o período de 2010 a 2013, identificamos quatro programas vinculados à Seme-Vitória. Porém, encontramos, no documento, somente o programa "Acesso e Permanência à Educação Básica com Qualidade" com alusão à educação especial, tendo ele a finalidade de

[...] garantir acesso à Educação Básica nas etapas da Educação Infantil, Ensino Fundamental e nas modalidades de Educação de Jovens e Adultos (EJA) e de Educação Especial (EE), com garantia das condições de permanência e de qualidade socialmente referenciada, considerando os espaços formais e os espaços não formais de acesso ao conhecimento científico-cultural. (VITÓRIA, 2009a). 
Entre as ações, destacava-se a de "Acompanhamento e atendimento na Modalidade de Educação Especial”, cujos objetivos eram assegurar o direito à educação dos alunos com deficiência, TGD e altas habilidades/superdotação e garantir condições objetivas para o atendimento com qualidade aos referidos alunos, tanto na classe comum do ensino regular quanto nos serviços de apoio especializados, bem como ampliar os serviços oferecidos pelo sistema municipal, por meio das salas de recursos multifuncionais, do Cedet e da política de educação bilíngue.

Nesse sentido, notamos que a educação especial foi contemplada nos planejamentos da administração municipal de 2006 a 2009 e de 2010 a 2013 como programa e/ou ação, o que demonstrava a intenção política do município para com essa modalidade de ensino, considerando, assim como Salvador (2012, p, 5), que "[...] o orçamento público é o que garante concretude à ação planejada do Estado e espelha as prioridades das políticas públicas que serão priorizadas pelo governo".

Nas Leis de Diretrizes Orçamentárias para os anos de 2008, de 2009 e de 2010, o texto era único e mais genérico, em termos de dados, não apresentando informações detalhadas referentes às áreas, secretarias e modalidades de ensino, como a educação especial. Encontramos apenas uma menção referente à educação na parte de objetivos, que orientaria a definição de prioridades e metas do município: "promover a universalização do acesso à educação infantil e ao ensino fundamental com qualidade" (VITÓRIA, 2007a, art. $2^{\circ}$, $\S 2^{\circ}$, inciso II; VITÓRIA, 2008e, art. $2^{\circ}, \S$ $2^{\circ}$, inciso II; VITÓRIA, 2009b, art. $2^{\circ}$, inciso II). Essa prioridade pode ser explicada pela implantação do ensino fundamental de nove anos na rede municipal de Vitória nesse período.

Nas Leis Orçamentárias Anuais para os anos de 2008, de 2009 e de 2010, verificamos, entre as ações da Seme-Vitória, a intervenção junto aos diferentes níveis e modalidades de ensino, no intuito de garantir a universalização do acesso de crianças, adolescentes, jovens e adultos à educação. A seguir, serão apresentados, na Tabela 21 , os valores previstos pela LOA para a educação, no município de Vitória, nos anos de 2008, 2009 e 2010. 
Tabela 21 - Valores previstos pela LOA à função educação - Vitória/ES 2008, 2009 e $2010(R \$)$

\begin{tabular}{llll}
\hline ANO & FUNÇÃO EDUCAÇÃO R\$ & CORRENTES R\$ & CAPITAL R\$ \\
\hline $\mathbf{2 0 0 8}$ & $311.934 .364,80$ & $283.243 .753,24$ & $28.690 .611,56$ \\
$\mathbf{2 0 0 9}$ & $335.688 .876,06$ & $309.247 .132,64$ & $26.441 .743,42$ \\
$\mathbf{2 0 1 0}$ & $353.552 .052,82$ & $313.143 .896,34$ & $40.408 .156,48$ \\
\hline
\end{tabular}

Fonte: LOA, Vitória 2008, 2009 e 2010. Elaboração própria.

Valores atualizados com base no INPC/IBGE de 12/2014.

$\mathrm{Na}$ LOA, era estabelecido o orçamento da educação, totalizando cerca de $R \$$ 312 milhões em 2008, $R \$ 336$ milhões em 2009 e $R \$ 354$ milhões em 2010, montante esse dividido entre despesas correntes $(R \$ 283$ milhões/R $\$ 309$ milhões/313 milhões, respectivamente) e despesas de capital ( $R \$ 29$ milhões/ $R \$ 26$ milhões/40 milhões, nesta ordem). Desse modo, cerca de 9\%, $8 \%$ e $11 \%$ dos recursos respectivamente, seriam destinados à compra de instalações, equipamentos e materiais permanentes, planejamento e execução de obras, bem como amortizações de dívida e concessões de empréstimos. O restante seria empregado para manutenção e funcionamento da rede municipal. Faz-se mister destacar que os recursos dirigidos à função educação eram significativos se comparados aos valores destinados às outras secretarias que compunham a PMV (Tabela 29).

No anexo oito da LOA, os mesmos valores apareceram distribuídos por "Demonstrativo das Funções, Sub-Funções e Programas por Projetos, Atividades e Operações Especiais" (VITÓRIA, 2008e; 2009b), o que nos possibilitou verificar o percentual previsto para ser gasto em cada uma das etapas e modalidades de ensino no município, como apresentado na Tabela 22.

Tabela 22 - Valores previstos pela LOA para as etapas e modalidades de ensino Vitória/ES 2008, 2009 e 2010 (R\$)

\begin{tabular}{cll}
\hline ETAPASE & VALORES/ANO R $\$$ VARIAÇÕES ANUAIS
\end{tabular}




\begin{tabular}{|c|c|c|c|c|c|}
\hline & 2008 & 2009 & 2010 & $2008-2009$ & $2009-2010$ \\
\hline $\begin{array}{l}\text { Ensino } \\
\text { Fundamental }\end{array}$ & $211.270 .085,61$ & $222.831 .597,21$ & $182.775 .535,12$ & $11.561 .511,60$ & $-40.056 .062,09$ \\
\hline $\begin{array}{l}\text { Educação } \\
\text { Infantil }\end{array}$ & $94.258 .518,60$ & $107.712 .437,14$ & $163.863 .947,22$ & $13.453 .918,54$ & $56.151 .510,08$ \\
\hline $\begin{array}{l}\text { Educação } \\
\text { Especial }\end{array}$ & $2.120 .554,76$ & $1.426 .778,36$ & $1.847 .827,24$ & - 693.776,40 & $421.048,88$ \\
\hline $\begin{array}{l}\text { Educação de } \\
\text { Jovens e } \\
\text { Adultos }\end{array}$ & - & - & $286.317,91$ & - & - \\
\hline $\begin{array}{l}\text { Outros (Apoio } \\
\text { administrativo) }\end{array}$ & $4.285 .205,82$ & $3.718 .063,35$ & 4.625.922,39 & $-567.142,47$ & $907.859,04$ \\
\hline $\begin{array}{l}\text { Valorização e } \\
\text { Capacitação } \\
\text { dos servidores }\end{array}$ & - & - & $152.502,94$ & - & - \\
\hline TOTAL & $311.934 .364,80$ & $335.688 .876,06$ & $353.552 .052,82$ & $23.754 .511,26$ & 17.863.176,76 \\
\hline
\end{tabular}

Fonte: LOA, Vitória 2008, 2009 e 2010. Elaboração própria.

Valores atualizados com base no INPC/IBGE de 12/2014.

Observamos na Tabela 22, que os valores direcionados às etapas e modalidades apresentaram oscilações significativas entre si e durante o período de 2008 a 2010. O ensino fundamental de 2008 para 2009 teve um aumento de 6\% (de aproximadamente $R \$ 12$ milhões) e, de 2009 para 2010, teve um decréscimo de aproximadamente $\mathrm{R} \$ 40$ milhões (18\%). A educação infantil apresentou uma trajetória ascendente de 2008 para 2009 (14\%) e de 2009 para 2010 (52\%). O valor destinado à educação especial variou nesse período, apresentando um decréscimo de $33 \%(R \$ 693.776,40)$ de 2008 para 2009 e um aumento de 30\% ( $R \$ 421.048,88)$ de 2009 para 2010.

Assim, por meio da análise da LOA, observamos que a educação especial receberia, no ano de 2008, 0,7\%, em 2009, 0,4\% e, em 2010,0,5\% da parcela do total previsto para todas as etapas da educação básica e modalidades, bem como para a formação dos profissionais do magistério da rede municipal de ensino de Vitória. Desse modo, verificamos, nesse documento, a diminuição no percentual que seria despendido à educação especial de 2008 a 2010, embora, o número de matrículas do público da educação especial no município tenha apresentado uma trajetória crescente nesse período, com um aumento de 44\%, conforme já apresentado. Diante desse contexto, no qual há o crescimento de matrículas de educação especial e, ao mesmo tempo, a redução no montante a ser destinado à 
sua manutenção e a seu funcionamento, consideramos que os recursos previstos para essa modalidade, no planejamento orçamentário, podem ter sofrido cortes por parte do governo, estar subestimados ou estar agregados aos valores destinados às outras etapas de ensino. Essa conjuntura de redução de verbas ou de problemas na gestão dos recursos destinados à educação especial também nos ajuda a compreender o porquê de não encontrarmos, nos documentos, alusão a novas contratações de profissionais e a novas construções no âmbito da educação especial, tampouco, a ações para a expansão no atendimento educacional especializado no âmbito do município.

Os valores destinados à administração da Seme-Vitória, cerca de $R \$ 4$ milhões em 2008 e 2009 e de R\$ 5 milhões em 2010, foram superiores aos direcionados às modalidades de ensino no município. Cabe acrescentar que nessa categoria ("Outros - apoio administrativo"), estavam previstos recursos para os espaços não formais da Seme-Vitória, fazendo com que houvesse um aumento nos valores orçados para esse fim.

Observamos, ainda, na LOA, a ausência de dados financeiros referentes à EJA e à formação de profissionais da educação nos anos de 2008 e de 2009. Vale ressaltar que, de acordo com os dados do Censo Escolar de 2008 e 2009, havia matrículas na EJA na rede municipal de ensino de Vitória. Nesse sentido, perguntamo-nos como foram custeadas as despesas para a manutenção das escolas que atendiam o público dessa modalidade de ensino nesses respectivos anos, tendo em vista que não foram previstos na LOA valores para esse fim. Além disso, não foram fixados recursos destinados à formação continuada para os servidores que atuavam nas etapas e modalidades de ensino na rede de ensino do município em 2008 e em 2009. Cumpre destacar que também havia registros de ações voltadas à formação continuada nos relatórios da Seme-Vitória, nesses respectivos anos. Desse modo, com base nos dados, consideramos que esses recursos estavam agregados aos valores destinados às outras etapas de ensino. Destacamos que somente no ano de 2010 há a criação de rubricas direcionadas à EJA, bem como um valor específico voltado à valorização e à capacitação dos profissionais de educação. Entretanto, não encontramos nenhuma legislação nacional ou municipal sobre prestação de contas públicas que orientasse tal procedimento ou alteração. 
A análise do PPA, da LDO e da LOA nos possibilitou observar que a educação especial integrava a agenda educacional no município de Vitória, partindo do pressuposto de que, para a efetivação de uma política pública, como a de educação especial, é necessário que ela esteja presente no planejamento do Estado que, por sua vez, constitui um espaço de correlações de forças (SALVADOR 2010; OLIVEIRA, F., 2001).

Assim, acreditamos que o fato de a educação especial ao estar prescrita nos documentos de planejamento orçamentário pode demonstrar a intenção do município em investir nessa modalidade de ensino ou pode representar a existência de grupos sociais que, de certa forma, conseguiram, no âmbito do processo de discussão e elaboração desses documentos, que a educação especial fosse contemplada no planejamento do município. Conforme Oliveira, F. (2001), a escolha do programa a ser implementado pelo Estado reflete os interesses de classe e de diferentes setores da sociedade, envolvendo negociações de seus representantes políticos, e o orçamento é a expressão desse processo.

Os documentos (PPA, LDO e LOA) referentes ao planejamento e à execução orçamentária do município de Vitória nos possibilitaram verificar ainda quais eram os rumos previstos para a educação, nos períodos de 2006 a 2009 e de 2010 a 2013, e para onde seriam direcionados os recursos da educação. Nesse sentido, a prioridade era garantir a universalização do acesso à educação às crianças, adolescentes, jovens e adultos, bem como sua permanência na escola. $E$ os valores previstos estavam voltados para as etapas da educação básica (educação infantil e ensino fundamental) e suas modalidades (educação especial e EJA), assim como para o apoio administrativo e a valorização e capacitação dos servidores. De acordo com Farenzena (2006, p. 99), a previsão da execução orçamentária assegura que os "recursos estejam disponíveis na medida das necessidades e do planejamento das instituições educacionais e dos órgãos administrativos dos sistemas de ensino".

Cabe ressaltar ainda que é nesse âmbito de planejamento orçamentário que ocorre a disputa política pelo fundo público, bem como o delineamento das prioridades do governo para os níveis e modalidades de ensino; portanto, são escolhas políticas que refletem a correlação de forças atuantes na sociedade (SALVADOR, 2010). Assim, faz-se necessário destacar a importância da participação da sociedade civil nesses espaços públicos de negociações e decisões, 
no âmbito do Estado, seja na discussão e elaboração da proposta orçamentária, em que essa sociedade possa explicitar suas necessidades e demandas relacionadas às etapas e modalidades de ensino, de modo a incluí-las no planejamento orçamentário; seja no controle dos recursos públicos destinados à educação.

Essa participação política no planejamento e na gestão dos sistemas educacionais brasileiros pode ser viabilizada por meio de mecanismos de diálogo e democratização existentes, tais como os conselhos de educação (Conselho Escolar, Conselho de Alimentação Escolar, Conselho de Acompanhamento e Controle Social do Fundeb), o orçamento participativo, entre outros espaços públicos, numa perspectiva de gestão democrática da educação. Nesse sentido, o planejamento orçamentário constitui um processo amplo e complexo de tomadas de decisões e disputas políticas, envolvendo uma pluralidade de atores com interesses diversos que, por sua vez, podem interferir na elaboração e na execução do orçamento.

Com base nas informações do que foi previsto no planejamento orçamentário no que se refere à direção das ações e dos recursos públicos direcionados à manutenção e ao desenvolvimento das etapas e modalidades de ensino, apresentaremos, no próximo item, as receitas voltadas à educação no município de Vitória.

\subsubsection{Receitas da educação na rede municipal de ensino de Vitória}

"A educação, ao situar-se no âmbito das responsabilidades do Poder público, compondo o núcleo central dos atuais sistemas de bem estar social, absorve quantidade expressiva de recursos públicos. Esses recursos, ao darem as principais condições materiais para

viabilizar a formulação e implementação das políticas educacionais, podem ser um limite, um obstáculo intransponível ao atendimento das necessidades e demandas por educação".

(CASTRO, 2005, p. 842).

Nesse item, procuramos mapear e analisar a receita destinada à educação no município de Vitória, oriunda dos impostos (próprios, estaduais e federais), transferências do FNDE e do Fundeb. Na Tabela 23, podemos verificar o levantamento da receita no período estudado. Cabe salientar que foram dispostos, nessa tabela, os valores de receita com e sem os valores de multas, juros de mora, 
dívida ativa dos impostos e aplicações financeiras dos valores de transferências do FNDE e do Fundeb, para que pudéssemos visualizar as diferenças no total das receitas destinadas à educação. Entretanto, para o desenvolvimento do nosso estudo, consideramos as receitas vinculadas à educação compostas do percentual mínimo de todos os impostos ${ }^{111}$, inclusive as multas e juros de mora e a receita da dívida ativa; mais o ganho do Fundeb (ou seja, a diferença positiva entre a contribuição para esses fundos e a receita com eles) e o seu rendimento financeiro; bem como as receitas vinculadas à educação, provenientes do FNDE, e os seus rendimentos financeiros.

111 Cumpre esclarecer que, para contabilização das receitas dos impostos, realizamos dois cálculos: um com os $25 \%$ previstos na CF/1988, considerados pela PMV, Comev e TC-ES, e o outro com os 35\% estabelecidos na Lei Orgânica do Município de Vitória/ES. 
Tabela 23 - Receitas destinadas à Educação - Vitória/ES 2008, 2009 e $2010(\mathrm{R} \$)$

\begin{tabular}{|c|c|c|c|c|c|c|}
\hline$\overline{\text { CATEGORIAS }}$ & $2008^{112}$ & $2008^{113}$ & $2009^{112}$ & $2009^{113}$ & $2010^{112}$ & $2010^{113}$ \\
\hline \multicolumn{7}{|l|}{ Impostos Próprios } \\
\hline IPTU & $58.221 .464,10$ & $50.209 .506,84$ & $58.032 .498,27$ & $50.146 .411,92$ & $57.915 .331,84$ & $50.925 .901,23$ \\
\hline ITBI & 26.800 .758 .75 & $26.152 .614,08$ & $28.492 .482,26$ & $27.154 .876,15$ & $35.484 .382,14$ & $34.891 .342,82$ \\
\hline ISS & $322.071 .369,86$ & $315.883 .641,58$ & $321.266 .310,90$ & $312.957 .864,02$ & $337.136 .364,37$ & $324.475 .860,48$ \\
\hline IRRF & $42.972 .643,27$ & $42.972 .643,27$ & $37.675 .646,07$ & $37.675 .646,07$ & $37.948 .230,29$ & $37.948 .230,29$ \\
\hline SUBTOTAL A & $450.066 .235,98$ & 435.218.405,77 & 445.466.937,50 & 427.934.798,16 & 468.484.308,64 & $448.241 .334,82$ \\
\hline \multicolumn{7}{|l|}{ Transferência da União } \\
\hline FPM & $95.422 .844,39$ & $95.422 .844,39$ & 87.138.111,95 & 87.138.111,95 & $89.274 .803,52$ & $89.274 .803,52$ \\
\hline ITR & $4.333,77$ & $4.333,77$ & $1.095,45$ & $1.095,45$ & 552,77 & 552,77 \\
\hline Desoneração & 7.103.916,06 & 7.103.916,06 & $6.261 .380,30$ & $6.261 .380,30$ & $5.722 .135,86$ & $5.722 .135,86$ \\
\hline SUBTOTAL B & $102.531 .094,22$ & $102.531 .094,22$ & $93.400 .587,70$ & $93.400 .587,70$ & $94.997 .492,15$ & $94.997 .492,15$ \\
\hline \multicolumn{7}{|l|}{ Transferência Estado } \\
\hline ICMS & $597.364 .106,78$ & $597.364 .106,78$ & 499.250.227,95 & $499.250 .227,95$ & $498.036 .467,14$ & $498.036 .467,14$ \\
\hline IPI & $14.268 .027,53$ & $14.268 .027,53$ & $8.859 .665,77$ & $8.859 .665,77$ & 12.101.317,41 & $12.101 .317,41$ \\
\hline IPVA & $36.434 .980,70$ & $36.434 .980,70$ & $40.324 .591,96$ & $40.324 .591,96$ & $38.882 .195,97$ & $38.882 .195,97$ \\
\hline SUBTOTAL C & $648.067 .115,01$ & 648.067.115,01 & $548.434 .485,68$ & $548.434 .485,68$ & $549.019 .980,52$ & $549.019 .980,52$ \\
\hline TOTAL $(A+B+C)$ & $1.200 .664 .445,21$ & $1.185 .816 .615,00$ & $1.087 .302 .010,88$ & 1.069.769.871,54 & $1.112 .501 .781,31$ & $1.092 .258 .807,49$ \\
\hline 25\% MDE / CF/1988 (1D) & $300.166 .111,30$ & 296.454.153,75 & $271.825 .502,72$ & $267.442 .467,90$ & $278.125 .445,33$ & 273.064.701,88 \\
\hline 35\% MDE / Lei Orgânica Vitória/ES (1E) & $420.232 .555,82$ & $415.035 .815,25$ & $380.555 .703,81$ & $374.419 .455,04$ & $389.375 .623,46$ & $382.290 .582,62$ \\
\hline Transferências de recursos do FNDE (2) & $13.395 .604,59$ & $13.395 .604,59$ & $13.543 .980,90$ & $12.722 .603,81$ & $14.456 .702,44$ & $14.408 .502,94$ \\
\hline Recursos destinados ao Fundeb & $134.976 .776,97$ & 125.109.548,04 & $127.608 .749,89$ & 121.917.036,74 & $128.192 .845,72$ & $130.439 .787,06$ \\
\hline Recursos Recebidos do Fundeb (3) & $125.867 .106,44$ & $125.867 .106,44$ & 122.189.471,81 & $122.189 .471,81$ & $130.502 .888,71$ & $130.502 .888,71$ \\
\hline $\begin{array}{l}\text { TOTAL GERAL DA RECEITA DA } \\
\text { EDUCAÇÃO }(1 \mathrm{D}+2+3)\end{array}$ & 439.428.822,33 & $435.716 .864,78$ & 407.558.955,43 & $402.354 .543,52$ & $423.085 .036,48$ & 417.976.093,53 \\
\hline $\begin{array}{l}\text { TOTAL GERAL DA RECEITA DA } \\
\text { EDUCAÇÃO }(1 E+2+3)\end{array}$ & $559.495 .266,85$ & $554.298 .526,28$ & $516.289 .156,52$ & $509.331 .530,66$ & $534.335 .214,61$ & $527.201 .974,27$ \\
\hline
\end{tabular}

Fonte: Finbra/Siope 2008, 2009 e 2010. Elaboração própria.

Valores atualizados com base no INPC/IBGE de 12/2014.

112 Valores corrigidos a partir dos dados do Siope, com dados de aplicações financeiras, juros, multas e dívidas ativas (2008, 2009 e 2010).

113 Dados sem os valores de Multas, Juros de Mora, Dívida Ativa e outros. 
Observamos, na Tabela 23, que o total geral de receitas destinadas à educação, no município de Vitória, seria de aproximadamente $\mathrm{R} \$ 439$ milhões, em 2008 (considerando os recursos provenientes dos $25 \%$ vinculados ao MDE na CF/1988, as transferências dos recursos do FNDE e dos recursos recebidos do Fundeb), ou 559 milhões (considerando os recursos provenientes dos $35 \%$ de impostos e transferências constitucionais vinculados ao MDE na Lei Orgânica do município de Vitória/ES, as transferências dos recursos do FNDE e dos recursos recebidos do Fundeb). Em 2009, seria de $R \$ 408$ milhões ou 516 milhões, respectivamente, e, em 2010, $\mathrm{R} \$ 423$ milhões ou 534 milhões, a serem aplicados à educação nas diferentes etapas e modalidades da educação básica. Assim, no período de 2008 a 2010, notamos uma redução de aproximadamente de $4 \%$ a 5\% no total dirigido à educação no município de Vitória, considerando a diminuição no total das transferências da União e do estado para o município nos anos de 2009 e 2010, em relação ao ano de 2008.

Cumpre destacar que no ano de 2009, verificamos um decréscimo (de $7 \%$ a $8 \%$ ) no montante destinado à educação, tendo em vista a redução (de $9 \%$ ) no total de receitas de impostos e transferências constitucionais do município nesse ano, decorrente da crise global que provocou implicações no orçamento do estado brasileiro, com contingenciamento na área da educação (PINTO, 2009). Podemos verificar que o município em questão demonstrou ter captado cerca de $R \$ 1,2$ bilhões de impostos e transferências constitucionais e legais no ano de $2008, R \$ 1,0$ bilhão em 2009 e 1,1 bilhões em 2010. Conforme aponta Castro (2011, p. 32), a vinculação de recursos de impostos para a educação "[...] é uma das medidas políticas mais importantes para garantir a disponibilidade de recursos para 0 cumprimento do vasto rol de responsabilidades do poder público nessa área". Entretanto, faz-se necessário destacar, como Farenzena (2001), que a vinculação de impostos está condicionada à flutuação da economia e das políticas fiscais desenvolvidas pelos governos, apresentando uma "estabilidade relativa". Desse modo,

[...] a estagnação econômica, a renúncia fiscal e os mecanismos que restringem a base de incidência dos percentuais mínimos do setor educacional (como o Fundo de Estabilização Fiscal, ou, hoje, a Desvinculação dos Recursos da União) são exemplos emblemáticos de fatores que impõem sérios constrangimentos ao planejamento e 
execução orçamentária da área da educação nos três níveis governamentais. (FARENZENA, 2001, p. 70-71).

Cabe destacar ainda que, no ano de 2009, se iniciou uma nova gestão no município (2009-2012), e, apesar de o Prefeito João Carlos Coser, do PT, ter sido reeleito, o gestor, no primeiro ano de governo, trabalhou com a LDO e a LOA do ano anterior, portanto, com o mesmo orçamento. Talvez isso ajude a compreender as discrepâncias nos valores de um ano para o outro. Em 2010, a receita total destinada à educação aumentou aproximadamente de 4\% em relação a 2009 (de $R$ \$ 408 milhões/R\$ 516 milhões, em 2009, para $R \$ 423$ milhões/R \$ 534 milhões, em 2010).

Uma primeira desagregação das informações da receita permite verificar quais foram as fontes gerais dos recursos captados pelo município (Tabela 24).

Tabela 24 - Receitas por Fonte - Vitória/ES 2008, 2009 e 2010 (R\$)

\begin{tabular}{|c|c|c|c|c|c|c|}
\hline \multirow{2}{*}{ FONTE } & \multicolumn{3}{|c|}{ Valores em $\mathbf{R} \$$} & \multicolumn{3}{|c|}{$\%$} \\
\hline & 2008 & 2009 & 2010 & 2008 & 2009 & 2010 \\
\hline $\begin{array}{l}\text { Receita de impostos } \\
\text { próprios }\end{array}$ & 450 & 445 & 468 & 37,48 & 40,97 & 42,11 \\
\hline $\begin{array}{l}\text { Receita de } \\
\text { transferência da } \\
\text { União } \\
\text { Receita de } \\
\text { transferência do } \\
\text { Estado }\end{array}$ & 648 & 548 & 549 & 54,98 & 50,43 & 49,35 \\
\hline $\begin{array}{l}\text { Total de Receitas } \\
\text { (R\$ bilhões) }\end{array}$ & 1,20 & 1,08 & 1,12 & 100 & 100 & 100 \\
\hline
\end{tabular}

Fonte: Finbra/Siope 2008, 2009 e 2010. Elaboração própria.

Valores atualizados com base no INPC/IBGE de 12/2014.

Os dados da Tabela 24 demonstram que os recursos provenientes dos impostos próprios (IPTU, ITBI, ISS e IRRF) representaram 37\% em 2008, 41\% em 2009 e 42\% em 2010, do total de recursos destinados à educação no município de Vitória, o que demonstra uma melhora na arrecadação e pode indicar um aprimoramento na fiscalização desses impostos no município (NASCIMENTO, 2012). Assim, a receita de impostos próprios do município teve uma evolução crescente nesse período: de $R \$ 450$ milhões, em 2008, para $R \$ 468$ milhões, em 
2010, um crescimento de aproximadamente 4\%. O aumento na receita resultante de impostos cria uma expectativa de que também haja uma ampliação de recursos direcionados à educação no âmbito municipal, haja vista o que aponta a literatura da área de financiamento, ao revelar que a capacidade de arrecadação própria dos municípios tem sido fator determinante para o aumento do volume de recursos a ser investido em educação (ANUNCIAÇÃO; VERHINE, 2006).

A receita oriunda da transferência constitucional da União representou, aproximadamente, $9 \%$ do total de impostos e transferências do município de Vitória, nos anos de 2008, 2009 e 2010, e a proveniente do Estado representou 55\% em 2008, 50\% em 2009 e 49\% em 2010. Cabe destacar que a receita transferida do Estado supera a receita própria arrecadada pelo município, mostrando a importância dessa transferência para a composição da receita da cidade de Vitória. Desse modo, podemos observar que os recursos advindos de transferências de receitas tributárias entre os entes federados são imprescindíveis para o financiamento da educação nos municípios. E isso resulta, no âmbito do federalismo brasileiro, no que concerne à educação, daquilo que preveem a CF/1988 (art.11) e a LDB/1996 (arts. 8, 9, 10 e 74): o regime de colaboração, as competências de cada ente federado e um sistema de transferências constitucionais de recursos públicos, para a oferta dos serviços educacionais, bem como a responsabilidade pelos gastos do sistema educacional entre as esferas de governo. Castro (2011, p.32) descreve esse processo:

[...] a União divide a aplicação de seus recursos na manutenção do sistema federal, na execução de programas próprios e em transferências para os sistemas educacionais e municipais. Por sua vez, os estados, na composição de seus recursos, somam os recebidos da União aos provenientes de suas fontes, os quais são utilizados na manutenção e expansão de seus sistemas de ensino. Finalmente, na composição dos recursos destinados à manutenção e expansão de suas redes de ensino, os municípios recebem recursos da União e dos estados, os quais são somados aos seus recursos próprios [...] com ação supletiva da União e dos estados, condicionada à plena capacidade de atendimento e ao esforço fiscal de cada esfera.

No intuito de estabelecer uma comparação das receitas do município de Vitória com as das outras capitais brasileiras, calculamos o valor da Receita Total per capita e Receita Própria per capita, a partir dos dados disponibilizados no Finbra. 
A Receita Total ${ }^{114}$ per capita do município de Vitória apresentou uma trajetória ascendente no valor da sua receita entre 2007 a 2010, com um crescimento de $4,77 \%$, exceto no ano de 2009 , que teve um decréscimo de $6 \%$. Ao compararmos a receita per capita de Vitória com as receitas per capita das capitais brasileiras ${ }^{115}$, analisadas por Bassi et al. ${ }^{116}$ (2013), observamos que o município acompanha o movimento de contínua elevação no valor da Receita Total per capita, como podemos observar na Tabela 25.

Tabela 25 - Receita Total per capita - Vitória/ES 2007-2010

\begin{tabular}{|c|c|c|c|c|c|}
\hline \multirow{2}{*}{ Município } & \multicolumn{4}{|c|}{ Valor per capita em $\mathbf{R} \$$} & \multirow{2}{*}{$\begin{array}{c}\% \text { crescimento } \\
2007-2010 \\
\end{array}$} \\
\hline & 2007 & 2008 & 2009 & 2010 & \\
\hline Vitória & 4.523 & 4.841 & 4.544 & 4.739 & 4,77 \\
\hline Campo Grande & 2.225 & 2.521 & 2.631 & 2.669 & 19,95 \\
\hline João Pessoa & 1.504 & 2.145 & 1.995 & 1.981 & 31,71 \\
\hline Teresina & 1.553 & 1.660 & 1.817 & 1.949 & 25,49 \\
\hline Curitiba & 2.850 & 2.906 & 2.949 & 3.209 & 12,59 \\
\hline Cuiabá & 1.727 & 2.041 & 1.905 & 1.966 & 13,83 \\
\hline Belém & 1.302 & 1.348 & 1.375 & 1.557 & 19,58 \\
\hline Porto Alegre & 2.771 & 2.903 & 2.931 & 3.176 & 14,61 \\
\hline Florianópolis & 2.273 & 2.401 & 2.585 & 2.775 & 22,08 \\
\hline Belo Horizonte & 2.273 & 2.738 & 2.653 & 2.862 & 25,91 \\
\hline Natal & 1.614 & 1.924 & 1.732 & 1.805 & 11,83 \\
\hline Boa Vista & 2.183 & 1.898 & 2.673 & 2.120 & $-2,88$ \\
\hline São Paulo & 2.844 & 3.051 & 3.037 & 3.386 & 19,05 \\
\hline
\end{tabular}

Fonte: Finbra 2007 a 2010. Elaboração própria.

Valores atualizados com base no INPC/IBGE de 12/2014.

\footnotetext{
114 Receita Total é a denominação utilizada para se referir à Receita Orçamentária, que compreende a soma das receitas recebidas pelo governo em um ano fiscal (BASSI et al., 2013).

115 São Paulo (SP), Minas Gerais (MG), Rio Grande do Norte (RN), Piauí (PI), Paraíba (PB), Mato Grosso), Mato Grosso do Sul (MS), Pará (PA), Roraima (RR), Rio Grande do Sul (RS), Santa Catarina (SC) e Paraná (PR).

116 "Relatório da Força Tarefa sobre Orçamentos" da pesquisa intitulada "Remuneração de professores de escolas públicas de educação básica: configurações, impasses, impactos e perspectivas", realizada junto ao Centro de Estudos e Pesquisas em Políticas Públicas de Educação (CEPPPE), da Faculdade de Educação da Universidade de São Paulo, e coordenada nacionalmente pelo Prof. Dr. Rubens Barbosa de Camargo em 12 estados e suas respectivas capitais, no período de 1996 a 2012.
} 
De acordo com Bassi et al. (2013, p. 22) "[...] esse crescimento, no entanto, foi marcado por diferenças substanciais no desempenho de cada uma, o que expressa e ressalta as diferenças entre as capitais pelas cinco regiões do país". $\mathrm{Na}$ classificação e distância entre o maior e o menor valor das capitais, o município de Vitória, com o valor da Receita Total per capita de $\mathrm{R} \$ 4.739$ em 2010, superou a cidade de São Paulo, que, mesmo com o menor incremento tributário, apresentou o maior valor per capita em 2010 , entre as capitais brasileiras, em torno de $\mathrm{R} \$ 3.386$ (BASSI et al., 2013).

A análise da Receita Própria ${ }^{117}$ per capita do município de Vitória, em analogia com a das outras capitais, também mostra um desempenho tributário positivo no período de 2007 a 2010, como podemos observar na Tabela 26.

$\mathrm{Na}$ classificação entre o maior e o menor valor das capitais, organizada por Bassi et al. (2013), o município de Vitória, com renda per capita de $\mathrm{R} \$ 1.441$ em 2010, ficou no patamar mais elevado, com valores iguais a $R \$ 1$ mil reais e valores maiores que esse, junto de São Paulo, que apresentou um valor de $R$ \$ 1.479 em 2010. O desempenho da arrecadação própria contribuiu para esse movimento (BASSI et al., 2013). Ainda segundo os autores,

[...] é notável também que as capitais de menor capacidade econômica foram aquelas que apresentaram o maior crescimento, o que contribuiu diretamente para a redução das desigualdades entre elas, embora bem mais aprofundadas que na categoria anterior. (BASSI, et al., 2013, p. 23).

Entretanto, o aumento da arrecadação própria não foi suficiente para garantir a autonomia financeira do município de Vitória, entendida, de acordo com Bassi et al. (2013), como a diminuição da dependência financeira de transferências de receitas tributárias arrecadadas e automaticamente repassadas pelo governo estadual aos cofres municipais, no caso, uma vez que não observamos uma melhora nos percentuais da Receita Própria per capita em relação à Receita Total per capita.

117 Receita Própria é a denominação utilizada para a categoria Receita Tributária, que, na classificação de receitas dos municípios, registra aquelas provenientes de impostos (BASSI et al., 2013). 
Tabela 26 - Receita Própria per capita - Vitória/ES 2007-2010 (R\$)

\begin{tabular}{lccccc}
\hline \multicolumn{1}{c}{ Município } & $\mathbf{5}$ Valor per capita em R\$ & 2010 & $\begin{array}{c}\text { \% crescimento } \\
\mathbf{2 0 0 7 - 2 0 1 0}\end{array}$ \\
\hline Vitória & $\mathbf{2 0 0 7}$ & $\mathbf{2 0 0 8}$ & $\mathbf{2 0 0 9}$ & $\mathbf{2 0 1}$ & 2,56 \\
Campo Grande & 1.405 & 1.439 & 1.412 & 1.441 & 43,37 \\
João Pessoa & 468 & 504 & 615 & 671 & 63,86 \\
Teresina & 238 & 320 & 369 & 390 & 40,23 \\
Curitiba & 169 & 189 & 206 & 237 & 19,20 \\
Cuiabá & 734 & 759 & 771 & 875 & 18,37 \\
Belém & 381 & 419 & 379 & 451 & 29,04 \\
Porto Alegre & 241 & 252 & 258 & 311 & 19,09 \\
Florianópolis & 859 & 929 & 916 & 1.023 & 22,75 \\
Belo Horizonte & 936 & 1.001 & 1.034 & 1.149 & 28,83 \\
Natal & 704 & 762 & 786 & 907 & 19,89 \\
Boa Vista & 367 & 392 & 405 & 440 & 15,78 \\
São Paulo & 228 & 216 & 276 & 264 & 17,19 \\
\hline
\end{tabular}

Fonte: Finbra 2007 a 2010. Elaboração própria.

A equação da composição dessas duas receitas mostra, segundo Bassi et al. (2013), o grau de dependência das unidades subnacionais em relação à transferência de recursos financeiros da União ou do fundo estadual. De acordo com os autores, "o esforço de elevar a arrecadação tributária própria significaria melhores condições pelo menos mais autônomas, para o desenvolvimento de políticas e atividades com recursos próprios" (BASSI et al., 2013, p. 13). O município de Vitória estava situado no grupo intermediário entre as capitais (entre $20 \%$ e $40 \%$ ), pois os percentuais que medem a proporção com que a Receita Própria per capita participa na Receita Total per capita ficaram em torno de $30 \%$, indicando sua dependência em relação às transferências externas (da União ou fundo Estadual). Nesse sentido, concordamos com Bassi et al. (2013, p. 25) quando ressaltam que

[...] a implantação de programas e políticas públicas e ampliação das existentes pelas capitais passaram a depender em maior proporção dos recursos arrecadados por outros níveis de governo do que da sua capacidade tributária própria. Esse aumento da dependência tem de ser relativizado em função de que muitos dos novos programas, bem como os recursos para a sua execução, advieram de convênios estabelecidos diretamente entre os municípios e a União.

No caso do município de Vitória, observamos, pela Tabela 23, que 0 município recebeu um percentual significativo (55\% em 2008, 50\% em 2009 e 49\% 
em 2010) da transferência estadual, o que contribuiu substancialmente para aumentar a sua receita total, tendo em vista que o Estado do Espírito Santo não recebeu complementação por parte da União. Nesse caso, era o fundo estadual que cumpria a tarefa de complementação financeira da Receita Total do município. Cumpre destacar, como o fazem Bassi et al. (2013, p. 26), que a

[...] composição entre Receita Total e Receita Própria tem impacto bastante significativo para os recursos que financiam a manutenção e o desenvolvimento do ensino a partir das políticas de fundos, na medida em que estas políticas instituem um valor aluno/ano em relação às matrículas, primeiro, do ensino fundamental, no Fundef, e, depois, da educação básica, no Fundeb.

Para aplicar o mínimo constitucional de 25\% em MDE, o município de Vitória deveria ter despendido ao menos $\mathrm{R} \$ 300$ milhões em 2008, 272 milhões em 2009 e R\$ 278 milhões em 2010 na área de educação. Segundo os dados coletados, no Relatório Resumido da Execução Orçamentária (RREO) (do Finbra e da Semfa) e atualizados pelo INPC/IBGE de 12/2014, a cidade gastou com MDE, em 2008, R\$ 302.653.837,78; em 2009, $R \$$ 318.896.302,15 milhões e, em 2010, $R \$$ 315.210.400,91 milhões, alcançando uma aplicação mínima de 25,21\%, 29,33\%, 28,33\%, respectivamente (VITÓRIA, RREO, 2008g, 2009d e 2010b).

Cumpre destacar que Vitória está entre os municípios que ampliaram a vinculação de recursos para a educação em suas leis orgânicas (OLIVEIRA, R., 2007). Assim estabelece a Lei no 1, de 5 de abril de 1990, que dispõe sobre a Lei Orgânica do Município de Vitória/ES:

Art. 213. O Município aplicará anualmente 35\% (trinta e cinco por cento) da receita resultante de impostos, compreendida a proveniente de transferências, na manutenção e desenvolvimento do ensino, na educação em geral e em obras de infraestrutura urbana.

$\S 1^{\circ}$ Do montante dos recursos de que trata este artigo, no mínimo de $25 \%$ (vinte e cinco por cento) serão aplicados, exclusivamente, na manutenção e desenvolvimento do ensino conforme determina o art. 212 da Constituição Federal.

$\S 2^{\circ}$ Durante o exercício financeiro o Poder Executivo publicará, bimestralmente relatório demonstrativo da execução orçamentária dos recursos de que tratam o caput.

$\S 3^{\circ}$ Havendo disponibilidade de caixa, devidamente comprovada pelo relatório, que ultrapasse a obrigação constitucional os valores 
excedentes serão aplicados em outras despesas (educacionais e em obras de infraestrutura).

$\S 4^{\circ}$ A realização das despesas referidas no parágrafo anterior dependerão [sic.] de prévia autorização legislativa, anualmente, devendo constar do projeto de lei do Poder Executivo, o demonstrativo anual da disponibilidade de caixa que ultrapasse a obrigação constitucional, a justificativa, o projeto ou programa, a classificação da despesa e o valor correspondente. (Redação dada pela Emenda à Lei Orgânica, no 18, de 14 de agosto de 2001). (VITÓRIA, 1990).

Viana (2006) destaca que a incorporação no texto da Lei Orgânica do município de Vitória/ES de, no mínimo, 35\% dos recursos municipais à educação, foi resultado de um amplo debate com a sociedade civil no período de sua elaboração, diante da "necessidade de ampliação da Rede Municipal de Ensino, com a qualidade mínima necessária para o desenvolvimento do ensino fundamental e da educação infantil" (VIANA, 2006, p. 75). Contudo, com a aprovação da Emenda no 18/2001, que realizou alterações na Lei Orgânica do município de Vitória/ES (VITÓRIA, 1990), apesar dos protestos e resistências por parte do movimento dos profissionais do magistério da rede municipal de ensino de Vitória, contrários à proposta do prefeito municipal de emendas à Lei Orgânica municipal, ocorreu a redução das verbas para a educação de 35\% para, no mínimo, 25\%, embora no caput do art. 213 tenha sido mantida a aplicação dos $35 \%$ da receita resultante de impostos na educação (VIANA, 2006).

Nesse sentido, a referida lei prevê o percentual de 35\% a ser aplicado nas despesas com a MDE, na educação em geral e em obras de infraestrutura urbana. Entretanto, no parágrafo $1^{\circ}$, destaca que no mínimo $25 \%$ serão aplicados exclusivamente na MDE, cumprindo a exigência de aplicação do percentual mínimo, previstos na CF/1988. Contudo, concordamos com Davies (2006b, p. 755) que esse percentual é concebido pelas autoridades políticas

[...] como limite máximo e não mínimo, como prevê a vinculação para educação. Ora, a referência para uma educação de qualidade para todos não pode ser o percentual mínimo dos impostos, mas sim no mínimo este percentual. Não é por acaso que a imensa maioria dos governos alega aplicar apenas o percentual mínimo, como se isso fosse suficiente para atender as necessidades educacionais da população. 
Os $10 \%$ que excedem a obrigação federal, segundo o parágrafo $2^{\circ}$, podem ser aplicados em outras despesas educacionais e obras de infraestrutura. Assim, não podemos afirmar que os $10 \%$ dos 35\% eram gastos com a educação. Nesse caso, de acordo com Oliveira, R. (2007), a ampliação da vinculação de recursos para educação pode significar, em alguns municípios, a redução de investimentos, na medida em que regulamenta outras despesas que não estão previstas na legislação federal, constituindo-se como "um recurso de marketing".

Os dados do Relatório Resumido da Execução Orçamentária mostraram que Vitória aplicava mais do que o mínimo estabelecido pela Constituição Federal (25\%); porém, não afirmavam se o município cumpria o que era previsto na sua Lei Orgânica (35\% da receita resultante de impostos), compreendida a receita proveniente de transferências, na manutenção e no desenvolvimento do ensino, na educação geral e em obras de infraestrutura urbana. O relatório não esclarece se as despesas com tais recursos foram contabilizadas nos $25 \%$ ou $35 \%$. Aparentemente, esse equívoco foi cometido pela PMV e aceito pelo TCE-ES. De acordo com Davies (2006a, p. 180), isso ocorre devido à "suposição (errada) de que tais recursos são apenas adicionais aos 25\%" e não aos 35\%; porém "[...] esses percentuais incidem sobre impostos próprios ou provenientes de transferências constitucionais e não sobre tais recursos extras" (DAVIES, 2006a, p. 180).

Nos relatórios de 2009 e 2010 do TCE-ES, não encontramos nenhuma referência que indicasse o não cumprimento do percentual de $35 \%$ a ser destinado à MDE, como estabelecido na Lei Orgânica do município de Vitória/ES. O TCE-ES, utilizando a base de cálculo composta de receitas provenientes de impostos e transferências e o levantamento das despesas realizadas com a educação, analisou se os gastos com MDE atenderam aos limites constitucionais estabelecidos para aplicação na educação básica e na remuneração dos profissionais do magistério em efetivo exercício. O relatório registra que a PMV cumpriu a determinação constante no caput do art. 212 da CF/1988, aplicando o montante ${ }^{118}$ de $\mathrm{R} \$ 314.988 .494,75$, em 2009, e de $R \$ 322.080 .287,56$, em 2010, correspondente a 28,97\% e 28,95\%, respectivamente, na MDE, ou seja, "acima do exigido constitucionalmente". Cumpre destacar que os valores de gastos em MDE apresentados nos relatórios do TCE-ES eram distintos dos que constavam no Relatório de Execução Orçamentária do Finbra

118 Valores atualizados pelo INPC/IBGE de 12/2014. 
e da Semfa. Essas diferenças nas fontes dos dados, segundo Raimundo Luiz Silva Araújo (2012) e Gouveia e Polena (2014), revelam as fragilidades das informações de despesas em educação, no caso brasileiro, e suas controvérsias.

O TCE-ES parece desconsiderar o percentual mínimo fixado na Lei Orgânica municipal e considerar apenas o cumprimento dos 25\% da CF/1988, ignorando, assim, as disposições do art. 69 da LDB/1996, que define que o percentual válido é o constante das Leis Orgânicas. Com base nessas informações, a educação municipal deve ter perdido recursos consideráveis, levando em consideração os $10 \%$ da diferença entre os 35\% da Lei Orgânica municipal e os 25\% da CF/1988. Para Davies (2006a), essa situação ocorre no âmbito dos municípios, com o objetivo de contabilizar como MDE despesas não aceitas como tais pela CF/1988 e pela LDB/1996. Nesse sentido, concordamos com Davies (2014, p. 135) quando afirma a pouca confiabilidade do controle social sobre a aplicação das verbas públicas por parte dos Tribunais de Contas, salientando que

[...] esta pouca confiabilidade não resulta necessariamente ou apenas de incompetência técnica de tais órgãos (ainda que estes problemas também existam), podendo e devendo ser interpretada como mais um dos mecanismos pelos quais as várias instâncias estatais subtraem recursos legalmente vinculados à área "social" (neste caso, a educacional) para favorecer setores do capital, políticos, ou os próprios setores da burocracia estatal mais poderosos e funcionais à ordem burguesa (o judiciário, os órgãos de repressão ou de manutenção da "ordem", etc.).

As transferências de recursos do FNDE eram oriundas do salário-educação e de outras transferências desse fundo (Programa Nacional de Alimentação Escolar, Programa de Trabalho Anual - Educação Inclusiva - formação de professores; Quota - estadual e municipal; Projovem Urbano; e Plano de Ação Articuladas à educação Básica - PAR/PDE), que transferiram para a conta da educação do município de Vitória cerca de $R$ \$ 13 milhões em 2008, R \$ 13,6 milhões em 2009 e $R$ \$ 14 milhões em 2010, como podemos constatar na Tabela 27. 
Tabela 27 - Transferências de recursos do FNDE - Vitória/ES 2008, 2009 e 2010 $(\mathrm{R} \$)$

\begin{tabular}{lccc}
\hline TRANSFERÊNCIAS DE RECURSOS FNDE & 2008 & 2009 & 2010 \\
\hline Salário Educação & $8.034 .681,59$ & $8.585 .128,82$ & $9.006 .511,20$ \\
Outras Transferências & $5.360 .923,00$ & $4.916 .452,02$ & $5.401 .991,74$ \\
Receita da aplicação financeira & - & $42.400,06$ & $48.199,50$ \\
\multicolumn{1}{c}{ TOTAL } & $\mathbf{1 3 . 3 9 5 . 6 0 4 , 5 9}$ & $\mathbf{1 3 . 5 4 3 . 9 8 0 , 9 0}$ & $\mathbf{1 4 . 4 5 6 . 7 0 2 , 4 4}$ \\
\hline
\end{tabular}

Fonte: Siope/ FNDE 2008 a 2010. Elaboração própria.

Valores atualizados com base no INPC/IBGE de 12/2014.

Farenzena (2012b, p. 111), ao analisar as transferências legais e constitucionais da União, entre 2006 e 2011, para estados e municípios, destaca que os valores triplicaram nesse período, principalmente pelo aumento da complementação da União ao Fundeb, e acrescenta que

[...] o PDDE foi a ação de transferência de recursos financeiros que teve crescimento mais expressivo, pois seus recursos foram multiplicados três vezes e meia, confrontando-se 2010 e 2006. No ano de 2009, as transferências do Pnae, do Pnate e do PDDE passaram a abarcar toda a educação básica, elevando suas quantias e, por consequência, as transferências constitucionais e legais.

Entretanto, para se garantir a equalização de oportunidades educacionais e um padrão mínimo de ensino de qualidade, segundo a autora, faz-se necessário problematizar as responsabilidades e as relações federativas, em especial, o papel da União na tentativa de assegurar um equilíbrio entre a oferta e capacidade de financiamento da educação entre os entes federados, pois não são os valores de assistência da União à educação básica dos municípios e estados "[...] atualmente praticados que garantirão maior justiça escolar, seja qual for a dimensão considerada: igualdade de acesso, de oportunidades ou de resultados na educação" (FARENZENA, 2012b, p.113).

No que tange aos recursos do Fundeb, observamos que, no ano de 2008, o município destinou ao Fundeb aproximadamente $\mathrm{R} \$ 135$ milhões e recebeu do fundo $\mathrm{R} \$ 125$ milhões, tendo um resultado negativo de dez milhões. Esse quadro se repetiu no ano de 2009, em que o município destinou ao Fundeb aproximadamente 
$\mathrm{R} \$ 128$ milhões e recebeu do fundo $\mathrm{R} \$ 122$ milhões, tendo um resultado negativo de seis milhões. Em contraposição, em 2010, a diferença entre o valor destinado, aproximadamente $R \$ 128$ milhões, e o valor recebido, $R \$ 130$ milhões, foi positiva em aproximadamente dois milhões de reais, como podemos visualizar na Tabela 28.

Tabela 28 - Receitas e despesas do Fundeb - Vitória/ES 2008, 2009 e 2010 $(\mathrm{R} \$)$

\begin{tabular}{lccc}
\hline RECEITAS DO FUNDEB & $\mathbf{2 0 0 8}$ & $\mathbf{2 0 0 9}$ & $\mathbf{2 0 1 0}$ \\
\hline Receitas destinadas ao Fundeb & $134.976 .776,97$ & $127.608 .749,89$ & $128.192 .845,72$ \\
Recursos recebidos do Fundo & $125.109 .548,04$ & $121.917 .036,74$ & $130.439 .787,06$ \\
Resultado Líquido da Transferência do & $-9.867 .228,90$ & $-5.691 .713,15$ & $2.246 .941,34$ \\
Fundeb & & & \\
Receita da Aplicação Financeira dos & $757.559,07$ & $272.435,07$ & $63.101,65$ \\
Recursos do Fundeb & $\mathbf{1 2 5 . 8 6 7 . 1 0 6 , 4 4}$ & $\mathbf{1 2 2 . 1 8 9 . 4 7 1 , 8 1}$ & $\mathbf{1 3 0 . 5 0 2 . 8 8 8 , 7 1}$ \\
\hline TOTAL & $\mathbf{2 0 0 8}$ & $\mathbf{2 0 0 9}$ & $\mathbf{2 0 1 0}$ \\
\hline DESPESAS DO FUNDEB & $\mathbf{1 2 1 . 0 5 2 . 2 8 9 , 2 8}$ & $\mathbf{1 6 1 . 4 0 9 . 6 5 1 , 1 8}$ & $\mathbf{1 9 2 . 7 5 6 . 8 1 7 , 4 5}$ \\
\hline Pagamento dos Profissionais do & $3.632 .610,88$ & $8.619 .475,07$ & $61.900 .537,62$ \\
Magistério & $117.419 .678,40$ & $152.790 .176,11$ & $130.856 .279,83$ \\
Educação Infantil & $622.287,33$ & 596,14 & 0,00 \\
Ensino Fundamental & $\mathbf{1 2 1 . 6 7 4 . 5 7 6 , 6 1}$ & $\mathbf{1 6 1 . 4 1 0 . 2 4 7 , 3 2}$ & $\mathbf{1 9 2 . 7 5 6 . 8 1 7 , 4 5}$ \\
\hline Outras despesas & \multicolumn{2}{c}{ TOTAL } &
\end{tabular}

Fonte: Finbra, Semfa 2008 a 2010. Elaboração própria.

Valores atualizados com base no INPC/IBGE de 12/2014.

Essa diferença entre o valor total que o município deduz de seus impostos para a composição do Fundo e o que ele recebe, decorre do mecanismo de redistribuição dos recursos do Fundeb no âmbito de cada estado e de seus respectivos municípios, realizado de acordo com o número de matrículas na educação básica. Cabe acrescentar, ainda, o que aponta Pinto (2007), no que se refere à mudança nos critérios de repartição do ICMS, no Fundef e também no Fundeb, na qual os municípios com maior receita tendem a transferir recursos para aqueles com menor arrecadação. Assim, a equalização financeira do Fundo provoca impactos diferenciados nos estados e municípios, sendo beneficiados aqueles governos que, por um lado, apresentam uma reduzida capacidade de financiamento da educação e atuam com significativa participação no atendimento aos alunos da educação básica, em detrimento de outros governos que, em virtude da magnitude de sua arrecadação e do número reduzido de matrículas, têm um percentual 
substancial de suas receitas retidas pelos fundos, ou seja, o retorno em proporção à matricula é menor que o montante subvinculado dos impostos (FERNANDES, 2004).

Cumpre destacar que o aumento nos valores recebidos do Fundeb (de $R \$$ 125 milhões, em 2008, para $R \$ 130$ milhões, em 2010) pelo município de Vitória parece não ter relação direta com o número de matrículas na educação básica, tendo em vista um decréscimo de $2 \%$ no total de matrículas na rede municipal de ensino nesse período. Esse crescimento nas receitas oriundas do Fundeb pode se vincular ao processo de implantação do Fundeb, concluído em 2009, quando o total de alunos matriculados na rede pública foi considerado na distribuição dos recursos e o percentual de contribuição do Distrito Federal, estados e municípios para a formação das receitas do Fundo atingiu o patamar de $20 \%$.

Observamos que, no ano de 2008, a rede de ensino do município de Vitória aplicou 99\% do Fundo da educação básica no pagamento dos profissionais de magistério e 1\% em outras despesas. Nos anos de 2009 e 2010, a verba total do Fundeb foi aplicada $100 \%$ no pagamento dos profissionais de magistério. Cumpre destacar que, nesses respectivos anos, os valores despendidos eram maiores que o montante recebido do Fundo. Esses dados podem ser compreendidos, considerando a existência de um fundo específico voltado ao ensino fundamental (Fuefum) no âmbito do município de Vitória, que era composto pelo retorno dos recursos do Fundeb mais 15\% dos demais impostos arrecadados pelo PMV e aplicados na remuneração do magistério. A seguir, detalharemos a constituição desse fundo na rede municipal de ensino de Vitória.

Para a prestação de contas, o município de Vitória se baseava nos procedimentos estabelecidos pelo TCE-ES, no caso, suas resoluções, que tinham o objetivo de "[...] instituir novos mecanismos adequados à fiscalização quanto ao cumprimento pleno do disposto no artigo 2012, da Constituição Federal, conforme disposto no artigo 11, da Lei n 9.424/96" (TC-ES, 2004). De acordo com Davies (2006c), os governos estaduais e municipais seguem as orientações dos Tribunais de Contas na sua prestação de contas, e não necessariamente as disposições legais da educação nacional. Acrescenta ainda 0 autor que as diferentes interpretações da LDB/1996, da EC/1996 e da Lei no 9.424/1996 produziram inúmeras resoluções no âmbito do TCE-ES. Assim, em 23 de setembro de 1997, o TCE-ES editou a Resolução no 144 (ESPÍRITO SANTO, 1997a), substituída, em 18 
de dezembro do mesmo ano, pela de no 145 (ESPÍRITO SANTO, 1997b). Em 1998, foi editada uma nova Resolução, a de no 149 (ESPÍRITO SANTO, 1998), substituída pela de no 154, de 22 de junho de 1999 (ESPÍRITO SANTO, 1999). Em 20 de abril de 2004, temos uma nova Resolução, a de nº 195 (ESPÍRITO SANTO, 2004), e finalmente outra Resolução, de n² 238, de 15 de maio de 2012 (ESPÍRITO SANTO, 2012), modificada pela Resolução no 260, de 21 de maio de 2013 (ESPÍRITO SANTO, 2013), que está em vigor até o presente ano e que instituiu novos mecanismos adequados à fiscalização quanto ao pleno cumprimento do percentual a ser aplicado na MDE.

Cumpre destacar que a Resolução de no 195/2004 vigorou até 2011, compreendendo o período do Fundef e do Fundeb, sendo substituída apenas em 2012 com a edição da última resolução. Faz-se necessário destacar ainda que, desde a resolução de 1997 até a de 2012, o TCE-ES orientou o estado do Espírito Santo e as prefeituras capixabas em procedimentos sobre a abertura de contas específicas para os recursos do Fundef e do Fundeb.

Destacaremos aqui a Resolução nำ195/2004, que vigorou no período de 2008 a 2010, período que elegemos para o desenvolvimento do nosso estudo. Assim, a Resolução propôs, em seu art. 3ำ a criação da conta Fundef, composta pelos 15\% dos impostos previstos no $\S 2^{\circ}$ do art. 60 do Ato das Disposições Constitucionais Transitórias da EC/1996:

Art. 3‥ Fundef será constituído apenas por uma conta corrente, aberta pela União no Banco do Brasil S/A, que terá como objetivo a distribuição dos recursos das receitas citada no artigo anterior ${ }^{119}$, cujos recursos serão transferidos automaticamente pelo Banco do Brasil para as contas específicas e vinculadas abertas pelo Estado e por seus respectivos municípios. (ESPÍRITO SANTO, 2004).

\footnotetext{
119 Art.2 O Fundo de Manutenção e Desenvolvimento do Ensino Fundamental e de Valorização do Magistério - FUNDEF será composto por quinze por cento dos recursos definidos no artigo 1ำ da Lei no 9.424/96.

$\S 1$ ํㅡㄹ Computar-se-á como base de cálculo para a transferência de recursos ao FUNDEF, em âmbitos estadual e municipal, a receita dos juros, das multas moratória e da correção monetária dos impostos de que trata o caput deste artigo, em respeito ao disposto na Lei Complementar ํㅡ 63/90.

$\S 2^{\circ}$ Em âmbito estadual, as receitas originárias do imposto sobre operações relativas à circulação de mercadoria e sobre prestações de serviços de transporte interestadual e intermunicipal e de comunicação deverão ser ajustadas nos termos dispostos no artigo $1^{\circ}$, inc. I, alínea "g", e do artigo $1^{\circ}$, $\S$ único, inc. II, desta resolução.
} 
No que se refere à conta do estado do Espírito Santo, a Resolução propunha, em seu art. 6”, que o governo deveria "[...] providenciar a manutenção, junto ao Banco do Brasil S.A. ou em qualquer outro banco oficial, de conta corrente específica, denominada Fundo de Ensino Fundamental Estadual - Funefe, vinculada à conta do Fundef" (ESPÍRITO SANTO, 2004).

Em relação aos municípios do estado do Espírito Santo, O TCE-ES propôs, no art. 10 da Resolução, que cada prefeitura municipal capixaba providenciasse, "[...] junto ao Banco do Brasil S. A., a abertura de conta corrente específica, denominada Fundo de Ensino Fundamental Municipal - Fuefum - em que conste consignado o nome do município e que seja vinculado à conta do Fundef" (ESPÍRITO SANTO, 2004). Nessa conta, deveriam ser depositados os $15 \%$ dos demais impostos arrecadados diretamente pela prefeitura (IPTU, ISS, ITBI, IPVA, IR dos servidores municipais e ITR, no caso dos governos municipais), que não entravam no Fundef, mas eram vinculados ao ensino fundamental até 2006, e os recursos do Fundef, destinados exclusivamente à manutenção e ao desenvolvimento do ensino fundamental e à valorização do magistério. Ao estabelecer que os $15 \%$ dos demais impostos seriam também destinados à valorização do magistério, a Resolução ampliou o percentual mínimo de 60\% previstos no Fundef para remuneração dos profissionais da educação.

O TCE-ES estabeleceu ainda, no âmbito do estado do Espírito Santo e dos municípios capixabas a criação de uma segunda conta, denominada de manutenção e desenvolvimento do ensino (MDE), abrangendo os $10 \%$ restantes (dos $25 \%$ ) de todos os impostos, não vinculados constitucionalmente ao ensino fundamental. Para Davies (2006c), esse procedimento constitui um equívoco, pois esse conceito (MDE), definido nos artigos 70 e 71 da LDB/1996, abrange todos os $25 \%$ dos impostos, não apenas os 10\%. O autor salienta ainda que a CF/1988 não estipula que o restante da percentagem dos $25 \%$, ou seja, os $10 \%$ ou os $15 \%$, seja destinado exclusivamente ao ensino fundamental e à educação infantil. A única determinação da CF/1988 era que, no Fundef, os 15\% dos demais impostos fossem aplicados no ensino fundamental, até 2006, e, no Fundeb, ou seja, após 2007, fossem destinados à manutenção e ao desenvolvimento da educação básica e à remuneração condigna dos trabalhadores em educação. 
Cabe ressaltar que nos demonstrativos de despesas do município de Vitória, até o ano de 2009, mesmo no âmbito do Fundeb, os recursos do Fuefum foram apresentados de forma separada das despesas próprias do município. E, na sua descrição, especificava-se que os recursos eram oriundos do Fundo Ensino Fundamental Municipal de Vitória e destinados às despesas exclusivas com 0 magistério. Essa forma de descrição dos dados de despesa com o pessoal dificultava identificar qual o valor despendido pelo município no pagamento dos profissionais do magistério e o total de recursos aplicados com o Fundeb, comprometendo o seu acompanhamento e o controle social por parte do Comev. A partir de 2010, o referido fundo não aparece mais nas prestações de contas, sem que fossem encontradas justificativas para tal nas fontes consultadas para esta pesquisa. Os recursos destinados ao pagamento dos profissionais do magistério aparecem especificados dentro das despesas da Seme-Vitória. Faz-se necessário destacar que apenas em 2012, com a Resolução nº 238/2012 (ESPÍRITO SANTO, 2012), modificada pela Resolução no 260/2013 (ESPÍRITO SANTO, 2013), houve alteração nos procedimentos do TC-ES para o Estado do Espírito Santo e municípios capixabas para apuração dos valores mínimos a serem aplicados na manutenção e no desenvolvimento do ensino.

Cumpre destacar ainda que, nos demonstrativos de despesas analisadas, de 2008 a 2010, observamos, assim como Viana (2006), que analisou as despesas do município de Vitória em 1998 a 2004, que a PMV omitia os 15\% de impostos próprios aplicados na remuneração do magistério do ensino fundamental, revelando uma aplicação e um percentual superior nas despesas dos profissionais do magistério. Quanto à aplicação na remuneração dos profissionais do magistério, o TCE-ES concluiu que o município também cumpriu o disposto na legislação, aplicando acima do percentual mínimo exigido, ou seja, dos recursos do Fundeb destinou 161,89\% em 2009, 165,19\% em 2010 às despesas com remuneração dos profissionais do magistério. Conforme já salientado, os valores acima de $100 \%$ referem-se aos recursos advindos dos 15\% dos demais impostos arrecadados pela PMV, somados ao montante de recursos que retornava do Fundeb e eram aplicados na remuneração do magistério. Cabe ressaltar que, apenas no relatório de 2010 (ESPÍRITO SANTO, 2010), o TCE-ES indica ser necessário que o gestor responsável apresente esclarecimentos sobre esse percentual, tendo em vista que 
superou o montante que recebeu do Fundeb. Porém, em consulta ao relatório, não encontramos nenhuma resposta e/ou justificativa referente a esse aspecto. Nesse sentido, concordamos com Davies (2014, p. 138) quando afirma que "além da grande fragilidade, as resoluções e relatórios apresentam uma série de omissões, equívocos e inconsistências" por parte dos Tribunais de Contas, no que se refere aos recursos da educação.

Ressaltamos ainda que as modalidades de ensino não apareceram na descrição das despesas do Fundeb, o que inviabiliza conhecer o montante de recursos voltados ao pagamento dos profissionais que atuavam na educação especial e na EJA e às despesas com a manutenção e o desenvolvimento dessas modalidades. Esse aspecto também foi observado por Rosilene Vieira (2014) e Di Pierro (2012) nas pesquisas de financiamento da EJA, quando evidenciaram que as despesas com essa modalidade estavam agregadas às das outras etapas de ensino, contribuindo para sua invisibilidade nas prestações de contas dos municípios. Na educação especial, esse aspecto foi destacado no estudo de Viegas (2014), quando inferiu, por meio das falas dos gestores, que os valores repassados pelo Fundeb entravam na rubrica do ensino fundamental e da educação infantil, sem especificamente fazerem a diferença na aplicação dos recursos para o atendimento educacional especializado. Desse modo, observamos que, embora a política do Fundeb tenha ampliado a sua abrangência, incluindo todas as etapas e modalidades da educação básica, os tipos de estabelecimentos e a jornada sobre as quais incidem as ponderações, elevando os recursos para a sua manutenção e seu funcionamento, a Lei 11.494/2007 prevê a aplicação livre dos recursos. Conforme Paulo Sena (2008, p. 325),

[...] as ponderações são elementos para a captação de recursos,
mas segundo esse dispositivo, o gasto é livre, isto é, pode-se captar
por uma etapa ou modalidade e gastar em outra. Mais do que isso,
pode-se no limite, captar determinado valor pela matrícula pública e
aplicá-la na conveniada e vice-versa. As ponderações podem até
orientar, mas não vinculam gastos.

Assim, não há garantias de que esses recursos estejam realmente destinados a todas as etapas da educação básica e modalidades de ensino. No caso da educação especial, pudemos constatar, no Capítulo 3 deste trabalho, no item 3.1, 
que os valores estimados para a educação especial apresentaram aumento contínuo no período de 2007 a 2010, decorrentes do fator de ponderação, do aumento da participação da União e da dupla matrícula, prevista pelo Decreto 7.611/2011, para os alunos que recebem o atendimento educacional especializado. Entretanto, não foi possível, na rede de ensino do município de Vitória, observar se esses recursos repercutiram na ampliação do acesso do público da educação especial ao sistema de ensino municipal e em melhorias no que tange às condições de sua permanência na escola, haja vista a impossibilidade de visualizar as despesas desta modalidade de ensino no âmbito do Fundeb, considerando que elas estavam agregadas junto às despesas da educação infantil e do ensino fundamental.

Nessa direção, a política do Fundeb não pode ser compreendida considerando apenas critérios objetivos, como o número de alunos matriculados em etapas da educação básica e modalidades de ensino e os seus respectivos fatores de ponderação, mas precisa ser entendida a partir das correlações de forças entre diferentes grupos de interesses no âmbito dos municípios, na distribuição de recursos e nas suas prioridades políticas. Daí decorre a necessidade de mudança nos padrões de prestações de contas dos recursos do Fundeb e na sua fiscalização no controle de suas aplicações, principalmente as relacionadas às modalidades de ensino no âmbito do fundo, partindo do pressuposto, como o faz Gouveia (2008, p. 393), de que colocar em evidência os recursos (aqui no caso, as despesas da educação especial no Fundeb) ou a falta de recursos

[...] implica evidenciar também a necessidade de ampliação do atendimento e aí sim continuar a disputa pelo aumento deste percentual, ou ainda por outras fontes de financiamento, posto que, o aumento da participação da União no Fundeb ainda não é suficiente para a garantia da universalização de uma educação de qualidade.

Nessa perspectiva, a invisibilidade das despesas da educação especial no âmbito do Fundo tem implicação direta nas políticas de financiamento dessa modalidade de ensino, na medida em que impossibilita avaliar os custos necessários para garantir uma educação de qualidade aos alunos com deficiência, TGD e altas habilidades/superdotação nos sistemas públicos de ensino. 


\title{
5.1.7 O destino dos recursos da educação: a (in)visibilidade da educação especial na análise das despesas das etapas e modalidades na rede de ensino municipal de Vitória
}

\begin{abstract}
"As despesas vinculadas são importantes despesas do Estado brasileiro para garantir direitos, contudo, nem sempre o fato de garantir a vinculação significa que os gastos são feitos de forma a garantir a justiça social e expandir os benefícios e serviços de forma universal, buscando erradicar as desigualdades sociais". (SALVADOR, 2012, p. 14)
\end{abstract}

Para análise das despesas da Seme-Vitória com educação, como citado anteriormente, optamos por apresentar dois tipos de dados: as despesas por função e subfunção da PMV e as despesas segundo a natureza. Iniciamos pelas despesas por função, dispostas na Tabela 29.

Tabela 29 - Despesas por função - Vitória/ES 2008, 2009 e 2010 (R\$)

\begin{tabular}{|c|c|c|c|c|c|}
\hline \multirow{2}{*}{ FUNÇÃO } & \multicolumn{3}{|c|}{ ANO } & \multirow{2}{*}{$\begin{array}{c}\text { Variação } \\
\text { 2008-2010 }\end{array}$} & \multirow{2}{*}{$\begin{array}{c}\text { Variação } \\
\%\end{array}$} \\
\hline & 2008 & 2009 & 2010 & & \\
\hline Legislativa & $21.825 .006,57$ & $22.915 .897,64$ & $23.626 .949,58$ & $1.801 .943,01$ & 8,25 \\
\hline Essencial à Justiça & $10.025 .117,83$ & $11.212 .980,03$ & $11.065 .952,18$ & $1.040 .834,35$ & 10,38 \\
\hline Administração & $166.742 .512,48$ & $158.741 .301,52$ & $167.448 .864,49$ & $706.352,01$ & 0,42 \\
\hline Segurança Pública & $23.700 .214,55$ & $22.870 .585,16$ & $19.308 .303,09$ & $-4.391 .911,46$ & $-18,53$ \\
\hline Assistência Social & $39.232 .164,52$ & $45.940 .678,48$ & $46.030 .716,79$ & $6.798 .552,27$ & 17,32 \\
\hline Previdência Social & $115.909 .643,90$ & $2.598 .822,35$ & $133.177 .490,88$ & $17.267 .846,98$ & 14,89 \\
\hline Saúde & $201.319 .410,49$ & $198.867 .055,08$ & $207.705 .121,52$ & $6.385 .711,03$ & 3,17 \\
\hline Trabalho & $4.225 .734,79$ & $4.209 .398,37$ & $7.868 .237,43$ & $3.642 .502,64$ & 86,19 \\
\hline Educação & $284.334 .103,17$ & $291.500 .201,04$ & $309.636 .563,65$ & $25.302 .460,48$ & 8,89 \\
\hline Cultura & $21.470 .668,90$ & $18.953 .995,45$ & $18.340 .316,85$ & $-3.130 .352,05$ & $-14,57$ \\
\hline Direitos da Cidadania & $12.186 .464,48$ & $10.328 .566,14$ & $9.930 .397,69$ & $-2.256 .066,79$ & $-18,51$ \\
\hline Urbanismo & $311.777 .554,69$ & $262.028 .588,19$ & $270.222 .611,95$ & $-41.554 .942,74$ & $-13,32$ \\
\hline Habitação & $23.073 .781,61$ & $27.197 .749,55$ & $32.880 .501,45$ & $9.806 .719,84$ & 42,50 \\
\hline Saneamento & $18.631 .570,48$ & $63.858 .256,59$ & $69.437 .631,74$ & $50.806 .061,26$ & 272,68 \\
\hline Gestão Ambiental & $46.986 .249,65$ & $52.700 .125,84$ & $46.653 .731,82$ & $-332.517,83$ & $-0,70$ \\
\hline Comércio e Serviços & $134.450,19$ & $81.212,45$ & $1.928 .706,32$ & $1.794 .256,13$ & 1334,51 \\
\hline Comunicações & $11.733 .865,06$ & $14.173 .346,65$ & $11.176 .804,16$ & $-557.060,90$ & $-4,74$ \\
\hline Desporto e Lazer & $16.434 .929,93$ & $16.751 .642,08$ & $9.573 .433,61$ & $-6.861 .496,32$ & $-41,74$ \\
\hline Encargos Especiais & $49.790 .520,42$ & $167.866 .744,55$ & $37.890 .188,86$ & $-11.900 .331,56$ & $-23,90$ \\
\hline TOTAL & $379.533 .963,7$ & $392.797 .147,10$ & 433.902.524,06 & $54.368 .560,35$ & 3,94 \\
\hline
\end{tabular}

Fonte: Semfa/Relatório RREO - Demonstrativo da execução das despesas por função e subfunção2008, 2009 e 2010. Elaboração própria.

Valores atualizados com base no INPC/IBGE de 12/2014. 
Ao analisarmos a despesa total por função no município de Vitória, de 2008 a 2010, percebemos uma trajetória crescente nesse período, com uma evolução de 4\%. Contudo, essas despesas apresentaram oscilações significativas entre si e revelaram inconstâncias em alguns valores, com redução ou aumento desproporcional de um ano para outro, por exemplo, a função Previdência Social, que, no ano de 2008, apresentou um total de despesa de aproximadamente $R \$ 116$ milhões, em 2009, de $R \$ 3$ milhões e, em 2010, de $R \$ 133$ milhões.

Cumpre destacar ainda as oscilações nos valores despendidos aos denominados "Encargos Especiais" (R\$ 50 milhões em 2008, R\$ 168 milhões em 2009 e 38 milhões em 2010). Nessa função, eram lançados os parcelamentos de débitos da Prefeitura, o pagamento de indenizações oriundas de processos de diversas esferas, o atendimento a decretos específicos e o pagamento de precatórios.

A função educação teve um aumento de 9\% de 2008 a 2010, representando a segunda maior despesa do município em 2008 (21\%), atrás apenas da função urbanismo (23\%); e a maior despesa do município em 2009 (21\%) e 2010 (22\%), seguida pelas despesas com urbanismo e saúde. Nessa perspectiva, ao compararmos a função educação com outras funções, em termos quantitativos de recursos, podemos perceber o seu lugar de destaque na política do município de Vitória. O destaque dado a essa função foi também apontado por Calinga Jordania Pergher (2007), no seu estudo no município de Getúlio Vargas/RS, ao analisar as despesas por função no município, haja vista a subvinculação da educação na CF/1988.

Nessa mesma direção, Nascimento (2012), ao analisar as despesas por função no Brasil na última década (2001 a 2010), evidenciou também que a educação foi a função que mais recebeu recursos no decorrer do período pesquisado. Entretanto, cabe destacar que, no município de Vitória, as funções que tiveram maior incremento em termos percentuais, no período de 2008 a 2010, foram as funções de Comércio e Serviços e Saneamento, tendo em vista a importância do setor terciário para a economia do município e os investimentos realizados nesse período no projeto de saneamento básico, com apoio financeiro do governo estadual e federal, por meio do PAC. 
Desse modo, as despesas por função foram um indicador importante, como nos aponta Castro (2005), para saber as prioridades da política do município e a importância relativa da área de educação, diante das diversas atividades governamentais, seja econômicas, seja em outras áreas sociais.

A seguir, apresentaremos, na Tabela 30, as despesas por Subfunção vinculadas a função educação.

Tabela 30 - Despesas por Subfunção vinculadas à educação - Vitória/ES 2008, 2009 e $2010(R \$)$

\begin{tabular}{|c|c|c|c|c|c|c|c|c|}
\hline \multirow{2}{*}{ SUBFUNÇÃO } & \multicolumn{5}{|c|}{ ANO } & \multirow[b]{2}{*}{$\%$} & \multirow{2}{*}{$\begin{array}{c}\text { Variação } \\
\text { 2008-2010 } \\
\end{array}$} & \multirow[b]{2}{*}{$\%$} \\
\hline & 2008 & $\%$ & 2009 & $\%$ & 2010 & & & \\
\hline $\begin{array}{l}\text { Ensino } \\
\text { Fundamental }\end{array}$ & 164.188 .29303 & 57.74 & 186.677597 .13 & 364.04 & 17888587168 & 5777 & 1469757865 & 8.95 \\
\hline $\begin{array}{l}\text { Educação } \\
\text { Infantil }\end{array}$ & $116.680 .877,03$ & 41,04 & $99.399 .283,23$ & 34,10 & $125.793 .544,29$ & 40,63 & $9.112 .667,26$ & 7,80 \\
\hline $\begin{array}{l}\text { Educação } \\
\text { Especial }\end{array}$ & $658.273,56$ & 0,23 & $412.465,15$ & 0,14 & $310.413,49$ & 0,10 & $-347.860,07$ & 52,84 \\
\hline EJA & 0,00 & 0,00 & 0,00 & 0,00 & $130.082,46$ & 0,04 & 0,00 & 0,00 \\
\hline $\begin{array}{l}\text { Formação de } \\
\text { Recursos } \\
\text { Humanos } \\
\text { Administração }\end{array}$ & 0,00 & 0,00 & 0,00 & 0,00 & $22.782,87$ & 0,01 & 0,00 & 0,00 \\
\hline Geral & $2.806 .659,55$ & 0,99 & $5.010 .855,53$ & 1,72 & $4.493 .868,87$ & 1,45 & $1.687 .209,32$ & 60,11 \\
\hline TOTAL & 284.334.103,17 & 100 & $291.500 .201,04$ & 100 & $309.636 .563,65$ & 100 & $25.302 .460,48$ & 8,89 \\
\hline
\end{tabular}

Com base nos dados, percebemos que o ensino fundamental recebeu mais recursos entre as subfunções, sendo cerca de 58\% em 2008, 64\% em 2009 e 58\% em 2010, o que revela uma tendência ascendente nesse período, tal como ocorreu com a educação infantil, com 41\%, 34\% e 41\%, respectivamente. Esse resultado também foi encontrado por Nascimento (2012) quando analisou as despesas por subfunção no Brasil, no período de 2004 a 2010, em que o ensino fundamental ultrapassou os $40 \%$ das destinações, em todos os anos.

A educação especial foi mantida e desenvolvida com recursos municipais. Estes representaram 0,23\% em 2008, 0,14\% em 2009 e 0,10\% em 2010, do total das despesas da PMV, demonstrando que o seu percentual decresceu no período, 
em contraposição ao número de matrículas de educação especial na rede municipal de ensino, nesse período, que apresentou um crescimento de 44\%, conforme já salientado. Essa redução nos valores despendidos à educação especial nos faz questionar como o município custeou essa modalidade de ensino, uma vez que o aumento de matrículas repercute em maiores despesas e pressupõe, por parte do município, maior investimento para a ampliação de sua oferta e serviços.

Os dados sobre a aplicação de recursos municipais na educação especial corroboram com o estudo de François Eugene Jean de Bremaeker (2011), cujos resultados mostraram que, em 2008, do montante de $R \$ 244.508 .221,49$ aplicados na função educação, a despesa com a subfunção da educação especial foi de $R \$$ 253.366.646, ou seja, 0,42\% das despesas da função educação, porém, muito maior em valores relativos do que no município de Vitória. Esse resultado também foi verificado nas despesas por subfunção no Brasil, no período de 2001 a 2010, por Nascimento (2012), que considerou irrisórios os recursos destinados à educação especial, diante dos custos e do número de pessoas que deveriam ser atendidas nessa modalidade. Desse modo, os valores destinados à educação especial não chegavam a $1 \%$ no âmbito dos municípios, pelos estudos aqui abordados.

A EJA teve as suas despesas registradas em subfunção apenas em 2010, como já mencionado, pois, nos anos anteriores, elas estavam agregadas na etapa do ensino fundamental, embora em 2008 e 2009 o município apresentasse matrículas dessa modalidade no Censo Escolar. Assim, observamos que as modalidades de ensino representavam, em termos percentuais, poucas despesas para o município (0,04\% para EJA e 0,1\% para educação especial, no ano de 2010$)$.

Vale destacar 0 quantitativo destinado à Administração Geral, aproximadamente $0,99 \%$ ( $R \$ 3$ milhões), 1,7\% ( $R \$ 5$ milhões) e 1,4\% (R\$ 4 milhões), respectivamente, do total de despesas da PMV nos anos de 2008, 2009 e 2010. Nesses valores estavam inseridas as despesas com espaços não formais da Seme-Vitória, considerados como ensino complementar na política de educação do município (Escola de Ciência e Física; Escola da Ciência Biologia e História; o Planetário; e a Praça da Ciência). Essa oscilação nos valores despendidos na subfunção “Administração Geral”, também foi observado por Nilson Gomes Moreira (2011) ao analisar a aplicação dos recursos em educação em dez municípios do estado do Ceará, no período de 2002 a 2009. O estudo desse autor apontou ainda 
que, em alguns municípios, essas despesas não foram registradas e/ou agregadas às outras subfunções.

Cabe ressaltar também que o movimento no total de despesas em educação, por função e subfunção, no âmbito da rede municipal de ensino de Vitória, acompanha o movimento de matrículas das etapas e modalidades, exceto no ano de 2010, quando observamos um decréscimo no número de matrículas e um aumento no valor da despesa (no ano de 2008, o número de matrículas era de 50.273 e o total de despesa foi de $\mathrm{R} \$ 284$ milhões; em 2009, houve um crescimento no número de matrículas para 50.436 e também aumento nas despesas para $R \$ 292$ milhões; e no ano de 2010, embora o número de matrículas tenha reduzido para 50.009 , as despesas totalizaram $\mathrm{R} \$ 310$ milhões).

Assim, as informações sobre as despesas por subfunção no município de Vitória possibilitaram conhecer quais eram as etapas e/ou modalidades enfatizadas na política da rede municipal de ensino de Vitória, no período de 2008 a 2010, ou seja, o ensino fundamental e a educação infantil, representadas nos valores destinados a essas etapas no total de recursos vinculados à função educação. Considera-se ainda, a definição da LDB/1996 quanto às competências de cada ente federado pela oferta educacional, na qual cabe ao município o atendimento prioritário na educação infantil e no ensino fundamental.

Faz-se necessário esclarecer também que as despesas da função educação e suas subfunções estavam vinculadas à receita do município (constituída pelos impostos próprios e de transferências da União e do Estado); portanto, não estavam embutidos nesses valores os percentuais de receitas advindas do Fundeb e de transferências do FNDE, como o salário-educação, por exemplo, ao contrário das despesas por natureza, que foram apresentadas na Tabela 31.

A análise das despesas de natureza, segundo Nascimento (2012), possibilita avaliar se o ente possui recursos para novos investimentos ou se o orçamento está comprometido com as despesas já existentes, relacionadas ao pagamento de pessoal, manutenção e desenvolvimento. No nosso caso, essa análise foi fundamental para conhecermos a capacidade de investimento do município para a ampliação do acesso do público da educação especial à rede municipal de ensino de Vitória, bem como sua permanência nas escolas. 
Tabela 31 - Despesas da Seme-Vitória segundo a natureza - Vitória/ES 2008, 2009 e $2010(R \$)$

\begin{tabular}{|c|c|c|c|}
\hline ESPECIFICAÇÕES DAS DESPESAS & 2008 & 2009 & 2010 \\
\hline Despesas Correntes (1) & $299.894 .517,68$ & $312.085 .215,61$ & $331.266 .867,33$ \\
\hline $\begin{array}{l}\text { Fundo Ensino Fundamental Municipal } \\
\text { Vitória }\end{array}$ & $112.931 .111,21$ & $145.890 .347,23$ & - \\
\hline Pessoal & $105.374 .988,46$ & $85.603 .931,91$ & $244.668 .649,30$ \\
\hline \multicolumn{4}{|l|}{ Custeio } \\
\hline Material de Consumo & $14.771 .943,09$ & 8.173.356,62 & $10.212 .321,80$ \\
\hline Serviços de Terceiros & $48.730 .959,88$ & $51.896 .061,62$ & $55.901 .790,54$ \\
\hline Diárias & $78.019,18$ & $50.617,40$ & $60.818,69$ \\
\hline $\begin{array}{l}\text { Transferências a instituições privadas sem fins } \\
\text { lucrativos }\end{array}$ & $17.893 .807,34$ & $20.255 .081,82$ & 19.598.691,57 \\
\hline Outras Despesas & $113.688,52$ & $215.819,00$ & $824.595,33$ \\
\hline Total de Custeio & $81.588 .418,01$ & $80.590 .936,46$ & $86.598 .217,93$ \\
\hline Despesas de Capital (2) & $15.309 .142,90$ & $12.683 .818,70$ & 13.132.867,77 \\
\hline TOTAL $(1+2)$ & $315.203 .660,58$ & $324.769 .034,31$ & $344.399 .735,10$ \\
\hline
\end{tabular}

Fonte: Semfa/Demonstrativos de natureza e despesa 2008, 2009 e 2010. Elaboração própria.

Valores atualizados com base no INPC/IBGE de 12/2014.

Identificamos que a Seme-Vitória, no ano de 2008, despendeu aproximadamente $R \$ 300$ milhões com despesas correntes, sendo cerca de $R \$ 218$ milhões com pessoal e $R \$ 82$ milhões com custeio, o que equivale a aproximadamente $73 \%$ e $27 \%$ em relação ao total de despesas, respectivamente. Cumpre esclarecer que o total de recursos destinado às despesas com pessoal foi somado aos valores dos recursos oriundos do fundo (Fuefum) voltado exclusivamente para o pagamento dos profissionais do magistério no âmbito do município. Em 2009 e 2010, o município destinou aproximadamente $\mathrm{R} \$ 312$ milhões e $R$ \$ 331 milhões, nessa ordem, com despesas correntes, sendo, respectivamente, $R$ \$ 231 milhões e $R \$ 245$ milhões com pessoal e $R$ \$ 81 milhões e $R \$ 87$ milhões com custeio. Desse modo, o órgão despendeu aproximadamente $74 \%$ com pessoal e $26 \%$ com custeio.

Observamos que, no período de 2008 a 2010, houve um aumento destinado às despesas correntes na Seme-Vitória de aproximadamente $11 \%$, que envolviam especificamente os gastos com custeio e pessoal, haja vista o aumento no número 
de escolas e no quadro docente do município. As despesas com o custeio, nesse período, apresentaram uma evolução crescente (6\%), com aproximadamente $R \$ 82$ milhões em 2008, R\$ 81 milhões em 2009 e $R \$ 87$ milhões em 2010, no âmbito da Seme-Vitória. Os dados levantados na pesquisa mostraram que as maiores despesas, nos anos de 2008 a 2010, eram com pessoal: 73\% em 2008 e 74\% em 2009 e 2010, reforçando a conclusões de outras pesquisas (PARO, 1982; CARVALHO, 2011).

Assim, foi possível observar, como Pergher (2007), que as despesas correntes ocupavam um lugar de destaque no município, ficando as despesas de capital com um percentual de aproximadamente 4\% em 2008, 2009 e 2010. Desse modo, pudemos constatar que as maiores despesas do município eram com a manutenção e o desenvolvimento do ensino nas escolas do município e com a remuneração dos profissionais do magistério e que poucos recursos eram destinados a investimentos para a expansão de vagas e melhoria na qualidade da educação ${ }^{120}$ na rede de ensino municipal de Vitória ${ }^{121}$. Daí decorre a importância de direcionar a atenção e a análise para esses gastos no financiamento da educação. As despesas com pessoal por etapas de ensino foram descritas na Tabela 32.

Tabela 32 - Despesas com pessoal por etapas de ensino -Vitória/ES 2008, 2009 e $2010(R \$)$

\begin{tabular}{ccccccc}
\hline & \multicolumn{3}{c}{ Valores em R\$ } & & \multicolumn{3}{c}{$\%$} \\
ETAPAS DE ENSINO & 2008 & 2009 & 2010 & 2008 & 2009 & 2010 \\
\hline Ensino Fundamental & $123.897 .676,60$ & $157.063 .360,42$ & $138.178 .584,41$ & 57 & 68 & 56 \\
Educação Infantil & $94.408 .423,08$ & $74.430 .918,72$ & $106.490 .064,89$ & 43 & 32 & 44 \\
\hline TOTAL & $218.306 .099,68$ & $231.494 .279,14$ & $244.668 .649,30$ & 100 & 100 & 100 \\
\hline
\end{tabular}

Fonte: Semfa/Demonstrativos de natureza e despesa 2008, 2009 e 2010. Elaboração própria.

Valores atualizados com base no INPC/IBGE de 12/2014.

120 Qualidade da educação entendida como "um conjunto de fatores intra e extra-escolares que se referem às condições de vida dos alunos e de suas famílias, ao seu contexto social, cultural e econômico e à própria escola" (DOURADO, 2007, p. 941).

${ }^{121}$ Cumpre ressaltar que essas afirmações se baseiam nas informações obtidas nas análises dos demonstrativos de despesas da Seme-Vitória. Não foi possível, neste estudo, investigar se as despesas com investimentos em educação eram contabilizadas em outras secretarias da PMV. 
Os dados da Tabela 32 evidenciaram que foram destinados às despesas com pessoal no ensino fundamental e na educação infantil, no município de Vitória, aproximadamente $R \$ 218$ milhões em 2008, $R \$ 231$ milhões em 2009 e $R \$ 245$ milhões em 2010. Nesse período, podemos observar uma contínua tendência crescente nas despesas com pessoal, um aumento de aproximadamente $12 \%$. Cabe destacar que os recursos destinados a esse gasto eram provenientes dos recursos do Fundeb e dos 15\% restantes dos 25\% dos demais impostos próprios do município aplicados na remuneração do magistério do ensino fundamental. Assim, podemos observar que os recursos oriundos do Fundeb (Tabela 28) destinados ao pagamento dos profissionais do magistério $(R \$ 121$ milhões em 2008; $R \$ 161$ milhões em 2009; e 193 milhões em 2010) representaram 56\%, 70\% e 79\%, respectivamente, do total de despesas com pessoal da Seme-Vitória. Desse modo, apenas os recursos do Fundeb não foram suficientes para o pagamento de todos os profissionais do magistério que atuavam no município de Vitória. Sendo necessária, portanto, a complementação dos $15 \%$ restantes dos recursos provenientes dos $25 \%$ dos impostos próprios do município vinculados aos gastos com MDE. Essa insuficiência de recursos do Fundeb para pagamento de pessoal também foi constatada por Marina Godoy (2014) no estado do Paraná, no período de 2007 a 2014.

Observamos ainda, na Tabela 32, que o ensino fundamental absorveu a maior parte dos recursos destinados à despesa com pessoal, uma vez que foram destinados cerca de 57\% em 2008, 68\% em 2009 e 56\% em 2010. Vale destacar que, no período analisado, o número de escolas e de matrículas nessa etapa de ensino era superior ao da educação infantil, como pudemos observar no Capítulo 5 deste trabalho, item 5.1 "A educação em Vitória/ES". Não podemos desconsiderar também a existência de um fundo específico (Fuefum) para o pagamento dos profissionais dessa etapa de ensino. Cabe acrescentar ainda que poderiam estar agregados nesses valores os gastos com profissionais que atuavam em outras modalidades de ensino no município, tendo em vista que, nos demonstrativos de despesas, esses dados não foram apresentados e o município não tinha uma classificação funcional para os professores que atuavam na educação especial e na EJA. De acordo com o Censo Escolar, havia alunos matriculados na EJA e na educação especial nas escolas do município nos anos de 2008, 2009 e 2010. Soma- 
se a isso o fato de que, em Vitória, os professores da educação especial que atuavam no atendimento educacional especializado não tinham cargos específicos.

No que se refere às despesas com pessoal da educação infantil, também observamos uma trajetória crescente nos recursos (aproximadamente $\mathrm{R} \$ 94$ milhões em 2008, R\$ 74 milhões em 2009 e $R \$ 106$ milhões em 2010), exceto no ano de 2009, no qual houve um decréscimo no montante destinado a essa etapa de ensino no município. Porém, os valores retomam o crescimento em 2010. Convém ressaltar que, no ano de 2009, houve aumento do número de escolas nessa etapa de ensino (de 44 para 45 unidades de ensino) e também aumento no número de matrículas (de 16.983 em 2008 para 17.844 em 2009), segundo os dados informados no Censo Escolar dos respectivos anos. Assim, quando consideramos o movimento de despesa com pessoal, tanto no ensino fundamental quanto na educação infantil, no período de 2008 a 2010, observamos que ele não acompanha a variação de matrículas nessas etapas de ensino. Desse modo, quando o número de alunos cresce, o valor destinado ao pagamento de pessoal diminui e vice-versa. Faz-se necessário destacar que estavam incluídos nas despesas de pessoal da rede municipal de ensino de Vitória os professores efetivos e os contratados.

No que se refere às despesas com pessoal em educação especial e da EJA, observamos que não havia uma especificação, no demonstrativo de despesas do município, voltada a essas modalidades de ensino, o que nos permite supor que essas despesas se apresentaram agregadas às das outras etapas da educação básica. Cabe destacar que, no município de Vitória, não havia um cargo específico para a educação especial, pois os profissionais que atuavam nessa área eram oriundos da educação infantil ou do ensino fundamental.

Ressaltamos, ainda, que também não foi possível observar, especificamente, as despesas com o magistério, na medida em que os dados do pessoal não foram apresentados de forma desagregada, discriminando os professores de outros profissionais que atuavam na realização de serviços de apoio técnico pedagógico (especialista educacional, coordenador de turno e pedagogo, que desempenhavam atribuições de coordenação, inspeção, supervisão, administração, inspeção, planejamento, avaliação e assessoramento em assuntos educacionais, ensino e pesquisa) e do quadro suplementar de cargos do magistério (berçarista, orientador 
de educação física e secretário escolar) lotados e em exercício nas escolas ou órgão/unidade administrativa da educação (VITÓRIA, 2006b).

Em continuação à análise das despesas correntes, dirigidas à manutenção e ao desenvolvimento do ensino, dispomos, na Tabela 33, as despesas de custeio na educação infantil, ensino fundamental, educação especial e EJA. Essas despesas se referem aos recursos despendidos para diversas atividades relacionadas ao adequado funcionamento dos estabelecimentos de ensino, como aquisição de material de consumo e de serviços ligados à informática, locação de veículos, equipamentos e imóveis, contratação de consultorias e empresas para conservação e pequenos reparos, pagamentos de subvenções sociais, diárias, passagens, intercâmbio cultural, serviços de estagiários, instrutores, serventes, vigilância, água, esgoto, energia elétrica, serviços de comunicação, publicidade, propaganda, vale transporte, uniformes, entre outros.

Tabela 33 - Despesas com custeio, por etapas e modalidades - Vitória/ES 2008, 2009 e $2010(R \$)$

\begin{tabular}{lcccccc}
\hline & \multicolumn{3}{c}{ Valores em R\$ } & & \multicolumn{3}{c}{$\%$} \\
ETAPA/MODALIDADE & $\mathbf{2 0 0 8}$ & $\mathbf{2 0 0 9}$ & $\mathbf{2 0 1 0}$ & $\mathbf{2 0 0 8}$ & $\mathbf{2 0 0 9}$ & $\mathbf{2 0 1 0}$ \\
\hline Ensino Fundamental & $48.590 .261,76$ & $45.874 .642,83$ & $50.098 .533,89$ & 59,56 & 56,92 & 57,85 \\
\hline Educação Infantil & $29.280 .905,36$ & $29.737 .903,66$ & $31.575 .003,22$ & 35,89 & 36,90 & 36,46 \\
\hline Educação Especial & $658.273,17$ & $411.130,45$ & $307.821,95$ & 0,80 & 0,51 & 0,36 \\
\hline EJA & - & - & $130.082,46$ & - & - & 0,15 \\
\hline Administração Geral & $3.058 .977,72$ & $4.567 .259,52$ & $4.463 .993,54$ & 3,75 & 5,67 & 5,15 \\
\hline $\begin{array}{l}\text { Valorização e } \\
\text { Capacitação dos } \\
\text { Servidores }\end{array}$ & - & - & $22.782,87$ & - & - & 0,03 \\
\hline \multicolumn{1}{c}{ TOTAL } & $\mathbf{8 1 . 5 8 8 . 4 1 8 , 0 1}$ & $\mathbf{8 0 . 5 9 0 . 9 3 6 , 4 6}$ & $86.598 .217,93$ & 100 & 100 & 100 \\
\hline
\end{tabular}

Fonte: Semfa/Demonstrativos de natureza e despesa 2008, 2009 e 2010. Elaboração própria.

Valores atualizados com base no INPC/IBGE de 12/2014.

Notamos que foi despendido com custeio um total de aproximadamente $R \$ 82$ milhões em 2008, R\$ 81 milhões em 2009 e $R \$ 87$ milhões em 2010, destinados às 
diferentes etapas e modalidades de ensino, apresentando uma evolução crescente no decorrer dos anos, com um aumento de aproximadamente 6\% de 2008 a 2010.

Merecem ainda destaque os valores destinados às despesas com custeio da administração geral da Seme-Vitória, cerca de $R \$ 3$ milhões (4\%) em 2008, de $R \$ 5$ milhões (6\%) em 2009 e de $R \$ 4$ milhões (5\%) em 2010, superando em muito os valores destinados às modalidades de ensino educação especial (0,8\% em 2008, 0,5\% em 2009 e 0,4\% em 2010) e EJA (0,2\% em 2010) no município. Essas despesas estavam vinculadas ao funcionamento e à manutenção da parte administrativa da Seme-Vitória, incluindo passagens, diárias, gêneros de alimentação, material de manutenção de bens imóveis e veículos, material de consumo, locomoção urbana, estagiários, locação de imóveis, vigilância, serviços de copo e cozinha e outros serviços de terceiros e também as despesas com o ensino complementar nos espaços não formais, mantidos pela PMV para atendimento aos alunos da educação infantil e do ensino fundamental. Faz-se necessário ressaltar que essa especificação "Administração Geral" se apresenta de forma genérica, possibilitando que diferentes despesas sejam alocadas sob essa denominação, 0 que dificulta a análise e o acompanhamento dos recursos destinados à manutenção e ao desenvolvimento do ensino.

No ano de 2010, apareceram duas novas especificações de despesas com a de custeio: "valorização e capacitação dos servidores", voltada para a formação continuada dos profissionais de ensino da rede municipal de Vitória; e a de "educação de jovens e adultos", segundo consta no Demonstrativo de natureza e despesa da PMV (2010). Cumpre ressaltar que essa modalidade de ensino, nos anos anteriores, não foi especificada nos demonstrativos de despesa do município, embora apresentasse alunos matriculados, como citado anteriormente. Uma hipótese é a de que as suas despesas estavam agregadas às outras etapas de ensino. Essa constatação também foi feita por Carvalho (2011, p. 228), quando relatou a dificuldade de avaliar os investimentos de estados e municípios em EJA:

Em geral, os pesquisadores acabam trabalhando com estimativas e/ou dados aproximativos, uma vez que o Brasil não possui um sistema adequado de acompanhamento de investimento na EJA por parte destes entes. É comum, por exemplo, que partes consideráveis de despesas nessa modalidade não sejam contabilizadas como investimento em EJA. [...] muitos entes federados não discriminam 
despesas com EJA, provavelmente por estarem englobadas nos recursos de MDE.

A educação especial, conforme disposto na Tabela 33, participou das despesas do custeio da secretaria, nos anos de 2008, 2009 e 2010, na proporção de aproximadamente 0,8\%, 0,5\% e 0,4\%, respectivamente. Dessa maneira, apresentou um decréscimo nos valores despendidos no funcionamento dessa modalidade de ensino, embora o número de matrículas do público da educação especial tenha aumentado na rede municipal de ensino, nesse período. Essa constatação poderia nos levar a afirmar, como Prieto e Gil (2011, p. 96), que "o custeio da educação especial não é mais caro, proporcionalmente, do que o custeio das demais etapas e modalidades". Entretanto, o fato de as despesas com pessoal não terem sido registradas nos demonstrativos do município pode sustentar a hipótese de que os valores de custeio da educação especial podem estar subdimensionados e agregados às outras etapas de ensino; por isso, a comparação dos gastos com outras etapas e modalidades torna-se difícil e complexa.

É interessante, contudo, verificar como foram efetuados os gastos descritos como custeio de educação especial, tendo em vista que um melhor detalhamento permite identificar com maior clareza o gasto público, como podemos observar na Tabela 34.

Tabela 34 - Despesas com custeio da educação especial - Vitória/ES 2008, 2009 e $2010(\mathrm{R} \$)$

\begin{tabular}{|c|c|c|c|c|c|c|}
\hline \multirow{2}{*}{ ITEM } & \multicolumn{2}{|l|}{2008} & \multicolumn{2}{|l|}{2009} & \multicolumn{2}{|c|}{2010} \\
\hline & $\mathbf{R} \$$ & $\%$ & $\mathbf{R} \$$ & $\%$ & $\mathbf{R} \$$ & $\%$ \\
\hline Subvenções Sociais (1) & $449.698,04$ & 68,31 & $48.006,51$ & 11,68 & $15.719,60$ & 5,11 \\
\hline Material de Consumo (2) & - & - & - & - & $1.143,77$ & 0,37 \\
\hline $\begin{array}{l}\text { Outros Serviços de } \\
\text { Terceiros (3) }\end{array}$ & $208.575,13$ & 31,69 & $362.385,78$ & 88,14 & $290.958,58$ & 94,52 \\
\hline Alimentação & _ & - & $23.862,78$ & - & - & - \\
\hline $\begin{array}{l}\text { Pró-Labore A Consultores } \\
\text { Eventuais }\end{array}$ & - & - & - & - & $10.893,34$ & - \\
\hline Locação De Imóveis & - & - & - & - & $50.834,31$ & - \\
\hline
\end{tabular}


Conclusão

\begin{tabular}{|c|c|c|c|c|c|c|}
\hline ITEM & 2008 & & 2009 & & 2010 & \\
\hline & $\mathbf{R} \$$ & $\%$ & $\mathbf{R} \$$ & $\%$ & $\mathbf{R} \$$ & $\%$ \\
\hline $\begin{array}{l}\text { Locação de veículos } \\
\text { automotores }\end{array}$ & - & - & $2.381,56$ & - & - & - \\
\hline $\begin{array}{l}\text { Locação de bens móveis e } \\
\text { outras naturezas }\end{array}$ & - & - & - & - & $3.901,53$ & - \\
\hline $\begin{array}{l}\text { Exposições, congressos e } \\
\text { conferências }\end{array}$ & - & - & - & - & $3.202,56$ & - \\
\hline $\begin{array}{l}\text { Fornecimento de } \\
\text { alimentação }\end{array}$ & - & - & - & - & $6.318,70$ & - \\
\hline $\begin{array}{l}\text { Instrutores - pagamento } \\
\text { hora/aula }\end{array}$ & $8.689,47$ & - & $12.510,58$ & - & - & - \\
\hline Intercâmbio técnico e cultural & - & - & $22.379,78$ & - & - & - \\
\hline $\begin{array}{l}\text { Serviço de seleção e } \\
\text { treinamento }\end{array}$ & - & - & - & - & $10.020,71$ & - \\
\hline Serviços gráficos e editoriais & - & - & - & - & 559,16 & - \\
\hline Vale transporte & $14.512,66$ & - & - & _- & $41.684,14$ & \\
\hline $\begin{array}{l}\text { Outros serviccos de terceiros, } \\
\text { pessoa jurídica }\end{array}$ & $185.373,00$ & - & $301.251,09$ & - & $163.544,12$ & - \\
\hline $\begin{array}{l}\text { Restituições de saldos de } \\
\text { convênios (4) }\end{array}$ & - & - & 738,16 & 0,18 & - & - \\
\hline Total $(1+2+3+4)$ & $658.273,17$ & - & $411.130,45$ & - & $307.821,95$ & - \\
\hline
\end{tabular}

Fonte: Semfa/Demonstrativos de natureza e despesa 2008, 2009 e 2010. Elaboração própria.

Valores atualizados com base no INPC/IBGE de 12/2014.

No custeio da educação especial, podemos observar que as despesas mais expressivas em termos percentuais, em 2008 (68\%), foram destinadas às Subvenções Sociais. Estas são utilizadas na cobertura de despesas de custeio das instituições públicas ou privadas sem finalidade lucrativa, segundo a Lei $\mathrm{n}^{\circ}$ 4.320/1964:

Art. 16. Fundamentalmente e nos limites das possibilidades financeiras a concessão de subvenções sociais visará à prestação de serviços essenciais de assistência social, médica e educacional sempre que a suplementação de recursos de origem privada, aplicados a esses objetivos, revelar-se mais econômica.

Parágrafo único. $O$ valor das subvenções, sempre que possível, será calculado com base em unidades de serviços efetivamente prestados ou postos à disposição dos interessados obedecidos os padrões mínimos de eficiência previamente fixados. (BRASIL, 1964). 
Nesse contexto, cumpre destacar as mudanças nas relações que fundamentam o capitalismo e suas configurações nos séculos $X X$ e $X X I$, bem como a redefinição do papel do Estado na execução e no financiamento das políticas sociais, entre as quais as educacionais (PERONI, 2009; BENATTI, 2011; BEHRING, 2008a), que se materializam na divisão de responsabilidades entre o Estado e a sociedade civil no provimento de serviços públicos à população. No caso da educação especial, essa parceria se (re)estrutura, segundo Bueno e Kassar (2005) e Romero (2006), na vinculação do Estado com o Terceiro Setor - a sociedade civil organizada -, constituído por organizações não-estatais que ofertam atendimento educacional ao público da educação especial, por meio do repasse de recursos públicos a essas instituições.

$\mathrm{Na}$ rede de ensino municipal de Vitória, os recursos de subvenções sociais foram voltados para instituições que tinham convênios com a PMV, como a Apae, para avaliação multidisciplinar dos alunos com deficiência intelectual e atendimento educacional especializado; a Associação Brasileira de Altas Habilidades/Superdotação e a Oficina de Artes de Vitória para atendimento aos alunos com deficiência, TGD e altas habilidades/superdotação, conforme consta no Plano de Trabalho de 2008/2009. Estudos de Kassar (2001), Mazzotta (2011), Bueno e Kassar (2005) já indicavam a forte presença de entidades privadas na oferta de serviços e na execução de políticas de educação especial, como já explicitado neste trabalho, embora ainda não tenhamos estudos na área da educação especial que comprovem ser mais econômico e vantajoso para o Estado prover subvenções sociais as instituições privadas.

Notamos que, nos anos posteriores, os valores de Subvenções Sociais, no âmbito da Seme-vitória, apresentaram um decréscimo de aproximadamente 96\% (2008 a 2010). Isso pode ser atribuído, segundo consta no relatório de ações realizadas da Cfaee, à não renovação do contrato de convênio da Seme-Vitória com a Apae, no ano de 2009, para o atendimento aos alunos com deficiência intelectual. Assim, notamos redução tanto nas despesas com as subvenções sociais dirigidas às instituições privadas de educação especial quanto na aplicação direta na modalidade de ensino no âmbito da administração municipal, o que nos possibilitaria pensar no barateamento da educação especial por parte Estado. 
Quando analisamos, porém, o Relatório Circunstanciado da Administração Municipal (2009-2012) (VITÓRIA, 2012c) em atendimento ao disposto no art.114 da Lei Orgânica Municipal da PMV (VITÓRIA, 1990), percebemos que as despesas com a Apae e demais entidades privadas de educação especial foram mantidas por meio da Secretaria de Assistência Social (Semas) e da Secretaria Municipal de Saúde (Semus), como podemos observar na Tabela 35.

Tabela 35 - Convênios da Prefeitura Municipal de Vitória/ES 2008-2013 (R\$)

\begin{tabular}{|c|c|c|}
\hline SECRETARIA & INSTITUIÇÃO & $\mathbf{R} \$$ \\
\hline & $\begin{array}{l}\text { Assoc. de Pais e Amigos dos } \\
\text { Vitória }\end{array}$ & \\
\hline \multirow{25}{*}{$\sum_{\underset{\omega}{W}}^{\infty}$} & 2008/2009 Co-Patrocínio & $280.868,18$ \\
\hline & Convênio & $44.165,12$ \\
\hline & 2009/2010 Termo de Responsabilidade & $217.650,10$ \\
\hline & 2009/2010 Termo de Responsabilidade & $47.951,37$ \\
\hline & Termo de Responsabilidade & $24.858,46$ \\
\hline & 2011/2012 Termo de Responsabilidade & $32.189,71$ \\
\hline & 2012/2013 Termo de Responsabilidade & $35.945,50$ \\
\hline & 2012/2013 Termo de Responsabilidade & $18.103,80$ \\
\hline & 2012/2013 Termo de Responsabilidade & $31.392,37$ \\
\hline & 2012/2013 Termo de Responsabilidade & $41.845,31$ \\
\hline & 2012/2103 Convênio & $145.402,52$ \\
\hline & TOTAL & $920.372,44$ \\
\hline & \multicolumn{2}{|c|}{$\begin{array}{l}\text { Assoc. dos Amigos dos Autistas do Estado do } \\
\text { Esp. Santo }\end{array}$} \\
\hline & 2008/2009 Convênio & $14.043,41$ \\
\hline & Termo de Responsabilidade & $3.281,47$ \\
\hline & Termo de Responsabilidade & $29.910,87$ \\
\hline & TOTAL & $47.235,75$ \\
\hline & \multicolumn{2}{|c|}{$\begin{array}{c}\text { Assoc. de Pais e Amigos e das Pessoas com } \\
\text { Síndrome de Down }\end{array}$} \\
\hline & 2009/2010 Termo de Responsabilidade & $31.392,21$ \\
\hline & 2009/2010 Termo de Responsabilidade & $57.893,33$ \\
\hline & TOTAL & $89.285,54$ \\
\hline & $\begin{array}{l}\text { Assoc. Brasileira par } \\
\text { Habilidades/Superdc }\end{array}$ & \\
\hline & 2009/2010 Termo de Responsabilidade & $9.922,60$ \\
\hline & TOTAL & $9.922,60$ \\
\hline & TOTAL GERAL SEMAS & $1.066 .816,33$ \\
\hline \multirow{3}{*}{$\underset{\text { W }}{\stackrel{\infty}{己}}$} & \multicolumn{2}{|c|}{ Assoc. de Pais e Amigos dos Excepcionais de Vitória } \\
\hline & 2008/2013 Convênio & $8.867 .157,64$ \\
\hline & TOTAL GERAL SEMUS & $8.867 .157,64$ \\
\hline
\end{tabular}


Conclusão

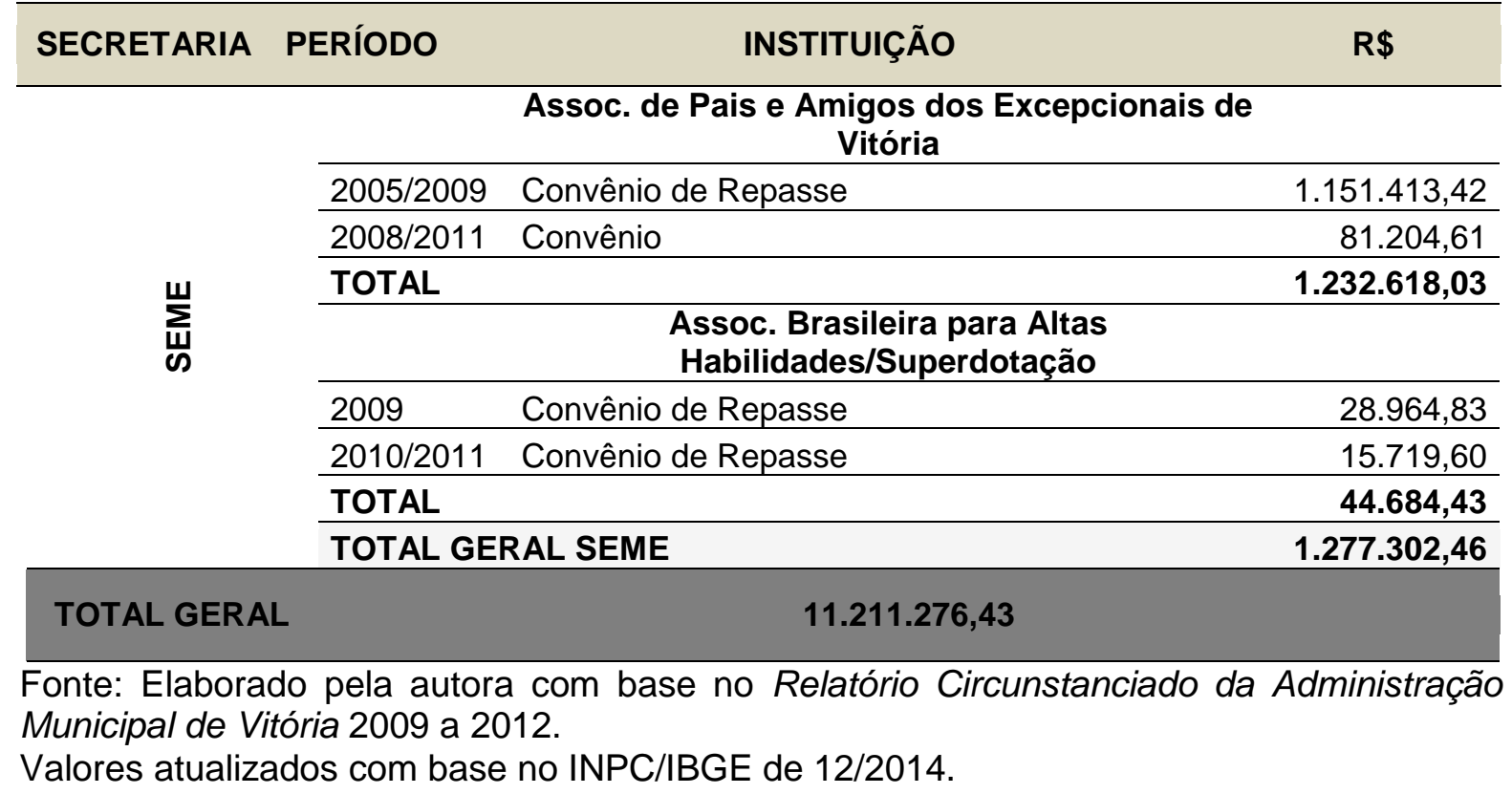

Evidenciamos que a PMV estabeleceu convênios com diferentes entidades privadas sem fins lucrativos que ofereciam serviços, incluindo os de educação substitutiva e complementar ou suplementar, ao público da educação especial do município de Vitória, por meio de cooperação técnica e financeira, no período de 2008 a 2013 , num total de $\mathrm{R} \$ 11.211 .276,43$.

Desse modo, por meio da Semas, a PMV destinou à Apae $R \$ 920.372,44$, de 2008 a 2013, para aquisição de equipamentos e materiais didáticos, readequação e adaptação do espaço físico da instituição, realização de eventos, desenvolvimento de projetos e pagamento de profissionais (fisioterapeutas, instrutores, entre outros) (VITÓRIA, 2012c). A Associação dos Amigos dos Autistas do Estado do Espírito Santo recebeu um total de $\mathrm{R} \$ 42.235,75$ para atendimento às crianças, adolescentes e jovens com autismo, reestruturação do espaço físico da instituição e aquisição de materiais e equipamentos adaptados para 0 atendimento a esse público (VITÓRIA, 2012c). A Associação de Pais e Amigos das Pessoas com Síndrome de Down do Espírito Santo absorveu um total de $\mathrm{R} \$ 89.285,54$ para aquisição de materiais e contratação de profissionais para o desenvolvimento de projetos e oficinas voltados ao atendimento de crianças e adolescentes. Por fim, à Associação Brasileira para Altas Habilidades/Superdotação foi destinado um total de 
$\mathrm{R} \$$ 9.922,60 para a criação do seu Núcleo de Apoio para o Desenvolvimento de Talentos - NADT.

A Semus, por sua vez, designou à Apae-Vitória, no período de 2008 a 2013, um total de $\mathrm{R} \$$ 8.867.157,64 para manutenção da oferta de serviços de atenção e saúde a munícipes que apresentavam deficiência intelectual e múltipla, bebê de risco, autismo e transtorno psíquico e transtorno familiar.

A Seme destinou, no período de 2005 a 2009, o valor de $R \$ 1.151 .413,42$ à Apae-Vitória, voltado à oferta de atendimento educacional especializado. De 2008 a 2011, repassou à Apae o total de $\mathrm{R} \$ 81.204,61$ dos recursos originários do FNDE/Programa Nacional de Alimentação Escolar (PNAE) em cumprimento ao art. 10 da Resolução no 32, de 10 de agosto de $2006^{122}$, e o valor de $R \$ 44.684,43$ à Associação Brasileira para Altas Habilidades/Superdotação, para a manutenção do Cedet, participação em eventos e desenvolvimento de projetos e pesquisas da área. Desse modo, notamos que o convênio com a Apae-Vitória para atendimento educacional especializado não foi renovado, como apontado anteriormente pelo relatório da Cfaee. Entretanto, faz-se necessário considerar que o Decreto oㅡ 7.611/11, admitiu, para efeito da distribuição dos recursos do Fundeb, o cômputo das matrículas efetivadas na educação especial oferecida pelas instituições comunitárias, confessionais ou filantrópicas sem fins lucrativos com atuação exclusiva na educação especial.

Assim, notamos que a PMV destinou às instituições privadas de educação especial recursos voltados ao atendimento educacional especializado em áreas que também ofereciam o mesmo tipo de atendimento, como a deficiência intelectual, e em áreas que não apresentavam oferta de serviços, como as das altas habilidades/superdotação e do autismo. Nessa perspectiva, notamos, como apontado em outras produções (MAZZOTA, 2011; KASSAR, 1998; LOUREIRO;

122 Art. 10. Os recursos financeiros destinados à alimentação escolar dos alunos matriculados em entidades filantrópicas, na forma prevista nos $\S \S 1^{\circ}$ e $3^{\circ}$ do artigo $5^{\circ}$ desta Resolução, serão transferidos para o respectivo município e ao Distrito Federal, que, a seu critério, poderão atendê-las mediante o fornecimento de gêneros alimentícios ou repasse dos correspondentes recursos financeiros.

Parágrafo Único - no caso de a Entidade Executora optar em repassar os recursos financeiros recebidos à conta do Pnae às escolas de que trata este artigo, somente poderá fazê-lo mediante formalização de termo de convênio, na forma estabelecida na Instrução Normativa $n^{\circ}$ 01/97, da Secretaria do Tesouro Nacional (BRASIL, 2006d). 
CAIADO, 2013), a forte presença da rede privada de educação especial na oferta dos serviços ao público da educação especial, embora, no município de Vitória, essa parceria se efetive, principalmente pela via da assistência social e da saúde, e também a disputa pelo fundo público no âmbito do Estado. Nessa direção, parecenos que a iniciativa privada conseguiu manter, no jogo das forças políticas, no âmbito da PMV, os seus interesses e recursos garantidos. Diante desse contexto, observamos a necessidade do Estado garantir maior controle sobre os recursos públicos destinados as entidades privadas de ensino, de modo a assegurar o acesso e a transparência nas informações, como prevê a Lei no 15.527/2011, no que se refere as verbas públicas aplicadas as ações e serviços direcionados ao público da educação especial.

Retomando as despesas com o custeio da educação especial no município de Vitória (2008 a 2010), notamos que as que mais se destacaram foram Outros serviços de terceiros, que envolvem despesas com pessoa física e despesas com pessoa jurídica. As despesas com pessoa física compreendem "despesas com a remuneração de serviços de natureza eventual prestados por pessoa física, sem vínculo empregatício" (CRUZ et al., 2001, p. 49). Estavam descritos, nesse elemento de despesa, os pagamentos para instrutores (hora/aula) que atuavam no Projeto Integrartes e Cedet e pró-labore a consultorias eventuais. Cabe destacar que as despesas com os estagiários não estavam descritas na classificação da educação especial, embora seus serviços estivessem previstos nos planos de trabalho do Cfaee. As despesas com esses profissionais estavam agregadas à educação infantil e ao ensino fundamental. O elemento despesas com pessoa jurídica, segundo Prieto e Gil (2011, p. 97), "pode ocorrer tanto no setor público quanto no setor privado e consiste no ato de contratar terceiro para realização de atividades que não constituem o objeto principal da empresa, órgão ou administração" e pode englobar tanto a produção de bens como de serviços. De acordo com os balanços e relatórios de atividades da Cfaee, as despesas vincularam-se às ações de formação continuada realizadas nos anos de 2008, 2009 e 2010 ${ }^{123}$, que envolveram recursos relacionados com locação de imóveis, locação de equipamentos e materiais

${ }^{123}$ Curso de tecnologias assistivas, comunicação alternativa e ampliada; curso de práticas de ensino da L1 e L2 para alunos surdos; curso de Pós-Graduação à distância interinstitucional de ensino superior; seminário de formação de gestores, entre outros cursos voltados à formação continuada dos professores de educação especial e de ensino regular que atuavam com o público dessa modalidade de ensino. 
permanentes, serviços de comunicação, exposições, congressos e conferências, fornecimento de alimentação, serviços de divulgação, impressão e encadernação, intercâmbio técnico e cultural, seleção e treinamento, vale-transporte e consultorias.

Cumpre ressaltar que as despesas com Locação de veículos automotores foram destinadas às assessorias realizadas pela Cfaee em colaboração com as equipes de educação infantil e EJA, bem como para a locomoção dos professores itinerantes de educação especial para atendimento no contexto escolar.

A concessão de Vales Sociais estava também entre os serviços oferecidos pelo município, para o transporte público municipal dos alunos com deficiência, TGD e altas habilidades/superdotação, tendo em vista o atendimento educacional especializado em escolas de referência e no turno oposto ao do ensino regular. Assim, observamos que os gastos em custeio da educação especial estavam articulados com os objetivos descritos no Plano de Trabalho da Cfaee e da política de educação especial do município.

De acordo com o que foi apresentado na Tabela 34, pela Semfa, não houve despesas com Materiais de consumo nos anos de 2008 e 2009 e apenas em 2010 foi registrado um valor de $\mathrm{R} \$ 1.143,77$. Esses dados, referentes a esse elemento de despesa, certamente não correspondia ao que era necessário para o funcionamento e a manutenção dos serviços oferecidos pelas escolas às pessoas com deficiência, TGD e altas habilidades/superdotação, considerando o número de alunos da educação especial e o valor irrisório, em 2010, despendido às despesas para compra de materiais de consumo. Assim, concordamos quando Prieto e Gil (2011) afirmam que os recursos para as despesas de custeio saíram de outras fontes, seja de outras rubricas orçamentárias da Seme-Vitória, seja de outros órgãos da administração. Cumpre destacar que a orientação da Cfaee era a de que esse tipo de despesa (custeio), inclusive para a manutenção e o funcionamento das salas de recursos multifuncionais, ficasse a cargo das próprias escolas, como constava na orientação do Plano de Trabalho de 2008/2009 (VITÓRIA, 2008c). Desse modo, as despesas de custeio da educação especial estavam agregadas às despesas de manutenção e funcionamento das escolas.

Esses detalhamentos referentes às despesas correntes (relacionados com materiais de consumo, serviços de terceiros, transferências a instituições privadas sem fins lucrativos e gastos com pessoal) reforçam a assertiva de que o município 
de Vitória possui pouca possibilidade de investimento voltado à expansão de vagas, a construções de novas escolas e à formação e valorização dos profissionais do magistério com aumento de salários e melhores condições de trabalho. O município destinou para despesas de capital aproximadamente $4 \%$ do total de despesas em 2008, 2009 e 2010, voltadas às etapas e modalidades de ensino, conforme apresentamos na Tabela 36. Esses resultados também foram constatados por Nascimento (2012) quando analisou as despesas de capital entre os entes federados - estados, Distrito Federal e municípios - no período de 2001 a 2010 , os quais, juntos, destinaram para investimento 8,5\% do total de despesas em 2010.

Tabela 36 - Despesas de Capital - Vitória/ES 2008, 2009 e $2010(\mathrm{R} \$)$

\begin{tabular}{lcccc}
\hline \multirow{2}{*}{ NíVEIS E MODALIDADES DE ENSINO } & \multicolumn{3}{c}{ ANO } \\
& $\mathbf{2 0 0 8}$ & $\mathbf{2 0 0 9}$ & $\mathbf{2 0 1 0}$ \\
\hline Educação Infantil & $5.972 .311,65$ & $7.381 .350,08$ & $7.339 .861,60$ \\
\hline Ensino Fundamental & & $9.323 .272,62$ & $5.265 .832,74$ & $5.760 .539,30$ \\
\hline Educação Especial & & & & \\
\hline $\begin{array}{l}\text { Outros equipamentos } \\
\text { permanentes }\end{array}$ & \multirow{2}{*}{ materiais } & & $1.334,70$ & $2.591,53$ \\
\hline Administração Geral & & $13.558,63$ & $35.301,18$ & $29.875,34$ \\
\hline \multicolumn{1}{c}{ TOTAL } & & $15.309 .142,90$ & $12.683 .818,70$ & $13.132 .867,77$ \\
\hline
\end{tabular}

Fonte: Semfa/Demonstrativos de natureza e despesa 2008, 2009 e 2010. Elaboração própria.

Valores atualizados com base no INPC/IBGE de 12/2014.

As despesas de capital, voltadas à aquisição de bens que integravam o patrimônio público do município, apresentaram oscilações no período pesquisado, com aproximadamente $R \$ 15$ milhões em 2008 e $R \$ 13$ milhões em 2009 e 2010.

Notamos que, no ano de 2008, o ensino fundamental reteve a maior parte dos recursos em despesas de capital, com aproximadamente $R \$ 9$ milhões, seguido pela educação infantil, com aproximadamente $R$ \$ 6 milhões, e pela administração geral, com aproximadamente $\mathrm{R} \$ 14.000,00$. Observamos que, nesse ano, não foi registrada nenhuma despesa com a educação especial, embora a rede municipal de ensino de Vitória apresentasse matrículas (906) de alunos com deficiência, TGD e altas habilidades/superdotação, de acordo com o Censo Escolar do ano de 2008. 
Nos anos de 2009 e 2010, a maior parcela das despesas de capital foi destinada à educação infantil (aproximadamente $R \$ 7$ milhões) ${ }^{124}$; e ao ensino fundamental (aproximadamente $\mathrm{R} \$ 5$ milhões e 6 milhões, respectivamente) e a menor parte foi destinada à educação especial $(R \$ 1.334,70$ e 2.591,53, nesta ordem). É importante observar que a educação infantil e o ensino fundamental responderam por aproximadamente $99,7 \%$ das despesas de capital, nesse período.

Cabe ressaltar que os valores de 2008, 2009 e 2010 ( $R$ \$ 13.558,63, $R \$$ 35.301,18, 29.875,34, nessa ordem), destinados à administração da Seme-Vitória para despesas dos serviços internos dessa Secretaria e do ensino complementar, superaram os valores destinados à educação especial ( $R$ \$ 1.334,70 em 2009 e $R \$$ 2.591,53 em 2010).

De acordo com as informações da Tabela 36, no ano de 2008, o município não despendeu recursos para compra de equipamentos e materiais permanentes para a educação especial. Assim, notamos que as despesas de capital dessa modalidade só foram registradas em 2009 e 2010, e sua participação foi de 0,01\% e 0,02\%, respectivamente. Os valores zerados (2008) ou ínfimos (2009 e 2010) não indicam que o município de Vitória nada ou tão pouco tenha investido na educação especial, tendo em vista que as despesas podem ter sido contabilizadas em outras etapas de ensino ou podem ter sido utilizadas verbas de outras fontes que não foram registradas nas despesas de capital. Acrescenta-se, ainda, a existência de número de matrículas do público da educação especial na rede municipal de ensino de Vitória no período de 2008 a 2010.

Dentro desse contexto, quando são analisadas as despesas de capital da educação especial e, dessa maneira, a capacidade financeira do município de Vitória, na expansão de vagas e em melhoria da qualidade de ensino e atendimento, observamos, como Nascimento (2012), que o município necessita de ajuda financeira da União para realização de investimentos educacionais, segundo a autora, "este ente demonstra na atual configuração financeiro-orçamentária brasileira como a opção de efetivação de metas de atendimento e qualidade na educação proposta pelo novo PNE” (NASCIMENTO, 2012, p. 123).

${ }^{124}$ Cumpre destacar o percentual de crianças fora da escola no município de Vitória, em 2010 (2,76\% de crianças de 4 a 5 anos ainda não frequentavam a escola - Pnud, 2013), e a necessidade de ampliação da oferta, principalmente a crianças de zero a três anos, nessa etapa de ensino, o que implicou a construção de novas escolas e a ampliação das unidades já existentes. 
Os valores destinados à despesa em educação também foram apresentados nos demonstrativos de despesa da Seme-Vitória por Programa de Trabalho, como descrito na Tabela 37.

Tabela 37 - Despesas em educação por Programa de Trabalho - Vitória/ES 2008, 2009 e $2010(R \$)$

\begin{tabular}{lccc}
\hline \multicolumn{1}{c}{ PROGRAMA } & \multicolumn{3}{c}{ ANO } \\
& 2008 & 2009 & 2010 \\
\hline Educação Infantil & $129.678 .395,54$ & $110.795 .522,05$ & $145.404 .929,70$ \\
Ensino Fundamental & $69.129 .221,15$ & $62.659 .844,35$ & $194.037 .657,61$ \\
Fundo Ensino Fundamental & $112.931 .111,21$ & $145.890 .347,23$ & - \\
Educação Especial & $658.273,17$ & $412.465,15$ & $310.413,49$ \\
EJA & - & & - \\
Valorização e Capacitação de Servidores & - & - & $130.082,46$ \\
Administração Geral & $2.806 .659,51$ & $5.010 .855,53$ & $4.493 .868,87$ \\
\hline \multicolumn{1}{c}{ TOTAL } & $315.203 .660,58$ & $324.769 .034,31$ & $344.399 .735,00$ \\
\hline
\end{tabular}

Fonte: Semfa/Demonstrativos de natureza e despesa 2008, 2009 e 2010. Elaboração própria.

Valores atualizados com base no INPC/IBGE de 12/2014.

Observamos, nas despesas por Programa de Trabalho, que o ensino fundamental reteve a maior parcela do gasto, com aproximadamente $58 \%$ do total despendido pela Seme-Vitória em 2008, 64\% em 2009 e 56\% em 2010. Essa etapa foi seguida pela educação infantil, que apresentou também oscilações no seu percentual de participação de despesa (41\%, 34\% e 42\%, respectivamente). A menor parcela foi destinada à valorização e à capacitação de servidores. Constatamos ainda que os valores destinados a administração geral da SemeVitória superam os valores das modalidades de ensino no município.

A EJA, com participação de 0,04\% em 2010, na despesa por Programa de Trabalho, e a educação especial, com participação de 0,2\% em 2008, 0,1\% em 2009 e 0,09\% em 2010, também apresentaram uma participação ínfima se comparada à das outras etapas de ensino ou ao número de alunos que cada uma atendia. 
Contudo, salientamos que esses valores podem estar subdimensionados, considerando que as despesas dessas modalidades estavam agregadas à educação infantil e ao ensino fundamental. Melchior (1991, p. 273) afirma ainda que "[...] o nível de detalhamento do orçamento-programa ainda não é suficiente para um efetivo controle social", devido a sua forma sintética de apresentação dos dados, o que dificulta o controle de sua execução. Nesse sentido, Peroni (2003), ao analisar as despesas por Programa de Trabalho no município de Campo Grande - MS, pôde verificar que entre essas despesas não foram registradas as referentes às rubricas de educação especial. Partindo do pressuposto de que essa modalidade teve suas atividades normais, no período de 1988 a 1998, a autora pôde deduzir que as despesas a ela referentes estavam computadas em outras rubricas, "o que demonstra o total descaso para com a transparência dos recursos públicos" (PERONI, 2003, p. 121).

A trajetória dos valores das despesas de educação especial na rede municipal de ensino de Vitória apresentou um movimento decrescente no período de 2008 a 2010 e essas despesas também foram reduzidas em relação ao que foi previsto na LOA, como podemos visualizar na Tabela 38.

Tabela 38 - Valores orçamentários e liquidados da educação especial - Vitória/ES 2008, 2009 e $2010(R \$)$

\begin{tabular}{cccccc}
\hline ANO & R $\$$ LOA & $\begin{array}{c}\text { DESPESA } \\
\text { LIQUIDADA R } \$\end{array}$ & $\begin{array}{c}\text { DESPESA } \\
\text { LIQUIDADA \% }\end{array}$ & $\begin{array}{c}\text { VARIAÇÃO } \\
\mathbf{R} \$\end{array}$ & $\begin{array}{c}\text { VARIAÇÃO } \\
\%\end{array}$ \\
\hline 2008 & $2.120 .554,76$ & $658.273,17$ & 31,04 & $-1.462 .281,59$ & 69 \\
2009 & $1.426 .778,36$ & $412.465,15$ & 28,90 & $-1.014 .313,21$ & 71 \\
& & & & & \\
2010 & $1.847 .827,24$ & $310.413,49$ & 16,80 & $-1.537 .413,75$ & 83
\end{tabular}

Fonte: LOA, Semfa/Demonstrativos de natureza e despesa 2008, 2009 e 2010. Elaboração própria.

Valores atualizados com base no INPC/IBGE de 12/2014.

Com base na diferença nos valores apresentados entre aquilo que foi previsto no orçamento e o que foi efetivamente gasto com a modalidade de educação especial, evidencia-se que os percentuais aplicados foram de $31 \%, 29 \%$ e $17 \%$, 
respectivamente. Diante desse quadro, podemos supor que essa diferença nos percentuais de um ano para outro pode ser compreendida a partir do deslocamento de recursos para outras rubricas, ou pode a educação especial servir como "base expiatória", ou seja, na LOA ser previsto mais exatamente para se ter folga para eventuais ajustes de contas na Seme-Vitória. Haja vista a inverossimilhança do montante despendido para as despesas da educação especial, já que não correspondiam aos valores necessários para a sua manutenção e seu desenvolvimento, considerando o número de alunos matriculados na rede municipal de ensino e o elevado custo dessa modalidade de ensino, de acordo com os resultados dos estudos de Cardoso (1997) e Moreira e Carvalho (2011).

É sabido que existe sempre uma distância entre aquilo que foi previsto no orçamento e o que foi executado, porém, quando essa diferença é constante, isso nos causa, no mínimo, estranhamento, trazendo-nos preocupação quanto à gestão de recursos públicos. De acordo com Melchior (1991, p. 284), "[...] talvez a questão mais substantiva de execução orçamentária seja a de fazer com que o dinheiro previsto no orçamento chegue à escola, para a atividade-fim, não se perdendo nos meandros da burocracia". Nessa perspectiva, embora o Fundeb tenha contemplado todas as etapas e modalidades da educação básica, tendo previsto ponderações diferenciadas para estas últimas, e mesmo que a Lei Orçamentária do município de Vitória tenha fixado um valor a ser despendido à educação especial, não há garantias de que esses recursos sejam investidos nessa modalidade de ensino, haja vista os valores irrisórios registrados nas despesas a ela referentes, nesse município.

Cabe observar, no Gráfico 11, se as despesas (total em MDE) acompanharam o movimento da receita de impostos e transferências vinculadas à educação e qual foi o percentual aplicado em MDE no período de 2008 a 2010. 
Gráfico 11 - Receita e despesa vinculadas à Educação e à MDE - Vitória/ES 2008, 2009 e 2010

\begin{tabular}{|c|c|c|c|}
\hline $1.400 .000 .000,00$ & \multirow{2}{*}{\multicolumn{3}{|c|}{+}} \\
\hline $1.200 .000 .000,00$ & & & \\
\hline $1.000 .000 .000,00$ & \multicolumn{3}{|c|}{$\rightarrow$} \\
\hline $800.000 .000,00$ & & & \\
\hline $600.000 .000,00$ & & & \\
\hline $400.000 .000,00$ & \multirow{2}{*}{\multicolumn{3}{|c|}{ 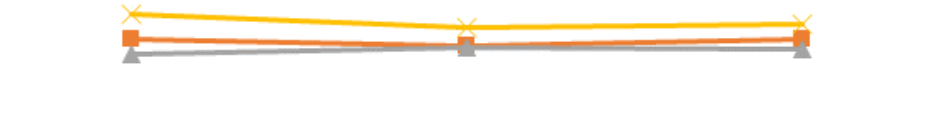 }} \\
\hline $200.000 .000,00$ & & & \\
\hline 0,00 & 2008 & 2009 & 2010 \\
\hline$\multimap$ Receita Total de Impostos & 1.200.664.445,22 & 1.087.302.010,90 & $1.112 .501 .781,33$ \\
\hline - - Despesas Total na Educação & $343.290 .478,58$ & $324.769 .034,31$ & $344.399 .735,00$ \\
\hline- Despesas Total em MDE & $302.653 .837,78$ & $318.896 .302,15$ & 315.210.400,91 \\
\hline $\begin{array}{c}- \text { Despesas estimadas em MDE } \\
35 \%\end{array}$ & $420.232 .555,83$ & $380.555 .703,82$ & $389.375 .623,47$ \\
\hline
\end{tabular}

Fonte: Finbra, Semfa 2008 a 2010. Elaboração própria.

Valores atualizados com base no INPC/IBGE de 12/2014.

Observamos que a despesa total aplicada na educação, resultante da soma de vinculação, fundos e outras fontes, como o salário-educação e demais transferências do FNDE, acompanhou o desempenho da receita total de impostos e transferências vinculadas, apresentando um decréscimo de 2008 para 2009 e um aumento de 2009 para 2010. A despesa total em MDE, financiada com recursos exclusivos de vinculação, apresentou uma tendência crescente de 2008 a 2010 em torno de 4\% (de $R \$ 303$ milhões em 2008 para $R \$ 315$ milhões em 2010), contudo, o seu movimento não acompanha o mesmo percurso da despesa total na educação e da receita total de impostos, tendo em vista o decréscimo na despesa total em MDE em torno de $1,15 \%$ de 2009 para 2010.

No que se refere ao percentual de despesa total em MDE realizada pelo município (resultante da vinculação de impostos destinados à educação), observamos uma oscilação: 25,21\% em 2008, 29,33\% em 2009 e 28,33\% em 2010, seguindo a mesma trajetória da despesa total em MDE, nesse período. Convém lembrar que o percentual aplicado em MDE estava acima dos $25 \%$ fixados pela CF/1988, porém distante dos 35\% estabelecidos pela Lei Orgânica Municipal. Os valores das despesas estimadas (considerando os 35\%) seriam de $R \$ 420$ milhões em 2008, R\$ 381 milhões em 2009 e R\$ 389 milhões em 2010. De acordo com a 
LDB/1996, o município deveria aplicar o percentual que consta na sua Lei Orgânica, se superior aos 25\% fixados na CF/1988, conforme já mencionado. Entretanto, a PMV não fazia nenhuma menção, nos demonstrativos de prestações de contas, nos relatórios do TC-ES e do Conselho Municipal de Educação de Vitória, a essa diferença, apoiando-se no $\S 3^{\circ}$, do art. 213 da Lei Orgânica Municipal (VITÓRIA, 1990), o qual prevê que, ultrapassada "a obrigação constitucional, os valores excedentes serão aplicados em outras despesas (educacionais e em obras de infraestrutura)". Tampouco fazia alusão aos 35\%.

A seguir, na Tabela 39, apresentamos as despesas típicas de MDE, com base nos dados descritos nos Relatórios Resumidos de Execução Orçamentária da PMV (VITÓRIA, RREO, 2008g, 2009d e 2010b).

Tabela 39 - Despesas com ações típicas de manutenção e desenvolvimento do ensino - Vitória/ES 2008, 2009 e 2010 (R\$)

\begin{tabular}{|c|c|c|c|c|c|c|}
\hline $\begin{array}{l}\text { ETAPAS E } \\
\text { MODALIDADES }\end{array}$ & 2008 & $\begin{array}{l}\text { Part } \\
\%\end{array}$ & 2009 & Part\% & 2010 & $\begin{array}{c}\text { Part } \\
\%\end{array}$ \\
\hline EDUCAÇÃO INFANTIL & $124.643 .237,15$ & 41 & $110.644 .956,42$ & 35,10 & $144.970 .186,65$ & 42,9 \\
\hline $\begin{array}{l}\text { Despesas custeadas com } \\
\text { recursos do Fundeb }\end{array}$ & $3.632 .611,01$ & - & $8.619 .475,07$ & - & $61.900 .537,62$ & - \\
\hline $\begin{array}{l}\text { Despesas custeadas com } \\
\text { outros recursos de } \\
\text { Impostos }\end{array}$ & $121.010 .626,14$ & - & $102.025 .481,35$ & - & $83.069 .649,03$ & - \\
\hline $\begin{array}{l}\text { ENSINO } \\
\text { FUNDAMENTAL }\end{array}$ & $178.404 .496,35$ & 58,8 & 204.180.330,39 & 64,77 & $192.587 .708,69$ & 57 \\
\hline $\begin{array}{l}\text { Despesas custeadas com } \\
\text { recursos do Fundeb }\end{array}$ & $118.547 .595,76$ & - & $152.828 .302,16$ & - & $130.856 .279,84$ & - \\
\hline $\begin{array}{l}\text { Despesas custeadas com } \\
\text { outros recursos de } \\
\text { Impostos }\end{array}$ & $59.856 .900,59$ & - & $51.352 .028,23$ & - & $61.731 .428,85$ & - \\
\hline ENSINO MÉDIO & 0,00 & - & 0,00 & - & 0,00 & - \\
\hline ENSINO SUPERIOR & 0,00 & - & 0,00 & - & 0,00 & - \\
\hline $\begin{array}{lr}\text { ENSINO } & \\
\text { PROFISSIONAL NÃO } & \text { NTTEGRADO } \\
\text { INTSO } & \text { ANSINO REGULAR }\end{array}$ & 0,00 & - & 0,00 & - & 0,00 & - \\
\hline OUTRAS & $658.273,56$ & 0,2 & $412.465,15$ & 0,13 & $440.495,95$ & 0,1 \\
\hline $\begin{array}{l}\text { TOTAL DE DESPESAS } \\
\text { COM AÇÕES TÍPICAS } \\
\text { DE MDE }\end{array}$ & $303.706 .007,06$ & 100 & $315.237 .751,96$ & 100 & $337.998 .391,28$ & 100 \\
\hline Fonte: Semfa/RREO & 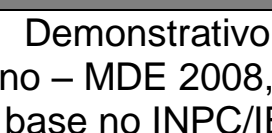 & ods & eitas e & esas & om & \\
\hline
\end{tabular}


Observamos que as despesas com ações típicas de MDE se concentraram nas etapas de ensino atendidas prioritariamente pela rede de ensino municipal de Vitória, ou seja, a educação infantil e o ensino fundamental. Este último reteve a maior parte dos recursos em 2008, 2009 e 2010, com 58,8\%, 64,8\% e 57\%, respectivamente. As despesas com a educação infantil representaram $41 \%$ em 2008, 35\% em 2009 e 42,9\% em 2010. O item "Outras" refere-se à aplicação em despesas nas demais atividades dirigidas ao ensino, mas que estavam vinculadas às receitas resultantes de impostos destinados à MDE. Notamos que a educação especial não consta nos demonstrativos de despesas de receitas e despesas com MDE, no Relatório Resumido de Execução Orçamentária - Anexo 8 (LDB/1996, art. 72) (VITÓRIA, RREO, 2008g, 2009d e 2010b), impossibilitando conhecer a participação da modalidade nas despesas em MDE. A nosso ver, a ausência da educação especial nesse formulário, que, por sua vez, era indicado pelo STN no "Manual de Demonstrativos Fiscais: aplicados à União, Estados, Distrito Federal e Municípios" (APÊNDICE C), que orienta a União, os estados, o Distrito Federal e os municípios para a elaboração dos relatórios e procedimentos contábeis das contas públicas, contribui para a não preocupação dos gestores em registrar a alocação de recursos destinados a essa modalidade de ensino no âmbito dos sistemas educacionais brasileiros, para a sua invisibilidade nas receitas e despesas destinadas à MDE e para não possibilidade de acompanhamento e controle dos recursos públicos da educação no âmbito do Estado brasileiro.

Faz-se necessário considerar ainda os recursos recebidos do governo federal pela rede de ensino municipal de Vitória, por meio dos programas federais, vinculados ao FNDE, voltados à educação especial. É importante destacar que os recursos advindos desses programas integravam a assistência financeira e técnica da União, prevista no art. 211 da CF/1988 no intuito de garantir equidade e padrão mínimo de qualidade na oferta educacional. Cruz (2011) destaca que, diante das diferenças na capacidade tributária e da disparidade nas condições de oferta de políticas públicas dos estados e municípios, é imprescindível a ação supletiva e redistributiva da União com vistas a equalizar as oportunidades educacionais.

Nesse contexto, segundo a autora, o FNDE assume o papel central na gestão das políticas do governo federal, por meio de programas voltados à educação básica, entre os quais o PDDE, que, com as políticas de assistência financeira 
voluntária, ou seja, efetivadas a partir da elaboração do Plano de Trabalho Anual (PTA), envia recursos para a execução dos demais programas a ele vinculados. Desse modo, o Programa Escola Acessível resulta da parceria entre o MEC, por meio da Secadi, o FNDE, as secretarias de educação do Distrito Federal, dos estados, dos municípios (entidades executoras) e as escolas (unidades executoras próprias) contempladas, com o objetivo de desenvolver ações de acessibilidade arquitetônica, bem como aquelas destinadas à disponibilização de tecnologias assistivas com vistas a garantir a inclusão dos alunos com deficiência, TGD e altas habilidades/superdotação em classes comuns. Para receber os recursos, as escolas elaboram o Plano de Atendimento e o remetem à secretaria de educação a qual se vinculam. Essa secretaria tem a função de examinar, consolidar e encaminhar ao MEC/Secadi, que irá validar e encaminhar ao FNDE a relação das escolas que serão contempladas pelo programa, para que esse órgão possa destinar os recursos financeiros de custeio e capital, por intermédio das entidades executoras, às escolas. No período de 2008 a 2012, algumas escolas do município de Vitória foram contempladas no programa Escola Acessível, como podemos observar nas Tabelas 40 e 41.

Tabela 40 - Número de escolas e valores recebidos do Programa Escola Acessível - Vitória/ES 2008-2012

\begin{tabular}{ccc}
\hline ANO & ESCOLAS & R\$ REAIS \\
\hline $\mathbf{2 0 0 8}$ & 20 & $332.000,00$ \\
2009 & 1 & $2.400,00$ \\
$\mathbf{2 0 1 0}$ & 13 & $202.000,00$ \\
$\mathbf{2 0 1 1}$ & 20 & $156.000,00$ \\
$\mathbf{2 0 1 2}$ & 6 & $65.000,00$ \\
TOTAL & $\mathbf{4 7}^{*}$ & $\mathbf{7 5 7 . 4 0 0 , 0 0}$ \\
\hline
\end{tabular}

Fonte: Elaborado pela autora com base nos dados do Simec 2008 a 2012.

* Cumpre destacar que algumas escolas foram contempladas mais de uma vez em anos distintos.

${ }^{125}$ Esse valor atualizado pelo INPC/IBGE de 12/2014, corresponderia a R \$ 986.342,62. 
Tabela 41 - Escolas contempladas pelo Programa Escola Acessível Vitória/ES 2008- 2012 em valores nominais $(R \$)$

\begin{tabular}{|c|c|}
\hline ESCOLAS & $\mathbf{R} \$$ \\
\hline CMEI ANA MARIA CHAVES COLARES & $10.000,00$ \\
\hline CMEI DR DENIZART SANTOS & $14.000,00$ \\
\hline CMEI JACYNTHA FERREIRA DE SOUZA SIMOES & $14.000,00$ \\
\hline CMEI JOAO PEDRO DE AGUIAR & $8.000,00$ \\
\hline CMEI RUBEM BRAGA & $7.000,00$ \\
\hline CMEI ZENAIDE GENOVEVA MARCARINI CAVALCANTI & $8.000,00$ \\
\hline EMEF ADAO BENEZATH & $14.000,00$ \\
\hline EMEF ADEVALNI S FERREIRA DE AZEVEDO & $8.000,00$ \\
\hline EMEF ADILSON DA SILVA CASTRO & $16.000,00$ \\
\hline EMEF ALBERTO DE ALMEIDA & $26.000,00$ \\
\hline EMEF ÁLVARO DE CASTRO MATTOS & $18.000,00$ \\
\hline EMEF ALVIMAR SILVA & $16.000,00$ \\
\hline EMEF AMILTON MONTEIRO DA SILVA & $21.000,00$ \\
\hline EMEF ANACLETA SCHNEIDER LUCAS & $32.000,00$ \\
\hline EMEF ARISTÓBULO BARBOSA LEAO & $8.000,00$ \\
\hline EMEF ARTHUR DA COSTA E SILVA & $24.000,00$ \\
\hline EMEF CASTELO BRANCO & $16.000,00$ \\
\hline EMEF CECILIANO ABEL DE ALMEIDA & $12.500,00$ \\
\hline EMEF CUSTÓDIA DIAS DE CAMPOS & $14.000,00$ \\
\hline EMEF EBER LOUZADA ZIPPINOTTI & $16.000,00$ \\
\hline EMEF ELIANE RODRIGUES DOS SANTOS & $8.000,00$ \\
\hline EMEF ELZIRA VIVACQUA DOS SANTOS & $16.000,00$ \\
\hline EMEF EXPERIMENTAL DE VITÓRIA - UFES & $14.000,00$ \\
\hline EMEF FRANCISCO LACERDA DE AGUIAR & $18.000,00$ \\
\hline EMEF HELOISA ABREU JÚDICE DE MATTOS & $8.000,00$ \\
\hline EMEF IRMA JACINTA SOARES DE SOUZA LIMA & $32.000,00$ \\
\hline EMEF IZAURA MARQUES DA SILVA & $8.000,00$ \\
\hline EMEF JOSE ÁUREO MONJARDIM & $7.000,00$ \\
\hline EMEF LENIR BORLOT & $10.000,00$ \\
\hline EMEF MAL MASCARENHAS DE MORAES & $26.000,00$ \\
\hline EMEF MARIA LEONOR PEREIRA DA SILVA & $10.000,00$ \\
\hline EMEF MARIA MADALENA DE OLIVEIRA DOMINGUES & $10.000,00$ \\
\hline EMEF MARIETA ESCOBAR & $26.400,00$ \\
\hline EMEF MAURO BRAGA & $16.000,00$ \\
\hline EMEF MOACYR AVIDOS & $7.000,00$ \\
\hline EMEF NEUSA NUNES GONCALVES & $38.000,00$ \\
\hline EMEF OCTACÍLIO LOMBA & $23.000,00$ \\
\hline EMEF OTTO EWALD JUNIOR & $34.000,00$ \\
\hline EMEF PAULO REGLUS NEVES FREIRE & $8.000,00$ \\
\hline EMEF PAULO ROBERTO VIEIRA GOMES & $14.000,00$ \\
\hline EMEF PREZIDEU AMORIM & $32.000,00$ \\
\hline EMEF PROFESSORA REGINA MARIA SILVA & $14.000,00$ \\
\hline
\end{tabular}


Conclusão

\begin{tabular}{lr}
\hline \multicolumn{1}{c}{ ESCOLAS } & \multicolumn{1}{c}{$\mathbf{R} \$$} \\
\hline EMEF PROF MARIA STELLA DE NOVAES & $9.000,00$ \\
EMEF RITA DE CÁSSIA OLIVEIRA & $8.000,00$ \\
EMEF SÃO VICENTE DE PAULO & $12.500,00$ \\
EMEF SUZETE CUENDET & $20.000,00$ \\
EMEF TANCREDO DE ALMEIDA NEVES & $26.000,00$ \\
\hline
\end{tabular}

Fonte: Elaborado pela autora com base nos dados do Simec 2008 a 2012.

Verificamos que, das escolas contempladas pelo Programa Escola Acessível, seis eram de educação infantil e 41 do ensino fundamental, totalizando um valor de $\mathrm{R} \$ 757.400,00$, no período de 2008 a 2012 . Vale ressaltar que os recursos eram destinados tomando como parâmetro os intervalos de classe de número de alunos e os correspondentes valores: até 199 alunos - R\$ 8.300,00; de 200 a $499-R \$$ $10.000,00$; de 500 a 1000 - $R \$ 12.500,00$; e acima de 1000 - $R \$ 15.000,00$ (BRASIL, 2013c). Assim, o valor a ser destinado a cada escola estava entre $R \$ 6.000,00$ e $R \$$ $9.000,00$, sendo despendidos, para a cobertura das despesas de custeio $80 \%$, e, para as despesas de capitais, os $20 \%$ restantes.

Cumpre destacar ainda que o município, no período de 2005 a 2011, também foi contemplado, pelo Programa de Salas de Recursos Multifuncionais, com 53 salas para 0 atendimento educacional especializado (SIMEC,2014). Nessa perspectiva, notamos que os recursos desses programas contribuíram para a ampliação do atendimento voltado ao público da educação especial nas escolas da rede de ensino de Vitória. Assim, faz-se necessário considerar que as políticas articuladas pelo governo federal são assimiladas pelos governos municipais, redefinindo ações e serviços destinados à educação. No que se refere à educação especial, a União tem, ao longo dos anos, despendido recursos financeiros via PDDE, em caráter suplementar, a escolas públicas e privadas de educação especial (PERONI, 2009), mediante fornecimento de materiais e equipamentos, formação de professores e proposições políticas e pedagógicas, com o objetivo de aprimorar a infraestrutura física e pedagógica da escola. De acordo com Garcia (2009, p. 10), a educação especial tem sido caracterizada pela 
[...] gestão regulada por editais, por meio dos quais o poder central define a política, a execução, os recursos e sua distribuição, as metas, os objetivos e as unidades executoras, quer sejam redes estaduais e/ou municipais de educação, escolas ou universidade submetem-se ao crivo central para desenvolver ou não projetos pouco compartilhados na sua concepção. Tal possibilidade implica, muitas vezes, em fontes indispensáveis de liberação de recursos para as chamadas unidades executoras.

No contexto do Estado brasileiro, que se constitui numa federação com três esferas de governo - União, estados e municípios - que possuem atribuições e competências específicas no setor educacional, referentes à sua regulação, ao planejamento, ao atendimento e ao financiamento, observamos a forte centralização das decisões políticas pelo governo federal. Desse modo, por meio de leis, resoluções, decretos, portarias, programas, projetos e outros, delineiam-se as políticas sociais e, portanto, políticas educacionais para os demais entes federados. De acordo com Farenzena (2012c), a organização político-administrativa da educação no Brasil combina duas diretrizes: a autonomia dos sistemas de ensino e a organização em regime de colaboração.

Dessa forma, "governos estaduais e municipais têm autonomia nas suas respectivas áreas de jurisdição na educação, mas a exercem subordinados a uma regulação posta por normas e ações de caráter nacional, quer dizer, que incidem sobre todos os sistemas" (FARENZENA, 2012c, p. 186), com implicações diretas e indiretas no planejamento e na gestão dos estados e municípios. Se por um lado, isso pode significar em possibilidade de articulação entre os entes federados de modo a garantir um padrão de qualidade em educação, por meio da articulação dos planejamentos locais ao planejamento da União, por outro lado, pode interferir na autonomia da gestão de políticas nos entes federados (FARENZENA, 2012c). Assim, percebemos, no município de Vitória, que as políticas de educação especial estão fundamentadas nas orientações das políticas federais e que os recursos advindos pelos programas federais se configuram como fonte importante para 0 desenvolvimento das ações voltadas às pessoas com deficiência, TGD e altas habilidades/superdotação.

No intuito de conhecer qual era o montante gasto por aluno no município de Vitória, calculamos o valor gasto-aluno-ano, que corresponde ao valor resultante da divisão dos recursos financeiros gastos nas etapas da educação básica (educação 
infantil e fundamental) e modalidades de ensino (educação especial e EJA) pelo número de alunos. De acordo com Castro (2005, p. 853), o gasto-aluno-ano caracteriza-se como indicador que reflete "[...] não apenas quanto da riqueza do país é destinado aos seus estudantes, no sentido de prover educação a cada um deles em cada ano, mas também qual a ênfase de gasto, por nível e modalidade educacional". Os valores foram descritos na Tabela 42. 
Tabela 42 - Gasto-aluno-ano - Vitória/ES 2008, 2009 e 2010 (R\$)

\begin{tabular}{|c|c|c|c|c|c|c|c|c|c|}
\hline \multirow{3}{*}{$\begin{array}{c}\text { NÍVEIS E } \\
\text { MODALIDADES DE } \\
\text { ENSINO }\end{array}$} & \multirow{2}{*}{\multicolumn{2}{|c|}{2008}} & \multirow{3}{*}{$\begin{array}{c}\text { Valor } \\
\text { gasto/aluno- } \\
\text { ano } \mathrm{R} \$\end{array}$} & \multicolumn{3}{|c|}{ VALOR GASTO-ALUNO- ANO } & \multirow{2}{*}{\multicolumn{2}{|c|}{2010}} & \multirow{3}{*}{$\begin{array}{c}\text { Valor } \\
\text { gasto/aluno- } \\
\text { ano R\$ }\end{array}$} \\
\hline & & & & \multicolumn{2}{|l|}{2009} & \multirow{2}{*}{$\begin{array}{c}\text { Valor } \\
\text { gasto/aluno- } \\
\text { ano } R \$\end{array}$} & & & \\
\hline & Valor & $\begin{array}{l}\text { № de } \\
\text { alunos }\end{array}$ & & Valor & $\begin{array}{l}\text { № de } \\
\text { alunos }\end{array}$ & & Valor & $\begin{array}{c}\text { № de } \\
\text { alunos } \\
\end{array}$ & \\
\hline \multicolumn{10}{|l|}{ Educação Infantil } \\
\hline Despesas de custeio & $29.280 .905,36$ & 16.983 & $1.724,13$ & $29.737 .903,66$ & 17.844 & $1.667,00$ & $31.575 .003,22$ & 16.257 & $1.942,24$ \\
\hline Despesa de Capital & $5.972 .311,65$ & 16.983 & 352,00 & $7.381 .350,08$ & 17.844 & 414,00 & $7.339 .861,60$ & 16.257 & 451,50 \\
\hline TOTAL & $129.661 .640,09$ & 16.983 & $7.635,00$ & $111.550 .172,46$ & 17.844 & $6.251,41$ & $145.404 .929,71$ & 16.257 & $8.944,14$ \\
\hline \multicolumn{10}{|l|}{$\begin{array}{l}\text { Ensino } \\
\text { Fundamental }\end{array}$} \\
\hline Despesas de custeio & $48.590 .261,76$ & 29.653 & $1.638,63$ & $45.874 .642,83$ & 29.004 & $1.581,70$ & $50.098 .533,89$ & 30.184 & $1.659,77$ \\
\hline \multicolumn{10}{|l|}{ Educação Especial } \\
\hline Despesas de custeio & $658.273,17$ & 906 & 726,57 & $411.130,45$ & 1.061 & 387,49 & $307.821,95$ & 1.308 & 235,34 \\
\hline Despesa de Capital & - & 906 & - & $1.334,70$ & 1.061 & 1,25 & $2.591,53$ & 1.308 & 1,98 \\
\hline TOTAL & $658.273,17$ & 906 & 726,57 & $412.465,15$ & 1.061 & 388,75 & $310.413,48$ & 1.308 & 237,32 \\
\hline \multicolumn{10}{|l|}{ EJA } \\
\hline Despesas de custeio & - & 2.731 & - & - & 2.527 & - & $130.082,46$ & 2.260 & 57,56 \\
\hline Despesa de Capital & _ & 2.731 & _ & _ & 2.527 & - & _ & 2.260 & _ \\
\hline
\end{tabular}

Fonte: Semfa 2008, 2009 e 2010. Elaboração própria.

Valores atualizados com base no INPC/IBGE de 12/2014. 
Podemos observar que os valores de gasto-aluno-ano das etapas da educação básica e modalidades de ensino apresentaram oscilações significativas no período pesquisado e também entre si. Desse modo, o valor gasto-aluno-ano da educação infantil, nos anos de 2008, 2009 e 2010, correspondeu a $R \$ 7.635,00, R \$$ $6.251,41$ e $R \$ 8.944,14$, respectivamente e o valor gasto-aluno-ano do ensino fundamental correspondeu a $R \$ 6.131,29, R \$ 7.178,45$ e $R \$ 6.428,49$, nessa ordem, considerando-se as despesas com custeio, pessoal e capital. São valores muito superiores aos despendidos com as modalidades de ensino. Em 2010, o valor gastoaluno-ano da EJA foi de $R \$ 57,56$; e o da educação especial $R \$ 237,32$.

Cumpre ressaltar que os patamares de gasto aluno-ano de ensino fundamental alcançados pela rede municipal de ensino de Vitória eram bem superiores aos valores de referência para redistribuição das receitas por meio do Fundeb, previstos como referência nacional em cada ano. O valor por aluno repassado aos municípios do estado do Espírito Santo, em 2010, referente a cada matrícula das séries iniciais do ensino fundamental urbano, foi de $R \$ 2.881,03^{126}$, valor, portanto, muito inferior ao de gasto-aluno-ano de Vitória $(R \$ 6.428,49)$ nesse ano. Nessa perspectiva, os dados permitem supor que a rede municipal de ensino de Vitória dispunha de condições financeiras suficientes para oferecer razoáveis condições de qualidade aos alunos matriculados em sua rede de ensino. Segundo Andréa Barbosa Gouveia e Andrea Polena (2014, p. 353),

[...] pode-se considerar que os municípios que na média se distanciam dos valores de referência $1^{127}$ no âmbito do Fundeb, ou seja, aqueles valores estimados como mínimo para o ensino fundamental - urbano, tem maiores condições de, ao executar as despesas, garantir incremento para o investimento nas etapas e modalidades de educação que tem comprovadamente mais custo como, por exemplo, educação infantil e educação especial [...].

O valor de gasto-aluno-ano da educação especial apresentou uma trajetória decrescente nos anos de 2008, 2009 e 2010, de $R \$ 726,57, R \$ 388,75$ e $R \$ 237,32$, respectivamente. Esses valores, a nosso ver, pareciam não corresponder aos

\footnotetext{
126 Valor atualizado com base no INPC/IBGE de 12/2014. O valor original era de $R \$ 5.058,40$.

127 Os valores de referência das Séries Iniciais do Ensino Fundamental Urbano foram de $R \$ 1.172,85$ no ano de 2008, de acordo com a Portaria $n^{\circ} 386$, de 17 de abril de 2009; de $R \$ 1.227,17$ segundo a Portaria no 496, de 16 de abri de 2010 e $R \$ 1.529,97$ conforme Portaria no 380, 6 de abril de 2011.
} 
valores reais despendidos ao público da educação especial no município de Vitória, uma vez que esses valores seriam insuficientes para a manutenção dessa modalidade de ensino de acordo com os resultados dos estudos de Cardoso (1997) e de Moreira e Carvalho (2011) que envolvem compra de equipamentos e materiais, pagamento dos profissionais, formação continuada, entre outras ações.

A discrepância nos valores de gasto-aluno-ano da educação especial e da EJA no município pode advir da não contabilização das despesas voltadas especificamente para essas modalidades de ensino. Essa discrepância pode se dar, seja no volume de recursos distribuídos entre a educação infantil e ensino fundamental e educação especial e EJA, seja na proporção contabilizada em uma mesma etapa da educação básica. Desse modo, podemos concluir que o cálculo do gasto-aluno-ano considerando apenas as despesas registradas da educação especial e/ou da EJA, tal como o exercício feito nesta pesquisa, pode subestimar o gasto de manutenção dessas modalidades de ensino no âmbito da rede municipal de ensino de Vitória.

Se compararmos os valores de gasto-aluno-ano da educação especial do município de Vitória com os valores aluno-ano estabelecidos no Fundeb e no CAQi, observaremos discrepâncias significativas, como podemos observar na Tabela 43.

Tabela 43 - Comparação entre o gasto-aluno-ano da educação especial do município de Vitória, o valor estimado pelo Fundeb/ES e o valor previsto pelo CAQi 2008,2009 e $2010(R \$)$

\begin{tabular}{cccccccc}
\hline ANO & $\begin{array}{c}\text { Gasto } \\
\text { aluno/ano } \\
\text { Município } \\
\text { de Vitória }\end{array}$ & $\begin{array}{c}\text { Valor } \\
\text { estimado } \\
\text { pelo }\end{array}$ & $\begin{array}{c}\text { Valor } \\
\text { previsto } \\
\text { pelo }\end{array}$ & Diferença Fundeb & \multicolumn{2}{c}{ Diferença CAQi } \\
$\mathbf{C A Q i}$ & $\mathbf{R} \mathbf{3}$ & $\%$ & $\mathbf{R} \$$ & $\%$ \\
\hline $\mathbf{2 0 0 8}$ & 726,57 & $3.763,68$ & $6.272,80$ & $3.037,11$ & 80,70 & $5.546,23$ & 88,42 \\
$\mathbf{2 0 0 9}$ & 388,75 & $3.453,70$ & $5.756,16$ & $3.064,95$ & 88,74 & $5.367,41$ & 93,25 \\
$\mathbf{2 0 1 0}$ & 237,32 & $3.238,91$ & $5.398,17$ & $3.001,59$ & 92,67 & $5.160,85$ & 95,60 \\
\hline
\end{tabular}

Fonte: Elaborado pela autora com base nos dados da Semfa; Portarias $\mathrm{n}^{\circ}=1.027 / 08, \mathrm{n}^{0}$ 788/09 e 26/10; e CAQi 2008, 2009 e 2010.

Valores atualizados com base no INPC/IBGE de 12/2014. 
No ano de 2008, o gasto-aluno-ano da educação especial na rede municipal de ensino de Vitória foi de $R \$ 726,57$, pelos resultados do cálculo feito para fins deste estudo, enquanto o valor estimado pelo Fundeb foi de $R \$ 3.763,68$, portanto, uma diferença de $81 \%$, e o valor previsto pelo CAQi foi de 6.272,80, representando uma diferença de $88 \%$ em relação ao gasto-aluno-ano da educação especial no âmbito da administração municipal. Essas diferenças aumentaram em 2009 (89\% Fundeb; 93\% CAQi) e 2010 (93\% Fundeb e 96\% CAQi). Assim, constatamos que o gasto-aluno-ano da educação especial do município estava abaixo dos valores previstos pelo Fundeb/ES e pelo CAQi, e que, os gastos estavam também, subdimensionados, haja vista a não inclusão do valor da despesa com pessoal e de outros recursos necessários à manutenção e ao desenvolvimento dessa modalidade de ensino, que estavam agregados as outras etapas de ensino. De maneira geral, os valores do gasto-aluno-ano das etapas da educação básica (educação infantil e fundamental) e modalidades de ensino (educação especial e EJA), na capital capixaba, acompanharam os valores de despesas e o movimento de matrículas, pois o gasto-aluno-ano aumenta quando o valor de despesa aumenta e o número de matrículas diminui.

Diante desse contexto, observamos as dificuldades e os desafios que perpassam o estudo do financiamento da educação especial, tendo em vista o modo de organização e funcionamento do estado brasileiro que não contribui para a transparência das informações dos recursos públicos aplicados à educação. Evidenciamos, assim, a necessidade de alterar a forma de registro dos dados referentes à educação especial nos demonstrativos de despesas da rede municipal de ensino de Vitória, de modo a garantir a visibilidade dos recursos alocados nessa modalidade no âmbito da educação básica. Nesse sentido, ficou evidente as complexidades que se configuram tanto na pesquisa sobre o financiamento da educação especial quanto na sua gestão no âmbito dos municípios.

Dessa maneira, observamos que a educação especial está inserida sob as mesmas normas de organização político-administrativa e de gestão previstas para as outras etapas da educação básica e modalidade de ensino. Desse modo, está inserida sob a organização de uma república federativa, em que cada ente federado tem suas responsabilidades, no setor educacional, na oferta, no planejamento e no financiamento em suas respectivas área de atuação prioritária: os municípios, no 
ensino fundamental e educação infantil; os estados, no ensino fundamental e ensino médio; e a União, na organização e no financiamento da rede pública federal e na prestação de assistência técnica e financeira aos estados e municípios, sendo os três entes também responsáveis pela oferta das modalidades de ensino em suas respectivas áreas de jurisdição. Ao mesmo tempo, a educação especial está sob a égide da descentralização do ensino, que historicamente tem sido a forma de gestão da educação no Brasil, "transferindo as competências da esfera central de poder para as locais" (AZEVEDO, 2002, p. 54).

Essa forma de gestão pode se configurar, segundo Azevedo (2002), como uma lógica economicista-instrumental de uma gestão pública gerencial, no intuito de garantir eficácia e eficiência dos serviços públicos, de acordo com as orientações neoliberais que preveem a redução do Estado às funções mínimas no processo de acumulação capitalista, com estratégias políticas e financeiras de grupos hegemônicos, que produzem implicações para as políticas sociais e, portanto, para a educação. Essas estratégias concretizam a partir da adoção de modelos de gestão voltados para o mercado em busca de avaliação e controle de resultados, bem como do desenvolvimento de programas e projetos que reproduzem o modelo gerencial de gestão de recursos financeiros na tentativa de assegurar custo-benefício. Entretanto, de acordo com Azevedo (2002, p. 55), a gestão também pode assumir uma perspectiva democrático-participativa

[...] que a toma como um dos meios de alargamento do espaço público, quando se busca o estabelecimento de relações sociais substancialmente democráticas. Nesse caso, os escalões locais participam da concepção das políticas, não se restringindo apenas a colocar em ação as decisões tomadas pelo poder central. Mas além do fortalecimento do poder local, a descentralização nessa perspectiva requer, concomitantemente, 0 estabelecimento de novas relações entre o Estado e a sociedade de modo que se abram os canais por onde fluam as demandas da população e, portanto, para que se efetive a participação da comunidade na gestão.

Nessa direção, acreditamos que as políticas educacionais, entre as quais a de educação especial, podem se desenvolver sob os parâmetros democráticos, explicitados por Azevedo (2002), com ampla participação política dos diferentes grupos sociais articulados com a luta pelo direito à educação para as pessoas com 
deficiência, TGD e altas habilidades/superdotação no âmbito dos diferentes espaços públicos, na elaboração das políticas, no planejamento orçamentário e no acompanhamento e controle social dos recursos aplicados na educação com vistas a redimensionar as formas de políticas, gestão e financiamento da educação brasileira. Estamos nos referindo, como o fazem Bassi e Camargo (2010, p. 288), a uma concepção de "caráter mais popular e democrática, que teria como objetivo a criação de maior transparência e publicização da administração pública, por meio do desenvolvimento de processo de participação e controle social sobre o Estado". Nessa perspectiva, José Carlos Vaz (2002, p. 271) apresenta um conjunto de desafios e possibilidades que se apresentam à gestão municipal com vistas à constituição de uma gestão democrática "que privilegie uma relação com a sociedade baseada na circulação de informações, na corresponsabilização e no controle social das ações do governo", tais como democratizar a gestão das políticas públicas (conselhos municipais, indicadores e avaliação pública da gestão e orçamento participativo); oferecer maior publicidade às ações do governo municipal (simplificação do orçamento e fornecimento sistemático de informações para a sociedade civil); garantir a impessoalidade no acesso aos serviços públicos (por meio de sistemas de solução de serviços públicos e ouvidoria pública); tornar os sistemas de informação da prefeitura acessíveis aos cidadãos; modernizar os processos administrativos; explorar o potencial de tecnologia da informação; e gerenciar informações privilegiando a cidadania. Os desafios apresentados podem se materializar em ações e políticas que estabeleçam uma nova relação entre Estado e sociedade, numa perspectiva mais democrática. 


\section{CONSIDERAÇÕES FINAIS: AS COMPLEXAS TRAMAS DO FINANCIAMENTO DA EDUCAÇÃO ESPECIAL}

Nesta pesquisa, tivemos como objetivo investigar a ação do Poder Público no provimento de recursos financeiros à educação especial na gestão da rede de ensino municipal de ensino de Vitória, no estado do Espírito Santo, diante do direito à educação e ao atendimento educacional especializado, assegurado, na legislação brasileira, às pessoas com deficiência, TGD e altas habilidades/superdotação.

Para tanto, partimos do pressuposto de que a garantia desse direito, a ampliação de sua oferta e a garantia de ensino de qualidade pressupõe investimento por parte do Estado no que tange ao aumento do fundo público à educação pública, no intuito de minimizar as desigualdades de acesso e permanência dessa população nos sistemas educacionais brasileiros.

Nesse contexto, fez-se necessário compreender a constituição do Estado e das políticas sociais nas suas diferentes configurações históricas, políticas e sociais, articuladas à caracterização do fundo público, como mediador da relação capitaltrabalho, no âmbito do arcabouço institucional do Estado. Este último é concebido, de acordo com Poulantzas (2000), como espaço público marcado pela correlação de forças entre classes e grupos sociais que compõem a sociedade e participam dos processos decisórios de formulação de políticas públicas. Esse pressuposto se distancia de uma concepção liberal de Estado, que o concebe como instância autônoma, com poder absoluto em relação às classes sociais, ou de uma concepção instrumentalista de Estado, que o compreende como mero instrumento passivo de uma única classe ou fração de classe. Para o autor, ao contrário dessas abordagens que entendem o Estado como bloco monolítico sem fissuras, cuja política se instaura de qualquer maneira, a despeito das correlações das forças, o Estado constitui um campo estratégico de lutas, relações de poder e contradições sociais, onde se entrecruzam diferentes grupos, num processo de disputa e negociação política, desempenhando um papel decisivo na configuração da ação pública.

A partir desses pressupostos, discutimos o financiamento da educação no Brasil e suas implicações para a educação especial, o qual envolve o orçamento público, a gestão dos recursos públicos, a vinculação constitucional de recursos, a 
presença da União, a descentralização do ensino e a responsabilização dos entes federados, bem como a correlação de forças no interior do Estado e, consequentemente, a definição de recursos públicos às instituições de ensino. Consideramos, como Farenzena (2006), que o ordenamento jurídico-normativo constitui elemento privilegiado de conhecimento das políticas públicas de financiamento da educação. Nesse sentido, procuramos, no decorrer do estudo, dialogar com os documentos legais que regulamentam a educação brasileira e que incorporam tais mudanças, como a CF/1988, LDB/1996, entre outros.

Discutir o financiamento da educação como política pública, isto é, como instrumento do Estado capaz de assegurar o direito à educação a uma população historicamente excluída dos processos de escolarização, implicou tanto (re)pensar o papel desempenhado pelo Estado e sua relação com a sociedade, perante as questões sociais, quanto reconhecer a natureza contraditória das políticas sociais que afirmam os direitos sociais, como a educação, e, ao mesmo tempo, limitam a sua efetivação, de acordo com a correlações de forças de diferentes classes e grupos sociais. Assim, não podemos desconsiderar que, no contexto do capitalismo, o Estado pode se distanciar mais ou menos da execução das políticas sociais com vista a atender aos interesses do capital. Entretanto, contraditoriamente, é no interior desse mesmo Estado que as correlações de forças se constituem e que podem promover movimentos de lutas que explicitem reivindicações e alcancem resultados positivos no atendimento às necessidades da população. Dessa maneira, as lutas populares permeiam a estrutura do Estado com suas relações de produção, sua organização hierárquico-burocrática e sua divisão social de trabalho. Assim, as políticas públicas são resultantes das contradições de classes inseridas na estrutura do Estado (POULANTZAS, 2000), isto é, de relações de forças e resistências que fazem dele uma expressão condensada da luta de classes em desenvolvimento.

Nessa perspectiva, o reconhecimento do direito à educação ao público da educação especial, estabelecida na CF/1988 e ratificada na LDB/1996 e em outras normativas posteriores, constituiu-se como resultado de um processo de luta que, segundo Cury (2002, p. 247), nasce do caráter contraditório que a acompanha:

[...] luta por inscrições mais democráticas, por efetivações mais realistas, contra descaracterizações mutiladoras, por sonhos de justiça. Todo o avanço da educação escolar além do ensino primário 
foi fruto de lutas conduzidas por uma concepção democrática da sociedade em que se postula ou a igualdade de oportunidades ou mesmo a igualdade de condições sociais.

Ao mesmo tempo, esse reconhecimento resultou da intervenção estatal no âmbito da política social no Brasil, alicerçada, segundo Evaldo Vieira (2001), ao longo do século $X X$, em direitos sociais variados e gradativamente conquistados por diferentes grupos sociais. Assim, o Estado passa a assumir a responsabilidade de implementar políticas públicas, inclusive políticas educacionais voltadas à garantia do direito à educação ao público da educação especial. De acordo com Clarice Seixas Duarte (2007, p. 694), com

[...] a adoção do modelo de Estado Social, impõe-se aos poderes públicos uma série de tarefas tendentes à realização de finalidades coletivas - as quais não se limitam à produção de leis ou normas gerais (como ocorre no Estado de direito liberal); tampouco à garantia de participação popular no processo de tomada de decisões (exigência do Estado democrático de direito). No Estado social de direito, é a elaboração e a implementação de políticas públicas objeto, por excelência, dos direitos sociais - que constituem o grande eixo orientador da atividade estatal, 0 que pressupõe a reorganização dos poderes em torno da função planejadora, tendo em vista a coordenação de suas funções para a criação de sistemas públicos de saúde, educação, previdência social, etc.

Estamos nos referindo a um Estado que desempenhe um papel ativo na efetivação dos direitos sociais, por meio de políticas educacionais, capaz de planejar suas ações, de oferecer serviços educacionais a todos, de atuar no combate às desigualdades sociais e de equalizar as condições de acesso, permanência e qualidade na educação. Nesse sentido, a concretização das políticas públicas, inclusive as educacionais, segundo Duarte (2007, p. 707), constituiu-se em uma tarefa complexa, pois "demanda a intervenção racional do Estado, em um conjunto de ações que envolvem, além da escolha de prioridades, a implementação de medidas legislativas, administrativas e financeiras". Portanto, é uma tarefa que exige planejamento, fixação de objetivos, definição de metodologias de ação e destinação de recursos, sem desconsiderar, como aponta Souza e Tavares (2013, p. 57), que "a possibilidade de maior ou menor equalização por meio dessas políticas, é resultado da correlação das forças sociais e da permeabilidade do Estado às pressões dela derivadas". 
No que se refere às políticas de educação especial, historicamente, as instituições privadas de educação especial assumiram um lugar privilegiado no Estado brasileiro, seja na ocupação de lugares estratégicos, por exemplo, na câmara de vereadores, nas assembleias legislativas, na câmara de deputados, no senado federal, na composição da Coordenação da Secretaria de Educação Especial do MEC, seja na influência direta ou indireta nas políticas de educação especial (KASSAR, 2001; MENDES, 1995; MORAES, V., 2011b). Nessa perspectiva, poderíamos supor que, de acordo com Poulantzas (2000), essas instituições tinham conseguido, em alguns momentos da história da educação brasileira, a hegemonia na ossatura material do Estado, na constituição de centros de decisão sobre as políticas de financiamento da educação especial em favor de seus interesses. Desse modo, elas se teriam constituído como classe privilegiada nas relações de forças no âmbito do Estado. Entretanto, no decorrer dos anos, essa configuração tem sofrido alterações, por meio do que Poulantzas (2000) denomina fissuras do Estado, onde se dá a inscrição da luta de classes na estrutura do Estado. Nesse contexto, as classes populares, representadas pelos movimentos sociais (das famílias, dos profissionais da educação, dos representantes políticos e os próprios sujeitos com deficiência, TGD e altas habilidades/superdotação), lutam por recursos públicos voltados ao atendimento educacional especializado nos sistemas públicos de ensino, num intenso processo de negociação perante interesses diversos que compõem o cenário político educacional. Como resultado dessa trajetória de luta, observamos a instituição de políticas públicas que asseguram direitos à população da educação especial, bem como a expansão da oferta de serviços de educação especial, por meio de ações e programas do governo federal que têm repercutido no aumento das matrículas dos alunos com deficiência, TGD e altas habilidades/superdotação nas classes comuns das escolas públicas.

Esse processo de correlações de forças no âmbito do Estado, entre grupos que apontam a precariedade da implantação de um sistema escolar inclusivo, representados pelas entidades privadas de educação especial, e outros grupos que defendem 0 atendimento educacional especializado nas escolas da rede regular pública de ensino, nos faz compreender as ambiguidades e lacunas presentes nas políticas de financiamento da educação especial, que, de um lado, asseguram o direito à educação e ao atendimento educacional especializado às pessoas com 
deficiência, TGD e altas habilidades/superdotação no contexto da escola pública regular, e, de outro lado, ainda asseguram recursos públicos para as entidades privadas de educação especial. Esse movimento demonstra as correlações de forças entre diferentes segmentos sociais no processo de elaboração de políticas públicas e na disputa política pelo fundo público no Estado brasileiro. De acordo com Oliveira F. (1998), essa disputa se desenrola no âmbito do orçamento do Estado, envolvendo conflitos de classes e grupos que negociam as prioridades a serem estabelecidas pelo governo na execução de políticas públicas.

Ao percorrermos a trajetória de financiamento da educação especial no Brasil, entrelaçada aos diferentes contextos históricos, políticos e econômicos que marcaram também o percurso da educação brasileira, notamos que foi no âmbito desse Estado, marcado por correlações de forças sociais, que, contraditoriamente, se deu a efetivação das políticas de educação especial voltadas ao atendimento às pessoas com deficiência, TGD e altas habilidades/superdotação, principalmente, no período do governo Lula (2003-2010) e durante o processo de implantação do Fundeb (2007-2010). Essa efetivação está expressa na expansão das matrículas, na aferição das mesmas, na oferta do atendimento educacional especializado pelos diferentes sistemas públicos de ensino brasileiros e na ampliação de investimentos voltados a essa modalidade de ensino, seja por meio de recursos vinculados à educação, por meio do Fundeb e da diferenciação no fator de ponderação, seja por meio de programas do governo federal (Programa de Salas de Recursos Multifuncionais, Programa Escola Acessível, Programa Educação Inclusiva: direito à diversidade entre outros).

Estudos anteriores, como o realizado por Gomes e Sobrinho (1996), no período de 1985 a 1994, evidenciaram que, antes de 2003, os recursos do Poder Público eram muito reduzidos, restritos às fontes da União, por meio de programas, e, prioritariamente, destinados às instituições privadas de educação especial. Durante a vigência do Fundef, Viegas e Bassi (2009) já constatavam, ao analisarem a trajetória de financiamento da educação especial no Brasil durante o período de 1996 a 2006, os efeitos positivos no que tange à expansão no número de matrículas do público da educação especial no Brasil, impulsionados, principalmente, pela política de fundos, processo esse que foi ratificado, ao desenvolvermos nosso estudo, no período de implantação do Fundeb (2007-2010). 
Na rede municipal de ensino de Vitória, buscamos analisar o esforço do Poder Público no provimento de recursos financeiros à educação especial, por meio da análise da oferta, das receitas e das despesas em educação, assim como verificamos se os seus gastos estavam articulados com os objetivos estabelecidos no planejamento orçamentário e com as necessidades dessa modalidade de ensino no município.

Notamos que as políticas de educação especial na perspectiva inclusiva e a configuração do novo fundo, com a inclusão de todas as etapas e modalidades implicaram o incremento do número de matrículas do público da educação especial no Brasil e no município de Vitória e também o aumento de recursos para a educação especial, como podemos observar nos valores estimados para a modalidade de educação especial no âmbito do Fundeb. Entretanto, as matrículas no cômputo do Fundeb não produziram o efeito indutor esperado em termos de ampliação de recursos para essa modalidade no âmbito do município pesquisado, tendo em vista que, embora o Fundeb tenha contribuído para o aumento de verbas destinadas às etapas e modalidades da educação básica, o seu direcionamento continuou a depender fortemente das decisões, negociações e correlações de forças de interesse no âmbito do governo local, que define, em última instância, a destinação de recursos para as diferentes etapas da educação básica e modalidades de ensino no contexto de sua administração. Conforme Gouveia e Silva (2012, p.36),

[...] a política de fundos parece apenas amenizar as diferenças de investimento, porém, essas continuam a depender fortemente das decisões de investimento local e do desenvolvimento econômico das cidades, que podem explicar os recursos complementares aos redistribuídos pelos fundos e a manutenção de patamares de investimento em educação completamente distintos.

Cabe ressaltar que essa realidade pode se constituir de maneira diferenciada nas demais capitais brasileiras, haja vista as desigualdades regionais quanto à destinação de recursos para garantir acesso, permanência e qualidade de ensino nos sistemas públicos de ensino. Nessa direção, Araújo, R. (2014) destaca que o Fundeb, embora tenha produzido a redução das desigualdades entre os municípios, 
principalmente, pela participação financeira da União, não trouxe melhorias significativas, capazes de garantir um padrão mínimo de qualidade.

Assim, concordamos com Farenzena (2014, p. 84) quando afirma que, como toda política, "o Fundeb tem suas questões controversas e disputadas, pela qual a política concebida sobre reformulações na sua trajetória". Desse modo, no que se refere à educação especial, faz-se ainda necessário ampliarmos a discussão acerca dos recursos financeiros voltados a essa modalidade de ensino, a (re)definição dos critérios de ponderação, a contagem de matrículas da rede particular de ensino para recebimento de recursos públicos, a articulação dos entes federados e, principalmente, o aumento da participação da União, na busca pela universalização do atendimento ao público da educação especial.

Nesse contexto, ao analisarmos o financiamento da educação especial no âmbito municipal, procuramos compreender as suas relações com o contexto de financiamento e gestão da educação básica e suas articulações com as políticas sociais e econômicas no Estado brasileiro no que tange à garantia à educação às pessoas com deficiência, TGD e altas habilidades/superdotação nos sistemas públicos de ensino. Para isso, fez-se necessária a consulta ao planejamento e execução orçamentária do município de Vitória, de modo a visualizarmos as ações previstas nas diretrizes, nos objetivos e nas metas da administração pública voltadas à educação especial; a identificação das fontes de receitas vinculadas à educação, que incluem, prioritariamente, os recursos oriundos da arrecadação de impostos (próprios do município, de transferências legais e constitucionais estadual e federal), da transferência do FNDE e do Fundeb; e a análise das despesas destinadas às diferentes etapas e modalidades de ensino no município de Vitória.

A disponibilização dos dados orçamentários no portal de transparência do município, inclusive os instrumentos formais de planificação orçamentária, como PPA, LDO e LOA, contribuiu, inicialmente, para o nosso acesso às informações; entretanto, isto não excluiu as dificuldades de compreender a realidade orçamentária da educação, devido ao vocabulário específico, ao modo de disponibilização e organização dos dados e à necessidade de um conhecimento na área de finanças públicas. Cabe acrescentar que a contabilidade pública, ao não oferecer os dados adequadamente desagregados por etapas e modalidades de ensino, nas descrições de receitas e despesas, dificultou uma análise mais detalhada dos recursos 
destinados ao financiamento da educação especial na rede municipal de ensino de Vitória.

Nesse sentido, no que se refere à gestão do financiamento da educação especial, quanto à transparência, organização e padronização dos recursos voltados a essa modalidade de ensino, observamos que as mudanças no padrão de financiamento da educação, com o Fundeb, não produziram significativas alterações nas formas de registros contábeis dos órgãos oficiais referentes às etapas e modalidades de ensino. Isso foi evidenciado pelas dificuldades que encontramos em visualizar as receitas e despesas destinadas à educação especial nas diferentes fontes de informação do governo federal (como o Finbra e o Siope), do governo estadual (TC-ES) e do governo municipal (Semfa, Seme-Vitória e o Conselho Municipal de Educação de Vitória). Os dados eram apresentados de forma agregada, o que impossibilitava identificar o que era alocado na educação especial. Assim, embora a rede municipal de ensino de Vitória apresentasse matrículas nessa modalidade de ensino, os valores apresentados pareciam não corresponder às despesas reais com a manutenção da educação especial no município, por estarem agregados aos recursos de outras etapas de ensino, como o ensino fundamental e a educação infantil. De acordo com Bassi e Camargo (2010, p. 300),

[...] de forma geral, as gestões municipais permanecem como zonas obscuras e resistentes a sua publicização em função de uma "tradicional forma de gestão", devido a procedimentos de reiteração burocrática da máquina pública; pode-se pensar adicionalmente que a condição de ser opaca permite à administração que os interesses estratégicos (econômicos e políticos) locais se realizem no âmbito do Estado.

Esse modelo de prestação de contas ainda engendra entraves tanto para a gestão da educação especial, no âmbito da União, dos estados e dos municípios, pois torna ainda mais complexo o planejamento e políticas públicas voltadas à garantia dos direitos à educação do público da educação especial; quanto para os pesquisadores (DI PIERRO, 2012; VIEIRA, R., 2014; PRIETO; GIL, 2011; GONZALEZ; PRIETO, 2012) que desenvolvem estudos referentes ao financiamento da educação especial e de outras modalidades de ensino. Em geral, eles trabalham 
com estimativas e/ou dados aproximados de gastos e/ou custos destinados ao atendimento às pessoas com deficiência, TGD e altas habilidades/superdotação.

Cabe acrescentar que as disparidades nos valores de despesas da educação infantil e ensino fundamental e modalidades de ensino (educação especial e EJA), nos diferentes órgãos oficiais, dificultam o acompanhamento e o controle dos recursos públicos na área de educação. Isso mostra a necessidade de padronização na metodologia de envio dessas informações e a criação de uma forma de registros dos gastos referentes às modalidades de ensino, na qual esses gastos estejam desagregados (custeio e pessoal) e sejam correspondentes aos valores reais aplicados a essas modalidades no âmbito da educação básica. Inclusive dos recursos públicos direcionados às instituições privadas que oferecem serviços de educação especial. Nesse sentido, talvez fosse possível discutir o custo-aluno-ano da educação especial na tentativa de garantir um padrão mínimo de qualidade.

Diante desse contexto, em que os dados financeiros da educação especial estavam agregados aos recursos da educação infantil e do ensino fundamental no município de Vitória, o que impossibilitava uma análise mais pormenorizada dos gastos despendidos a essa modalidade e a visibilidade dos investimentos do Estado para assegurar o direito à educação ao público da educação especial, realizamos aproximações do esforço do Poder Público com a educação especial, a partir dos registros de receitas e despesas encontrados no planejamento orçamentário e nos demonstrativos de despesas da Seme-Vitória.

Observamos que o sistema municipal de ensino de Vitória tentava garantir o ensino público à sua população, por meio da oferta da educação infantil, do ensino fundamental, da EJA e da educação especial. Nessa perspectiva, apresentava diversas ações que absorviam recursos e representavam investimento, por parte do Estado, no intuito de efetivar o direito à educação. Foi possível identificar, ainda, que a educação especial integrava o planejamento orçamentário de Vitória. O valor destinado à modalidade ficou em torno de um milhão de reais, o que representou 0,7\% em 2008, 0,4\% em 2009 e 0,5\% em 2010 do total previsto para os gastos com a educação no município. Partindo do pressuposto de que para a concretização de uma política pública é necessário que ela integre a agenda educacional do município, acreditamos que a sua inclusão no planejamento orçamentário nos indica a intenção do Poder Público municipal em investir na educação especial. Contudo, 
cumpre destacar que os valores previstos na LOA estavam longe de garantir um ensino de qualidade para o público da educação especial, pois eram reduzidos, considerando-se 0 número de alunos com deficiência, TGD e altas habilidades/superdotação matriculados na rede municipal de ensino de Vitória e os altos custos de desenvolvimento e manutenção da educação especial, apontados nos estudos de custo-aluno da área de financiamento em educação que preveem a necessidade de um investimento duplicado para garantir um padrão de ensino de qualidade.

No que tange às receitas aplicadas em educação, observamos que o município de Vitória tinha um total de $\mathrm{R} \$ 439$ milhões em 2008 (considerando os recursos provenientes dos $25 \%$ vinculados ao MDE na CF/1988, as transferências dos recursos do FNDE e dos recursos recebidos do Fundeb) ou 559 milhões (considerando os recursos provenientes dos 35\% de impostos e transferências constitucionais vinculados ao MDE na Lei Orgânica do município de Vitória/ES, as transferências dos recursos do FNDE e dos recursos recebidos do Fundeb). Em 2009, tinha $R \$ 408$ milhões ou 516 milhões, respectivamente, e, em 2010, $R \$ 423$ milhões ou 534 milhões, nessa ordem, a serem aplicados à educação nas diferentes etapas e modalidades da educação básica, representando um aumento de aproximadamente de $4 \%$ a $5 \%$ nesse período. Esse crescimento foi resultante do desempenho tributário crescente do município, no que tange a sua receita própria de impostos e a seu desempenho positivo no que se refere à receita per capita total e receita própria per capita, se comparada com a das outras capitais brasileiras. Contudo, a sua arrecadação própria não foi suficiente para garantir a sua autonomia financeira, tendo em vista a sua dependência em relação às transferências externas, principalmente, da esfera estadual, o que mostrava a relevância dessa transferência para a composição da receita do município. Diante desse contexto, observamos a importância do regime de colaboração entre os entes federados para garantir recursos à educação no âmbito dos municípios e dos estados, que são os principais responsáveis pela oferta da educação básica no Brasil.

As receitas destinadas à educação especial estavam englobadas no total de recursos dirigidos à educação no município de Vitória, no período de 2008 a 2010, na medida em que a educação especial constitui-se como modalidade da educação básica, podendo, por conseguinte, ser integrada ao financiamento educacional do 
município. Cumpre acrescentar que o município também recebeu recursos do FNDE/PDDE, por meio dos programas do governo federal para o atendimento ao público da educação especial: o Programa de Salas de Recursos Multifuncionais e o Programa Escola Acessível. Vale destacar ainda que, no âmbito do Fundeb, os valores estimados para o município de Vitória para essa modalidade de ensino apresentaram uma trajetória crescente, em decorrência da diferenciação nos fatores de ponderação, do aumento da participação da União e da dupla matrícula da educação especial, computada quando o aluno estava também matriculado no atendimento educacional especializado, o que, em tese, garantiria mais recursos para essa modalidade no âmbito da rede municipal de ensino de Vitória.

Em relação às despesas, verificamos que a educação ocupava um lugar de destaque nas despesas por função na PMV, na medida em que representava $21 \%$ em 2008 e 2009 e 22\% em 2010, do total de despesas da prefeitura, o que demonstrava que a educação era priorizada na gestão do município de 2008 a 2010, em termos quantitativos, ao compararmos com as outras funções da administração municipal. As análises de despesas por subfunção revelaram que as etapas de ensino fundamental e educação infantil retiveram a maior parte dos recursos vinculados à função educação. A educação especial representou 0,23\% em 2008 , 0,14\% em 2009 e 0,10\% em 2010 da despesa por função em educação no município. Esse resultado foi ratificado quando analisamos as despesas por natureza, classificadas em correntes (pessoal e custeio) e de capital, e constatamos que o ensino fundamental e a educação infantil absorveram a maior parte dos recursos, tendo em vista que as despesas das modalidades estavam agregadas a essas etapas de ensino no município de Vitória.

No que se refere às despesas da educação especial registrados nos balanços da Seme-Vitória, observamos que os valores despendidos com pessoal não foram descritos, visto que o município não tinha uma classificação funcional para os profissionais que atuavam na educação especial, uma vez que esses profissionais eram oriundos da educação infantil e/ou do ensino fundamental. Os valores apresentados das despesas com custeio pareciam estar subdimensionados, tendo em vista que estavam agregados às despesas das etapas de ensino. As despesas por Programa de Trabalho da educação especial, por exemplo, foram de $0,2 \%(R \$$ $658.273,17)$ em 2008, 0,1\% ( $\$$ \$ 412.465,15) em 2009 e $0,09 \%(R \$ 310.413,49)$ em 
2010, do total despendido ( $\mathrm{R} \$ 315$ milhões em 2008, $\mathrm{R} \$ 325$ milhões em 2009 e $\mathrm{R} \$$ 344 milhões em 2010) para a educação no município, valores diminutos, considerando-se o número de matrículas do público da educação especial na rede municipal de ensino de Vitória: 906 em 2008, 1061 em 2009 e 1308 em 2010. E os serviços oferecidos para o trabalho e atendimento dos alunos com deficiência, TGD e altas habilidades/superdotação.

No que diz respeito ao valor gasto-aluno-ano das etapas da educação básica (educação infantil e ensino fundamental) e modalidades de ensino (educação especial e EJA) no município de Vitória, observamos que esse valor sofreu oscilações no período de 2008 a 2010. Cumpre destacar que o valor gasto-alunoano do ensino fundamental era superior ao valor de referência nacional para redistribuição do Fundeb, o que nos faria supor que a rede dispunha de condições financeiras para garantir um ensino de qualidade aos alunos matriculados na rede de ensino. Porém, quando analisamos o montante destinado às modalidades, verificamos que esse montante parecia não corresponder aos valores reais despendidos para o desenvolvimento e a manutenção da educação especial e da EJA e estava agregado às etapas de ensino. Desse modo, os valores do gastoaluno-ano da educação infantil e do ensino fundamental também podem estar superestimados. Os valores do gasto-aluno-ano da educação especial foram de $\mathrm{R} \$$ 726,57 em 2008, $R \$ 388,75$ em 2009 e $R \$$ 237,32 em 2010, valores, portanto, irrisórios se comparados aos valores previstos no Fundeb e no CAQi para essa modalidade de ensino. Dessa maneira, consideramos que não se pode ter uma política adequada de financiamento da educação especial sem informações claras, precisas e pormenorizadas dos recursos alocados para essa modalidade de ensino no âmbito do financiamento da educação básica. Assim, faz-se necessário (re)pensar os demonstrativos fiscais dos recursos da educação e criar instrumentos que promovam a visibilidade e a transparência do financiamento dessa modalidade de ensino nos sistemas educacionais.

O desenvolvimento desta pesquisa mostrou as complexidades e desafios da própria área de financiamento, em especial da educação e, de forma mais pronunciada, da educação especial no Brasil, diante da capacidade desigual de financiamento entre as esferas públicas, a ampliação da oferta de qualidade na educação e a fiscalização e o controle dos recursos educacionais. A pesquisa ainda revelou algumas temáticas a serem abordadas em outros estudos sobre 
financiamento e educação especial tais como o valor do custo-aluno-ano da educação especial, considerando os diferentes tipos de atendimento dessa modalidade de ensino e a diversidade de necessidades educacionais especiais apresentadas pelo alunado nas diferentes categorias do público da educação especial; as implicações da dupla matrícula no Fundeb; os recursos públicos despendidos pelas secretarias de saúde, assistência social e outras às instituições privadas de educação especial que oferecem serviços para as pessoas com deficiência, TGD e altas habilidades/superdotação; o processo de controle social dos recursos destinados à educação especial no âmbito do Fundeb e no âmbito da gestão das administrações públicas, realizado pelos órgãos de acompanhamento e fiscalização como o Tribunal de Contas e os conselhos de educação; e o processo de participação da sociedade civil e dos profissionais da educação nos processos de planejamento orçamentário da educação.

Nessa perspectiva, foi possível verificar que o financiamento da educação especial sofre influência das correlações de forças políticas, econômicas e sociais em torno do fundo público no âmbito do Estado brasileiro, representadas essas forças por diferentes grupos com interesses diversos que, por sua vez, interferem na constituição de políticas públicas, engendrando implicações na consolidação de direitos de cidadania, entre estes o direito à educação. Segundo Gomes e Sobrinho (1996), os processos decisórios sobre os recursos financeiros constituem, em geral, arenas de competição e conflitos incessantes entre diferentes atores sociais, com interesses diversos. Nesse contexto de negociação, insere-se o setor educacional, que participa desse processo e disputa os respectivos recursos no intuito de garantir condições para cumprir seus objetivos prescritos pela legislação, entre os quais a oferta de uma educação de qualidade à todos. No caso da educação especial, nesse jogo de correlações de forças, no âmbito do orçamento do Estado, há disputa por recursos entre as diferentes etapas e modalidades, e existem, ainda, relações de disputa entre o Poder Público e as entidades privadas, que também tentam assegurar (e têm conseguido) participação no fundo público. Ao final, as decisões decorrentes desse processo complexo de negociações se transformam em políticas públicas que refletem escolhas, que não são apenas técnicas organizacionais, mas, prioritariamente, políticas de diferentes grupos sociais que compõem o arcabouço institucional do Estado. Portanto, a concretização do direito à educação para o público da educação especial pressupõe políticas educacionais que garantam 
recursos e mudanças na gestão financeira, no âmbito da administração pública municipal e também nas demais esferas de governo, de modo a assegurar às pessoas com deficiência, transtornos globais do desenvolvimento e altas habilidades/superdotação educação de qualidade nos sistemas públicos de ensino.

Nessa perspectiva, um ensino de qualidade em todos os níveis, etapas e modalidades está articulado ao aumento do fundo público para a educação pública, à gestão democrática da educação, o controle social e à definição do regime de colaboração entre os entes federados, conforme foi estabelecido no PNE 20142024, na Meta 20. E, pressupõe, ainda, um redimensionamento das relações público/privado, que têm marcado a história da educação especial no contexto da educação brasileira, no intuito de universalizar o atendimento escolar, da educação infantil ao ensino superior, à população com deficiência, TGD e altas habilidades/superdotação.

Ao final desse percurso, concluímos com a tese: a impossibilidade de obter valores efetivamente aplicados na educação especial pelo Poder Público municipal, diante da organização da gestão político-financeira das verbas destinadas à educação, que não favorece o acompanhamento e o controle social dos recursos públicos, voltados a essa modalidade de ensino nos sistemas educacionais brasileiros, assim como, dificulta o estudo do financiamento da educação especial no âmbito das esferas públicas no Brasil. 


\section{REFERÊNCIAS}

ABREU, Daniela de Moraes Garcia de. O privado e o especial: análise de um recorte do atendimento educacional de alunos com necessidades educativas especiais na rede privada do Rio Grande do Sul. 2002. Dissertação (Mestrado em Educação) - Programa de Pós-Graduação em Educação, Universidade Federal do Rio Grande do Sul, Porto Alegre, 2002.

ABRUCIO, Fernando Luiz. Os laços federativos brasileiros: avanços, obstáculos e dilemas no processo de coordenação intergovernamental. 2000. Tese (Doutorado em Ciência Política). Programa de Pós-Graduação em Ciência Política, Universidade de São Paulo, São Paulo, 2000.

ADRIÃO, Theresa et al. Uma modalidade peculiar de privatização da educação pública: a aquisição de "sistemas de ensino" por municípios paulistas. Educação \& Sociedade, Campinas, v. 30, n. 108, p. 799-818, out. 2009.

ADRIÃO, Theresa; CAMARGO, Rubens Barbosa de. A gestão democrática na Constituição Federal, de 1988. In: OLIVEIRA, Romualdo Portela de; ADRIÃO, Theresa (Orgs.). Gestão Financiamento e direito à Educação: análise da Constituição Federal e da LDB. 3. ed. São Paulo: Xamã, 2007.p.63-72.

ALMEIDA, Mariângela. Lima. de. Formação continuada como processo críticoreflexivo-colaborativo: possibilidades de construção de uma prática inclusiva. 2004. Dissertação (Mestrado em Educação) - Programa de Pós-Graduação em Educação, Universidade Federal do Espírito Santo, Vitória, 2004.

AMARAL, Nelson Cardoso. Para compreender o financiamento da educação básica no Brasil. Brasília: Líber Livro, 2012.

ANDERSON, Perry. Balanço do neoliberalismo. In: SADER, Emir; GENTILI, Pablo (Org.). Pós-neoliberalismo: as políticas sociais e o estado democrático. Rio de Janeiro: Paz e Terra, 1995. p. 9-23.

ANTUNES, Ricardo. Adeus ao trabalho? São Paulo: Cortez, 1995.

ANUNCIAÇÃO, Marcos Paulo Pereira da; VERHINE, Robert Evan. A relação entre as variações no compromisso financeiro dos municípios com a educação e o desempenho escolar. Eccos: Revista científica. v. 8, n. 2, p. 253-504, jul./dez. 2006

ARAÚJO, Edgilson Tavares de. Parcerias Estado e organizações especializadas: discursos e práticas em nome da integração/inclusão educacional das pessoas com deficiência. 2006. Dissertação (Mestrado em Serviço Social) - Programa de Estudos Pós-Graduados em Serviço Social da Pontifícia Universidade Católica de São Paulo, São Paulo, 2006.

ARAÚJO, Gilda Cardoso de. Estado, direitos de cidadania e direito à educação: do programa ao diagrama. In: REUNIÃO ANUAL DA ASSOCIAÇÃO NACIONAL DE 
PÓS-GRADUAÇÃO E PESQUISA EM EDUCAÇÃO, 30. 2007, Caxambu. Anais... Disponível em: <http://www.anped.org.br>. Acesso em: 26 out. 2012.

. Direito à educação básica: a cooperação entre os entes federados. Revista Retratos da Escola, v.4, n. 7, p. 231-243, jul./dez. 2010.

ARAÚJO, Raimundo Luiz Silva. Desvendando o perfil dos gastos educacionais dos municípios brasileiros. Educação \& Sociedade, Campinas, v. 33, n. 121, p. 12151233, out./dez. 2012.

Limites e possibilidades da redução das desigualdades territoriais por meio do financiamento da educação básica. 2014. Tese (Doutorado em Educação) - Programa de Pós-Graduação da Faculdade de Educação, Universidade de São Paulo, São Paulo, 2013.

. É possível diminuir as desigualdades entre os municípios brasileiros por meio de uma política de fundos na educação? In: II ENCONTRO DA ASSOCIAÇÃO DE PESQUISA EM FINANCIAMENTO DA EDUCAÇÃO, 2. 2014. Paraná. Anais... Paraná: UFPR, 2014.p.50-64.

ARAÚJO, Vania Carvalho de. A cidade como espaço público de educação e de afirmação da cidadania: a experiência de Vitória/ES, Brasil. Revista Brasileira de Política e Administração da Educação. Porto Alegre, v. 27, n. 12, p. 1-152, jan./abr. 2011.

ARELARO, Lisete Regina Gomes. Resistência e submissão: a reforma educacional na década de 1990. In: KRAWCZYK, Nora; CAMPOS, Maria Malta; HADDAD, Sérgio (Org.). $O$ cenário educacional latino-americano no limiar do século XXI: reformas em debate. Campinas, São Paulo: Autores Associados, 2000. p. 95-116.

ARELARO, Lisete Regina Gomes et al. Passando a limpo o financiamento da educação nacional: algumas considerações. Revista Adusp, São Paulo, n. 32, p. 30-42, 2004.

ARRUDA, Marcos. ONGs e o Banco Mundial: é possível colaborar criticamente? In: TOMMASI, Lívia De; WARDE, Mirian Jorge; HADDAD, Sérgio (Org.). O Banco Mundial e as políticas educacionais. 6. ed. São Paulo: Cortez, 2009. p.41-74.

AZEVEDO, Janete Maria Lins de. Implicações da nova lógica de ação do Estado para a educação municipal. Educação \& Sociedade, Campinas, v. 23, n. 80, p. 4971, setembro. 2002.

BAPTISTA, Cláudio Roberto; JESUS, Denise Meyrelles de. (Org.) Avanços em políticas de inclusão: o contexto da educação especial no Brasil e em outros países. Porto Alegre: Mediação/CDV/FACITEC, 2009.

BARDIN, Laurence. Análise de conteúdo. Lisboa: Edições 70, 1995.

BASSI, Marcos Edgar. Financiamento da educação especial: inclusão em Santa Catarina. Poiésis, Santa Catarina, v. 6, n. 10, p. 377-394, jul./Dez. 2012. 
Matrícula e financiamento da educação básica na rede municipal de ensino de Florianópolis. In: II ENCONTRO DA ASSOCIAÇÃO DE PESQUISA EM FINANCIAMENTO DA EDUCAÇÃO, 2., 2014. Paraná. Anais... Paraná: UFPR, 2014.p.359-376.

BASSI, Marcos Edgar; CAMARGO, Rubens Barbosa de. Estilo de gestão da educação municipal: implicações para a gestão democrática e controle social.

Revista Brasileira de Política e Administração da Educação, Porto Alegre, v. 26, n. 2, p. 209-408, maio/ago. 2010.

BASSI, Marcos Edgar et al. Relatório da força tarefa sobre orçamentos. In: Remuneração de professores de escolas públicas de educação básica: configurações, impasses, impactos e perspectivas. São Paulo: Faculdade de Educação - USP, 2013.

BEHRING, Elaine. A política social no capitalismo tardio. São Paulo: Cortez, 2002.

Brasil e contra-reforma: desestruturação do Estado e perda de direitos. São Paulo: Cortez, 2008a.

. Acumulação capitalista, fundo público e política social. In: BOSCHETTI, Ivanete et al. (Org.). Política social no capitalismo: tendências contemporâneas. São Paulo: Cortez, 2008b.p.44-63.

Crise do capital, fundo público e valor. In: BOSCHETTI, Ivanete et al. (Org.). Capitalismo em crise, política social e direitos. São Paulo: Cortez, 2010.p.13-34.

BENATTI, Marielle Moreira Santos. O financiamento público das instituições nãoestatais de educação especial em Campo Grande - MS (2001-2005). 2007. Dissertação (Mestrado em Educação) - Programa de Pós-Graduação em Educação, Universidade Federal de Mato Grosso do Sul, Mato Grosso do Sul, 2007.

. O financiamento público das instituições não-estatais de educação especial em Campo Grande - (2001-2005). VI CONGRESSO BRASILEIRO MULTIDISCIPLINAR DE EDUCAÇÃO ESPECIAL E VII ENCONTRO DA ASSOCIAÇÃO BRASILEIRA DE PESQUISADORES EM EDUCAÇÃO ESPECIAL, 6., 2011. Paraná. Anais... Paraná: UEL, 2011.p.3478-3488.

BENEVIDES, Maria Victoria de Mesquita. Cidadania e democracia. Revista Lua Nova, São Paulo, n. 33, p. 5-16, 1994.

BEZERRA, Giovani Ferreira. Tensões e contradições na política nacional de inclusão escolar: sobre a Secadi. In: VII CONGRESSO BRASILEIRO MULTIDISCIPLINAR DE EDUCAÇÃO ESPECIAL E VIII ENCONTRO DA ASSOCIAÇÃO BRASILEIRA DE PESQUISADORES EM EDUCAÇÃO ESPECIAL, 7., 2013. Paraná. Anais... Paraná: UEL, 2013.p.945-958. 
BOBBIO, Noberto. Reformismo, socialismo e igualdade. Novos Estudos, n. 19, dez. 1987.

. Estado, governo, sociedade: por uma teoria geral da política. Rio de Janeiro: Paz e Terra, 2004.

BOGDAN, Robert; BIKLEN, Sari. Investigação qualitativa em educação: uma introdução à teoria e aos métodos. Portugal: Porto, 1994.

BORGES, Carline Santos et al. Convênios e acordos firmados entre o poder público e instituições especializadas no estado do Espírito Santo. In: V CONGRESSO BRASILEIRO DE EDUCAÇÃO ESPECIAL E VII ENCONTRO NACIONAL DOS PESQUISADORES DA EDUCAÇÃO ESPECIAL, V, 2012, São Carlos, Anais... São Carlos: UFSCar, 2012.p.1582-1596.

BOROWSKY, Fabíola. O público e o privado na educação especial brasileira: primeiros apontamentos. In: XXVI SIMPÓSIO BRASILEIRO DE POLÍTICA E ADMINISTRAÇÃO DA EDUCAÇÃO, 26., 2013. Recife. Anais... Recife: UFPE, 2013.p.1-15.

BOSCHETTI, Ivanete. Implicações da reforma da previdência na seguridade social brasileira. Psicologia \& Sociedade, Belo Horizonte, v. 15, n. 1, p. 57-96, jan./jun. 2003.

Seguridade social na América Latina após o dilúvio neoliberal.

Observatório da Cidadania. Rio de Janeiro, v. 11, p. 91-98, 2007.

. A Insidiosa corrosão dos sistemas de proteção social europeus. Serviço Social \& Sociedade, São Paulo, n. 112, p. 754-803, out./dez. 2012.

BRASIL. Constituição (1824). Constituição Política do Império do Brazil. Coleção das leis do Império do Brasil. Rio de Janeiro: Imprensa Nacional, 22 abr., 1824.

. Ato Adicional n. 16, de agosto de 1834. Coleção de Leis do Império do Brasil. Rio de Janeiro: Imprensa Nacional, 1834.

. Decreto no. 4.682, de 24 de janeiro de 1923. Crea, em cada um das emprezas de estradas de ferro existentes no paiz, uma caixa de aposentadoria e pensões para os respectivos empregados. Coleção das leis do Império do Brasil. Rio de Janeiro, 24 jan. 1923. v. 1, p. 126.

Constituição (1934). Constituição da República dos Estados Unidos do Brasil. Diário Oficial da União [da] República dos Estados Unidos do Brasil. Rio de Janeiro: Imprensa Nacional, 16 jul., 1934.

. Constituição (1937). Constituição da República dos Estados Unidos do Brasil. Diário Oficial da União [da] República dos Estados Unidos do Brasil. Rio de Janeiro: Imprensa Nacional, 10 nov., 1937. 
. Constituição (1946). Constituição da República dos Estados Unidos do Brasil. Diário Oficial da União [da] República dos Estados Unidos do Brasil. Rio de Janeiro: Imprensa Nacional, 18 de set., 1946.

. Decreto ํ‥48.961, de 22 de setembro de 1960. Institui a Campanha Nacional de Educação e Reabilitação de Deficientes Mentais. Diário Oficial [da] República Federativa do Brasil, Brasília, 23 set. 1960. Seção 1, p. 1.

. Lei no. 4.024, de 20 de dezembro de 1961. Fixa as Diretrizes e Bases da Educação Nacional. Diário Oficial [da] República Federativa do Brasil, Brasília, 27 dez.1961. Seção 1, p.1.

. Lei o․ 4.320, de 17 de março de 1964. Estatui normas gerais de direito financeiro para elaboração e controle dos orçamentos e balanços da União, dos Estados, dos Municípios e do Distrito Federal. Diário Oficial [da] República Federativa do Brasil. Brasília, 1964.

. Lei no.5.692, de 11 de agosto de 1971. Fixa diretrizes e bases para o ensino de $1^{\circ}$ e $2^{\circ}$ graus, e dá outras providências. Diário Oficial [da] República Federativa do Brasil, Brasília, 12 ago. 1971.

. Decreto no. 72.425, de 3 de julho de 1973. Cria o Centro Nacional de Educação Especial (CENESP), e dá outras providências. Diário Oficial [da] República Federativa do Brasil, Brasília, 4 jul.1973. Seção 1, p. 1.

. Portaria Interministerial no. 477, de 11 de agosto de 1977. Estabelece diretrizes básicas para a ação integrada do MEC e do MPAS no campo do atendimento a excepcionais. Diário Oficial [da] República Federativa do Brasil, Brasília, 20 ago.1977. Seção 1, p. 1.

. Portaria Interministerial $\mathrm{n}^{0}$. 186, de 10 de março de 1978. Regulamenta a Portaria ํㅜ 477, de 11 de agosto de 1977. Diário Oficial [da] República Federativa do Brasil, Brasília, 20 mar.1978. Seção 1, p.1.

. Emenda Constitucional ํ‥24, de 1 de dezembro de 1983. Estabelece a obrigatoriedade de aplicação anual, pela União, de nunca menos de treze por cento e pelos Estados Distrito Federal e Municípios de, no mínimo, vinte e cinco por cento da renda resultante dos impostos, na manutenção e desenvolvimento do ensino. Diário Oficial [da] República Federativa do Brasil, 24 dez. 1983. Seção 1, p. 20465.

. Lei nํ.7.348, de 24 de julho de 1985. Dispõe sobre a execução do $\S 4^{\circ}$ do art. 176 da Constituição Federal, e dá outras providências. Diário Oficial [da] República Federativa do Brasil, Brasília, 25 jul. 1985.

. Decreto ํo.93.613, de 21 de novembro de 1986. Extingue órgãos do Ministério da Educação, e dá outras providências. Diário Oficial [da] República Federativa do Brasil, Brasília, 24 nov.1986. Seção 1, p. 1. 
. Constituição (1988). Constituição [da] República Federativa do Brasil.

Brasília: Senado Federal, 1988.

. Lei $n^{0} .7 .853$, de 24 de outubro de 1989. Dispõe sobre o apoio às pessoas portadoras de deficiência, sua integração social, sobre a Coordenadoria Nacional para Integração da Pessoa Portadora de Deficiência - Corde, institui a tutela jurisdicional de interesses coletivos ou difusos dessas pessoas, disciplina a atuação do Ministério Público, define crimes, e dá outras providências. Diário Oficial [da] República Federativa do Brasil, Brasília, 25 out.1989. Seção 1, p. 1.

. Decreto no.99.678, de 8 de novembro de 1990. Aprova a estrutura regimental do Ministério da Educação e dá outras providências. Diário Oficial [da] República Federativa do Brasil, Brasília, Distrito Federal, 8 nov. 1990. Seção 1, p. 21345.

. Lei no.8.490, de 19 de novembro de 1992. Dispões sobre a organização da Presidência da República e dos Ministérios e dá outras providências. Diário Oficial [da] República Federativa do Brasil, Brasília, 19nov.1992. Seção 1, p. 1.

. Ministério da Educação. Secretaria de Educação Especial. Política Nacional de Educação Especial. Brasília: MEC/SEESP, 1994.

. Ministério de Administração Federal e da Reforma do Estado. Plano Diretor da Reforma do Aparelho do Estado. Brasília, 1995.

. Lei de Diretrizes e Bases da Educação Nacional- LDBno.9.394, de 20 de dezembro de 1996. Diário Oficial [da] República Federativa do Brasil, Brasília, 23 dez. 1996a.

. Lei no.9.424, de 24 de dezembro de 1996. Dispõe sobre o Fundo de Manutenção e Desenvolvimento do Ensino Fundamental e de Valorização do Magistério. Diário Oficial [da] República Federativa do Brasil, Brasília, 26 dez. 1996b. Seção 1.

. Emenda Constitucional №.14, de 12 de setembro de 1996. Modifica os artigos 34, 208, 211 e 212 da Constituição Federal e da nova redação ao art. 60 do Ato das Disposições Constitucionais Transitórias. Diário Oficial [da] República Federativa do Brasil, 13 set. 1996c. Seção 1, p. 18109.

. Portaria $n^{\circ} .42$, de 14 de abril de 1999. Atualiza a discriminação da despesa por funções de que tratam o inciso I, do $\S 1^{\circ}$, do art. $2^{\circ}$, e $\S 2^{\circ}$ do art. $8^{\circ}$, ambos da Lei ํo. 4.320, de 17 de março de 1964; estabelece conceitos de função, subfunção, programa, projeto, atividade, operações especiais e dá outras providências. Diário Oficial [da] República Federativa do Brasil, Brasília, Distrito Federal, 15 abr. 1999a. Seção 1, p. 4.

. Decreto n‥3.076, de $1^{\circ}$ de junho de 1999. Cria, no âmbito do Ministério da Justiça, o Conselho Nacional dos Direitos da Pessoa Portadora de Deficiência Conade, e dá outras providências. Diário Oficial [da] República Federativa do Brasil, Brasília, 2 jun.1999b. Seção 1, p.1. 
. Decreto n‥3.298, de 20 de dezembro de 1999. Regulamenta a Lei no 7.853, de 24 de outubro de 1989, dispõe sobre a Política Nacional para a Integração da Pessoa Portadora de Deficiência, consolida as normas de proteção e dá outras providências. Diário Oficial [da] República Federativa do Brasil, Brasília, 21 dez. 1999c. Seção 1, p.10.

. Lei Complementar no.101, de 4 de maio de 2000. Estabelece normas de finanças públicas voltadas para a responsabilidade na gestão fiscal e dá outras providências. Diário Oficial [da] República Federativa do Brasil, Brasília, 4 maio 2000.

. Lei no 10.172, de 9 de janeiro de 2001. Aprova o Plano Nacional de Educação e dá outras providências. Diário Oficial [da] República Federativa do Brasil, Brasília, 10 jan. 2001a.

. Portaria Interministerial no.163, de 4 de maio de 2001. Dispõe sobre normas gerais de consolidação das contas públicas no âmbito da União, estados e municípios, e dá outras providências. Diário Oficial [da] República Federativa do Brasil, Brasília, Distrito Federal, 7 maio2001b. Seção 1, p. 15-20.

Decreto nº.3.956, de 8 de outubro de 2001. Promulga a Convenção Interamericana para a Eliminação de Todas as Formas de Discriminação contra as Pessoas Portadoras de Deficiência. Diário Oficial [da] República Federativa do Brasil, Brasília, 9 out. 2001c. Seção 1, p.1.

Conselho Nacional de Educação. Câmara de Educação Básica. Resolução CNE/CEB n‥ 2, de 11 de setembro de 2001. Diretrizes Nacionais para a Educação Especial na Educação Básica. Diário Oficial [da] República Federativa do Brasil, 14 set. 2001 d. Seção 1E, p. 39-40.

. Conselho Nacional de Educação. Câmara de Educação Básica. Resolução CNE/CP no 1, de 18 de fevereiro de 2002. Institui Diretrizes Curriculares Nacionais para a Formação de Professores da Educação Básica, em nível superior, curso de licenciatura, de graduação plena. Diário Oficial [da] República Federativa do Brasil, Brasília, 9 abr. 2002a. Seção 1, p.31.

. Lei no 10.436, de 24 de abril de 2002. Dispõe sobre a Língua Brasileira de Sinais - Libras e dá outras providências. Diário Oficial [da] República Federativa do Brasil, Brasília, 25 abr. 2002b. Seção 1, p.23.

. Portaria no.2.678, de 24 de setembro de 2002. Aprova o projeto de Grafia Braille para a língua Portuguesa e recomenda o uso em todo território nacional.

Diário Oficial [da] República Federativa do Brasil, Brasília, 26set.2002c. Seção 1, p. 1.

. Lei no 10.845, de 5 de março de 2004. Institui o Programa de Complementação ao Atendimento Educacional Especializado às Pessoas Portadoras de Deficiência, e dá outras providências. Diário Oficial [da] República Federativa do Brasil, Brasília, 8mar. 2004a. Seção 1, p. 1. 
Decreto no.5.159, de 28 de julho de 2004. Aprova a Estrutura Regimental e o Quadro Demonstrativo dos Cargos em Comissão e das Funções Gratificadas do Ministério da Educação, e dá outras providências. Diário Oficial [da] República Federativa do Brasil, Brasília, 29 jul. 2004b. Seção 1, p.7.

. Ministério Público Federal. $O$ acesso de alunos com deficiência às escolas e classes comuns da rede regular de ensino. Brasília: Procuradoria Federal dos Direitos do Cidadão, 2004c.

. Decreto $\mathrm{n}^{0} .5 .374$, de 17 de fevereiro de 2005. Fixa, para o exercício de 2005, o valor mínimo anual por aluno de que trata o art. $6^{\circ}$, $\S 1^{\circ}$, da Lei ํo. 9.424, de 24 de dezembro de 1996, e dá outras providências. Diário Oficial [da] República Federativa do Brasil, Brasília, 18 fev. 2005a.

. Ministério da Educação. Secretaria de Educação Especial. Educação Inclusiva: direito à diversidade. Documento orientador. Brasília, 2005b.

. Lei no.11.274, de 6 de fevereiro de 2006. Altera a redação dos arts. 29, 30, 32 e 87 da Lei no.9.394, de 20 de dezembro de 1996, que estabelece as diretrizes e bases da educação nacional, dispondo sobre a duração de 9 (nove) anos para o ensino fundamental, com matrícula obrigatória a partir dos 6 (seis) anos de idade. Diário Oficial [da] República Federativa do Brasil, Brasília, 7fev. 2006a. Seção 1, p.1.

. Conselho Deliberativo do FNDE. Fundo Nacional de Desenvolvimento da Educação. Resolução CD/FNDE o‥4, de 13 de março de 2006. Dispõe sobre os processos de adesão e habilitação e as formas de execução e prestação de contas, referentes ao Programa de Complementação ao Atendimento Educacional Especializado às Pessoas Portadoras de Deficiência (Paed), e dá outras providências. Diário Oficial [da] República Federativa do Brasil, Brasília, 14 mar. 2006b. Seção 1, p.1.

. Conselho Deliberativo do FNDE. Fundo Nacional de Desenvolvimento da Educação. Resolução CD/FNDE no.28, de 14 de julho de 2006. Dispõe sobre os processos de adesão e habilitação e as formas de execução e prestação de contas, referentes ao Programa de Complementação ao Atendimento Educacional Especializado às Pessoas Portadoras de Deficiência (Paed), e dá outras providências. Diário Oficial [da] República Federativa do Brasil, Brasília, 15 jul. 2006c. Seção 1, p. 1.

. Conselho Deliberativo do FNDE. Fundo Nacional de Desenvolvimento da Educação. Resolução CD/FNDE ํo.32, de 10 de agosto de 2006. Estabelece as normas para a execução do Programa Nacional de Alimentação Escolar - PNAE. Diário Oficial [da] República Federativa do Brasil, Brasília, 11 ago. 2006d. Seção 1, p. 1.

Emenda Constitucional o‥53, de 19 de dezembro de 2006. Dá nova redação aos arts. 7, 23, 30, 206, 208, 211 e 212 da Constituição Federal e ao art. 60 do Ato das Disposições Constitucionais Transitórias. Diário Oficial [da] República Federativa do Brasil, Brasília, DF, 20 dez. 2006e. Seção 1, p. 5. 
Decreto $n^{\circ} .6 .003$, de 28 de dezembro de 2006. Regulamenta a arrecadação, a fiscalização e a cobrança da contribuição social do salário-educação, a que se referem o art. 212, § 5으, da Constituição, e as Leis ํo.9. 424, de 24 de dezembro de 1996, e o..9. 766, de 18 de dezembro de 1998, e dá outras providências. Diário Oficial [da] República Federativa do Brasil, Brasília, 28 dez. $2006 \mathrm{f}$.

. Decreto $n^{0} .6 .094$, de 24 de abril de 2007. Dispõe sobre a implementação do Plano de Metas Compromisso Todos pela Educação, pela União Federal, em regime de colaboração com Municípios, Distrito Federal e Estados, e a participação das famílias e da comunidade, mediante programas e ações de assistência técnica e financeira, visando à mobilização social pela melhoria da qualidade da educação básica. Diário Oficial [da] República Federativa do Brasil, Brasília, 25 abr. 2007a. Seção 1, p. 5.

. Lei no.11.494, de 20 de junho de 2007. Regulamenta o Fundo de Manutenção e Desenvolvimento da Educação Básica e de Valorização dos Profissionais da Educação - FUNDEB, de que trata o art. 60 do Ato das Disposições Constitucionais Transitórias; altera a Lei ํo.10.195, de 14 de fevereiro de 2001; revoga dispositivos das Leis ํ‥9.424, de 24 de dezembro de 1996, ㄲo.10.880, de 9 de junho de 2004, e no.10.845, de 5 de março de 2004; e dá outras providências. Diário Oficial [da] República Federativa do Brasil, Brasília, 21 jun. 2007b.

. Decreto №.6.253, de 13 de novembro de 2007. Dispõe sobre o Fundo de Manutenção e Desenvolvimento da Educação Básica e de Valorização dos Profissionais da Educação - FUNDEB, regulamenta a Lei no.11.494, de 20 de junho de 2007, e da outras providências. Diário Oficial [da] República Federativa do Brasil, Brasília, 14 nov. 2007c. Seção 1, p. 18.

Edital n‥1 de 26 de abril de 2007d. Programa de implantação de salas de recursos multifuncionais. Disponível em: <http://portal.mec.gov.br/arquivos/pdf/2007_salas.pdf>. Acesso em: 5 mai. 2012.

. Portaria Normativa Interministerial no. 18, de 24 de abril de 2007. Dispõe sobre a criação do Programa de acompanhamento e monitoramento do acesso e permanência na escola das pessoas com deficiência beneficiárias do benefício de prestação continuada da assistência social. Diário Oficial [da] República Federativa do Brasil, Brasília, Distrito Federal, 26 de abr. 2007e. Seção 1, p. 6.

. O Plano de Desenvolvimento da Educação: razões, princípios e programas. Brasília: MEC, $2007 f$.

. Fundo Nacional de Desenvolvimento da Educação. Portaria ํo.41, de 27 de dezembro de 2007. Divulgação a especificação das ponderações entre diferentes etapas, modalidades e estabelecimentos de ensino, a serem seguidas em 2008 no âmbito do Fundeb. Diário Oficial [da] República Federativa do Brasil, Brasília, Distrito Federal, 28 de dez. 2007g. Seção 1, p. 1.

. Portaria Normativa Interministerial no.1.030, de 6 de novembro de 2007. Define e divulga os parâmetros anuais de operacionalização do Fundeb para o 
exercício de 2007; atualiza e divulga o valor da complementação da União ao Fundeb em 2007. Diário Oficial [da] República Federativa do Brasil, Brasília, Distrito Federal, 7 de nov. 2007h. Seção 1, p. 1.

\section{Política Nacional de Educação Especial na Perspectiva da Educação} Inclusiva. Brasil: MEC/SEESP, 2008a.

Decreto n․6.571, de 17 de setembro de 2008. Dispõe sobre o atendimento educacional especializado, regulamenta o parágrafo único do art. 60 da Lei no.9.394, de 20 de dezembro de 1996, e acrescenta dispositivo ao Decreto no.6.253, de 13 de novembro de 2007. Diário Oficial [da] República Federativa do Brasil, Brasília, 18 set. 2008b. Seção 1, p. 26.

. Portaria Ministério da Educação no -844 , de 8 de julho de 2008. Diário Oficial [da] República Federativa do Brasil, Brasília, Distrito Federal, 9 de jul. 2008c. Seção 1, p. 23.

Decreto Legislativo no.186, 9 de julho de 2008. Aprova o texto da Convenção sobre os Direitos das Pessoas com Deficiência e de seu Protocolo Facultativo, assinados em Nova lorque, em 30 de março de 2007. Diário Oficial [da] República Federativa do Brasil, Brasília, 10 jul. 2008d. Seção 1, p. 1.

. Fundo Nacional de Desenvolvimento da Educação. Portaria nํ.932, de 30 de julho de 2008. Aprova a resolução da Comissão Intergovernamental de Financiamento para a educação básica de qualidade para o exercício de 2009. Diário Oficial [da] República Federativa do Brasil, Brasília, Distrito Federal, 31 de jul. 2008e. Seção 1, p. 1.

. Portaria Normativa Interministerial nํ.1.027, de 19 de agosto de 2008. Define e divulga os parâmetros anuais de operacionalização do Fundeb para o exercício de 2008 e revoga a Portaria Interministerialn-598. Diário Oficial [da] República Federativa do Brasil, Brasília, Distrito Federal, 20 de maio. 2008f. Seção 1, p. 1.

. Conselho Nacional de Educação. Câmara de Educação Básica. Resolução CNE/CEB no.4, de 2 de outubro de 2009. Diretrizes operacionais para o atendimento educacional especializado na educação básica, modalidade educação especial.

Diário Oficial [da] República Federativa do Brasil, 5 out. 2009a. Seção 1, p. 17.

. Decreto no.6.949, 25 de agosto de 2009. Promulga a Convenção

Internacional sobre os Direitos das Pessoas com Deficiência e seu Protocolo Facultativo, assinados em Nova York, em 30 de março de 2007.Diário Oficial [da] República Federativa do Brasil, Brasília, 26 ago. 2009b. Seção 1, p. 3.

. Ministério da Educação. Portaria №.777, de 10 de agosto de 2009. Aprova a resolução da Comissão Intergovernamental de Financiamento para a educação básica de qualidade para o exercício de 2010. Diário Oficial [da] República Federativa do Brasil, Brasília, Distrito Federal, 11 de ago. 2009c. Seção 1, p. 1. Portaria Normativa Interministerial no.788, de 14 de agosto de 2009. Define e divulga os parâmetros anuais de operacionalização do Fundeb para o exercício de 
2009. Diário Oficial [da] República Federativa do Brasil, Brasília, Distrito Federal, 17 de ago. 2009d. Seção 1, p. 1.

. Portaria Normativa Interministerial no. 386, de 17 de abril de 2009. Divulga demonstrativo final da distribuição dos recursos do Fundeb, relativos ao exercício de 2008. Diário Oficial [da] República Federativa do Brasil, Brasília, Distrito Federal, 24 de abr. 2009e. Seção 1, p. 1.

. Instituto Brasileiro de Geografia e Estatística. 2010a. Disponível em:<http://www.cidades.ibge.gov.br/xtras/perfil.php?lang=\&codmun=320530\&search =espirito-santo|vitoria $>$. Acesso em: 6 abr. 2014.

. Câmara dos Deputados. Projeto de Lei no. 8.035, 20 de dezembro de 2010b. Aprova o Plano Nacional de Educação para o decênio 2011/2020 e dá outras providências. Disponível em:

<http://www.camara.gov.br/proposicoesWeb/prop_mostrarintegra?codteor $=831421 \& f$ ilename $=P L+8035 / 2010>$. Acesso em: 20 de out. 2013.

. Fundo Nacional de Desenvolvimento da Educação. Portaria nํ․873, de 1ํㅜ de julho de 2010. Aprova a resolução da Comissão Intergovernamental de Financiamento para a educação básica de qualidade para o exercício de 2011. Diário Oficial [da] República Federativa do Brasil, Brasília, Distrito Federal, 2 de jul. 2010c. Seção 1, p.

. Medida Provisória nº. 483, de 24 de março de 2010. Altera as Leis no.10.683, de 28 de Maio de 2003, que dispõe sobre a organização da Presidência da República e dos Ministérios, e №.8.745, de 9 de dezembro de 1993, que dispõe sobre a contratação por tempo determinado para atender a necessidade temporária de excepcional interesse público, e dá outras providências. Diário Oficial [da] República Federativa do Brasil, Brasília, 24mar. 2010d. Seção 1, p. 1.

Portaria Normativa Interministerial n‥538-A, de 26 de abril de 2010. Retifica e divulga os parâmetros anuais de operacionalização do Fundeb para o exercício de 2010. Diário Oficial [da] República Federativa do Brasil, Brasília, Distrito Federal, 5 de maio. 2010e. Seção 1, p. 1.

. Conselho Nacional de Educação. Câmara de Educação Básica. Parecer no.8, de 5 de maio de 2010. Estabelece normas para aplicação do inciso IX do artigo 4ํ da Lei no 9.394/96(LDB), que trata dos padrões mínimos de qualidade de ensino para a Educação Básica pública. Câmara da Educação Básica, Brasília, 5maio. $2010 f$.

. Ministério da Educação. Secretaria de Educação Especial. Manual de orientação: Programa e Implantação de Salas de Recursos Multifuncionais. Brasília, 2010g.

Portaria Normativa Interministerial no. 496, de 16 de abril de 2010. Divulga demonstrativo final da distribuição dos recursos do Fundeb, relativos ao exercício de 2009. Diário Oficial [da] República Federativa do Brasil, Brasília, Distrito Federal, 19 de abr. 2010h. Seção 1, p. 1. 
. Decreto n‥7.611, de 17 de novembro de 2011. Dispõe sobre a educação especial, o atendimento educacional especializado e dá outras providências. Brasília: Presidência da República, 2011. Diário Oficial [da] República Federativa do Brasil, Brasília, 18 nov. 2011a. Seção 1, p. 12.

. Decreto $n^{\circ} .7 .480$, de 16 de maio de 2011. Aprova a estrutura regimental e o quadro demonstrativo dos cargos em comissão do grupo direção e assessoramento superiores - DAS e das funções gratificadas do Ministério da Educação e dispõe sobre remanejamento de cargos em comissão. Diário Oficial [da] República Federativa do Brasil, Brasília, 17 maio. 2011b. Seção 1, p. 1.

. Ministério da Fazenda. Secretaria do Tesouro Nacional. Portaria $n^{\circ} .683$, de 6 de outubro de 2011c. Estabelece regras para a inserção de dados no Sistema de Coleta de Dados Contábeis e Fiscais dos Entes da Federação - SISTN e dá outras providências. Disponível em:

<http://www3.tesouro.fazenda.gov.br/legislacao/download/contabilidade/Port683_201 1_SISTN.pdf>. Acesso em: 20 out. 2013.

. Campanha Nacional pelo Direito à Educação. Educação pública de qualidade: quanto custa esse direito? 2 ed. São Paulo: Campanha Nacional pelo Direito à Educação, 2011d.

. Ministério da Educação. Portaria no. 1.322, de 21 de setembro de 2011. Aprova a resolução da Comissão Intergovernamental de Financiamento para a educação básica de qualidade para o exercício de 2012. Diário Oficial [da] República Federativa do Brasil, Brasília, Distrito Federal, 22 set. 2011e. Seção 1, p. 1.

. Portaria Normativa Interministerial №. 380, de 6 de abril de 2011. Divulga demonstrativo final da distribuição dos recursos do Fundeb, relativos ao exercício de 2010. Diário Oficial [da] República Federativa do Brasil, Brasília, Distrito Federal, 7 de abr. 2011 f. Seção 1, p. 1.

. Decreto №.7.690, de 2 de março de 2012. Aprova a estrutura regimental e o quadro demonstrativo dos cargos em comissão e das funções gratificadas do Ministério da Educação. Diário Oficial [da] República Federativa do Brasil, Brasília, 6 mar. 2012a. Seção 1, p. 15.

Senado Federal. Projeto de Lei da Câmara ํ‥103, 25 de outubro de 2012b. Aprova o Plano Nacional de Educação PNE e dá outras providências. Disponível em: $<$ http://www.senado.gov.br/atividade/materia/detalhes.asp?p_cod_mate=108259>. Acesso em: 20 de out. 2013.

. Ministério da Educação. Resolução n‥ 8, de 25 de julho de 2012. Aprova as ponderações aplicáveis entre diferentes etapas, modalidades e tipos de estabelecimentos de estabelecimento de ensino da educação básica, para vigência no exercício de 2013. Diário Oficial [da] República Federativa do Brasil, Brasília, Distrito Federal, 26 jul. 2012c. Seção 1, p. 1. 
. Lei ํㅜ. 12.796, de 4 de abril de 2013. Diário Oficial [da] República

Federativa do Brasil, Brasília, 4 abr. 2013a.Seção 1, p. 1.

. Ministério da Educação. Secretaria de Educação Continuada, Alfabetização, Diversidade e Inclusão/ Secretaria de Educação Superior. Programa Incluir. Documento orientador. Brasília, 2013b.

. Ministério da Educação. Secretaria de Educação Continuada, Alfabetização, Diversidade e Inclusão. Programa Escola Acessível. Documento orientador. Brasília, 2013c.

. Decreto no -8.162 , de 18 de dezembro de 2013. Aprova a Estrutura Regimental e o Quadro Demonstrativo dos Cargos em Comissão e das Funções de Confiança da Secretaria de Direitos Humanos da Presidência da República e remaneja cargos em comissão. Diário Oficial [da] República Federativa do Brasil, Brasília, 19 dez. 2013d. Seção 1, p.47.

Censo da Educação Básica: 2012 - resumo técnico. Brasília: Instituto Nacional de Estudos e Pesquisas Educacionais Anísio Teixeira, 2013e.

. Lei no 13.005, 25 de junho de 2014. Aprova o Plano Nacional de Educação PNE e dá outras providências. Diário Oficial [da] República Federativa do Brasil, Brasília, 26 jun. 2014a. Seção 1, p.1.

. Direito à educação Inclusiva: por uma escola e um mundo para todos. Semana de Ação Mundial. São Paulo: Campanha Nacional pelo Direito à Educação, 2014b.

BREMAEKER, François Eugene Jean de. A política de fundos para a educação e o impacto nas finanças dos estados e dos municípios. In: GOUVEIA, Andréa Barbosa; PINTO, José Marcelino Rezende Pinto; CORBUCCI, Paulo Roberto. Federalismo e políticas educacionais na efetivação do direito à educação. Brasília: Ipea, 2011.p.51-68.

BRZEZINSKI, Iria. Pedagogia, pedagogos e a formação de professores: busca e movimento. Campinas, São Paulo: Papirus, 1996.

BUENO, José Geraldo Silveira. Educação especial brasileira integração/segregação do aluno diferente. São Paulo: EDUC/PUSP, 1993.

. Processos de inclusão/exclusão escolar, desigualdades sociais e deficiência. In: JESUS, Denise Meyrelles de.; BAPTISTA, Cláudio Roberto.; VICTOR, Sonia Lopes. Pesquisa e educação especial: mapeando produções. Vitória: Edufes, 2006.p.105-124

BUENO, Carmelita Cristina; KASSAR, Mônica de Carvalho Magalhães. Público e Privado: a educação especial na dança de possibilidades. In: ADRIÃO, Theresa; CAIADO, Katia Regina Moreno. Convenção Internacional sobre os direitos das pessoas com deficiências: destaques para o debate sobre a educação. Revista Educação Especial, Santa Maria, v. 22, n. 35, p. 329-338, set./dez. 2009. 
CAMARGO, Rubens Barbosa de; BASSI, Marcos Edgar. Gestão democrática na escola pública: participação e controle social no âmbito de um sistema de ensino. In: CORREA, Bianca Cristina; GARCIA, Teise Oliveira (Orgs.). Políticas educacionais e organização do trabalho na escola. São Paulo: Xamã, 2008.p.97-128.

CAMARGO, Rubens Barbosa de; PINTO, José Marcelino de Rezende; GUIMARÃES, José Luiz. Sobre o financiamento do plano de desenvolvimento da educação. Cadernos de Pesquisa, São Paulo, v. 38, n. 135, set./dez. 2008.

CARDOSO, Dalva Guaracyra Martins. Custos da educação especial: análise comparativa do custo/aluno em escola da rede municipal do Rio de Janeiro. 1997. Dissertação (Mestrado em Educação) - Programa de Pós-Graduação em Educação, Universidade Católica de Brasília, Brasília, 1997.

CARNOY, Martin. Estado e teoria político. Campinas: Papirus, 1988.

CARVALHO, Marcelo Pagliosa. As políticas para a educação de jovens e adultos nos governos Lula (2003-2010): incongruências do financiamento insuficiente. 2011. Tese (Doutorado em Educação) - Programa de Pós-Graduação da Faculdade de Educação, Universidade de São Paulo, São Paulo, 2011.

CASTEL, Robert. As metamorfoses da questão social: uma crônica do salário. Petrópolis: Vozes, 1999.

CASTRO, Jorge Abrahão de. Financiamento e gasto público da educação básica no Brasil e comparações com alguns países da OCDE e América Latina. Educação \& Sociedade, Campinas, v. 26, n. 92, p. 841-858, out. 2005.

Financiamento e gasto público na educação básica no Brasil: 1995-2005. Educação \& Sociedade, Campinas, v. 28, n. 100, p. 857-876, out. 2007.

Financiamento da educação pública no Brasil: evolução dos gastos. In: GOUVEIA, Andréa Barbosa; PINTO, José Marcelino Rezende Pinto; CORBUCCI, Paulo Roberto. Federalismo e políticas educacionais na efetivação do direito à educação. Brasília: Ipea, 2011.

CELLARD, André. A análise documental. In: POUPART, J. et al. A pesquisa qualitativa: enfoques epistemológicos e metodológicos. Petrópolis: Vozes, 2008.

CHESNAIS, François. A mundialização do capital. São Paulo: Xamã, 1996.

CHIZZOTTI, Antônio. Pesquisa em ciências humanas e sociais. São Paulo: Cortez, 1995.

COIMBRA, Marcos. Abordagens teóricas ao estudo das políticas sociais. In: ABRANCHES, S. et al. Política social e combate à pobreza. Rio de Janeiro: Zahar, 1987.p. 65-104.

CORRÊA, Darcísio. Estado, cidadania e espaço público: as contradições da trajetória humana. ljuí: Unijuí, 2010. 
CORRÊA, Nesdete Mesquita. O financiamento da educação especial na rede municipal de ensino de Campo Grande - MS (1998-2006). In: SEMINÁRIO NACIONAL DE PESQUISA EM EDUCAÇÃO ESPECIAL, 4., 2008, Rio Grande do Sul. Anais... Rio Grande do Sul: UFES, UFRGS, 2008. CD-ROM, p. 1-11.

. A educação especial e o plano de ações articuladas (PAR): em foco o programa de implantação de salas de recursos multifuncionais. In: SIMPÓSIO BRASILEIRO DE POLÍTICA E ADMINISTRAÇÃO DA EDUCAÇÃO, 25, 2011. São Paulo. Anais... São Paulo: PUC, 2011.p.1-14.

COSTA, Sandro Coelho. O Pacto de federalização e a responsabilidade pelo financiamento da educação infantil e ensino fundamental no Brasil. In: II ENCONTRO DA ASSOCIAÇÃO DE PESQUISA EM FINANCIAMENTO DA EDUCAÇÃO, 2.,2014. Paraná. Anais... Paraná: UFPR, 2014.p.109-126.

COUTINHO, Carlos Nelson. Contra a corrente: ensaios sobre democracia e socialismo. São Paulo: Cortez, 2000.

CRUZ, Flávio da et al. Comentários à Lei no. 4.320. 2. ed. São Paulo: Atlas, 2001.

CRUZ, Rosana Evangelista da. Federalismo e financiamento da educação: a política do FNDE em debate. In: GOUVEIA, Andréa Barbosa; PINTO, José Marcelino Rezende; CORBUCCI, Paulo Roberto. Federalismo e políticas educacionais na efetivação do direito à educação no Brasil. Brasília: Ipea, 2011.p. 79-94.

CURY, Carlos Roberto Jamil. A educação e a primeira constituinte republicana. In: FÁVERO, O. (Org.). A educação nas constituintes brasileiras 1823-1988.

Campinas: Autores Associados, 1996, p. 69-80.

. Direito à educação: direito à igualdade, direito à diferença. Cadernos de Pesquisa, São Paulo, n. 16, p. 245-262, jul. 2002.

. O público e o privado na história da educação brasileira - concepções e práticas educativas. In: LOMBARDI, José; JACOMELI, Mara e Silva, Mara. 0 público e o privado na história da educação brasileira - concepções e prática educativas. Campinas: Autores Associados, 2005.p.03-29.

. Estado e políticas de financiamento em educação. Educação \& Sociedade, Campinas, v. 28, n. 100, p. 831-855, out. 2007.

DANANI, Claudia. El espacio público ensulaberinto: las políticas sociales y lãs confrontaciones del universalismo. In: GLUZ, Nora; ARZATE SLAGADO, Jorge (compiladores). Particularismo y universalismo em las políticas sociales: el caso de la educación. Bueno Aires: UNGS-Universidade Autônoma del Estado de México, 2010, p. 1-17.

DAVIES, Nicholas. O Fundef e o orçamento da educação: desvendando a caixa preta. Brasília: Xamã, 1998. 
. Os Tribunais de Contas de São Paulo e sua avaliação dos gastos governamentais em educação. Eccos: Revista Científica, São Paulo, v.8, n.1, p. 1252, jan./jun. 2006a.

. Fundeb: a redenção da educação básica? Educação \& Sociedade, Campinas, v. 27, n. 96, p. 753-774, out. 2006b.

. Os procedimentos adotados pelo Tribunal de Contas do Espírito Santo para verificar os recursos vinculados à educação, 2006c. Disponível em: $<$ http://www.redefinanciamento.ufpr.br/ArquivoTextos/nicholas10.pdf>. Acesso em: 20 out. 2013.

. Controle estatal ou social das verbas da educação? In: PINTO, José Marcelino; SOUZA, Silvana Aparecida de (Orgs). Para onde vai o dinheiro?: Caminhos e descaminhos do financiamento da educação. São Paulo: Xamã, 2014.p.133-146.

DECLARAÇÃO DE SALAMANCA. Sobre princípios, política e prática em educação especial. Espanha, 1994. Disponível em: <http://www.regra.net/educacao/salamanca.htm>. Acesso em: 12 ago.2012.

DI PIERRO, Maria Clara. O financiamento público da educação de jovens e adultos no Brasil no período de 1985/1999. In: REUNIÃO ANUAL DA ASSOCIAÇÃO NACIONAL DE PÓS-GRADUAÇÃO E PESQUISA EM EDUCAÇÃO, 23., 2000, Anais... Caxambu. Disponível em: <http://www.anped.org.br>. Acesso em: 16 abr. 2014.

. A configuração do ensino de jovens e adultos no estado de São Paulo sob a vigência do Fundeb: resultados preliminares de uma pesquisa em andamento. In: REUNIÃO ANUAL DA ASSOCIAÇÃO NACIONAL DE PÓS-GRADUAÇÃO E PESQUISA EM EDUCAÇÃO, 35., 2012, Anais... Caxambu. Disponível em: <http://www.anped.org.br>. Acesso em: 16 abr. 2014.

DOURADO, Luiz Fernandes. Políticas e gestão da educação básica no Brasil: limites e perspectivas. Educação \& Sociedade, Campinas, n. 100, p. 921-946, out. 2007.

DRAIBE, Sônia; HENRIQUE, Wilnês. "Welfare State", crise e gestão da crise: um balance da literature internacional. Revista Brasileira de Ciências Sociais, São Paulo, v. 5, n. 6, p. 53-78, fev. 1988.

DUARTE, Clarice Seixas. A educação como um direito fundamental de natureza social. Educação \& Sociedade, Campinas, n. 100, v. 28, p. 691-713, out. 2007.

EDNIR, Madza; BASSI, Marcos. Bicho de sete cabeças: para entender o financiamento da educação brasileira. São Paulo: Petrópolis: Ação Educativa, 2009.

ENGELS, Friedrich. A origem da família, da propriedade privada e do Estado. São Paulo: Global, 1986. 
ESPING-ANDERSEN, Gosta. As três economias políticas do Welfare State. Luz Nova, São Paulo, n. 24, p. 85-116, set. 1991.

ESPÍRITO SANTO. Secretaria do Estado da Educação. Lei no. . 5.474, de 6 de outubro de 1997. Dispõe sobre o processo de municipalização do ensino público no Espírito Santo. Disponível em:

$<$ http://www.al.es.gov.br/antigo_portal_ales/images/leis/html/lo5474.htm>. Acesso em: 20 out. 2013.

ESPÍRITO SANTO. Secretaria do Estado da Educação. Conselho Estadual de Educação. Resolução no. 2.152, de 7 de janeiro de 2010. Dispõe sobre a educação especial no Sistema Estadual de Ensino do Estado do Espírito Santo. Diário Oficial [do] Espírito Santo, Vitória, 26 fev. de 2010.

ESPÍRITO SANTO. TCE. Resolução no. 144, de 23 de setembro de 1997. Institui mecanismos adequados à fiscalização do cumprimento pleno do disposto no artigo 212 da Constituição Federal. Diário Oficial [do] Espírito Santo, Vitória, 26 set. $1997 a$.

ESPÍRITO SANTO. TCE. Resolução №.145, de 18 de dezembro de 1997. Substitui a Resolução de n‥144/97, que instituiu mecanismos adequados à fiscalização do cumprimento pleno do disposto no artigo 212 da Constituição Federal. Diário Oficial [do] Espírito Santo, Vitória 23 de dez. 1997b.

ESPÍRITO SANTO. TCE. Resolução nํ.149, 15 de abril de 1998. Substitui a Resolução de no. 145/97, que instituiu mecanismos adequados à fiscalização do cumprimento pleno do disposto no artigo 212 da Constituição Federal. Diário Oficial [do] Espírito Santo, Vitória, 20 abr. 1998.

ESPÍRITO SANTO. TCE. Resolução no.154, de 22 de junho de 1999. Substitui as Resoluções de n‥145/97 e n‥149/98, que instituíram mecanismos adequados à fiscalização do cumprimento pleno do disposto no artigo 212 da Constituição Federal. Diário Oficial [do] Espírito Santo, Vitória, 29 jun. 1999.

ESPÍRITO SANTO. TCE. Resolução nํ․195, de 20 de abril de 2004. Institui novos mecanismos adequados à fiscalização quanto ao cumprimento pleno do disposto no artigo 212, da Constituição Federal, conforme disposto no artigo 11, da Lei nº.9.424/96. Diário Oficial [do] Espírito Santo, Vitória, 26 abr. 2004.

ESPÍRITO SANTO. TCE. Relatório de prestação de contas anual da Prefeitura Municipal de Vitória, referente ao exercício de 2009. Vitória, 2009.

ESPÍRITO SANTO. TCE. Relatório de prestação de contas anual da Prefeitura Municipal de Vitória, referente ao exercício de 2010. Vitória, 2010.

ESPÍRITO SANTO. TCE. Resolução ํㅜ․238, de 15 de maio de 2012. Institui novos mecanismos adequados à fiscalização quanto ao pleno cumprimento do disposto no artigo 212, da Constituição Federal e art.60 do seu ADCT, bem como nos artigos 26, inciso II, e 27 da Lei Federal no. 11494/07. Diário Oficial [do] Espírito Santo, Vitória, 16 maio 2012. 
ESPÍRITO SANTO. TCE. Resolução ํㅡ.260, de 21 de maio de 2013. Modifica a Resolução TC ํo. 238 de 15 de maio de 2012. Diário Oficial [do] Espírito Santo, Vitória, 22 maio 2013.

EVANGELISTA, Olinda. Apontamentos para o trabalho com documentos de política educacional. Disponível em:

<http://www.gepeto.ced.ufsc.br/downloads/Produo\%20Acadmica/Trabalhos\%20em\% 20Eventos/trab_evento_olinda_apontamentos_p_o_trab_c_docs_de_politica_educac ional.pdf>. Acesso em: 16 mar. 2012.

FALEIROS, Vicente. Natureza e desenvolvimento das políticas sociais. Capacitação em serviço social e política social, módulo 3. Brasília: UnB, Centro de Educação Aberta, Continuada a Distância, 2000. p. 41-56.

FARENZENA, Nalú. Diretrizes da política de financiamento da educação básica brasileira: continuidades e inflexões no ordenamento constitucional-legal (19871996). 2001. Tese (Doutorado em Educação) - Programa de Pós-Graduação em Educação, Universidade Federal do Rio Grande do Sul, Porto Alegre, 2001.

FARENZENA, Nalú. A política de financiamento da educação básica: rumos da legislação brasileira. Porto Alegre, RS: UFRGS, 2006.

. Panoramas do gasto público e da oferta de educação básica na perspectiva da esfera estadual. Fineduca - Revista de Financiamento da Educação, Porto Alegre, v. 2, n. 6, p. 1-15. 2012a.

- A assistência financeira da União às políticas educacionais locais. Revista Retratos da Escola, Brasília, v.6, n.10, p. 105-117. Jan./Jun. 2012b.

. Relações intergovernamentais nas políticas de educação básica no Brasil: a assistência da União aos governos subnacionais em foco. Revista Uruguaya de Ciencia Política, Montevideo, v. 21, n. 1, p. 183-202. 2012c.

. Equiparação das capacidades de financiamento da educação básica no âmbito do Fundeb: uma exploração. In: II ENCONTRO DA ASSOCIAÇÃO DE PESQUISA EM FINANCIAMENTO DA EDUCAÇÃO, 2. 2014. Paraná. Anais... Paraná: UFPR, 2014.p.81-93.

FERNANDES, Florestan. A revolução burguesa no Brasil. Ensaio de interpretação sociológica. 3. ed., Rio de Janeiro: Editora Guanabara, 1987.

FERNANDES, Francisco das Chagas. Fundo de manutenção e desenvolvimento da educação básica - Fundeb. In: COELHO, Rita de Cássia; BARRETO, Ângela Rabelo. (Orgs.) Financiamento da educação infantil: perspectivas em debate. Brasília: UNESCO, Brasil, 2004.p.125-132.

FERREIRA, Júlio Romero. A nova LDB e as necessidades educativas especiais. CEDES, Campinas, v. 19, n. 46, set. 1998. 
Políticas educacionais e educação especial. In: REUNIÃO ANUAL DA ASSOCIAÇÃO NACIONAL DE PÓS-GRADUAÇÃO E PESQUISA EM EDUCAÇÃO, 23., 2000, Anais... Caxambu. Disponível em: <http://www.anped.org.br>. Acesso em: 26 out. 2012.

. Políticas públicas, educação especial e inclusão escolar. In: SEMINÁRIO DE EDUCAÇÃO INCLUSIVA, 9., 2005, Vitória. Anais... Vitória, ES: UFES, 2005.p. 61-64.

Financiamento da educação básica: o público e o privado na educação especial brasileira. In: FÁVERO, Osmar et. al. Tornar a educação inclusiva. Brasília: UNESCO, 2009.p. 55-64.

FERREIRA, Maria Cecilia Carareto. Ressignificando as práticas pedagógicas da escola comum na perspectiva da educação inclusiva. In: SEMINÁRIO DE EDUCAÇÃO INCLUSIVA, 9., 2005, Vitória. Anais... Vitória, ES: UFES, 2005.p. 6578.

FERREIRA, Maria Cecília Carareto; FERREIRA, Julio Romero. Sobre a inclusão, políticas públicas e práticas pedagógicas. In: GÓES, Maria Cecília Rafael;

LAPLANE, Adriana Lia Friszman. Políticas e práticas de educação inclusiva. 2 ed. Campinas: Autores Associados, 2004. p. 21-48.

FLORES, Maria Marta Lopes. Capitalismo, salas de recursos multifuncionais e inclusão escolar. In: VII CONGRESSO BRASILEIRO MULTIDISCIPLINAR DE EDUCAÇÃO ESPECIAL E VIII ENCONTRO DA ASSOCIAÇÃO BRASILEIRA DE PESQUISADORES EM EDUCAÇÃO ESPECIAL, 7., 2013. Paraná. Anais... Paraná: UEL, 2013.p.1130-1140.

FOUCAULT, Michel. Microfísica do poder. Rio de Janeiro: Edições Graal, 1998.

. Vigiar e punir: nascimento da prisão. Petrópolis: Vozes, 2005.

FRANÇA, Marileide Gonçalves. No entrelaçar das complexas tramas políticas e sociais da inclusão escolar: o trabalho do professor de educação especial. 2008. Dissertação (Mestrado em Educação) - Programa de Pós-Graduação em Educação, Universidade Federal do Espírito Santo, Vitória, 2008.

FREITAS, Soraia Napoleão. O direito à educação para a pessoa com deficiência: considerações acerca das políticas públicas. In: BAPTISTA, Cláudio Roberto; JESUS, Denise Meyrelles de. (Org.). Avanços em políticas de inclusão: o contexto da educação especial no Brasil e em outros países. Porto Alegre:

Mediação/CDV/FACITEC, 2009.p. 221-228.

FRIGOTTO, Gaudêncio. Os circuitos da história e o balanço da educação no Brasil na primeira década do século XXI. Revista Brasileira de Educação, Rio de Janeiro, v.16, n. 46, p. 235-254, jan./abr. 2011.

GARCIA, Rosalba Maria Cardoso. Discursos políticos sobre inclusão: questões para as políticas públicas de educação especial no Brasil. In: REUNIÃO ANUAL DA 
ASSOCIAÇÃO NACIONAL DE PÓS-GRADUAÇÃO E PESQUISA EM EDUCAÇÃO, ANPED, 2004. Caxambu. Minicurso - GT15. 2004a.

GARCIA, Rosalba Maria Cardoso. Políticas públicas de inclusão: uma análise do campo da educação especial brasileira. 2004. Tese (Doutorado em Educação). Universidade Federal de Santa Catarina, Florianópolis, 2004b.

. Política de educação inclusiva e trabalho pedagógico: uma análise do modelo de educação especial na educação básica. In: SEMINÁRIO NACIONAL DE PESQUISA EM EDUCAÇÃO ESPECIAL, 4., 2008, Rio Grande do Sul. Anais... Rio Grande do Sul: UFES, UFRGS, 2008. 1 CD-ROM, p. 1-19.

. Política e gestão da educação especial nos anos 2000: a lógica gerencial. In: XXIV SIMPÓSIO BRASILEIRO DE POLÍTICA E ADMINISTRAÇÃO DA EDUCAÇÃO E III CONGRESSO INTERAMERICANO DE POLÍTICA E ADMINISTRAÇÃO DA EDUCAÇÃO, XXIV, 2009, Vitória. Anais... Vitória: UFES, 2009. p. 1-14.

. Política de educação especial na perspectiva inclusiva e a formação docente no Brasil. Revista Brasileira de Educação. Rio de Janeiro, v. 18, n. 52, p. 101-119, jan./mar. 2013.

GARCIA, Rosalba Maria Cardoso; MICHELS, Maria Helena. A política de educação especial no Brasil (1991-2011): uma análise da produção do GT15 - educação especial na Anped. Revista Brasileira de Educação Especial. Marília, v. 17, p. 105-124, maio/ago. 2011.

GIL, Antônio Carlos. Como elaborar projetos de pesquisa. São Paulo: Atlas, 1991.

GIL, Juca et al. Gestão das políticas de atendimento aos alunos com necessidades educacionais especiais em municípios paulistas. Jornal de políticas educacionais, Curitiba, n. 7, p.15-24, jan./jun. 2010.

GIRON, Graziela Rossetto. Políticas públicas, educação e neoliberalismo: o que isto tem a ver com cidadania? Revista de Educação PUC-Campinas, Campinas, n. 24, p.17-26, jun. 2008.

GLAT, Rosana; FERREIRA, Julio Romero. Panorama Nacional da Educação Inclusiva no Brasil. In: Educação Inclusiva no Brasil: Diagnóstico Atual e Desafios para o Futuro, Rio de Janeiro, v. 1, p. 1-63, 2003.

GOBETE, Girlene. Política educacional no município de Vitória no período de 1989 a 2004: implicações nas políticas de educação especial. 2005. $199 \mathrm{f}$. Dissertação (Mestrado em Educação) - Programa de Pós-Graduação em Educação, Universidade Federal do Espírito Santo, Vitória, 2005.

GODOY, Marina de. Vencimento inicial, média de vencimentos e carreira dos profissionais do magistério no estado do Paraná durante o Fundeb (2007-2012). In: II ENCONTRO DA ASSOCIAÇÃO DE PESQUISA EM FINANCIAMENTO DA EDUCAÇÃO, 2., 2014. Paraná. Anais... Paraná: UFPR, 2014.p. 236-254. 
GOMES, Candido Alberto; SOBRINHO, José Amaral. Educação Especial no Brasil: perfil do financiamento e das despesas. Brasília: MEC/SEEP/UNESCO, 1996.

GONZALEZ, Roseli Kubo; PRIETO, Rosângela Gavioli. Financiamento da educação especial em município paulista: algumas aproximações com o tema. In: V CONGRESSO BRASILEIRO DE EDUCAÇÃO ESPECIAL E VII ENCONTRO NACIONAL DOS PESQUISADORES DA EDUCAÇÃO ESPECIAL, V, 2012, São Carlos, Anais...São Carlos: UFSCar, 2012.p. 7475-7488.

GOUVEIA, Andrea Barbosa. Orçamento participativo, controle social e o poder público municipal: a experiência de União da Vitória/PR (1997-2000). 2002. Dissertação (Mestrado em Educação) - Programa de Pós-Graduação em Educação, Universidade de São Paulo, 2002.

. Políticas e financiamento na EJA: as mudanças na política de financiamento da educação e possíveis efeitos na EJA. Eccos - Revista Científica, São Paulo, v. 10, n. 2, p. 379-395, jul./dez. 2008.

GOUVEIA, Andrea Barbosa; SOUZA, Ângelo Ricardo de. Perspectivas e desafios no debate sobre financiamento e gestão da educação: da Conae a um novo PNE.

Educação \& Sociedade, Campinas, v. 31, n. 112, p. 789-807, jul./set. 2010.

GOUVEIA, Andrea Barbosa Gouveia; SILVA, Isabelle Fiorelli. O gasto aluno-ano no Paraná (Brasil) e a situação de financiamento da educação nas regiões metropolitanas do Estado. Perspectiva, Florianópolis, v. 30, n. 1, p. 305-331, jan./abr. 2012.

GOUVEIA, Andrea Barbosa; ALVES, Thiago; MINHOTO, Maria Angélica. Relatório da força tarefa "Dados educacionais". In: Remuneração de professores de escolas públicas de educação básica: configurações, impasses, impactos e perspectivas. São Paulo: Faculdade de Educação - USP, 2013.p. 1-152.

GOUVEIA, Andrea Barbosa; POLENA, Andrea. Financiamento da educação e condições de qualidade: um estudo exploratório de casos municipais. In: II ENCONTRO DA ASSOCIAÇÃO DE PESQUISA EM FINANCIAMENTO DA EDUCAÇÃO, 2.,2014. Paraná. Anais... Paraná: UFPR, 2014. p.342-358.

HÖFLING, Eloisa de Mattos. Estado e políticas (públicas) sociais. CEDES, Campinas, ano XXI, n. 55, p. 30-41, nov. 2001.

IAMAMOTO, Marilda Villela. A questão social no capitalismo. ABEPSS. Temporalis, Brasília: Abepss/Grafine, ano II, n. 3, jan.jun. 2001.

JACOBI, Pedro Roberto. Estado e políticas sociais - revisão das principais reflexões no capitalismo avançado, na América Latina e no Brasil. São Paulo: Mimeo, 2003. 
JANNUZZI, Gilberta de Martino. A educação do deficiente no Brasil: dos primórdios ao início do século XXI. Campinas, São Paulo: Autores Associados, 2004.

JESSOP, Bob. O Estado, o poder, o socialismo de Poulantzas como um clássico moderno. Revista Sociologia Política, Curitiba, v. 17, n. 33, p. 131-144, jun. 2009.

KASSAR, Monica de Carvalho Magalhães. Liberalismo, neoliberalismo e educação especial: algumas implicações. CEDES, Campinas, ano XIX, n. 46, p. 16-28, set. 1998.

Reforma do Estado e Educação Especial: preliminares para uma análise. Revista de Educação PUC-Campinas, Campinas, n. 11, p. 24-34, nov. 2001.

. Percursos da constituição de uma política brasileira de educação especial inclusiva. Revista Brasileira de Educação Especial, Marília, v. 17, p. 41-58, maio/ago. 2011a.

. Educação Especial na perspectiva inclusiva: desafios da implantação de uma política nacional. Educar em Revista, Curitiba, Brasil, n. 41, p. 61-79, jul./set. $2011 b$.

KRAMER, Sonia; NUNES, Maria Fernanda. Gestão pública, formação e identidade de profissionais da educação infantil. Cadernos de Pesquisa, São Paulo, v. 37, n. 131, p. 423-454, maio/ago. 2007.

LAPLANE, Adriana Lia Frisman; PRIETO, Rosângela Gavioli. Inclusão, diversidade e igualdade na Conae 2010: perspectivas para o novo Plano Nacional de Educação. Educação \& Sociedade, Campinas, v. 31, n. 112, p. 919-938, jul./set. 2010.

LAVILLE, Chirtian; DIONNE, Jean. Análise de conteúdo. A construção do saber: manual de metodologia de pesquisa em ciências humanas. Porto Alegre: Artmed, 1999.

LOPES, Eliane Marta Teixeira; GALVÃO, Ana Maria de Oliveira. História da educação. Rio de Janeiro: DP\&A, 2001.

LOUREIRO, Aline Dozzi Tezza; CAIADO, Katia Regina Moreno. Educação especial na educação básica: análise de matrículas em um município paulista. Cadernos de Pesquisa em Educação - PPGE/UFES, Vitória, ES., a. 10, v. 19, n. 37, p. 39-58, jan./jun. 2013.

LUCA, Tânia Regina de. Direitos sociais no Brasil. In: PINSKY, Jaime; PINSKY, Carla Bassanezi. História da cidadania. São Paulo: Contexto, 2010, p. 469-493.

LÜDKE, Menga; ANDRÉ, Marli Elisa Dalmazo Afonso de. Pesquisa em educação: abordagens qualitativas. São Paulo: EPU, 1986.

MALHEIROS, V. Vitória do Futuro/2002. Políticas Públicas de Integração Social, 2002. Disponível em: <http://www.vitoriadofuturo.org.br>. Acesso em: 26 out. 2012. 
MARSHALL, Thomas Humphrey. Cidadania, classe social e status. Tradução de Meton Porto Gadelha. Rio de Janeiro: Zahar Editores, 1967.

MARTINS, Inês de Oliveira Ramos. Pedagogos, professores e a construção do trabalho coletivo: a busca por uma escola inclusivo-reflexivo-crítica. 2005.

Dissertação (Mestrado em Educação) - Programa de Pós-Graduação em Educação, Universidade Federal do Espírito Santo, Vitória, 2005.

MAZZOTTA, Marcos José da Silveira. Educação Especial no Brasil: história e políticas públicas. 6.ed. São Paulo: Cortez, 2011.

MELCHIOR, José Carlos de Araújo. O financiamento da educação no Brasil. São Paulo: EPU, 1987.

. Financiamento da educação: gestão democrática dos recursos financeiros públicos em educação. Revista Brasileira de Estudos Pedagógicos, Brasília, v.72, n. 172, p. 262-290, set./dez. 1991.

MELETTI, Silvia Márcia Ferreira. Indicadores educacionais sobre a educação especial no Brasil e no Paraná. Educação \& Realidade, v. 39, n. 3, p. 789-809, jul./set. 2014.

MELETTI, Silvia Márcia Ferreira; BUENO, José Geraldo Silveira. O impacto das políticas púbicas de escolarização de alunos com deficiência: uma análise dos indicadores sociais no Brasil. Linhas Críticas, Brasília, Distrito Federal, v. 17, n. 33, p. 367-383, maio/ago. 2011.

MENDES, Enicéia Gonçalves. Deficiência mental: a construção científica de um conceito e a realidade educacional. 1995. Tese (Doutorado em Psicologia).

Programa de Pós-Graduação em Psicologia, Universidade de São Paulo, São Paulo, 1995.

A radicalização do debate sobre inclusão escolar no Brasil. Revista Brasileira de Educação, Rio de Janeiro, v. 11, n. 33, p. 387-559, set./dez. 2006a.

Inclusão: é possível começar pelas creches? In: REUNIÃO ANUAL DA ASSOCIAÇÃO NACIONAL DE PÓS-GRADUAÇÃO E PESQUISA EM EDUCAÇÃO, 29., 2006b. Caxambu. Disponível em: <http://www.anped.org.br>. Acesso em: 26 out. 2007.

. Breve histórico da educação especial no Brasil. Revista Educación y Pedagogía, n.57, v. 22, maio-ago. 2010.

MINAYO, Maria Cecília de Souza et al. (Org.). Pesquisa social: teoria, método e criatividade. Petrópolis. Rio de Janeiro: Vozes, 1994.

. $O$ desafio do conhecimento: pesquisa qualitativa em saúde. 11. ed. São Paulo: HUCITEC, 2007. 
MINTO, César Augusto. Educação Especial: da LDB aos planos nacionais de educação do MEC e proposta da sociedade brasileira. Revista Brasileira de Educação Especial, Rio de Janeiro, v. 6, n.1, p. 1-26, 2000.

MISHRA, Ramesh. Society and Social Policy. Londres: Macmil, 1981.

Editora, 1995.

O Estado-providência na sociedade capitalista. Oeiras, Portugal: Celta

MOEHLECKE, Sabrina. As políticas de diversidade na educação no governo Lula.

Cadernos de Pesquisa, São Paulo, v. 39, n. 137, p. 461-487, maio/ago. 2009.

MONLEVADE, João. Educação pública no Brasil: Contos \&De\$conto\$. CeilândiaDF: Idea Editora, 1997.

MONLEVADE, João; FERREIRA, Eduardo Batista. O Fundef e seus pecados capitais: análise do Fundo, suas implicações positivas e negativas e estratégias de superação de seus limites. Ceilânida, Distrito Federal: Idea, 1997.

MORAES, Valdete Aparecida Veiga de. Publicização/Privatização da educação especial no Paraná: gestão Requião (2003-2010). In: VI CONGRESSO

BRASILEIRO MULTIDISCIPLINAR DE EDUCAÇÃO ESPECIAL E VII ENCONTRO DA ASSOCIAÇÃO BRASILEIRA DE PESQUISADORES EM EDUCAÇÃO ESPECIAL, 6., 2011. Paraná. Anais... Paraná: UEL, 2011a.p. 3465-3477.

. Publicização/Privatização da educação especial no Paraná: gestão Requião (2003-2010). 2011. Dissertação (Mestrado em Educação) - Programa de Pós-Graduação em Educação, Universidade Tuiuti do Paraná, Curitiba, 2011b.

MOREIRA, Laura Ceretta. Cursos de licenciatura com bases inclusivas: impressões de alunos com necessidades educacionais especiais e de seus professores. In: SEMINÁRIO DE PESQUISA EM EDUCAÇÃO ESPECIAL, 2., 2006, Vitória. Anais trajetórias de pesquisa. Vitória, 2006. 1CD-ROM.

MOREIRA, Laura Ceretta; CARVALHO, Ana Paula de. Custo Aluno Qualidade inicial (CAQi) para alunos com deficiência incluídos no ensino medido público de Curitiba. In: SIMPÓSIO BRASILEIRO DE POLÍTICA E ADMINISTRAÇÃO DA EDUCAÇÃO, 25, 2011. São Paulo. Anais... São Paulo: PUC, 2011.p. 1-12.

MOREIRA, Nilson Gomes. Aplicação dos recursos da educação: estudo exploratório em municípios cearenses com melhores resultados do ldeb. Dissertação (Mestrado em Educação) - Programa de Pós-Graduação em Educação, Universidade Estadual do Ceará, Fortaleza, 2011.

MOTTA, Luiz Eduardo. Estado e sociedade civil num contexto democrático: arenas de conflitos e de constituição de direitos. Alceu - Revista de comunicação, cultura e política, Rio de Janeiro, v. 8, n. 16, p. 185-204, jan./jun. 2008.

. Nicos Poulantzas, 30 anos depois. Revista Sociologia Política, Curitiba, v. 17, n. 33, p. 221-228, jun., 2009. 
. Poulantzas e o direito. Dados - Revista de Ciências Sociais, Rio de Janeiro, v. 53, n. 2, p. 367-403, 2010.

NASCIMENTO, Ana Paula Santiago do. Avanços e retrocessos na oferta da educação infantil no Brasil: análise financeiro-orçamentária dos recursos destinados a essa etapa da educação 2001-2010. 2012. Dissertação (Mestrado em Educação) - Programa de Pós-Graduação em Educação, Universidade de São Paulo, São Paulo, 2012.

NETTO, José Paulo. Crise do socialismo e ofensiva neoliberal. São Paulo, Cortez, 1993.

. Capitalismo monopolista e serviço social. 4 ed. São Paulo: Cortez, 2005.

NEVES, Lúcia Maria Wanderley; PRONKO, Marcela. Atualidade das ideias de Nicos Poulantzas no entendimento das políticas sociais no século XXI. Germinal: Marxismo e Educação em Debate, Londrina, v. 1, n. 2, p. 97-111, jan. 2010.

NUNES, Leila Regina D'Oliveira de Paula; FERREIRA, Julio Romero. Deficiência mental: o que as pesquisas brasileiras têm revelado. In: ALENCAR, Eunice M. Soriano de. (Org.). Tendências e desafios da educação especial. Brasília: SESPMEC, 1994.p. 50-81.

OLIVEIRA, Jaime Antônio de Araújo; TEIXEIRA, Sônia Maria Fleury. (Im) Previdência social: 60 anos de história da Previdência no Brasil. Petrópolis, Vozes; (Rio de janeiro): Associação Brasileira de Pós-Graduação em Saúde Coletiva, 1985.

OLIVEIRA, Fabrício. Economia e política das finanças púbicas: uma abordagem crítica da teórica convencional, à luz da economia brasileira. Belo Horizonte, 2001.

OLIVEIRA, Francisco de. Os direitos do antivalor: a economia política da hegemonia imperfeita. Petrópolis, Rio de Janeiro: Vozes, 1998.

OLIVEIRA, Romualdo Portela de. O financiamento da educação. In: OLIVEIRA, Romualdo Portela de; ADRIÃO, Theresa (Org.). Gestão Financiamento e direito à Educação: análise da Constituição Federal e da LDB. 3. ed. São Paulo: Xamã, 2007.p.83-122.

. O Plano Nacional de Educação: algumas questões para debate. Jornal de Políticas Educacionais, Curitiba, n. 9, p. 3-10, jan./jun. 2011.

ORGANIZAÇÃO DAS NAÇÕES UNIDAS. Convenção sobre os direitos das pessoas com deficiência, aprovada pela Assembleia Geral da ONU em dezembro de 2006. Disponível em: < http://www.bengalalegal.com/onu.php>. Acesso em 5 dez. 2012.

PARIZZI, Roseli Aparecida. A prática pedagógica do professor de educação especial: aprendendo a ensinar com a diversidade. 2000. Tese (Doutorado em Educação). Programa de Pós-Graduação em Educação do Centro de Educação e Ciências Humanas, Universidade Federal de São Carlos, São Carlos, 2000. 
PARO, Vitor Henrique. O custo do ensino público no Estado de São Paulo - estudo do custo/aluno na rede estadual de primeiro e segundo grau. Cadernos de pesquisa, São Paulo: Fundação Carlos Chagas, n. 43, p. 3-29, nov. 1982.

PEREIRA, Cléia Demétrio. Política de convênio na oferta de serviços de educação especial no município de Braço do Norte - SC. In: SEMINÁRIO NACIONAL DE PESQUISA EM EDUCAÇÃO ESPECIAL, 6., 2011, São Paulo. Anais... São Paulo: UFES, UFRGS, UFSCar, 2011. CD-ROM, p. 1-11.

PEREIRA, Potyara Amazoineida Pereira. Política social: temas \& questões. São Paulo: Cortez, 2008.

PERGHER, Calinca Jordânia. Mapeamento da capacidade de financiamento da rede municipal de ensino de Getúlio Vargas - RS: gastos, condições de oferta e trajetória do processo educativo (1993-2005). 2007. Dissertação (Mestrado em Educação) - Programa de Pós-Graduação em Educação, Universidade Federal Rio Grande do Sul, Porto Alegre, 2007.

PERONI, Vera Maria Vidal. Política educacional e o papel do Estado no Brasil dos anos 90. São Paulo: Xamã, 2003.

. O Público e o privado na educação: interfaces entre estado e sociedade. São Paulo: Xamã, 2005. p.116-135.

. Políticas educacionais e a relação público/privado. In: REUNIÃO ANUAL DA ASSOCIAÇÃO NACIONAL DE PÓŞ-GRADUAÇÃO E PESQUISA EM EDUCAÇÃO, 32., 2009, Anais... Caxambu. Disponível em:

<http://www.anped.org.br>. Acesso em: 26 out. 2012.

PERONI, Vera Maria Vidal; OLIVEIRA, Regina Tereza Cestaride.; FERNANDES, Maria Dilneia Espíndola. Estado e terceiro setor: as novas regulações entre o público e o privado na gestão da educação brasileira. Educação \& Sociedade, Campinas, v. 30, n. 108, p. 761-778, out. 2009.

PINTO, José Marcelino de Rezende. Os recursos para a educação no Brasil no contexto das finanças públicas. Brasília, Distrito Federal: Plano, 2000.

A política recente de fundos para o financiamento da educação e seus efeitos no pacto federativo. Educação \& Sociedade, Campinas, v. 28, n. 100, p. 877-897, out. 2007.

. O financiamento da educação no governo Lula. Revista Brasileira de Política e Administração da Educação, Porto Alegre, v. 25, n. 2, p. 185-384, maio/ago. 2009.

PINTO, José Marcelino de Rezende Pinto; ADRIÃO, Theresa. Noções Gerais sobre Financiamento da educação. Eccos: revista científica, São Paulo: Centro Universitário Nove de Julho, v. 8, n. 1, p. 23-46, jan./jun. 2006. 
PLETSCH, Márcia Denise. Educação especial e inclusão escolar: uma radiografia do atendimento educacional especializado nas redes de ensino da Baixada Fluminense / RJ. Ciências Humanas e Sociais em Revista, Rio de Janeiro, EDUR, v. 34, n. 12, jan./jun., p. 31-48, 2012.

PNUD, 2013. Programa das Nações Unidas para o desenvolvimento, Atlas do Desenvolvimento Humano no Brasil. Disponível em:<http://www.pnud.org.br>. Acesso em: 6 abr. 2014.

POLO, José Carlos. Planejamento e orçamento no município. In: PRASEM, FUNDESCOLA, MEC. Guia de consulta. Brasília: MEC, 1999.p. 295-329.

POMILIO, Ana Lacerda et al. O financiamento da educação especial no estado de São Paulo (2007-2010). In: V CONGRESSO BRASILEIRO DE EDUCAÇÃO ESPECIAL E VII ENCONTRO NACIONAL DOS PESQUISADORES DA EDUCAÇÃO ESPECIAL, V, 2012, São Carlos, Anais...São Carlos: UFSCar, 2012.p. 6777-6790.

POULANTZAS, Nicos. Fascismo e ditadura: a III Internacional face ao fascismo. Porto: Portucalense Editora, 1972.

As classes sociais no capitalismo de hoje. Rio de Janeiro/RS: Zahar, 1975.

Poder Político e classes sociais. 2.ed. São Paulo/SP: Martins Fontes, 1977.

O Estado, o poder, o socialismo. São Paulo: Paz e Terra, 2000.

PRIETO, Rosângela Gavioli. A construção de políticas de educação para todos. 2001. Disponível em

$<$ http://www.educacaoonline.pro.br/index.php?option=com content\&view=article\&cati $\mathrm{d}=5$ :educacao-especial\&id=61:a-construcao-de-politicas-publicas-de-educacao-paratodos>. Acesso em: 5 jun. 2013.

. Pesquisa sobre políticas de atendimento escolar a alunos com necessidades educacionais especiais com base em fontes documentais. In: JESUS, Denise Meyrellesde.; BAPTISTA, Claudio Roberto; VICTOR, Sonia Lopes. Pesquisa e educação especial: mapeando produções. Vitória: Editora, p. 29-58, 2006.p. 3958.

. Gestão das políticas de atendimento aos alunos com necessidades educacionais especiais em municípios paulistas. In: IX ENCONTRO DE PESQUISA EM EDUCAÇÃO DA REGIÃO SUDESTE, IX, 2009, São Carlos. Anais... São Carlos: UFSCar, 2009, CD-ROM, p. 1-9.

PRIETO, Rosângela Gavioli Prieto; GIL, I-Juca-Pirama Camargo. Gestão das políticas de atendimento aos alunos com necessidades educacionais especiais em municípios paulistas. Relatório de Pesquisa. São Paulo: Faculdade de Educação - USP, 2011. 
REBELO, Andressa Santos. Os impactos da política de atendimento educacional especializado: análise dos indicadores educacionais de matrículas de alunos com deficiência. 2012. Dissertação (Mestrado em Educação) - Programa de PósGraduação em Educação, Universidade Federal do Mato Grosso do Sul, Campo Grande, 2012.

A transmutação do conceito de atendimento especializado na legislação educacional brasileira (1988-2011). In: REUNIÃO ANUAL DA ASSOCIAÇÃO NACIONAL DE PÓS-GRADUAÇÃO E PESQUISA EM EDUCAÇÃO, 36., 2013. Caxambu. Disponível em: <http://www.anped.org.br>. Acesso em: 16 abr. 2014.

RODRIGUES, Alberto Tosi. Sociologia da educação. Rio de Janeiro: DP\&A, 2002.

ROMERO, Ana Paula Hamerski. Análise da política brasileira para a educação especial na década de 1990: configuração do atendimento e atuação do terceiro setor. 2006. Dissertação (Mestrado em Educação) - Programa de Pós-Graduação em Educação, Universidade Estadual de Maringá, Maringá, 2006.

ROMERO, Ricardo Montoro. Fundamentos teóricos de la política social. In: BRACHO, Carmem A; FERRER, Jorge G. Política Social. Madrid: McGraw-Hill, 1998.p. 33-50.

ROSANVALLON, Pierre. A nova questão social. Brasília: Instituto Teotônio Vilela, 1998.

ROSSINHOLI, Marisa. Política de financiamento da educação básica no Brasil: do FUNDEF ao FUNDEB. Brasília: Líber livro, 2010.

SALVADOR, Evilásio. Fundo público e seguridade social no Brasil. São Paulo: Cortez, 2010.

Fundo público e o financiamento das políticas sociais no Brasil. Serviço Social em Revista, Londrina, n. 2, v. 14, p. 4-22, jan./jun. 2012.

SANTOS, Maria Aparecida Rodrigues da Costa. Brincarte: implicações de um programa de educação integral em desenvolvimento.In: SIMPÓSIO BRASILEIRO DE POLÍTICA E ADMINISTRAÇÃO DA EDUCAÇÃO, 25, 2011. São Paulo. Anais... São Paulo: PUC, 2011.p. 1-13.

SANTOS, Maria de Paula Gomes dos. O Estado e os problemas contemporâneos. Florianópolis: CAPES, 2009.

SAVIANI, Dermeval. A nova lei da educação: trajetória, limites e perspectivas. Campinas, São Paulo: Autores Associados, 1997.

PDE- Plano de Desenvolvimento da Educação: Análise crítica da política do MEC. Campinas, São Paulo: Autores Associados, 2009.

SENA, Paulo. A legislação do Fundeb. Cadernos de Pesquisa,São Paulo, v. 38, n. 134, p. 319-340, maio/ago. 2008. 
SHIROMA, Eneida Oto; CAMPOS, Rosilene Fátima; GARCIA, Rosalba Maria Cardoso. Decifrar textos para compreender a política: subsídios teóricometodológicos para análise de documentos. Perspectiva, Florianópolis, v. 23, p. 427-446, jul./dez. 2005.

SILVA, Isabelle Fiorelli. Fundeb e o princípio de equidade: a questão da universalização do acesso à educação básica. In: II ENCONTRO DA ASSOCIAÇÃO DE PESQUISA EM FINANCIAMENTO DA EDUCAÇÃO, 2., 2014. Paraná. Anais... Paraná: UFPR, 2014.p.22-41.

SILVA, Shirley. Exclusão do público, inclusão do privado: a terceirização dos serviços na educação especial. In: REUNIÃO ANUAL DA ASSOCIAÇÃO NACIONAL DE PÓS-GRADUAÇÃO E PESQUISA EM EDUCAÇÃO, 24., 2001, Anais... Caxambu. Disponível em: <http://www.anped.org.br>. Acesso em: 26 out. 2012.

SILVA, Tomaz Tadeu da.Documentos de identidade: uma introdução às teorias de currículo. 2. ed. Belo Horizonte: Autêntica, 2004.

SINGER, Paul. A cidadania para todos. In: PINSKY, Jaime; PINSKY, Carla Bassanezi. História da cidadania. São Paulo: Contexto, 2010.p.191-261.

SIQUEIRA, Maria da Penha Smarzaro. Industrialização e empobrecimento urbano: o caso da Grande Vitória, 1950-1980, Vitória: EDUFES, 2001.

SOARES, Maria Clara Couto. Banco Mundial: políticas e reformas. In: TOMMASI, Livia De; WARDE, Mirian Jorge; HADDAD, Sérgio (Org.). O Banco Mundial e as políticas educacionais. 6. ed. São Paulo: Cortez, 2009.p. 15-40.

SOBRINHO, Reginaldo Célio; LAVAGNOLI, Camila Fuzato; FONSECA,Maysa Guimarães da. Políticas públicas e financiamento em educação especial. In: SIMPÓSIO BRASILEIRO DE POLÍTICA E ADMINISTRAÇÃO DA EDUCAÇÃO, 25, 2011. São Paulo. Anais... São Paulo: PUC, 2011.p. 1-2.

SOBRINHO, Reginaldo Célio; PANTALEÃO, Edson. A relação "público-privado" e o financiamento da educação especial: reflexões sobre os processos políticos no estado do Espírito Santo. In: V CONGRESSO BRASILEIRO DE EDUCAÇÃO ESPECIAL E VII ENCONTRO NACIONAL DOS PESQUISADORES EM EDUCAÇÃO ESPECIAL, V, 2012, São Carlos, Anais...São Carlos: UFSCar, 2012.p. 6701-6715.

SOUZA, Ângelo Ricardo de; TAVARES, Taís Moura. A política educacional como ferramenta para o direito à educação: uma leitura das demandas por educação e as propostas do Plano Nacional de Educação. In: MELETTI, Silvia Márcia Ferreira; BUENO, José Geraldo Silveira. Políticas públicas, escolarização de alunos com deficiência e a pesquisa educacional. São Paulo: Junqueira \& Marin, 2013.p. 5371.

TEIXEIRA, Francisco José Soares. O neoliberalismo em debate. In: TEIXEIRA, Francisco José Soares; OLIVEIRA, Manfredo Araújo de. Neoliberalismo e 
reestruturação produtiva: as novas determinações do mundo do trabalho. São Paulo: Cortez, 1996.p. 195-252.

TRIVIÑOS, Augusto Nibaldo Silva. Introdução à pesquisa em ciências sociais: a pesquisa qualitativa em educação. São Paulo: Atlas, 1987.

UNESCO, Declaração Mundial de educação para todos. Tailândia, 1990.

VASQUEZ, Daniel Arias. Desequilíbrios regionais no financiamento da educação: a política nacional de equidade do Fundef. Revista de Sociologia e Política, Curitiba, n. 24, p. 149-164, jun. 2005.

VAZ, José Carlos. Desafios para a incorporação da transparência em um modelo de gestão municipal. In: CACCIA-BAVA, Silvio; PAULICS, Veronika; SPINK, Peter (Orgs.). Novos contornos da gestão local: conceitos em construção. São Paulo: Programa Gestão Pública e Cidadania/EAESP/ FGV, 2002. P. 267-286.

VIANA, Arthur Sérgio Rangel. O Fundef no Espírito Santo: alguns processos instituídos nas políticas públicas para o ensino fundamental do município de Vitória. 2006. Dissertação (Mestrado em Educação) - Programa de Pós-Graduação em Educação, Universidade Federal do Espírito Santo, Vitória, 2006.

VIEGAS, Luciane Torezan. Educação Especial no Rio Grande do Sul: uma análise da oferta e das políticas educacionais no período de 1988 a 2002. In: SIMPÓSIO BRASILEIRO DE POLÍTICA E ADMINISTRAÇÃO DA EDUCAÇÃO, 24, 2009. Vitória. Anais... Vitória: UFES, 2009a.p. 1-15.

Financiamento da educação: estudos preliminares sobre a educação especial. In: SEMINÁRIO NACIONAL DE PESQUISA EM EDUCAÇÃO ESPECIAL, 5., 2009, São Paulo. Anais... São Paulo: UFES, UFRGS, UFSCar, 2009b. 1 CDROM. p. 1-11.

A reconfiguração da educação especial e os espaços de atendimento educacional especializado: análise da constituição de um centro de atendimento em Cachoeirinha/RS. 2014. Tese (Doutorado em Educação) - Programa de PósGraduação em Educação, Universidade Federal do Rio Grande do Sul, Porto Alegre, 2014.

VIEGAS, Luciane Torezan; BASSI, Marcos Edgar. A educação especial no âmbito da política de fundos no financiamento da educação. Reflexão e ação, Santa Cruz do Sul, v. 17, p. 54-87, 2009.

VIEIRA, Evaldo. Estado e miséria social no Brasil: de Getúlio a Geisel. 2 ed. São Paulo: Cortez, 1985.

. Políticas sociais e direitos sociais no Brasil. Comunicação \& Educação, n. 9, p. 13-17, maio/ago. 1997.

A política e as bases do direito educacional. CEDES, ano XXI, n. 55, p. 929, nov. 2001. 
VIEIRA, Rosilene. Expectativas e frustações: a inclusão da EJA no Fundeb. In: II ENCONTRO DA ASSOCIAÇÃO DE PESQUISA EM FINANCIAMENTO DA EDUCAÇÃO, 2.,2014. Paraná. Anais... Paraná: UFPR, 2014. p. 94-108.

VIEIRA, Sofia Lerche. A educação nas constituições brasileiras: texto e contexto. Revista Brasileira de Estudos Pedagógicos, Brasília, v. 88, n. 219, p. 291-309, maio/ago. 2007.

. Educação básica: política e gestão da escola. Brasília: Líber Livro, 2009.

VIEIRA, Sofia Lerche; ALBUQUERQUE, Maria Gláucia Menezes. Política e planejamento educacional. 3. ed. Fortaleza: Edições Demócrito Rocha/EdUECE, 2002.

VIEIRA, Sofia Lerche; FARIAS, Isabel Maria Sabino de. Política educacional no Brasil. Brasília: Líber Livro Editora, 2007.

VITÓRIA. Lei no. 1, de 5 de abril de 1990. Dispõe sobre a Lei Orgânica do Município de Vitória. Disponível em:

$<$ http://www.legislacaoonline.com.br/vitoria/images/leis/html/011990.html>. Acesso em: 5maio 2012.

VITÓRIA. Vitória do Futuro: plano estratégico da cidade 1996-2010. Vitória: PMV, 1996.

VITÓRIA. Lei no. 4.747, de 27 de julho de 1998a. Institui o sistema municipal de ensino do município de Vitória. Disponível em:

<http://sistemas/vitoria.es.gov.br/webleis/leis/arquivos/1998/L4747.pdf>. Acesso em: 05 mai. 2012.

VITÓRIA. Lei no. 4.746, de 27 de julho de 1998b. Dispõe sobre a organização e funcionamento do conselho municipal de educação de Vitória. Disponível em: $<$ http://sistemas/vitoria.es.gov.br/webleis/leis/arquivos/1998/L4746.pdf>. Acesso em: 5 maio 2012.

VITÓRIA. Resolução no. 6 de 20 de outubro de 1999. Fixa normas para educação infantil no Sistema Municipal de Vitória. Disponível em:

$<$ http://www.vitoria.es.gov.br/arquivos/20090828_resol_06_99_seme_comev.pdf>. Acesso em: 5 maio 2012.

VITÓRIA. Vitória do Futuro/2002. Vitória, ES: Prefeitura Municipal de Vitória, 2002.

VITÓRIA. Plano de Trabalho-2003. Vitória, ES: SEME/SPP/CFAEE - Coordenação de Formação e Acompanhamento à Educação Especial, 2003.

VITÓRIA. Lei no. 6.375, de 14de setembro de 2005. Dispõe sobre o Plano Plurianual - PPA para o período 2006/2009. Disponível em:

<http://sistemas/vitoria.es.gov.br/webleis/arquivos/2005//6375.pfd>. Acesso em: 5 maio. 2012. 
VITÓRIA. A educação infantil no município de Vitória: um outro olhar - 2006a. Disponível em:

<http://www.vitoria.es.gov.br/arquivos/20100218_educacaoinfantil_doc_.pdf > . Acesso em: 5 maio 2012.

VITÓRIA. Lei no. 6.754, de 16 novembro de 2006b. Institui o Plano de Cargos, Carreira e Vencimentos do Servidor do Magistério Público do Município de Vitória. Disponível em: <http://sistemas.vitoria.es.gov.br/webleis/Arquivos/2006/L6754.pdf>. Acesso em: 5 fev. 2014.

VITÓRIA. Lei no. 6.948, de 13 de julho de 2007a. Dispõe sobre as diretrizes para a elaboração da lei orçamentária de 2008 e dá outras providências. Disponível em: <http://sistemas.vitoria.es.gov.br/webleis/Arquivos/2007/L6948.PDF>. Acesso em: 5maio 2012.

VITÓRIA. Lei no. 7.124, de 14 novembro de 2007b. Altera as Leis nº. 4.746 e 4.747, de 27 de julho de 1998, que dispõem respectivamente, sobre a organização e funcionamento do Conselho Municipal de Educação de Vitória e institui o Sistema Municipal de Ensino do Município de Vitória e dá outras providências. Disponível em: <http://sistemas.vitoria.es.gov.br/webleis/Arquivos/2007/L7124.pdf>. Acesso em: 05 fev. 2014.

VITÓRIA. Plano de Trabalho-2007c. Vitória, ES: SEME/SPP/CFAEE Coordenação de Formação e Acompanhamento à Educação Especial, 2007.

VITÓRIA. Agenda Vitória 2008/2028. Vitória, ES: Prefeitura Municipal de Vitória, 2008a.

VITÓRIA. Decreto no.13.747, de 28 de fevereiro de 2008b. Institui o conselho de Alimentação Escolar do município de Vitória - CAE e dá outras providências.

Disponível em:

<http://sistemas.vitoria.es.gov.br/webleis/Arquivos/2008/D13747.PDF>. Acesso em: 05 mai. 2012.

VITÓRIA. Plano de Trabalho-2008/2009. Vitória, ES: SEME/SPP/CFAEE Coordenação de Formação e Acompanhamento à Educação Especial, 2008c.

VITÓRIA. Resolução n.7, de 10 de dezembro de $\mathbf{2 0 0 8 d}$. Fixa normas relativas à organização e funcionamento do Ensino Fundamental na Rede Municipal de Ensino de Vitória, Espírito Santo. Disponível em:

$<$ http://www.vitoria.es.gov.br/arquivos/20080828_resol_07_08_seme_comev.pdf>. Acesso em: 5 maio 2012.

VITÓRIA. Lei no. 7.527, de 7 de julho de 2008e. Dispõe sobre as diretrizes para a elaboração da lei orçamentária de 2009 e dá outras providências. Disponível em: <http://www.sistemas.vitoria.es.gov.br/webleis/arquivos/2008//7527.pdf>. Acesso em: 05 mai. 2012.

VITÓRIA. Lei n. 7.633, de 15 de dezembro de 2008f. Estima a receita e fixa a despesa do município de Vitória para o exercício de 2009. Disponível em: 
<http://www.sistemas.vitoria.es.gov.br/webleis/arquivos/2009//7633.pdf>. Acesso em: 5 maio 2012.

VITÓRIA. Relatório Resumido de Execução Orçamentária. Vitória, 2008g.

VITÓRIA. Lei no. 7.845, de 9 de dezembro de 2009a. Dispõe sobre o Plano Plurianual - PPA para o período 2010/2013. Disponível em:

<http://www.legislacaoonline.com.br/vitoria/images/leis/html//78452009.html>. Acesso em: 5 maio2012.

VITÓRIA. Lei no. 7.756, de 22 de julho de 2009b. Dispõe sobre as diretrizes para a elaboração da lei orçamentária de 2010 e dá outras providências. Disponível em: <http://www.sistemas.vitoria.es.gov.br/webleis/arquivos/2009//7756.pdf>. Acesso em: 5 maio 2012.

VITÓRIA. Lei no. 7.847, de 17 de dezembro de 2009c. Estima a receita e fixa a despesa do município de Vitória para o exercício de 2010. Disponível em:

$<$ http://www.sistemas.vitoria.es.gov.br/webleis/arquivos/2009//7847.pdf>. Acesso em: 5 maio 2012.

VITÓRIA. Relatório Resumido de Execução Orçamentária. Vitória, 2009d.

VITÓRIA. Plano de Trabalho-2010. Vitória, ES: SEME/SPP/CFAEE - Coordenação de Formação e Acompanhamento à Educação Especial, 2010a.

VITÓRIA. Relatório Resumido de Execução Orçamentária. Vitória, 2010b.

VITÓRIA. Decreto no. 15.071, de 21 de junho de 2011. Estabelece critérios para matrícula e permanência de alunos da Rede Municipal de Ensino de Vitória no Projeto Educação em Tempo Integral. Disponível em:

$<$ http://sistemas.vitoria.es.gov.br/webleis/Arquivos/2011/D15071.PDF>. Acesso em: 5 maio 2012.

VITÓRIA. Vitória em foco. Vitória, ES: Prefeitura Municipal de Vitória/Secretaria Municipal de Gestão Estratégica, 2012a.

VITÓRIA. PREFEITURA MUNICIPAL DE VITÓRIA. História de Vitória. Disponível em: $<$ http://www.vitoria.es.gov.br/turismo.php?pagina=historiadevitoria $>$. Acesso em: 28 jul. $2012 b$.

VITÓRIA. Relatório Circunstanciado da Administração Municipal (2009-2012). Vitória, 2012c.

WEBER, Marx. Economia e sociedade. Brasília: UmB/Senado Federal, 2004. 
APÊNDICES 
APÊNDICE A - Roteiro de entrevista com os gestores da Seme-Vitória

\author{
UNIVERSIDADE DE SÃO PAULO \\ FACULDADE DE EDUCAC̄̃̃O \\ PROGRAMA DE PÓS-GRADUAÇÃO ȨM EDUCAÇÃO
}

\title{
ROTEIRO DE ENTREVISTA COLETIVA
}

1) Apresentar os objetivos da Pesquisa e dados coletados e analisados até o presente momento.

2) Dados educacionais do Município de Vitória:

a) Quem informa os dados do município para o Censo, Finbra e Siope?

b) Há algum tipo de acompanhamento sistemático desse processo? Em caso positivo, este é feito por quem, com qual frequência e por meio de quais procedimentos?

c) O que explica as disparidades nos dados do município nessas diferentes fontes?

d) Quando (mês) é realizado o preenchimento desses dados?

e) Os dados referentes às etapas e modalidades de ensino são lançados de forma agregada ou separada?

f) Quais as consequências desse processo em termos de planejamento e políticas para as etapas e modalidades de ensino?

g) Quais são os desafios e dificuldades para descrever as despesas efetuadas pelas etapas e modalidades de ensino?

3) Planejamento orçamentário da educação municipal de Vitoria:

a) Como é realizado?

b) Quem participa?

c) Quais são os desafios e dificuldades?

4) Receitas da Secretaria Municipal de Educação de Vitória

a) Como são lançadas as receitas do município (a receita própria e as receitas oriundas das transferências)? Os valores estão agregados ou separados?

b) Nos dados apresentados na receita própria do município estão incluídos os valores dos juros, multas e dívida ativa? Em caso negativo, onde são lançados?

c) Os valores do Fundeb estão agregados aos valores da receita do município?

d) Onde são informados os valores de transferências voluntárias na prestação de contas do município?

e) Existem receitas específicas para educação especial nos anos de 2008 a 2010 ?

f) Quais recursos o município recebe do governo federal para aplicação na modalidade de educação especial? 
g) O município tem convênios com entidades privadas para oferta de educação especial?

h) Há alguma verba de outra secretaria municipal para financiar a educação especial?

5) Despesas da Secretaria Municipal de Educação de Vitória

a) As despesas apresentadas na execução orçamentária e financeira referem-se à educação ou à Secretaria Municipal de Educação?

b) Por que os valores de pessoal das modalidades de ensino estão agregados às etapas da educação básica?

c) Como garantir visibilidade das despesas das modalidades?

d) Os inativos estão agregados nos valores de despesas da Prefeitura de Vitória?

e) Por que não existem dados de despesas em EJA e formação em 2009? Não existia EJA? Não houve nenhuma ação de formação em 2009 ?

f) Nas despesas do Fundeb, identificamos que o município gastou mais do que recebeu do Fundo. O que explica essa situação?

6) Questões

a) Existia um Fundo Específico do Ensino Fundamental em 2009? Por quê? E por que foi extinto em 2010?

b) A Lei Orgânica do município de Vitória prevê 35\% para educação. Porém, os dados revelam que o município aplica $25 \%$. Onde são aplicados os demais $10 \%$ ? 


\title{
UNIVERSIDADE DE SÃO PAULO \\ FACULDADE DE EDUCAC̄̃̃O \\ PROGRAMA DE PÓS-GRADUAÇÃO EM EDUCAÇÃO
}

\section{TERMO DE COMPROMISSO}

\begin{abstract}
Eu, Marileide Gonçalves França, Doutoranda em Educação da Universidade de São Paulo, realizei entrevista com a da Secretaria Municipal de Educação de Vitória.

Estou consciente de que os dados coletados nessas entrevistas serão usados como elementos de análise para a minha tese, assim como podem vir a ser usados também em futuros trabalhos acadêmicos.

Será resguardado o anonimato dos sujeitos de pesquisa, usando nomes fictícios para referir-me a eles na relação do relatório final de pesquisa.
\end{abstract}

Vitória, de de 2014.

\section{Marileide Gonçalves França}

\author{
Professora Doutora Rosângela Gavioli Prieto \\ Professora Orientadora
}




\section{UNIVERSIDADE DE SÃO PAULO \\ FACULDADE DE EDUCAÇÃO \\ PROGRAMA DE PÓS-GRADUAÇÃO EM EDUCAÇÃO}

CONSENTIMENTO INFORMADO

$\mathrm{Eu}$,

Secretaria Municipal de Educação de Vitória autorizo à, Doutoranda Marileide Gonçalves França a realização da entrevista.

Estou consciente de que os dados coletados nessas entrevistas serão usados como elementos de análise para a tese da referida doutoranda, assim como podem vir a ser usados também em futuros trabalhos acadêmicos.

Será resguardado o anonimato dos sujeitos de pesquisa, usando-se nomes fictícios para referir-se a eles na relação do relatório final de pesquisa.

Vitória,

de de 2014.

Assinatura da professora 


\section{APÊNDICE D - Manual de demonstrativos fiscais: aplicado à União, Estados, Distrito Federal e Municípios}

\begin{tabular}{|c|c|c|c|c|c|}
\hline \multirow{2}{*}{\multicolumn{6}{|c|}{ RECEITAS DOENSINO }} \\
\hline & & & & & \\
\hline \multirow[b]{2}{*}{ RECEITA RESULTANTE DE IMPOSTOS (caput do art. 212 da Constituiçâo) } & \multirow{2}{*}{$\begin{array}{l}\text { PREVISAOO } \\
\text { INICIAL }\end{array}$} & \multirow{2}{*}{$\begin{array}{l}\text { PREVISAO } \\
\text { ATUALIZADA } \\
\text { (a) }\end{array}$} & \multicolumn{3}{|c|}{ RECEITAS REALIZADAS } \\
\hline & & & No Bimestre & \begin{tabular}{|c|} 
Até o Bimestre \\
$(b)$
\end{tabular} & $\begin{array}{c}\% \\
(c)= \\
(b / a) \times 100\end{array}$ \\
\hline 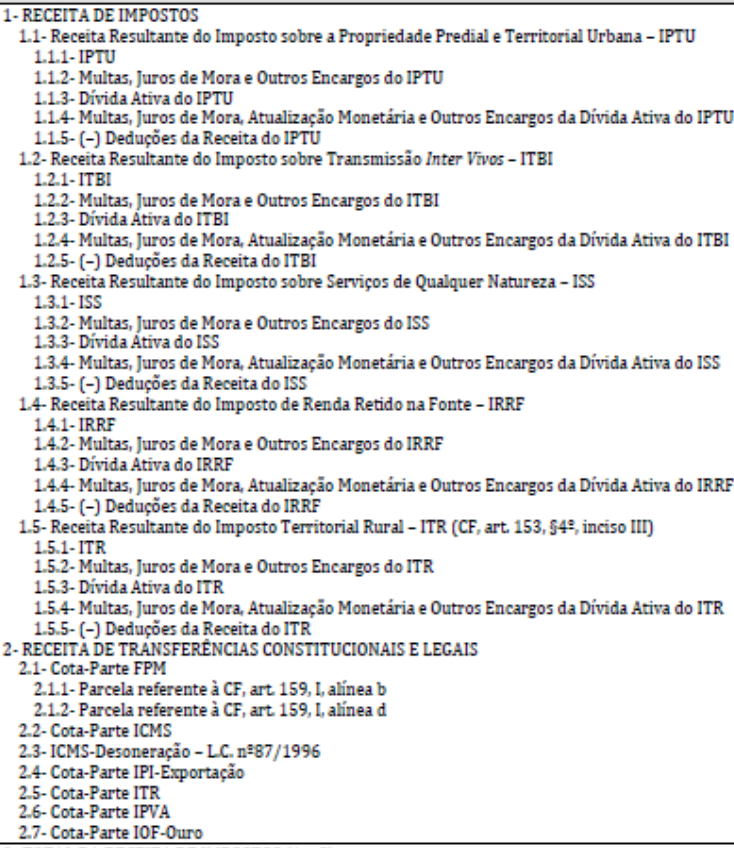 & & & & & \\
\hline \multicolumn{6}{|l|}{ 3-TOTAL DA RECEITA DE IMPOSTOS $(1+2)$} \\
\hline \multirow[b]{2}{*}{ RECEITAS ADICIONAIS PARA FINANCIAMENTO DO ENSINO } & \multirow{2}{*}{$\begin{array}{l}\text { PREVIS } \not O O \\
\text { INICIAL }\end{array}$} & \multirow{2}{*}{$\begin{array}{l}\text { PREVISAOO } \\
\text { ATUALIZADA } \\
\text { (a) }\end{array}$} & \multicolumn{3}{|c|}{ RECEITAS REALIZADAS } \\
\hline & & & No Bimestre & \begin{tabular}{|c|} 
Até o Bimestre \\
(b)
\end{tabular} & $\begin{array}{c}\% \\
(c)= \\
(b / a) \times 100\end{array}$ \\
\hline 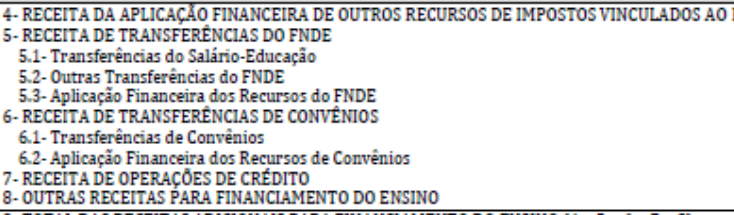 & & & & & \\
\hline \multicolumn{6}{|l|}{ 9-TOTAL DAS RECEITAS ADICIONAIS PARA FINANCIAMENTO DO ENSINO $(4+5+6+7+8)$} \\
\hline \multicolumn{6}{|c|}{ FUNDEB } \\
\hline \multirow[b]{2}{*}{ RECEITAS DO FUNDEB } & PREVISAO & PREVISAO & \multicolumn{3}{|c|}{ RECEITAS REALIZADAS } \\
\hline & INICIAL & $\underset{\text { (a) }}{\text { ATUALIZADA }}$ & No Bimestre & $\begin{array}{c}\text { Até } \circ \text { Bimestre } \\
(\mathrm{b})\end{array}$ & $\begin{array}{c}\% \\
(c)= \\
(b / a) \times 100\end{array}$ \\
\hline 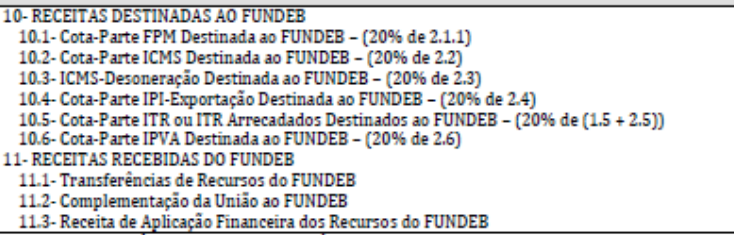 & & & & & \\
\hline 12-RESULTADO LIQQUIDO DAS TRANSFERENANCLS DO FUNDEB $(11.1-10)$ & & & & & \\
\hline 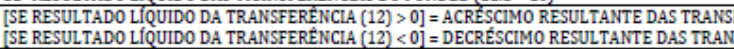 & & & & & \\
\hline
\end{tabular}




\begin{tabular}{|c|c|c|c|c|c|}
\hline \multirow[b]{2}{*}{ DESPESAS DO FUNDEB } & \multirow{2}{*}{$\begin{array}{l}\text { DOTAC,AO } \\
\text { INICIAL }\end{array}$} & \multirow{2}{*}{$\begin{array}{l}\text { DOTACAOAO } \\
\text { ATUALIZADA } \\
\text { (d) }\end{array}$} & \multicolumn{3}{|c|}{ DESPESAS LIQUIDADAS } \\
\hline & & & No Bimestre & $\begin{array}{c}\text { Até o Bimestre } \\
(\mathrm{e})\end{array}$ & $\begin{array}{c}\% \\
(f)= \\
(e / d) \times 100\end{array}$ \\
\hline \multicolumn{6}{|l|}{ 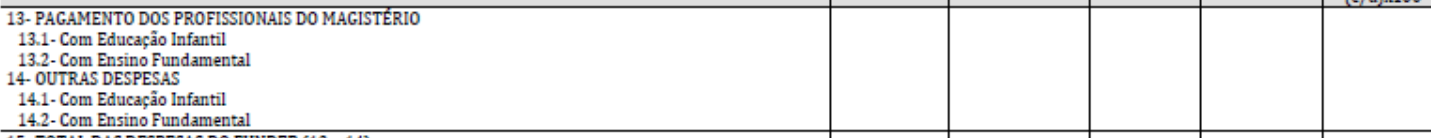 } \\
\hline \multicolumn{6}{|l|}{ 15-TOTAL DAS DESPESAS DO FUNDEB $(13+14)$} \\
\hline \multicolumn{5}{|c|}{ DEDUÇĈES PARA FINS DE LIMITE DO FUNDEB PARA PAGAMENTO DOS PROFISSIONAIS DO MAGISTÉRIO } & VALOR \\
\hline \multicolumn{6}{|l|}{$\begin{array}{l}\text { 16. RESTOS A PAGAR INSCRITOS NO EXERCICIO SEM DISPONIBILIDADE FINANCEIRA DE RECURSOS DO FUNDEB } \\
\text { 17. DESPESAS CUSTEADAS COM O SUPERAVIT FINANCEIRO, DO EXERCICIO ANTERIOR, DO FUNDEB }\end{array}$} \\
\hline \multicolumn{6}{|c|}{ 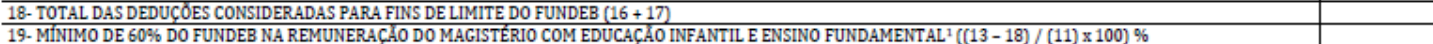 } \\
\hline \multicolumn{4}{|c|}{ CONTROLE DA UTILIZACAOZ DE RECURSOS NO EXERCICIO SUBSEQUENTE } & \multicolumn{2}{|c|}{ VALOR } \\
\hline \multicolumn{4}{|l|}{ 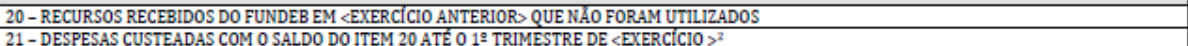 } & & \\
\hline
\end{tabular}

\section{MANUTENCÅO E DESENVOLVIMENTO DO ENSINO - DESPESAS CUSTEADAS COM ARECEITA RESULTANTE DEIMPOSTOSE RECURSOS DO FUNDER}

\begin{tabular}{|c|c|c|c|c|c|}
\hline \multirow{3}{*}{ RECEITAS COM AÇŐES TIPICAS DE MDE } & \multirow{2}{*}{$\begin{array}{l}\text { PREVISÁO } \\
\text { INICLAL. }\end{array}$} & \multirow{2}{*}{$\begin{array}{l}\text { PREVISISO } \\
\text { ATUALIZADA } \\
\text { (a) }\end{array}$} & \multicolumn{3}{|c|}{ RECEITAS REALIZADAS } \\
\hline & & & No Bimestre & $\begin{array}{l}\text { Até o Bimestre } \\
\text { (b) }\end{array}$ & $(c)=(b / a) \times 100$ \\
\hline & \multicolumn{5}{|c|}{ 22-IMPOSTOS E TRANSFERENCIAS DESTINADAS AMDE (25\% de 3$)^{3}$} \\
\hline \multirow[b]{2}{*}{ DESPESAS COM AÇŌES TIPICAS DE MDE } & \multirow{2}{*}{$\begin{array}{l}\text { DOTACAO } \\
\text { INICIAL }\end{array}$} & \multirow{2}{*}{$\begin{array}{c}\text { DOTACAO } \\
\text { ATUALIZADA } \\
\text { (d) }\end{array}$} & \multirow{2}{*}{$\begin{array}{l}\mathrm{DE} \\
\text { No Bimestre }\end{array}$} & SPESAS LIQUIDA & \\
\hline & & & & $\begin{array}{c}\text { Até o Bimestre } \\
(\mathrm{e})\end{array}$ & $(f)=(e / d) \times 100$ \\
\hline \multicolumn{6}{|l|}{$\begin{array}{l}\text { 23- EDUCACGAO INFANTIL } \\
\text { 23.1- Despesas Custeadas com Recursos do FUNDEB } \\
\text { 23.2- Despesas Custeadas com Outros Recursos de Impostos } \\
\text { 24. ENSINO FUNDAMENTAL } \\
\text { 24.1- Despesas Custeadas com Recursos do FUNDEB } \\
\text { 24.2- Despesas Custeadas com Outros Recursos de Impostos } \\
\text { 25- ENSINO MÉDIO } \\
\text { 26- ENSINO SUPERIOR } \\
\text { 27. ENSINO PROFISSIONAL NÃO INTEGRADO AO ENSINO REGULAR } \\
\text { 28- OUTRAS }\end{array}$} \\
\hline \multicolumn{6}{|l|}{ 29- TOTAL DAS DESPESAS COM ACCOES TÍPICAS DE MDE $(23+24+25+26+27+28)$} \\
\hline \multicolumn{4}{|c|}{ DEDUÇOEES CONSIDERADAS PARA FINS DE LIMITE CONSTITUCIONAL } & \multicolumn{2}{|c|}{ VALOR } \\
\hline \multicolumn{6}{|c|}{ 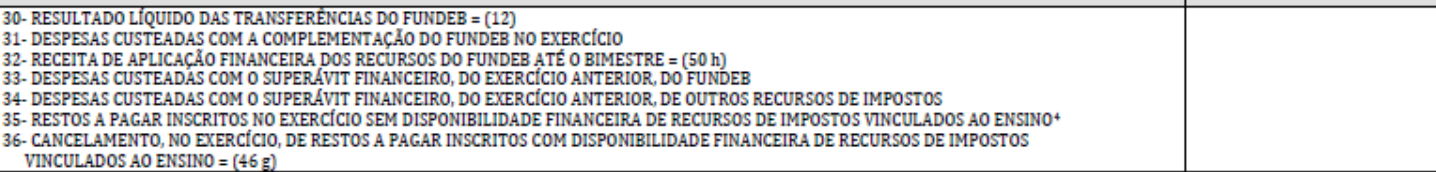 } \\
\hline \multicolumn{6}{|c|}{$\begin{array}{l}\text { 37- TOTAL DAS DEDUCCOES CONSIDERADAS PARA FINS DE LIMITE CONSTITUCIONAL }(30+31+32+33+34+35+36) \\
\text { 38- TOTAL DAS DESPESAS PARA FINS DE LIMITE }((23+24)-(37))\end{array}$} \\
\hline \multicolumn{4}{|l|}{$\begin{array}{l}\text { 38. TOTAL DAS DESPESAS PARA FINS DE LIMITE }((23+24)-(37)) \\
\text { 39- MINIMO DE 25\% DAS RECEITAS RESULTANTES DE IMPOSTOS EM MDE }((38) /(3) \times 100) \%\end{array}$} & & \\
\hline
\end{tabular}
39. MINIMO DE 25\% DAS RECEITAS RESULTANTES DE IMPOSTOS EM MDE' $((38) /(3) \times 100) \%$

\section{OUTRASINFORMACÖES PARA CONTROLE}

\begin{tabular}{|c|c|c|c|c|c|}
\hline \multirow[b]{2}{*}{ OUTRAS DESPESAS CUSTEADAS COM RECEITAS ADICIONAIS PARA FINANCIAMENTO DO ENSINO } & \multirow{2}{*}{$\begin{array}{l}\text { DOTACAOO } \\
\text { INICIAL }\end{array}$} & \multirow{2}{*}{$\begin{array}{l}\text { DOTACAOA } \\
\text { ATUALIZADA } \\
\text { (d) }\end{array}$} & \multicolumn{3}{|c|}{ DESPESAS LIQUIDADAS } \\
\hline & & & No Bimestre & \begin{tabular}{c|} 
Até o Bimestre \\
$(\mathrm{e})$
\end{tabular} & $(f)=(e / d) \times 100$ \\
\hline \multicolumn{6}{|l|}{ 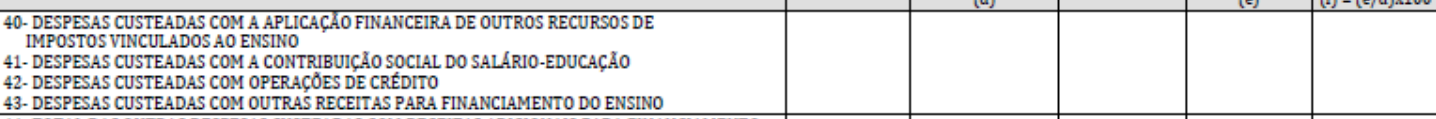 } \\
\hline \multicolumn{6}{|l|}{$\begin{array}{l}\text { 44. TOTAL DAS OUTRAS DESPESAS CUSTEADAS COM RECEITAS ADICIONAIS PARA FINANCIAMENTO } \\
\text { DO ENSINO }(40+41+42+43)\end{array}$} \\
\hline \multicolumn{6}{|l|}{ 45-TOTAL GERAL DAS DESPESAS COM MDE $(29+44)$} \\
\hline $\begin{array}{l}\text { RESTOS A PAGAR INSCRITOS COM DISPONIBILIDADE FINANCEIRA } \\
\text { DE RECURSOS DE IMPOSTOS VINCULADOS AO ENSINO }\end{array}$ & \multicolumn{2}{|c|}{ SALDO ATE O BIMESTRE } & \multicolumn{3}{|c|}{$\begin{array}{c}\text { CANCELADO EM }<\text { EXERCICIO> } \\
(\mathrm{g})\end{array}$} \\
\hline \multicolumn{6}{|l|}{ 46- RESTOS A PAGAR DE DESPESAS COM MDE } \\
\hline \multirow{2}{*}{\multicolumn{3}{|c|}{ FLUXO FINANCEIRO DOS RECURSOS }} & \multicolumn{3}{|c|}{ VALOR } \\
\hline & & & $\begin{array}{c}\text { FUNDEE } \\
(\mathrm{h})\end{array}$ & & FUNDEF \\
\hline 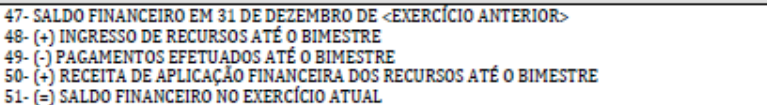 & & & & & \\
\hline
\end{tabular}

50- (+) RECEITA DE APLICACAO FINANCEIRA DOS

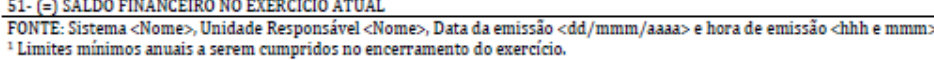

"Art. 21, 22, Lei 11.494/2007: "Até 5\% dos recursos recebidos à conta dos Fundos, inclusive relativos à complementaçăo da Uniâo recebidos nos termos do $\$ 1^{2}$ do art. 6? desta Lei, poderâo ser utilizados no 19 trimestre do exercício imediatamente subsequente, mediante abertura de crédito adicional"

Caput do art 212 da CF $/ 1988$

† 0 s valores referentes à parcela dos Restos a Pagar inscritos sem disponiblidade financeira vinculada à educaçäo deveräo ser informados somente no RREO do úitimo bimestre do exercício. $s$ Limites mínimos anuais a serem cumpridos no encerramento do exercício, no âmbito de atuaçäo prioritária, conforme LDB, art. 11, V. 
ANEXOS 


\section{ANEXO A - Autorização para pesquisa \\ UNIVERSIDADE DE SÃO PAULO - SP FACULDADE DE EDUCAÇÃO PROGRAMA DE PÓS-GRADUAÇÃO EM EDUCAÇÃO}

São Paulo, 15 de setembro de 2011.

À Secretaria Municipal de Educação de Vitória

Prof $^{a}{ }^{-} r^{a}$ Vânia Carvalho de Araújo

Prezada Senhora:

Vimos, pelo presente, solicitar autorização para que a aluna Marileide Gonçalves França, regularmente matriculada no Programa de Pós-Graduação em Educação da Universidade de São Paulo, realize a sua pesquisa de doutorado intitulada "Gestão das políticas de financiamento da educação especial no contexto da educação básica" no município de Vitória-ES. A referida pesquisa tem como objetivo investigar/analisar a ação do Poder Público no provimento de recursos à educação especial na gestão dos municípios da Grande Vitória, no contexto de financiamento da educação básica. A metodologia utilizada será a pesquisa documental. Para tanto, envolverá a consulta aos documentos produzidos nessa secretária nos anos de 2009 e 2010: balanços da execução financeira dos municípios, relatórios anuais de atividades, além de documentos oficiais, como resoluções, normativas, portarias e decretos referentes à educação especial e ao financiamento da educação, bem como das orientações internas do sistema de ensino municipal.

Certos de contarmos com a participação dessa Secretaria de Educação no desenvolvimento deste estudo, agradecemos a colaboração.

Atenciosamente,

Prof ${ }^{\mathrm{a}}$. Dr ${ }^{\mathrm{a}}$.Rosângela Gavioli Prieto 